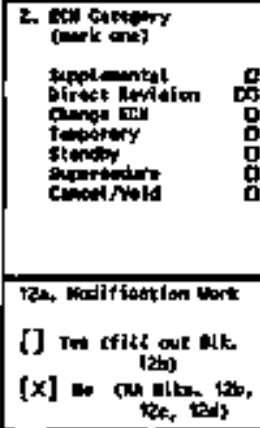

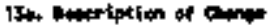

This rewision of the Singlo-Shal] Fabk Intorid Stabitization (S\$T-IS\} Project Plan wedifies the orjginal thres cases (basa case and two alternates) and establishos a fourth case as the S5T-IS basaline scenaris. This fourth case scenario is based an

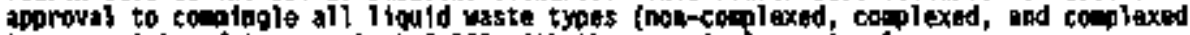
transuranic) ano to pen tank $(-103$ with the organic layer in slace.

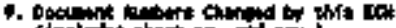

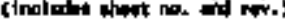
Haf-2358, Rev+4
Wh.
H.M. Fi.

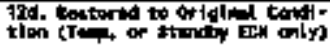
in

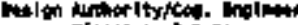

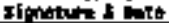

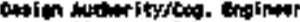

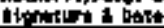

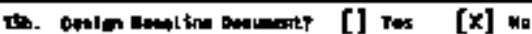




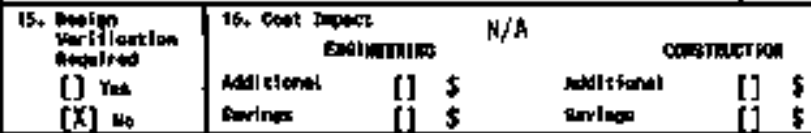

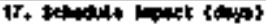

HA

Inprasume []

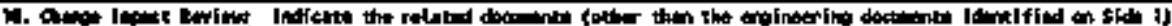

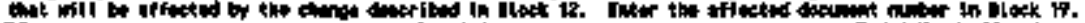
10000

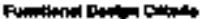

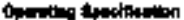

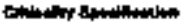

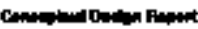

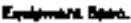

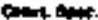

Brameno

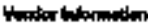

on Menue

Fupitant

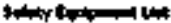

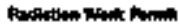

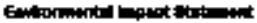

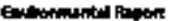

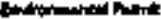

[]

[]

[]

[]

[]

[]

[]

[]

[]

[]

[]

[]

[]

[]

[]

[]

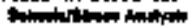

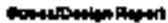

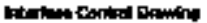

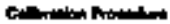

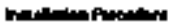

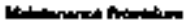

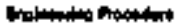

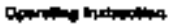

Opartar Arowere

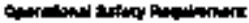

ED Drumial

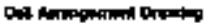

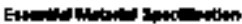

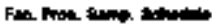

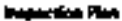

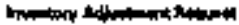

[]

[]

[]

[]

[]

[I

[]

[]

[]

[]

[]

[]

[]

[]

[]

Tek

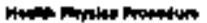

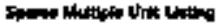

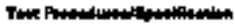

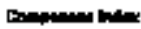

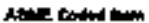

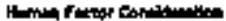

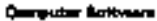

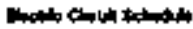

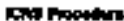

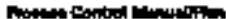

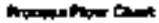

homing Anention

Nekter fin

Hens?

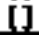

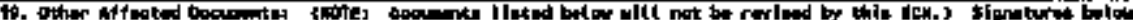

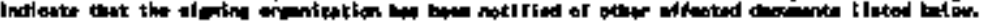

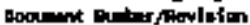

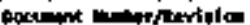

boament buter terlefor $\mathbf{H} / \mathbf{h}$

T. Haprenle

Hemirk

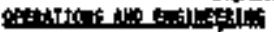

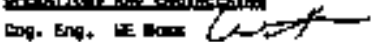

cos.

든

Eadity

Inwiren.

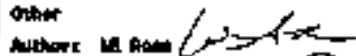

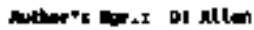

Dou dele-
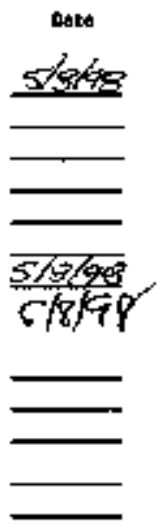

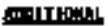

spertive

Dats

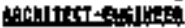

IF

ex

entaty

antar

Inverin.

othor

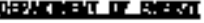

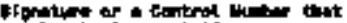

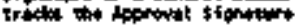


MiF-2358, Rev. I

\title{
Single-Shell Tank Interim Stabilization Project Plan
}

\author{
W. E. Ross \\ Lockhoed Martin Fanford Corpatu, Richland, Wh 9955 \\ U.5. Department of Energy Contract DE-ACo6-96RLL3z00
}

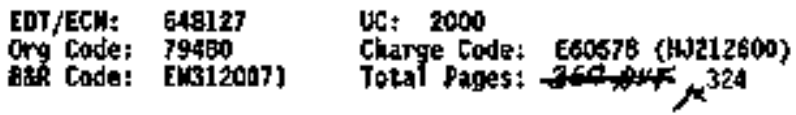

Key Words: Twis, Single-Sholl Tank, Interin Stabilization, Salt Nell Pumping

Abstract: This project plan ottablithes the masagent franmerk for conduct of the TWRS Single-Shal1 Tank Intarill Stabit12atiop comptet ion progras. Speciftealyy this plan defines the misston nads and requirements: tecinnical objectives and approsch; orgatizationa? structure, roles, responsibilities. and interfaces; and operational mothods. This plan serwes as the project executionsl basoline.

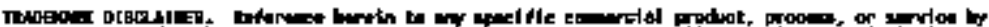

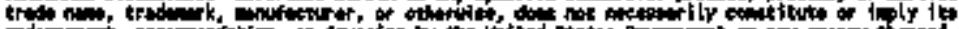

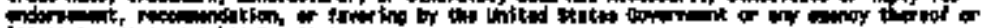

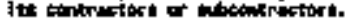

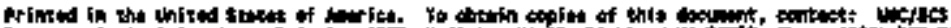

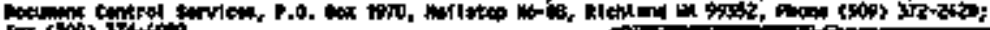
Fa (W0) 374
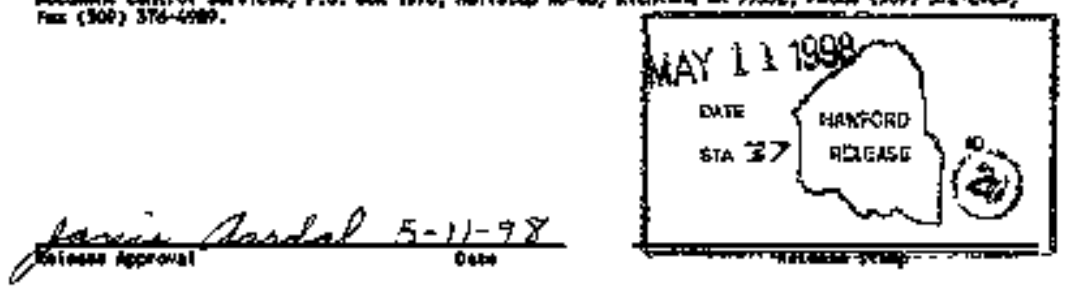


\section{necond of Feviace}

(1) meing Mistis

Fif-2538

Pane 1

(a) THite

Stingle-Shell Tank [nterim Stabi]ization Prołect P]an

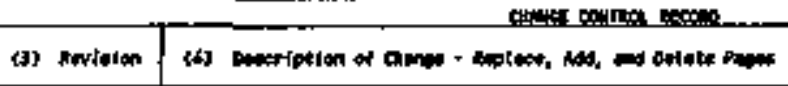

0

(J) EDT-624124, 5/11/98

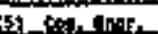

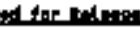

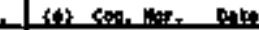

fis 1 Replates Rav. 0 and establithes fourth case

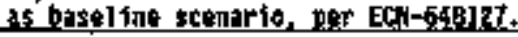

UE Ross DI Allen

We Rastof Pallen

Prilin deg $\mathrm{C}^{2}=$ 


\section{Single-Shell Tank Interim Stabilization Project Plan}

W. E. Ross

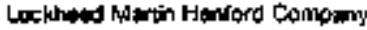

R. D. Smith

D. T. Vadimiroff

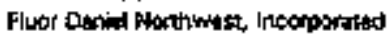

D. V. Freernan

MACTEC

J. R. Blggs

V. C. Boyles

J. O. Honeymen

J. R. Kriskovich

K. Pamell

R. F. Raven

D. J. Saueressig

S. E. Seeman

W. R. Swita

Locltoos Mutin Hanterd Company

Dowe Pulbhed

Mar 1998

Pepared for the U.S. Department of Energy

Fhor Darid Haxiond, lnc.

P.o. Bog $+0,0$

Richlind, whathingmen

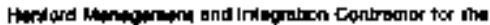

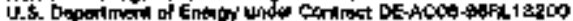


Lew Bactima

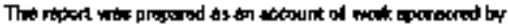

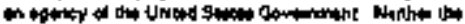

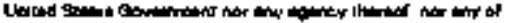

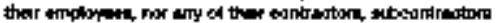

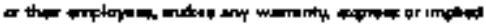

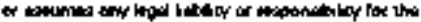

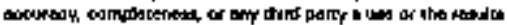

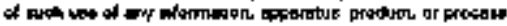

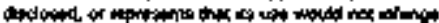

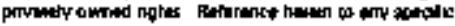

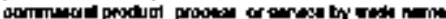

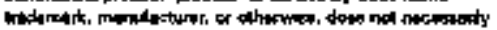

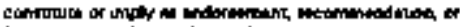

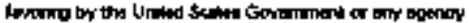

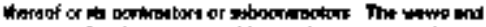

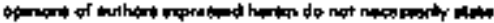

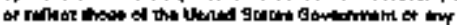
apseroy thentos:

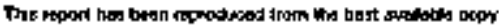

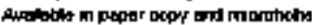

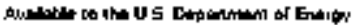
and it acmitrocano inom

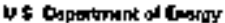

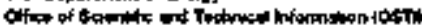

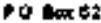

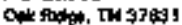

다 더 $\$ 7308401$

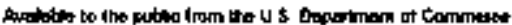

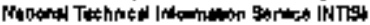

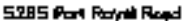

Encofids, VA22181

trobl 497-400

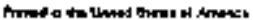

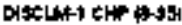




\section{HNE-2358 RoY 1}

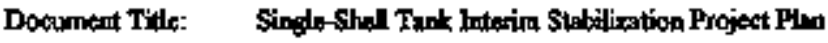

Approved by:

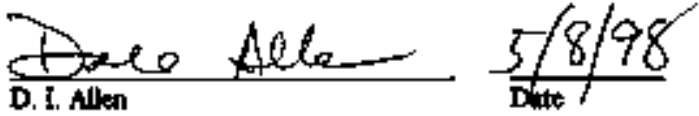

Direclex, Tank Wulte Operstions

Tark Waglo Remediation Syotem 
HNF-2358 ReY. 1

This page intentionally left blank 


\section{EXECDTTVE SUMMARY}

Solid and liquid radioaxtive waste comirues to be stored in i49 single-shedl tanks (SSTS) at the Fenford Site. To date, 119 tanks have had most of the prompable liquid ntmoved by interim stabilization. Thirty tanks temain to be stabilized. One of these tanks (C-i06) will be stabilized by retriesal of the tank contents. The renaining 29 atuks will be interim stabilized by saltwoll pumping. In the sumune of 1997 , the U.S. Depertmenl of Energy (DOE) placed a moratoriurin on the startup of additional saltwell punaping systems bechuse of funding consuraints and proposed modifications to the Harford Federol Facility Agreensent and Comsent Ords (Tri-Party Agraement) (Ecology at al. 1996) mikstones to the Washington State Eepartment of Ecology (Ecology).

In a letler dated Fetruary 10, 1998, "Final Determination Purguant to Hanford Federal Facility Agresment and Consent Order (Tri.Party Agreement) in the Malter of the Disapproyal of the DOE's Change Control Forti thM-41-97-01" (Filzsimmons 1998), Ecology disapproved the DOE Change Control Form \#M-4I-S?-01. In response, Fluor Datied Hanford, Inc. (FDH) direcred Lockheed Martin Hanford Corporation to Inldale developerent of a project plan in a ketta dated Fatruary 25, 1998, "Direction for Bavilopment of an Aggreagive Single-Shell Tank (SST) Interim Stabilization Ccompletion Project P]an in Support of Hanford Federal Facility

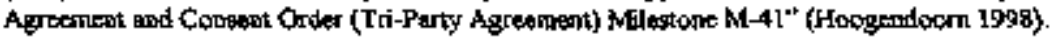

In a lotter dated Mach 2, 1998, "Request for an Aggressive Sinde-\$heil Tank (SST) Inderim Stabilization Completion Project Plan" (Sieracki l998a), the DOE realitmed the need for an aggrassive \$\$T interim stabizzation completion project plan to support a fralized Tri-Panty

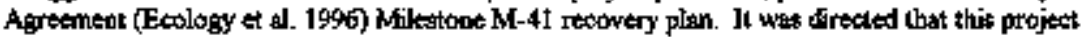
plan be based on realistic assumptions and consider three separale funding scenarios:

- Case *1 - Maximum fampoup with flomding not a biriting factor

- Cate ll2 - Assulme an additional 85.6 million in April 1998, a supptemental appropriation of \$13.3 million in September, and \$1 3.7 millison anch suboraysut. Alscal yeari (FY)

- Cose H3 - Assumber anditional \$5.6 milion in FY 1998 and \$1 1.7 million each subsequent $\mathbf{F Y}$.

Lockheed Martin Hanford Corporation assembled a task tean to develop the requested project plan, utiliziag an approagh similar to that used to devekp the Tant Wagte Remmediagion Systerc tetrieval and dipposel miasion readintess-to-proceed cerlificalion package detivered in Jazuary 1998. Enabfing assumptions were developed and reviowed with Tank Waste Reroedintion System contr aclor apd DOE naangement. A systematic appropach inchuting the creation of a mistion andlysis, contideration of tecturical alternatives, the developenent of Lewel I logiss kir ench of the 29 tanks remaining to be stablized, decomposition to more detailed task descriptions, and the devekopratert of teshniteal basis review packages was used to develop an 


\section{EXECUTTVE SUMMARX}

updated cost and schechle baseline for Case 1. Two additional furding cases, with funting constraints, werte generded by constraisuing aelinities on the Case 1 schetule.

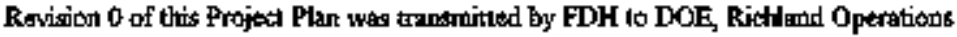
Office (RL) on Manch 3I, 1998. Subsequent discussions indicated that none of the three cases mert the needs of the program. The near term funding requirements of Cose l were not deemed to be achievalte. Cases 2 and 3 were unacecptably long. with ueilher being completed ptior to 2010 .

Based on feedback ftom these fiselustions and documented in Alken 1998. Sieracki 1998b. and Umek 19gs, the Projact Hanfort Manapgennot Comiract developed Casg 4, hereafter referred to as the Base Case. Several conservative assumptions were relased, and a more realistic flunding profile was suggested. This case was trangrairted to RL. on April 8, 1998.

The nagjor changes are:

- Approwal to co-mingle all liguid wagto types (noncomplexed, complexed, and complexed tringuraric)

- Pungy C-103 with the orgarric layer in plact.

Funding comparisons and profites are shown in Tables ES-1 and ES-2.

Table ES-I. Funding Comparisons.

\begin{tabular}{|c|c|c|}
\hline Conge & Iotal Projear Coss & Prófect Contipletion I Pase \\
\hline Cage ? & \$126 million & Septerrber 2003 \\
\hline Base Case (Case 4) & $\$ 119$ million & September: 2004 \\
\hline
\end{tabular}

Tabte ES-2. Funding Profiles ( $\$$ in milions).

\begin{tabular}{|c|c|c|c|c|c|c|c|}
\hline & FY 1998 & FY 1999 & FY 2000 & FY 2001 & FY 2002 & FY 2003 & FY 2004 \\
\hline Cabe 1 & 20.5 & 32.8 & 26.9 & 27.3 & 12.7 & 5.7 & - \\
\hline $\begin{array}{c}\text { Base Ca9s } \\
\text { (Case 4) }\end{array}$ & 13.7 & 16.7 & 18.3 & 19.0 & 20.3 & 18.4 & 12.7 \\
\hline MYWP & 12.3 & 14.4 & 11.0 & 12.1 & 8.1 & 4.4 & - \\
\hline
\end{tabular}

$F Y$ - fipod year.

MYWP = Militi-Yegr Work PJw. 
HNF-2358 Rey. 1

\section{EXECUTTRVE SUMMARY}

The current Tri-Party Agrement milestode to complete saltwell pusnping by September 2000 is not recoverabla, based on the physical time thecessary to pump the liquid from

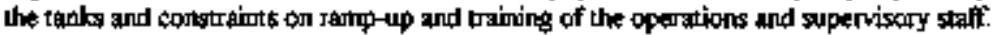

The technical work scope that comprises the SST Interim \$tatilization Project ressults in significant schedule risk. Physictal and chermical consorainks associated wíth sed twell pumping ressult in large statisstical variation in predicted punping durations. It is not possibje to predict wib certinity the actual pumping durtitions and completion daters. Critical risks havs bean identiffed and are addressed in the Critital Risk Madagenemt List inctuded as Table 3-1.

This projera plan destribes the orgonization that is necessary to execule the Base Case schedule. A dedicated project tears with command of the operational, maintenance, elgineerisgand supporting resources neaded to mest the project schectule is describer ln addition, the management systems and controls to be ulified to control and execute the activities also are described. 
HNF-2358 Rev I

This page intentionally left blank 
HNF-2358 Rev 1

\section{CONTENTS}

1 0 INTRODUCTION

20 MISSION AWALYSIS 2-1

2 I INTRODUCTKON 2-1

211 Purpos $2-1$

212 Massion 8cope $2-1$

213 Massion Tuman $2-1$

22 SINGLE-SHELL TANK INTERDM STABLIZATTON PROJECT PROBLEM 2-2

22 I PToblern Background $2=2$

222 Problers Definrtion 2-3

223 Mryor Issues Owervew 2-3

23 MISSION \$TATEMIENT 2-3

2 \& SINGLE-SHELL TANK INTERIM STABILZATION PROJECT BOUNDARY AND INTERFACES ? 2-3

24 I Progranmatuc Inuerthes 2 2-5

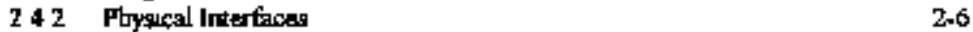

243 Intertil Inketaces $2-6$

244 Inputs and Outputs 2-?

25 SINGLE-SHELI TANK INTERDM STABLIZATION PROJECT INITIAL \$TATES ANW ENT STATES 2-?

25 I Intral States $2-7$

252 End Stater 2-11

26 MISSION LIFE CYCLE

261 Specrication 2-15

262 Proarteruent $2-15$

263 Installauon 2-15

264 Operatiou 2-16

265 Isolalon 2-16

27 MISSION-LEVEL REQUIREMENTS 2-16

2 B SINGLE-SHELL TANK INTERDM STABDIZATION PROJECT GOALS, OBJECTIVES, AND MEASURES OF SULCESS

281 Gools ard Objectrves $\quad 2-17$

2 B 2 Measures of Success $2-18$

3 9 KEY ENABLDWG ASSLMTTIONS, RISKS, AND RECOMAMENDATIONS

31 ENABLING AS\$SUMPIIONS 3-1

31 I Progect 3.1

3 I 2 Opecatung 3.1

313 Texhology/Equpmari

314 Permititig 3-3

32 MALOR RISKS 3-4

3 RECOMMENDATIONS FOR RISK MITIGATION 3-5 
CONTANTS (Cont)

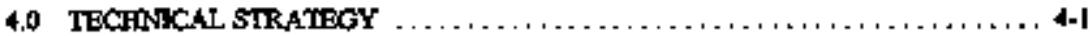

4.1 TECHNICAL APPROACH $, \ldots, \ldots, \ldots, \ldots, \ldots, \ldots, \ldots, \ldots, \ldots$, 4]

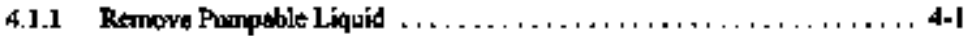

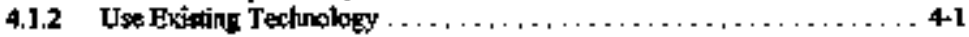

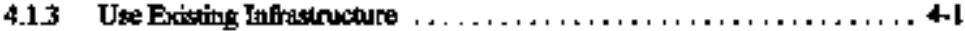

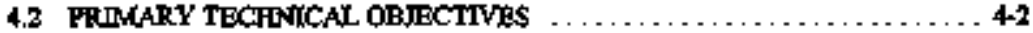

4.2.1 Expefile Schedule $\ldots \ldots \ldots \ldots \ldots \ldots \ldots \ldots \ldots \ldots \ldots \ldots \ldots, \ldots, 2$

4.2.2 Co-mingling of Whasto $\ldots \ldots \ldots \ldots \ldots \ldots \ldots \ldots \ldots \ldots \ldots, \ldots, \mathbf{4 - 2}$

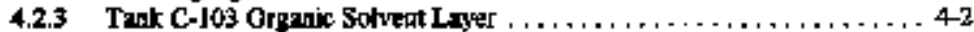

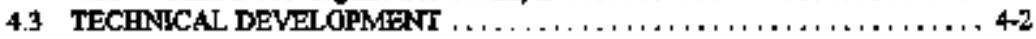

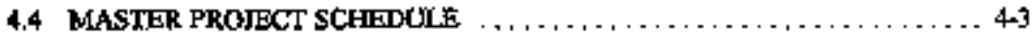

4,5 FACILITY CONFIGURATION $\ldots \ldots \ldots \ldots \ldots \ldots \ldots, \ldots \ldots \ldots, 4,4$

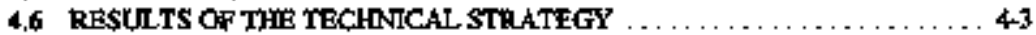

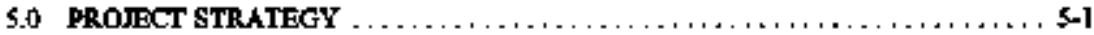

S.1 OPERATIONS AND MAINTENANCE STRATEOY $, \ldots \ldots \ldots, \ldots, \ldots, 5,1$

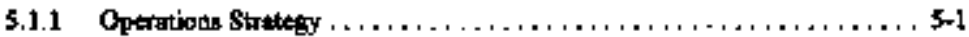

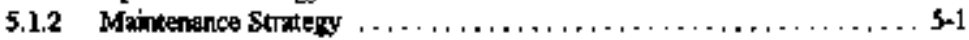

5.2 NUCLEAR SAFETY AND LGCENSINO STRATEGY $, \ldots, \ldots \ldots \ldots, \ldots$, s-2

5,3 ENVROMNMENTAL PERMATTING STRATEGY $\ldots \ldots \ldots \ldots \ldots \ldots \ldots$, S-2

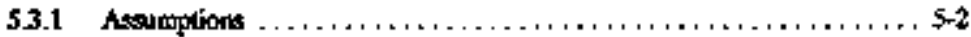

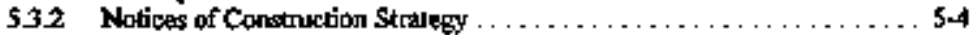

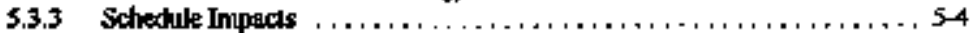

6.0 SRKGLE-SHELL TANK INTERM STABIIZATION PROIECT BASELINE , . . . , 6-1

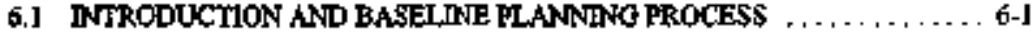

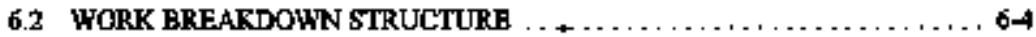

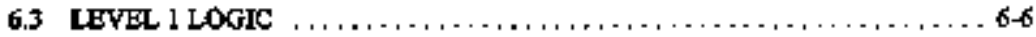

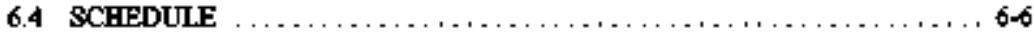

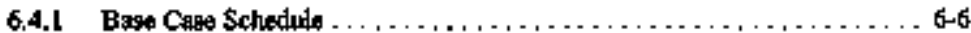

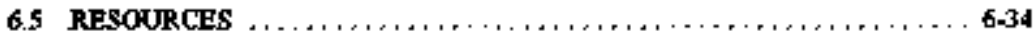

6.5.1 Base Cape Coge by Work Brestedowa Structure . . . . . . . . . . . . 6-34

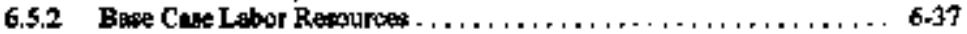

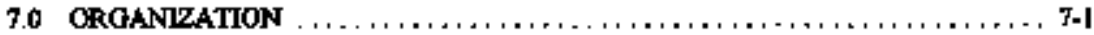

7.1 ORGANIZATIGNAL \$TRUCTURE $\ldots \ldots \ldots, \ldots, \ldots, \ldots, \ldots, \ldots, 7-1$

7.1.1 Tenk Waste Opentions Orpainization $\ldots \ldots \ldots \ldots \ldots \ldots \ldots \ldots$, . I

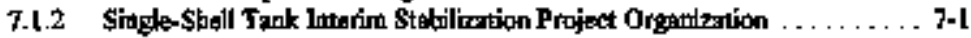

72 ROLES AND RESPONSIBILITIES $\ldots \ldots \ldots \ldots \ldots \ldots \ldots \ldots, \ldots, \ldots, \ldots$

72.1 Tank Wate Operations $\ldots \ldots \ldots \ldots \ldots \ldots \ldots \ldots \ldots \ldots \ldots, 7.6$

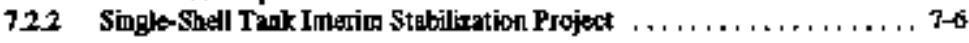




\section{CONTENTS (Cont)}

\&O MANAGEMENT APPROACH S-1

81 BUSINESS OPERATIONS 8 -1

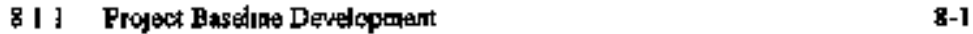

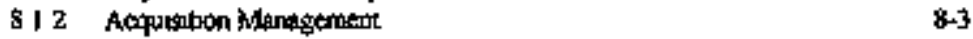

B13 Perfortionte Assuratiot $\quad 8.4$

814 Managentent Systems $8-6$

B 2 ENGINEERING 8-7

B 2 I Systems En:minennig 8.7

B 22 Engryecing Process

B 23 Tecturiel Basetine 8.8

824 Alterpatrves Mansgement 8-8

B 3 INTEGRATED SAFETY MANAGEMENT SYSTEM

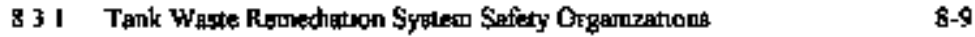

84 DECISION MANAGEMENT \&-1I

85 RISK MANAGEMENT 8-11

\& 6 CONFGURATION MANAGEMENT $8-12$

87 INTERFACE MANAGEMIENT 8-13

\& 8 STAKEHOLDER AFFAIRS \&-14

B \& I Begulatcor Partactpation

B \& 2 Publuc Puthempation 8-15

90 REFERENCES 9.1

\section{APTENDIXES}

A INTERTM \$TABLLATION HISTORY A-1

B ALTERNATTES AND TECHNOLOGY CON\$WERED

C SLNGLE-SHELL TANK INTERIM STABILIZATION EXTERNALLY DMPOSED REQUTREMENTS

C-เ

D SINGLE-SHELL TANR INTERMM \$TABILIZATION INTEGRATED

SCHEDULE DETAH

D-1

E \$NNGLE-\$SFLL TANK DNTERIM STABILIZATION LEVEL L LOGICS S-L 


\section{LIȘT OF FIGURES}

2-1 Single-Shen Tanl: Intejm Siabibzation Project System Bolundery and Interfaces

2-2 Single-Shell Tank Farms Interum Strbilization Probress Stalus

2-3 Saltwell Pumping System:

4-1 Waste Flow for Single-Shel Tank Interim Stabilization System Fow Diegram

4-2a A atad AX Farm Pyping Configuration

4-2b BY Farm Pipiog Configuration

42e S and SX Farms Piping Configurraion $4-8$

4-2d T Farm Piping Cótifioration

4-2e U Fanm Pongog Configuration

4-3 Doublic-Contejned Recterver Taslk and Tank Farm Subsystem Pumping Requirements

4 Cumblative Performance Requirements

45 Rerdibyal of Rarlipactince Material

4-6 244-S Double-Contained Recterive Tant Loards

4-7 Crase-Site Transferers

6.1 Tank Waste Rerreedıatıon \$ystem Wọk Ersakdown Structure

64 Single-Shell Tank Intertu Stabilization Integraled Strmmary Pumping Schedule, Base Cose 
HNF-2358 Rov ]

\section{IST OF FIGUREs (Comt)}

T-1 LMHCT Tunk Waste Remeduahon System Organnatron

7-2 Tank Waste Operatrons

7.3

7-3 Charactenzetion Projeat Dryanzatron

$7-4$

7-4 Interm Stabilization Projex1 Orgamization

$7-5$

8-I Example of Sungie-Sbel Tank Actirutues

8.5 


\section{LIST OF TABLES}

1n1 Funding Comparsons

1-2 Funding Profiles (\$ id itllons) I-2

2-1 Present Coulants of Singhe-Shell Tanks to be Pumped 2-8

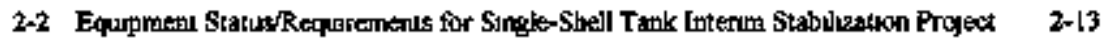

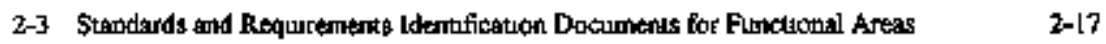

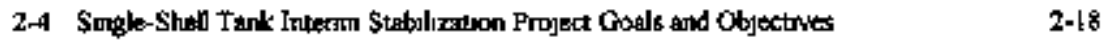

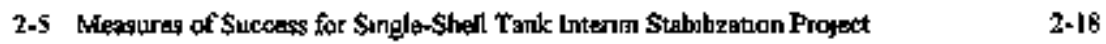

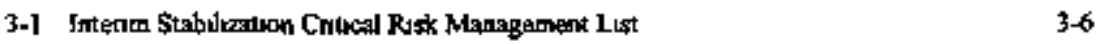

4-1 Pumpung Durathons 44

4-2 Porformance floqurements of Miajor Subsystotng 4-16

4-3 Eysporator Carapagn Schedule 4-17

5-I Single-She-1 Irtennm Stabrization Permutung Strategy S-3

6-I Sugle-Shell Tank Imerim Slabilzation Level I LogorWork Breakdown \$nucure Crosswalk

6.2 Singlo-Shed Tank Intenm Stabiluzation Prodect, Escalated Babe Case Costs by Focal Year

6-3 \$ongle-Shell Tank Intenra \$tribulathon Base Care Cast By Work Breakdown Sinuchure, (Unescalated) Tolel Coat (\$000) for Year

6-4 Sugle-Shen Tank Intenm Stabjlealion Base Case Full Time Equrvalents By Work Broakdown Structure

B-1 Work Breakdown Struchure Peffornance Reporthng Levets 8-4

B-2 Stigle-Shel Tank Imearit Siabulazauon Imerfaces 


\section{LSST OP TERMS}

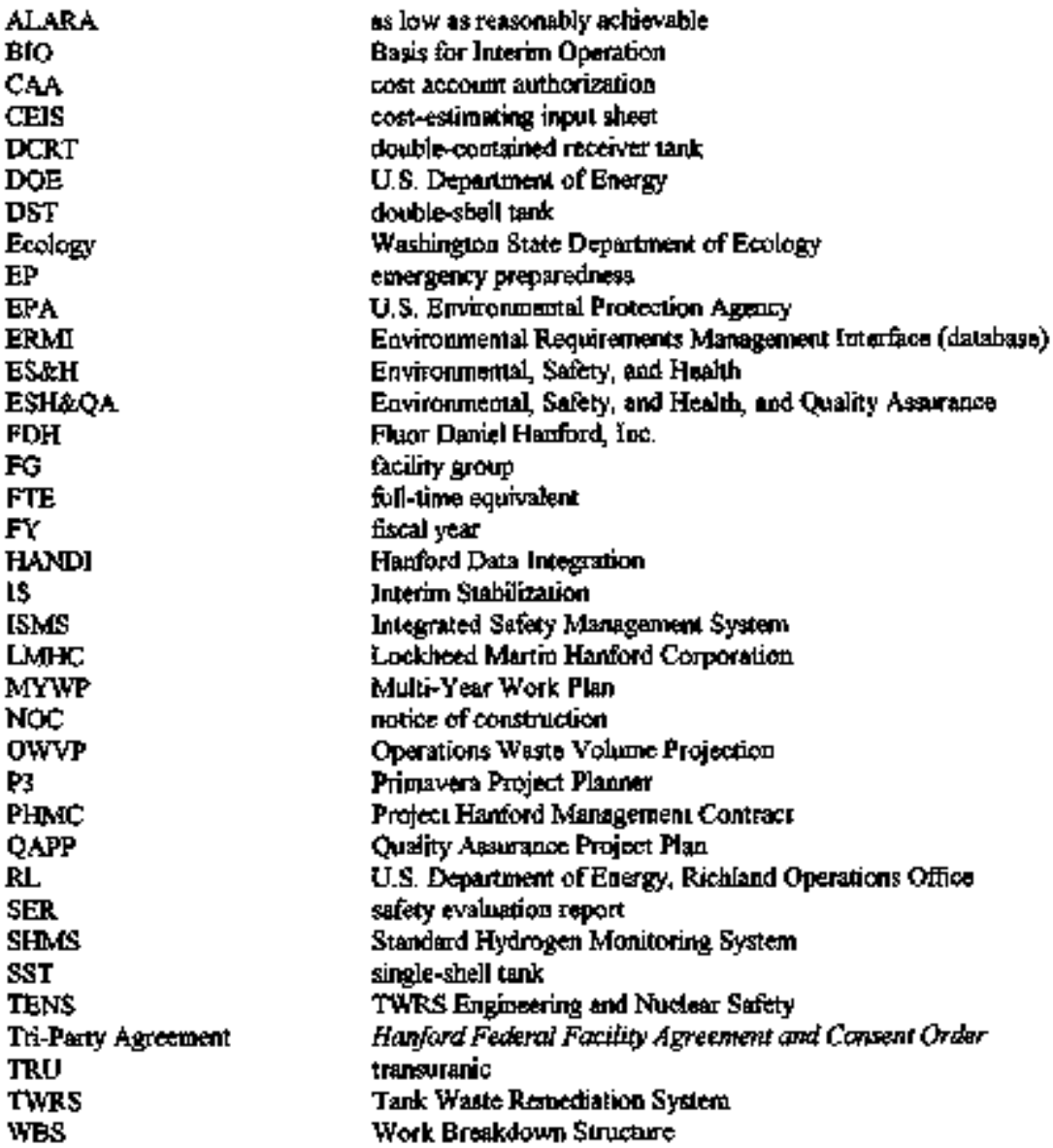




\section{DEFINTIONS}

Construction Prodets:

Froject W-0S8

Projoa W-1SI

Project W-2il

Project W-314

Project W-320

Saltwell Pranping

Saltwell System
Crobs Site Iransfer line (Projext W-aS8) is the cross-site waste transifor line between East and West tomk farms.

Tank A2-101 Mfrer Pump Test (Project W-151) provides a waste mixing system in double-shell Tank $A Z$ - 10 I and performs a temopgeration togt of this aystem in support of wast retritwal and thudge washing activities

Inutial Tank Retrieval Systerms (Project W-211) provides waste mixing and retrieval systeons in ten double-shell tanks to prepare waste feed fipr delivery to privalte contratiors.

Tank Farm Resioration and Safe Operationa (Project W-314) prowide upgrades to the waste transfor syatem necosary to ensure safe, retiatle transerer capatoility to ouppost feed detivaty.

Tank C-106. Wasta Retrieval Shicting gystent (Project W-320) provides a reutieval system in Talk C-106 for retriesing the C.106 sludge as part of the high-leved waste fesd.

Single-ahell tank interim stabilization, renaying pumpable liquid thom single-shell tanks using a jet or subner ribje purap

Couffiguration consisting of piping with an inlet sureen and conkaiting either a submersible pump or a foot valvo assemably at its lower end. 
HNF-2358 Rev. I

\section{STEGLE-SHILL TANK INTHRIM STABIEIZATION PROJXCT PLAN}

\section{I,0 INTRODUCTHON}

In a letter dated Febtury 10, 1998, "Fonal Determination Pursuant to Hanford Federal Facility Agreement and Coneen Order (Tri-Party Agreement) in the Matder of the Disapproval of

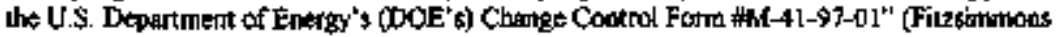
1998), the Wasthigton Strit Depurtenex of Ecology (Ecology) ditapproved theDOE Change Control Formt \#M-A]-97-01 In Tesponse, Fhar Danid Hanford, Inc. (FDH) directed Lockbeed Martin Hanford Corparation (LMHC) to initiate developmean of s project plin in a letter dathed Febnary 25, 1998, "Direction for Development of an Aggrassiye Single-Shell Tank (SST)

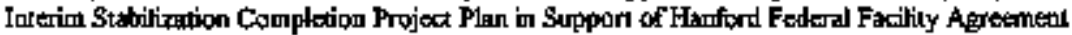
and Consent Order (Tri-Party Agreement) Milestone M-41" (Hoogendoom 1998).

It a letter tated March 2, 1998, "Requega for an Aggrestive Single-Shell Tank (SST) Interim Stabilizalion Completion Project Ptan" (Siaracki 19986), the DOE reaftirmed the direction that FDH and LMIC develog to adgressive Singde-Shell Tałk (SST) Interim Sıbilization (IS) complation project ptan to support a finalized Hayford Federal Facility Agreanent and Corstent Order (Tri-Party Agretenent) (Ecology at al. 1996) Milestone M-41 recovery plan lo was directed that chis project plan be based on realialic asamptions and consider three separate

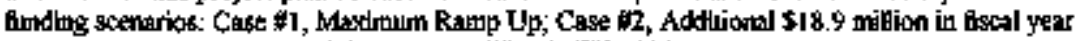
(FY) 1998; and Case W, Addritional \$5.6 million in FY 1998.

Revision 0 or this Project Plap was trangritted by FDH to DOE, Richland Operations Office (RL) on March 3], 1998. Subsequent discussions inticated that none of the three cases met the needs of the prograrn. The near term funding requirements of Case 1 were not deened to be achievable. Cases 7 and 3 wera umacceptably long, with nettber being completed prior to 2010 .

Based on feethack fiom these discussions and documented in Alleth 1998, Sitracki 1998b. and Uarek 1998, the Projecl Hanford Maragerpent Contract (PHMIC) doveloped Cabe 4, hercafter refiarted to as the Bess Cage. Several conservitive assumptions were relaxed, end a more realistic funding profite was suggested. This case was uansmitted to RL on April 8, 1998.

The major thanges are:

- Approvgl to w-midge all liquid waste type (troncomplexed, contepleved, and cormplexed tranturatic [TRU])

- Purm C-103 with the orgaric layer in place. 
Fundigg conparisong and profiles are stown in Tables I-I and l-2.

Table l-1. Funting Comparibong.

\begin{tabular}{|c|c|c|}
\hline Casse & Tolal Project Cost & Project Completion Dare \\
\hline Case 1 & $\$ 120$ million & September 2003 \\
\hline Base Case (Cose 4) & $\$ 119$ million & September 20044 \\
\hline
\end{tabular}

Table 1-2. Funding Profiles ( $\$$ in millions).

\begin{tabular}{|c|c|c|c|c|c|c|c|}
\hline & FY 1998 & FY 1999 & FY 2000 & FY 2001 & FY 2002 & FY 2003 & FY 2004 \\
\hline Case 1 & 20.5 & 32.8 & 26.9 & 27.3 & 12.7 & 5.7 & - \\
\hline $\begin{array}{c}\text { Bast Case } \\
\text { (Case 4) }\end{array}$ & 13.7 & 16.7 & 18.3 & 19.0 & 20.3 & 18.4 & 12.7 \\
\hline MYMP & 12.3 & 14.4 & 11.0 & 12.1 & 8.1 & 4.4 & - \\
\hline
\end{tabular}

$\mathrm{FY}=$ firstl rear.

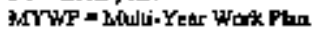

This project plan establisshes the maragement framework for conducting an aggressive SST ISN/solaton program. The LMLC used a plan-dewelopment procest modeled after the Tank Wagle Remediation \$ygtern (TWRS) Waste Feed Detivery Readiness-to-Rrocsed certification process completed in lasuerry IS95.

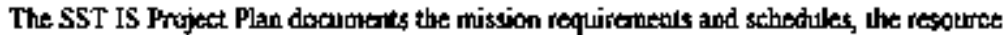
requirements, and the biantigentent sirategies athd pobcies for accomptisting the SST IS Project misgion. It defines the systens and practices used in establish consistenty for business practices, engineeriag physical conflguration, and facility documentation and will be used to maintain this consistency throughout the project 括e cyclo, particularly al changess aro made. Specifically, this

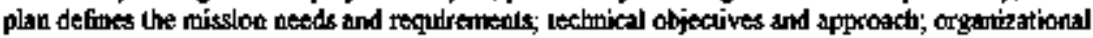

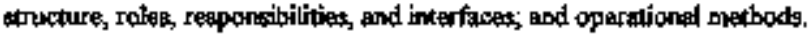

Once DOE has completed its negoliations with Ecology on the palh forwatd lor the SST IS Project, this plan and itts supporting detail will be updated to form the project execulion baseline. 


\subsection{MISSION ANALYSIS}

\subsection{INTRODUCTION}

\subsubsection{Purpaste}

As required by the LMIHC owerall rysierra approsacb, this section evaluates the probilam

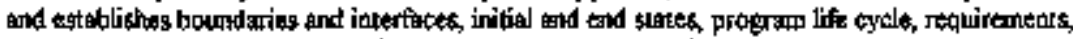
gonls, objectires, ond meatures of success For the S5T IS Project mistion

\subsubsection{Mising \$oopt}

As defined by HNF-SD-WM-MAR-008, Tatk Waste Rentediatron Systew Missuan Anatysis Roport (Acree 1998), the \$\$T IS Project mission inchudes the activities needed to accointistish the following

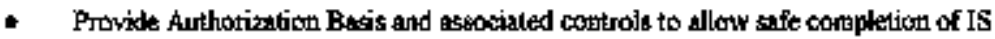
Latks associated with saffety issuiss

- Consuruct and maintain the equipment necessary so saffy remowe pumpable liquid

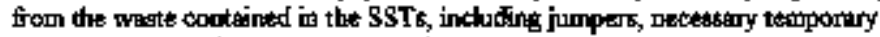
overgound lines, fammable gas moritors, extausters, and necessury jugtrumentation and controb

- Remove pumpoble hiquid from the SSTs and trangfer this hiquid to the double-shell Lanks (DSTs)

- Operate the penfyistg syttemt unil the slabilization criterio are met

- Perform the neceratary andysis and produce the nexessitry documentetion

- Interim isolate the ghabilized SSTs to ensure that uo likpuilis ender the tank before the start of retrieval

\subsubsection{Mtsiten Tinitis}

Pumping of liquids from the SSTs has been ougoing since 1976. The present Tri-Parly Agreement (Ecology at al 1996) major nilegtone M-41-00 currently requires conpletion of perming and ispolation of the tanks by September 30, 2000 Thís Project Plan will complese SST IS and isokation in September 2004 
HENF-2358 Rer. 1

\section{2,2 \$NNGLE-\$HELL TANK INTERIM \$TABILZATION PRONECT PROBLEM}

\subsubsection{Probleen Backgound}

Large wobumes or radionctive waste, a kegacy from the Hanford Site's miggion of weapons-

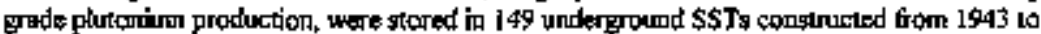

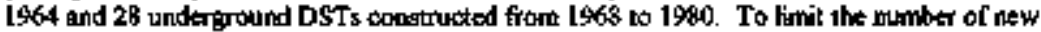
DSTs that had to be constructed to store Jiquid radicactive waste, DOE anthorized concentration of the waste linuids until the goluble salts were precipitated. These procipitated saltes wire allowed to estle in the SST. Stimificant froe supetroutants were pumped from most of the SSTs

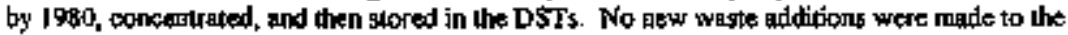
SST 6 afler 1980. However, the SST 6 have sets bevere tervice and are well beyond their design Ffe. Leakage of waste from 67 of the SSTs to the kank farm vadose zone is assumed or has becen confirmed.

To resduce the potential of fiurther SST kelkage, an approuch was deweloped using : central screen wed and a low-capocity jet pump instelled in the well to ramove the drainable biquid. Lichuid in the tank duains to this central well, driven by the pressure of the interstitial tiopuid in the bed (head hejglt). To moximize the rate of drainage at all times, the liquid in the well is

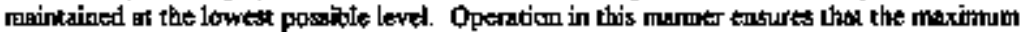
drainable liguidd is fernoved as quiekty as possible. This process has been defined as "interin stabilization."

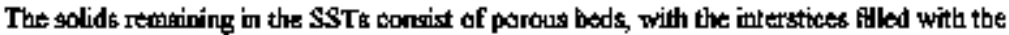
remaining radioaclive waste liquids. Depending on the particle sizes of the solid beds, varying anmounts of figuid are trupped in the solids beds. For beds with refalively large panticle sizes, the

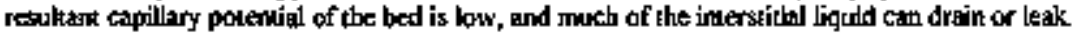
For very fine particles, the cepidery potential is very tigh, and little of the interstitial liguid can 由rain or leak. On avetage, 3.79 liters (1 gallon) of salh calke may contadn 1.26 liters to 2.53 liters (L/3 to $2 / 3$ gellon) of drainable liquid, while 3.79 livers (I gallon) of slodge may contain 0.379 thar to 0.95 liter ( $1 / 10$ to $1 / 4$ gaton) of daiasble liguid.

Therefore, the time to remove interatitial biquid can be an much as severed yearg, depending on solution properthes, solids portingty, sufface tention of the hipuld on the wetted solids, head height, well diasseter, and solution viscosity. Puraping generally continures urtil the inflow into

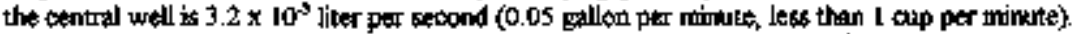
Flush water teeded to keep the prump and screen clest exceeds the $3.2 \times 10^{4}$ liter per second (0,05 gallon per minute) criterion, so continuing pumping would only resulf in rearpuing the water added to the system, rither than continuring to remone fiquid waste fion the sofids. 


\subsubsection{Problem Definition}

Sixty-seven of the Id9 SSTs are assuned to have leaked liguid to the vadose zone over part yeare. The liquid from all tankg that have not yet bean interim atabilized mush, therefore, be removed to reduce the potential for further leakage. The SST IS trission covers 29 such thrtks that atil contain pumpable tiquid. Among the 29 tanks are BY-105, BY-10S, and SX-104, which are esumed leakerg. The other SST, Tank C-106, will be stabilized by another project

\subsection{Majer Isuat Overview} follows:

Major itsles that dominste the removal of liquid tyase from the SSTs at this time are as

- Punpint Rate - There is uncertainty in the pumplng rate for etach latk and uncertairty in the total opersting efficiency for pumping operations The tolal operating efficiency probalty las bigher uncertaimty than previously calculated besuse of the incrase in safely equipmentiregulations, inchuding additional

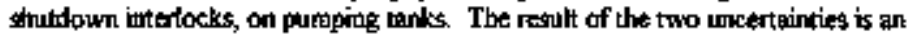
uecertaitsy in the overall puniping rate.

- Project Priority - Completion of uhis project will require contimucus, forased effort and appropriate and usably funding

- SST Tank A-30l - Pumping of SST Tenk A-IOI will require an amesdment wo the centent Atrthorization Basis with RL epproval.

\subsection{MIS\$YON STATEMENT}

The mission of the SST IS Project is to reduce the probability and consequence of S\$T leoks to the vadose zone by renowing sulfikient pumpable liquid from the tanks in a safe, coriptiant, and efficient masines to ines the defited IS criterie and to isolate the tanks to the maximum extent postiblo

\section{SINGLE-SHYL TANK INTERIM STABILIZATION PROJECT BOUNDARY AND INTERFACES}

Figure 2-1 shows the SST IS Project bystem boundary and interfaces. The following sections describe the programmeatie, physical, and iuternal inlerfaces identified on the figure. 


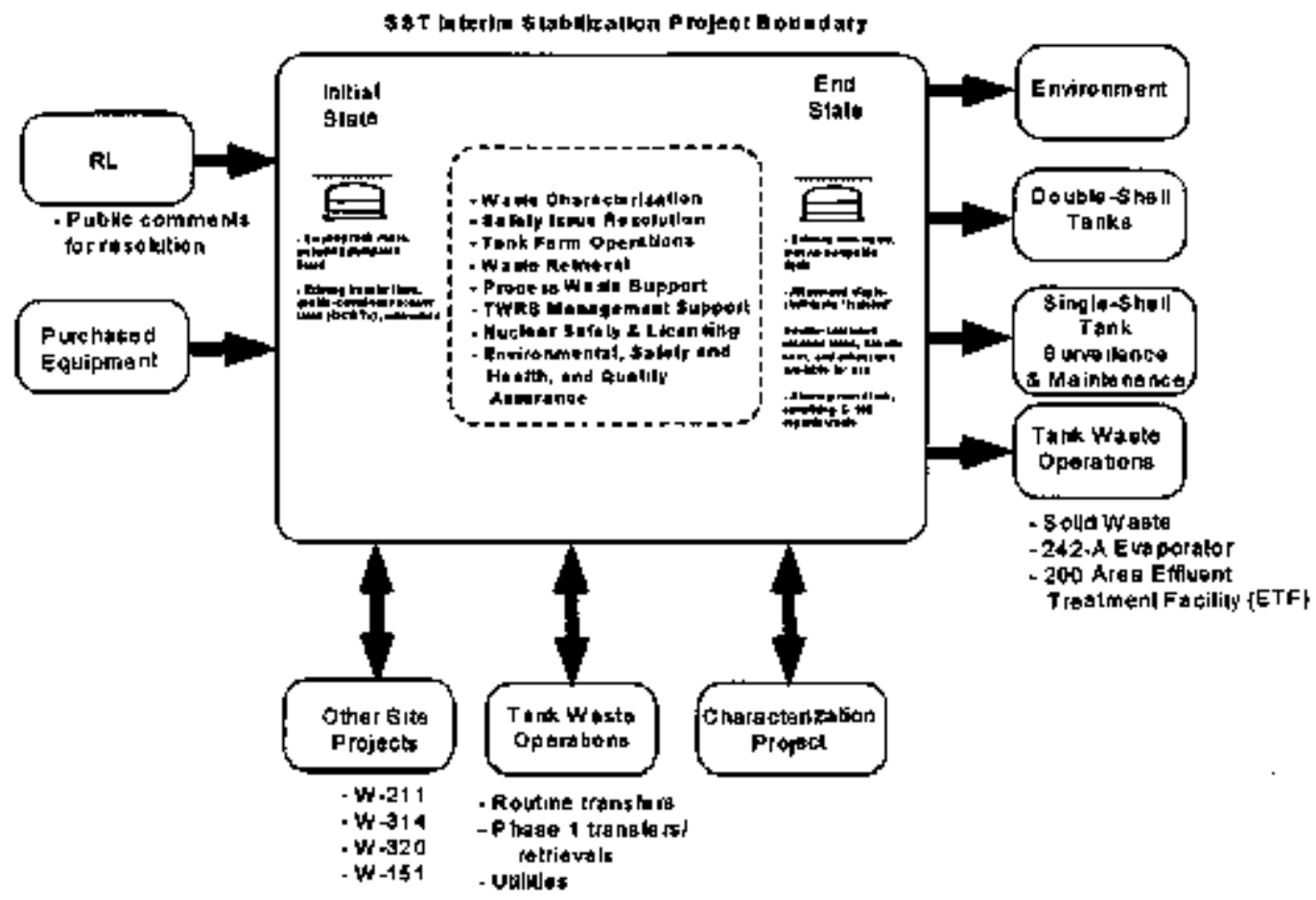

Fjgure 2-1. Siogle-SheD Tank Interim Stabilization Project System Boundary and Interfaces. 
HNF-2358 Rew. 1

\subsubsection{Proprangatic Interfecex}

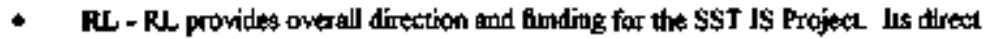
interation is with FDH The subcontractor regponstile for execulion of the project is LABSC.

- Tank Wuste Operatlows - As parl of the TWRS tafte-sorage otjective, "Conduct Waste Consolidalion and Reatuction Activitics." Tank Wagte Operitions is responsible for managing tatk waste induding the resduction of weste volume. Operations is also Jesponsiblo for ensuring that systems and equipment used in conmonon by Operstions and the SST IS Projest remsin in operating order. Operations will be responsible for the routioe survellathe of the tanks being stabilized and wil continute these surveillance activities until the waste is retrieved. The IS organization will matsage the surveillance entivities netded for their operations of equipment stch as liquid-level ingrumentation.

- Evaporalor Operstions - The fole of Evaporator Operalions is to reduce the volume of waste as idartified by DST Dperations to maintain sufficient free volume to cary out transfers for the SST IS Project and other operalions. In

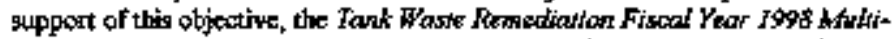
Year Work Plon (MYPP) (LMHC 1997a) and the Operastons Faste Volupse

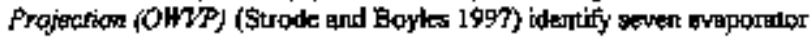
empuigins to be petformed during the years 1999 through 20002. Approximately

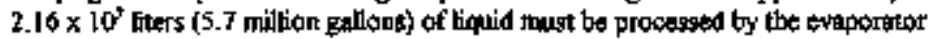
to ensure that DST space is arailable.

- Characterization - The Tank Waste Charactericalion Project is responsibte for sampling and characterizing tank waste for numerous projects. The SST IS Project and the Tank Wart Claracteqcization Project must enguro that thair work is imitgrated. Sampting and characterization efforts in suppott of the SST iS Project will be congistent with the activities and practices discussed in the annual 8eproting plans.

- Tank Wuste Hetrieval Construction Projects - Several constnuction projects (W-21L, W-314, W-320, and W-151) will be occurring in lie lank farms at the same ime as the SST IS Project. Thete will vefy likely be a number of intefaces botween these conetraction projests and the SST IS Projoct.

- Tank Wade Retrieval Operations - Depenting on the hinal gchextule for the $\$ \$ \mathbf{S T}$ IS Project, it may begin to interisect with the Plase 1 TWRS ratioved of watte. It is espectally iniportamt that transfers by the SST is Projeci do not impact upaste feed envelopes defined for Phase 1 . In adrition, basne of the prochuct of the SST IS Project will be used in preparation of Phase 1 feed 


\subsubsection{Physical Interfaces}

- Tank Watte Opentious - Tank Waste Dperations' management pf tank waste, pending waste relrieval operations, indudes trangler al waste between lanks using the same tank farmes, talks, pipelines, and other equipratenk that will be uged by tha S8T IS Project.

\section{2,43 Intemal Iaterinces}

- Watte Charistedzation - An imponask part of the SST IS Praject is the

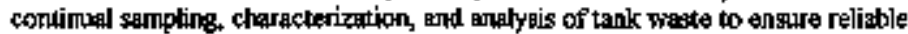
pumping times and wraste compatibility deternination.

- Safety Inue Reswutinn - Safely Lague Regolution is responsible for compiling the basis for the imtefith stabilization or Tank $\mathrm{C}-103$ without removal of the organic layer. Removal of the orgaric layer is independent of the closure of the organic unrevieved afefty question. Safery Itoue Resolution will also evaluate flemmable gas ewohuion dering IS so the appropriateness of tammoble gas controls can be reviewed.

- Nuclear \$afety and Licensing - Nuctear Safety and Licensing is responsible for ensuring that the serfety Authotimalion Basis is in place for the operations then are reguired to carry out the \$\$T IS Project.

- TWRS Environental - Environmental is responsible for eusuring thal proper permits and notixes of constrution (NOC) are writien and transcrirted through FDH and RL to the propar atsle and regulatory agenteies. Envirommental is also responsible for informing IS of any pormit copditions ubat must be incorporated inlo their procedures before start-lup.

- Tank Waste Oparzition - Tank Waste Oparations is fespongäle for carrying ourt the day-10-day operational activities, maimearance, and survellances and moniloritg of the DST, $\$ 5 T$, and doublo-contained recegiver tank (DCRT) systems and trantier systems.

- TWRS Management - The TWRS mangement structure is responsitie for extablishing priorities and providing managanent direction and pyersight to the sST IS Project.

- Procens Enginetriag - Process Engintering is respongible for deteruining purap rates and durations, determining the proboble behavior of waste during pumping and transfer, and conducting wagte corropatibjlity assessnnents. Process Enoinesing also will perform engiveding tudiss or analsses to provide rocomumadatations for istproving puraping performance. 
HNF-2358 Rey, 1

\subsubsection{Inputs and Ontpuls}

\subsubsection{Inpots.}

- Poblix Review - Any plan that identifies completion of the aritinel Tri-Party Agresement mílestone after Seprember 2000 will be subject ta a public comment periog.

- Mansgetoed Direction and Support - RL provides tirection and funding for this project through FDH.

- Pokckased Equiponeut - New equifiment and unaterials from outside sources are an input to this projest.

\subsubsection{Outpuls.}

- Saltwell E,iqgid to Doubie-Shell Tanka - Approximately 26.1 million liters (6.9 minfivn gallont) of linuid wate will be outpul to DSTs over the courge of the project

- Gageaut Emwents - Exhausters connected to the $\$ \$ Y 9$ during purmping are expected io produce limired fiftered gasectus efiluetsis to the almosphere and are addressed within the approprinte NOC

- Solld Wasit - Some contamimated ecpuiponent in use on the S5T IS Project is expected to fail. In other cases exigtivg equipment will have to be removed to enable installation of required equlpunest to support the SST IS PToject. Current procedures exist to determine if the comtanuinated equipment is rexusqble ot netds to be disposed of as wate If the equipment is wate, these prosedures will be used to propecty cattegorize the waste and determine the diposal mathod.

\subsection{SINGLE-SBELL TANK INTERIM STABILXATION FROUECT INITLL STATES AND END STATES}

\subsubsection{Initial Strtes}

2,8,1.1. Singte-Shed Tantl to be Interim Stabilized Twenty-nime SSTs remain to be interim stabilized during the SST IS Project. The listing of these tanks, along with their prepemt gtatus and characteristics of their contenks, is stown in Totote 2-1. The tantes contein virying ancouls of supernakant, salteake, and shedge. The seltcake and studge have varying anoutsts of pumpable liquid in them Figute 2.2 identifies the current status of SSTs. 
Table 2-1. Present Comtents of Single-Shell Tanks to be Pumped (2 Sherts)

\begin{tabular}{|c|c|c|c|c|c|c|c|c|c|c|}
\hline \begin{tabular}{|l|} 
Tank \\
tumbertiep
\end{tabular} & 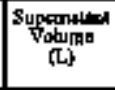 & Romiging & Solketim & 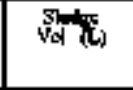 & 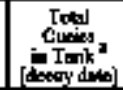 & 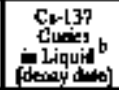 & Treg & Toed & 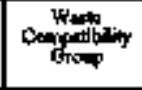 & 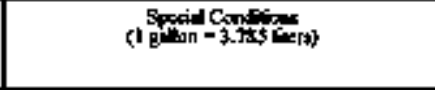 \\
\hline EAST & & & & & & & & & & \\
\hline A-101 & $1,940,0001$ & $2,599,000^{2}$ & $1,560 \times 000$ & 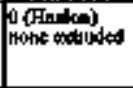 & 2,780000 & Lingon & $1 / 794$ & $1,940,000$ & Doerploved & 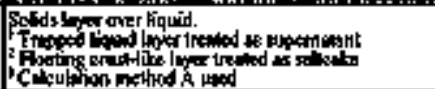 \\
\hline Ax-101 & 690,0001 & 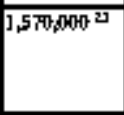 & $2,0100,000,0$ & 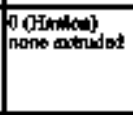 & 3,7000000 & $\begin{array}{l}493,000 \\
\text { Litsut }\end{array}$ & ifing & ow & 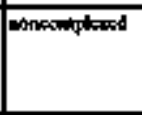 & 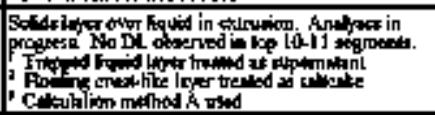 \\
\hline BY-J05 & 0 & $624, \sqrt{100})^{r}$ & $1,306,0002$ & $5 \%, 0002$ & 2,1700000 & 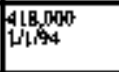 & 243 & $\lim _{3 \rightarrow \infty}$ & teonanephisud & 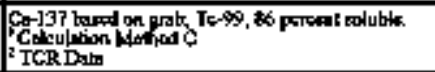 \\
\hline $8 \% 106$ & 6 & $903,000^{1}$ & $2,0,0,000^{2}$ & $360,000^{\top}$ & 350000 & S6900 & $391 \mathrm{Ci}$ & 1,10000 & epnos-fined & 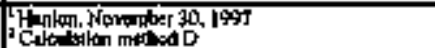 \\
\hline C.100 & $283,000^{1}$ & $205,000^{2}$ & 01 & $\operatorname{asc} 1,000^{\prime}$ & 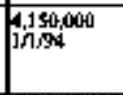 & WLAOH & 213 & $\operatorname{lom}_{0}$ & monplened & 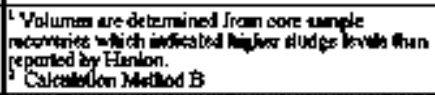 \\
\hline WET & & & & & & & & & & \\
\hline $9-101$ & 45,000 & $+0,0,00^{2}$ & $3 \pi, 000 \mid$ & $924,000^{\prime}$ & ibijod & $\begin{array}{l}233000 \\
10 \operatorname{Lig}^{\circ}\end{array}$ & 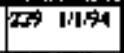 & 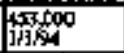 & $\Leftrightarrow<x+4$ & 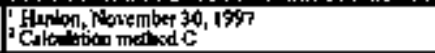 \\
\hline $9-102$ & 6 & $875,000^{3}$ & $8,063,0004$ & $15,100^{\mathrm{t}}$ & 1,5000000 & $\begin{array}{l}350,000 \\
101694\end{array}$ & 240 & ingoing & ooncompleted & 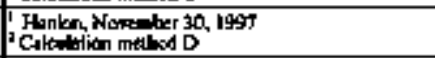 \\
\hline$\$ 0103$ & $64000^{\circ}$ & 3.6, $0000^{2}$ & 3570001 & $57800^{r}$ & $\begin{array}{l}6000000 \\
10134\end{array}$ & 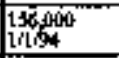 & 260 1/194s & $\lim _{104}$ & conocintered & 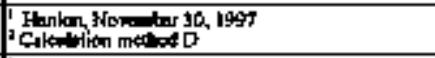 \\
\hline $5+106$ & $201,000^{2}$ & 851,0001 & $1810,00^{2}$ & ta catruded & jogod & $\begin{array}{l}360000 \\
1094\end{array}$ & 1/94 & 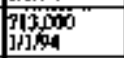 & ronochapterd & 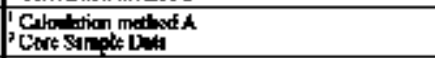 \\
\hline 3.107 & 53,0004 & $20,2,000^{2}$ & 201,0006 & $1, \operatorname{La} 9,0000^{\circ}$ & $1,240,000$ & 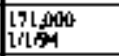 & 98 & 130400 & moocliphined & 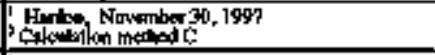 \\
\hline 5109 & 01 & $564000^{2}$ & 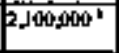 & 490001 & pogen & $\begin{array}{l}84,8006 \\
16194\end{array}$ & 1954 & $165, \infty x_{0}$ & eoochlated & 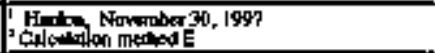 \\
\hline sili & 87,0001 & $759, \mathrm{DNO}^{2}$ & $1,430,000^{r}$ & $526,000^{1}$ & $\begin{array}{l}924,0100 \\
1 / 154\end{array}$ & $\begin{array}{l}334, \sqrt{n+10} \\
1 i 164\end{array}$ & $\begin{array}{l}5] 1 \\
\text { InIMA }\end{array}$ & 652000 & wotrolithed & Fuplon, Nowimber 30, 3997 \\
\hline $8-112$ & 01 & 153,0001 & $1,957,0000^{2}$ & $23,0000^{\prime}$ & 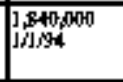 & $\begin{array}{l}466,0000 \\
010404\end{array}$ & ingas & $\begin{array}{l}\cos 000 \\
\operatorname{lig} \theta 4\end{array}$ & 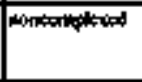 & 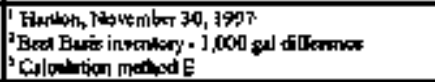 \\
\hline $5 x-101$ & $4 ; 000$ & $535,000^{7}$ & $1,300,000^{2}$ & 424,000 & $\begin{array}{l}1,5,50,0000 \\
j / 1, j 4\end{array}$ & $\begin{array}{l}2600000 \\
\text { LuLS4 }\end{array}$ & $\begin{array}{l}131 \\
1 / 1 / 94\end{array}$ & 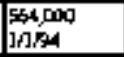 & cotions & 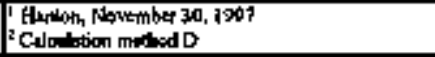 \\
\hline $9 x-100$ & 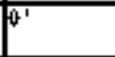 & $745,000^{\circ}$ & $|, 6| 2,0004$ & $40,3,000^{2}$ & $\begin{array}{l}1,500,000 \\
1,1,94\end{array}$ & $\begin{array}{l}376,0000 \\
\text { ullog }\end{array}$ & 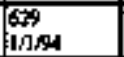 & 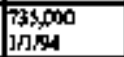 & enocentered & 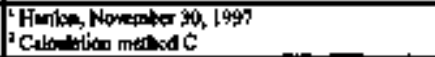 \\
\hline $9 x-1 \overline{4}$ & $4,600^{1}$ & $90101000^{3}$ & 2, & $\cos 200^{2}$ & 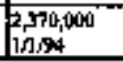 & $\begin{array}{l}\operatorname{sos} 0000 \\
\text { liles }\end{array}$ & $\begin{array}{l}500^{\circ} \\
1004\end{array}$ & $\begin{array}{l}\sec x, 0 x \\
\operatorname{lin} 94\end{array}$ & unocergiened & 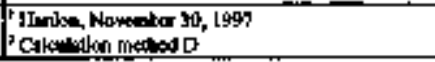 \\
\hline
\end{tabular}


Talble 2.1 Pragent Comtents of Single-Shel Tanks to be Pulped (2 Shete)

\begin{tabular}{|c|c|c|c|c|c|c|c|c|c|c|}
\hline Tant & Poment & 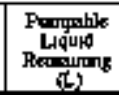 & Sulvation & 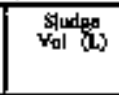 & 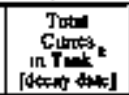 & $\frac{\text { Csist] }}{\text { Cunts }}$ & 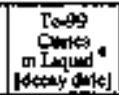 & 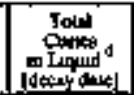 & 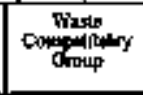 & 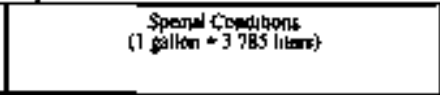 \\
\hline $5 x-104$ & 31 & $358,000^{3}$ & $1,80,00]^{1}$ & $5] 5,0000^{1}$ & $\begin{array}{l}2,140,000 \\
1 / 1 / 190\end{array}$ & $\begin{array}{l}418,000 \\
11194\end{array}$ & $\begin{array}{l}\text { SAB } \\
\text { IIISAd }\end{array}$ & $\left\{\begin{array}{l}313,000 \\
1 / 194\end{array}\right.$ & nonemilptetud & 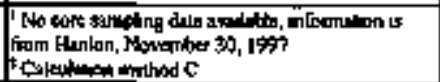 \\
\hline $5 \times .105$ & 31 & $1,0 \times 4,00^{3}$ & $2,309,0001$ & $236,000^{1}$ & $\begin{array}{l}2,310,000 \\
1,1 / 34\end{array}$ & $\begin{array}{l}513,000 \\
1,1 / 94\end{array}$ & TT5 Lilgd & $\begin{array}{l}\text { LbLoj000 } \\
\text { LIIA4 }\end{array}$ & poocrociplend & 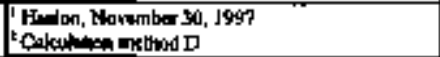 \\
\hline SX:106 & $231,600^{7}$ & 955,0001 & $1,780,0001$ & as $a x^{\prime}$ & $1,420,000$ & $\begin{array}{l}319,000 \\
1, A S\end{array}$ & $\begin{array}{l}525 \\
1 / 194\end{array}$ & $\begin{array}{l}523,1000 \\
1 / 194\end{array}$ & 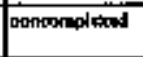 & 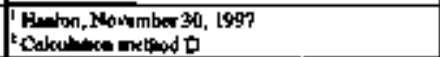 \\
\hline 7-150 & $0^{\prime}$ & $8+8006$ & 0 & $1,353,500^{\prime}$ & $\begin{array}{l}19,300 \\
\text { III,94 }\end{array}$ & 525 & $14 \quad 1 / 1 / 94$ & \begin{tabular}{|l}
452 \\
1/494
\end{tabular} & becosampleasot & 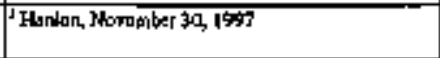 \\
\hline 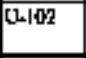 & $6800^{\circ}$ & $5066 \times 10^{3}$ & $1,158,0001$ & $16+\infty x^{d}$ & $\begin{array}{l}780000 \\
11104\end{array}$ & $\begin{array}{l}246,000 \\
1104\end{array}$ & $\begin{array}{l}350 \\
1 / 104\end{array}$ & $\begin{array}{l}478,0060 \\
151044 \\
\end{array}$ & complaxed & 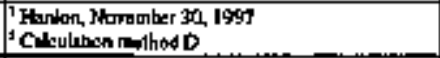 \\
\hline 02103 & $\$ 3,00^{\prime}$ & $713, \sqrt{10} 0^{2}$ & 1570,0001 & $121,600^{1}$ & $\begin{array}{l}1,450,0003 \\
11 / 194\end{array}$ & $\begin{array}{l}320,000 \\
1 / 194\end{array}$ & 44d 1/194 & $\begin{array}{l}540,0006 \\
1 / 404\end{array}$ & oumplesud & 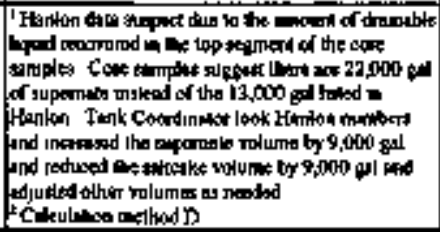 \\
\hline $0-105$ & $140,000^{7}$ & $6+4,00^{3}$ & $1,370,0001$ & $121,000^{1}$ & $1,200,000$ & $\begin{array}{l}324,00 \\
1194\end{array}$ & $\begin{array}{l}446 \\
\operatorname{lil} 194\end{array}$ & \begin{tabular}{|l}
630,0009 \\
1194 \\
194
\end{tabular} & emplexced & 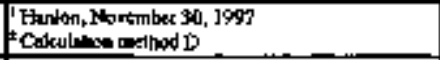 \\
\hline$\sqrt{1-106}$ & $5,000^{\prime}$ & $251000^{3}$ & $7 \infty 0001$ & 98,0001 & $\begin{array}{l}645,000 \\
1 / 194\end{array}$ & $\begin{array}{l}172,00 \\
1,1 / 44\end{array}$ & 297 & $\begin{array}{l}337,000 \\
\text { unligd }\end{array}$ & oomotented & 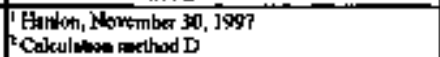 \\
\hline W.เी & 117,0001 & $\Delta 43,000^{2}$ & 130,000 & $37000^{1}$ & $\begin{array}{l}\text { 45,pon } \\
1,1,94\end{array}$ & $\begin{array}{l}34000 \\
1 / 1 / 94\end{array}$ & $\begin{array}{l}344 \\
1 / 194\end{array}$ & $\begin{array}{l}340,000 \\
\text { li/Na4 }\end{array}$ & nonesuplexad & 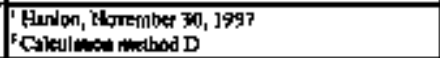 \\
\hline U-Los & $91,0000^{1}$ & $720,0000^{3}$ & $1,500,000^{1}$ & $1120,0000^{\prime}$ & $\operatorname{tin}_{5 \infty 60} 000$ & $\begin{array}{l}3290000 \\
596\end{array}$ & Ist Litgd & $\begin{array}{l}641,000 \\
1 / 194\end{array}$ & tancomplexod & 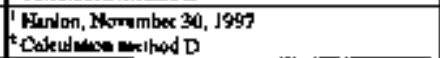 \\
\hline $\mathrm{U}-108$ & $32,000^{1}$ & $605,000^{3}$ & $3,0,001$ & $182,6000^{\prime}$ & $\begin{array}{l}50,000 \\
13,00\end{array}$ & $\begin{array}{l}271,000 \\
1 / 90\end{array}$ & $\begin{array}{l}\text { SA5 } \\
\text { Iils4 }\end{array}$ & $\begin{array}{l}529,000 \\
11194\end{array}$ & eomplatiod & 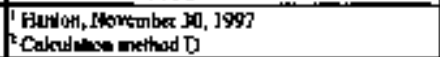 \\
\hline |1-HII & a & $419000^{1}$ & $1.150,0001$ & $8,4 x)^{1}$ & $\begin{array}{l}938,000 \\
1,1 / 940\end{array}$ & $\begin{array}{l}198,000 \\
g / 1 / 190\end{array}$ & $\begin{array}{l}2350 \\
\text { lilised }\end{array}$ & $\begin{array}{l}335,000 \\
\text { U1,94 }\end{array}$ & 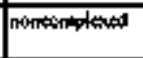 & 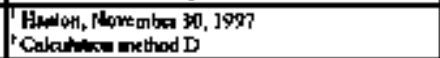 \\
\hline
\end{tabular}

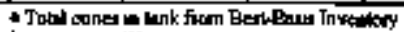

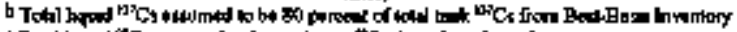

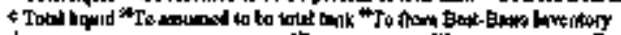

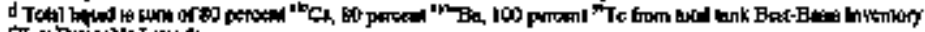

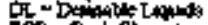

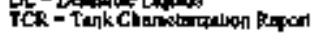




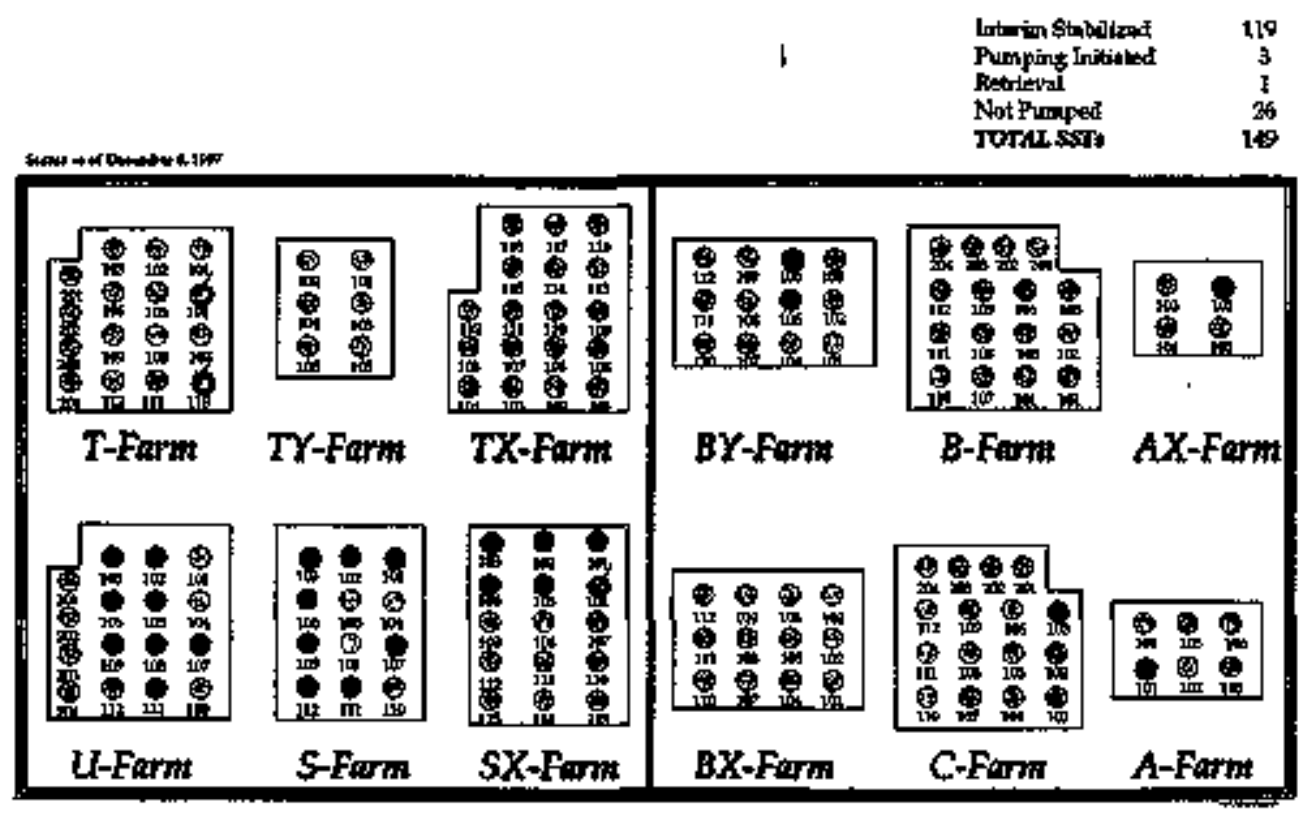

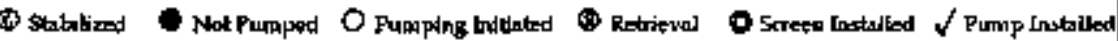

Figure 2-2. Single-Shell Tank Fams Irterion Stakjizntion Progress Sialus 
Intexim gabilization of the tanks requires corlain equiptremt and presesting which magy itelude the following

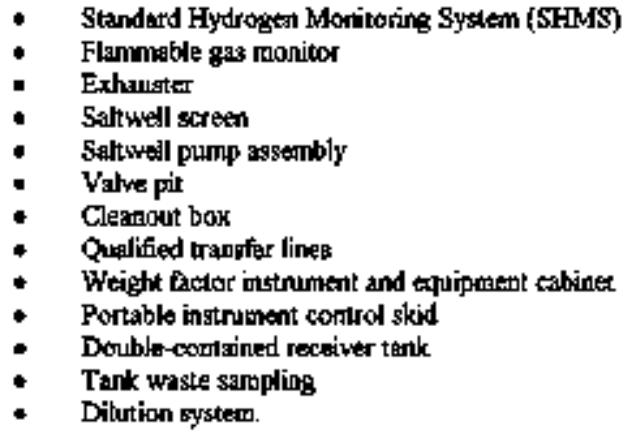

The begic equipmeat to support pumping is ahown in Figure 2-3. Table 2-2 idendifeg the prestall phyrical slauts and requirements of equipment and protesset for the 29 SSTs to be pumped during the SST IS Project.

2.5.1.2. Dowble-Swell Tanks. The DSTs that wit recoive liqutd flon the SSTs inchude SY-102, AP-107, AP-106, AY-102, AP-108, and AN-101. Other DST, may be uged as required. These tanks contain yarious types and anounts of waste as described in Fark Tawk Swmwary Report for Month Ending October 3/, J097, (Hianlon 1997) The quintity of waste in individual lanks changes from lime to time. As liquids accumulate they are saged for evaporator fead.

\subsubsection{Tank Eqvipment gad Wasit Materlalt Prestenl slans of Iant tquiponent is inchuded} in Table $2-1$.

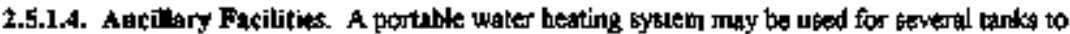
dilute the waste thal has characteristics tor phugging transfiar lines.

\subsubsection{Dend Scates}

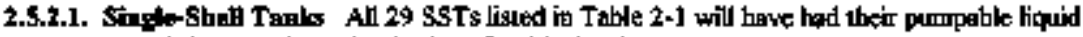
renowed in satistaction of the 1S criteria defined in \$ection 2.T. Further, the SSTg will be

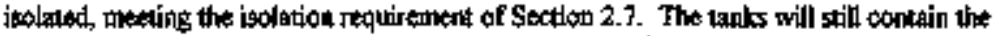

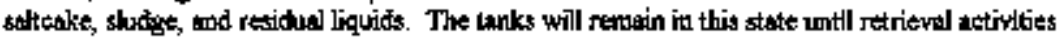
are initiated

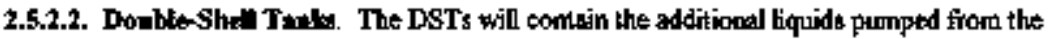
SSTs (less the anount of water Temoved by the 242-A Evaporator) as a regsil of successtul conclusion of the SST IS Prajer. 

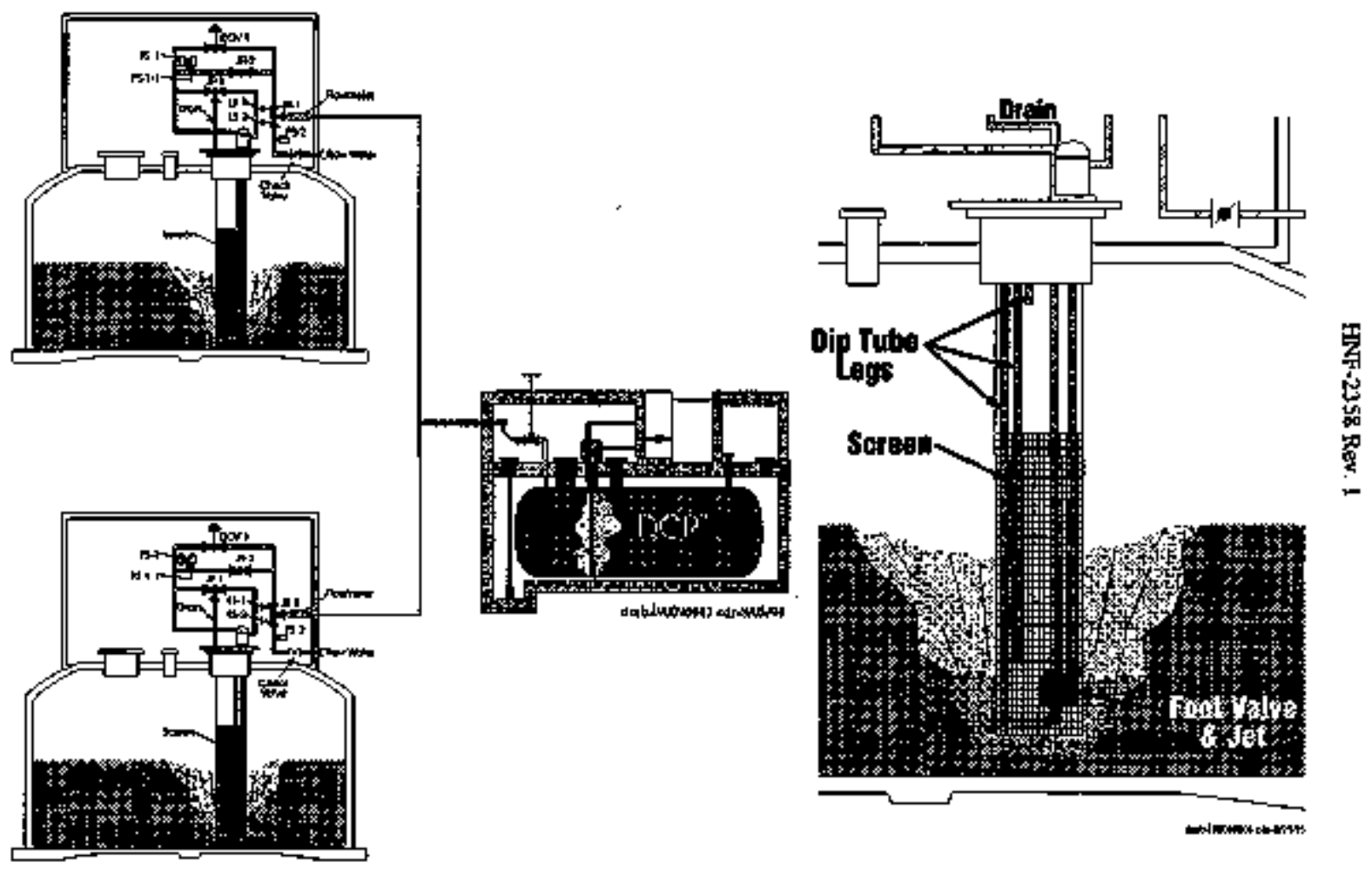

Figura 2-3. Saltwell Purruping Syted 
Table 2-2 Epaipanent StatugReguirements for Single-Shell Tank Interim Stabizalion Projed (2 Sheeds)

\begin{tabular}{|c|c|c|c|c|c|c|c|c|c|c|c|c|c|}
\hline Tank W & 8HMAS & FOM & Exdimititr & $\begin{array}{l}\text { sonlweth } \\
\text { Serean }\end{array}$ & 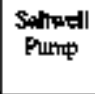 & $\begin{array}{c}\text { Vulue } \\
\text { Pin } \\
\text { Jumplpe }\end{array}$ & $\begin{array}{l}\text { Cower } \\
\text { Blackes }\end{array}$ & 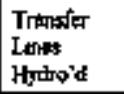 & $\begin{array}{l}\text { Y्रFE } \\
\text { Cobweat }\end{array}$ & $\begin{array}{l}\text { P1C } \\
\text { Stkat }\end{array}$ & DCRT & Somplptang & 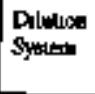 \\
\hline$A \cdot 101$ & c & R & $c$ & $c$ & $\mathrm{R}$ & $R(3)$ & $\mathrm{R}$ & $R(4)$ & $N / A$ & c & NA & & R \\
\hline$A X+101$ & $\mathrm{R}$ & $\mathbf{R}^{\prime}$ & $\mathbf{R}$ & $\mathrm{c}$ & $\mathrm{R}^{\prime}$ & $\mathrm{c}$ & $c$ & $\mathrm{R}^{3}$ & Wra & a I & $\mathrm{N} / \mathrm{A}$ & & $\mathrm{R}$ \\
\hline BY-105 & c & R & R & R & $R$ & N/A & $\mathrm{R}$ & $R(\mathbf{I})$ & R & $N / A$ & c & & \\
\hline BY. 106 & $c$ & R & $\mathbf{R}$ & $\mathrm{c}$ & $R^{2}$ & $N / A$ & R & $R(1)$ & $\mathbf{R}$ & $N / 8$ & c & & \\
\hline 대 103 & NR $^{4}$ & 2 $\mathrm{R}$ & $\pi$ & $c$ & $\mathrm{R}$ & $\mathrm{R}(1)$ & $\mathrm{R}$ & R & NA & $\mathbf{R}$ & $\mathrm{NA}$ & & $R$ \\
\hline $8-101$ & $\mathrm{c}$ & $\mathbf{R}$ & $\mathbf{A}$ & $\mathrm{c}$ & $R$ & $R$ & $\mathrm{R}$ & $\mathrm{R}$ (3) $0 \mathrm{GT}$ & $\mathrm{N} / \mathrm{A}$ & k & c & & \\
\hline $5 \cdot 102$ & R & A & R & $c$ & R & $\mathrm{R}(2)$ & R & $R$ (d) Oपा & $N_{A}$ & $\mathbf{R}$ & c & & \\
\hline 8-103 & $m^{\prime}$ & R (2) & $\mathbf{F}$ & $c$ & $\mathrm{R}$ & $\mathrm{R}$ & $R$ & $\mathrm{R}(1) 0 \mathrm{GT}$ & NAS & R & c & $\mathbf{R}$ & \\
\hline $8-106$ & $\mathrm{c}$ & $\mathbf{R}$ & $\mathbf{R}$ & $\mathrm{R}$ & i & $R(2)$ & $\mathbf{R}$ & $\mathrm{R}$ (4) OGT & $\mathrm{HFA}$ & $R$ & $\mathrm{c}$ & & \\
\hline 5.107 & $\mathrm{~K}$ & $\mathrm{R}$ & $\mathrm{R}$ & $c$ & $\mathrm{R}$ & $\mathrm{R}(1)$ & $\mathrm{R}$ & $\mathrm{R}(2)$ & $N / A$ & $\mathrm{R}$ & c & & \\
\hline$s-109$ & $c$ & $\mathrm{R}$ & $\mathrm{R}$ & $\mathrm{R}$ & R & $\mathrm{k}(2)$ & $\mathbf{R}$ & $\mathrm{R}(3)$ & $H_{A}$ & $\mathrm{c}$ & c & & \\
\hline 5.111 & $c$ & $\mathrm{R}$ & R & R & $\mathrm{R}$ & $R(1)$ & $R$ & $R(2)$ & $N_{A}$ & R & c & & \\
\hline $8-112$ & $c$ & $\mathrm{~A}$ & $R$ & $\mathrm{R}$ & $\mathrm{R}$ & $R(1)$ & $\mathrm{R}$ & $\mathrm{R}(3)$ & N/A & R & $c$ & R & \\
\hline $5 x, 101$ & 6 & R & $C^{\prime}$ & $R$ & $\mathrm{R}$ & $R(2)$ & $R$ & $R(3)$ & $N_{A}$ & R & c & c & R \\
\hline $8 \times 1102$ & $R$ & R & $\mathrm{c}^{\prime}$ & R & $\mathrm{R}$ & $R(9)$ & $\mathrm{R}$ & $R(d)$ & $N / A$ & R & $\mathrm{c}$ & R & $R$ \\
\hline $8 x-1003$ & A & $\mathrm{A}$ & $c^{\prime}$ & $\mathrm{c}$ & $\mathrm{R}$ & R $(2)$ & $R$ & $R(0)$ & $\mathrm{N} / \mathrm{A}$ & R & $\mathrm{c}$ & c & R \\
\hline$\$ 5 \times 104$ & 5 & c & $\mathrm{C}^{3}$ & $c$ & $c$ & $c$ & f & $c$ & $N_{A}$ & c & c & c & A \\
\hline $5 x-105$ & $c$ & $\mathrm{R}$ & $c^{\prime}$ & $\mathrm{R}$ & $\mathrm{R}$ & $R(2)$ & $\mathrm{R}$ & $\mathrm{R}(3)$ & $N / A$ & $\mathrm{~A}$ & $c$ & $R$ & $\mathrm{R}$ \\
\hline $5 \times .106$ & $c$ & R & $C^{2}$ & $\mathrm{R}$ & $\mathrm{R}$ & $R$ (3) & $R$ & $\mathrm{R}(\mathbf{d})$ & NNA & E & $c$ & $\mathrm{c}$ & $\mathrm{R}$ \\
\hline T-10,4 & NRK & $\mathrm{c}$ & NR & $c$ & $\mathrm{c}$ & $\mathrm{c}$ & $c$ & c & $N / A$ & $\mathrm{c}$ & c & I. & \\
\hline סנויד & $c(\mathrm{NR})$ & C & $\mathrm{ln}$ & $\mathrm{c}$ & c & c & c & c & Nh & $\mathrm{c}$ & c & $\mathrm{c}$ & \\
\hline
\end{tabular}




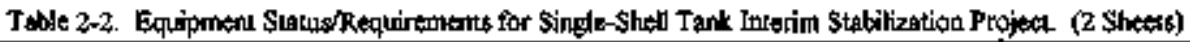

\begin{tabular}{|c|c|c|c|c|c|c|c|c|c|c|c|c|c|}
\hline$T$ Tate & SHMts & Foul & Exheusier & $\begin{array}{l}\text { Salruall } \\
\text { Screal }\end{array}$ & $\begin{array}{l}\text { Salcustl } \\
\text { Puтाр }\end{array}$ & $\begin{array}{c}\text { Yalve } \\
\text { Pĭ } \\
\text { herepet }\end{array}$ & Coner & $\begin{array}{l}\text { Trumsolt } \\
\text { Lines } \\
\text { Hydno'd }\end{array}$ & $\begin{array}{l}\text { WFIE } \\
\text { Cobunet }\end{array}$ & $\begin{array}{l}\mathrm{PLC} \\
5 \mathrm{kik}\end{array}$ & DCRT & Sertipling & $\begin{array}{l}\text { Dilution } \\
\text { System }\end{array}$ \\
\hline $\mathrm{U}-102$ & $R$ & $R$ & $R$ & $R$ & R & $R(2)$ & R & $x(0)$ & R & $N / A$ & $c$ & & \\
\hline U. [03 & $c$ & $R$ & $\mathbf{R}$ & $\mathbf{R}$ & $\mathbf{R}$ & $R(2)$ & $\mathbf{R}$ & $\mathbf{R}(\mathbf{3}\}$ & $R$ & $\mathrm{~N} / \mathrm{A}$ & $\mathrm{c}$ & & \\
\hline U.10s & c & F & $\mathbf{R}$ & $\mathbf{R}$ & $\mathbf{R}$ & $R(3)$ & R & R. (4) & $R$ & NIA & C & & \\
\hline $\mathrm{U}-10 \%$ & $c$ & R & $\mathbf{R}$ & $\mathrm{R}$ & R & $R(1)$ & $\mathrm{R}$ & $R(2)$ & K & NtA & $R$ & & \\
\hline U-I0s & $c$ & $\mathrm{R}$ & R & $R$ & $\mathrm{R}$ & $R$ (2) & $\mathrm{R}$ & $R(3)$ & $\mathbf{R}$ & NA & R & & \\
\hline U.Iogs & c & $\mathbf{R}$ & $\mathbf{R}$ & $\mathbf{R}$ & $\mathbf{R}$ & $\mathrm{R}(2)$ & $R$ & $R(3)$ & R & $\mathrm{N} / \mathrm{A}$ & $\mathbf{R}$ & & \\
\hline [D-ES। & $\mathrm{NR}^{4}$ & $R(\xi)$ & $R$ & $\mathrm{R}$ & $R$ & $\mathrm{R}(2)$ & R & R (3) & $R$ & $N^{\prime} / A$ & $\mathbf{R}$ & P & \\
\hline
\end{tabular}

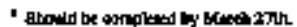

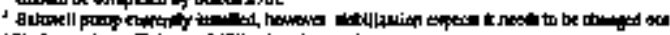

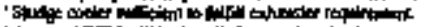

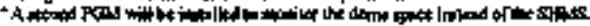

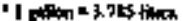

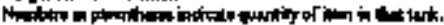

$c=0$.

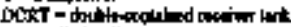

I几 - Dîtiont

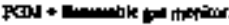

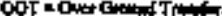

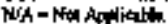

$\mathrm{N}_{\mathrm{H}}=$ Noct Btraind

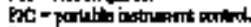

$\mathrm{B}$ - Repured

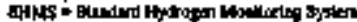

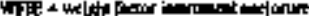




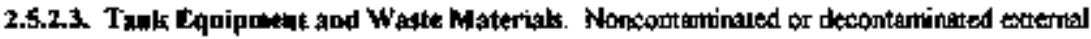
tork equipment, such ss exhuusters, SHRSS, and pumping control systems, will be avalable for other operational uses. In-1ank contaminatad oxuipmert such as pumps and saltwell screens, will

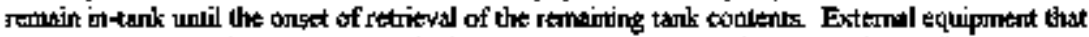
arnot be decontaninated and reused will be transferres to Operalions for ultimate ditposal in the solid Waste Program.

2.5.2.4. Anclllary Facilities The W-0Ss water-heating syalems (or equiwatem) will be available as a source of hot water for transfer line flughes.

\subsection{MISSION LIFE CYCLE}

The \$\$T IS Projegt life cycle is primarily obe of "operation." However, tome design, procurement, and installation functions are required for a number of the SSTs. In addition, the tanks will be "igclated" forllowing completion of pumping. Beceause many of the tanks unust be pemped at the same lime to maintain schedules, it is expexted that each tank will go through its own life cycke with time. The complate listing of the plases of the lifecycle ane as follows.

\subsubsection{Specifiestion}

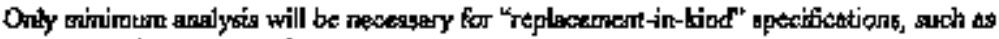
those needed for extisuguers and flammable gas monitors.

\subsubsection{Pracuremant}

This project may be dependert on the timely procuromentetibrication of a number of

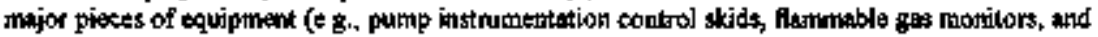
exhausters) and midnor equipment (E.g, centrifugal puraps, jet purws, and jumpers) and cinsumabtes.

It is antcipated that tuistellaneous equiptentent sanch as the salnuell screens, junaper asserabties, pump agoerblies, and sirnilar ilems will be procured and fabricated at the Hanford shops.

Both onsite and offsite voodors will be used for procurament activitieg.

\subsubsection{Installation}

Tuenty-gix S\$T will require installation of the equipment nosesery to pump and transfar the hiquids. The other there 1amks (T-104, T-1 10, and SX-104) have completed his procest and initiared purnping. 
HRF-2358 Rev. 1

\section{2,6,4 Operation}

The majority of the tife cycle for this project will take place in the operalion phate. Section 4.0 deats with the techrical surategy for this phase and corptritas screral figures deppicting ik. Tank pumping durations will qary from less that dix mondits to ower 30 mouths.

\subsubsection{Isolotion}

Following punping, exch tank will be isolated per the requirment in Section $2 . ?$.

\subsection{MISSION-LEYEL REQUIREMINNTS}

The basic mission-lewed requirement for the SST IS Project is to rethouve the purmetable liquird from the 29 SSTs referenced in Sertion 2,5.1. The criteria for reporpal, as originally stated in the July 1984 letier from RL to the General Manager of Rockwetl Hanford Operationt, is axcopted belpur:

"Protoed with remowal of interstitial liquid (sallwell pumping) from those single-shell tenks comtriating 250,000 gatlong of interstitipl linquid

"Once a saltwell system is insalled, pumping will continue umtil the 0.05 gpm punping limilation is ochievsd. In the event the system experiences a thajor maintenance failure and the lank comians more tham 50,000 gallons, the bystem will be repairediteplaced and restarted. If the tank contains less than $\$ 0,000$ gallons and the 0.05 pumping limit bes not

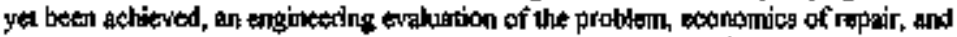
personnel radiation exposure will be conducted to determine the leatsinility of fintber pumping. The decisjon to contiave or not continue puruping. will be based upen whtat is considered technikally and exononikally practicable and consistent with as bow as reastonably achievabue (AL,ARA) principles

"If a single-shell tank is not sehedaled fot saltwell putrping, it will be stpemale pusnped if

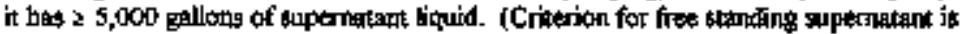
5,000 gallons)." (Lawrence 1984)

This requirtonent is peessibied in the TWRS administrative prosedure 'Tank Farm Focility

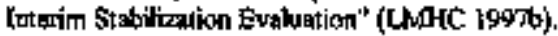

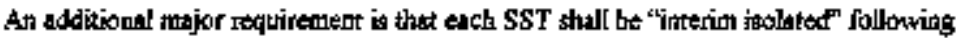
gucoesstill IS. Isolation ter this project is defined as that condition reacted after placing at jeast

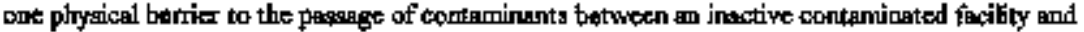

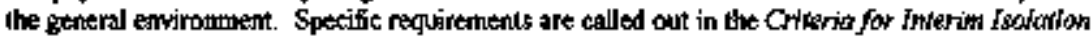

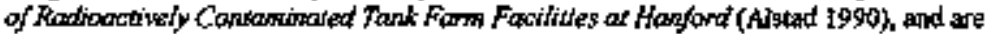
procedurafized in "Tank Farm Feccifly Interiou Isolation" (LMIFC 19976). 
The SST IS Project, its tytorss, and its processeg mugt alst getisfy numberdus axternally inposed requirements and galidance. These requirements also fetate, in part, the work scope, schedule, and budget for the tasts supporting the SST IS Mission. Sourdes of these regnirements include prosulgated biws and regubliont, orders and dizectives, implemetling procentures, contractual docouments, and ativer planning guidance. The requiremomts derived trom thesse

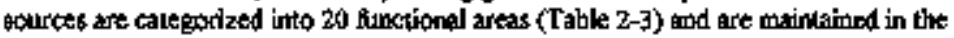

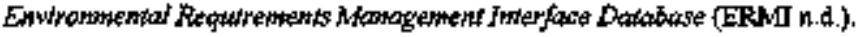

Table 2-3. Standarts and Requirements Ideatification Dacuments for Functhonal Areas.

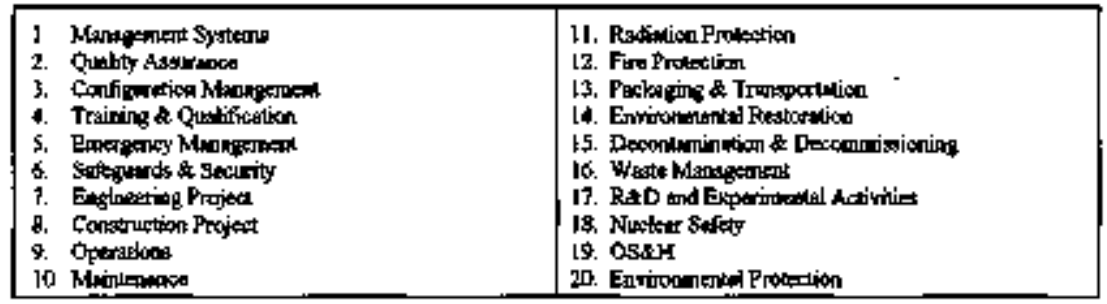

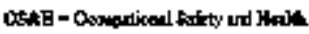

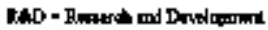

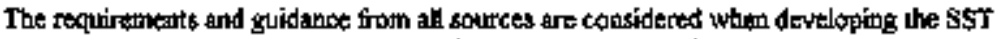
IS Projoct technits baseline, when defaing misgion work scopo, wad for eslabisting

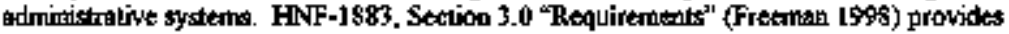
adfitional detail on requirements and guidance, and Appendix C identifies those externally inposed requivenents that specifically affect the \$ST IS Project.

\subsection{SINGLE-\$BELL TANK INYERIM \$TABUUYTTON PHOJECT GOALS, OBJECTIVES, AND MEASURTS OF SUCCKSS}

\section{1,8,1 Gayle and Objectives}

The pritary goals and otedectives for the SST Is Project mistion darived trom the Tri-Party Agrement (Ecology el aI. 1996) M-4l series nilkstones and identifled it Table 2-4. 
Table 2-4. Sivgk-Shell Tant Interim Stabilization Project Ooals ant Objectives.

\begin{tabular}{|c|c|}
\hline Goatl & Otjeative \\
\hline 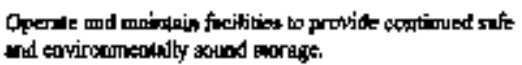 & 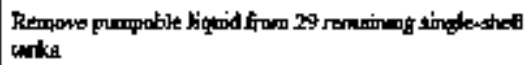 \\
\hline 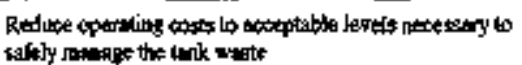 & 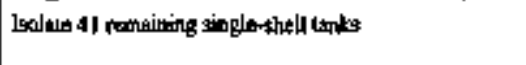 \\
\hline
\end{tabular}

\subsubsection{Mestunes of Suecess}

The measures of success for the SST IS Project are baed on the desined eted stale for the project. These neasuros will be used to veify that the SST IS Project is effectively wxecurting its mistion. Table 2-5 summaries the measures of success for the SST IS Project and state.

Table 2-5. Measures of Success for Single-Sbeel Tatek Interim Stabilizalion Project.

\begin{tabular}{|c|c|}
\hline 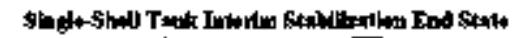 & 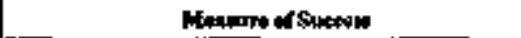 \\
\hline 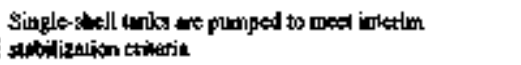 & 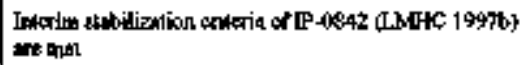 \\
\hline Ptries is withia scheodale & 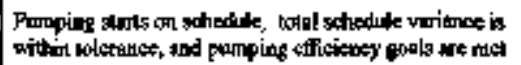 \\
\hline Fopiere is within burfed & 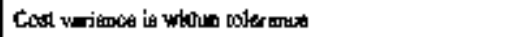 \\
\hline 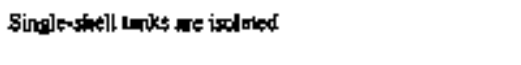 & 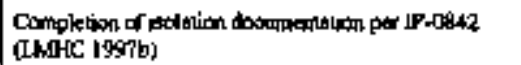 \\
\hline
\end{tabular}




\section{3,0 KEY ENAFLING ASSUMPTION\$, RUSK\$, AND RECOMMENDATIONS}

\section{I ENABLING ASSUMPTIONS}

The following wsumptions are used for the sebeduling of the SST IS Project. assuraptiong. In some cases, poralled actions are bring puryued that represent higher risk alt These atsunptions were developed on the besis of the relatrive kyel of risk, and the schedule logic is constructed using these orratives that, if adopted, would reduce the schedule duration.

\subsubsection{Profect}

3.1. L.1. DOE Orders. DOE will contimue to wankge the Hantord Site and the SST IS Program. DOE Orders are assumed to remein as they are with no critical thanger affecting the program

3.1.1.2. Sakety/Enviromental Jasers. It is eqguried that there will be no new gatety or enviromenteat issuts idealifted that aftet the SST is Progeam.

3.1.1.3. Tank C-106. Tamk $C-106$ will be stabilizad by Project $W-320$ and is not incheded in the S5T IS scope. Juterim isolation of Tank C.] 06 is inchuded in the SST IS scoupe.

\section{3,12 Operating}

3.1.2.1. 5Y-102 Avalabulicy. Tank $\$ Y-102$ is the only IST aqaiable in the 200 West Area to

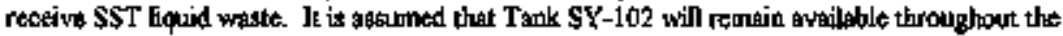
duration of the IS Program. This would assume there are no acev serfay issues affecting Tank SY-102 and then the curram schedule for retrieval remaing the sane and is not accelerated. This also assumes thes at SST biquids are compatible with the existing liguids it the tank.

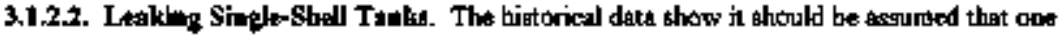
new leaker will be deckared each year. Though a leaker bas not been declared in ower four years, and the population of remining tank continues to decrease, it will be assumed that no more than one leaker per year will be experienced.

3.1 23. Protram Interferemeces. In the case wheree a physical interferance is identified with another progran (e.g., retrieval) or combirueton ptoject (e.g., W-320, W-211), the SST IS Project will eviderate that intertace and try associsted impact. The SST is will fund the work

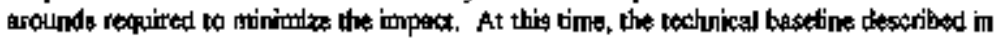

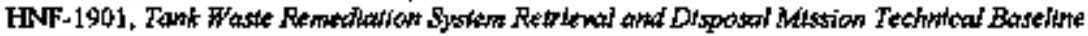

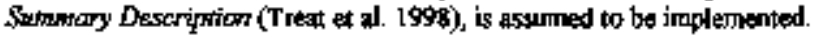

3. 1.2.4. Equppadent Procurement. Major equipntent, if required, can costinue to be chatained affite as donie to the pasa. 
3.1.2.5. Crow-\$ite Trander Capabiny. The capplility to tangfer waste cross-site trom the

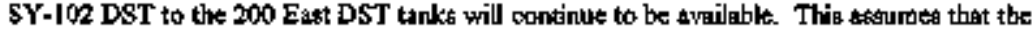
exigtimg mogg-site line will remain availstle until the new crosg-site line (Project W-0SS) is avalable lo Operations. Tumover of the new crogs-site transforr sybitem to Operations is schepduled for April 1998.

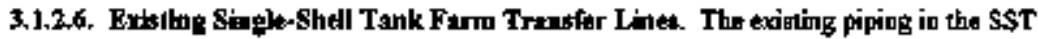
farms and transfer lines 10 the DST receiver tatks is primarily single-wall drect-buried piping. lt

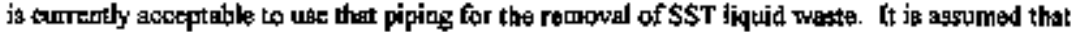
the piping will remain available for use by this pogram. The majocity of this piping will be disconerected or capped during the isolation phase of the program.

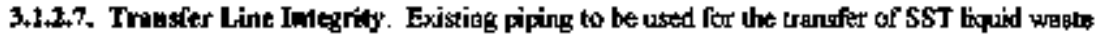
requires hydrostatic togtijg bafowe in is used. It is assumed that po greater than 20 percent of

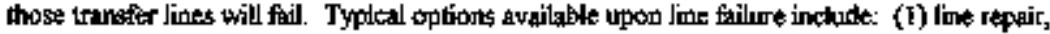
(2) altemagte routing, and (3) above ground transfer piping.

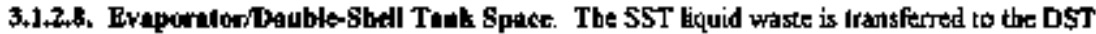
tank farmb. Il is ascumed thet tank spece is available to recoive the $\mathbf{S} \mathbf{S T}$ liquid and thet ovaporator campaiges will be performed as needed.

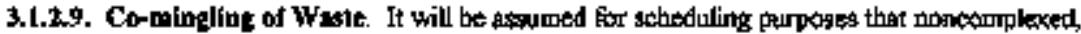
complaxed, and conplexed-TRU waste may be co-mingled Weat Area Tak $\$ Y-I 02$ is the only DST avtilable to roceive Watte. Approval to co-mingle liquid waste will be in place by Jamary 1 , 2000, Gaining this approvil is geen as high risk. Failure to approve co-mingling will extend the schedule by approximately 12 doroths.

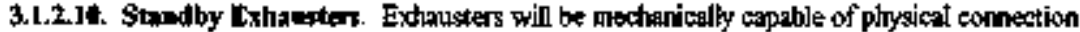
to a maximum of 3 tanks. The eapability is beged on plyytical syotem perarneters and physical Initations in the farm. Standiby is defined as physically connected to the tank ind isolated by a valve at the tank riter and a value at the exhaugter, if conmested to multiple tanks. The exhlauster will only be started and run during the period of time when elevaled gas concendralions dictate fits opestition.

3. L.2,11. Stmindby Ixhausters. Four of the tix exhausters procured by the stabilizalion program

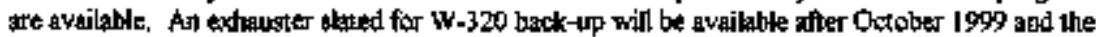

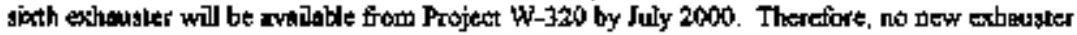
procurwont is nopessery.

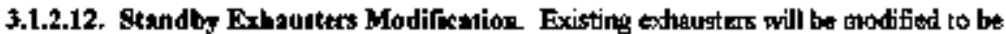
compliant with requirements of a major stack, but will be approyed to allow minor stack desiguation. This will allow for lexible usage in the future.

3.1.1.13, End-State Analys4. The organic nitrate end-state ayalysis will be acceptable for each of the SST tanks after rourowal of the biquid. 
3.1.2. L4. Single-Siell Tank Pumping Performance. Hittorieal dala was uilized to sea the anticipated pumping rotes, durationst, and effleitencies. Pumping rotes will utilize waste type and characterization data. Pumping duralion wil be determined from the estimated liquid avalable at the projecled pumping efficiency rate of 60 percent.

3.1.2.15. Operator Tradiag. The agkressive schedule for saltwell puruping wil requie the addition of a gignificand number of operators. This is also affected by the bargaining unit poticy of bumping from the reduction of staff ot other facilibes. It will be assumed that an eightr-month lead time will be required to obtain and train any additional operators.

3.1.2. 16. Optrater Tmmovtr. As a vesult of the ongoing and projected downsizing of PHMC facilities. an excess of lacility operators and other crafts has been declared under the 1997 Labor Agreement between FDH and the Hanford Alomic Metal Trades Council There is a potential for these bargaiming unit pertonnel to displace the targaining units persomel cumetitly assigned to the SST IS organization. The tornower rate rosulting fiond the operater displacenpents is assumed to be 25 percent annually.

\subsubsection{Tetboologoldqulpmeat}

3.1.3.1. Tank BY-10S Cement. It I956. 57.2 metric tons (63.0 short (ons) of Portland cemem were added to Tank BY-105 to test is properties as an immobilization agent for likguid warte. The consistency or configuration of the fesultant cement nixture has not been eslabtished.

Sempling is gcheduled for late FY 1998. $h$ is assonved that dither a tochurology new to TWRS operations or addiontal equipment will be required to eut through the cembent mixure to allow installation of the galtweel sereect.

3.1.3.2. Tank C-103 Organic Layer. Authorization to pump Taak $C$ - I03 with the organic layer in place will be given by RL by Apn 30, 1999, and an accepabte receiver tank will be identifed.

3.1.3.3. Hot Water Ditadoa Systems. Seyerd of the tanks renaining to be statilized conkain waste that requires diturtion to minimize the potential of transefer line plugging or gelling during uandfer or wilhin a DCRT before deliwery to the DST. It is assumed that a maximum of nine skids will be required for dihulion of thoge tankg. These skidg will inchude a water tank, a singlepass wectic tuenter, and $\mathbf{x}$ pump.

\subsubsection{Permittint}

3,1,4,1. Pagsively Ventilufed Tanks. As is the cerrent practices, paggively ventilated tanks will tớt require an $\mathrm{NOC}$.

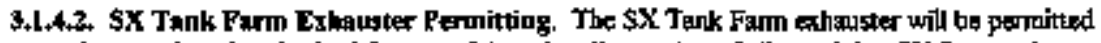

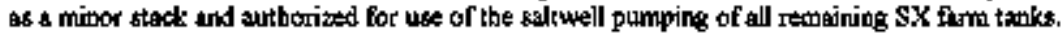


3.1.4.3. Portable Exhaws1er Pernitting. The NOC approval will degignate all portable

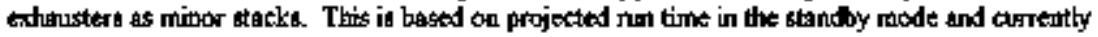
avaidable sampling.

3.1.4.4. Thab A-103 Autborzatien Bosis. Tank A-101 will be pumped using the Basit for Interim Operation (BIO) as the Authorization Basis. The requirements for salwwell pumping Tamk

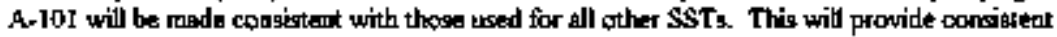
conurols and tratuing while providing exulvateat ovetrall safely.

3.1.45. Autboriation Basis (Fiomnable Cas Facility Growp 2). The Aurthoricution Basis for the saltwell puthping of facidity group (FG)2 tanks submitted on August 21, 1997, will be approwed and transmitted to the PHMC no later than March 30, 1998. Assumptions for the comtent of the safity erahustion report (SER) are as follows.

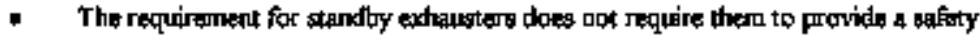
class function.

- Rl will direcr use of stand by exhalusters on all remaining unstabilized tarks silh the exception of Tanks T-10 and T-110, and the SX Tank Farm.

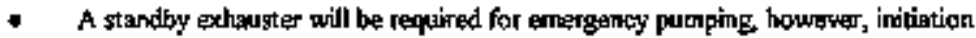

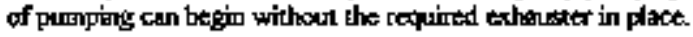

- Flammable gas mondtoring equdpment will be required in two locations per tank. The dome space will be monitored and a separate fimmbable gas monitor will be optrated in the pump pits.

3.1.4.6. Fonding Levels. After FY 1998, funding sbowe the cument basetine will be arailable to support reasoneble project ramp-up and sustained operations. Fimding will be carricd ove fritr yesr 10 year.

3.1.4.7. Tariks BY-105 and BY-106. Tanks BY-105 and BY-106 will be pumped at the same tiras to optimize cost and sphedule.

\section{3,2 MAJOR RJSKS}

The Stabilization Cridical Risk Managenneat List (Table 3-1) identifies the milical rigkt

Risks asscciated wilh the S5T IS Project were addressed at two lewels. Technieal basis

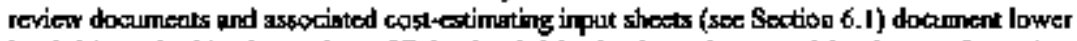
level risks and mitigating actions. Higher leved risks that have the potential to impact the projext as a whol pore identified by senior manageramt reviow of the project mission and exeeputiop plank. A riak bis wat establibued and potential crätical risks wetre identifled. Risk hikelinood and consequence ware thot ovghated using the criteria incleded in the "Risk Marpegentent P1an," 
HNF-IP-0842. Vol. IV. Section 2.6 (LMHC 1997b), and the associated procedures. Rigks with risk values of medium or high were placed on a Critical Risk Management List (see Toble 3-I).

\subsection{RECOMMENDATIONS FOR RISK MTIIGATION}

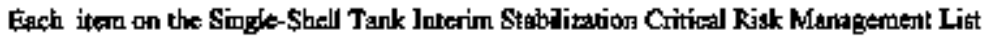
(see Tabte 3-1) was reviened and a mitigation action was doveloped as nexessary. These unigating actions are identified on the lisot. $T_{p}$ increase progrtsm sertaimty, mumy of the mitigating

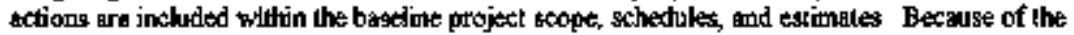
magthude and comptexity of this projext, aggessive rigk magegement is required to maintain the besseline achescude and cott.

Critical ciak itemes and risk mitigation sctivities will be stapused on a regular basit. Mainteriatice of risk status is the responsitility of the individual idemified on the risk list. 
Table 3-I Interim Stabilization Critieal Risk Management List (4 Sbeets)

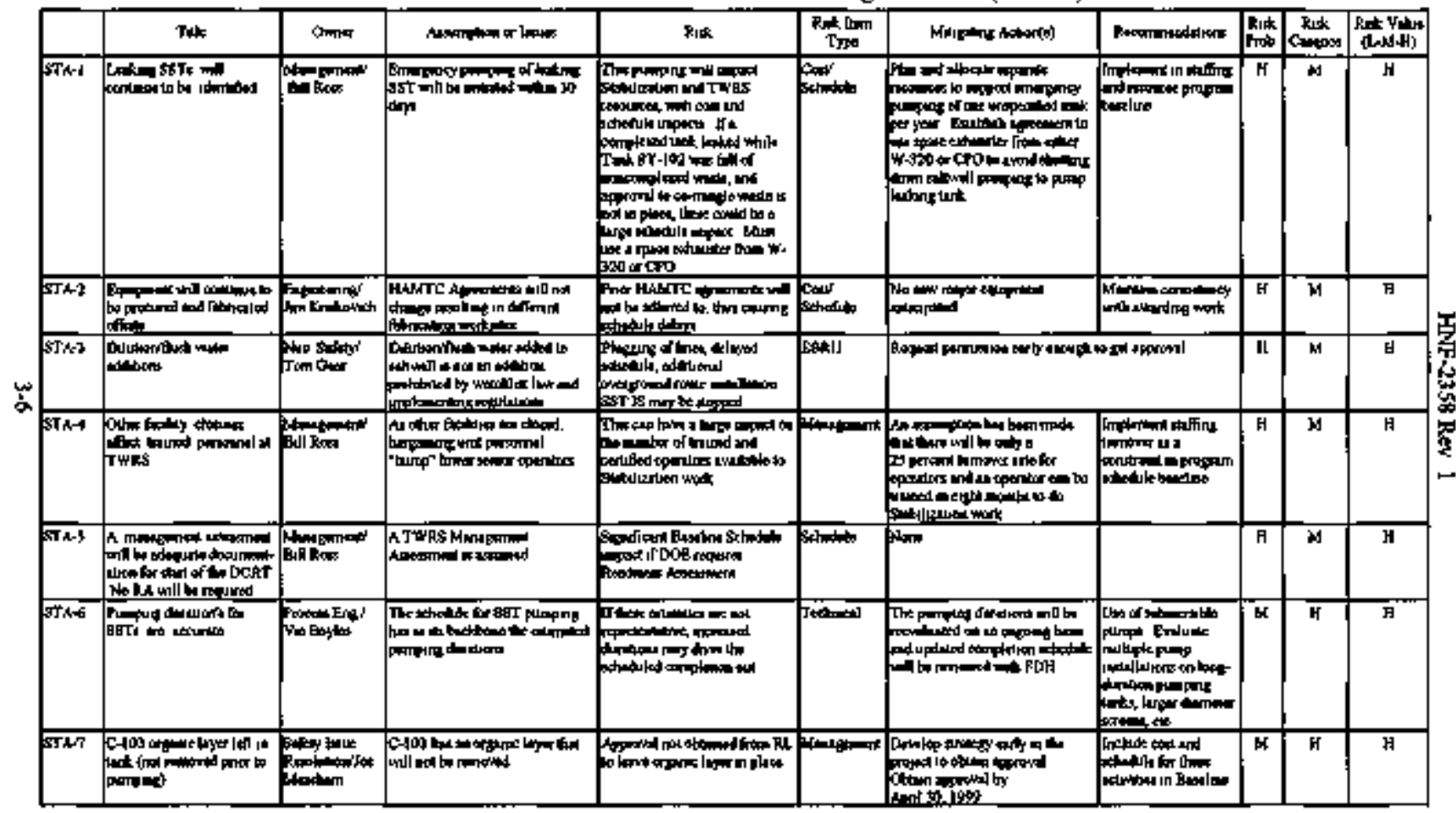


Table 3-I Interim Stabiization Critical Risk Management List (4 Shets)

\begin{tabular}{|c|c|c|c|c|c|c|c|c|c|c|}
\hline & Tult & Omar & 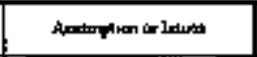 & Esth & Pritim & Mi4 & Recomprodeloge & Rit: & Rin & 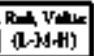 \\
\hline stass & 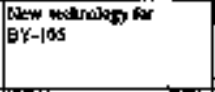 & 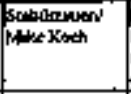 & 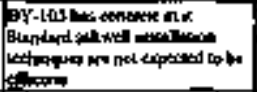 & 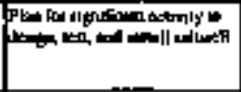 & Tectomi & 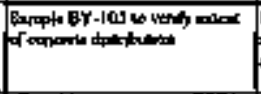 & 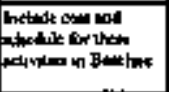 & Nd & $\mathbf{H}$ & 日 \\
\hline STAN & 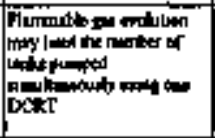 & Trocea Bnet & 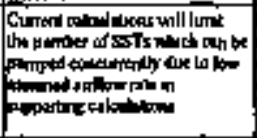 & 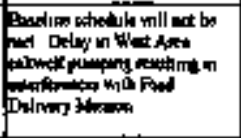 & Tecturual & 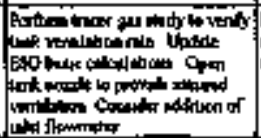 & 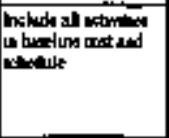 & W & $\mathbf{K}$ & 盯 \\
\hline SThro & 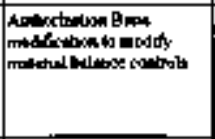 & 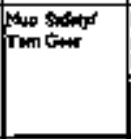 & 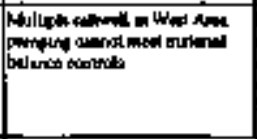 & 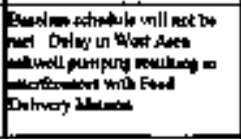 & Tackmal & 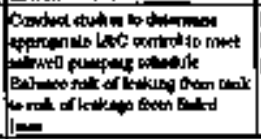 & 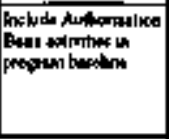 & $\mathbf{H}$ & Wh & H \\
\hline \$TA-II & 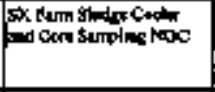 & 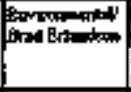 & 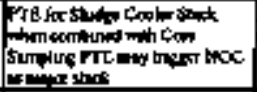 & 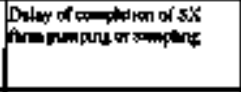 & Twolnal & \multicolumn{2}{|c|}{ 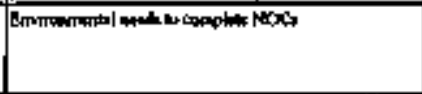 } & $\mathbf{H}$ & $M$ & $\boldsymbol{H}$ \\
\hline \$T/A-12 & 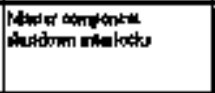 & 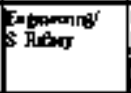 & 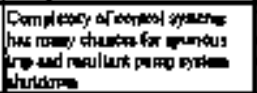 & 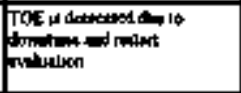 & Ttelinal & 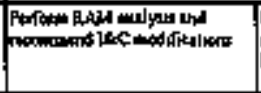 & 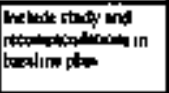 & $\bar{H}$ & $M$ & 日 \\
\hline ETA-B & Lophtst: & 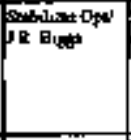 & | & 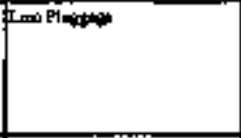 & Tectmuxal & 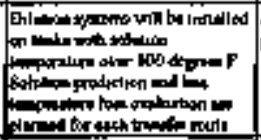 & 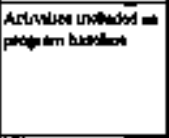 & $\mathbf{K}$ & $M$ & 日 \\
\hline SIshelt & Li2sv ponp fulure & רוn & 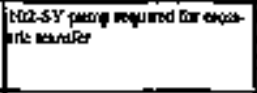 & 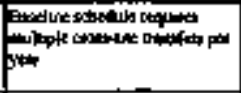 & Tectrune & 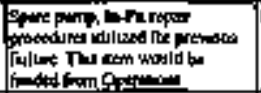 & None & $\overline{4}$ & н & 旦 \\
\hline STA-1S & 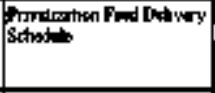 & 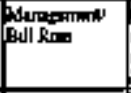 & 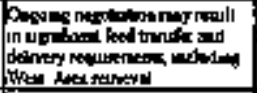 & 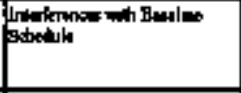 & Nhomemint & 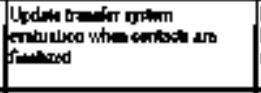 & 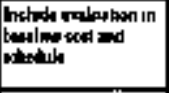 & ) & $M$ & b6 \\
\hline ETh-F & 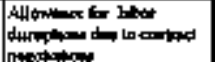 & Nill Rom & 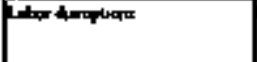 & 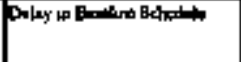 & | & ptom & & 1 & $\mathbf{H}$ & $M$ \\
\hline
\end{tabular}


Table 3.1 Interim Stabilizaton Critical Risk Manageroent List (4 Sheets)

\begin{tabular}{|c|c|c|c|c|c|c|c|c|c|c|}
\hline & Two & مبسر & A & Enen & Phition & 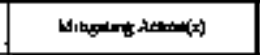 & 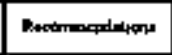 & Ruth & 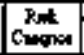 & 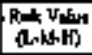 \\
\hline EThJT & 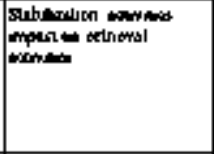 & 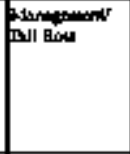 & 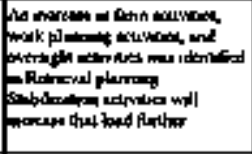 & 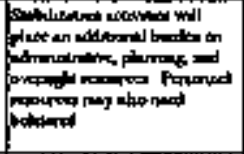 & Schuille & 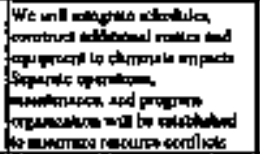 & Milugen & $\mathbf{4}$ & $M$ & Md \\
\hline $5 x+13$ & 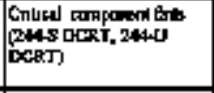 & 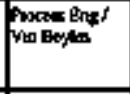 & 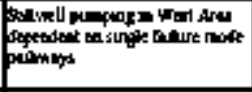 & 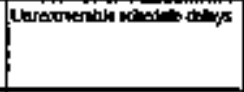 & Fratle & 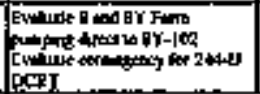 & Milugang witie & 1 & H & $\mathbf{M}$ \\
\hline $5 T+619$ & 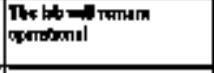 & 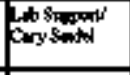 & 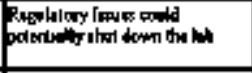 & 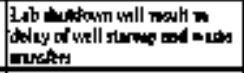 & stoutuly & \multicolumn{2}{|c|}{ 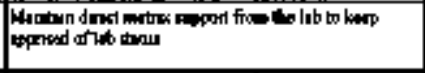 } & $\mathbf{N}$ & $M$ & $m$ \\
\hline ETALA & 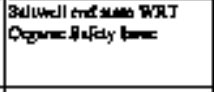 & Tam Sark & 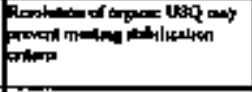 & 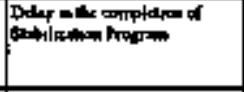 & tonathly & Namp & 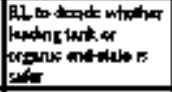 & 1 & $\mathbf{H}$ & $M$ \\
\hline $5 S^{\prime}-2 E$ & 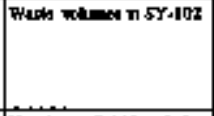 & 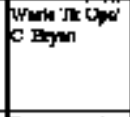 & 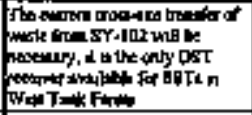 & 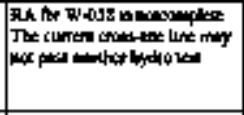 & Teernum & 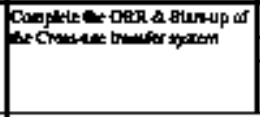 & 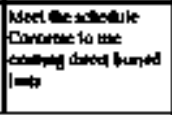 & 1 & $\overline{\mathbf{H}}$ & $\bar{M}$ \\
\hline STA2 & 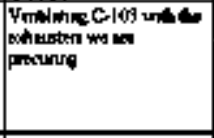 & Yesmenne' & 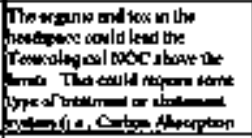 & 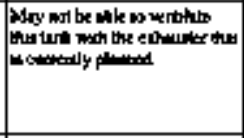 & feetried & \multicolumn{2}{|c|}{ 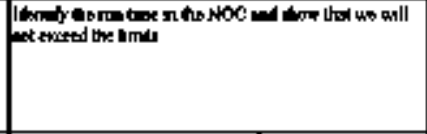 } & H & m & $M$ \\
\hline $5 T A D$ & 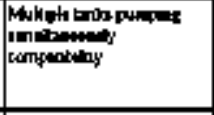 & 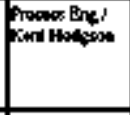 & 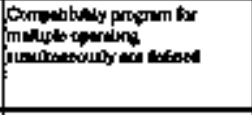 & 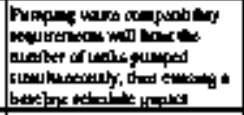 & Jeximed & 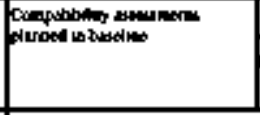 & 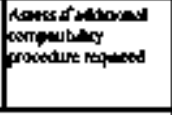 & i & M & $M$ \\
\hline STARA & 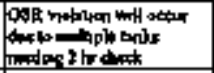 & 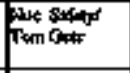 & 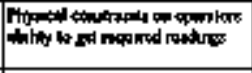 & 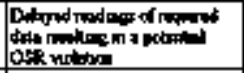 & Inthed & \multicolumn{2}{|c|}{ 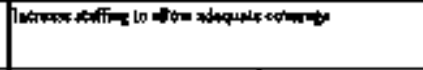 } & $\mathbf{M}$ & $M$ & $M$ \\
\hline STht5 & 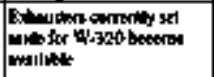 & Aprtilill kno & 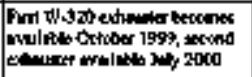 & 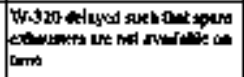 & tecinnum & 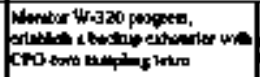 & 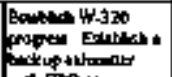 & G & $\mathbf{K}$ & H \\
\hline
\end{tabular}


Table 3-1 Intermm Stabjization Critical Ríak Mantigemear Lus (4 Sheeti)

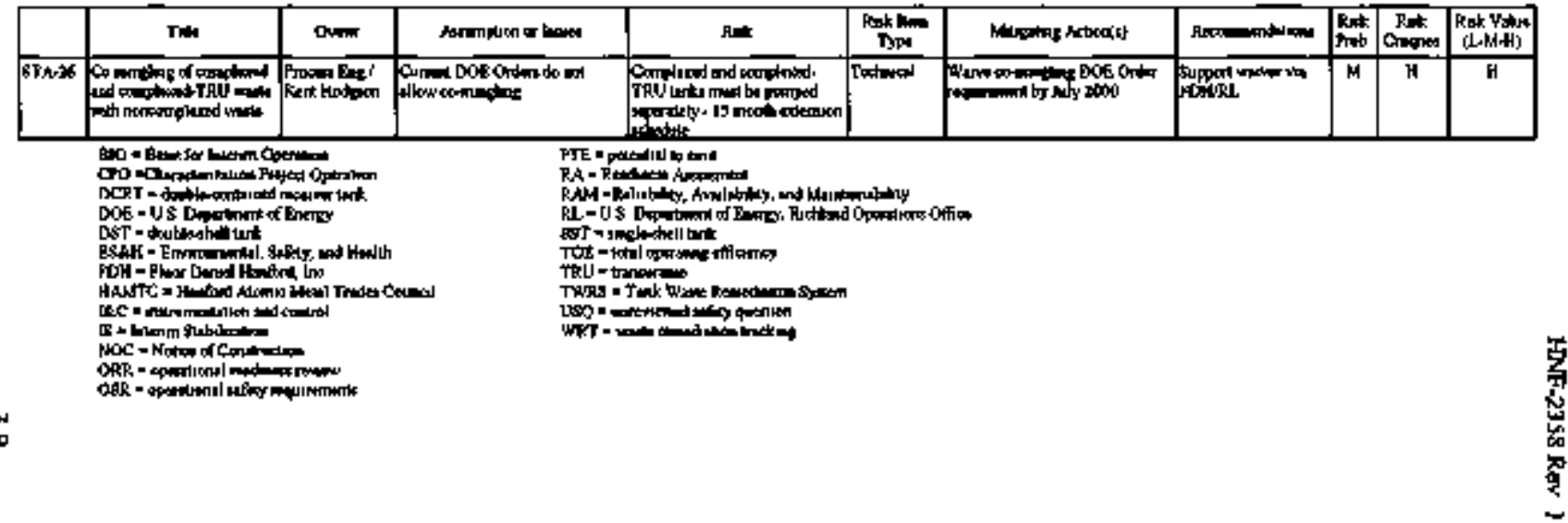


HWF-2758 Rov 1

This pago jutentrorally keft blank 


\section{4.* TICBNKCAL STRATEGY}

\section{I TLĆnNLCAL APPROACH}

Using the enabling asyumptions Aigcusged ir Section 3,1, a technical atrategy was

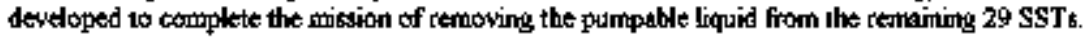
This strategy is criseussed below.

\subsubsection{Remowe Panpable Liquid}

The project's prienary mission will be accomplished by removal of pumpable liquid from

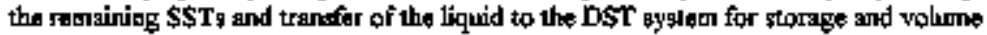
management penting ils use for immobiliation fed. The remeining solids will be stored in the

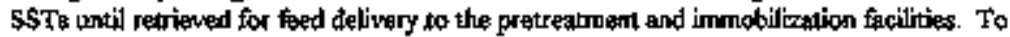
prevent intrusion of water, the SST piping and other accest poins will be cul, etopped, wid sealed pondiug waste retrieval for treatmenl and disposal. The nozeles in the pump pit will be sealed so that a miscouted waste transfier from anolher cource canot ocous. Retrieval of the SSTs beyond Tank C-106 begins in 2004 and is scheduled to be completed by 2018 under the Tri-Party Agrement (Ecology ta lal. 1996).

\subsubsection{Use Extsilng Technelogy}

Use of the exjsting s:altwell pumping technology will cantioue with the widiticn of maiessary trangfer, seffey, and control systems neaded to secel the approved Authorizalion Basis. Deployment of suppemental technivues or development and deployment of new technology will be rexuiced to complete the stabilization of BY-105. In wertain anses, additional rigk-reduction

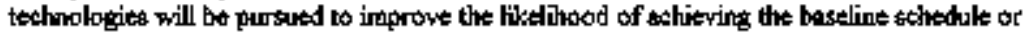

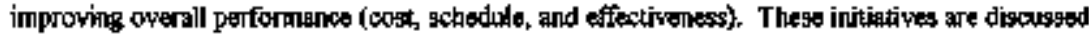
in Appendix B. Wilh the limited duration of the progrem, we do bot expent to ochieve dromatio performance improvement of the saltuell systems (i.e., we are at the bimits of technology pending retrieval of the tank contento).

\subsubsection{Use Eniving Ifrattrektare}

The SST IS Projext will maximize use of the existing tank farm jofitstructurte (pumping systems, single coulajed lises, DCRTs, wahe and transfer boxes, and the new cross-site transfer Ime avaidable later this FY). The 242-A Eveporalor and the 200 Area Effluent Treatrant Facility will be used to munage the DST tank tpace. Whec necessary, the groject will utivize sections of radiation-shielded, abouegrount waste tanafer lias to facilitate the transter of pumped livuid to tho DST aystim. If existing trat:after lines forll or do not pass the presture tests, alternative routings will be exartuied and, if necessary, temporary oworgeund double-encaged trandifr lines will be installed and usod. 


\section{4,2 PRIMARX TECENICAL OANTCTIYES}

The primary lechnical objextives needed to be achiewed by the techuical stratesy ate discarsed tedow.

\subsubsection{Expodite Schepdule}

To limil the potertial leaknge to the envirpument, the \$ST 1\$ missiop will be completed as early as poseible. The long-duration putimping lanks have been scheduled to that as toon de practicative.

\section{Co-mingting of Wante}

Per DOE direction, this plan assumes the complaxed, nonconplexed, and comploxed-TRU

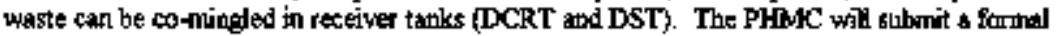
requzal for authorization to co-minglo these waste types. Prior requeste for allowing co-raingling have bean approved silh the proper written justification and atalysit of the wate involyat. The mogt recent approyal ja pumping of complexed waste from Tank AY-IOI to Tank AW-IO2.

\subsubsection{Tank C-103 Organic \$alvent Layer}

Per DOE direcion this plan atsurnes that Tank C.103 can be interim stabilized without.

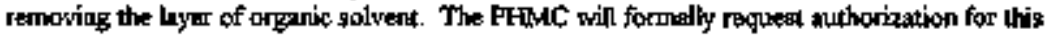
approsach.

\subsection{TECHNICAL DEVELOPMENT}

To purnp the waste from Tank BY-I05, additional techuical dewelopmett work is required. Tank BY-Jos has a very hard sarfice layer of Portland coment (depth unknown).

It I995, IS program personnd attempted to install a saltweil pump inlo an existing salıwell screat in 'Tank BY.105. When they begen clearing the screen with a water lance, they found a very hasd laye of material netar the surface of the waste. Subsequerit interigation idemtified that Pordand cement hard been added to this tank in I966. Recent core-sampling activittes also haye encountered the bard material.

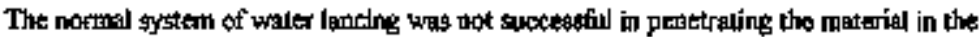
stiwell screen. Other lechnologies are needed to support installation of a rew saltwell scricen and subsecputent pumping. This togk consists of devekping and testing equigment that an out through the hard aurface and allow a saltwell serese and pump to be lowered into the tatak This dewelopment work will iudude degign, testing. obtgiaing the proper safety approwak, afd working wilh exlsung Hanford Sile crafl persortmel 10 taim them in the use of this equipment. 


\subsection{MASTER PAOJECT SCHEDULE}

An integrated SST IS masset project sebedule was developed utilizing the pumping durations identified in Tablo 4-I, the tochnical abjectives digcussed in Section 4.2, and the Jogistical timits ingoded by the existing plitysical systems - tubanced by limitod additional conguruction. The priutary schedule constratint is the pumping duration on iddividust tanks. In the 200 Eart Aras, the sctuedule dnrations ara dominated by projected long purrping turations of AX-101 and A.101, and the "sperial cases" of BY-105 and C-103 wtich reqube installation of additional equipment before saltwet permping is initiated in the 200 West Afea, the primary considerarion is the large number of tank that unust be estabilized.

\subsection{FACIIITY CONPIGURATHON}

The 29 SST 6 , the combeclions to the DCRTs and the supporting D\$Ts can be sumamarized and modaled as ghown on Figurs 4-I. The figure inficates thal the U Farm tank wastes are collected in the 244-U DCRT, wrile boh the $\$ X$ and $S$ farm tank wastes ere collected in the 244\$ DCRT, and so on tha 200 Wegt Area DCRT nust be iransferted to SY-102 and

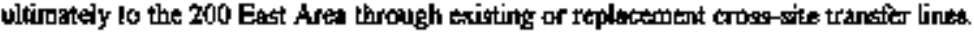

The piping for each of the DCRTs and \$STs that require permping hawe been identified andi are presented in summary form on: Figure 4-z. Assessment of the curtent conditions of the piping systems and aupporting control and leak-datection systems was developed and inchuded in the Level 1 Logic developed for each SST.

\subsection{RESULTS OP THE TECHENICAL STRATEGY}

A model of the technical gtrategy, based on Figure 4-2, was constnucted using the updated initial ituentories, projected pumping durtions and yiuds, and DCRT and DST syttem configurationg. Overall syoten pertormance as a function of time, as well as individus subsystert performatce, wera eyaluated uaing typical average and peak requiremestis. These requirements wero compared to reasonabio subsystem capabilities, and in sonete cases startup and operalional

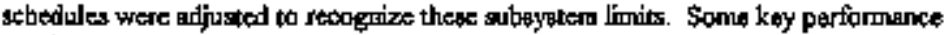
requirements and results are presented in Figures 4-3 through 4-7 and Tables 4-2 and 4-3 and are described below.

Figure 4-3 presenls the pumping requirements of the DCRT and farm subsystems as a function of tirse. The bulk of the walate volupe is renoved from the $S$ and $\$ X$ Farm systern, wilh the U Farm system the next highea producer. 
Table 4-I. Pumping Durations.

\begin{tabular}{|c|c|c|c|c|}
\hline Afen & Tant: Fomाu & $\operatorname{Tm}_{\mathrm{m} k}$ & Purmp Tims: (Days) & Woste Type \\
\hline \multirow[t]{24}{*}{$w_{0}=1$} & \multirow[t]{8}{*}{ SFarm } & 5.101 & 294 & Ninepriplexed \\
\hline & & $\$=102$ & 595 & Néncompleved \\
\hline & & 5. 103 & 198 & Nerosurapletiod \\
\hline & & S. 106 & 495 & Ntomompleted \\
\hline & & $5-107$ & 204 & Heocentiphested \\
\hline & & 5109 & 300 & Neoteximplesed \\
\hline & & s-111 & 48 & Ncoocomplexwed \\
\hline & & S-112 & 300 & Nomonuplenod \\
\hline & \multirow[t]{6}{*}{ SXFWTा } & $s x \cdot 101$ & 375 & Cordepted \\
\hline & & $\$ \mathrm{x}+102$ & 500 & Notociontiptared \\
\hline & & $3 x-100$ & 625 & Noscomplexted \\
\hline & & sx-104 & 589 & Nortompleyed \\
\hline & & $5 \times \cdot 105$ & 684 & Ninoctuplaxed \\
\hline & & $5 \times \cdot 106$ & 553 & Nomoocoponosit \\
\hline & \multirow[t]{2}{*}{ T Finn } & $\mathrm{T}-104$ & 18 & Nomocotingexped \\
\hline & & T-110 & 180 & Nonoon mpened \\
\hline & \multirow[t]{8}{*}{ U F जाम } & $v_{1}-102$ & 316 & Compteripe \\
\hline & & w.103 & $4 \$ 9$ & Complated \\
\hline & & U.10s & 3803 & Comigntar \\
\hline & & $U-106$ & 147 & Complened-TRU \\
\hline & & U-107 & 388 & Nowcooplexped \\
\hline & & 13-108 & 452 & Wurkempleypd \\
\hline & & $\mathrm{v}-109$ & +22 & Complesed \\
\hline & & U.l1 & 285 & W'्lmoorplanent \\
\hline \multirow[t]{5}{*}{ Em } & h Fall & $A=101$ & 974 & Conpowated \\
\hline & AXFm & $A \times-101$ & 78 & Nomocourpleased \\
\hline & \multirow[t]{2}{*}{ BYFEm } & BY-105 & 136 & Ncoocoruptexed \\
\hline & & BY-]106 & 821 & Noncoruppexed \\
\hline & CFann & C-10B & $\pi 7$ & Coonptenved \\
\hline
\end{tabular}

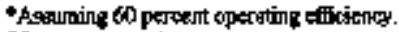

TRU = transurteris. 


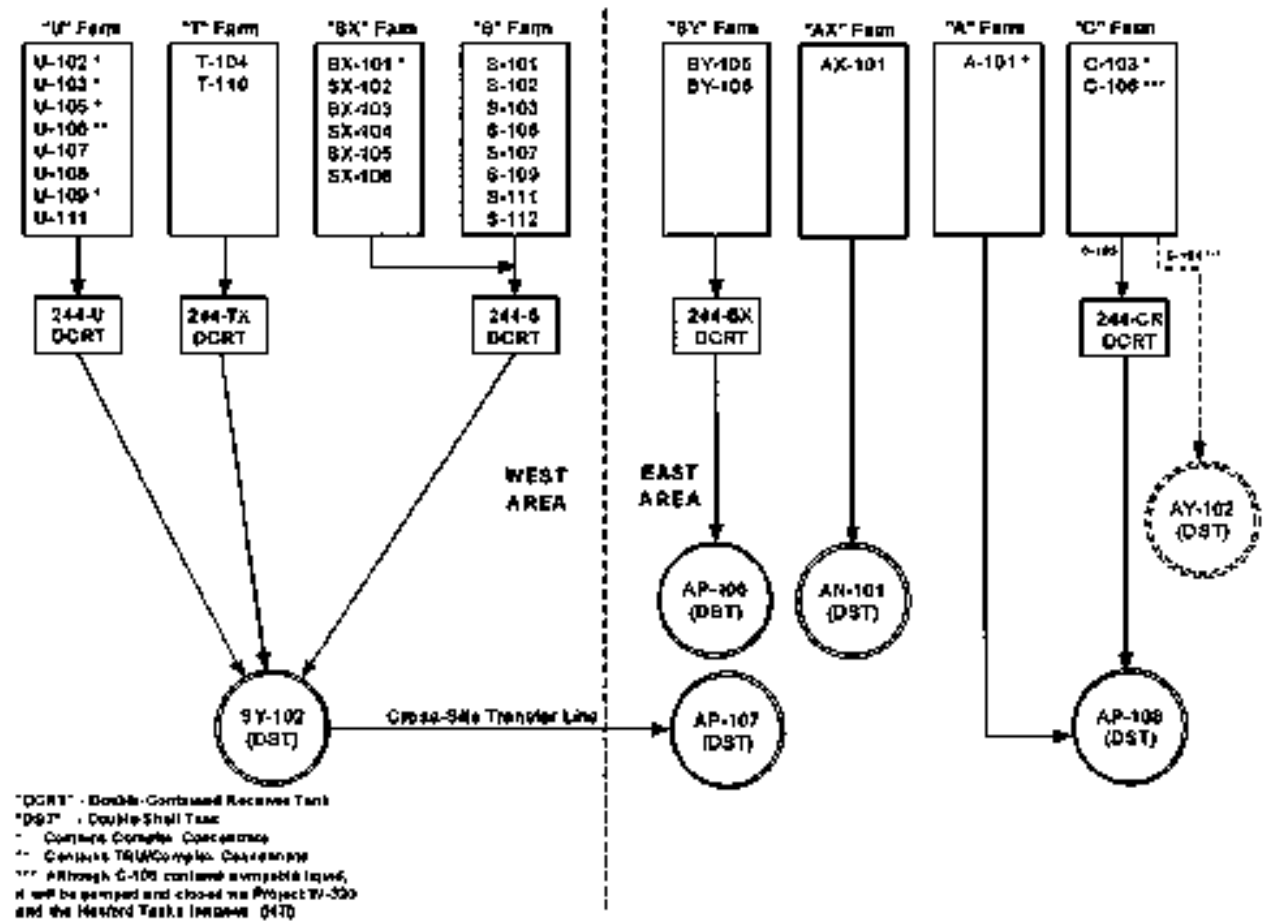

Figure 4-L. Waste Flow for Singio-Shed Tank Interim Stabilization System Flow Dingram. 
ol
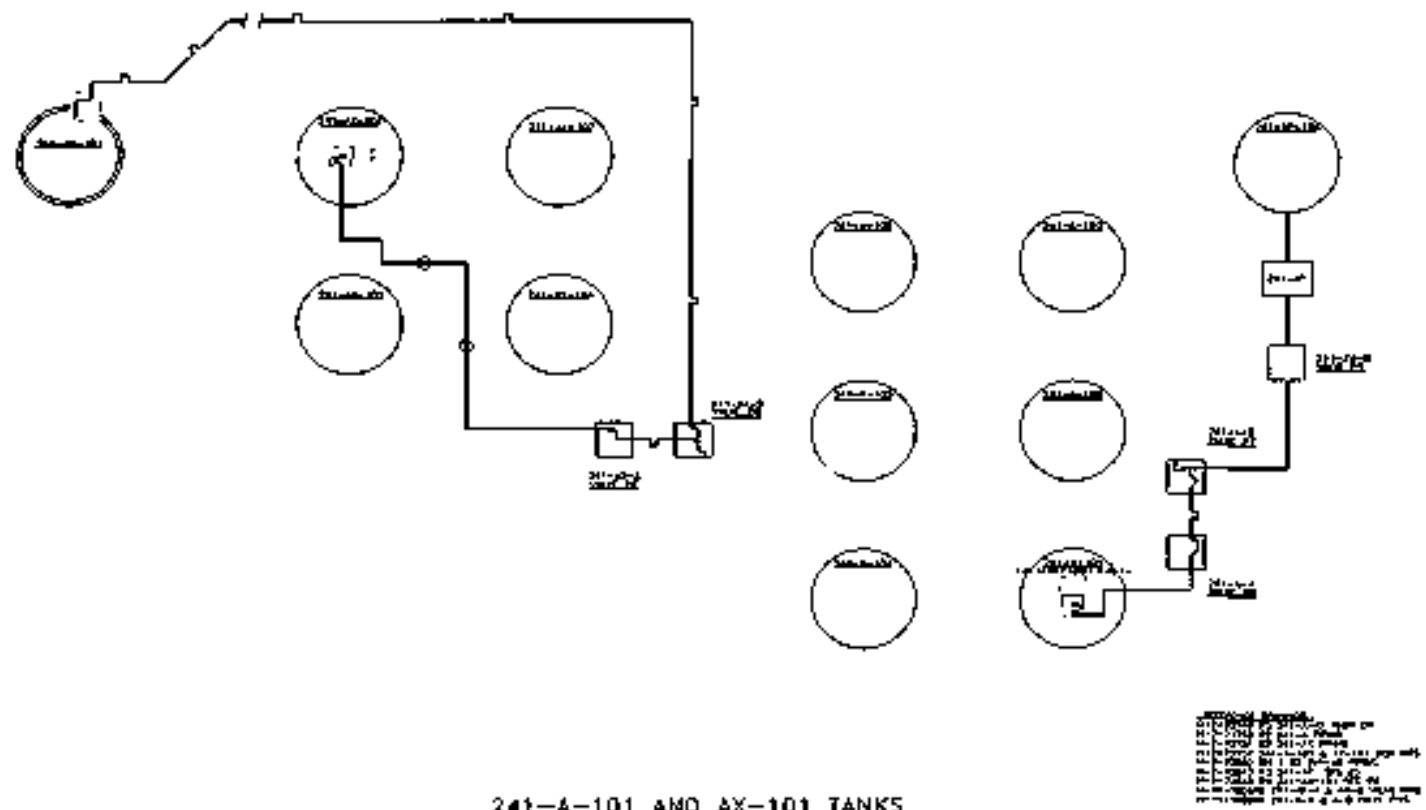

Figure 4-26. A and AX Farm Pjping Configuration. 


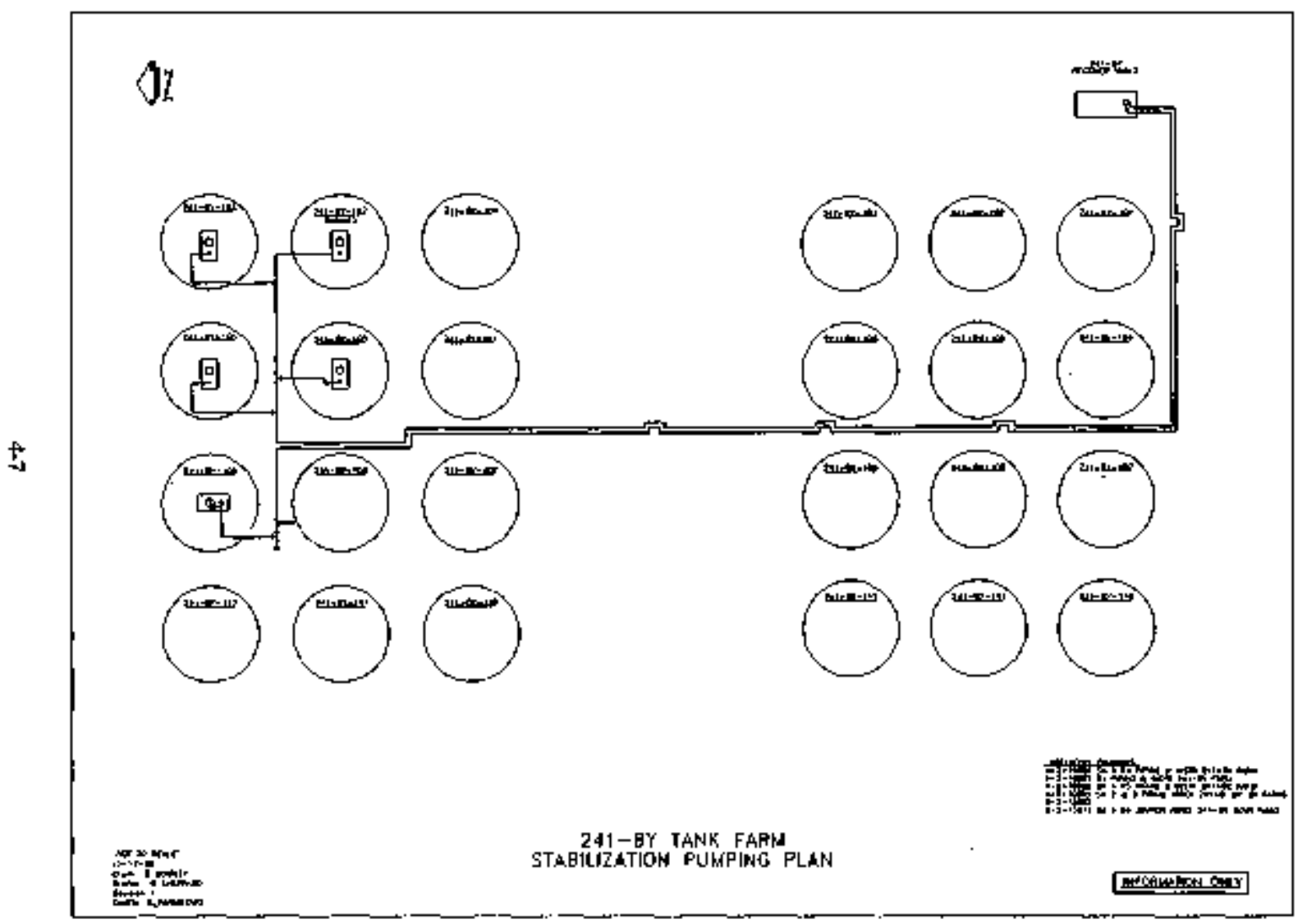

Figres 4-2b. BY Funn Piping Conffiguration 


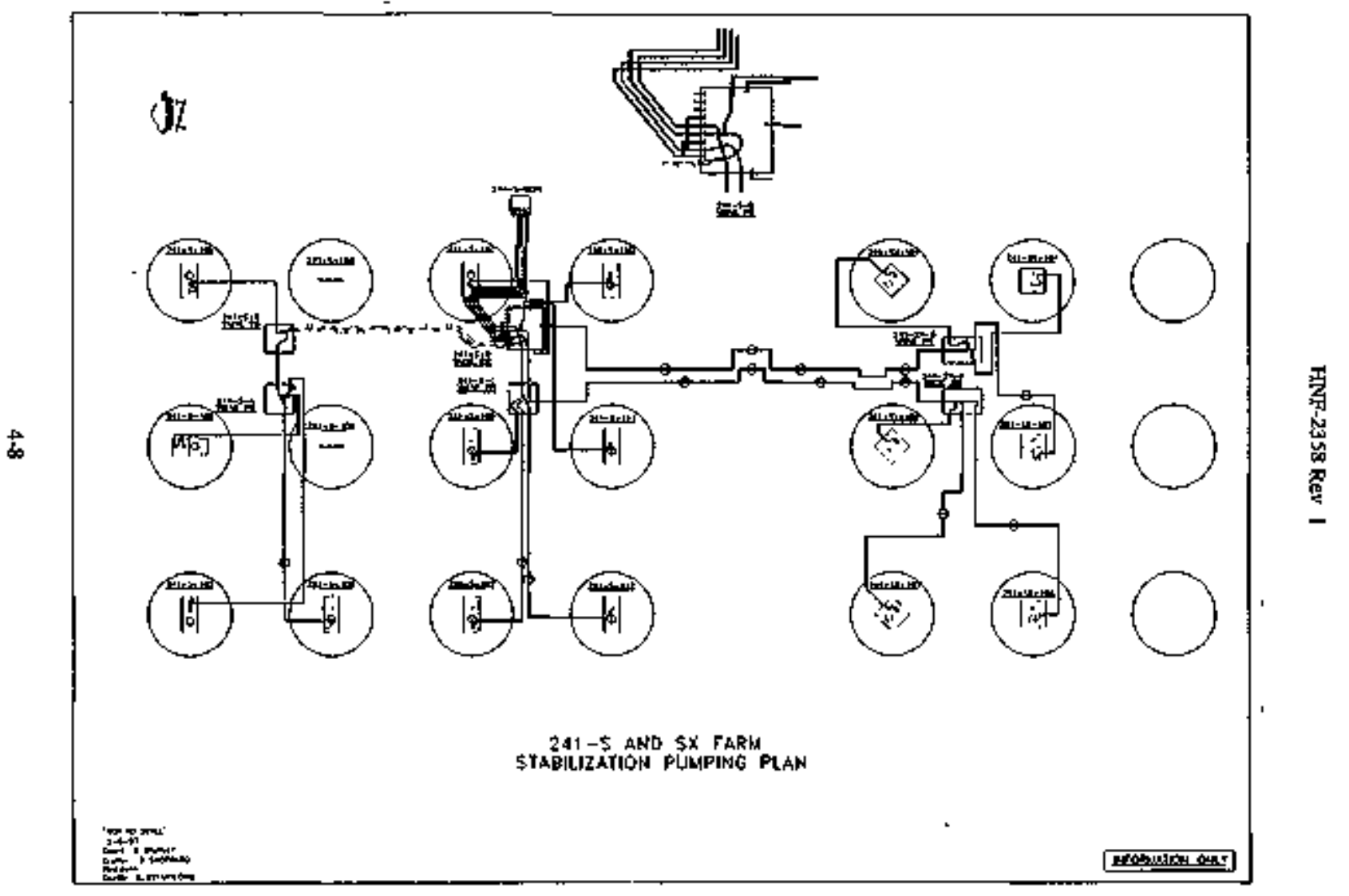

Figure 4-2c S and SY Fara Piping Conflguration 


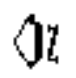

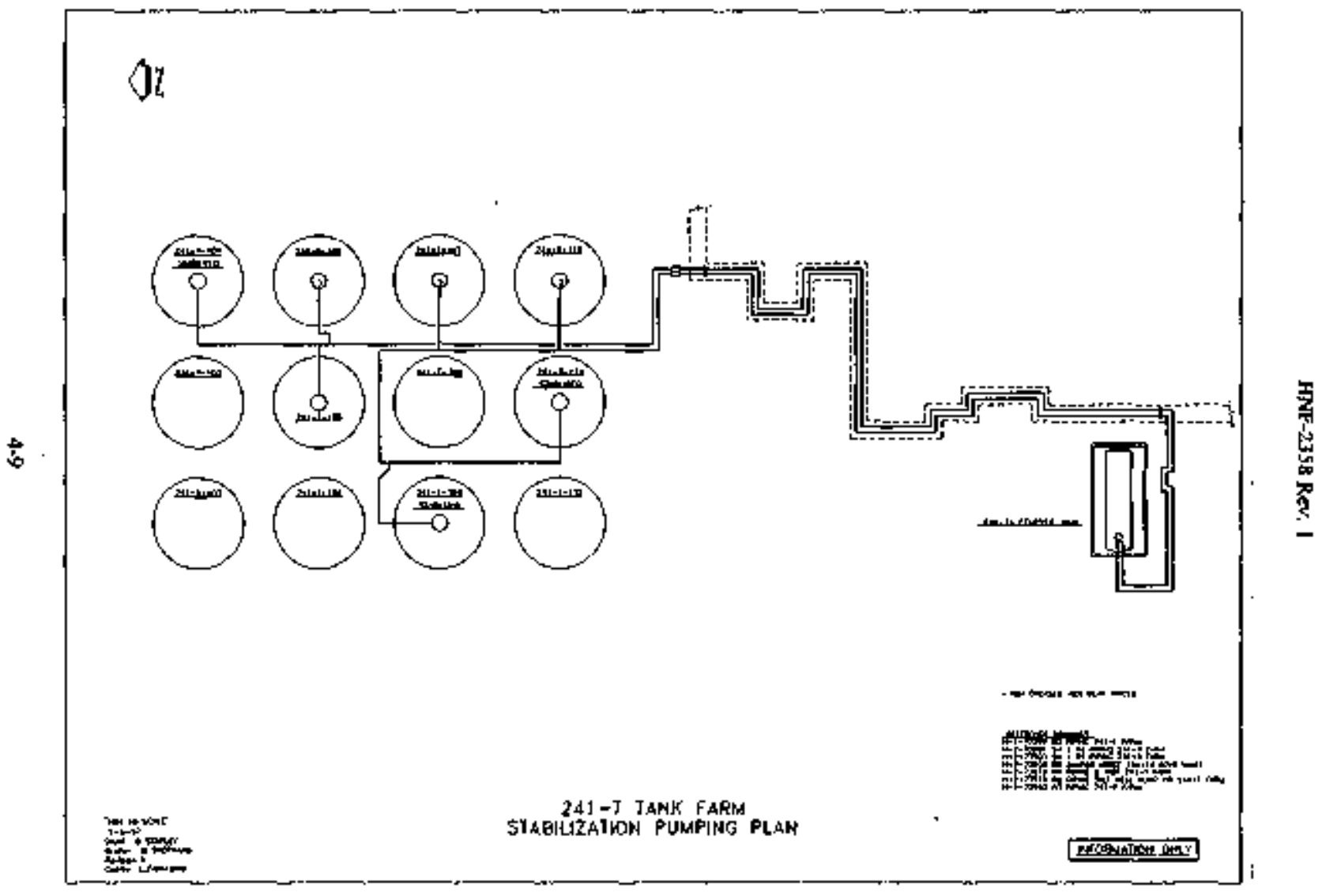

Figure 4-24 T Farra Piping Contiguration 
j)

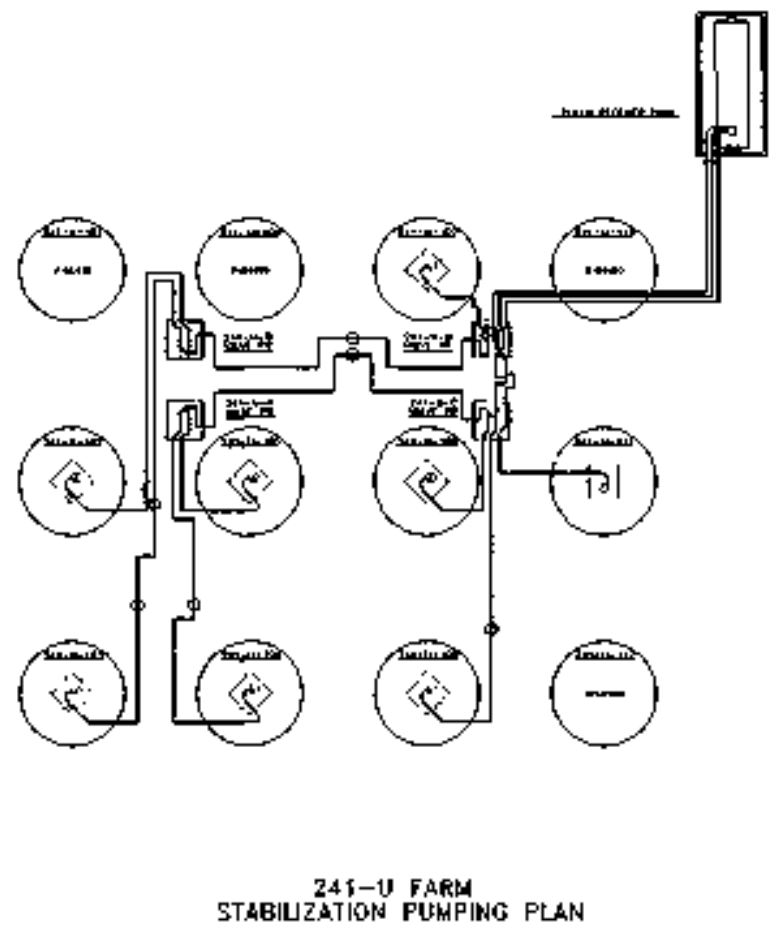




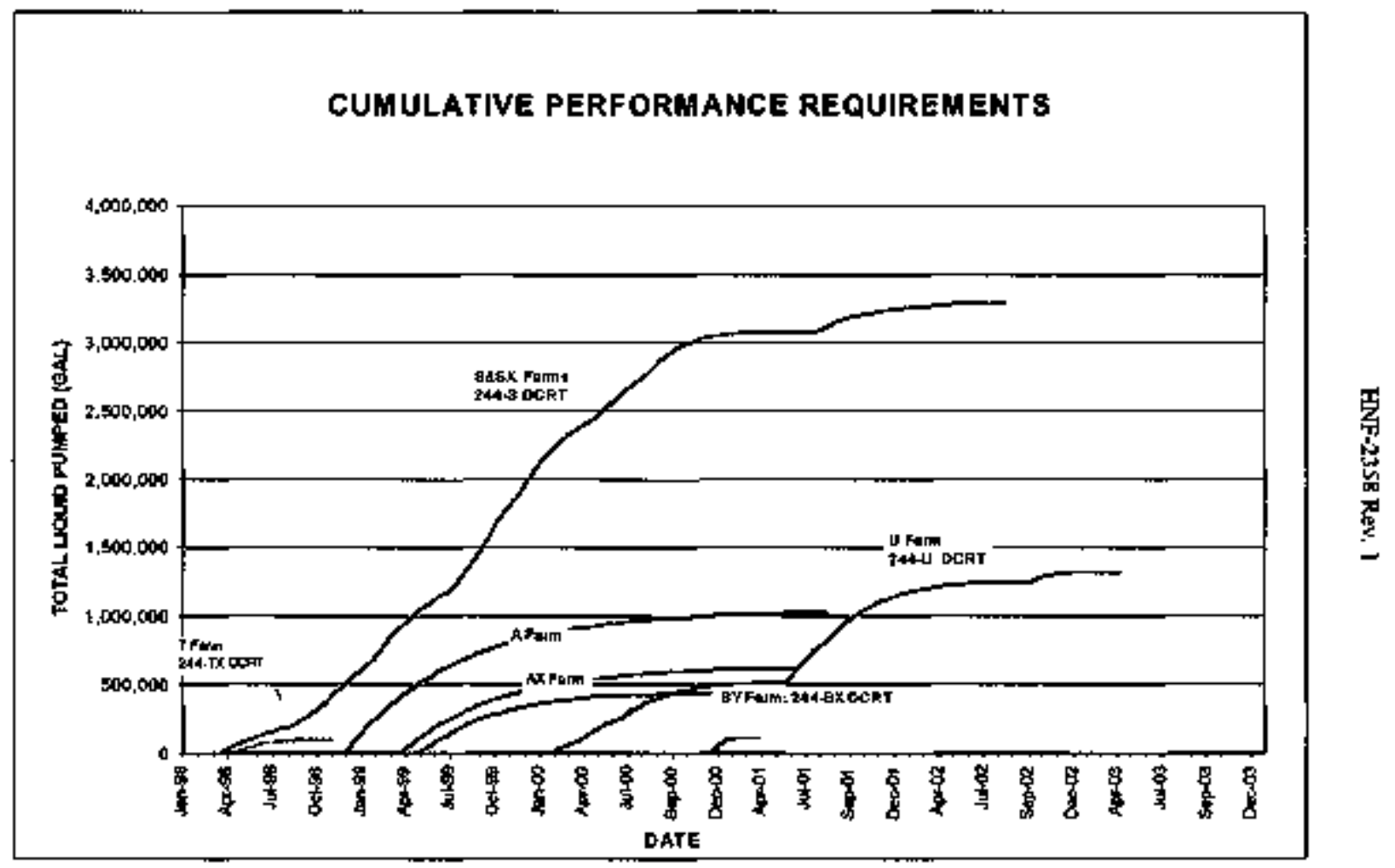

Figure 4.3. Double-Contined Receiver Tank and Tank Fanm Subsystem Puotping Requirements. 


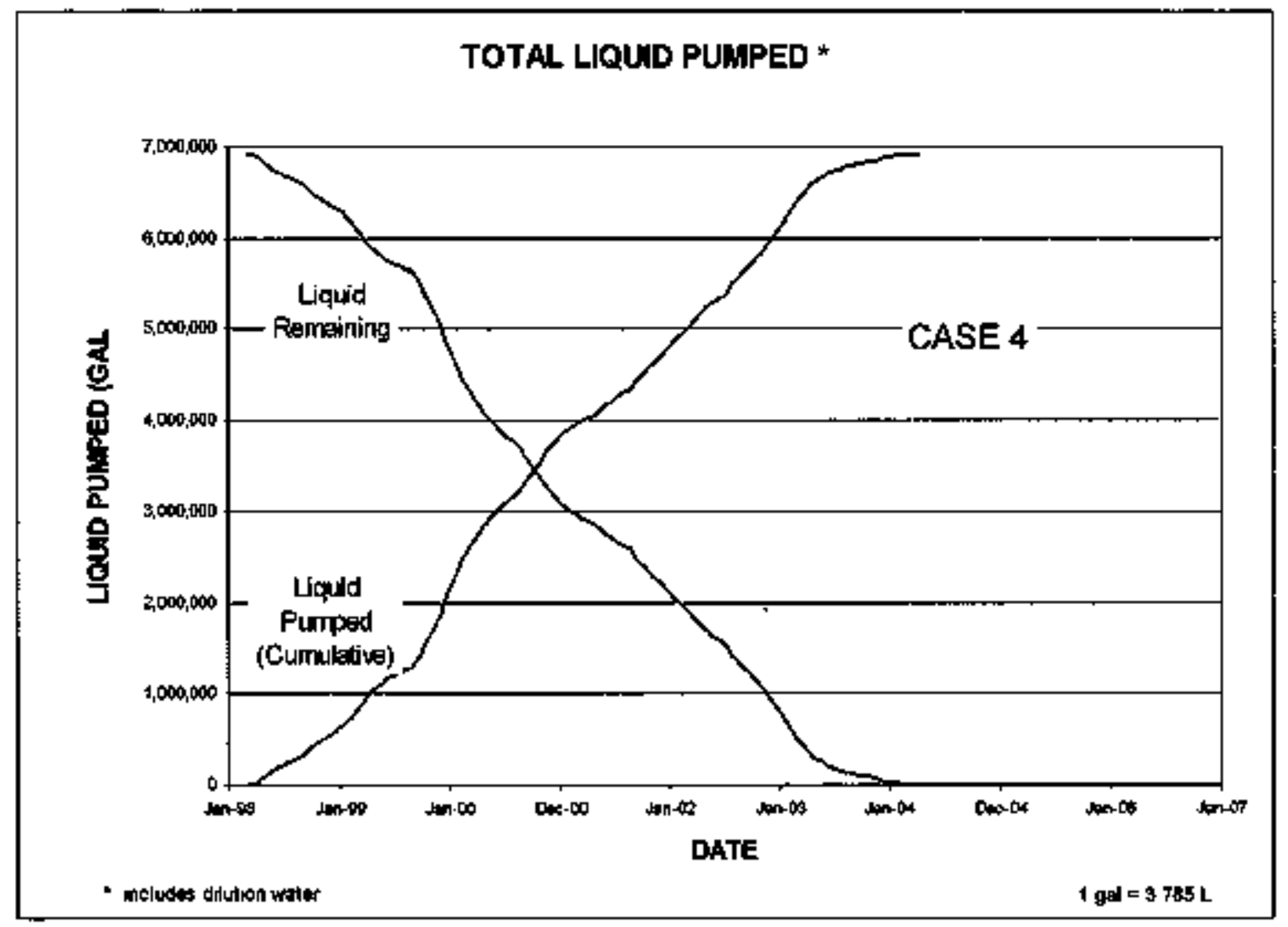

Figare 4-4 Cumulative Performanse Requerements 


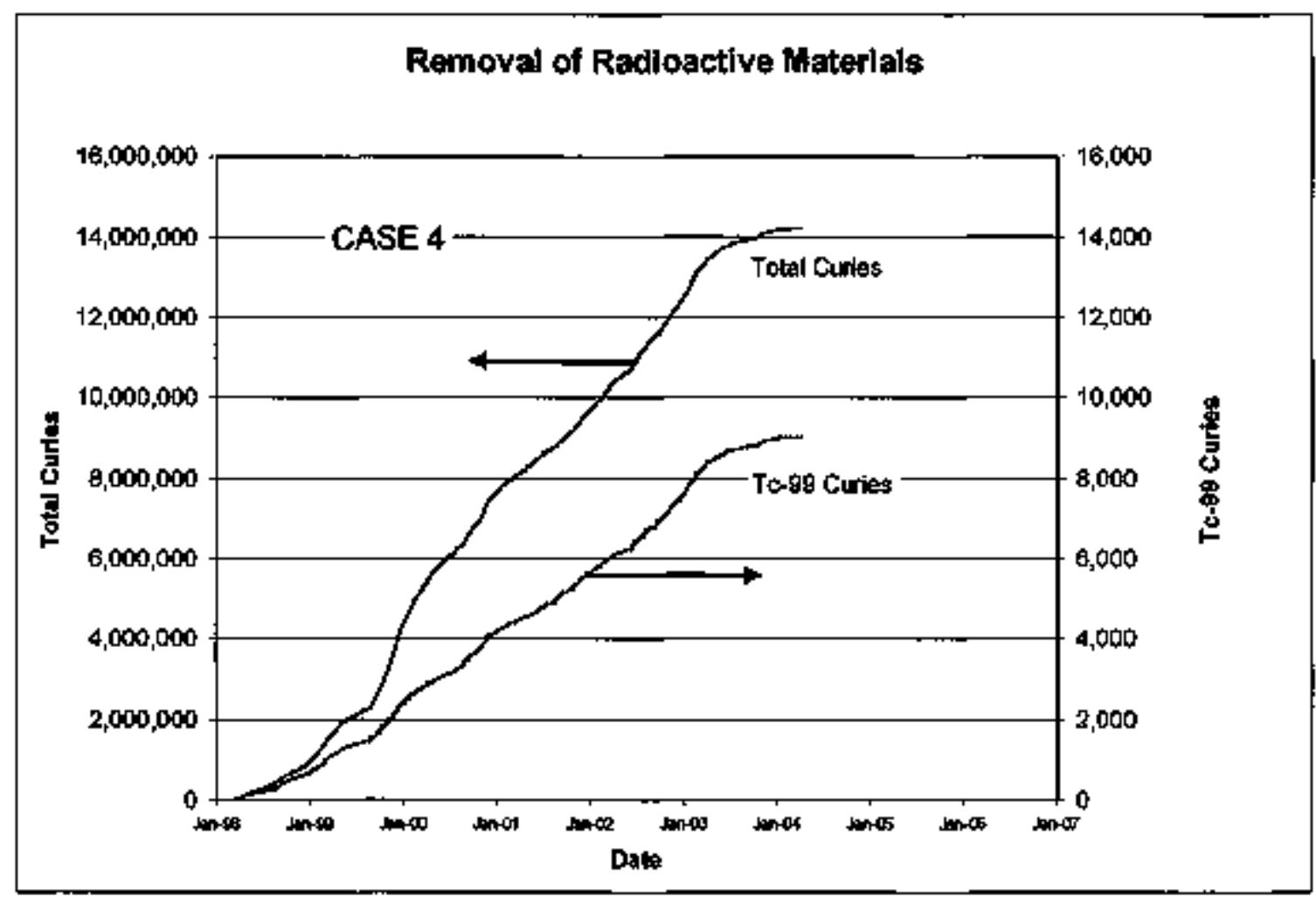

Figure 4-s Remoyal of Rafioadive Maders] 


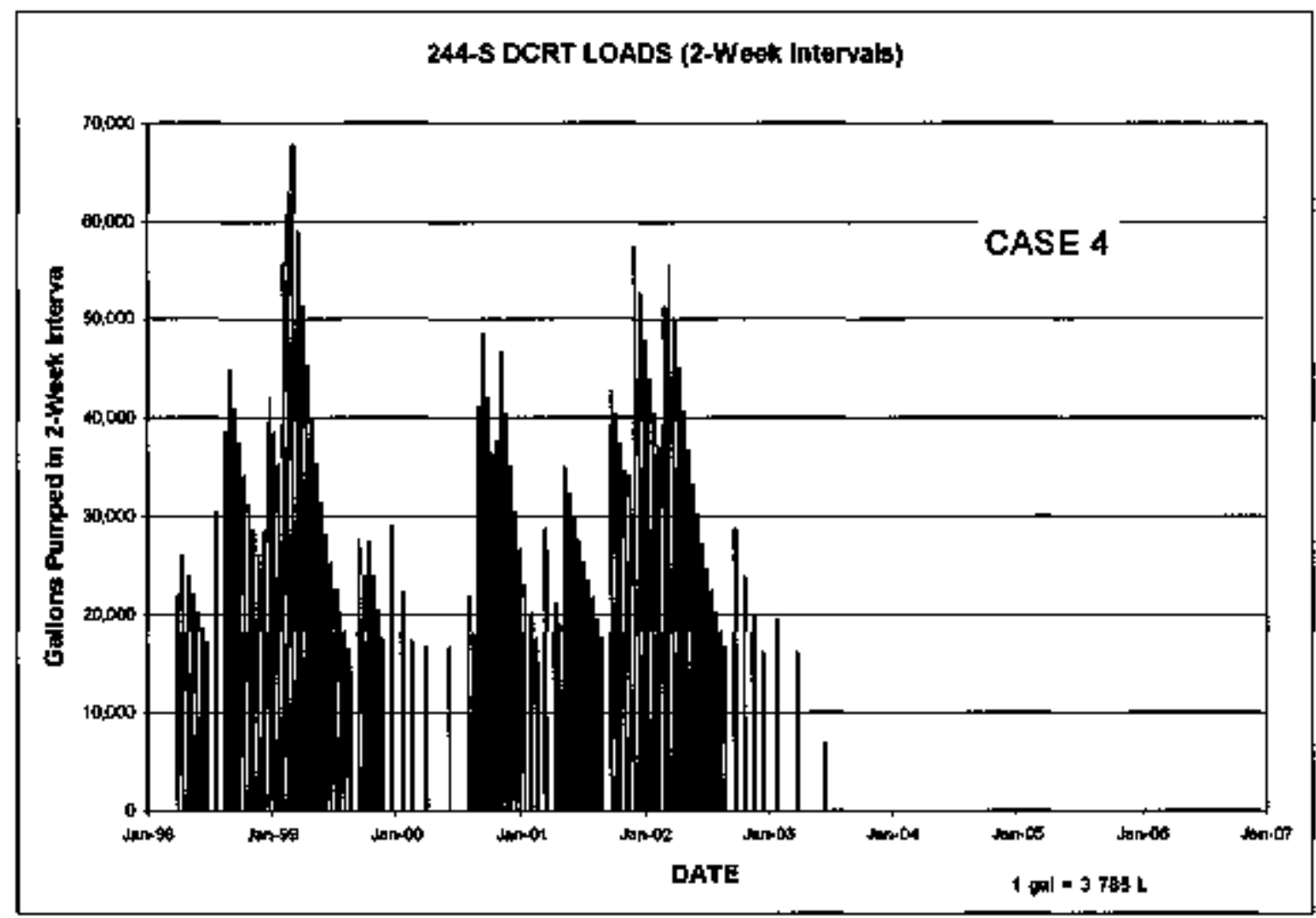

Figure 4-6 244-S Dowble-Contained Receiver Tank Lasds 


\section{CROSS-SITE TRANSFERS}

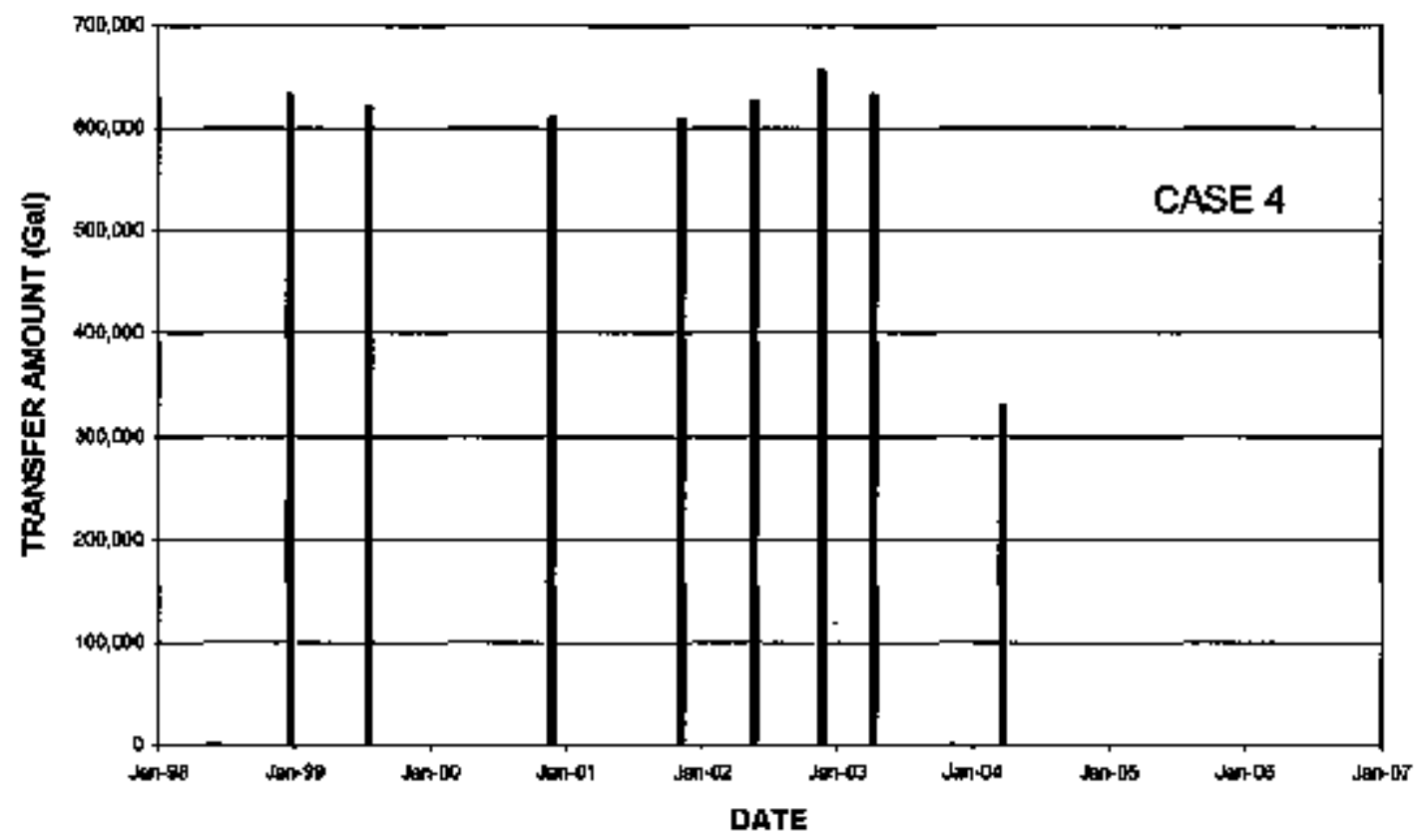

$1 \mathrm{gal}=3796 \mathrm{~L}$

Figure 4.7 Cross-Sñe Transfers 
HiN-2358 Rey. 1

Table 4-2, Perforalance Requirentonts of Major Subsystems.

\begin{tabular}{|c|c|c|c|}
\hline Equipuneal & 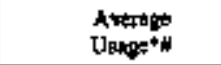 & Peak Uanget & $\begin{array}{l}\text { Nonilnd } \\
\text { Rmingét }\end{array}$ \\
\hline 244-S DCRT & $\begin{array}{l}\text { JB, G00 pal hoded over } \\
54 \text { uneds period }\end{array}$ & $33,9 \infty \infty_{\text {g }}$ & 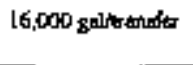 \\
\hline 24\$-TX DCRT & $\begin{array}{l}6,800 \text { galloweds oner } \\
12 \text { wed pariod }\end{array}$ & 176000 plineded & 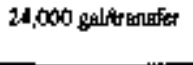 \\
\hline ZA4UUDRT & $\begin{array}{l}\text { 21.300 galihreek oभed } \\
26 \text { urd peridt }\end{array}$ & 34,400 gatlistak & 24,000 gnlitrentas \\
\hline 244-BX & 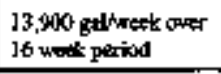 & 19,000 balknets & 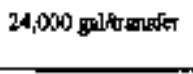 \\
\hline $2445 R$ & 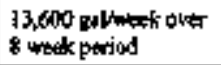 & $24,0,00$ datwerk & 15,000 orlentser \\
\hline Crues-Sint Trastar tine & 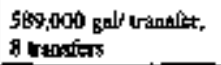 & 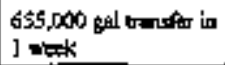 & 680,000 gallotantor \\
\hline
\end{tabular}

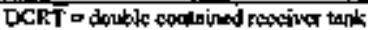

-1 jocor = 3.735 liter.

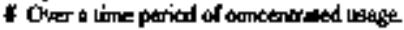


HINF-2358 Rev 1

Tabite 4.3 Evaparator Compang Schedule

\begin{tabular}{|c|c|c|c|c|c|c|}
\hline Cाmpпम中 & $\begin{array}{l}\text { Start } \\
\text { Dute }\end{array}$ & $\begin{array}{l}\text { S्रrastros } \\
\text { Taph(s) }\end{array}$ & Smant & Whetered Irot & $\begin{array}{c}\text { Foed Vobme } \\
\text { (Koply }\end{array}$ & $\begin{array}{c}\text { Patdistet } \\
\text { Twik }\end{array}$ \\
\hline \$ & \multicolumn{6}{|c|}{ 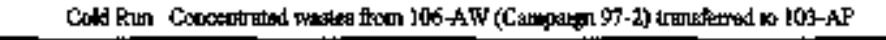 } \\
\hline 99.1 & 399 & $\begin{array}{l}\text { Dreat to } \\
\text { IOL-A }\end{array}$ & $\begin{array}{c}\text { J02-AY, 106-AP, } \\
\text { IOS-AP }\end{array}$ & Div & $1000+$ & IOS-AP \\
\hline \multirow[t]{2}{*}{$99-2$} & 899 & $1 \sigma^{2}-\mathbf{A P}$ & k02-SY $A$ IOK-AP & DN-SHL A DN & $1000+$ & 105-AP \\
\hline & 999 & $\underset{102-A \mid W}{D m a c k}$ & IO4AW & DN & 700 & I05AP \\
\hline $0,-1$ & $7 \% 0$ & JOM-AP & $102-8 Y$ \& $106-A P$ & DN-9uL \& CNN & $1000+$ & $\begin{array}{l}105-A P \\
304-A W \\
101-A P\end{array}$ \\
\hline QI-I & 2501 & $107 \cdot A P$ & IOS-SY \& IOI-AN & DNSSWL & $1000+$ & IOL-AP \\
\hline all-2 & Ino & 107-AP & 10G-AP \& 106-AP & $\begin{array}{l}\text { DN-SthL } \\
\text { DC-Sप्रL }\end{array}$ & $1000+$ & $\begin{array}{l}|Q| l-A P \\
\text { JO4-AWU }\end{array}$ \\
\hline 02-I & 11002 & $\operatorname{los}-A \mid$ & 105-AW $\boldsymbol{A}$ 101-A & $\begin{array}{l}\text { DN \& DN } \\
\text { DCSWL }\end{array}$ & $1000+$ & $104-A N$ \\
\hline $02-2$ & 102 & $107-A P$ & J02-SY a I05-AW & $\begin{array}{c}\text { DNWEC-SHL } \\
\text { DN }\end{array}$ & $1000+$ & $\begin{array}{l}104-A N \\
103-A P\end{array}$ \\
\hline
\end{tabular}

DC - Duhls cmpleced wotr.

DN = hlate nonsornptexed whas

SwL = galtaked hqud 
Figare 4-4 illustrates the cumulative performatice of the project beseline siralegy. A total of 20.4 million liters ( 5.4 million gallans) of waste remains to be purned. Over $\$ 0$ percent of the total pumpable volume is renowed by Sejperaber 2002 , with 99 percent remowed by Stpuember 2003.

Figure 4-5 stious the camulalive ambunt of radioactive thatertal (eurles) removed by the project. The total puries entry represents the near-term risk from thorter tived isotopes axch as cesium-[3]. The tocturctium-99 curve ropresents remboval of long-term riak

Figure 4-6 dequicts the pumping requirements for the DCRT 244-S. The high loards required to be pamped from this tarik make it the roost likely "botteneck" in the syttem. Other DCRT konds are much lowers An alternative to bypass this DCRT will be evaluated.

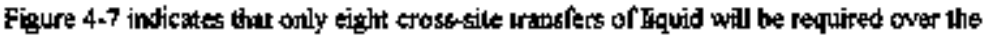
life of the project.

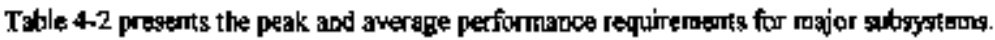
These performance regtirememts were estimated and cormpared to the normal capacity of the DCRTs and cross-itis teansfer system. This evaluation indicates that the 244-\$ DCRT is very near to, or exteds, lis nommit capacity. Evaluations to address this risk are ineluded to the project baseline. It may be possible to bygass some or all flow directly to Tank \$Y-102, regolving Lits issue directly.

To support liquidt-valume reduction duning the SST IS Projats, the 242-A Evaporstor will be acheduled to run two evaporator canppigas per yoar through year 2002. Table 4-3 ideotifics the evaporalor schedule. 


\section{5,0 PRDJET STRATEGY}

\section{S.1 OPERATTONS AND MAINTENANCE STRATEGY}

The ramp-up and the extent of the fietd activities neceseary to exocatt this baseline mission sre unprecedented. Substantial upgrades to the operations and meintenance strategy are required.

\section{S.1.1 Operations Siralegy}

The SST IS Project operations grategy is based on the applicable requirements

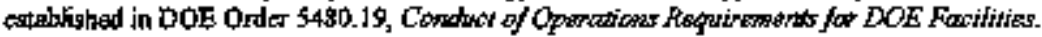
The applicability matrix for DOE Order 5480.19 is deffned in HNF-IP-0842, Volume IL, Section 4.1.1 (LMGHC 1997)). The SST IS Project operatiogs strategy condists of a dedicated 24-how-pes-dey, severi-day-per-week shift operations for momitoring and control of SSTs thal are actively pumping Interim stabilization equipment preparationa, tank isolation, and irturusion prevention activities will contist of a normal dedicated fro-day-per-uveck (Menday through Friday) day-stift operation. The potential exists for a second-shift-pet-day (suing shift) operation for lank preparation as condritione allow, to mainkain SST pemping sturtups as plenned.

In additicm, the SST IS Project wil achicye and maintain the capability to initisue pornping of a declared leaking SST within 30 days with the exception of Tanks C-103 and BY-10S.

Standard operating practices and procedures witl be performad in accordance with

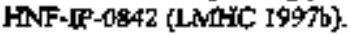

\section{S.1.2 Maintepance Stratexy}

The thation of the IS period is ditectly affexted by the total operating efficiteng of the purnping systetn. This plan is based on an average of $\$ 0$ percent availability of the waltweel purroging gystem. For tanks wlh long pumping durations, increased operaing efficieacy call resuli in dramatic inprovements to the overall complexion schedule.

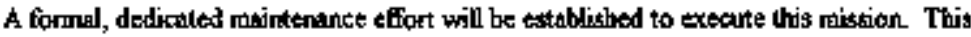
strategy is based on the requicements establisted in DOE Order 4330.4B, Maintmose

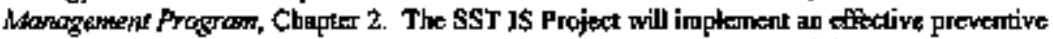
and predictive mentitenance program lhat balances early detection of conditions thas will lead to equipreant faihure and actions that wili ensare retiability over its design lift wilh ALARA. ensideration of the mainterunce persormel

The \$ST IS maintersance sturtegy will continue to axcept the run-to-failure phílosophy of equipmend in high-sadiation and high-contaminalion areas. In other cases, retiability-centered maintenance and preatictive snaintenance techniques will be used consistent with DOE 


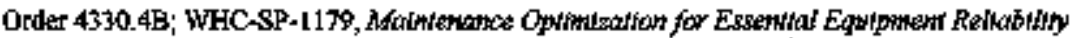
(Steffion 1996): Grood Practies MA-307, Preventive Malntemance, (INP0 85-092); and Good Practice Ma-316, Plant Predicthe Mulntersence, (INTOO 89-009).

The stralegy for $\mathbf{\$ S T}$ is Project maintenance will consist of the propert skilt mix of crafts to support equipment intstallation; prevealive, predictive, and corrective maimtemankes; and equipment removal. The Maintenance Onganization wil conkirue to work the dsy shif five days per wodk to acomplish the effort. However, if necessary, stift support sill be implemented to stopport equipment operability to maint tin pumping efficierrecies for specifle tonk operotions.

Maintenance prectices and proceatures will be parformed in accordance with HNF-P-0942 (LMHC 1997b).

\section{\$.2 NUCLEAR SAFETY AND LFCENSING STRATEGY}

The 30 SSTs yet to be interim stabilized (including Tank C-106) hase been sefarated into two categories, FG2 and FG3 per Tank Wase Renediation Sygtem Basis for Intertm Opterctiont (FOH lG97a) FG2 is made up of $\$$ STS that are postulated to hawe the potentiat for a large

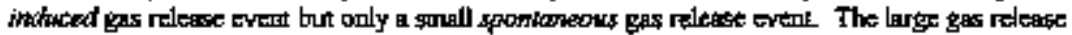
exents pastulated for FG2 SSTs are thase incheced by globaly wastedistarting aperation FG3

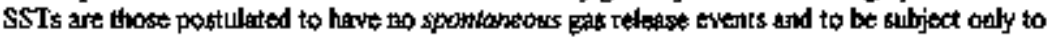
snall indicen gas rejeate extents.

DOE rectly approved an SER that authorizes IS activities for FG2 atd FG3 SST except Tant A-I01. The additional coutrols directed by DOE will be implemented prior to resuming the SST IS program. An addilionol Authorization Basis change will be requlred to pump Tank A-loi.

\subsection{CNVIRONMENTAL PERMITTING STRATEGY}

Table S-1 identifies relationstips between the tanks to be pumped and their regulatory status. Additional safely guidauce is expected from RL to ihe form of an SER

\subsubsection{Asoumpilons}

- All tanks (except T-10 and T-110) will require aclive, standby ventilation to unitigate fammable $g$ as concerns. The veptilation systems will be operated only st flamalable gas concentrations of 25 percent of grealer. 
Table 5-1 Single-Shell Interim Stahilization Permitting Straxtegy

\begin{tabular}{|c|c|c|c|}
\hline Tank & Systemp Deachobon & Noc Sumus & FY \\
\hline SX-104 & 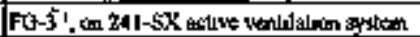 & Shart fionm wothplate & $199 \mathrm{~B}$ \\
\hline $5 \times-110$ & 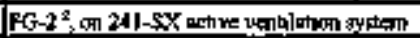 & 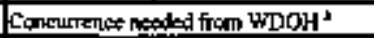 & 1998 \\
\hline T-jo4 & F07-3, painemaly ventalated & Wo $\mathrm{KOC}$ thrulued & 1998 \\
\hline$T+18$ & Fo-3, passurely wentalaled & No NOC repured & 1998 \\
\hline A- $|0|$ & 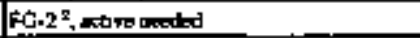 & 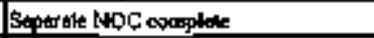 & 1,999 \\
\hline 8-102 & FOt.2, geduve noeded & 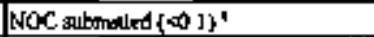 & 1999 \\
\hline 5.103 & 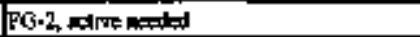 & 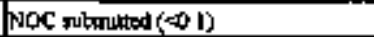 & 1999 \\
\hline $5-106$ & 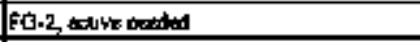 & NOC Bubrouked $(\infty-2)$ & 1999 \\
\hline$A X-10]$ & 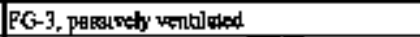 & NOC splemented ( 401$)$ & 2000 \\
\hline$B Y \cdot 105$ & 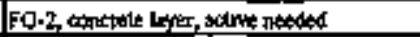 & NOC sobrindled (-a) I) & 2000 \\
\hline $8 Y-106$ & FG-2, nalive nosiled & NoC sulenttod $(-6,1)$ & 20010 \\
\hline 5.101 & ES.2, oduste nealed & 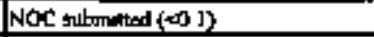 & 2000 \\
\hline $5-107$ & FG-2, Acthve neoded & NOC sulfontted $(-\infty) \mathrm{dj}$ & 2000 \\
\hline 3-109 & FG.2.2 tarte netested & WOC salemented $(-40 \mathrm{~J})$ & 2000 \\
\hline 5.111 & FG- 2 , osquve noeded & NOC sulminted (-4) I) & 2000 \\
\hline c-100 & FO-3.pasalnety yantulad & 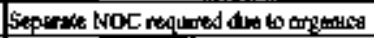 & 2001 \\
\hline 5.132 & FQJ.2, neldre manded & NOC submuled ( 40 & 2001 \\
\hline sx: $10 \mathrm{~s}$ & 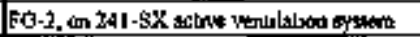 & 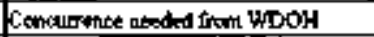 & 2000 \\
\hline $5 \times=|0|$ & 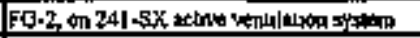 & 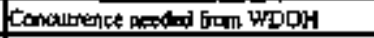 & 2002 \\
\hline $9 x-102$ & 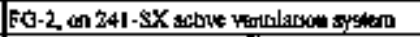 & 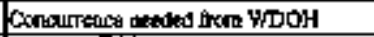 & 2002 \\
\hline $5 x-103$ & 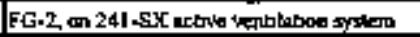 & Contaluturę neoded fram YDOH & $20 \times 2$ \\
\hline$\underline{\mathrm{U}}-\mathbf{3 0 0}$ & FG-2 bedve Dexiled & NOC subentted ( $(0) 1)$ & 20012 \\
\hline ए-]10 & FG-2, antve neaded & 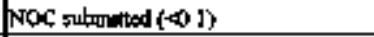 & $20 \times 2$ \\
\hline$[1-102$ & 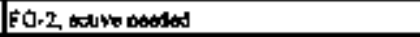 & 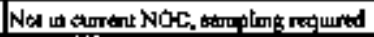 & 2003 \\
\hline 프-]105 & FG-2, paflve noeind & NOC sulm & $20 \times 3$ \\
\hline บ-107 & 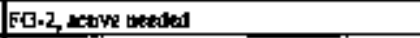 & 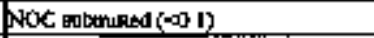 & 2003 \\
\hline$\underline{1} \cdot 189$ & FG-2 welpe ardad & NoC robaufted $(-0,1)$ & 2003 \\
\hline U.III & EO.2. thire beaded & 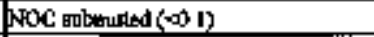 & 2003 \\
\hline फ-106 & 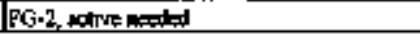 & NOC, subsinted $(-4)$ l) & 2003 \\
\hline
\end{tabular}

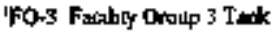

TFo-2 Fechly Group 2 Iadk

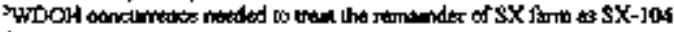

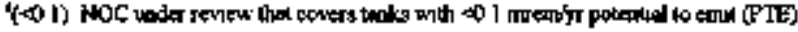

FY = fischl yer

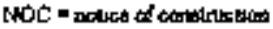

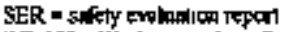

WONH = Washingtow Stete Deparument of Heatlo 
HNF-2058 Rev. 1

- The SX Fosm ventilation system (studge cooler) will be used to satisfly the SER ventilation requirembatt.

- FG3 anks with passive fihers only do not need a separale NOC.

- An NOC for Tank C-103 will be writlen at a later date because of the organic contert

- Tanks A-101 and SX-104 have separate NOCs curtently approved

- The standty aheust stacks will moet complianke requirements to provide the meximum operaional flexibity to TWRS activitites.

\subsubsection{Notkes of Construktion Strategy}

- In addition to soparate NOCC for Tankg A-101 and \$X-104, arother "generic" NOC for minor stacks (potential to anil of less than $1 \times 10^{6}$ siever per year [0. I meendyr]] has been submitted. The NOCC is in the connuant incorporation cycte. All SSTs rematining to be statilized are inchuded in this NOC except for SX tanks (vertilated by the studge cooter), U-102 (inadequate sampting date currently Exists) and C-103 (organic layter itsue)

- If ternks or activities energe that exced the "minot" stack criteria, anther NOC may laye to be submíted for tarks with a potential to enil of greater than $1 \times 10^{6}$ sievert per year (0.1 mothityr).

\subsubsection{Schedule Inqpact*}

- The SX tanks will require concurrence inom the Washington \$late Department of Heslth that the remaining $\mathbf{S X}$ saltwall activities do not increase the potential to ondi, following the logic of tho $\$ X-104$ NOC. If this concurrence is not given, an Notc will hava to be submotted.

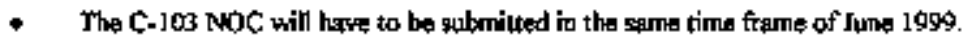

- The additional tanks in the colt-years would be permitted using this same strategy. 


\subsection{SINGLE-SHELL TANK INTERIM STABIJRATHON PRONECT BASELLINE}

\subsection{INTRODUCTION AND BASELINE PLANNING PROCTSS}

This section provides a sumnary of the bageline (scopes thesdule, and cont) to complete the SST IS Projext. This baseline was prepared in accordance with the RL lotter to FDH (Sieracki L998) and followion correspotwertice from FDH to LMHC (Hoogendoom 1998). LMAKC to FDH (Wood 1998), and RL to FDH (Sieracki I998b and Sieracki 1998c).

DOE iritially directed the preparation of three scentrios for crimpleting SST IS. The

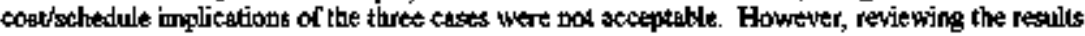

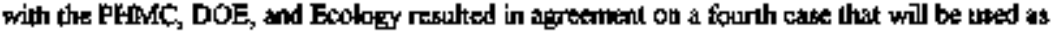

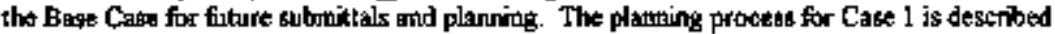
below, The information developed for Case 1 was then modified to reflect gods and constrahts of the Bare Case for thit revition of the Project Plan.

The sygtamatic and controlled babeline planning process developed and implenneriked

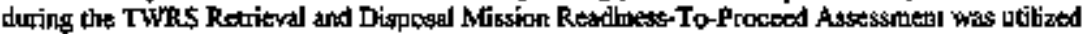
io dervedop Case I for SST is.

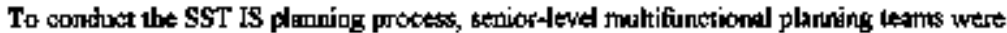

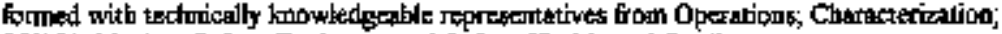

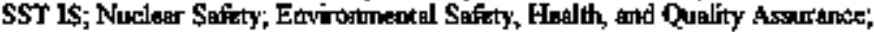

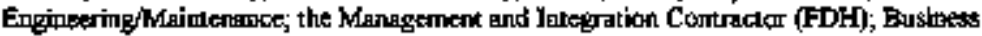
Management (acheduling and cost stimatigig); and the Chier Francial Officer. Teem leads were aspigned to the planning efforl commensurele with the lype of work being addrested. Use of

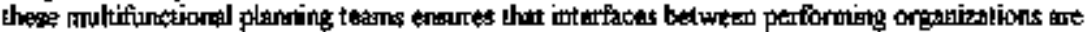
identified for each activity and serieg of activities and that programb, projects, and operalions work are integrated.

To define the soope of work, Leval 1 logic diagiants prers prepared to address all rectired

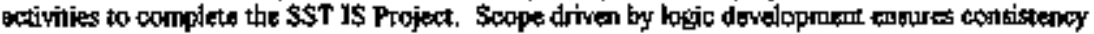

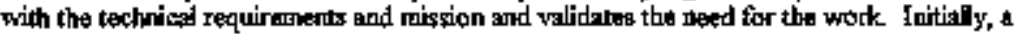
venteric logic dingrara was developed that illugtrates the typical activities (and the relatioushipg) aecestary to perform anfe and compliart tank satabilization and isolation, This logic diagrant includes reference activities, program-unique activities, and tank-unique activities. Uying this gentric logic, as well as other technical ard engigeering data, tank-specific Level I logic diagrams were developed to fully define the stope of work for each of the 29 tanks in the project.

Following developmenl of the tank-specific logic diagrans, the SST is Project Work Brealdown Structurte (WBS) was prejered as the framework for definith the remaining project whorkscope.

Using the proyect WBS and activitives idearited on the Level I logle diagrams, technied bagis revicew narratives were prepared to fully defime and document the 1echnicel basis, 
stamptions, tisks, and ialetfaces for each trivity. The technied basis review narratives inchude the following informalion:

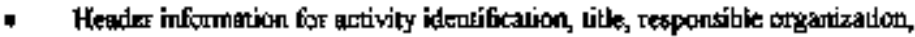
responsible manager, technical conternt, and duration

- Technical basig

- Reference doouments and reports

- Enabling assupuptions

- Functional requirements and deliverables

- Conection with Gher activitiesiorganizations

- Trade studies

- Decisions medefrequited

- Risk isoues

- Plan lo resolye riskipalh fonward

- Courtacs

- Funther action recommended

- Approved gignalutres.

With the scope and activily definition provided by the Level 1 logic fiagrams and tectinical basis review narritives, the planming tesms then broke down each of the activities and its kgic to prepare tbe essential eomponents for technial busis reyiew packages. These compontents inelude the following:

- Technica basis review (Levell 1 logie activity) control logs

- Technical betis review narralives

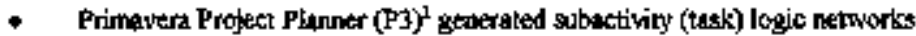

- Snbactivity (takk) cold-estimating input tbets (CEIS)

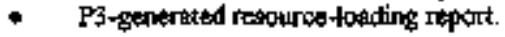

This lewel of detail is necessary to adequarely defing and docament the basio for the stopt

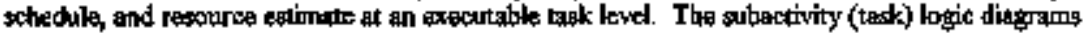
provide titles for the tasks, predecessor and successor activities, durations, and logic ties. The CElSs define the subactivity (1agk) scope, resoures, basis of estimatie and assumpitions.

'Primavera is a trademinck of Primavera Systemt, Inc. 
The following data are docamented on the CElss.

- Hapder informalion inchuding subactivity (tagl) title, reference technical besis review number, activity ownar, proparer, dale prepared, revision number, schedule

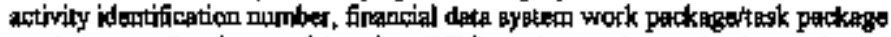
nurber, overall estimate of duration, TWBS number, and earted yalue inethod.

- Subtakk activiky number

- Orrve codes

- Subtask description

- P3 resource code

- Organization code

- Cost edencent

- Fund type

- Resource descriptín

- Note referemiter

- Totul anculat (of resourcea)

- Uatitg of rescurse

- Scope description

- Egtimating abeumptiong/exclutugions/riaks

- Bssis of estimate

- Estimate stago and method

- Reforence documperis

- Notes.

The CEISs were prepared by the plantring tedins wilh the astistarke of profestionsl schedulers and cost eslitrators using detaided desk instnuctions and gardelines. These completed estimates are activity based and represent a wedl-documented, traceable scope and basin for the thimete at the executable task level comenesturate with the stage of the work and the level of acope defínition avalabłe. 
Using the Lovel I logic diagrams, data fion the deaft technical basis reviou packaged, and other infornation, as required, a detalled irtegrated schedule was developed it P3. This base schedule is task orienled, resaarce boaled, and logically driven and contains a critical path. This schedule is iraceable to the logic diagrams, WRS, activity owners (performing organizations), and technical basts review datr includiag the CEISs. This schedule wrs reviewed and retised to refime

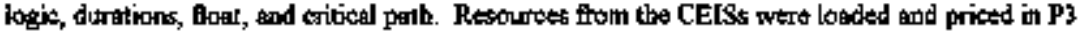
to produce the base case cos! and labor resource (fi]l-irge equivaleat [FTE]) summaries for work defined in the Lond I logic diagends. FY 1998 FDH-approved labor-rate tabkes were used in P3 for pricing.

The final tochnichal bagis reviow pachages (Rey. O) wero prepared from the approyed achadula, consisting of and supported by the technical basis review packaga control logs, echnicat

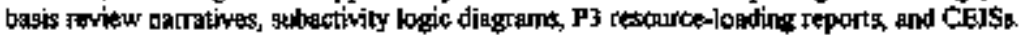
These packages wore approved by both the activity owners and project managenedr.

A very cost-effective and efficient apprasach was utifized tor preparalion of \$ST IS Project technical basis review data packages. Fully constituted techutical bagis review packageg (comtrot logs, technical besis roview sarralives, subactivity logic diagrams, CEISs, and PJ regource roports) were assembled for all activities (boxes) shown on the generic Loved I logic diagrant. These technical basis review packages bacame the "library" of data ubed to deviliop the 29 tank

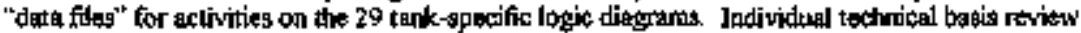
packages were not prepared for each activity on the 29 tank-spexific logic diagramb.

Each of the 29 tank "data files" wag assernbted uaing a tank-apecific logic matrix that

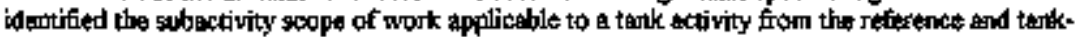
unique "bibrary" of technical basig review packepgex. This malrix was complated through a

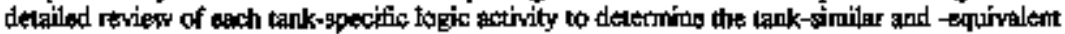
activities from the genseric reference technical bassis review packages. This approach growides for a reference back to the "Iibrary" of scope, schedule, end estimate data withourt unnettssery dupfication of tectutical basis review package domamentalion. The latk-specitic logic matrix is included in each tank "data fle."

\subsection{WORK EREAKDOWN STEUCTURS}

Figute 6-1 depicts the TWRS WBS to Lovel 6. SST Maintentince and Operations

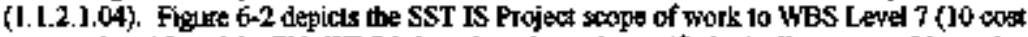
accounts) and Level B. This WWS is besed on the capk-stecifie logie diagryens and is used as the framewotk for scope fefinition, schesuling estimating, budgeting. and mangging the work. For this projest plan, the WBS hus betn revised to idedtify (1) ondy the remuining scopte of work (contpkted work is not thown), (2) numerous WBS Leved 8 atd bejow changes to facilitate incorportion of agw or revised scope defined by the kotic and technical basis review developunent plamining, and (3) the ardition of WBS \# 1.1.2.1.04.72 to break ourt pemping operations for the 29 remaining \$STs.

In Figares 6-1 and 6-2, the SST IS Project is identified as part of Tank Wagt Operations (WBS 1.1.2.1). Near-term WoS changes are axpected to reflect moving the project to Watte Characterizalion (WBS 1.1.2.4). 


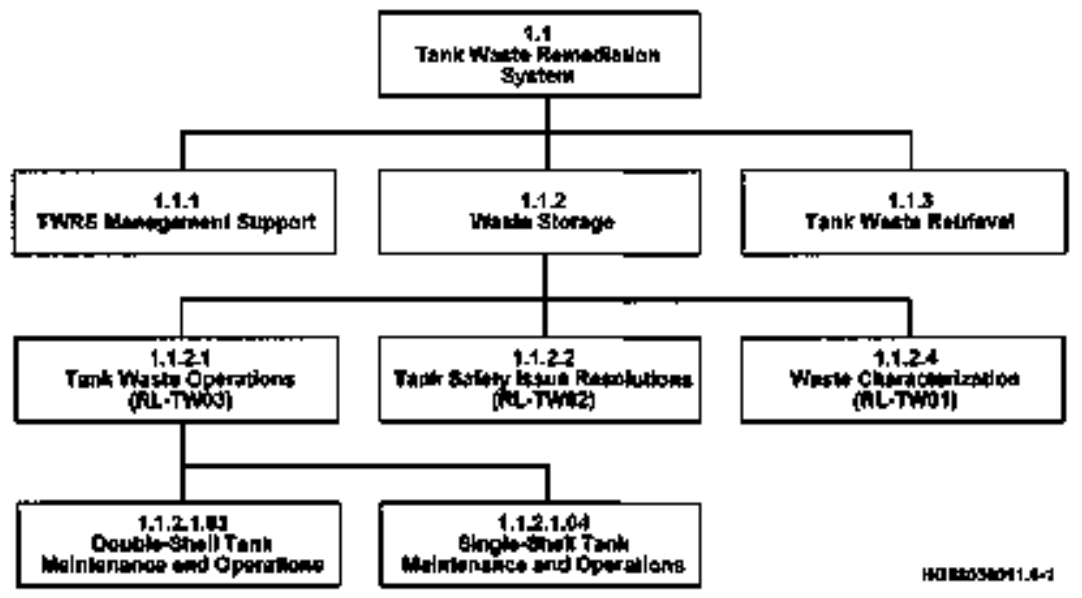

Figure 6-J Tank Waste Remeatiation System Work Breakdown Stnucture 


\subsection{LEVEL I LOGIC}

The Lewel 1 logic diagrans urere developed to defite the scope of work requited to complete the SST IS Project. The bogic diggrams are took for translating the project milsingn requirements idetiflest in Section 2.0 itto a seguence of activities and logical interdependencies

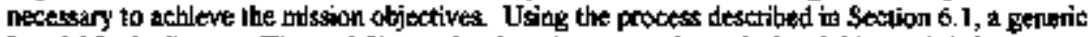
Level 1 logic diagratr (Figure 6-3) was deweloped to cover the typical activitiks and their

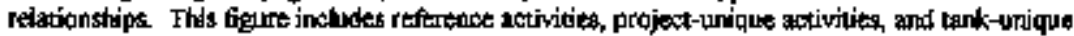
activitiog.

Twenty-nine tank-gpecific Level l lagic diagrams (Appendix E) were then developed to idkantify tank-specific activities induding tank-unique activilies, sinnibar activities, and equivalent activities. The similar and equivaleat activities are defined by their rebationships to the refertence activities on the Figure 6-3 kogic diagram. These bogic diagrams are traceable to the TWRS program (Level 0) logic that is uasod to identify the giructure of activilies necossory los actieve the antire integrated TWRS mission (Iire cycle). SST IS is ropresented on the procratm (Level 0) togic by Box 623, "Perfonn Saltwell Pumping and Intewsion Pressention," consistent with the activity coding on the Level ] lowic diagrams (23X.XXX).

The Level I logic diagrams were then used as the basis for preparing the technical basis

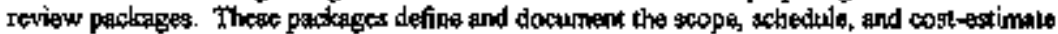
torgeline data and are urder configmation coptrol. The level I logic diagrams identify the

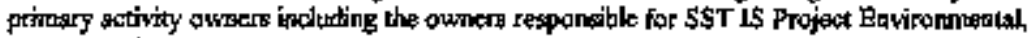
Nucdeat Saforylicensing, Characterization, Dperations, and Projects and RL. The dingrams also depict the logic tias and congieted activities. Breakdown of the Level 1 logic diagrarns through thes techrical busis review planning process results in the kgic-driven, resource-loaded, criticalpath orcheduik (refer to Section 6-4).

The Lovel 1 logis diagrams and schodule are integrated with the WBS. Table 6-1 is a worswalk of the Level 1 logic diagram activities to the WBS.

\subsection{SCHEDULE}

\subsubsection{Base Case Solvedult}

Using the process detcribed in Section 6.1, a detailed base cate SST IS integrated deteil schedule (Appetedix D) was developed. Figure 6-4 identifies the pumping durations tord counpletion diats from the schedule for stabilization of each tank. Figure 6-5, an integrtated RL-WBS summary schedude, whe generoted from the Appendix D detailed schedule.

The bare case detailed schedule is formalted to identify Leved l logic activitien wilhin anch WhS Lovel 8 elememt. The schedule was developed from, and is consistemt wilh, the Level 1 logic diagrams and technical basis review package data doveloped to define the scope, gethedule, and cost tor the renatinder of the \$ST IS Project, effectine Apil 1, 1998. This schedule was prepared in P3, is talk oriented, logically drivea, and reocurce loaded, and conaing a critical path. 


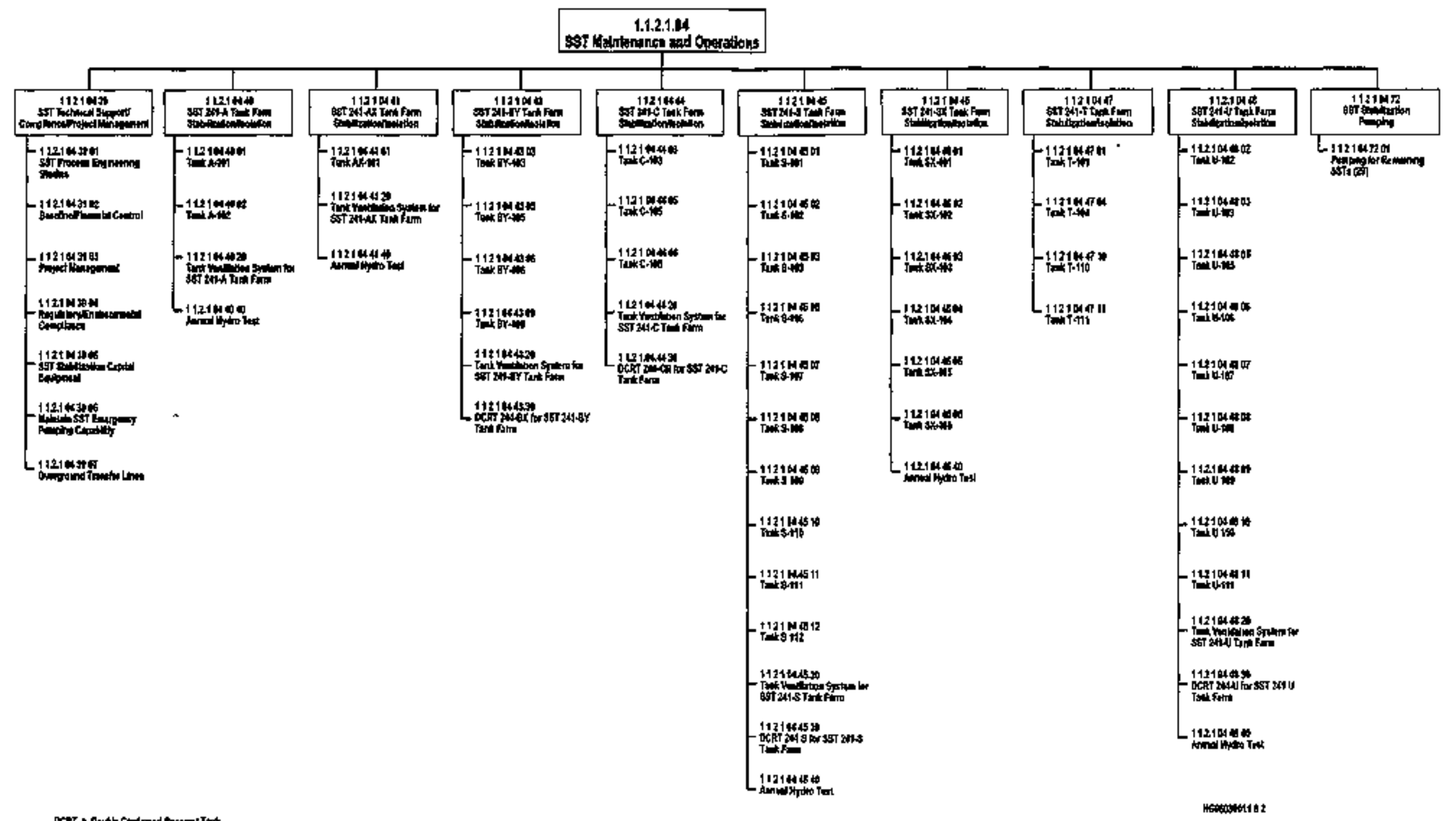




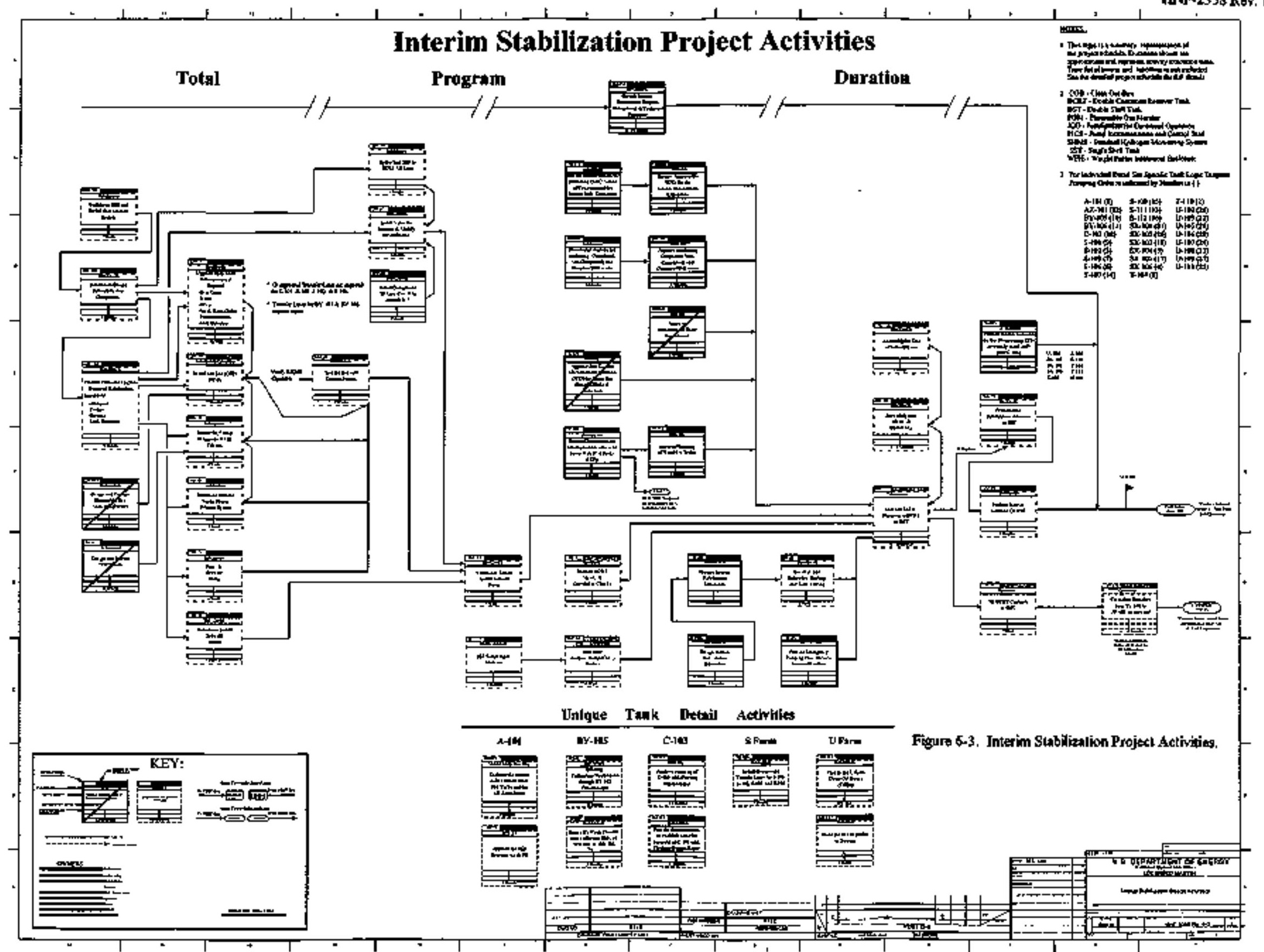


Tabto 6-1. Sindo-shed Tank Interin Stobllisalio Loved I Logit'

Work Breakdown SAractere Crastwall. (IS Stetit)

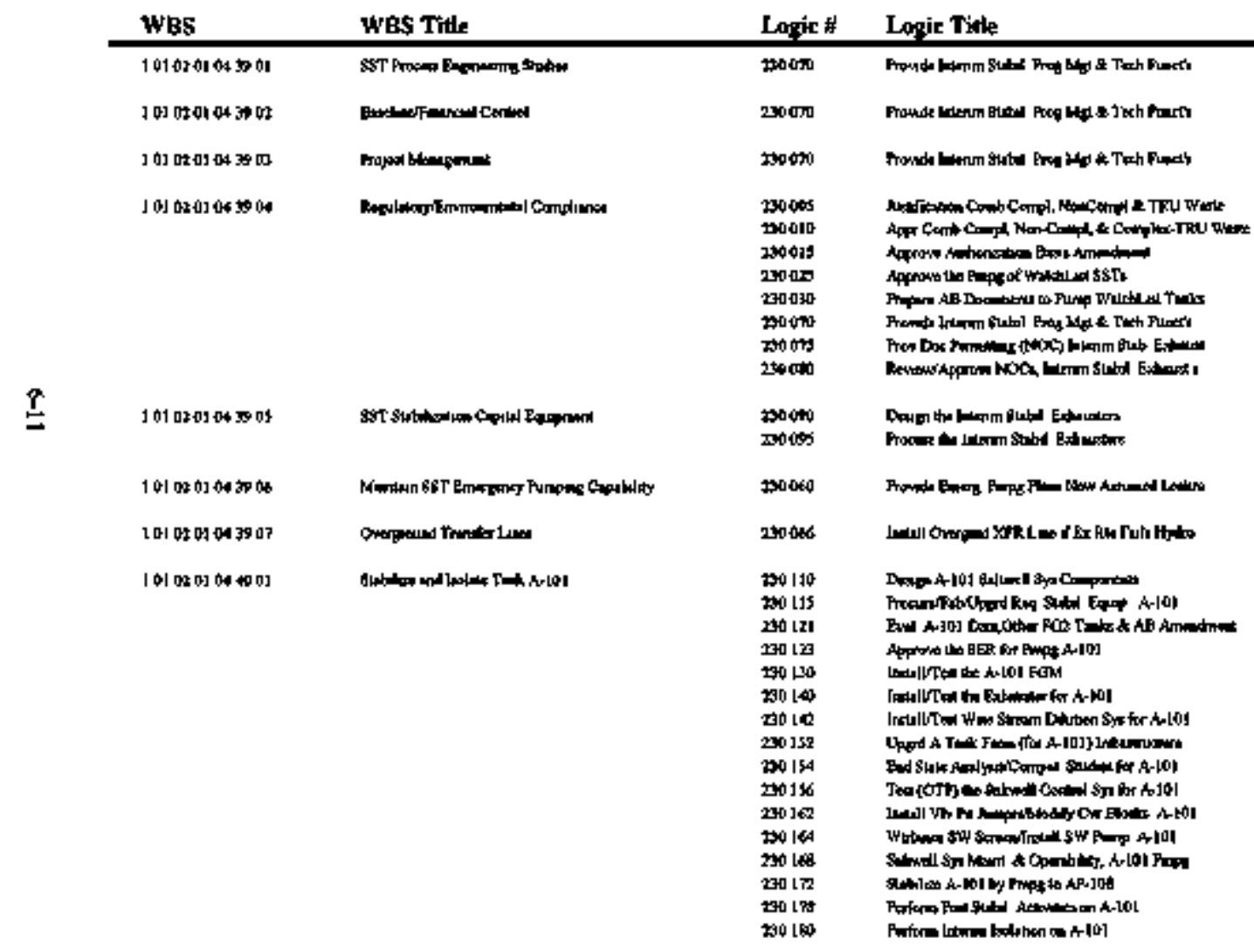


Table 6-1. Single-Shen Tank Interion Stabileation Leved I Logiet

Work Breakdown Structure Crouswall. (15 Skeets)

\begin{tabular}{|c|c|c|c|}
\hline Was & WES Tide & Lopic \# & Logic Title \\
\hline 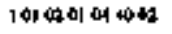 & 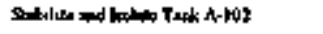 & 2ho oess & 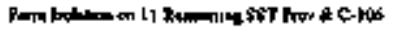 \\
\hline J 01020104 40 20 & 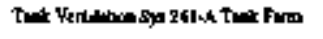 & 3140 & 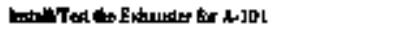 \\
\hline J 01020104 को & 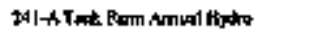 & 2014 & Mnf \\
\hline J 0902010401 & 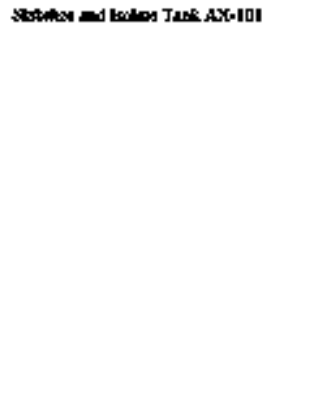 & 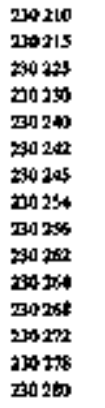 & 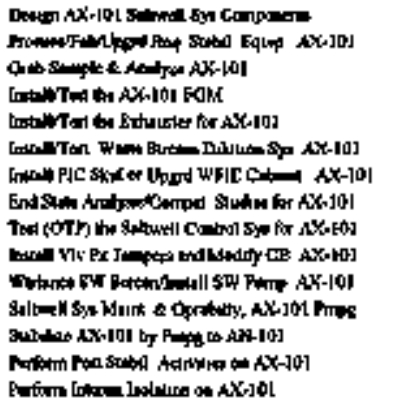 \\
\hline 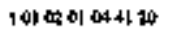 & 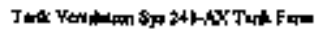 & $2 \$ 0$ 20 & 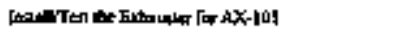 \\
\hline 1010201044140 & 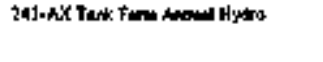 & $\operatorname{mos} 274$ & 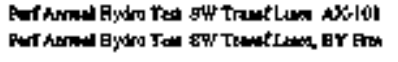 \\
\hline 101 他证 04 w & 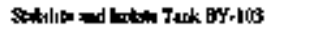 & 2009 & 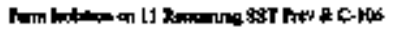 \\
\hline 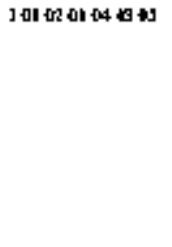 & 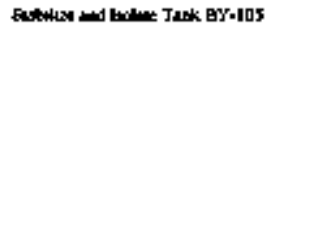 & $\begin{array}{l}230305 \\
20307 \\
30310 \\
20015 \\
230300 \\
20390 \\
20345 \\
20354 \\
230354\end{array}$ & 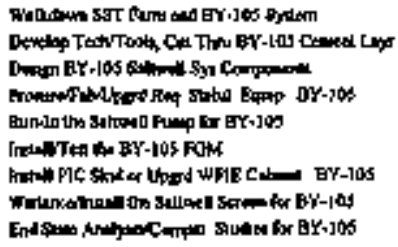 \\
\hline
\end{tabular}


Table 6-I. Simele-Shen Truk Interwa Stabfizetion Lewed 1 Logikt

Work Brealtudow Struelure Crosowalk. (15 \$heetu)

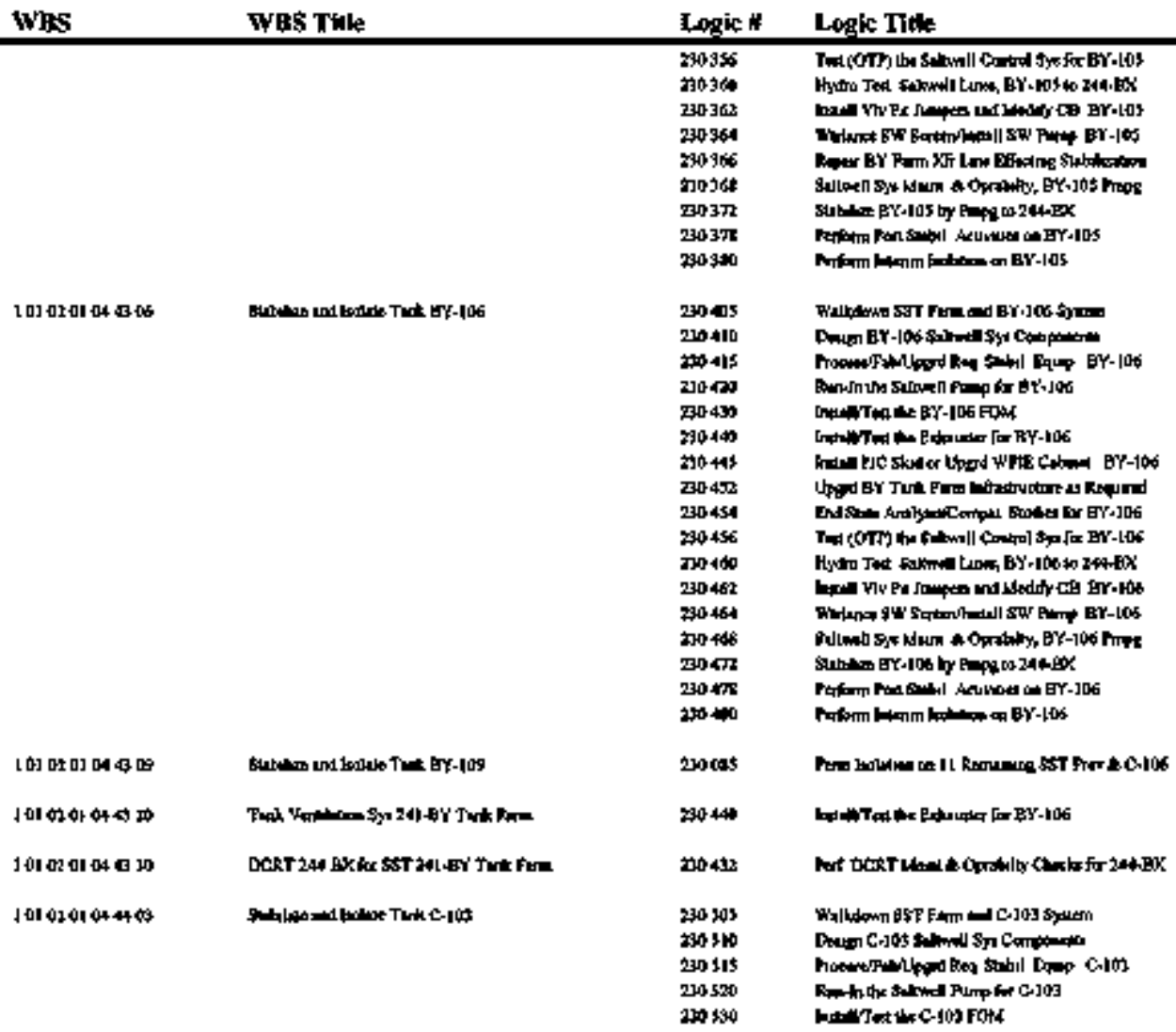


Tabje 6-I. SIngle-Shen Tank Interia Stabilization Level 1 Losici

Work Breakdown Struthe Crosswalle. (1S \$hesti)

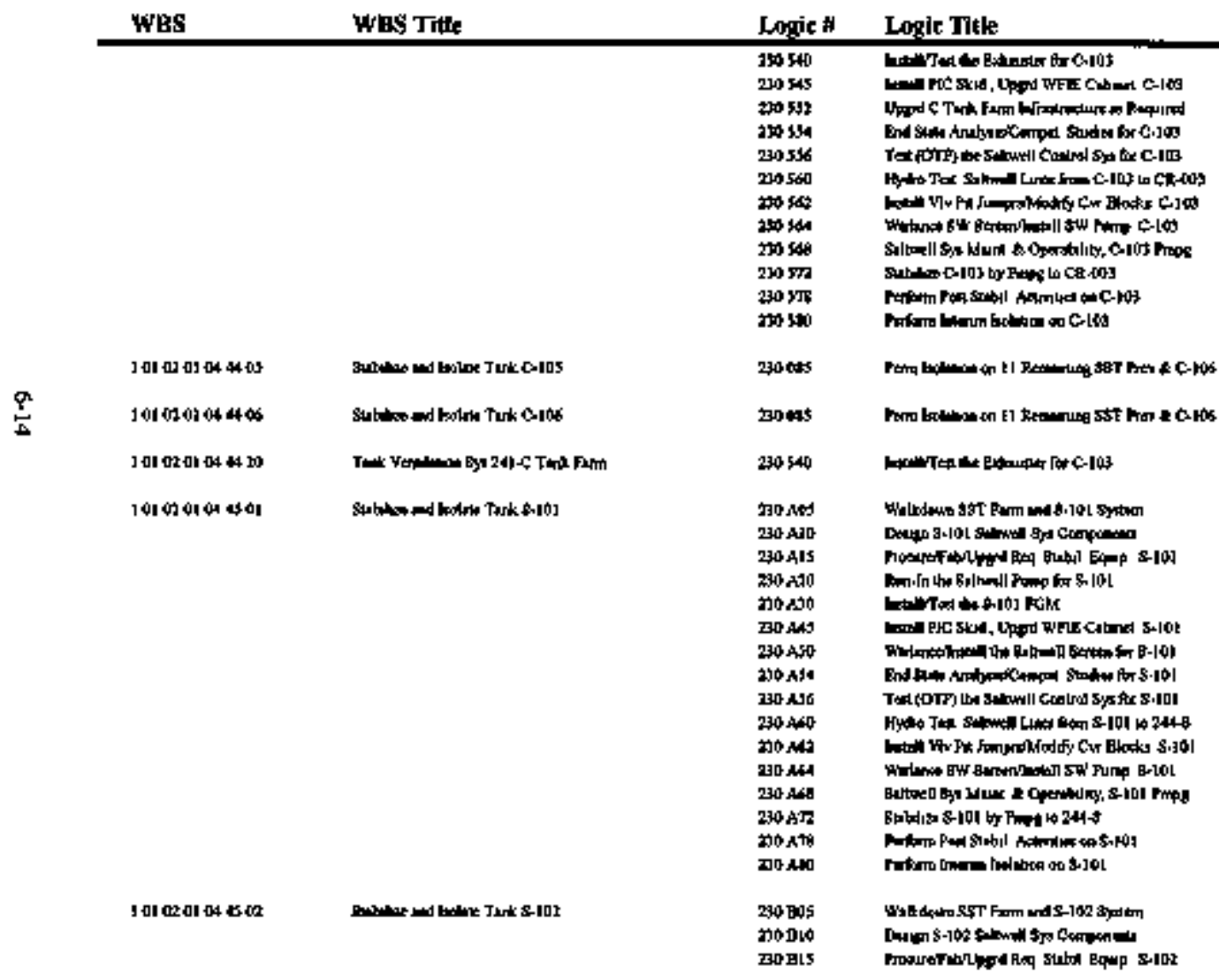


Table 6-1. Single-Shell Tank Interim Siablikntion Level 1 Lofinkt Work Breakdown Structure Creaswalk (15 Sheets)

WBS

Itel 的 ol 14 $15 \%$

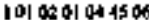

wBS Title

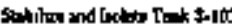

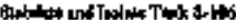

Lopic \# Lapic Tite

\begin{tabular}{|c|c|}
\hline $2307 \times 0$ & 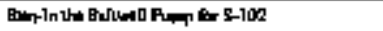 \\
\hline 230 Bato & 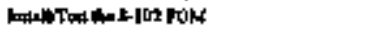 \\
\hline $20 \mathrm{Bmo}$ & 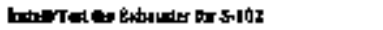 \\
\hline tot? Ba? & 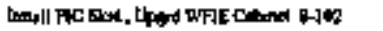 \\
\hline Y010 & 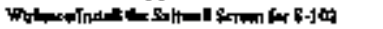 \\
\hline 出口 bos & 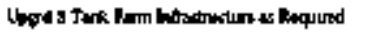 \\
\hline Zugsi & 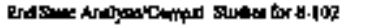 \\
\hline 29086 & 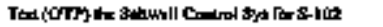 \\
\hline 270,805 & 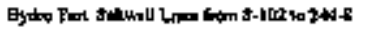 \\
\hline 200002 & 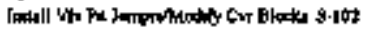 \\
\hline 2904 & Whece \& 4 Som \\
\hline 光口DS6 & 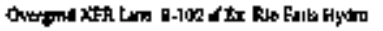 \\
\hline 230 TSE & 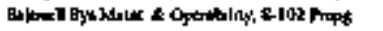 \\
\hline $270 \mathrm{Bn}$ & 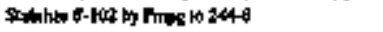 \\
\hline zato Bit & 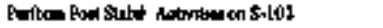 \\
\hline 2ato & Porren [- \\
\hline zachs & 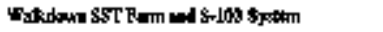 \\
\hline 20010 & 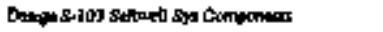 \\
\hline 270 디가 & 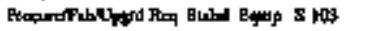 \\
\hline 2900 & 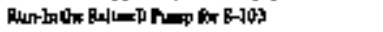 \\
\hline tath cors & 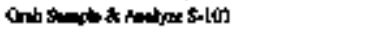 \\
\hline It口 CS4 & tonentertersids Fon \\
\hline 230 cht & 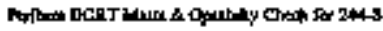 \\
\hline 23000 & 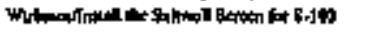 \\
\hline $230 \mathrm{cs}$ & 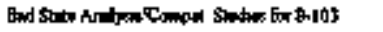 \\
\hline 200 & 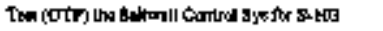 \\
\hline $\mathbf{Z Q \phi 6}$ & 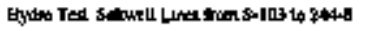 \\
\hline 23002 & 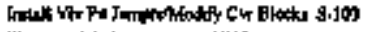 \\
\hline $2 \pi 064$ & 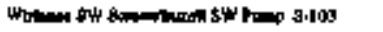 \\
\hline $20<x$ & 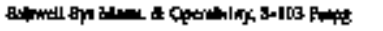 \\
\hline 230 cht & 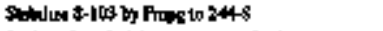 \\
\hline tate cer & 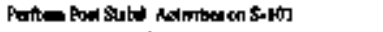 \\
\hline 2000 & 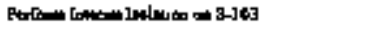 \\
\hline 23a Dos & 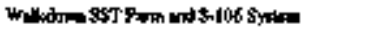 \\
\hline Zыם Dю & 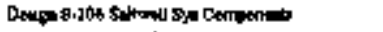 \\
\hline 200015 & 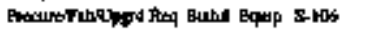 \\
\hline F01000 & 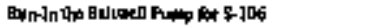 \\
\hline
\end{tabular}


Table 6-1. Single-Shell Tank Interim Stabllization Level I Loglet Work Beselodown Suructure Crossws:" (15 Streets)

WDS

$\cot 03$ or od ds

1 마 Dot 마 De 43 ot

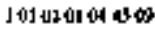

WBS Titu

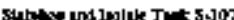

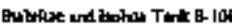

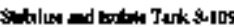

Lotic \#

230030

2000

200 DM?

230 我数

230054

230 054

29006

$2500 \times 4$

2notion

230 D64

200 Cat

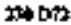

$23007 t$

2300007

$230 \mathrm{D} 00$

20ens

200 El0

20019

20 pers

230 800

ito Ess

$230 \mathrm{ESC}$

DOESG

$23 \mathrm{~B} B$

25000

$230 \mathrm{EG4}$

20 ES:

27. 67

$230 \mathrm{E}$;

troE品

230045

Dofors

230 FID

$2 \mathrm{~s} P \mathrm{P}^{\circ}$

Tho Pro

230

\section{Lagic Tintt}

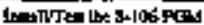

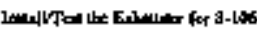

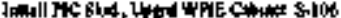

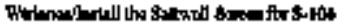

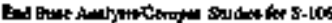

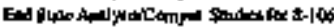

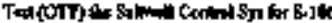

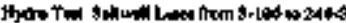

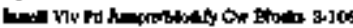

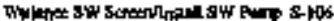

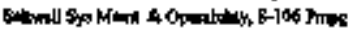

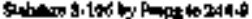

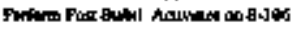

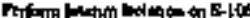

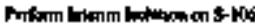

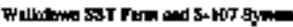

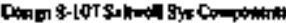

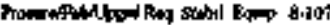

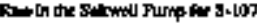

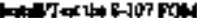

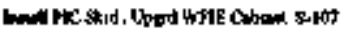

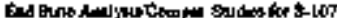

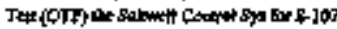

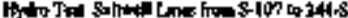

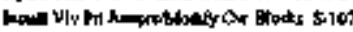

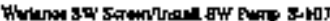

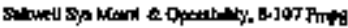

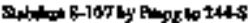

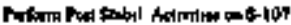

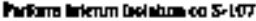

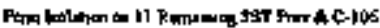

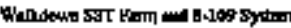

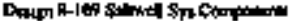

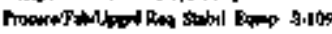

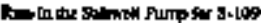

In: 
Table 6-1. Singk-Shat Tank Interim S1abilixation Lewel 1 Lojict Work Brealudewn Stracture Crottwalk. (I5 Strets)

\section{WES}

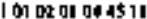

I W Ot. 04012
WES Title

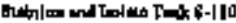

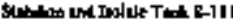

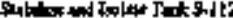

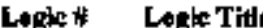

\begin{tabular}{|c|c|}
\hline $230 \mathrm{Fad}$ & 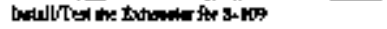 \\
\hline 230 Fas & 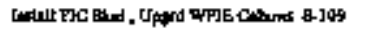 \\
\hline $230 \mathrm{FY0}$ & 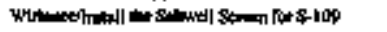 \\
\hline $250 \times 4$ & 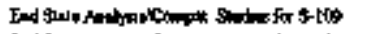 \\
\hline $230 \mathrm{FSA}$ & 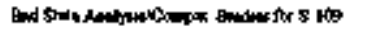 \\
\hline $230 \mathrm{rs4}$ & 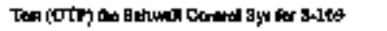 \\
\hline $\pm 90 \mathrm{FeO}$ & 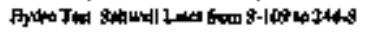 \\
\hline $2 \times 0$ rat & 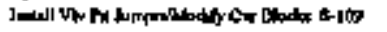 \\
\hline $20 \times 1 \times 4$ & 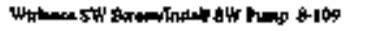 \\
\hline 230 tor & 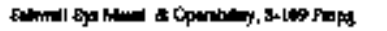 \\
\hline 230,72 & 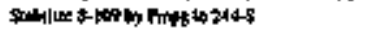 \\
\hline INo Fit & 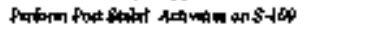 \\
\hline 250 ind & 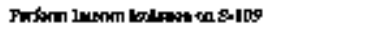 \\
\hline $230 \mathrm{rm}$ & 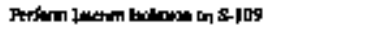 \\
\hline 2000 & 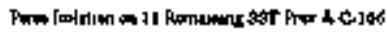 \\
\hline 230 oos & 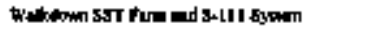 \\
\hline 20010 & 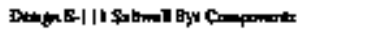 \\
\hline 200013 & Procualdat/ \\
\hline $230 \cos$ & 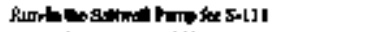 \\
\hline 230030 & 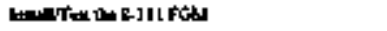 \\
\hline 1400 & 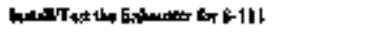 \\
\hline 25004 & 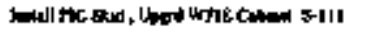 \\
\hline 230 - & 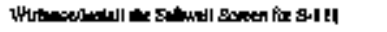 \\
\hline 130054 & Fed Bulx \\
\hline 210056 & 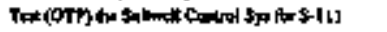 \\
\hline 23000 & 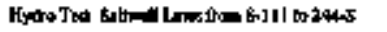 \\
\hline 230 thts & 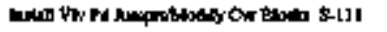 \\
\hline 230064 & 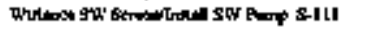 \\
\hline 290068 & 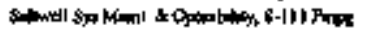 \\
\hline $330 \mathrm{n}$ & 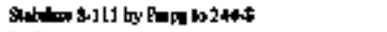 \\
\hline 23007 & 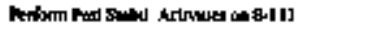 \\
\hline 2000 & 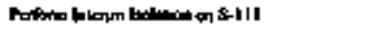 \\
\hline 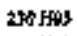 & 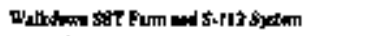 \\
\hline 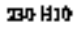 & 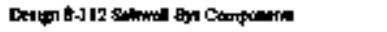 \\
\hline בנג 230 & 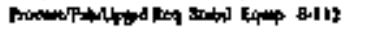 \\
\hline ID & 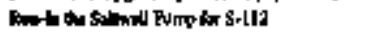 \\
\hline
\end{tabular}


Tabje 6-1. SIngle-Shell Tank Interin Stabilizalion Lewd I Lopiet

Wark Breskdown Structure Crouswent. (15 Sheet)

WBS

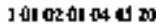

$\stackrel{9}{\frac{0}{2}}$

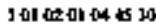

1016201044940

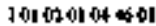

WEST Title

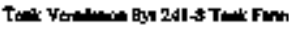

DCRT 144-s [m SST 241-6 Tha Fwh

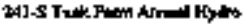

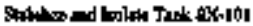

Loric i

$230 \mathrm{Kas}$

230 HCO

200 日十

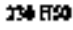

230

$230 \mathrm{KC6}$

$290 \mathrm{HeO}$

27861

I $\mathrm{RA}$

$23 \%$ HAS

$230 \mathrm{~km}$

$200 \mathrm{HW}$

230110

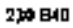

Itson

Do $1 \times 0$

mon

政为

200 10 10

230 B?d

23000

एव

20115

2000

23005

$2 \% 130$

2010

$\operatorname{man} 145$

30 oso

20154

230186

20000

$230 \mathrm{mI}$

230164

$\sin 6 \mathrm{~s}$

\section{Logic Tite}

Gub Sunte as andyz:

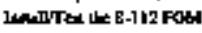

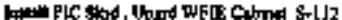

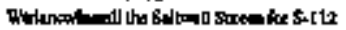

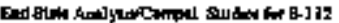

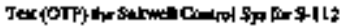

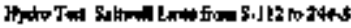

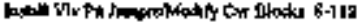

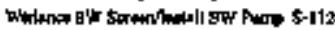

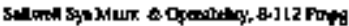

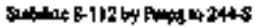

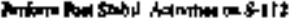

nitim berim beviluce an 3-1]2

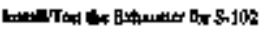

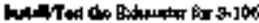

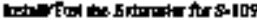

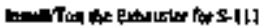

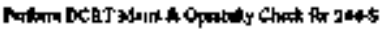

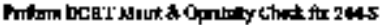

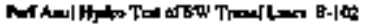

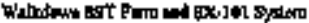

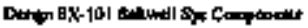

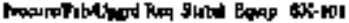

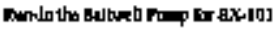

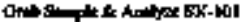

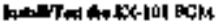

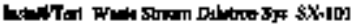

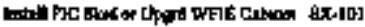

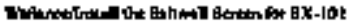

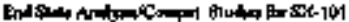

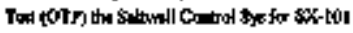

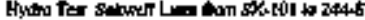

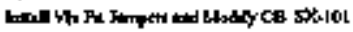

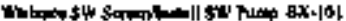

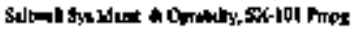




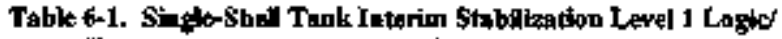

Work Braladown Strocture Creswalk. (IS Sheets)

WES

$101020104+602$

101020104603

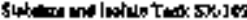

Whs Title

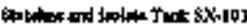

Loghe H

wh

tom

200

230 kJ

$20 \times 10$

$200 \mathrm{Kr}$

230130

230 K25

$230 \times 30$

$290 \mathrm{~K}+1$

2100XAs

$230 \mathrm{ket}$

$230 \times 54$

$190 \mathrm{KS}$

sol $\mathrm{k}$ eO

200500

$150 \mathrm{R} 64$

j50 Kat

$290 \times 72$

$230 \mathrm{KR}$

20 KO

230 Los

$230 \mathrm{LL}$

130 Lis

to 54

IJ9 L)

200 LA2

150 Lis

20104

30 LS

23 U.

IJo Lot

27056

$23015 t$

236 โ27

istit Lit

IJo Ls:

\section{Legle Titte}

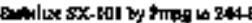

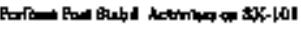

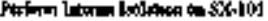

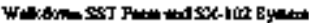

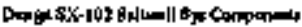

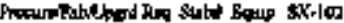

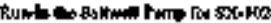

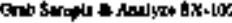

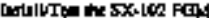

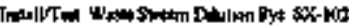

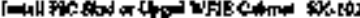

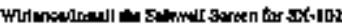

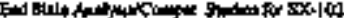

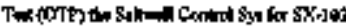

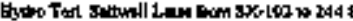

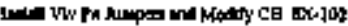

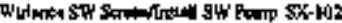

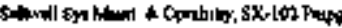

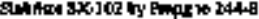

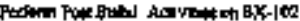

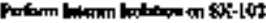

Woxtomisst Ftre and SX.10J 5yme

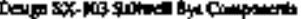

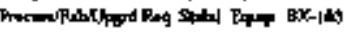

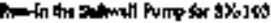

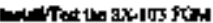

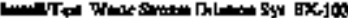

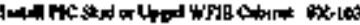

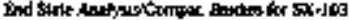

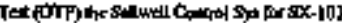

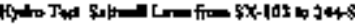

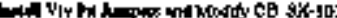

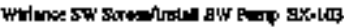

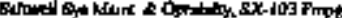

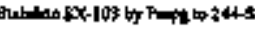

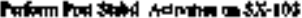

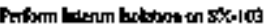


Table 6-1. Stingle-Sheil Tank Iaverim Stabilization Level 1 Logte' Work Breskdewn Structure Crosigalk. (15 Swets)

\section{WhS}

101 영 이 어 46 는

1010001044600

J $01001040 \%$
WhS Tille

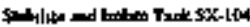

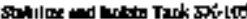

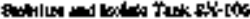

\section{Logic i Logic Title}

\begin{tabular}{|c|c|}
\hline 200302 & 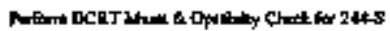 \\
\hline 200104 & 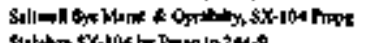 \\
\hline Dother & 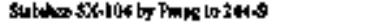 \\
\hline अMTा & 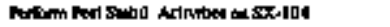 \\
\hline 27040 & 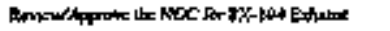 \\
\hline $\mathbf{d} \boldsymbol{d} \mathbf{W} \boldsymbol{x}$ & 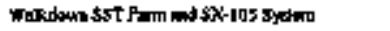 \\
\hline TूWIO & 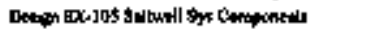 \\
\hline 230 בנה & 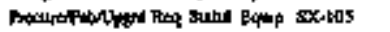 \\
\hline 2032 & 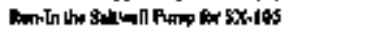 \\
\hline 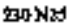 & 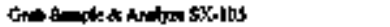 \\
\hline דN. & 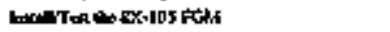 \\
\hline $230 \mathrm{~N}+2$ & 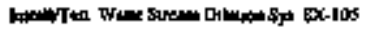 \\
\hline 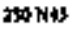 & 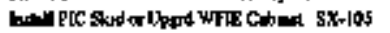 \\
\hline 230 N190 & 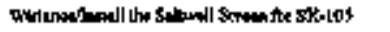 \\
\hline $230 \times 54$ & 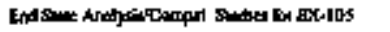 \\
\hline 230356 & 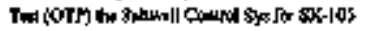 \\
\hline 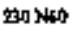 & 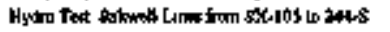 \\
\hline $24 \times 192$ & 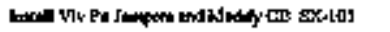 \\
\hline $230 N 64$ & 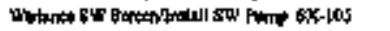 \\
\hline Itowat & 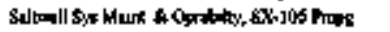 \\
\hline 2נח & 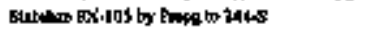 \\
\hline 2) NT: & 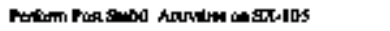 \\
\hline 7X0NDO & 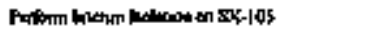 \\
\hline 20 pos & 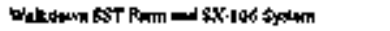 \\
\hline $\boldsymbol{Z} \boldsymbol{Z}$ & 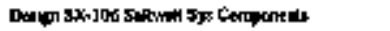 \\
\hline ZMFPIS & 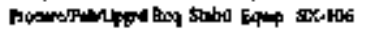 \\
\hline 20 pyo & 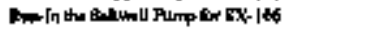 \\
\hline 200 & 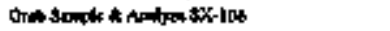 \\
\hline 230 pu & 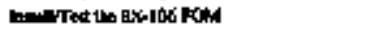 \\
\hline 2) P42 & 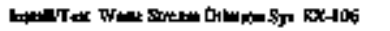 \\
\hline 2084 & 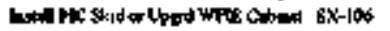 \\
\hline $250 \mathrm{PIO}$ & 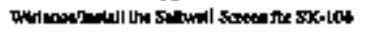 \\
\hline $230 \mathrm{P32}$ & 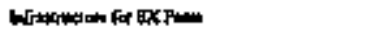 \\
\hline $2 \times 004$ & 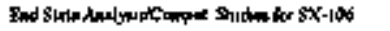 \\
\hline 930t6 & 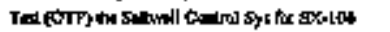 \\
\hline $200 \mathrm{ect}$ & 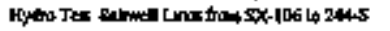 \\
\hline
\end{tabular}


Table 6-1. Single-Shell Tank Interina Stabikation Level 1 Logief Wark Breskdowa Struttart Crostwalk (15 Shetde)

\begin{tabular}{|c|c|c|c|}
\hline Was & Was Title & Lafic & Lotgic Tile \\
\hline & & 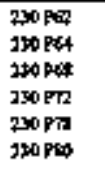 & 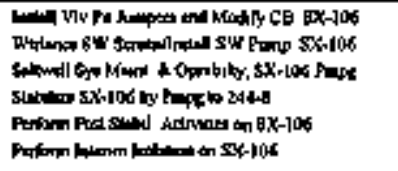 \\
\hline 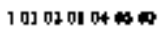 & 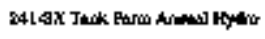 & $\mathbf{m} 0 \mathbf{3} 74$ & 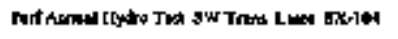 \\
\hline 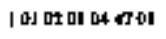 & 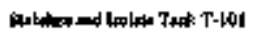 & 230 ads & 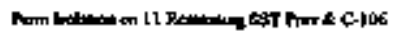 \\
\hline 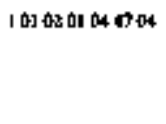 & 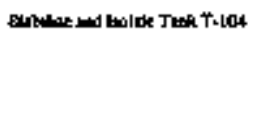 & 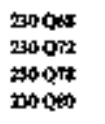 & 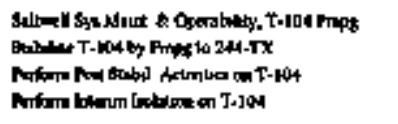 \\
\hline 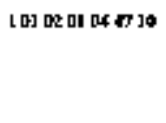 & 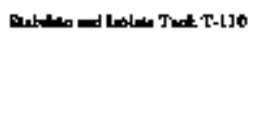 & 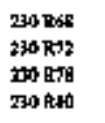 & 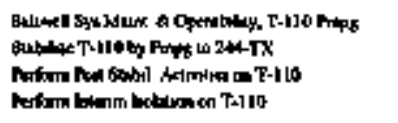 \\
\hline 1010201040311 & 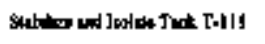 & ało ors & 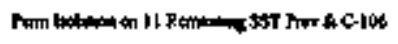 \\
\hline Lot or as outar & 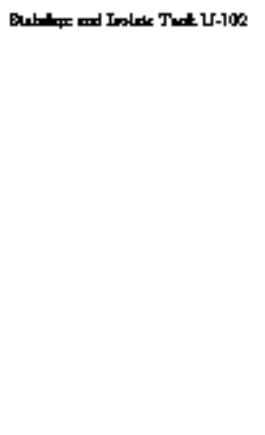 & 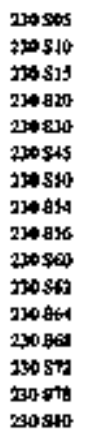 & 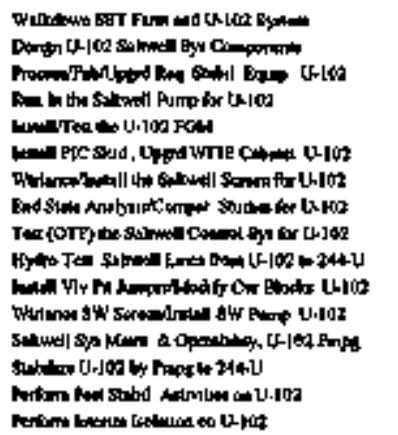 \\
\hline
\end{tabular}


Table 6-1. Single-Shell Tank Interim Siabllanton Leved 1 Loplot

Wark Breshdawn Structurs Crosswall. (IS Shetis)

WBS

10102 이 어 48 a3

10100 ol OA AR OS was T1tk

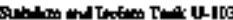

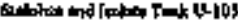

\section{Logles Lete Tith}

\begin{tabular}{|c|c|}
\hline rotos & 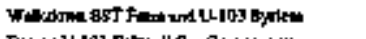 \\
\hline $2 \$ 0 \mathrm{~T} \sqrt{0}$ & 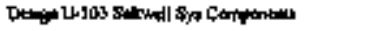 \\
\hline $\begin{array}{l}\text { 240 T13 } \\
\text { 210 T力s }\end{array}$ & 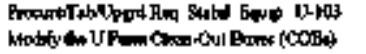 \\
\hline Fot? & 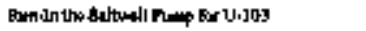 \\
\hline 2305730 & 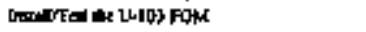 \\
\hline zotom & 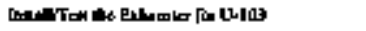 \\
\hline $290 \mathrm{Tu}$ & 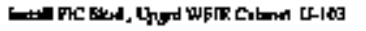 \\
\hline $200 \mathrm{r}+3$ & 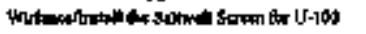 \\
\hline 230 Tsy & 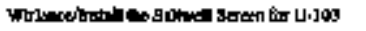 \\
\hline $2 \boldsymbol{2} \mathbf{T} \boldsymbol{A}$ & 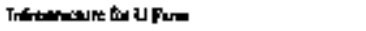 \\
\hline $20 \mathbf{T H}$ & 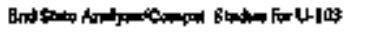 \\
\hline $201 \times 6$ & 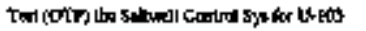 \\
\hline मृण & 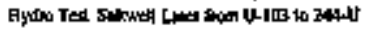 \\
\hline 2010 & 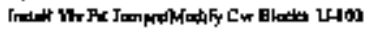 \\
\hline ath 304 & 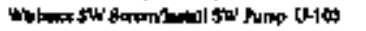 \\
\hline T20 Je: & 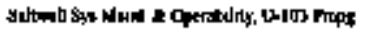 \\
\hline 허마교 & Bublux \\
\hline 200 T7t & 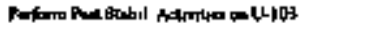 \\
\hline $\boldsymbol{2 0}$ & 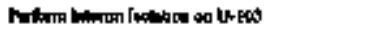 \\
\hline zalkor & 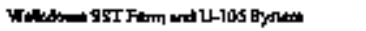 \\
\hline $\mathbf{x} \boldsymbol{H} \mathbf{U} \mathbf{t}$ & 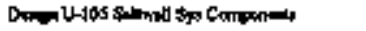 \\
\hline Inous & 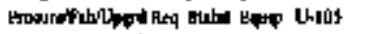 \\
\hline 230120 & 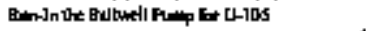 \\
\hline zentoro & 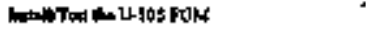 \\
\hline Trous & 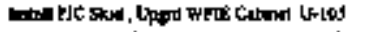 \\
\hline $230 ب 0$ & 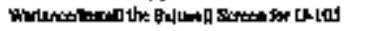 \\
\hline 2001). & 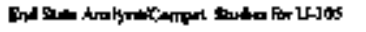 \\
\hline 刀0U\% & 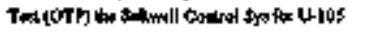 \\
\hline moutror & 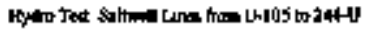 \\
\hline 230uk2 & 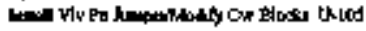 \\
\hline 230146 & 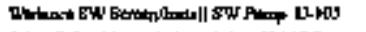 \\
\hline 290168 & 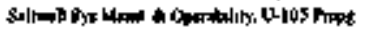 \\
\hline żoty2 & 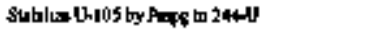 \\
\hline $2300 \pi$ & 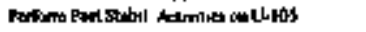 \\
\hline 24000 & 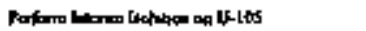 \\
\hline
\end{tabular}


Table 6-1. Sintle-Sted Tontk Interin Stabilization Lovel 1 Lopie' Work Arealudow Strurture Crosswail (IS Shbedt)

\begin{tabular}{|c|c|c|c|}
\hline WES & FYBS Tinte & Logic f & Logle Title \\
\hline I Ol & 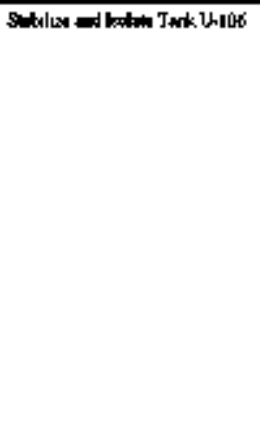 & 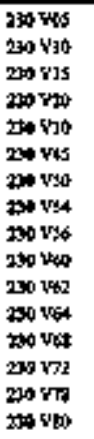 & 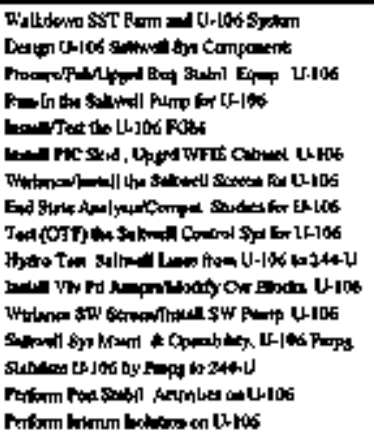 \\
\hline 3olorol 04 \& ớr & 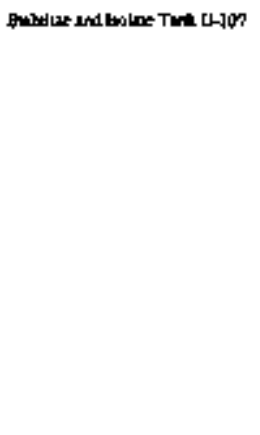 & 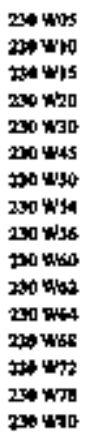 & 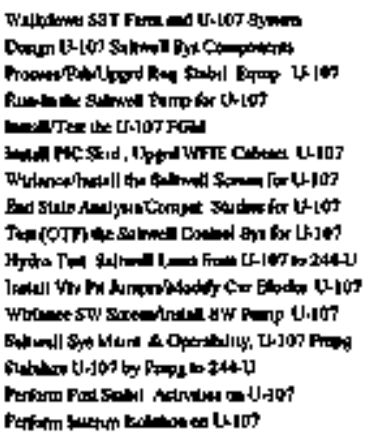 \\
\hline 1010201044000 & 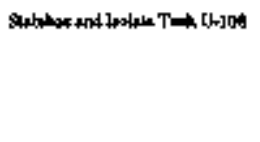 & $\begin{array}{l}200 \times 04 \\
230 \times 10 \\
200 \times 13 \\
200 \times 00 \\
200 \times 25\end{array}$ & 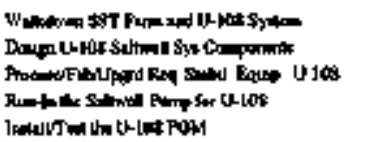 \\
\hline
\end{tabular}


Tab[e 6-1. Singte-Shell Tank laterin Stabilzation Level 1 Logict work Brealkdown Stracture Crosswalk (15 Shetts)

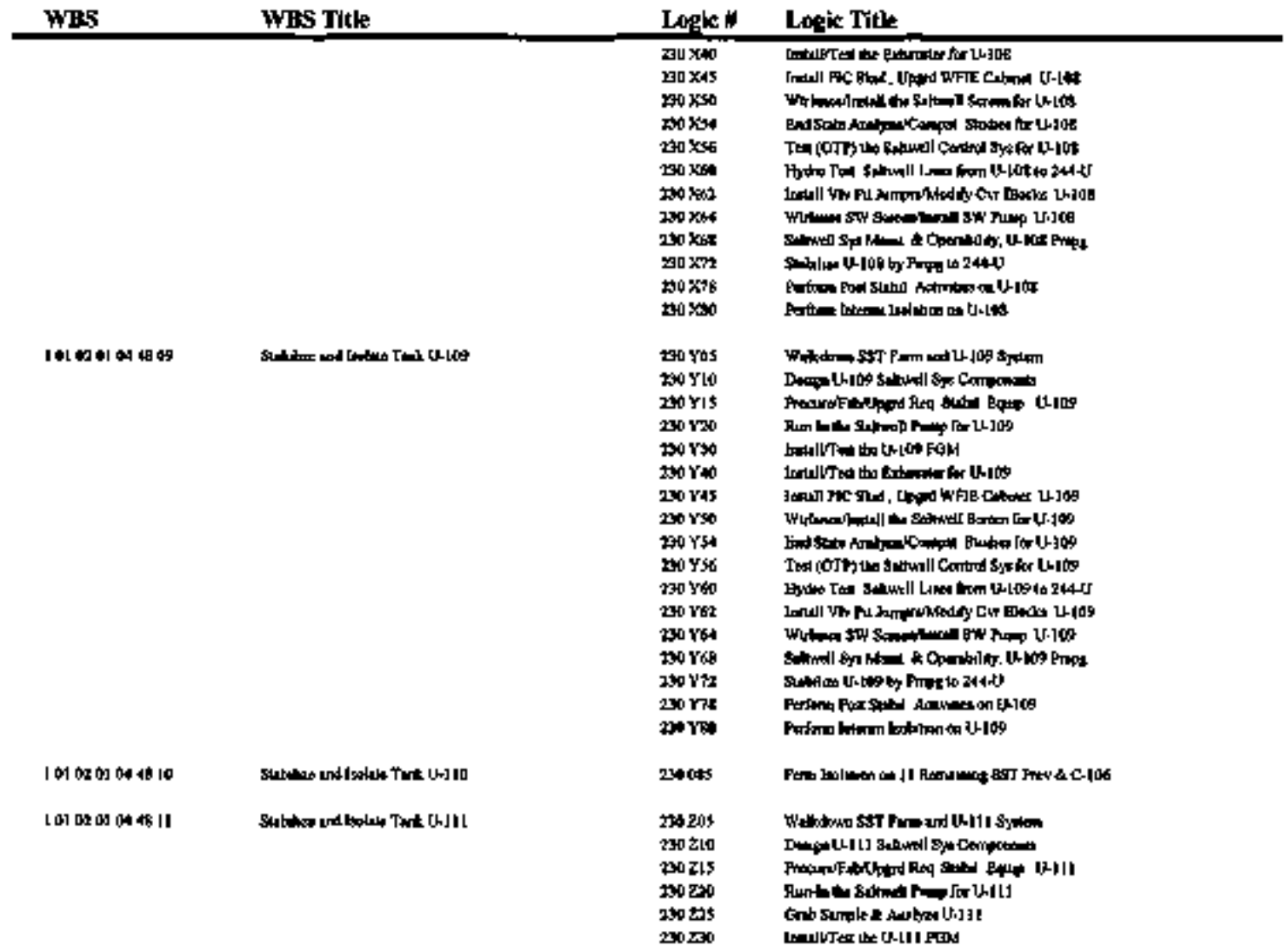


Table 6-1. Single-Shell Tank Iutorim S1sbullzation Leved 1 Lopiof

Work Brealudown \$tracture Clrattwalk (15 \$bets)

WBS

WBS Title

1 or or oc o4 4s 30

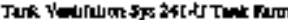

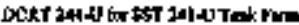

3050201044330

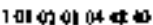

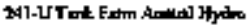

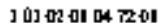

Lagen L Logle Thite

200 g45

240 230

200?d

270

230 2녕

खोo 2 th

Za 263

Ta zed

20020

से०2012

בDी टाओ

खण 70

toutpo

2010 $\mathrm{X}=0$

1970 Y40

ได้ Tา

Z广大

20 33

20012

200 TR4

2012

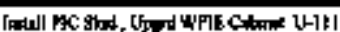

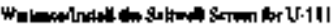

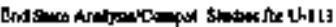

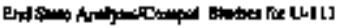

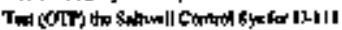

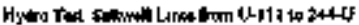

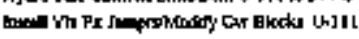

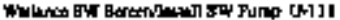

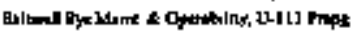

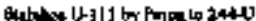

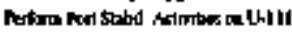

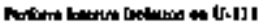

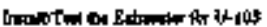

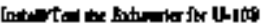

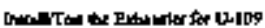

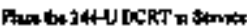

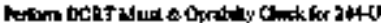

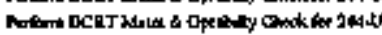

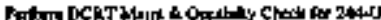

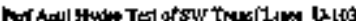

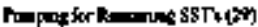

GB o the Hack

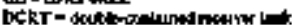

BCRT= doctitione

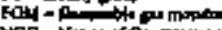

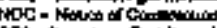

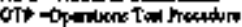

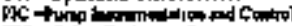

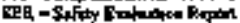

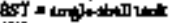

$\$ W$-Edlow

TR: [l - trithes

The

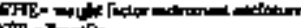

$x$ Pि - Trunt? 


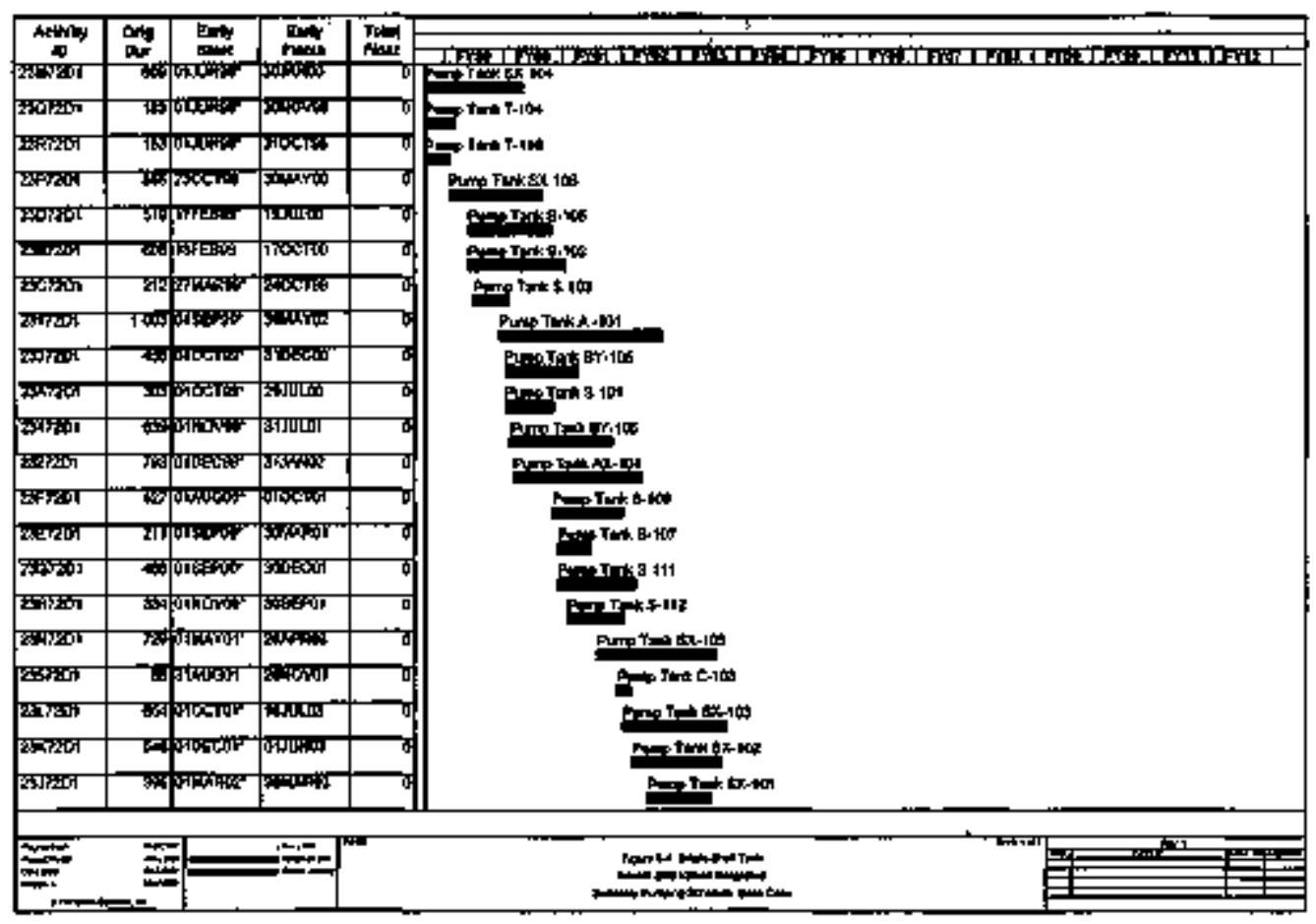

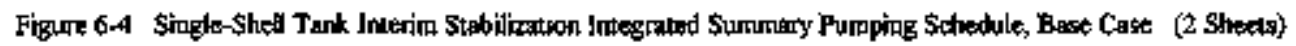




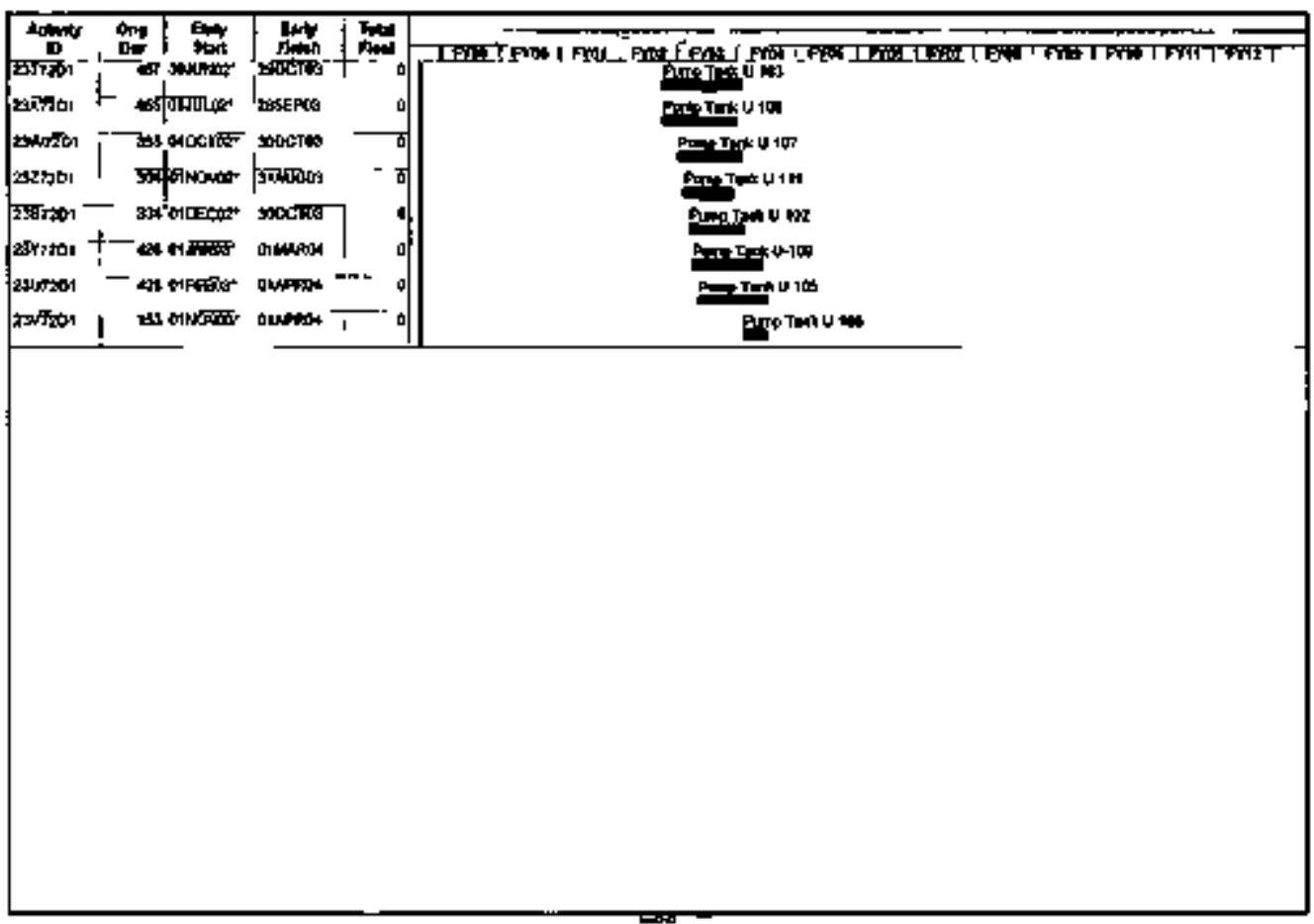

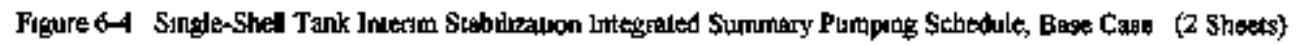




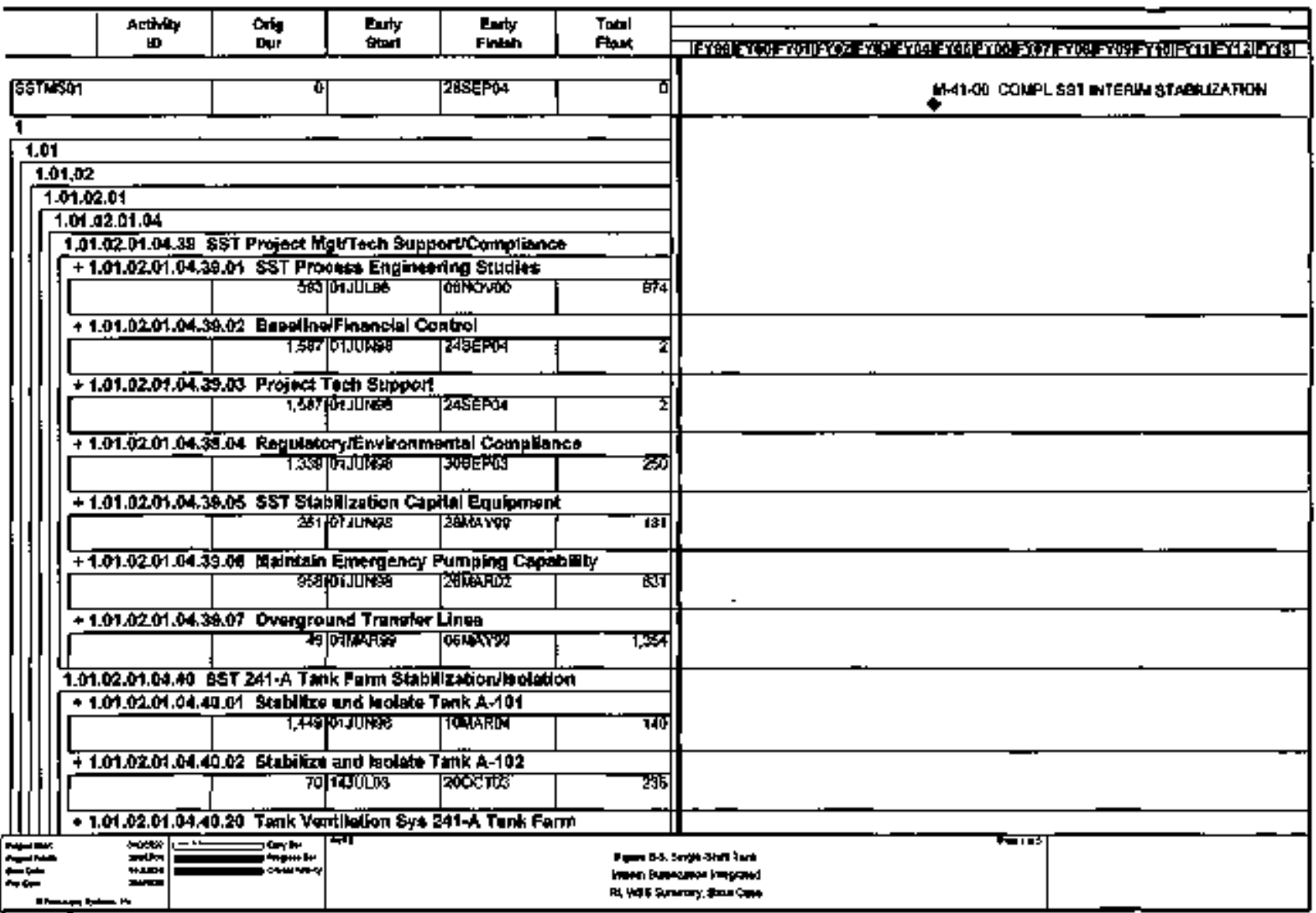

Figare 6-5. Singlo-Shel Jank Imesim \$tabilization Integuated RL WB\$ \$ormmary, Batse Case. (S ahoets) 


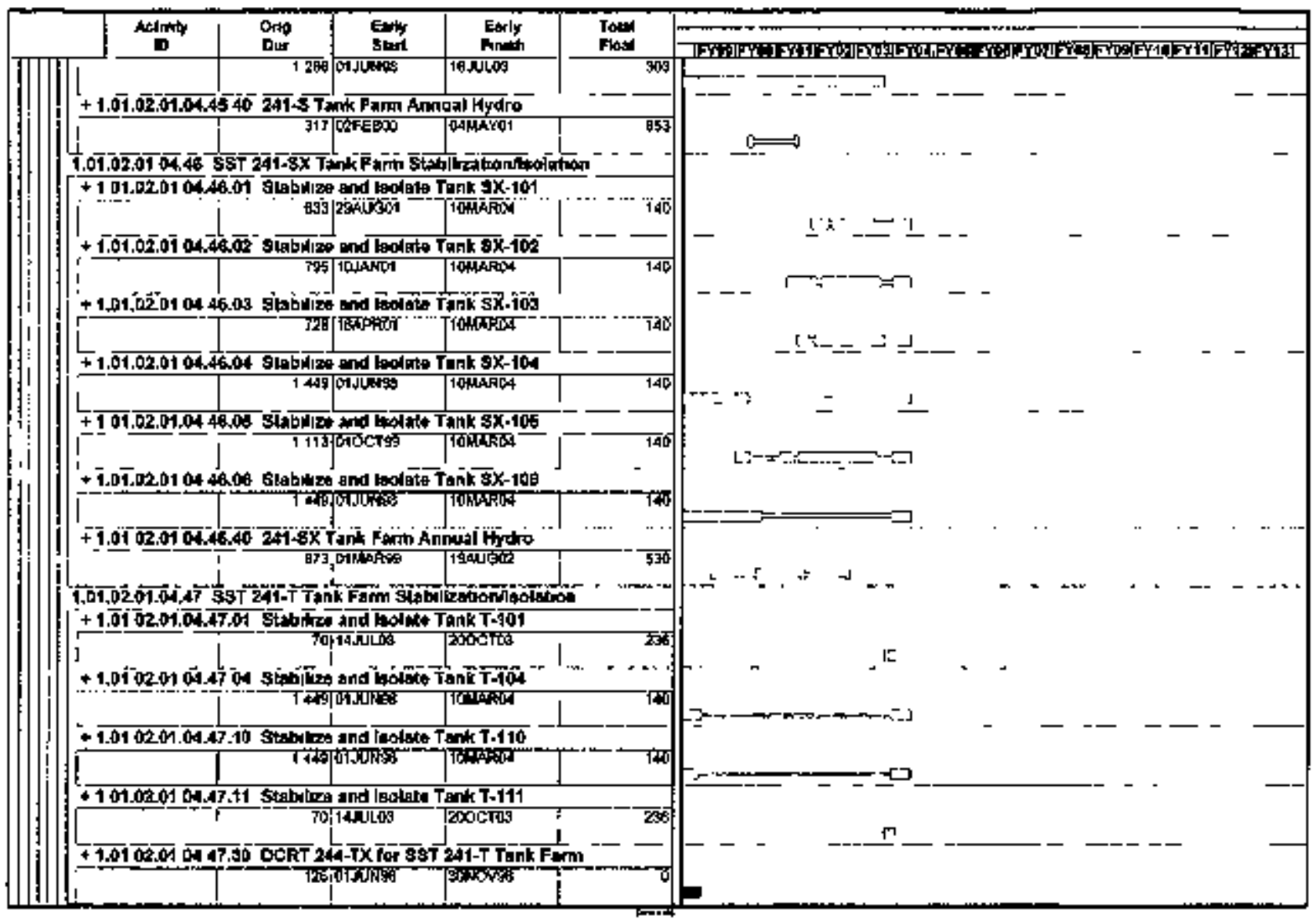

Flogro 6-5. Single-Shedl Tank Interion \$tabilizallon lintegrated RL waS SUmmary. Base Case (5 shetis) 
The schedule is traceable to the kgic dingrarns, technic日d bagis resiew packnges, WBS, and

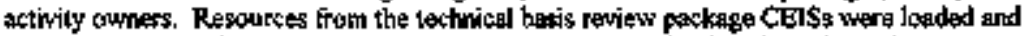
priced in P3 to produce the base case cost and F TE summarieg found in tbis section.

The base case gchedule was developed using a managesble rarap up to full operationg, uniborm funding for the duralion of the project, and at orderly demobilization at the completion of work in FY 2004. It is coustrained by the avaibatity of traioed personneh, equipmant, and other terhinictl and regilatory josuts.

- Pesconnal limits were based on the availability of persontos from the exisuing staff ated the time required to trim additlonal personted in specillc calegories.

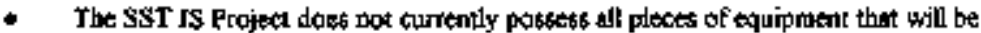
rexpired to complete the raission. The engyinescing and procurerdert rycked have beten inthuded to ensure that the equipmeat is avaulable to support the proposed puriping pequeaces and durations.

- The techinical iganes are included as logical stepe lo pump spocific tamls. An Euminle of this is the installation of a saltwetl serten in Tank BY-l0S. This lank conteins 62 tans of Porlingd cenorrt.

- The regulatory jogues addresped in the schectute are the NOC for installation of

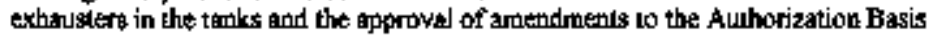
dacuratinls.

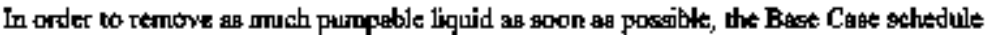

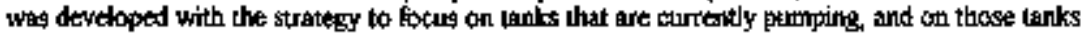

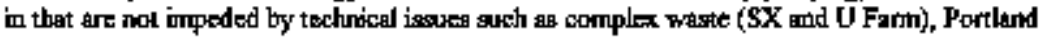

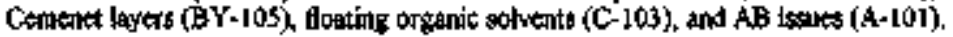

Initially pumping will focus on S-Farm, since there are no techniced issues and it will provide good dafa for evaluation of thanumable gas releaseg during puonping. In addition, there are

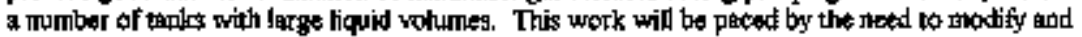
install grandby exhausters before punpibs can be initiated. Punping will be initiated in 200 Esat

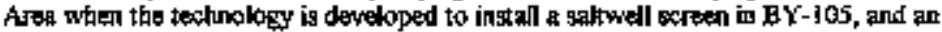
authorization bessis is appsoved to punp A-10\}. To the extent that it does oot extend the overall schedule, activities widl tend to concenlrate in one geographix area at a time (j.e., tonk farm) to minimize the overall project casts. The focus will thot shif to SX and U Farmo as soon as resources become arailable.

Work scope for the balance of FY 1998 will focus on activities to support the folkwing:

- Mainlain jumping opteralionts in SSTs already in progresss or near start-up (T-104. T-110).

- Determing the pumpebility of $\$ X$ Farm wastes and, if appropriote, modify the SX-104 diluition dybtem and restart purbing in this tank 
- Prepare and intiate pumping in SX-105, which is ventilated by the SX-Fatm shutget copler.

- Iniliake preaperations for $\mathbf{S - F a r m ~ w h e r e ~ p u m p i n g ~ i s ~ s c l i k e d u l e d ~ t o ~ b e g i n ~ i n ~ r a r t y ~}$ FY 1999.

- Maintain a 30-dey tmergency purnoping capabiltity for \$\$T.

- Initiate modification to the onsite axhaugters to meed the ragquiremeals of the AB.

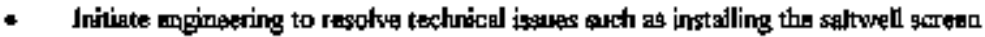
in BY-I0S.

This schedule, which would complete interim stabilization in 2003, is aggressive. It wil

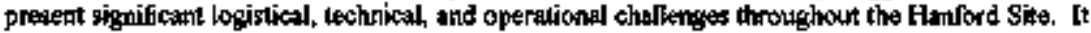
should be noted that this scheduse will be extyended by 12 thonths if co-mirgling of wastes is dizapproved.

\subsection{RESOURCES}

\subsubsection{Bnse Case Cost by Work Brenkdown Strukture}

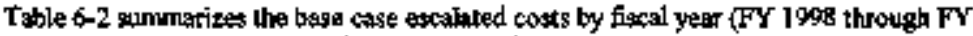
2004) that are necessary to complete the remainder of the SST IS scope of work deflned in the detailed P3 schedule. Tstble 6-3 prowides the base case unascalated costs by WisS. Pricing for these spreadsheets uag perfomed in P3 using the curtent FDH-approved labor-rate trbles and other approved pricing data (labry and material adders, General and Administrative, moterial procurement eale, etc.). The costs in Tables $6-2$ and $6-3$ are consjstent with the detailed base case schedule diecussed in Section 6.4.I and are supported by the technical tessis reviour packsage data including the CEIS estimates used to rescurce loss the ativities in the schedule.

Tatate 6-2. \$ingle-\$bedl Tank Imterim Stabilization Project, Egealated Bese Caga Cods by Fiscal Yaer.

\begin{tabular}{|c|c|c|c|c|c|c|c|c|}
\hline Com & Total & FY L988 & F 19\%9 & $\mathbf{F} 20 \mathrm{~m}$ & FY 2001 & $\mathbf{r} 20 \mathrm{~m}$ & EY 2009 & FY 2904 \\
\hline Total Cos in 198\% Dolkes & {$[16,439$} & 12,202 & 18,820 & 18,347 & 19,707 & 18,579 & 17,028 & IL,I4I \\
\hline Fodd Eectedetim & 9,598 & $\mathbf{\theta}$ & SD国 & 1,003 & 1,640 & 2000 & 3,426 & 1,931 \\
\hline Tonel Eacaloled Cost & {$[26,031$} & 12,802 & 19,397 & 19350 & 21,347 & 20,609 & $\mid 9,454$ & 19,072 \\
\hline
\end{tabular}

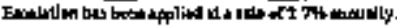


Tablo 6-3 Single-Sbell Tank Itterim Stabilization Base Cage Cost By Work Breakdown Structure (Unescalared)Total Cogt (\$o00) for Year. (2 sheets)

\section{FiL WES}

Tot 0 एक 043901

101020404502

101020004003

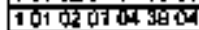

T01070104 3905

101 त2 01043008

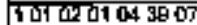

1010201044001

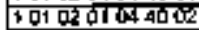

1010201044030

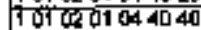

101020104 d1 01

1 का क्रिण बन

Tot az

1010201044303

1द1 0ृ20104 4305

o. 101020404430

它

1010201044320

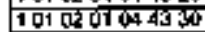

101020104 dar

101020104140

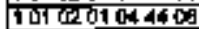

1010201044430

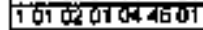

1010201044502

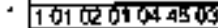

Tण1020104d500

1010201044605

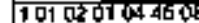

: $\frac{1010201041508}{2}$

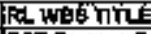

SST Proctss Engrimining Sudies

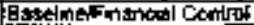

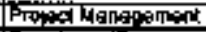

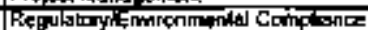

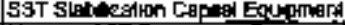

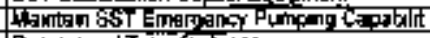

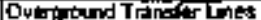

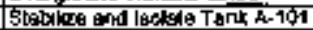

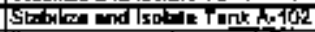

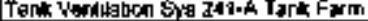

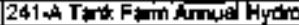

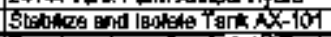

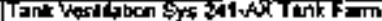

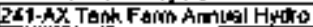

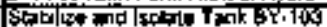

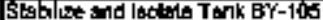

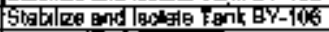

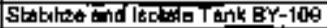

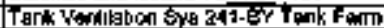

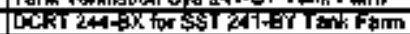

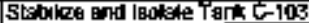

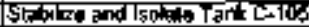

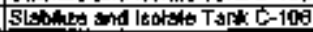

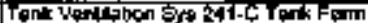

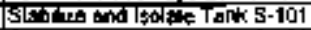

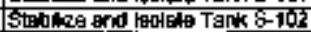

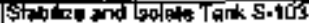

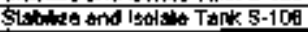

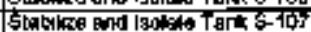

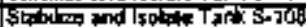

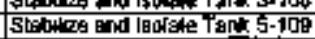




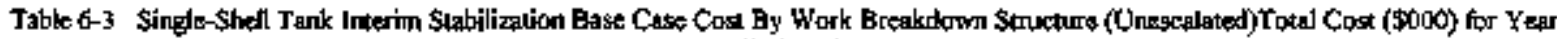
(2 sheets)

\begin{tabular}{|c|c|c|c|c|c|c|c|c|c|}
\hline 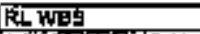 & 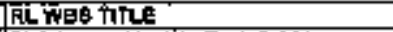 & TOTAL & FY 1900 & PY 19g g & FY 20000 & Frato1 & Fr 2000 & FY 20003 & Fr zo04 \\
\hline 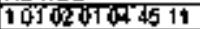 & 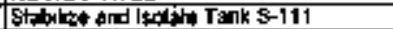 & $1,67 \mathrm{~B}$ & & & 81 & 370 & 9 & 9 & 218 \\
\hline 104001044530 & 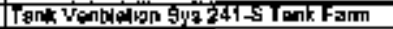 & 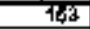 & 38 & 38 & 绦 & & & & \\
\hline 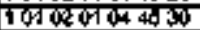 & 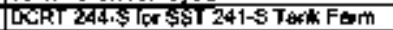 & 2,306 & 128 & 376 & 369 & SFE & उतना & उक्र & \\
\hline 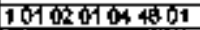 & 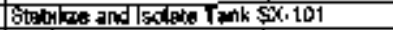 & 7,685 & & & & को & क्षा & 证里 & 218 \\
\hline TOTOR WTA & 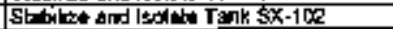 & 2,0033 & & & & 1,382 & 247 & (187 & $21 B$ \\
\hline 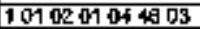 & 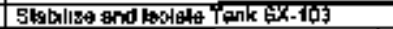 & 1,54 & & & & 950 & 227 & 180 & Z1E \\
\hline 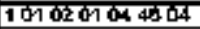 & 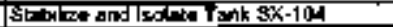 & rist & TTY & 823 & $\mathbf{T M}$ & & & क्व & Z16 \\
\hline 10100010440 & 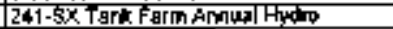 & s35 & & I5f & 35 & 135 & 67 & & \\
\hline 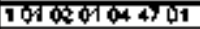 & 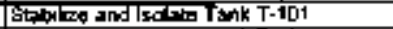 & 214 & & & & & & 290 & 4 \\
\hline 1070004044704 & 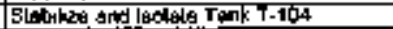 & 445 & 147 & 73 & & & & g & 218 \\
\hline 101801044\% & 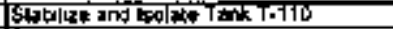 & 617 & उद्ध & 74 & & & & $\mathbf{9}$ & 210 \\
\hline 1010201094711 & 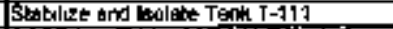 & 214 & & & & & & 210 & 4 \\
\hline 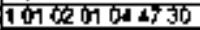 & 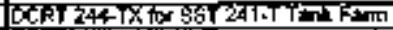 & राह & 97 & 42 & & & & & \\
\hline 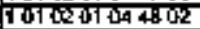 & 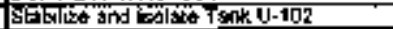 & 1,561 & & & & & $12 \pi$ & Ald & 2E9 \\
\hline 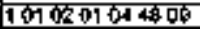 & 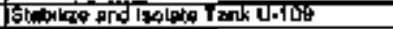 & $7,6,5$ & & & & & 理 & (189 & 404 \\
\hline 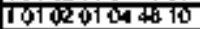 & 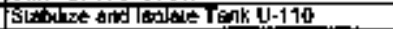 & 214 & & & & & & $2 \pi$ & 4 \\
\hline 10020104411 & 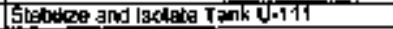 & 2,162 & & & & & 1,428 & $\mathbf{5 1 7}$ & 218 \\
\hline 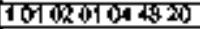 & 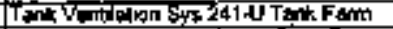 & 116 & & & & & T15 & & \\
\hline 100201040 & 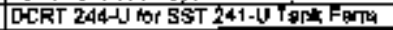 & 1,$8 ; 3$ & & & & SAD & 200 & $7 \mathrm{G} 5$ & Wद्या \\
\hline 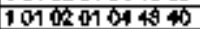 & 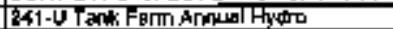 & 270 & & & & & & 270 & \\
\hline \multirow[t]{2}{*}{ 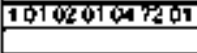 } & 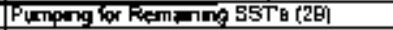 & 3,6001 & (j) & $2,7 \mathrm{~A}$ & 547 & 5,390 & 4,70\% & 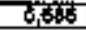 & 1,186 \\
\hline & REPORT TOTAL & $111,7 \notin 7$ & 8.152 & 18.929 & 18.347 & 19.707 & 18,573 & 17,026 & 1114 \\
\hline
\end{tabular}




\section{6,5,7 Base Cuse Lobor Regonnces}

Table 64 sumutarizes the FTEs by WBS and fiscal year that are necessonty to comploite the semainder of the SST is scope of work as defined in the base cese P3 detailed schectule. This

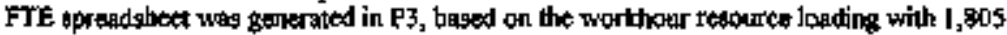
worthours par year aseumed. The labor resources havia been exded in the CEIS a and schedule by P3 resource tode, cost elemert, and resource despription.

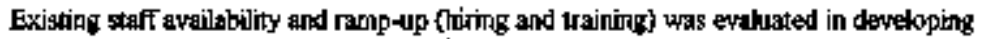
the schedule to ensure liad the plan is achievable. Tank pumping opstalionts have been logictly grouped and scheduled to provide for the mast efficient use of resources. 
Ri. WBST

Tर्ठ十 $02010307 \%$

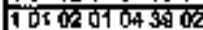

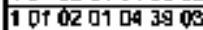

1010201043904

10102 of 04 3906

1 वरण

1वस्टिम तब 3007

101001044001

1010201044002

1010201044020

1010201044040

10 000104 4F01

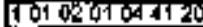

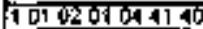

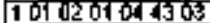

101 万ुराण

p. 1010201044300

फण020104409

4010201044320

तु 02070443

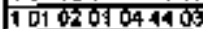

1010 वर्य

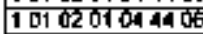

1010201044420

T010201044601

101020104450?

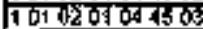

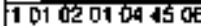

1010201044507

- 10102010445 0\%

10102010400
RL WES T,THE

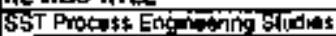

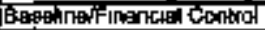

Froject Lanegament

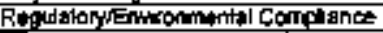

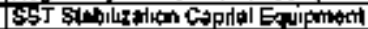

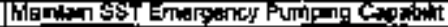

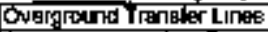

SLabong and lo:

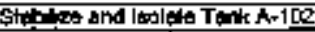

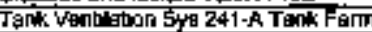

241-A Tenk FE:m Anratipl Hydro

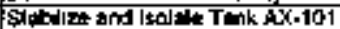

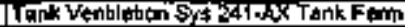

$2410 \mathrm{X}$ T

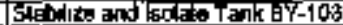

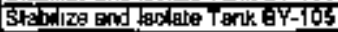

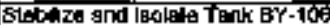

statialza and leolele Tenk BY.108

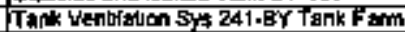

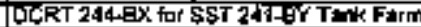

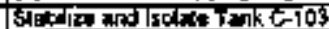

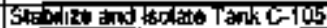

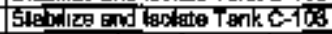

Telk Verthled syen 2J1-C Tenk form

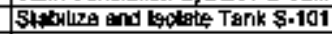

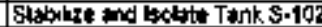

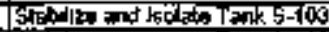

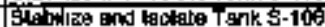

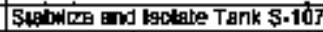

stiblize and betata Tank S.10

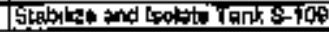

\begin{tabular}{|c|c|c|c|c|c|c|}
\hline FY TFB & FY 1998 & $5 Y 2000$ & FY 2001 & FY 2002 & FY 2000 & $\overline{F Y 2004}$ \\
\hline 033 & Q112 & 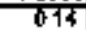 & & & & \\
\hline 263 & 160 & 160 & 18 & 170 & 033 & 053 \\
\hline 815 & 1047 & $9 \$$ & 890 & 835 & 554 & $4 \pi$ \\
\hline 2274 & 1435 & 1435 & 1236 & 1108 & 631 & 610 \\
\hline 1130 & 365 & & & & & \\
\hline 206 & 125 & 万然 & एक्ष & 0 क्ष & & \\
\hline & 154 & & & & & \\
\hline 114 & 294 & 159 & $15 S$ & 102 & 007 & D啲 \\
\hline & & & & & 402 & 003 \\
\hline & 037 & & & & & \\
\hline & 084 & 084 & 084 & & & \\
\hline 347 & 37 & $17 B$ & $19 \mathrm{gk}$ & Q\$5 & 007 & 009 \\
\hline & $73 \mathrm{~F}$ & & & & & \\
\hline & D64 & 192 & & & & \\
\hline & & & & & 1 和 & 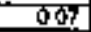 \\
\hline 457 & ह13 & 259 & ס87 & & $00\}$ & 0的 \\
\hline & 585 & $22 B$ & 198 & & 007 & 0 여 \\
\hline & & & & 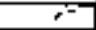 & 492 & 00 \\
\hline & 037 & & & & & \\
\hline & & 27 & 112 & & & \\
\hline & & & 6 & $2 \bar{\theta}^{2}$ & वof & 6 的 \\
\hline & & & & & प极 & Dob \\
\hline & & & & & प92 & 003 \\
\hline & & & 037 & & & \\
\hline & 569 & 420 & & & 007 & प्रफ \\
\hline 2700 & 8 & 19 & & & DOT & Dळ \\
\hline 679 & 1021 & $\delta \$ A$ & & & Dof & 058 \\
\hline 817 & 474 & 233 & & & $00\}$ & 口国 \\
\hline & & 506 & 381 & & प्रि & 098 \\
\hline & & & & & D我 & 003 \\
\hline & & 867 & 356 & & Dô? & 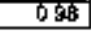 \\
\hline
\end{tabular}




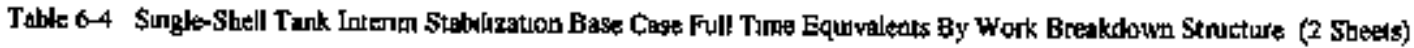

\begin{tabular}{|c|c|c|c|c|c|c|c|c|}
\hline Fit WaB & AL Wes TIRE & FY 1906 & FY 1999 & FY 2000 & FY 2001 & FY 20072 & FY 2000 & FY 2004 \\
\hline 1070201044511 & 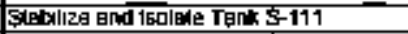 & & & 692 & 315 & 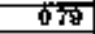 & 007 & प日B \\
\hline 1070201044512 & 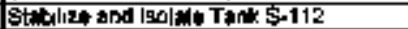 & & & $8 d 5$ & 425 & b02 & 007 & D昰 \\
\hline 10 गुण & 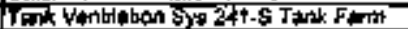 & 100 & 637 & 073 & & & & \\
\hline 1010201044530 & 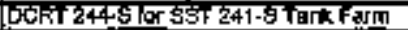 & 214 & 213 & 23 & 3. & 3.34 & 24 & \\
\hline 1010201044540 & 2415 Tark Farm AnInral hodr & & & Tह & 3.85 & & & \\
\hline 1010201044601 & 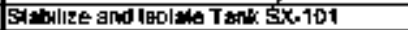 & & & & 427 & 737 & 154 & $0 \mathrm{BQ}$ \\
\hline 101001044602 & 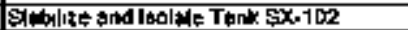 & & & & 1089 & 203 & +5 & 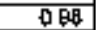 \\
\hline 10 प्रति & 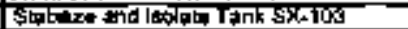 & & & & $\sqrt{44}$ & 786 & T4t & to 980 \\
\hline 10020104404 & 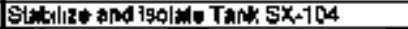 & 2 然 & 297 & प94 & & & $B 07$ & 098 \\
\hline 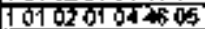 & 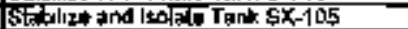 & & & 245 & 841 & 184 & $6 \%$ & (1988 \\
\hline 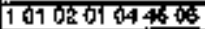 & Ista & Ei/4 & $2 \sqrt{3}$ & T35 & & & Dor & D的 \\
\hline 1010201044640 & 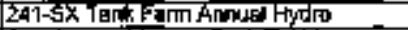 & & 192 & 529 & 12月 & 054 & & \\
\hline 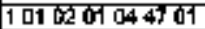 & 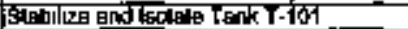 & & & & & & 062 & 003 \\
\hline 1010201044704 & 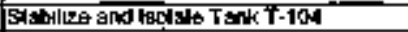 & 370 & 0 更 & & & & 007 & $0 \%$ \\
\hline 1010201044710 & 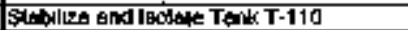 & 783 & 062 & & & & 007 & 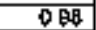 \\
\hline रकासण & 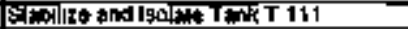 & & & & & & 62 & 005 \\
\hline 1010201044330 & 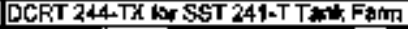 & 180 & 029 & & & & & \\
\hline $1070201043 \%$ & s.5. & & & & & 585 & 487 & $T$ \\
\hline 10102010416053 & 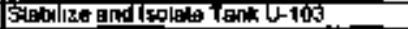 & & & & 127 & 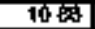 & 325 & 124 \\
\hline 101020104 4. OS & 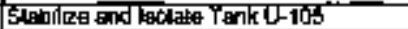 & & & & & 562 & 434 & 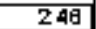 \\
\hline 1010201044906 & 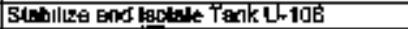 & & & & & & 799 & 443 \\
\hline 1010201044807 & 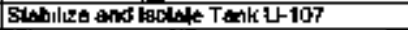 & & & & & 837 & 300 & 122 \\
\hline 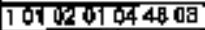 & 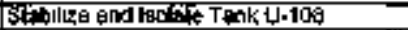 & & & & 153 & $\theta 00$ & $3 \sqrt{2}$ & 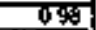 \\
\hline 1010201044809 & 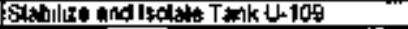 & & & & & 629 & $A B^{2}$ & $2 \mathrm{HA}$ \\
\hline 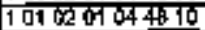 & 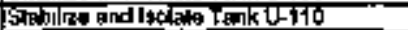 & & & & & & $0 \%$ & 009 \\
\hline 1010201044611 & Fabilize and & & & & & 113 列 & 434 & 0 698 \\
\hline 1010201044820 & 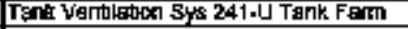 & & & & & 110 & & \\
\hline 10102004489 & 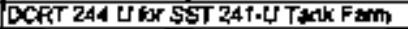 & & & & 401 & 139 & 494 & 304 \\
\hline 1010004040 & 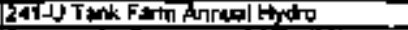 & & & & & & 255 & \\
\hline \multirow[t]{2}{*}{$10100007 \overline{2}$} & 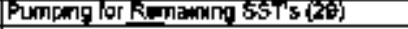 & 2516 & $2+12$ & 354 & 5126 & F51 & 牙44 & 1181 \\
\hline & REFONT TOTAL & 17201 & 12428 & 14607 & 15720 & IABER & 13110 & $\$ 241$ \\
\hline
\end{tabular}

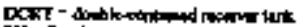

VW - Bandyer

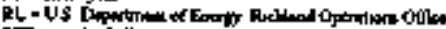

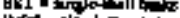

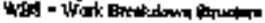




\section{HDNF-2358 Rev |}

Thir paige intention:ally left blank 


\subsection{ORGANIZATION}

The ranop-up and extept of the field activities necossary to excente this bagelime mission are unpresedented in the history of the TWRS IS Project To effexinely mathage this level of activity, the creation of a focused operational tearc is required $\cdots$ a toam that commandy the

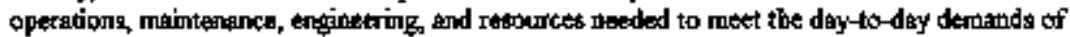

the schedule TWRS will establish a separate, dedicated operational unit supported by a seconded enginearieg finction and the maintenance and support resources required to moet the beatline sthedule

\section{I ORGANIFaTIONAL STRUCTURT}

LMFC has established an organizationgd structure (Figure 7-1) to manage ThRS as a project and to provide requigite corporate aupport This atruelure is designed to alpport all TWRS Project tritsion objectives (resolve safely issues, safe storage. characterization.

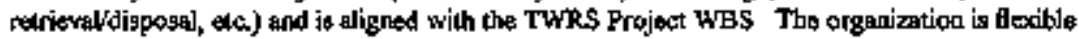

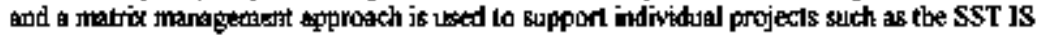
Project The organizational diornents supporting the SST IS Project are described in this section with roles and reaponsibilities defied in Section 72

\subsection{Takk Wate Operations Organiation}

Tank Waste Operations manages and directs, in a safe and efficienl roannor, operations,

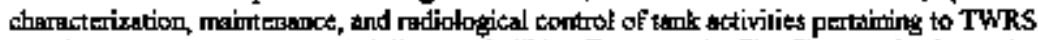
permitted treatment, storage, and disposal facilities (Figure 7-2) The Characterizalion and Stabilization Project deftrent of this organization (Figure 7-3) is respons'ble for Characterization sctivition and the actirities of ihe SST IS Project

\subsubsection{Sagk-Sbel Tank Interie Stabilkat5on Project Organtration}

A trewly formed SST IS Opeations organization (Figure 7.4) will manage and direct, in a safe and efficient manner, the octivities for removing as much pumpeble superngtaml and interstitial Equid as practicable from the remaining 29 thoninterim-stabilized S8Ts, for transterring this liquid to the DSTs, and for performing SST intrusion prevention to awoid inatwertent liquid aditition 


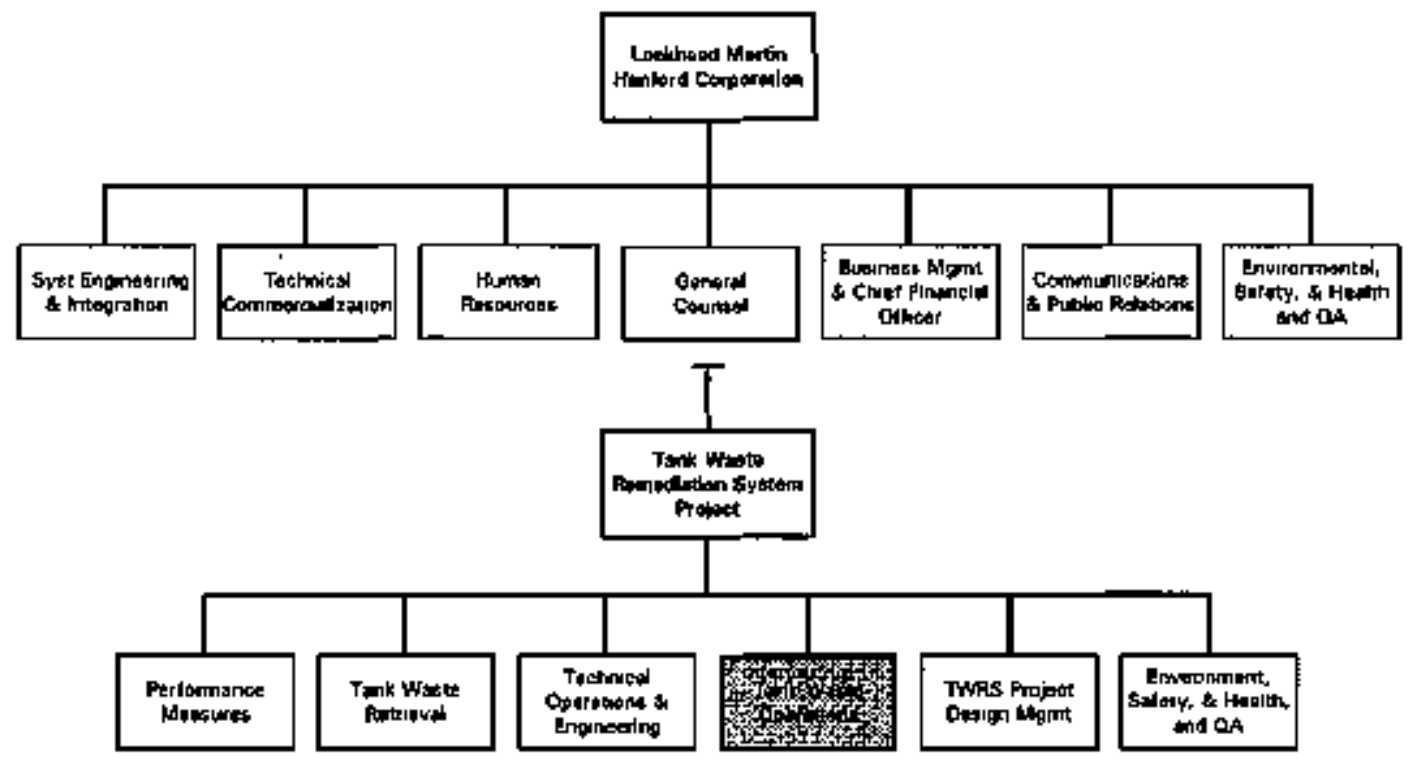

Figure 7:1 LaIHC/Tomk Whaste Reunediation System Otgatrizution 
79600

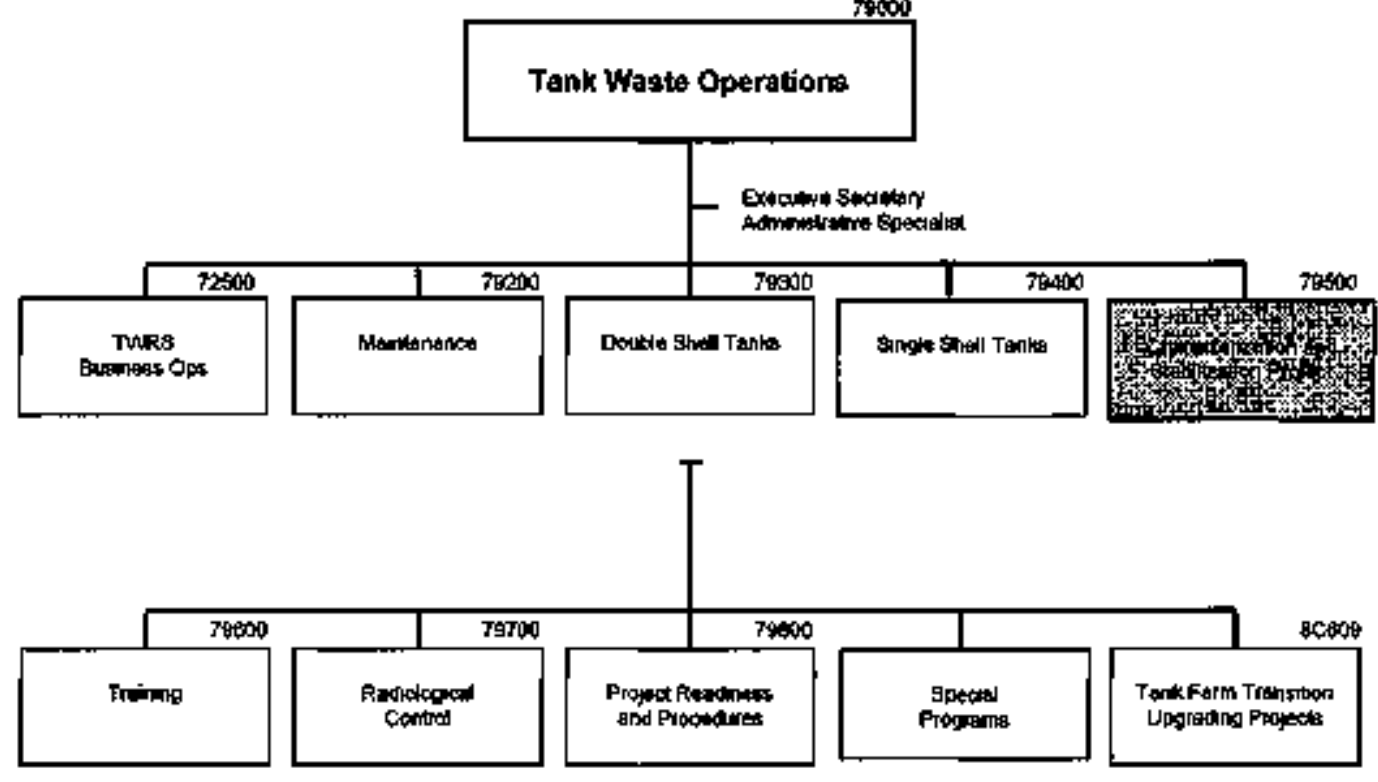

Fugure 7.2. Tank \$raste Operations. 


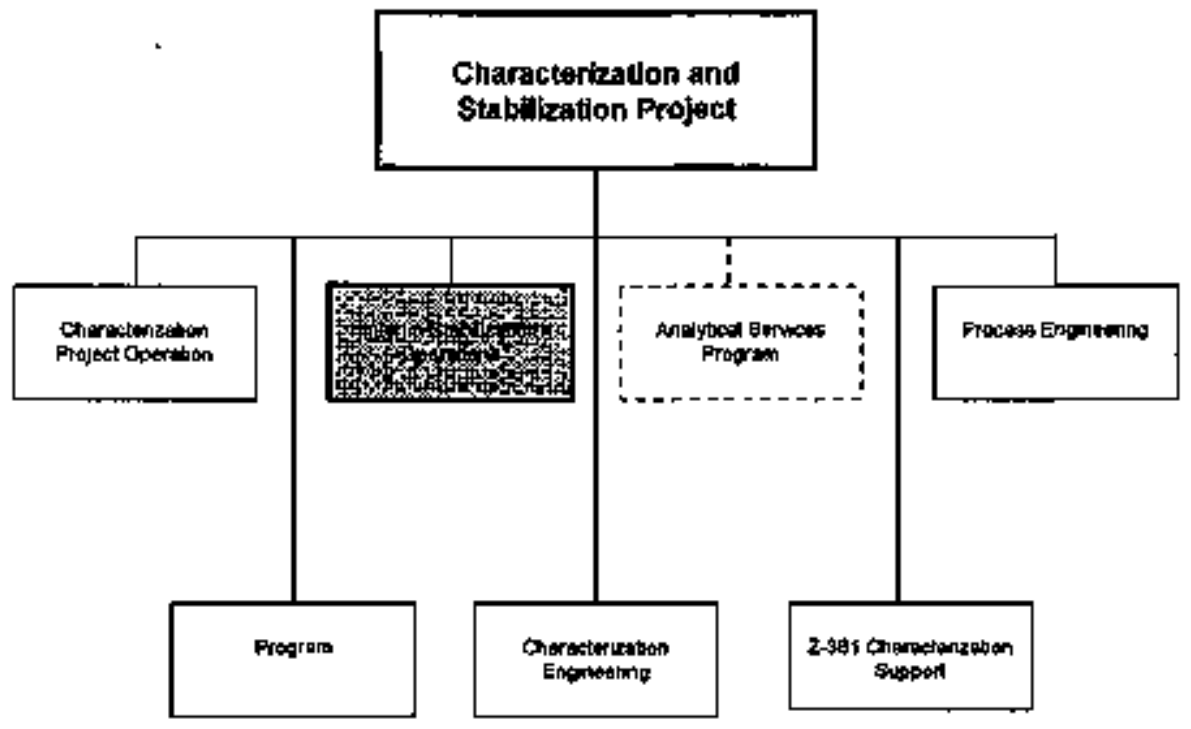

Figure 7-3. Cbaracterization Projext Organization. 


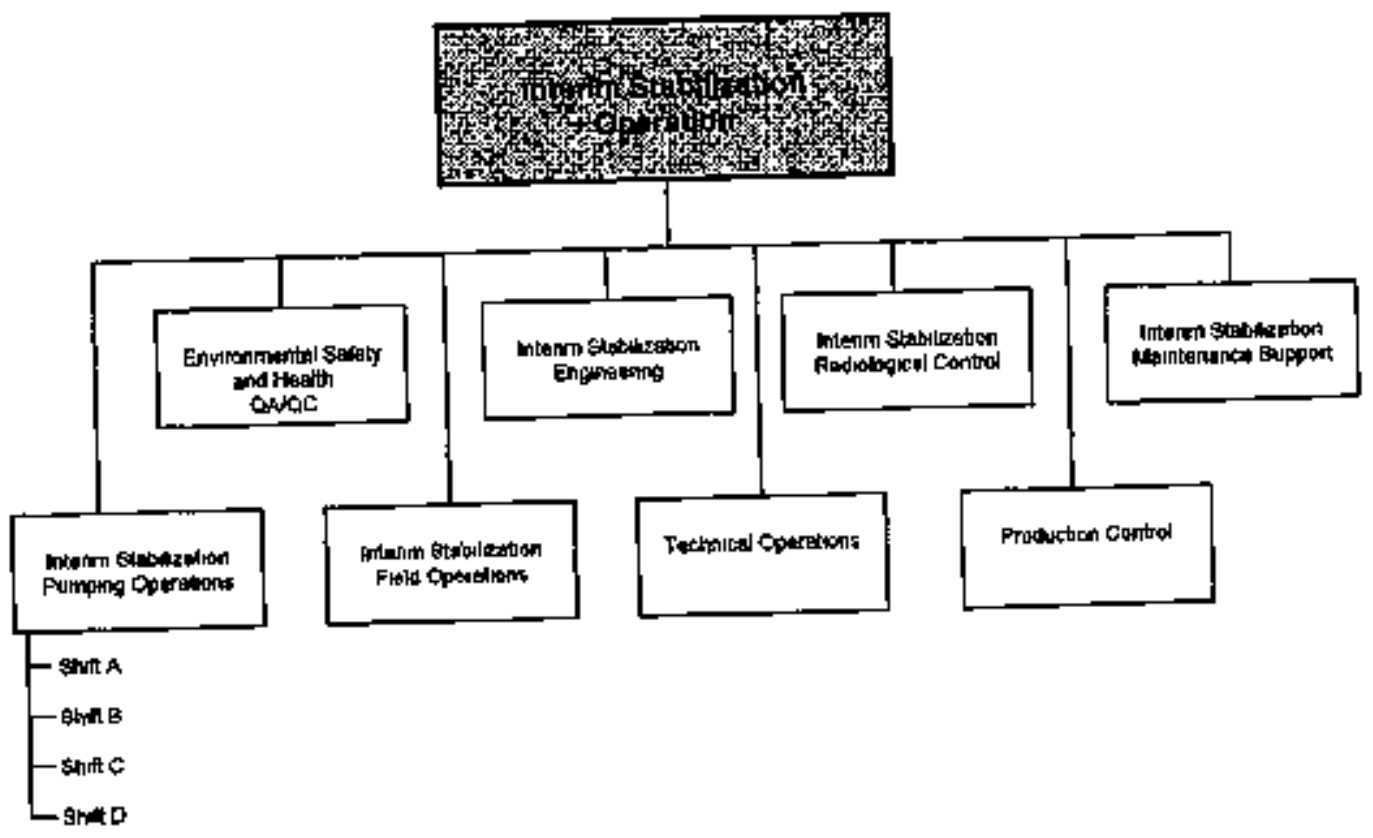

Figure 1-4 Interin Subbilization PToject Orgmbation. 
HNF-2358 Rev. 1

\subsection{ROLES AND RSSPONSLIIITITS}

\subsubsection{Tank Waste Operations}

Tavk Waste Operations is reaponsible for managing 177 underground storage lanks (149 SSTs and 28 DSTs) in a safe and efficient manner that encarres compliance wilt DOE orders and Federill, stale, and local laws and regolations and achieves the misston goals and objectives of DOE, FDH, and the \$ST IS Profact. The D\$T and \$\$T shift managers are respopsitie for the

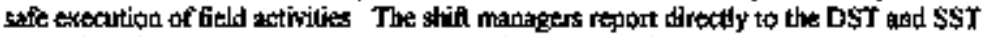
Operations facilly atanagers, who feport ta the director of Tank Waste Optrations.

Specificaloy, Tank Waste Operations is responsilide for the safe handing separation, storage, and monitoring of highty radioactive biquid waste stored in the underground tanks. Radicaclive tioquid wastes are recejved for inlerim storage into the DST systern by truck, rail car, or transfer lines from exdemal sourcess such as B Pkant, Phutounum Finishing Pland, and

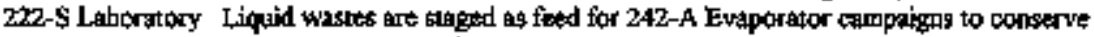
DST space through waste volume fechuction. The 242-A Evaporator outpul slurties tre telumed to the DST system for interim slorage

Tank Waste Oparations maitsteins a standard of performanke for formal conduct of operations, maintenance, and radiologicad control by its personnel in accordance witt the

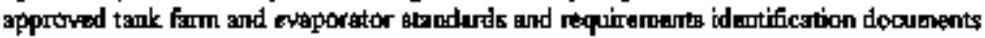
Suryedlance activities necessary to sappont the safe storage nission, iocluding SST IS, are performed using approved procedures. Specific responsibititics include the operations raquired to retrieve and uranger waste to the evaporator for waste-volume rechulion.

\subsubsection{Single-SLell Tank Interm Stobilisation Project}

The SST IS Project Operation organization is responsible for managing assigned fatilities, aquiponenl, and activities in a aafe and efficient mamer that ensures complikance with DDE ordars and Federal, slate, and local bars and regulations and achieves the mission goals and objective of the \$\$T IS Project

Spexiflcally, the SST IS Project Operations is responsible for safe removal (transfer) and

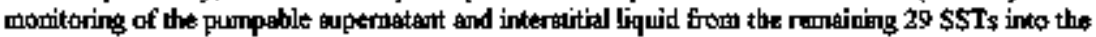
DST system. These activities include equipraent design, procurement, insallation, mointenance and, aftar punping has betn sompleted, equipment rempvial. Tha \$ST is Projert Operations is also responsible for performing instnusion prevention activitis such as distormetting, blanking, or cappiag pipelines from tank bygtems and instalking bartiors to awoid inadvertent lichidd addition into imterim-stabilized $\mathbf{\$ S T}$ s. 
HNF-2358 Rey. 1

\section{\$O MANAGEMTNT APPROACH}

Overall managament of the growth of both field and budget activities requires the

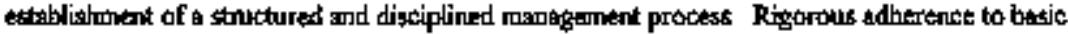
tusiness management rults begins with well-defined work logins and a solid estimaling basis

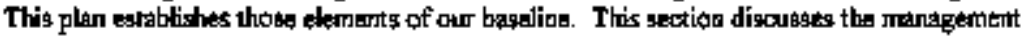
approach for execution ind evohution of the project bastetine

\section{QI BUSINESS OPGRATIONS}

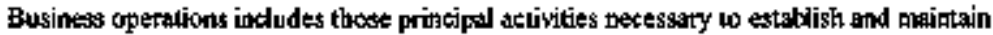
the \$ST I\$ Project project bageline Thage aclivities inchude planring for, and prowiding mput to,

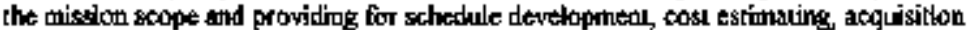
tranagenent, and performanse nacnitoring.

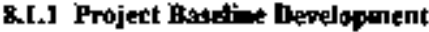

The integralled begelire developorest process is identified in Section 6.1 That is, the physical conflgaration and operational requiremens defined in the rechnical baseline drive the WBS, work defímition, Lovel 1 Logies, spporting critical-path amalystes, and basseline sebedules.

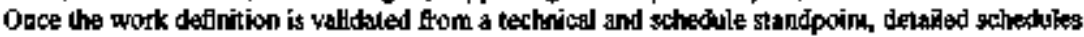
are developed and actirities are reqpource loaded. Adjustments then are made to lowed the reworrces and neat schedule and budget constraints imposed on the project The fingl scops, schedile, and supportiag cost agtimates congtitute the \$ST IS Project basedine and serve tos the basis for developing the MYWP (LMHC I997a) and reportiag execantion-year performance.

Development of this project besedine il a mature iterative process that considers customer nesds, determines organization priorities, defines technical approuches, equablishes schedules, and develope anthual budgets. This anvual process refines execention year planting and further refines and validates the technical baseline and the outyear planning (inchuding budgets).

In preparation for each upcoming flscal year, a baseline record file is prepared and kept in the Bussings Manngement offices. This record fill inchudes a copy of the approved, signed cost

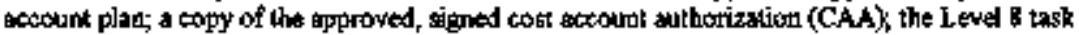
risk an:alysis sheet, the baseline tanget schedule for that cost acoount; and a copy of the

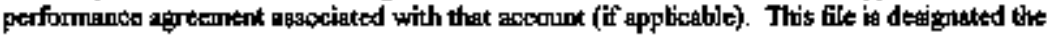
"FY 1998 Project Maragerment Plan" and is idemitied by the particutar cost account number. Il is

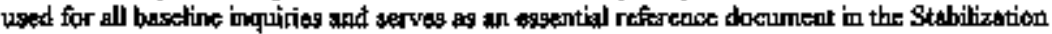
Program for FY 1998 .

t.L.1. Work Scope The ganaral wort degriigtion for the SST IS Project scopo is tatablithed in SST IS Level 1 Logics in Appeadix E. These logies are enhanced program evaluation and review technipureg charts depicting in a box and lins format, the major activities, their 


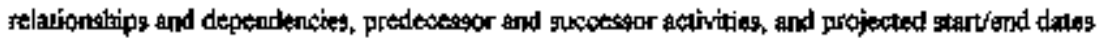
and duratious. The logies are derived from the Level 0 Logies for the TWRS Project and ather \$ST IS Project-ralated work logios. The logics are developed and maintained in a compuler. based project glanning systerc referted lo ts the P3. Liput to, and modification of the P3 database is anbject to configarrtion condrol, ensuring that the SST IS Project ecope carnot be alterced without the autharization of appropriat manasers.

Activity boxes in the SST IS Project Level 1 Logics are further broken down into sets of

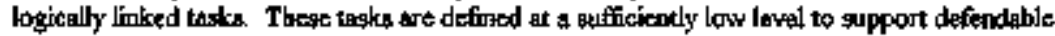
analyses of the duration ath cost of each task. Techtical basis reporis are gencrated for tach Leved 1 Logic activity. These reponts provide backgound aumumaries and identify enabling assumptions; responsible orgatrizations; tectirtical contacls for activitias; inlerfices and link other activities; predecessor and successor activities; rigks; and other information necessary to

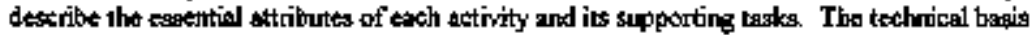
reports are subject to configuration controd.

The S5T IS lagics; technical basis reports: and the lists of requirements, ensbling ussumptions, risks, dexisions, approved techinical baseline documents, and annual DOE gridance al are ugad to develop arnual SST is mission plans. These platus deteribe the purpore,

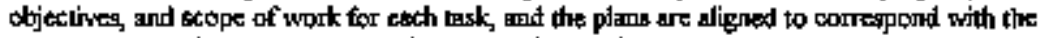
WBS work activities. Each plan ibcludes specific aclivities to be implemented, work products and detlierables required, dustorater and quallity oxpectations for the work, work product dependencies, product interface agreements, and key assumptions thet we tlecestary for tho work to proceed. The plans establish secheduled for work product delivery consistent with project schedules. Finally, the plans ibentify resource nests (estimaled by discipline and type) and earimated costs bated on these profocted ragource deeds. Obre resources are agresd to by the responsible projoct managers, the plans are sabjest to configuration control.

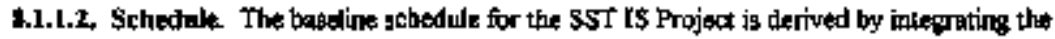

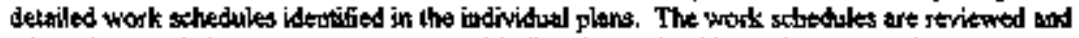
adapted as neodud w ensure congistmcy with direction and guidance from RL and FDH on preparing the annusi MYWP. The SST IS mitsion schedukes are aligned with the WBS and art

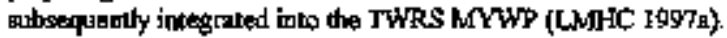

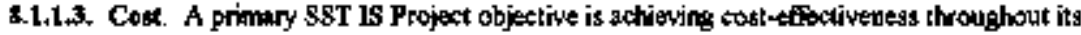
life cyate waile motting or excesding technictal and schedule objectives. Thward this ond, the SST IS Project has implemejted a streamhined managentert system and will contimut to improve productivity and optimize resources. Risł assessments will be incorporated into project decisions.

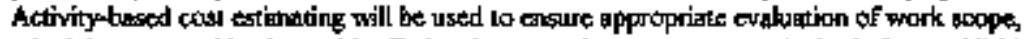

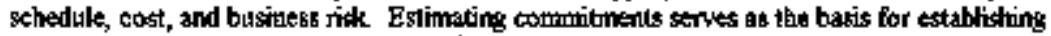
budgets and ulimately as the basis for performance measeronkent. The pricing rantes and factors used to support the budget plertring prosest are ditroxted by FDH Changes to these rates and Factors will be adjregsed through the formal change-eoutrol process.

The SST IS PToject Manager will ensare that cost estimales and revised estimales are based on current plans and work muthorizations and that ite basis for cogt entimates is congistert 
with the documented project scope and schedule beaseliaes Periodic reviews will be conducted on the fitancial status and variance reports prepared by Businest Management. Based on review of

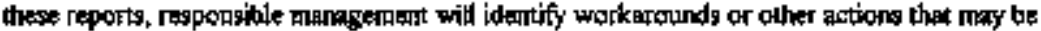
requined to eliminate variances or miligate the inpact of auch variankes.

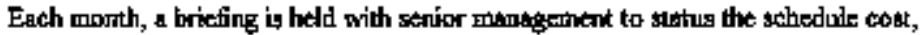
performasce, athd variances of the previous monlh SST IS accomplistaments, issures, concerns, inpacts, corrective measures, and milagtone are also revioved The briefing conchudes with a thret-mouth kodkabead. These atatus mitetings have prover to be essential to the suctess of the integration of the Stabilization Prcject with all other SST operations and project support functions. Reporte are issured following these monthly meet'ings and provide resential data to tho cost account managers and the TWRS managers to eusire that they haye update at hand for all cost accounth, schedutes, and ongoing oornminments.

\subsection{Axquisition Mansponent}

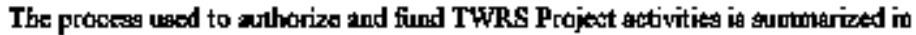

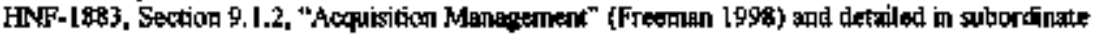
procedures. The following briefly describes this process os it velotes to the S8T IS Ptoject.

81.2.1. Wark Autbarkation. TWRS tank farm work and the SST IS Project work are authorized by division directorkProjecl Baseline Sumumary managers at WBS Level 5 (actirity) though use of rub-operations tirectives Thege Project Beseline \$ummary mangigas/Activity

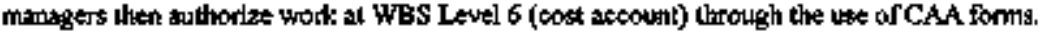

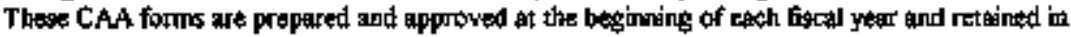
the project-managementiplan cost-accerunt records, kept in the Business Monagement offices

At each level (activily, cost accoum, atc), the assigned managers are vested with the responsibility and muthority for salistimctory pertormance and conpletion of aseigned work within

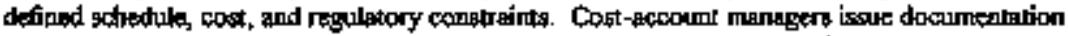
thas defines work at the cosk-Accounk level, work-packinge level, and associaled task-package loyel.

8.1-2.2. Subcoitracting. The cost-account manage determines the work scope to be subcontracted when offigite support is required in accomplishing the particular cost account, watt package, or task. The cost-actouml teanager is aleo responsible for developing any reguired task orders, specifications, statentents of work, and/of acceptapce criterig. LWHC Contrits and Procerrement supports the eost-accoumt mantagex in developing a request for proposal and for other bunctions.

No major expipment plortheses (extausters, flammabje gas mounhors, Portable Instnument Controls) are anticipated to support the Bese Case. 


\section{t,1,3 Performance Asturante}

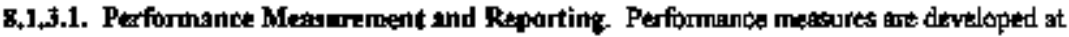
all inanggemenl levels (activily, cost wocoun, ekc.) and afe aimed st achiowing best-in-class performance in cost, schedule, guaglity, and mortcforce productivity. Performanca vervius pian is measured, and performance variances are mottlored and toutrolled. Rexovery plans are . developed by the respontiole manager for variances that exceed jdentified threstold tolerances. Performancs meaturatient is also uged to deselop trends and prectict future performance.

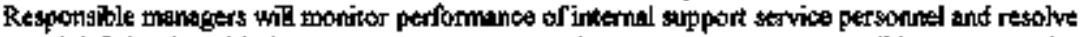
noted deficioncies with the appropriate support-service managers. The regponible mannagers also have the authority to rejoct empocous costs chagged to therir work eccoumls.

Table 8-1 identifies the minimum levels of porformance reporting Reporting at a rorw

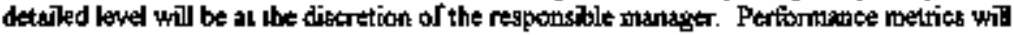

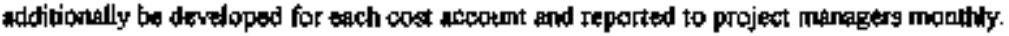

Table 8-1. Wort Bresklodown Sirucher Paformance Reportíng Levalk.

\begin{tabular}{|c|c|c|c|c|c|}
\hline \multirow{2}{*}{ 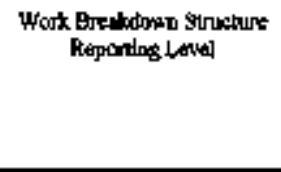 } & \multicolumn{5}{|c|}{ Tant Watte Reardiation Syrten Projest } \\
\hline & Cost ACCOUnd & $\begin{array}{l}\text { Projizal } \\
\text { Mropger }\end{array}$ & $\begin{array}{l}\text { Livislico } \\
\text { Diurecter }\end{array}$ & $\begin{array}{l}\text { Exectutive } \\
\text { Mongament }\end{array}$ & 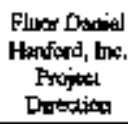 \\
\hline d Projed Exseline Sumanary & 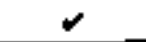 & $\bullet$ & $\boldsymbol{\nu}$ & $\downarrow$ & $\boldsymbol{v}$ \\
\hline S Aceisity & 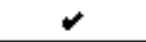 & 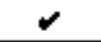 & $\boldsymbol{v}$ & & \\
\hline 6 Cuet Arxank & 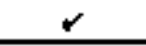 & 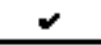 & & & \\
\hline 3 Wodk Pentmpe & $\checkmark$ & & & & \\
\hline $8 \mathrm{~T} \times \mathbf{k}$ & $\checkmark$ & & & & \\
\hline
\end{tabular}

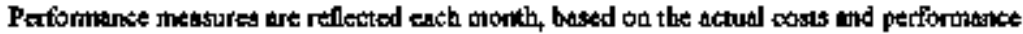
reported in the firangial systern. Firgure 8.1 is an example of the SST activities, and idenlifies bud geted cost of work schoctuled, burdgeted cost of work pexformed, and actual cost of work performed. Pertomance is also metsured thyough the use of numerous fnetrics inctuding, but uas

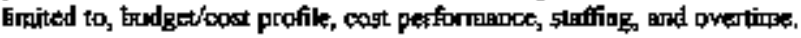

6.1.3.2. Continuous Process Inpwovement. The SST IS Project quality policy comnits all organizations to the principle of contipuous process inprovement. Process incmovernent is achieved when key processets are wetl undersiood and regularly examined for improvement opportunities. Each SST IS mavager is required to plan, schedule, and conduct assagments of 


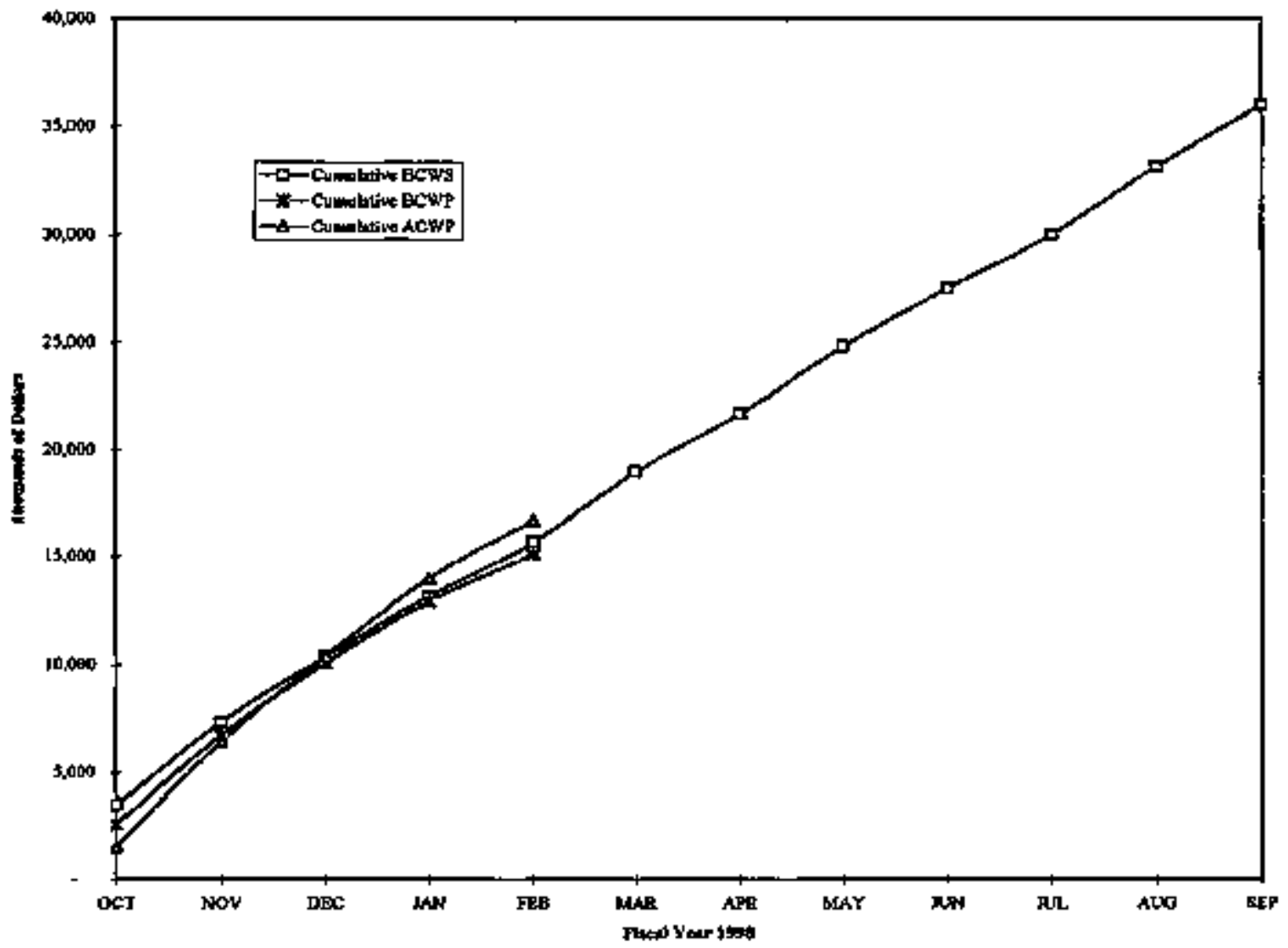

Figure go-1 Example of Sinde-Shęl Tynk Activities 
their Iranagement systems and processes. The HNF-IP-C842, Fank Faste Rontedation Systent

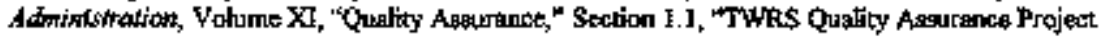
Plan" (LNCHC 1997b) identifies injpiementing procedures for managemeat askesement and olher evelupative processes. The TWRS Quality Aasurance organization provides oversight of the \$ST IS Project self-3seessment processes. In addition, SST is Project facilivies are reglilarly firieued by the PHMC Facility Evaluation Board, as well as by other organizations external to TYFR.

\section{g,1.4 Managemert \$ysteme}

The following sections describe the informalion resource madagement and decision modefing systems and tools in ube by the SST IS Project. Other koy systems and proberses are described in the remainder of Setion 8.9 .

8.1.4.1. Informstion Resaurce Mantwent Syatewt. Much of the success of the S\$T IS Project maragenent approach will rely on the ability to acguire atid atalyze madagentent information Currestly the SST IS PToject uses several sitewide (e E., Financial Dala Sygtern, P3, Job Comtrol Syrtom) and in-house systems (k-., Process Monitoring and Control Systems) to manage information. Most of these systems are standalonte systems that need improvituents in integration and data sharing to be effecive thanagenent cools.

The SST IS Project will use the PHMC Fanford Data Integratkon 2000 System (HANDI 2001) to escist in its maragennent processes. The FDH HANDJ 2000 Project, described in HNF-1743, HLNDI 2000 Project Extettion Plam (FDH 1997b), will integride the major Hanfard Site business processes and their supporting information gygtems. It will egtatiligh iudustry-standard work processes through business process enhancemetst and inplemettation of a sed of integrated, commercial off the-sheif enterprise sespurce pianuing software products. This integration system rill reduce costs, provide better control, reduce the risk of noweonionninces, improve affety, improve productivity, and inprove owerall process integrity.

The core business processes that HANDI 2000 will address are project mangerrent;

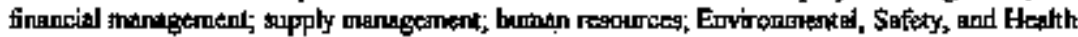
(ES\&th): and work manggemenl. Curreul plans are to ituplemenl these processes silewide, with

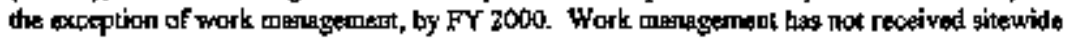
imptenintation approval; it is expoted to be piloted by the SST IS Project in FY 1998 and inplemented thereatur.

8. 1.4.2. Decision Models. The SST IS Project uses process models and andysis lools to assist in decigion-making processes. The most popular of these modess is the schestuling and resource planning tools for projest plenning particularly the P3 applitertion, that will produce schestules with logic ties defining interdependence of the activities. These tooks belp entsure that the resources are avaliable to perform timely wort. 


\subsection{ENGINETRING}

The tainitering prosegs apptiad to the S\$T IS Project uses a systeras approach, This process ensures that the technical baseline supports the identified mission neetals and requirements. In this process the requirements are determined; the gystem is assessed; the existing 1achryical bogeline is vetifled; new hardwars is deakged, constructed/propured, installed, togted; and operations ard maintenance are supported.

The enginesing opponach takes into tecoumt the fact that 4 majority of the SST IS Project system atready exists and modifications and tnaintenance to support the SST IS mission are under way. The existing systern and these ongoing activities are being assegsed to ensare that they will

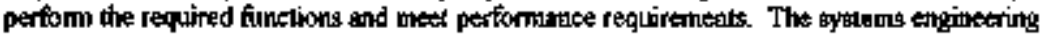
forus is in Aaveloping the fumbtiong, requirenterals, concepts, and iategration of activities,

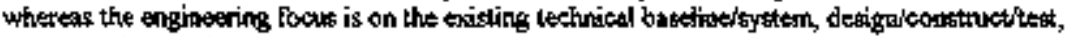
and optrations and mainterance suppost.

\subsubsection{Syattas Bnquetring}

Bystems enginerering is the fimdemestad tool for understanding and developing complesed syotenus throughoput their life cycle. The systens engineering process it described in

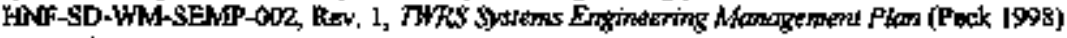
and the implementing procedures contsined in HNF-IP-0842, THRS Aldrintstration

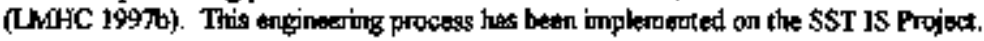

The top-level elemertie of this process inchude a mission analysis and definition of an operations and paintenarce concept for the SST IS Project. The SST IS mbstion has been analyzad with a particular foous on ideptifying the requiremants aseociated with top-level functions, major facilities, the Authorlzation Basis, regthlations and DOE orditrs, recorrds of decisions, and the Tri-Farty Agroernent (Eootogy et al. 1996).

The exigting facilities and ongoibg projects are being astested wo deternime the epplicabilily of existing systeria/componeuts athd to identify any dew systeras/comptentents that need 10 be deployed and the requirements for documentation (e.g., new spaitications or updaues of existing fubctional dessign criteria). Technical perfommance meagures are being eqlabtished, based on the speciffcations and risk evaluattons, to gain insigh tate the evolving trapability of the system and to manage risk. Tert and evaluation will be platuned and conducted as required to

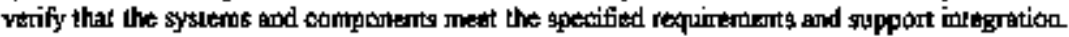

\section{2,2 Fnginteriot Proctst}

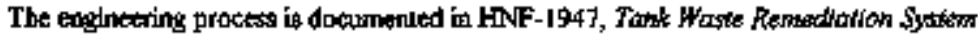
Enginering Pids (Exifay 1998). This plan describes the enginecring procts and the conterols being pot in place to support the tectinical basetine defiurition and to manage its control, evolution, and implementation to fied operations. The engineering plan provides tho vision for the 
engineering required to support the SST IS mission, which includes integraled data mannagersont

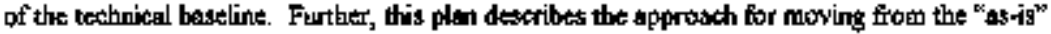
condition of engineering praxtice, systems, and facilities to the desired "to-be" configaration.

The systems engineering process described in Section $8.2 \mathrm{I}$ is an integral part of the overall enginearing process. Exibting ayderos arre analyxed to mogure that their fumctionality and pperrability will mett mistion ineeds ind system specifications. New systems dre defided through diversative generation analysis, tode studies, engjneering studies, and speciefty enginetring

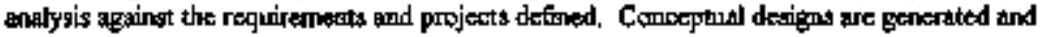
project babelines establikhed. Techrical authorties (design aulhorities and tognimant engineers) direct this process once the formai assesgnairtievaluation ensures the aeed for pow or mpodified hardwrare Detign, construction, and testing activities follow colcteptlal design The Engineering oreanization supports Operalions and Maimenartce by managing technical infortation (e.g. drawings, anstysis, vendor information, and squipment).

\subsubsection{Testhical Bxtedne}

The tecluical batefine generaled by this procest is summarized in Section 60

\section{Q.2.4 Ahennthes Mansgement}

Alternatives management generally cam be castegorized into throt major areas:

- Evahuation of techrical alternatives for processes, system dosignas and spetifications, and equipment selecton

- Coutimgoncy planning

- Ideatification and development of optimization opporturities

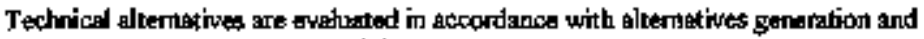
amelysis pusetces described in the TWRS Systems Engmeering Mamagentent Plan (Peck 1998). The yarious exiating alternativas gabestion and analyas sturties and thore that are plamed in support of the SST IS Project are described in Section 6.0 An abalysis of the allernatives and teclenology cotsidered is inctuded in Appendix $B$

\subsection{INTTGRATED SAFETY MANAGNMENT SYSTEM}

The dijective of an Integraled Satety Manzgement System (ISMS) is to facilitate soyfe

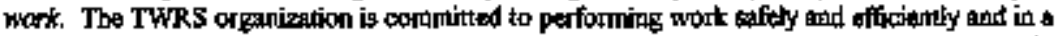

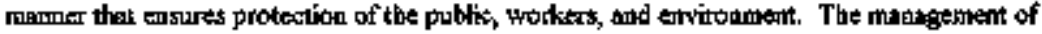
safety fianctions and attivities is mo integral aspect of the TW'RS Project and is aroonplished through inegration of safty mandgement inco all tacets of work planning and execulion. The 
ISMS establishes one ES\&H manggement sybtem that integrares requirements into work planking and execution and identifies requirements reflexting DOE's comeniment to a "standardg-based" safoty prowarn and the safely concopls.

The ISMS provides the thechanism for increased worker involvemett in wrok planning (includiag hasard and environenencal impach ideortification), aralysig and control, and feedback' improvemenk prosesed. Effective inptententation of the ISMS incorporates the best practices of, and supports the accomplishment of, the Vohuntary Proteclion Program, the enhanced work

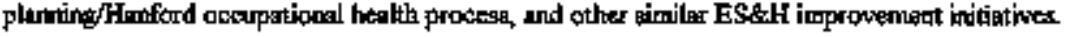

HNF-1883, Sextion 9.3, "Integrated \$afety Manzegement \$ystem," (Freeman 1998) provides additional detail on ISMSS objectives and the roles and tespontiodities of the integrated organizations supporting this effort. The following sections summarize this detail and descithe the relevande to the SST IS Project.

\subsubsection{Tank Waste Remediatian Syste: Safoty Orqaniations}

The TWRS Enviomumentai, Safey, and Health, and Quality Atsurance (ESH\&QA) organization, TWRS Radiological Combol, and TWRS Enginesing and Nuclesr Safey (TENS) provide health and safey servicts to the TWRS Project. Thede ongatizations use the ISMS to

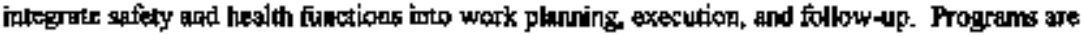
in place to everset implementation of DOE orders and Federal, state, and local lawe and rogulationts; porform audiks to verify compliance with regulatory and lepal operational

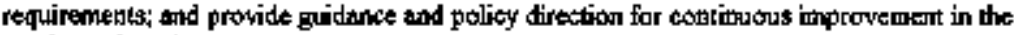
sonduct of work.

\subsubsection{Tank Waste Renedistion Syiten Envirenmealal, Safety, and Healuh, and Quality} Asonraber.

- Environnetatal. The Enwironment:al Progaam facilitates TWRS Project complianse by defisition and overight of emironmental regalatory requirements. Stabifzation acivities are compontints of the Tri-Party Agretrotist (Ecolosy al al. 1995) under M-41. The unit procesges of stabilization are evaluated to determine pervitting requiretients. The HNF-1773, Tank Waste Rewediation Systess Ervitrownentaf Progrom Plow (Bordeman 1998), prowides additional detail on the

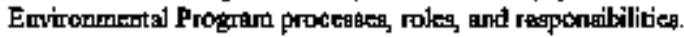

- Salety and Henhl. TWRS Safoty is a muluidisciplined organization encompassing Industrial Safexy, Industrial Hygieds, and Fife Protection. The Safety program is implenterned through nuentrous Project Hanford Pollinirs and Procedures for Occupational \$afety and Health and Fire Protection;

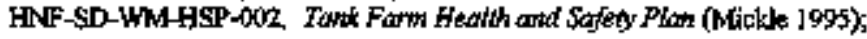


HNF-[P-0842, Volume ]X, Section I.], "TWRS Safecy Trogram Plan" (Freeman 1998); and TWRS-specifice andmistrative and quabity procedurea Stabilization activilies are covered by these procedures. Safey is integrated through the wotk planeing process and the safery overigigh function.

- Quplity Assurance. The TWRS Project contractor implements its quality

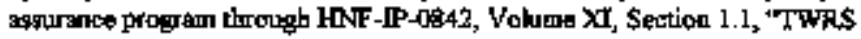
Quality Assurance Program Phan (QAPP)" (LMMC 19976) and the Quality Assurbace organization. An inplementation matrix in the Quelity Assurnoce Progitur Plan (QAPP) summarizes flowdown of fequirtinents to procectures. The procedures control the quality assurance process for the etrite TWRS Project. The QAPP is fevieuwed frevited andulaly to accomunadate changes in requirements, activilies, organization, or facilities. Stabllization activities fill under the QAPP and subprdinate procedures.

- Nudear Sajety. Nuetear safety enconapasses gystems and aclivities that mintimize

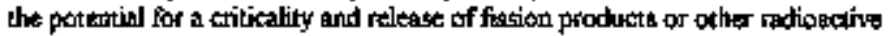
materials than could adversely affect the eavinument, the workers, and the public The TWRS TENS organization is responaibla for performing the engineering and auclear safety andyses to support this objective. The ESHRQA organization is responsible for the overinght of these analyses and reviow of the docturnants. produced. This relationship ensures that the integrity of an independent technical review is preserved. Conmumicetion ensures that the roles botwoen the two groups ate clearly defined and that duplication of wotk is avojded. Stabilization activities and work are evahuated in the same manner as all TWRS activitiogs to ensure that the Autborization Basis requirements are mex.

- Enertency Preparadmats. The Emtrgency Preparedness (EP) Progrian is an indegral element of the ISMS; the EF program is described in WHC-[P-097], Tank

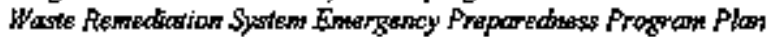
(Rowland 1996). The TWRS EP orgatization worts it conjunction with the sitewide EP organization, which incledes RL, and Projezt Hanford Manalgement team subcoulractors. The TWRS Project facility-specific roquiretintents are identifled and implemented by THRS EP. Stablization activities Gall under the overigight of TWRS EP, these activities are covvered by the current hazards astestinent.

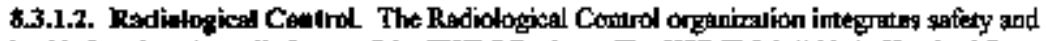
bealth functions into all phases of the TWRS Project. The HSRCM-1 (1994), Hanford Site Ratiological Control Mansol, outines the complance program for 10. CFR 835, "Ocrupational Radiation Frotestion." The Radiological Control ofgantzation implemenols this program through support and oversight of TWRS Project work, inctuding the SST IS Project activities, This effort invalves the generation of radiation wort perwith for relevant wort and the assignmeat of radiological control techricians as appropriate. 


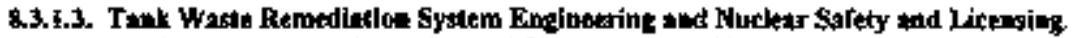
For the TWRS Project, the muclear anfety activities are executed by the Nuclear Safiely atd Listenting orgatizition, reporting to lie TENS Director. This fimetional orpport group ensures

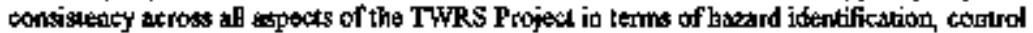
development, \$tructures, systems, and conponarts specification; Autborization Bagis document peeparation, DOE order comptance, and appratches to dealing with lectmical uncertainty. Stabilization activities are evaluated for comptiance with the Authorizotion Bosis and other

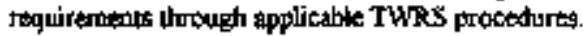

\subsection{DECIȘION MANAGEMENT}

Dexision management provides traceability for offected decisions theyough the gratied use of a rigorous and melhodical decigion-praking process. The SST IS Project management proceds

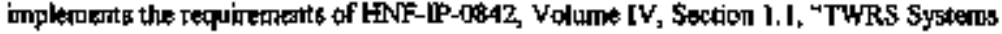

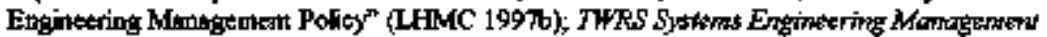
Ptan (Pectr 1998), and WHC-LP-0842, Vohume IV, Section 2, ?, "TWRS Decigion Manageraent Procedure" (LNIFC 1997b). In accordances with these references, a filly implemented decision mankgement process will be fillowed for major \$\$T Is misgion deciagons.

A gradect approach to implementing this process is allowad for decisions of leser inipact. It is the responsibility of the designated decision maker to deternine the degere to which the full decision managennent process is apptied to individual decisions. In ruch cases, SST IS Project

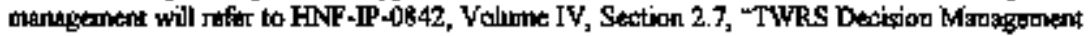
Procedure" (IMLCC 1997b) for specific guidance.

\section{M.S RISK MANAGCMENT}

The SST IS Project has imaplamented a digcipfined approsch to project risk managrement to

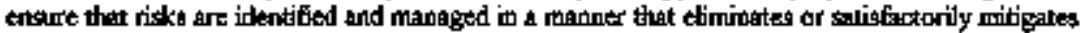
their inapacl. Risk ovaluation activities are enbeddod in the SST IS Project management

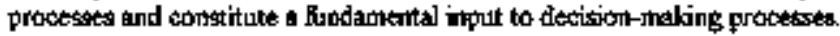

The SST IS Project risk munagertent process is intended to reduce these rigks to an accepiable keved turough a process of risk assessment, anabsis, and handling. It is also intended that rigks be communicated to the appropriate decigions makkers. The \$ST IS Project risk management project is based on the requirements of HNF-IP4(1S42, Volurine IV, Stetion I.], TWRS Systems Engineering Muragenent Pallcy (LMHC 1997b), and the TWRS Systems

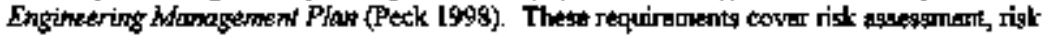
analysis, and risk handling.

The SST IS Project will implemettit these requirements through HNF-[P-0842, Volupe IV, Section 2.6, TWRS Projoct Rist Mamagennene Procedure (LMTC 1997b); 


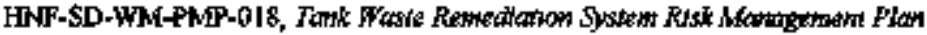
(Ziraratrobind 1998); and risk management implentertation plang, as required. In response to this guidance, the SST IS Project will perform the following:

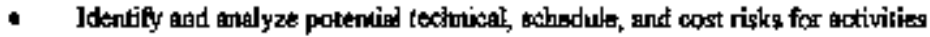

- Drovalop and maintria rigli maneggement listg identifying the risks, their posgible consequences, a measure of their relatiwe importance, and the plowthed talligalion actions

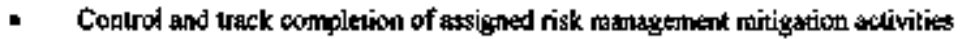

- Communicale risk project atatus through rollup of cists to the appropriate managyoment lovels and cross corrangnication with the appoopriake client counderpats at each leved

The SST [S Project technical basis revitw documentation (refer to Section 6.1) and the Single-Shedl Tank Interim Stabilizatjon Critical Risk Manasement List it Appendix B are the pritipal managerneft tools used to identify, analyze, and track project risks and their redated issios. Technicel bagis roview documents are deveioped for eacb key actryly identified on the SST IS Projel Leved 1 Logics in Appendix $E$ and incorporyte an agsessment of tochrictal, schedules and cost risks reisting to that activity. Risk lists are used to complle, communicale, and track risks and sctions takeri to mítigate auch risks.

\subsection{CONFIGUAATHON MANAGEMTNT}

Condiguration managenent is an inlegrated approach 10 conlyolfing the tochnical, cost, schedule, omd adrunistrative infordation necessay to manatge the SST IS Project activities it supports managenent of the SST IS Project baseline (technical and contractual) by proviting the prechanisgen to idertity, document, and control the functional and physical charsacteristics of the SST IS Projeet products, particularty as chaniges tre being made.

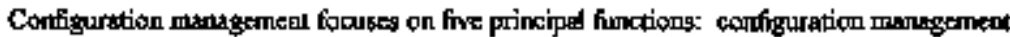
system managentent, configaration identificstion, configuralion stats accourting change conlirol,

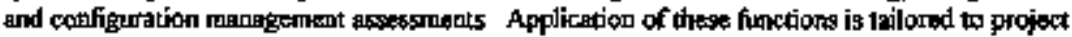
requirements, and chjertives remtion the same throughout the project life cyale: identify confiporition items, identify confipuration iuformation to be controlled for each ilen, and control that information. Critical to this prosess is identifying the as-built contiguration of project structures, systems, and componenis; the ctrange conteol tiresholds for moditying this configaration; and the kevd of aplbority required fore such changes.

The TWhS configuration management poticy and requirements are defined and described

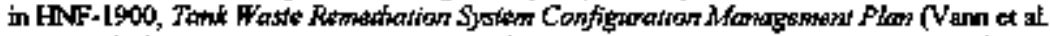
1998) The intplementation process and mechanims used to establish and eninition covfiguration corrtrot are al so described in HNF-1900 Sptecific ndechanisms and requirementg are addressed in 
Atetil by TWRS procedures referenced by FINF-1900. Additiond actions being taksen to improve the implementation of corffiguration mannagement are identified in HNF-SD-WMS-CMH-0I4, Rev. C (Vann 1998).

Tank Wagte Operations has appointed a Tank Wagte Operations configuration oungement represtelative, who is responsible for identifying conigigrution items and

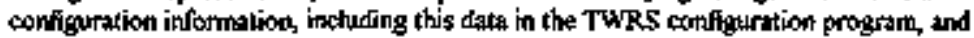
maintaining its tawceability ond consistency with sowrse requicenomus. This offort covers the

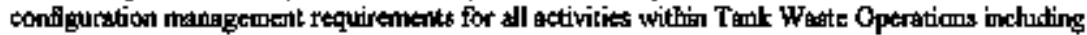
thosg of the SST IS Project.

\section{O.J PNTRRPACE MANAGCMENT}

A major objective of interface managentent and control is to torm ogreedsents that allow

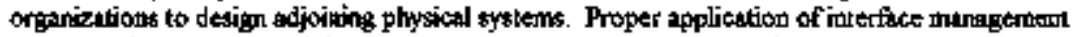
and control processes tegult in chucture systepols, and components that physically hit and fianction together without misthatch, onission, interferences, or digposition. imirfuce management and control akso tougt be imposed when an organizational intertace is identified. Typically, idenlified interfaces are to other iderntl TWRS projects (e.t. Waste Retrievad and Disposal. DST Operalions, or Characterization) or to external projects (e.g. Waste Managenkn* Project in the cese of 242-A Evaporator Operation).

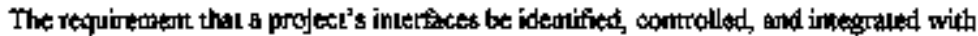
other projects and activitien is found in WHC-SD.WM-SEMP-002, TWRS Systems Engineenting Maragement Pfon (Peck 1998) and WHC-IP-0842, Volume [V, Section 2.8, "Interface Confmid" (LWHC 1997b).

The SST IS Proted interfaces primarily will be documented and controlled by the MYWP

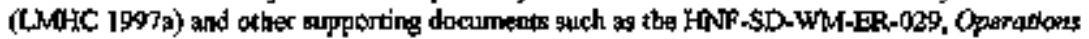
Waste Yotume Profection (OWYP) (Sirode and Boyles 1997). The Waste Maragernemt Project uses the OWYP *s the bosig for its planing. Whare required, the SST IS Project will estabiligh

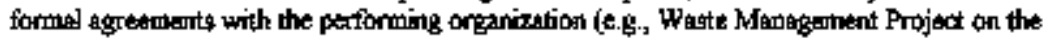
AYailability of the 242-A Evaporator to procoss accumulated liquid waste it the DSTs). Perfomance agioust interfict requiremteals will be monitored. The following key interfaces affect the SST IS Project. 
The \$ST IS Project interfaces are listed in Table 8-2 bellow and described in Section 2.4.

Table 8-2. Singk-Shell Tark Interin Statibzation Intetfaces.

\begin{tabular}{|c|c|}
\hline 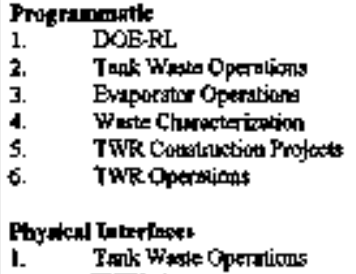 & 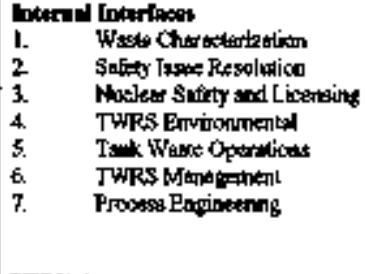 \\
\hline
\end{tabular}

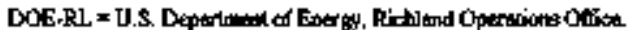

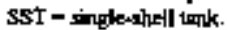

TWR = Tank Woske Retricyed.

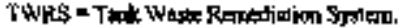

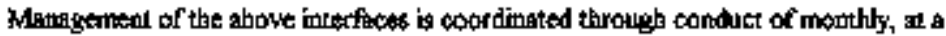
mintmum, meetings with the affeted pories. The purpose of these moetings is to provide information in ectivities to all affected organirstions, to discuss jssues and confficts, and to resolse any interface problems that ensy arise.

A DST Waste Inventory Control group meeting is conduched monthy. The charter of this group will be expanded to include Survaillsnce, TWRS Safe Storage Operations, and \$\$T iS Project statusing The Wasce Imentory Control group discusses waste transfiers, waste volunte projections, ad twell pumping schedul es, evaporator campaitgns, wonstruction project interferences, and privalizationt iasule. Action items from ptior metetingt are discussed and dosed as applienble. Now action iterts are identifled and doctunentod in mesting inimutes.

The charler for the Wate Inventory Control group is documented is HIN-IP-0842, Vohume I, Sectión 3.12 "Tank Famm Adminicastion Manual" (LMHC 19y/h).

\section{S.8 STAKEHOLDER APFADRS}

\subsection{Regulater Participinion}

RL has requesied regular meelmos with the PHMC Team in which the Washington Department of Ecology would be ineluded, to discargs \$tatilization issues. Such meetings art broing ptanned and coordinated through the FDH IWRS Project Directlon Office. Any other rexuests fiom IL will be handled theough FDH as woll 


\subsection{2 rublic Partiçipntipe}

Any pubtic participation will be handlad per tbe HINF-MP-012, Integraced Hadford' Commanications Plop (FDH $1997 \mathrm{7c}$ ) subtritted by FDH to DOE It identifies key Hatford Site

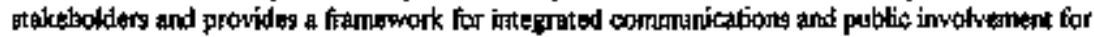
the Hinford Site. The LMFIC and FDH support RL in the conmunication of the TWRS Propect activities to stakeholders, tribes, and other interested parties. 
HNN-2358 Rev I

This page integritionally left boank 
HNF-2358 RpY, 1

\subsection{RSPERTNCDS}

\section{Codf of Federal Repulations}

I0 CFR 835, "Ocauprtional Radiation Prolection," Code of Federal Regulations, ag amended.

\section{Databated}

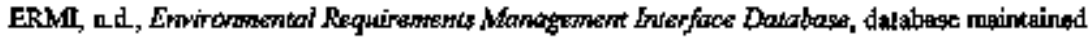
by Lockbeed Martiu Hanford Corporation for Fluor Damid Hanford, Inc. , Richland. Wastington.

\section{Institude of Noclese Powar Oparations}

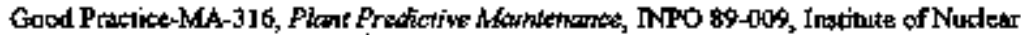
Power Operations, Alanta, Georgiga

Good Practice-MA-30T, Prevevthe Maritenance, INPO 85-032, Itislitule of Nuclear Power Operations, Atkila, Oroorgig.

\section{U.S. Department of Energy Ordera}

DOE Order 4330,4B, Maintentunce Moungement Progras, U.S. Diparimem of Energy. Wastingtor, D.C.

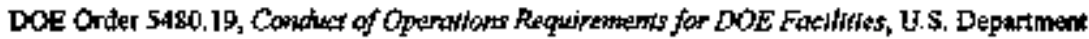
of Energy, Waqhingtor, D.C.

\section{Docament:}

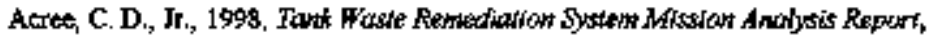
HNF-\$C-WM-MAR_00g, Rev, 3, prepared by Loctheed Martia Hanford Corporation for Fluor Danled Hanford, Ine., Richland, Washington.

Allen, D. I., 1998, "Subcontract Numbor go232764-9-K001; Proposed Palh Forutrid for Hanford

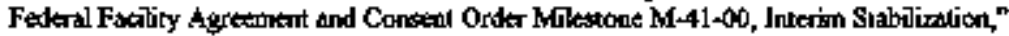
(letter LMIHC-9851940 R3, to A. M. Utrek, Fhor Daried Hatord, Inc., April 7, 1998), Lockbeod Mantin Harford Corporration, Rinhland, Waphington. 


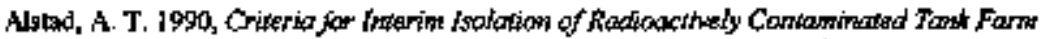
Facifities at Hanford, WHC-SD-DM-TI-O9?, Westinghouse Hanford Company, Richland, Washingtor

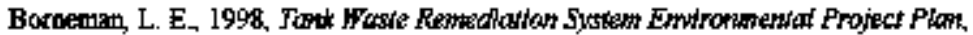

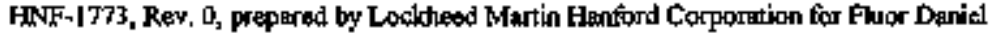
Hantord, Ince. Kicbland, Wathingtoon.

Ecology, EPA, and DOE, I996, Hanford Fedaras Facility Agptement and Corsent Order, 2 vols, Washington State Departmenl of Ecology, U.S. Egvironraental PTotection Agency, and U.S. Departirent of Energy, Clympia, Falphigton.

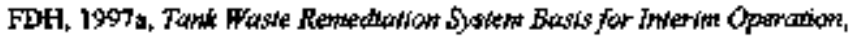
HNF-SD-WM-Blo-001, Flug̣t Deried Hanford, Inc., Richlembl, Washington.

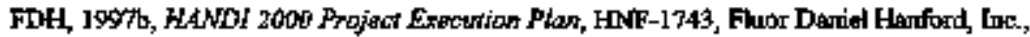
Richland, Washinglon.

FDH, 1997e, Integtated Honford Cotwhtwhertions Plat, HNF-MP-012, Rev. 0, Fhor Daniel Hanford, Inc., Rjetland, Waghington.

Filzaimurons, $T_{1,}$ 1998, "Finat Deteruination Pursuapt to Harfond Federai Facility Agroement and Cousern Orier in (Tri-Party Agrtemeat) in the Matter of the Disapproval of lie DOE's Change Control Form WM-41-97-9I," (letter to J. D. Wugporer, RL, Fehnuary 10, 1998), Wathington State Departmeat of Ecology, Olywipia, Wastingtom.

Freetinan, D. V., 1998, Tank Watte Romediation System Progrenty Plan, HNF-1883, Rev. 1. prepared by Lockheed Martin Harford Corporation for Fhror Daniet Hanford. Kne.. Richlond, Wastington

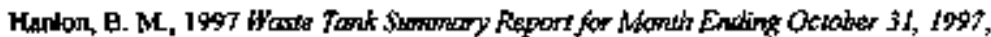
HNF-EP-0182-115, prepered by Lockheed Mantin Hatuord Corporation for Fluor Daniel Hanford, Inc,, Richkand, Washimpton.

Hoogendoom, W.. 1998. "Direction for Develcpuent of an Agrsessive Single-\$bell Tank (SST) Interim \$tabilization Compietion Project Plan in \$upport of Hanford Foderal Faribity

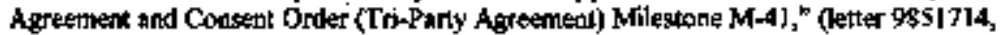
to R. F. Wooks, Loskheed Martin Hanford Corporation, Febeuary 25, 1958), Flewor Daricl Hantord, Inc., Richland, Wastimgton

HSRCM-1, 1994, Hanford Stite Radiological Control Manwal, Rey, 2, prepared for the U.S. Deparimeul of Energy. Riehland, Operstions Office, by the Hanford Site Contractors and managed by Pacific Nontriwest Nötipnal Eabor atory Records Mamogement Ofirce, Ristard, Wastington. 
Lawrence, M., 1984, "Wagte Managemenx Programatic Change," (tetter to P. G. Lorenzini,

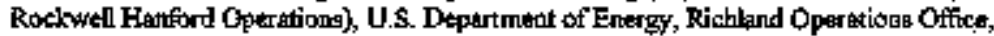
Rictiand, Washington.

LMHC, 1997a, Tank Waste Remedlarion Fiscal Year 1998 MAlu-Year Work-Plon, HNF-SP-1230, Rev. D, prepared by Loclteed Martin Hanford Corporalion for Fuor Daniel Hanford, inc., Richland, Wathingron.

LWHC, 1997b, ThRS Administration, HNF-[P-0842, Lockheed Martin Harford Corporation for Fhor Darried Hanford, Inc., Richlaud, Washington.

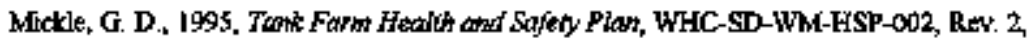
Weatinghouse Hantord Compatay, Richland, Washingtom.

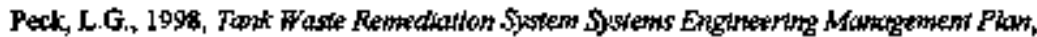
HNF-SD-WM-SEMAP-D02, Rev. 1, Fr'tpared by Lockteed Martin Hanford Corporation tor Fluor Daniel Hanford, Inc., Riehland, Washington.

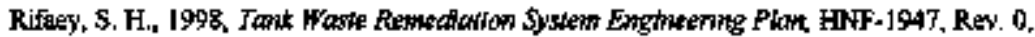
preparad by Lortheed Martin Hanford Corporation for Fluor Danied Hanford, Inc. Richland, Washiugton.

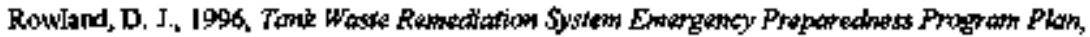
WHC-[P-0971, Westinghouse Hanford Corapeny, Richlard, Wathington.

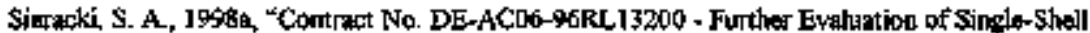
Tank Interim Stabilization Conpletion Project Plath," (Ielter 98-WSD-968, to H. I. Hatch, Fluer Dartid Hanford, Jnc. April 9, 1998), U.S. Depertment of Energy. Richland Oparations Ofict, Richland, Waphrigton.

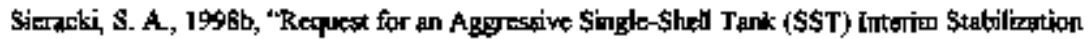
Completion Project Ptan, "Netter 98-DSD-034, to H. J. Hatch, Fluer Dariel Hablord, Inc., Wiarth 2, 1998), U.S. Department of Energy, Richlerd Operations Ofice, Richland. Washington.

Sirracki, S. A, 1998c, "Contract No. DE-AC06-96RL13200 - Palh Forward for Sinde-Shell Intexim Statiilization Completion," (letter 98-WSD-075 to H. J. Hatch, Fhuor Daniel

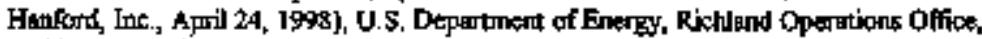
Bichland, Wathingtob.

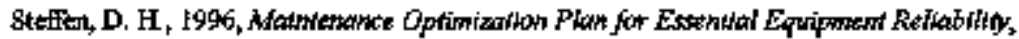
WHC-SP-1179, Wesinghouse Hanford Company, Richiatd, Wastington.

Strode, I. N., and V. C. Boyles, 1997, Oparations Waste Volume Proketron (OWJT). HNF-\$S-WM-ER-D29, prepared by Locktheed Martim Hanford Corporation for Fhur Daniel Hauford, Ink. Richland, Wathington. 
Freat, R., P. Bartey, T. J. McLougdlin, R. D. Potter, R. E. Raympond, and W. L. Wulli, 1998,

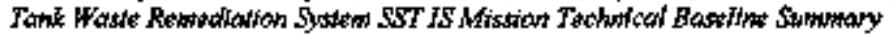
Deseription, HNF-1901، Rey. 0. prepared by Lockheed Martin Hantord Corporation for Fluror Danid Harford, Inc., Richland, Wabhington.

Uimek, A. M, 1998, "Controct Number DE-ACOS-96RL13200, Proposed Path Forward for Hanford Federal Facifly Agreetent and Consent Order Milestone M-41-100, Interim Stabilization," (letter FDH-9851919A R3, to J. E. Kinzer, RL, April 8, 1998), Fluor Danied Hanford, Inc., Richland, Washington.

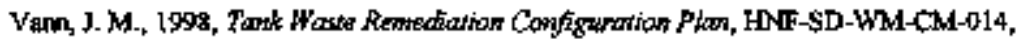
Rey. C, preparted by Lockhoed Mentin Hauford Corporalion for Fhucr Daniel Hauford, Inc. Richland, Washington.

Vam, J. M, E. R. Hamm, and R. D. Crisp, 1996, Tant Faste Resediation System Configuratton Marmagement Plow, HNF-1900, Rev. O, prepared by Locklveed Marrin Hanford Corporation for Furos Danied Hanford, lnc, Richland, Washinguen.

Wood, R. F., 1998. "Subcontracd "180232764-9.K0001, Single-Shell Tank Interim Stabilization

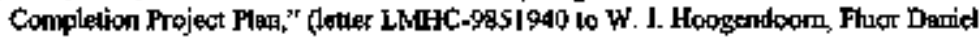
Hertord, Inc., Martb 9, 1998), Lodkheed Martin Hanford Cotporatiou. Richlaad. Waghington.

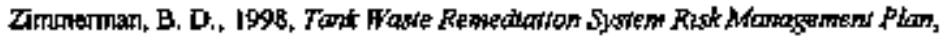
HNF-SD-WM-PMP-019, Rev. 2, preptered by Lockteed Martin Hanford Conporation for Furor Daniel Hanford, Inc., Richkand, Washingtort 
HNF -2358 Rey 1

APPENDLX A

INTERDM \$TABILIZATION BISTORY

A-i 
HNF-2358 Rev I

This page indentiontally left blank

A-it 


\section{APPENDIX A \\ INIRRPM STABILIZATION HISTORY}

\section{Introdeetlo:}

The U.S. Department of Enerigy (DOE) har ahifted its minin objective from production of special nuclear material to clearup of facilijes and restoration of ins manuracturing siles. With

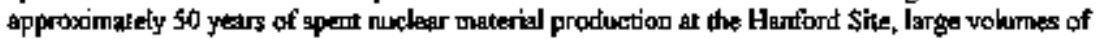
liquid wasse by-products that consist of radioactive and toxic chemical mixitures bave accuraulated. Liquid wastest are stroned in large underground waste storage tatks that are

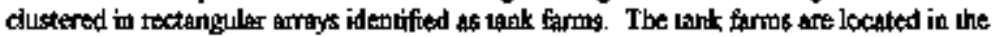
200 Weat and 200 East Areas of the Hatiord Sile.

Between 1943 and 1964, 149 single-sheif tanks (S5T) were designed and construcled in the 200 Artas. Wistes wers added to these tanlks from 1943 until Noveruber 1980 . Each of the 12 tank farmis contains ftom 4 to 18 SSTs. To provide additional space and to elininato the poteutial for 1ank leakage to the vadose zonte, a double-shell tank (DST) tometruction program corurateed in 1968 .

To linit the number of new DSTs that had to be constnucted to store liquid fadicactive waste, DOE authorized concentration of the waste liquids until the gohuble salts were precipitated. These precipilated salts were allowed to selte in ihe SSTs. Significant free supenatarts were puraped firom most of the \$\$S by 19\$0, concentrated, and then stored in DSTs. No new waste additions were made to the SSTs after 1980. Howewer, the SSTs have setn severe service and

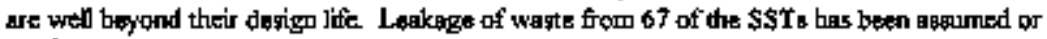
confirmed.

To redure the potertiel of finther leakngc, an approtech was developed using a centril scroen urell and a low-capacity jet pump was installed in the wel 10 remoye the drainatio liquid. Liquid in the tank Arosias to tris central wed, driven by the pressure of the interstitial Jichuid in the bod (head height). To maximize the rate of drainage at all times, the liquid in the well is

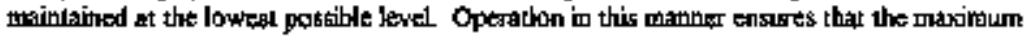
drainable fiquid is removed as quickly as postible. This process hits besen defined as "interin stabilitrotion."

The solids remeining in the SSTs consist of porous beds, with the interstices filled with the remaining radioantive waste lifgurds, Depending on the particte sizes of the solid beds, varying amsunts of tiquid are trapped it the solids beds. For beds with relatively large particle sizes, the reanltant cagillary potential of the bed is low, and much of the interstitial liquid car frain or lealfFor very fme partides, the capillary potential is very high, and little of the interatitial lingid can drain or leak. On average. 3.79 liters (1 gallon) of salt cake may contain 1.26 Eters to 2.53 liters (1/3 to $2 / 3$ of a gallon) of draiobble liquid, while 3.79 liters (I gailon) of sludge may contain 0.379 inter 100.95 lites (t/10 10 $1 / 4$ of a gallon) of drainable linuin. 


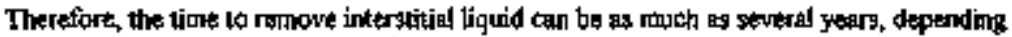
on sohution properties, solids poratity, surfuce tension on the liquid on the welled solids, head height, well dianoter, and sohution viscosity. Pumping generally contineses until the inflow ioto the central well is $3.2 \times 10^{3}$ like per second (0.05 gallon per minutes, less that 1 aup per minute). Flush water needed to keep the punp and screen clear exceeds the $3.2 \times 10^{3}$ liter per second

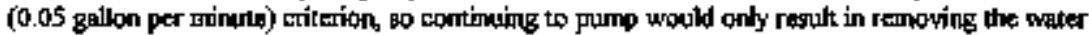
added to the syseren, rauher than continuing to remove liguid waste from the solids.

Prototypical operation of altwells began in 1976 and continued intermittertly through 1978. A karger scale commitment to install and operate saltwells began it 1979.

\section{Interim Stabjization}

Of the 149 SST, 119 have bete interise stubilized. This itcludes removal of purtpable liquids in accordance with the identified criteris, concentralion of the liguid through eyaporation, and tran ufer of the concentroute to DSTs. This interim stabilization step was talken to mitigate the consequences of a leaking tank. Each of the 30 SSTs awaiting ioterim stabilization contains between 174, 100 liters $(46,000$ galkons $)$ and 3,607,000 libers (953,000 gallons) of wapte, much of which is pumpable liquid. Figare A-1 reflects the murnber of tatiks punped per year. Figure A-2 reflects the volume pumined per year.

Fased on the Aedign life, the severe service, and the number of tanks aurrenily idtentified as assunated or confirmed leakers, there is no techurcal or engineering resson to ber remaining to be interim statibzed will sok fail in the future. Thereforts the remaiming 30 tamls will be interim stabilized wo mitumize fuwre leak potemial and as at inuegal part of the ongroing DOE clearup objective.

Irterim stabilization of the $\$ S T$ is a DOE pbitective and a critical stop in the Honford Federal Faclity Agrement and Cortent Order (Tri-Proty Agreement) (Ecology te al. 1996). Stabilization is required to support retrieval and ultimale waste disposal objectives, with the likety

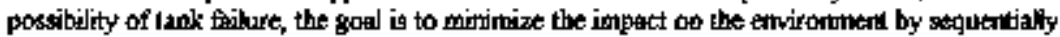
stabilizing the tanks. are atpieved:

End-point criteria for iaterim stabilizaion of SSTs are reached when all of the following

1. Each tank cantains less than 189,200 liters ( $\$ 0,000$ gallons) of drainable inter alitial linuid, besed od ether a 45 persemt porosity or the porosity detertinined during ackest purmping

2. Each tank contains less than 18,920 liters $(5,000$ gallont) of superantant (Lbe Hequid above the solids in waste storage tanks) 


\section{HNF-2358 Rev. I}

3. If a $3.2 \times 10^{3}$ liter per muibute (0.05 gallon per minute) or less pumping rate has

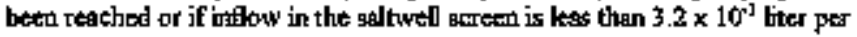
second (0.05 gallon per minute) and each lank has less than 189,200 liters $(50, \infty 00$ galtonв) of drainabte interstitial liquid.

\section{Intrusion Preqvęutien (Interita Lolation)}

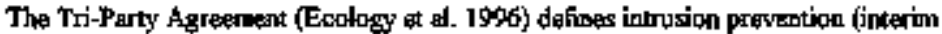

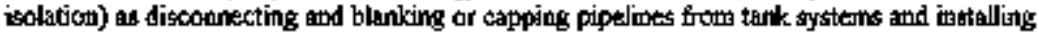
barriers to ayoid inadvertent liquid addition. Intrugion prevention is conplete when the necessary

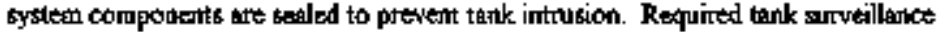
inscrursentation devices are not disconsected or disabted during the intrusion prevention process.

End-point criteria for intrusion prevention of SST are rescbed when all of the following are achioved:

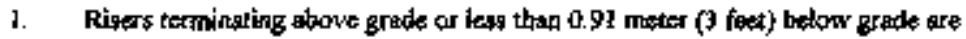
sealed

2. Couffinement covet for pits, cells, valls, tc., are bealed for tanks that have risers teralinating in a confinet area

3. Fipelines entering any tank or abovegjade structure connected to a tank are sasled with tlosure devises.

\section{Mafareace}

Ecology, EPA, and DOE, 1996, Hasford Fedprat Factlity Agreemsent and Consent Onder, 2 vols., Wasjington Stale Departimert of Ecology, U.S. Emironmetial Protection Agency, and U.S. Departrint of Energy, Otyripita, Washington. 


\section{Interim 119 Stabilized Tanks}

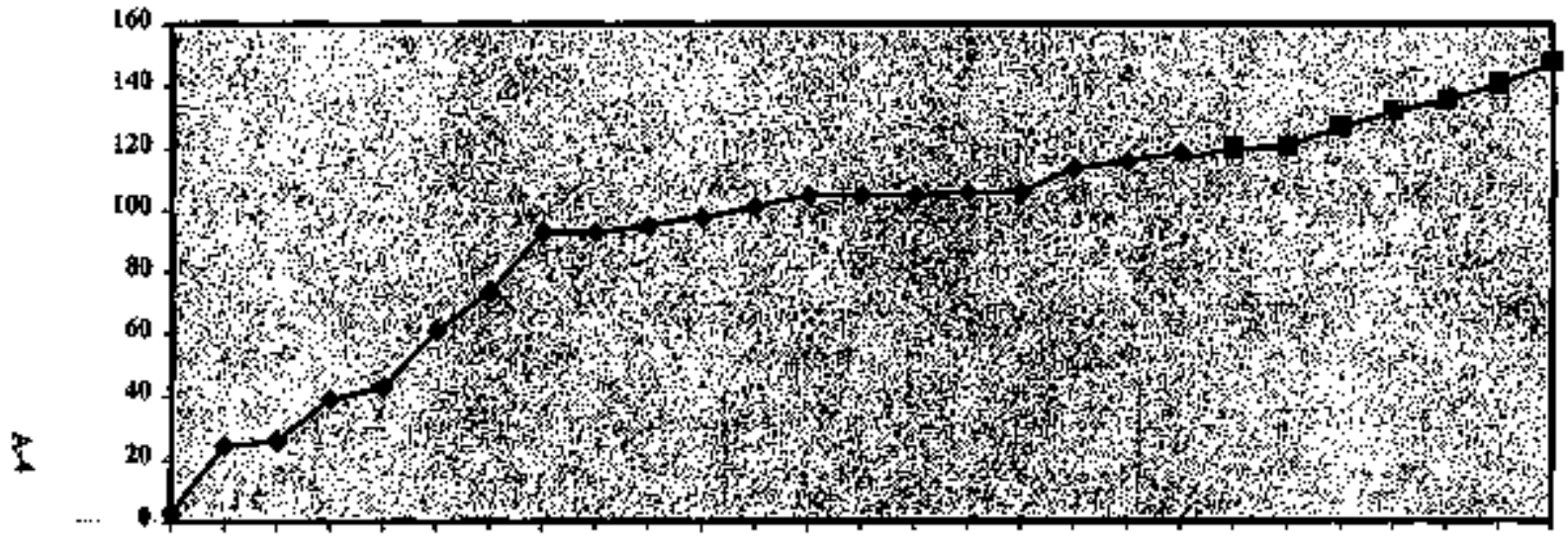

คै

\section{$1978(\mathrm{FY})-1997(\mathrm{FY})$

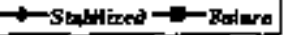

I19 Swbilked Tonks

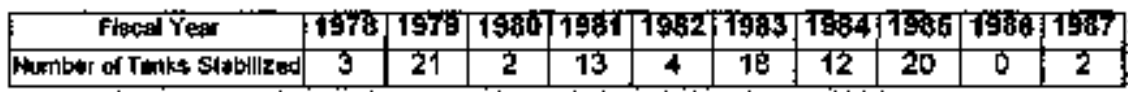

\begin{tabular}{|c|c|c|c|c|c|c|c|c|c|c|}
\hline Flset Y Y & 2988 & 1989 & T980 & Tध99 & T1992 & 1993 & TF94 & 1995 & 1998 & 790 \\
\hline thember of Tanks Stab" & 3 & 3 & 4 & 0 & & 1 & 0 & 8 & $\overline{2}$ & 3 \\
\hline
\end{tabular}

\begin{tabular}{|c|c|c|c|c|c|c|c|}
\hline Frecal Year & 1998 & 1990 & 2000 & 2001 & 2002 & 2003 & 2004 \\
\hline puntber od Tanks Satrized & 1 & 1 & 6 & 5 & 4 & 5 & 7 \\
\hline
\end{tabular}

$1998(F Y)-2004(F Y)$

2y Stabilized Tanks (148 Total)

Tำ

Figure A-l. Interim 119 Stabilized Tants. 


\section{Accumulated Gallons Pumped}

\section{(1979 - 2004)}

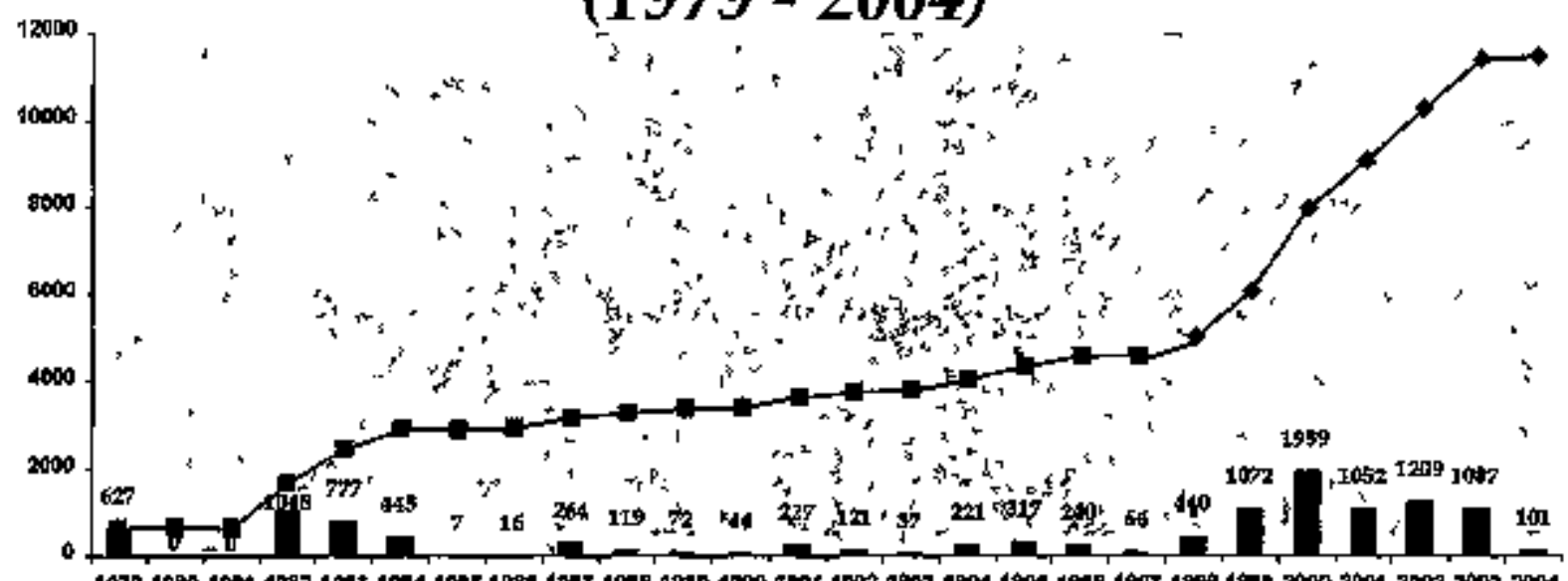

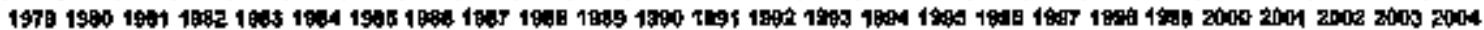

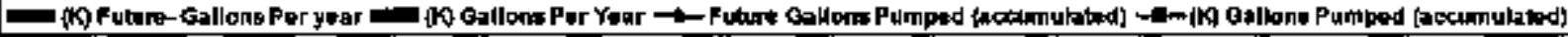
$1979(F)-[997(F Y)$

4,648(K) Gallons Pamped

\begin{tabular}{|c|c|c|c|c|c|c|c|c|c|}
\hline & & 1980 & 1981 & 180 & 198 & 984 & 199 & 8 & \\
\hline & 62 & 0 & 0 & 1048 & $7 \pi 7$ & 445 & 7 & 16 & \\
\hline
\end{tabular}

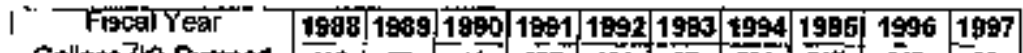

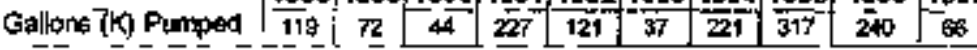

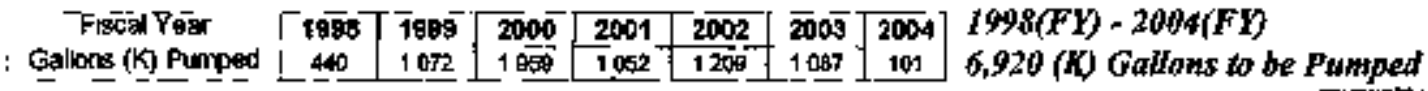

Frourer A-2 Galons Pumped Pec Fistal Year 
HNF-2358 Rey ]

This page mtemtionaly keft Hank 
HNF-2358 Ror 1

APPENDCX $B$

ALTERNATIVES AND TLCINOLOGY CONSIDERED

B-i 
HNF.2358 REV. I

This page intentionslly loft blank. 


\section{CONTENTS}

B2 0 ALTERNATIVE APPROACHES

B2 I ENHANCED SALTWELL PLNPPFG

B.2

B2 2 D-TANK CAPLLARY PUMPING OR ABSORPTIONN

B2 3 ACCELERATED RETREEVAL

B2 4 ELECTRO-OSMO\$IS

B2 5 ALTERNATING-CURRENT HEATING

B26 MICROWAVE HEATING

B2 7 WTPED-FILIM EVAPORATICIN

B2 B DN-TANK SOLIDIFICATION

E2 9 CLOSE-COUPLED BARRIERS

B2 10 SCREENING

B3 0 ENHANCEMENT TO THE SALTWELL PUMPING TECHNOLOGY BASELINE B.7

B3 I MULTLPLE PUMPSSNELLS

B3 2 INCREASED WELL DLAMETER

B.7

E3 3 ALTERNATIVE PUMPS

B-s

B3 4 WATER ADDITIONS TO OPEN PORE STRUCTURE

B-8

B3 5 "MIINTNG" OF RADLAL CHANNELS TO INKREASE WELL PRODUCTFON RATE

B4 O SALTWELL PUMPING SYSTEMS LOGISTLC ENHAWCEMENTS AND CONTISGENCY

B4 I DOUBEE-CONT AINED RECEIVER TANK LOGISTICS AND WORKAROUNDS

B4 2 USE OF 1R-S6 FOR EMERGENCY PUMPING OF COMPLEXANT TANKS

E4 3 LANE-INPLUGGNGG TOOLS

B4 4 ADDITIONAL WASTE-VOLUME STORAGE CONTINGENCY

B5 0 "SPECIAL CASE" TECHNOLOGY

B-12

BS I TANK EY-1OS "CONCRETE" TANK

B-12

E5 2 ORGANIC COMPLEXANT CO-MINGLING

B6 0 POTENTLAL COST AND SCHEDULE PERFORMANCE ENHANCEEMENT

B-14

B7 O REFERENCE

B-14 
HNF-2358 ReY 1

\section{LST OF FIGURES}

B-I Compristave Saltwell Itritow Compared to 10-Inch \$creent

B-9

\section{LIST OF TAELES}

B-1 Altemairye Approaches for Intershtual Laqud Contaument B-6

B-2 Podeatol Rugk Reductuon, Cost, and Schedule Benefils from Technology atrd Rosk Reduction Actuvitues

B-15 


\section{APPENDIX B \\ ALTERNATIVES AND TECHNOLOGY CON\$\$lbERED}

A sunumary atternativas and technology gcreaning revient was conducted to idemafy promising alternalives that should be evalualed as part of the ascalenated Single-Shell Tank (SST) Interim Siabilization (IS) Project. The review was conducted at theo lewds. Frist, broad technical altematives were dewloped to the current technical tratefine approach to prewent 10akege of the interstitial liquid to the environmenl. Secoudly, technology entiancements to the ejisting saltwell pumping system tecknology were idemified and eythaled. Fitally, specific wols

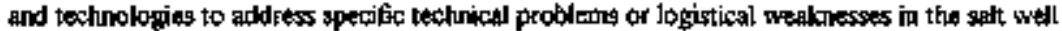
pumping systems were identified.

The iderntified alternativers were quathilaivety evaluated with respecl to potential cost or scherdule impact, the feagibility of the alternative, and the bikely deployment schectule and its potential irupacts to downstream retrieval and imrabliention processing. Evahation of trems that apyeared to bave significant potential for riak reduction of the basedine cost and schedules wore frdicted in the progersm schedule.

\section{B1.D TECHNICAL DESCRIPTION OF THE PROBLEM}

To evaluate potential alternatives, it is important to undershand the techmical aspeste of the problem. As a result of previous production history, various waste siuries were transereded to the

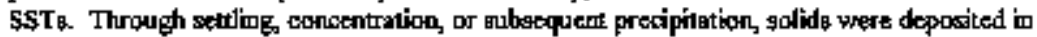
various layers, usurilly with relatively small particle sizes. Most recenlly, vacum evaporatorcrystallizers were operated in both the 200 Eagt and 200 Wogt Areas producing slurries with relativaly large particla sizes lo reduce overall wate wohme. The slurries produced by the exaporator-cyst.llizers were deposited in SSTs that hed sigrificant ayailable space.

Once the solids were senled from the waste sluries, the clarifed bupernate waste eventually transferred into the druble-sticll tank (DST) system No new waste additions have been nade to the SSTs since 1980 .

The solids remaining in the SSTs ate provens in stracture, snd the ports are filled with sapernate likuid. The various layers of precipitated solids have widety differing particle sizes and verying pore sizes as a result. The interstitial liquid is of varyiting chemical and phyticel cheracteristics. The solutions are generally in chenical equilorium with the solids they are in contart with at the golution temperature. The pore sizes of the porolus bed are amall enought to txchibit singuificant capillary potential, ranging form a few inches of head for soume large solids to kens of feot for fine sludge solids. Whenever the saturated liquod loved is higher than the capalary potential, the interstitial Jicquid can flow to areas of lower potential. 
Any lime an SST develops a kak, lite interstitial liquid al a pressure above the copillary poterntial of the solids bed cen flow ourt of the tank.

To redure the potential for liquid leakage out of any faikd \$ST, the U.S. Department of

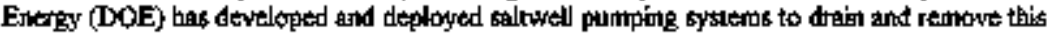
imerstilial liquid. A central screened well is trastalled in the conter of the tank, while a spexially

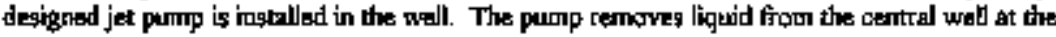
same rate that it drains to the well. In doing so, the saltwell resiscyes the drainable liquid at the fastest rate possibte. Once eagugh liquid is remowed, the excess postertial is restuced to the point where inflow into the well is rechuced to less than 0.19 liter per minute (0.05 gallon per minute). At this rate, the vast majority of the drainable Equid lass been removed, and flush water additions

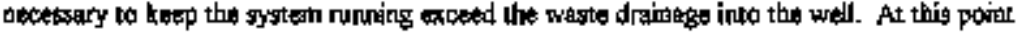
staltwell pumping is ferlared complete, and the tank is isolated to ensure that water intrision does mot occur until the tants is prepared for relrieval.

At the completion of the saltwell pumping activities, the solids remaining in the tank still

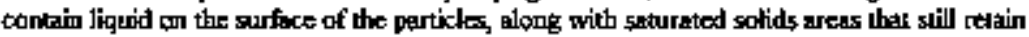
liquid by the copialary' potential of the solids bed, which cannot lealk unless additional water is added to the systers.

\section{B2.4 ALTERNATIYE APPEOACHES}

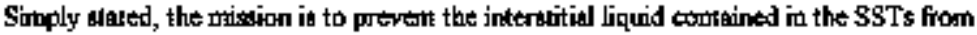
leabing to the environment until the waste can be retrieved and inmobilized. Becauge the waste in many of the SST s will not be retrieved util the period 201 1-2018, the Equid must be tittetr remowed or contained tor 10 to 20 years.

The alteratives identified are to temose the liquid from the tank, solidify the fiquid in the

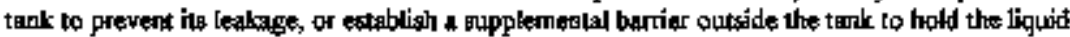
in the tank pending retrieval. Following it a brief description of the identified aliecrutives.

\section{B2.1 ENHANCED SALTWELL PUMPING}

Enhance saltwell pumping is basically a continuation of the baseline lechnology, enhanced by some of the inprovements that will be discussed in Section B3.0.

\section{B1,2 IN-TANK CAPILEARY PUMTING OR ABSORPTION}

to-tank capillary pumping or atsorption woutd ube a very fine and absortecol material installed in cored holes in the latrk. The absorbent waterial has a much higher capilary head and will axtract interstifial liquid at a slow rate from both the drainable sal lcakeg and nondraimable shudges. As the material becomes solurated, jit is reuroved and replaked with fresh material. 
Typical maveriads woudd be clays that aro coupatible with downstream inmabilization to the

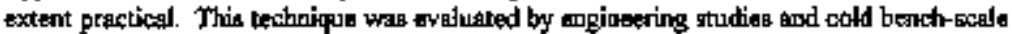
demonstration it the late 1970s. At that time, the amerunl of inert material added to the lank was determined to be very large, which ragults in significant increages in the volume of inmobilized Jow-activity waste and high-level weste glass, and the time to wetheve any signifocant hiquid revoval was very long. The conly idemlitied feasible application was after the drainable liguid was renoyed or as part of min-tank dogure techniqua.

\section{G2.3 ACCELERATCD RETRILYAL}

Acced araled retrieval would utilize cither basefine sluiting tectronology or other technology to rermoval the interstitial liquid, along with all of the remaining wagte fion the \$ST. This effectively "leapfrogg" tha salkwell completion schedula by accelerating retrieval, as is occurring with the C-106 duining system. However, based on the curreat state of slulcing Iectunology, and the liwited DST volume, it is vary unlikely that one or more retrieval systams could be deployed in the time it would talke to complete tallwell puenpings, bectuse of the amoumt of carital coustrustion required (\$20 to $\$ 80$ million).

One alternative apptosch would add a solids-kacking elemem, similar to the ore-leaching

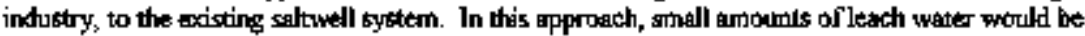
distributed on the surface of the solids in the tank. This leach water woukd dissolve the salt, flow to the cartral well, and be tringferred to the DST sygtem. The ampont of water added would be adjugled lo maict the amount of solution removed. The leach water would also open up channels

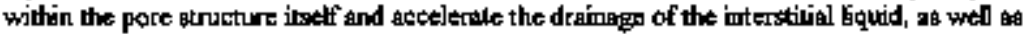
diluting the interstitital linguid. It appess that the salt could be completely disgolved within a

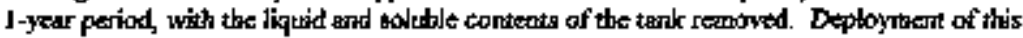
"rajnbird tetrieval" concept has wery low capilal costs, because il uses the oxisting saltwell

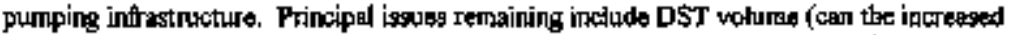
volume in the DST tystem be managed?) and significant kevels of regulater and slaketeolder conserms. For tanks that contain a majurity of sohble solids and have a long projected pumping time, this might be a feasible alterinative to cut the pumping duration oind program costs.

\section{B2.4 ELECTR0-08MOSIS}

Elattro-osmotis could accelerate the me of drainuge by the gddition of an electriegl potential to drive drainage of the liquid, is addition to the gravity head that driveg dranage in the bersedioe approsch. Electrodes would be installed around the perintetra of the Wraste, and a direct-

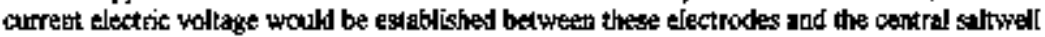
sween. The electrical volthge caures the interstitial liquid to flow to the central well at a higher relt. The tectnology is widely used in civil ensinerring and exviuotunental remediation to dewater soils and shidges. 
Latporatury end bench-scale work was conduced at Arizona \$true Universidy and at the Honford Site in the late 1970s. Electro-omosis was inteasible in the bighly eouducive eolution

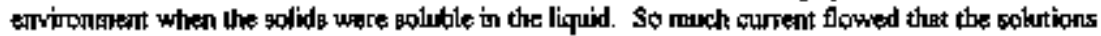

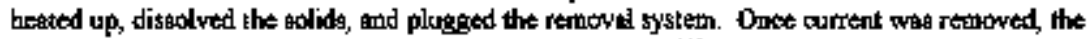
solution cooled and formed a lage salt mass that was very difficult to dissolve or mechanically

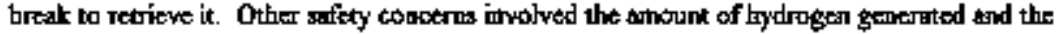
potential for electrockenical corrostion of the tank ilselt.

\section{B2.5 ALTERNATING-CURRENT BTATING}

Alternating-current heating is a technique to remove water from the interstilial tiquid of the tank3, thereby rocucing the volums of liquid that can leak Again, electrodes are ingtallod around the waste ittwior, with a central electrode to complete the altenating-current circuit. A highYohage allernating-current source is connected botween the proineter olectiodes and the central

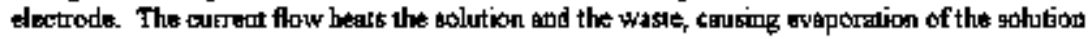
in the kanks. The vapor is removed by the tank wertilation gystem. Condensers and offigas filiration would seed to be provided. The condensore from this operation may need to be revaporated by the exaporalor before discharge to the 200 Area Eflluent Trealment Facifity becasive of enteaiomant.

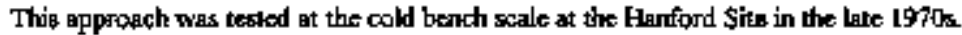
As expected. sigtrificant heal was generated. However, heating of the solution resuled in the dissohution of the soletile constituents and in some tases resudiod in metting of the salt isselt.

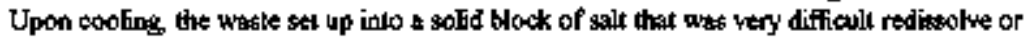
retrieve. Safety issues regarding tha trigh-temperaturt effects on the tank sructures, garay electrical anremts tond electrochemical corrosion, hydrogen generation, and propegalion of fires in some tanks with organics all made applikation of this techripue problematic.

\section{B2,6 MICROWAYE HEATING}

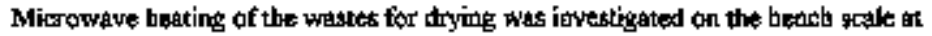
combereid leboratories in Conseds, as well as at the Hantord Site in the lase 1970s. While adjustement of the radic frepuencitas to coupla with the tank wate to generate heal was possible, resuls were similar to the allemating-carreth hesting disxussed above. Additional sefety conkechs with the high-energy radio-frequency generator; wave goides, and rodiation exposure to personned algo werce significant.

\section{B2.T WIPED-FIM EVARORATION}

Wiped-file evaporation wrould be installed í an SST riser. Waste wodd be transferred from the wank to the wiped-fiam eyaporator and undergo subatsandial conkentiation. The

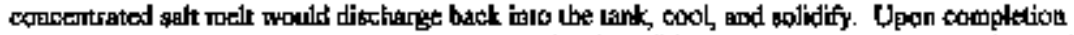
the waste would be in a snaller waste valume, with the bolids ascentially existing as a solid block 
of salt. Full-scale protolype sold testing on both Savanuah River and Hanford Site waste lypes was completed in 1976 at Savanoth River. Both sites deterroined that tha wasto form was too dificult to retrieve and decided against deptoyment.

\section{B2.8 IN-TANK SOLIDIFICATION}

Iti-tank solidification by the addition of concrete or clay has beat lested aud denoustrated at both \$avannah Risor and the Hanford Site. Simale addition of concrote or clay has opt been efifoctive at Hanford. Englneesting eyaluainons show lhat substamial mixing of the councete or chy is required to effectively immobilize the wastes. This can be nocomptisted by jet-mixing injection

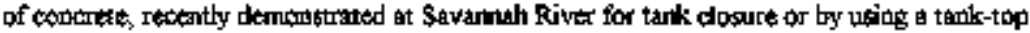
waste exinuder thas necharically mixes the waste with the solidification medium. Similar

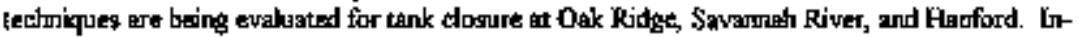
lank sobdaficalion woukd essentially eliminate the abibiy 10 ensily retrieve the waste for subsequent immobilization and would be sibabte only if diaposal of the wagte in-tank ware determined to be desirable.

Other techriques such as in sint vitrification have been considered (Tank Waste Ramediation \$ystem Eavironmental Irapact \$taicenent). The cursent state of technology of in situ vitrificalion does not appear 10 support the immobilization of an enorite tamk. If in situ disposal were feagible, techoodogy dervelopment of this approach would be degirable, becanse the glass woste form generally is superior to cement or clay forms.

\section{B2.9 CLOSE-COUPLED BARRIYR5}

Close-oruspled barriers instaled wriecreath the tanks to contain any leaking wastes beve boen proposed aumerous times to meet a variety of programmalic grals. Previous engigeering evalualiouts concluded that the cast to constauct \& merubrane (tilher injextion or freeze barfier) was top greal for the beneiti attrieved. Demonstrating that the barrier is truly containing the waste is problematic. Technology to construct ap impermegble membfane beneath the complex tank and farm gtructure is sod now gysilable, even though there aro promiging techniquans under evaluation by the Hauferd Tanks Initiative Progran. Dewelopretent and deptoyment of barriers is

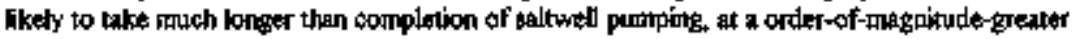
cost per 10rik ( $\$ 10-\$ 100$ wilkon per tank).

\section{BZ10 SCREENING}

Screning of Table B-I indictes that only enhancentent of the existing stluwell-pumping lechnology and "rainbird retrieval" appear to hase programanatic benefit in a time frame comparable to the bescline, without compromising future refrieval and inmobilization. This 


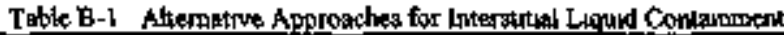

\begin{tabular}{|c|c|c|c|c|c|}
\hline 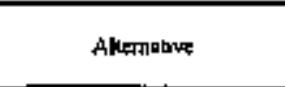 & $\begin{array}{c}\text { Exstang } \\
\text { Texhoology }\end{array}$ & 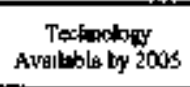 & $\begin{array}{l}\text { Deplopinenl } \\
\text { Fetulualty }\end{array}$ & 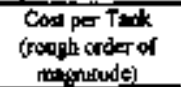 & Impaed on Dyeposal \\
\hline Salnule pull pungeng & $\bar{X}$ & & 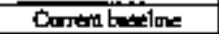 & 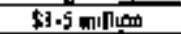 & Bat isgunfinctol \\
\hline 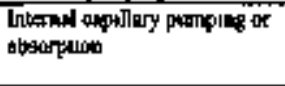 & $\mathbf{X}$ & & 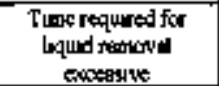 & $\sqrt{\text { WA }}$ & 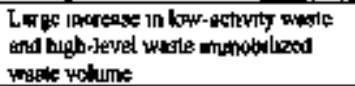 \\
\hline \multicolumn{6}{|l|}{ 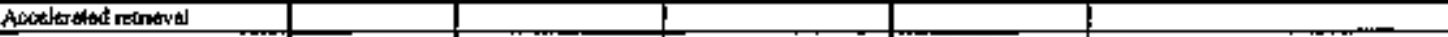 } \\
\hline 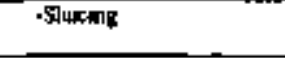 & $X$ & & 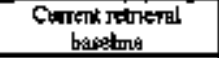 & 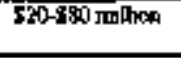 & None \\
\hline -"Rmbard retureval" & $\mathbf{X}$ & & 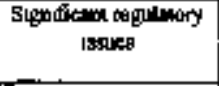 & 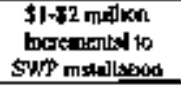 & 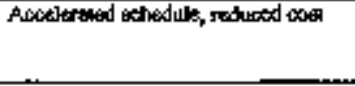 \\
\hline Electru-uampopa & $\bar{x}$ & & 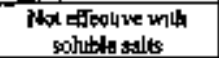 & $55-510 \mathrm{melhun}$ & 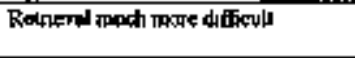 \\
\hline 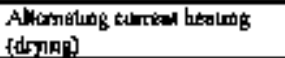 & & $\bar{x}$ & 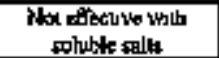 & $95+510$ malloira & Retruind mbch rewre difboulu \\
\hline Wherowave beacung (dirying) & & $\overline{\mathbf{X}}$ & 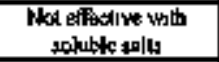 & 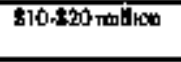 & 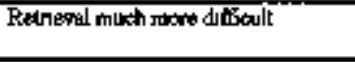 \\
\hline Whed-film arapkradice & $\bar{X}$ & & 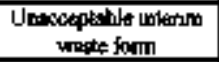 & \$5-\$10 भiflikn & Rednesal vary dificolu \\
\hline \multicolumn{6}{|l|}{ In-tank inamohtilizaluon } \\
\hline 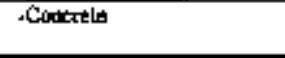 & $\mathbf{X}$ & & 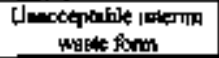 & 5]-\$10 mallatn & Retreval not fenable \\
\hline fery & $\bar{X}$ & & 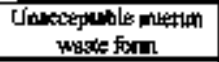 & $\$ 1.55 \mathrm{~mm} / \mathrm{ken}$ & 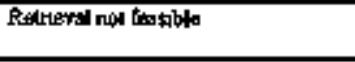 \\
\hline -In stbo yirdeatikm & & $\mathbf{X}$ & 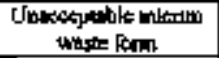 & 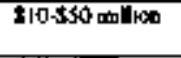 & Retristal not fistolk \\
\hline C̈noseosupled batrax & & Maylex & 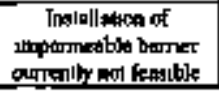 & 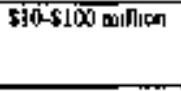 & 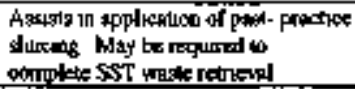 \\
\hline
\end{tabular}

N/A a aol applkable

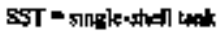

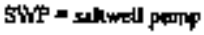


suggests that teclutical activivies to increase the effoctiventegs of salt well puraping and consideration of the feasibility of acceleraled retritval by condrolled water additiont shruld be conducted early in the progran to improve the cost and schedule pefformance of the baseline.

\section{B3.0 ENHANCEMTNT TO THE SALTWELL PUMTING TECHNOLOGY BASELINE}

A number of inutintives were idenufhed that could enhanced the currenl program baseline tecthology, etthec by itcreasing the punaping rate for tanks that heve significat sapernate or by intreasing the rote at which hipuids drain to the certtral sallwetl.

\section{B3.J MULTIPLE PUMP\$NWRL.S}

Fo some tanks the ingtallation of a second screen and salrwell pump may be featible. Analyzis is required to determine whether there is a net ionproyenteut in solids draingog rate or if the second purpp offectively "gterves" the primary purp. Axcess lo jigers with adequate diameter and purmp pitt is also problematic. In chses where no rigers exits, inatallation of a new entry into

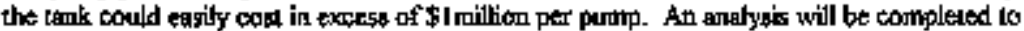
delermine the the costhenefin of additional pumps and wells in selected single-shell tanks.

\section{B3.2 YNCREASED WELL DLAMETER}

Reviewitg the basic equations that describe rafial flow through porous mefia, one can derive that the flow into the central well is proportional to the ratio of the outer regervoir diankter to the cenural well diameter. The pseudo-sieady-atate equation describing this radiel flow is given in Practical Petrolesm Reservorir Engineering Methods (Stider 1976).

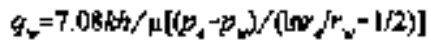

where

$$
\begin{aligned}
& \phi_{-}=\text {flow rate into wel (bartels) } \\
& k=\text { constank } \\
& h=\text { height of solids layer (fi) } \\
& \mu=\text { fluid visconily (ctenlipciste) }
\end{aligned}
$$

$\mathrm{P}_{\mathrm{z}}=$ pressure at tank wall (psig)

$p_{a}=$ pressure at galt well (psig)

$\Gamma_{0}=$ radius at lank wall (feot)

$i_{w}$ - radiels al sald well (ftet). 
Plotting the compartson of well rattos and the expected flow indicate that a doubling of the wrell

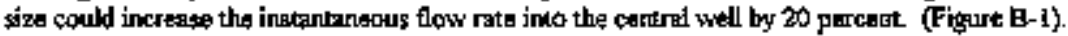

Nol al of the remaining SST redure installation of sadiwells, and many will nol allow the

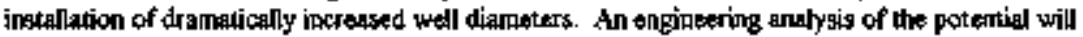
be completed

\section{B3.3 ALTLKNATJVE FúMips}

When a tank contains significank fies supefrute, instalkation of a subriersible purap may prove to be effective for the initis renooval of this Giquid. While this will oot actelerote the dranage of the solids, it will reduce the leakablo inventory in the shortagt period of time.

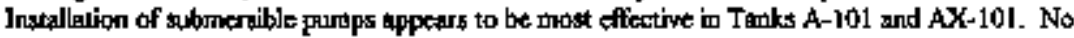
current Authorization Basis approval exists to allow use of submersible pumps in these tanks. An

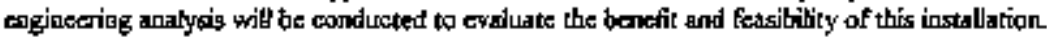

With the requiretrents for flannsble gas controls being applied to many of the ranaining

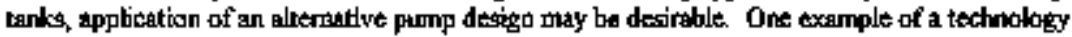
of this type might be the AEA, Jas, fluidic punap. A fhuidic pump utilizes compressest air as motive force and has on moveable parts in the tenk or pump pit. The Tank Focus Atea has demoustraced the use of this type of pump in the Gumite and Associated Tanks at Oak Ridge and is currertly developing a tank bampling systam at Savamab Rivar and the Harford Site using thí technology. An initial engineering evalualion of the development and deptoymem of a foridic application to the saltwell-pumping progran will be performed. While the fluidie purap moy alleviate some safey and operational concerns, the period of developmout nry be too long to be effectivo for this application

\section{B3.4 WATER ADDITIONS TO OPEN PORE STRUCTURE}

For tanks that contain soluble salts, the addilion of grall ambunts of water to the surfare of the solids wil dissolve sonte of the wase solids, opering draintage ebanthells within the solids and increasing the drainage rate of the contained liquids. While there may be significant regalatory cosperns about the addition of water to the SSTs, actederation of the cromptetion of saltwell pumaing may outwigh the concerns.

An mpinering ovahustion will be conducted 10 determine if a process leat of this process thould be completed. Engineering judgement suggeats that the pumping duration couk be reduced by 20 to 40 pereant by this approach. 


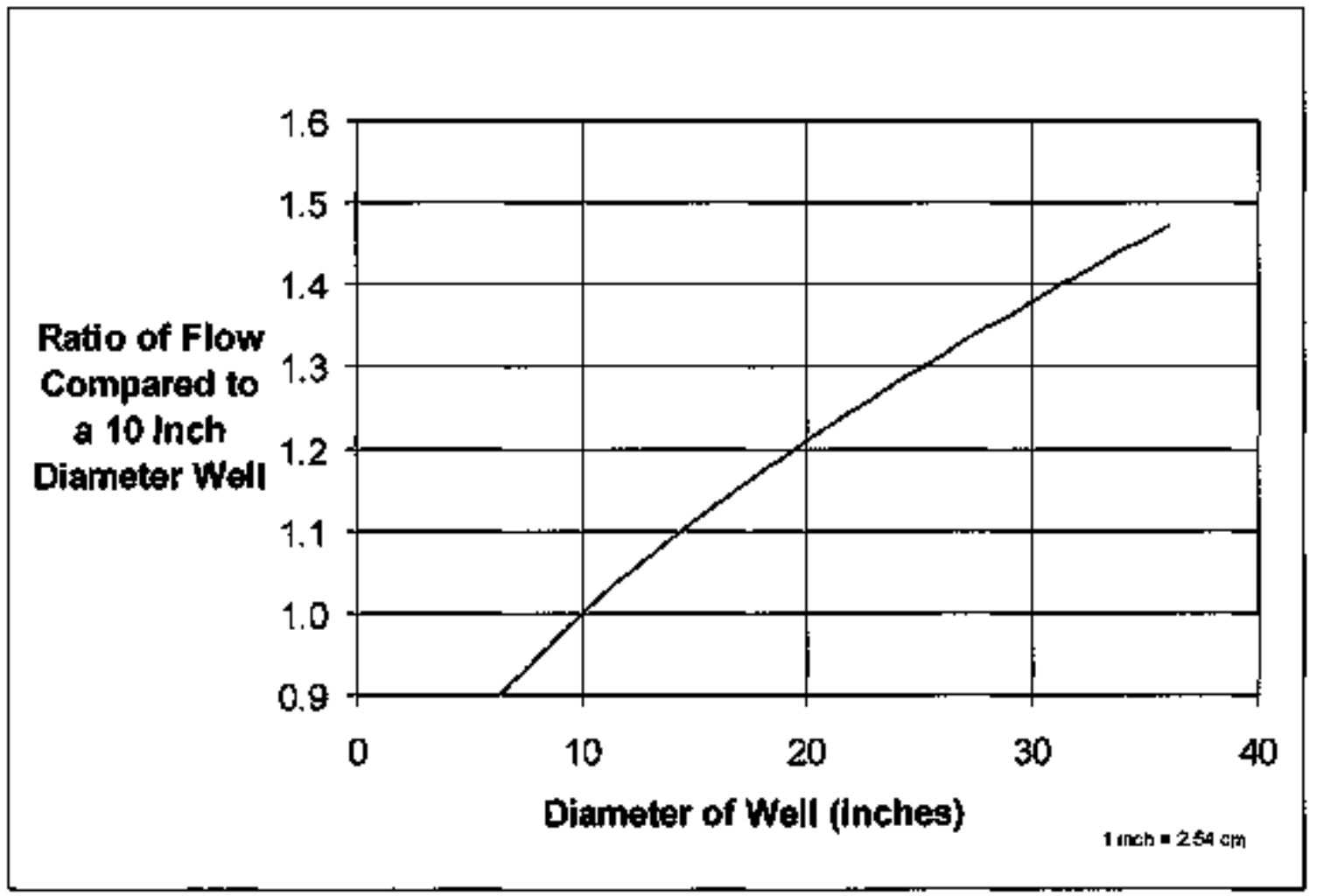

Figure B-1. Comparative Seltwell Intlow Compared to 10-Inch \$creen 


\section{B3.5 "MIINING" OF RADIAL CHANNELS TO INCREASI WELL PROOUUCTHON RATE}

Because the distance that the liguid must flow through the portur solid bed controls the rate of duimage of the solids, it appears that mithing of radial chanmels could storten the drainage tine drathatically. A siudy of the effectiyeness of the radial channels will be completed.

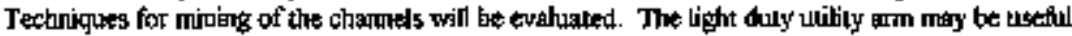
for this application, usitis some of the retrieval end tefectors developed by the Tark Force Area and demonstrated at Dak Ridge. Sorte of the technology being demongtrated by the Hanford Tank Initialive also may be directly applicatie.

\section{B4.0 SALTWELL PUMPING SVSTTEMS LOGISTIC ENBANCEMENTS AND CONTUFGLNCY}

The systerus andysis of the sal lwell pumping physical system identitied several pinch points and potential comtingency capabilities. Tectmology and angireering activitios were recomantended to address these opesationd itsues.

\section{BA.1 DOUBLE-CONTARED RECEIVER TANK LOGISTICS AND WORKAROUNDS}

As discussed in the mission analygig contained in Section 2.0, the 244-\$ and 244-U doublecontainad receiver tanks (DCRT) hase several extended periods of operation well above hislorical production averages. The Operations organization has identified several gources of concern including the ability to sugain trangfers from the DCRT's at 2 or 3 per wetk and muidain the nectssary matrial balances $10 \mathrm{ktep}$ the sysiem opesational while multiple saliwells are operating.

It magy be foassibe to bypass the 244-\$ DCRT and toangfit the pumped lifuid dirtedy io \$Y-102. This will reduce the dowitione of the saltwell systems it $S$ and $\$ X$ Farms, which mugt be shut down whenever the DCRT is fill and is transtering to \$Y-102. Becsulue the beseline plan

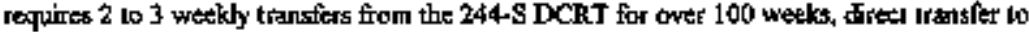
SY.102 could stabetantially woce S and \$X Farmis pump dountime. A new apponch to

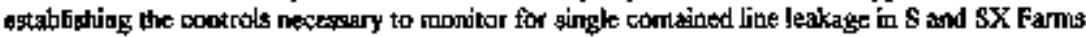
will neted to be developed, tart abould be fessibje. A similar workaround should be evaluated for 244-U DCRT. 


\section{B4.2 USE OF LR-56 FOR LMERGENCY PUMPING OF COMPLEXANT TANKS}

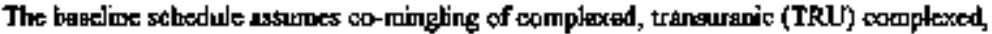
and roncomptexed wastes. DOE has not approved co-mingling of noncomplexed, complexed. and TRU wastes.

The major valnerability is that one of the conptexed tanks nary begin leaking before DOE approval is received. To maintain seppogation, all noscomplexed westo saltwels would need to be shux down while this tank was emergency pumping. The remaitring compleses tanks may be accelorated so that the overall program duration does not exiend dramatically.

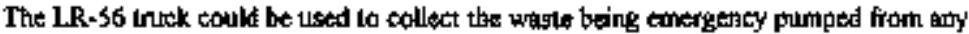
leaking corrplexed or TRU-complexed lank. This would allow the remeining tronctumplexted wiste saltwed to to continue to pump uritbout a major schepdule diaruption. An enginesting study would treed to be made to assess the logistics of using the LR-S6 tarik tndic for this purpose.

\section{BA.3 LUNE-UNRLUGGING TOOLS}

The baseline plan assumes that 20 percent of the single contained lines will fail a bydro test or will be plugged, preventing their use. In these cases, mo overground bine will be inatalled to work around thege ocourremen.

The Federal Energy Tectunology Center is aurtetisth soliciting privale sector tectinology

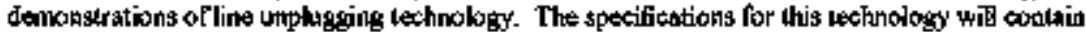
requirements for both Savarnah River and Hanford Site line confingurations. Demonstration of selected uechrologies will be conducted at Savannah Rdver in 1998. Successful desnonetraion of this tedfology may allow unphugging of saltwell and trangfer lines. This could avoid the neet to install so many replacement Eines.

\section{4,4 ADDTTONAL WASTE-VOLUME STORAGE CONTINGENCY}

Dilution of saltwel bquid to control line phuggage and dissohulion of salts will increase the volume of lignids produced by the sahwed project. The volume of liqnid resulting from saltwell pumping is ode of the hargesl factors in the manigemetu orDST space. Proctuction of too much biquid could resull in delays of the completion of saltwell pumping or impacis to the preparation of feed to the immobitization contratiors. 
The eraporator is usod as the primary technique to renrove water from the 200 East Arte DST sysuem, but limitationts in the ]evel of concentration of the 290 West Area will linix its effectiveness.

To keep both the saltwell pumping project and the feed delivery mission on track, particularly as changes occur iu the current baseline for both, additional wotume managernent cechniques may aped to be arailable.

Sinke the curbeslation of the Mullifintion Waste Tank Facifly tank construction project, options over the stort term are wery himited. Other than etimimation of segregalion and tompatibility ruks, or utilization of requirts sparte sptce, there do tot appear to be aby easy answers. Constnuction of thew DST space will take 100 long to solve the near-tem pointial

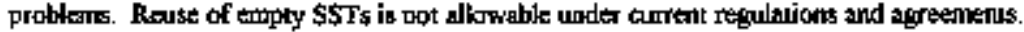
However, use of a containmetr bladder inside of an empty $\$ \$ I$ may be acceptable to the

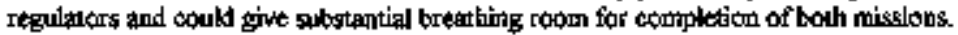
An engineering eraluation of the feasibility of a bladder approach will be complated.

\section{BS.0 "STECLAL CAST" TECHNOLOOGY}

Seweral speciftc issues require development, depłoyment, or assegsment of lechudologies not aurrently avaliable to the SST ratibilization project. This section discugses the alternatives that will need to be evaluated to thet the baselime project requirements or to address significant echedule dirivers.

\section{BS.1 TANK BY-10S "CONCRETE" TANK}

In 1995, the inlerim stabilization project attempted to install a taltwent pump into an existing sultwell screete in Tank BY-I0S. In alteripting to clear the strect with a waler lance. employses found a vary hard layer of material near the gurface of the waste. Subsequent

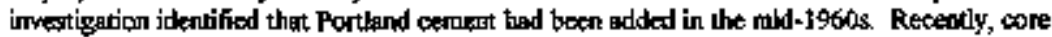
sampling was altempled ard very berd molerial was exccunuered near the waste surface. The aormal systent of water lancipg was not successtul in pentrating the chaterial in the saltwell screes.

Tectmology needs to be developed and lested to allow the installation of a new salturall

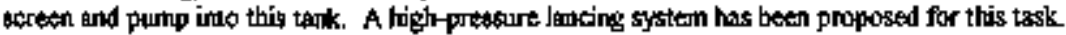
Existing stral-diameter high-pressure lances bave been used at the Hanford Site but the larger sybterc anrently does dot exist. Onces thas system is developed, built, and tested. il will be used to install the pump and saltwell sireed 
Becauge there is a significamt amoumt of Portland cement in this tank, pumping will have to be monitered very closely. One concem is thal as the liquid waste is pumped wel of the lank, the cement will stay atlached to equiponenl serpended from the tank done. Monitoring of the lank dowe deflection will be required to ensure thet the conerete does not cause a problem with the lank.

\section{B5.2 ORGANIC COMPLEXANT CO-MINGLENG}

DOE hag established a requirement to maintain segregation of wastes comtaining organic coniplexants, TRU complexed waste, and noncomplexed wiastes. Principad concems fesult from the behavior of the complexant that can sohubilize plutonimm and otber tranguramic gubstances and can make the rormally inumobile TRU conssituenis mobile. This ean increase the envitonmental iigk of any leaks that uight occur. A second concern is the bebavior of the wiste during pretreaiment and innobilization. The Hauford Sire's baseline disposal flowstert atsumes separalion of the high-level waste into high-] Inmobilization and diaposal of the high-level flaction is much greater then the immobilieation and

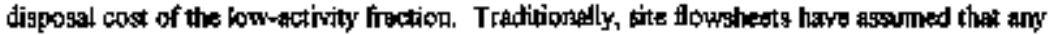
TRU contained in the codmplexed waste must be spatsated to allow disposal of the remainder as low-activity waste. Any comptexed waste coming in condact with TRU compounds contgined in sludge could produced larger quantities of TRU complexed waste, requiring more costly treaument befote immobilization.

Findly, some of the tiquid wastes containing organics from complexants and ather sources have shown waste characteristics that limit the extent of concentration that can be achieved in the Evaporator. This is inportand co allow maximum utilization of DST spates in the 200 East Area and to limit the potential impacts on saltwell pumping and feod deFvery activities.

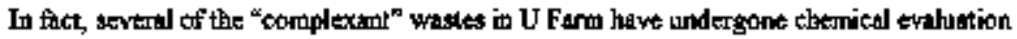
that shows that the complexant ability of the wastes has been destroyed. As a result, several of the tanks previousdy calegorized as complexant waste tase no longer required to be segregaled. The degradalion of the organic caused by radiolygig and other chemical processes is experted to occur wherevers gimilar condlitions occarr.

Satuples of the remaining complexanl wastes will be taked, ond the comblextant abiity will be evaluated, along with other important compatibility parameters. The ability of evaporation of the wastes will be established Based on this data, most (If toot all) of the complexed tallks are expected to be tesategorized.

Also, the current contracts in place with the immobilization vendors show on fiftertence in

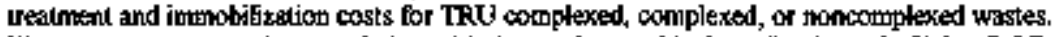
These contracts are under negotiation with the wendors at this time. By the end of May, DOE expects to award any conuraces for treatrient and inmobizization services for both low-activity 
waste and high-level waste feeds. Once these epntracts are in plece, the cotthentefit of contioning to segengate complexed, TRU-complexed, and noncomplexed waste will be resvaluated for any' wastes that magy atil be desigrated as complexed.

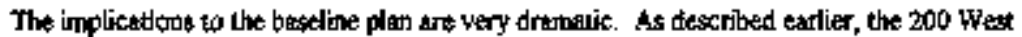

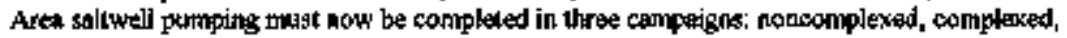

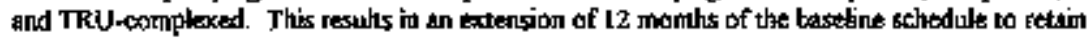
regregation. Anty chunges to either the complexed designation or DOE's acteptance of an updated costbenefit analysis based on updated vendor treatment and irmobilization wondract prices will have a dramatic effoct on stlwell purining completion schedule and program costs.

\section{B6.0 POTENTLAL COST AND SCHEDULE PERFORMANCE ENHANCEMENT}

A summary of the potenial benefits of the above-discussed ahematives has been summarized in Table B-2. It each case the recommonded activities discuased abouve have been inchuded it the bastime plan Completion of the items holds the potential lo substantially reduce progeram cost and schedula.

\section{B7.9 REFERTNCE}

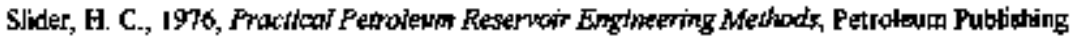
Compeny, Tulga, Oldetome. 


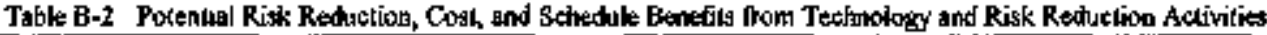

(2 Sheets)

\begin{tabular}{|c|c|c|c|c|}
\hline Inxuptive & 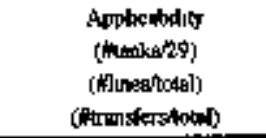 & 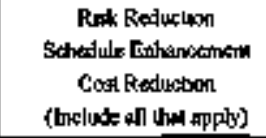 & 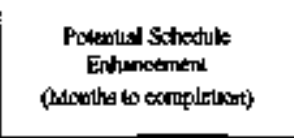 & $\begin{array}{l}\text { Poldondul Cixal Itapects } \\
\text { (of any) }\end{array}$ \\
\hline 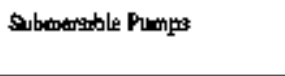 & 2 Itorkesing lanks & 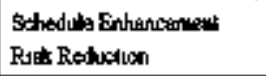 & 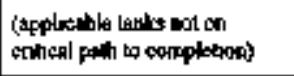 & $805-100$ \\
\hline $\begin{array}{l}\text { sersX Dirtot litutiter to SY. } \\
\text { ]02 }\end{array}$ & 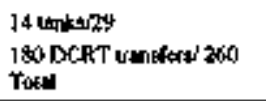 & 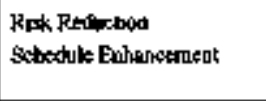 & 6-17 nowhs & $5 x-12 k$ \\
\hline Mithple Pumptruldels & 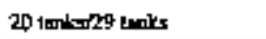 & Ruk Reladito & (J)tenoun & [robulale Cost werease \\
\hline 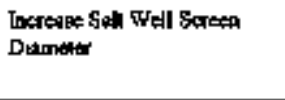 & 20 tanka129 unks & $\begin{array}{l}\text { Schieduk Enharperpept } \\
\text { Ruk Relnadicn }\end{array}$ & 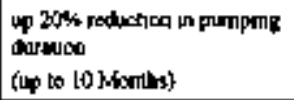 & $55.104 \mathrm{~A}$ \\
\hline 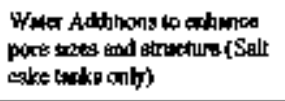 & 20 Sp|t Cakp tanks 29 & 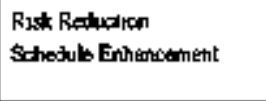 & 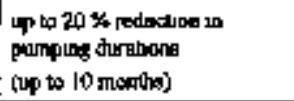 & $\$ 5-10 * 0$ \\
\hline 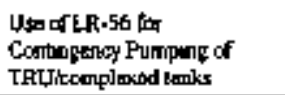 & $5 \operatorname{Ln} k \times 2 \pi 9$ & Rusk R=Ausing & 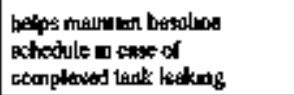 & \\
\hline Lure Utphopgon Tock & $\begin{array}{l}40 \text { sectoons of dursel burted } \\
\text { reuters }\end{array}$ & $\begin{array}{l}\text { Rust Relualican } \\
\text { Cost Rotusticn }\end{array}$ & 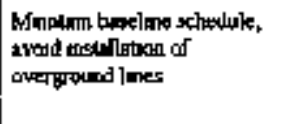 & 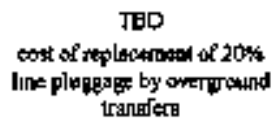 \\
\hline 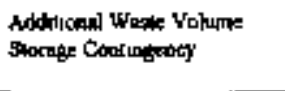 & NIA & Rrik Restadicn & 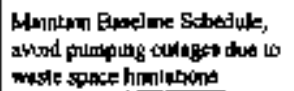 & 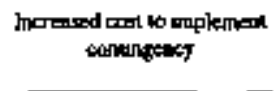 \\
\hline
\end{tabular}


Table B-2 Potential Risk Reduction, Cost, and Schedule Benofits from Technology and Rist Reduction Activiuies (2 Sheets)

\begin{tabular}{|c|c|c|c|c|}
\hline 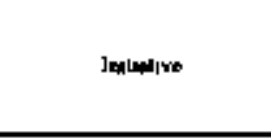 & 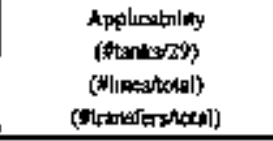 & 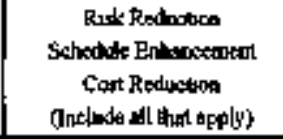 & 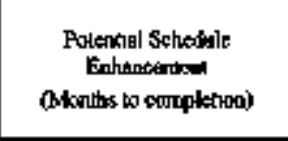 & 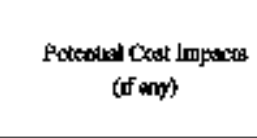 \\
\hline 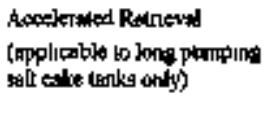 & 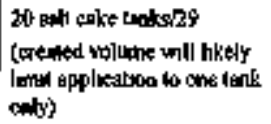 & 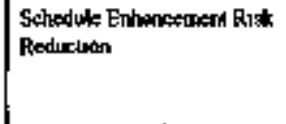 & 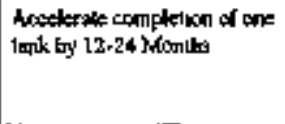 & 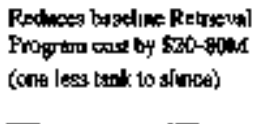 \\
\hline
\end{tabular}


HNF-2358 Rev, ]

\section{APRENDLX C}

\section{SINGLE-SERLL TANK INTERIM STABILIZATTON} EXTERNALLY MPOSED REQUIREMENTS 
HNF.2358 Rev. I

This page intemtionaly left baank

C-ii 
HNF-2359 Rer 1

\section{LST OF TABLES}

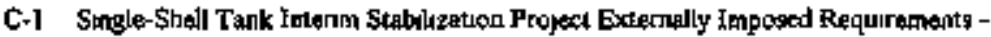
Code of Federil Regutationts

C-2 Sngje-Shell Tank Jntenn Stablization Project Exterrisly Inposed Requirements Washongton Adraurstrattre Codo

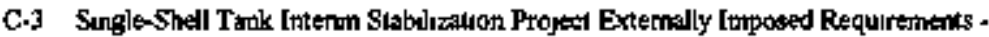
Departruent of Energy Orders and Other Federal Repulanors

C.4 Source Document DOE/RL-95-92, Hanford Suratege Plan

C-5 Sowre Dowment DOEJElS-0222D, Draft Herford Remodal Action Enmrontentel Impact Statement and Coraprehenssve Land Use Ftan

C.6 Source Document DE-AC06-96RL13200, Projen Hanford Management Contract, Fhor Deruet Hanford, Ine

C-7 Soumçe Document DOE/RL-89-10, Hantord Federal Facllyy Agreesmetrt and Consent Orda (Tr-Party Akreerneat), Rev 4 
HNF-2358 Rev 1

This page intentionally left blank

Civ 
HNF.2358 Rev I

APPENDIX C

SINGLE-SHCLL TANK INTERTM STABILZATON EXTERNALLY CMPOSED REQUIREMENTS

Table C-1 Single-Sheal Tank Interim \$tabilization Froject Exyernally Inwosed Requiremeosts Code of Federal Regulations (4 Sheets)

\begin{tabular}{|c|c|c|}
\hline & Tuls & $\begin{array}{c}\text { Comment } \\
\text { (sogufictan inkqual arzas) }\end{array}$ \\
\hline 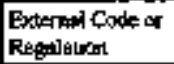 & 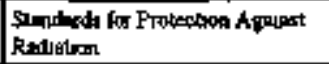 & - Aecess cortuol, \\
\hline JQCFR 61 & 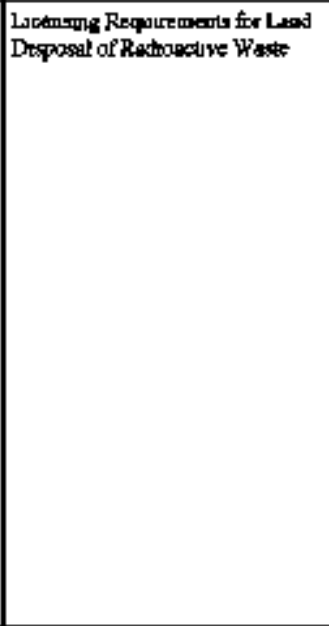 & 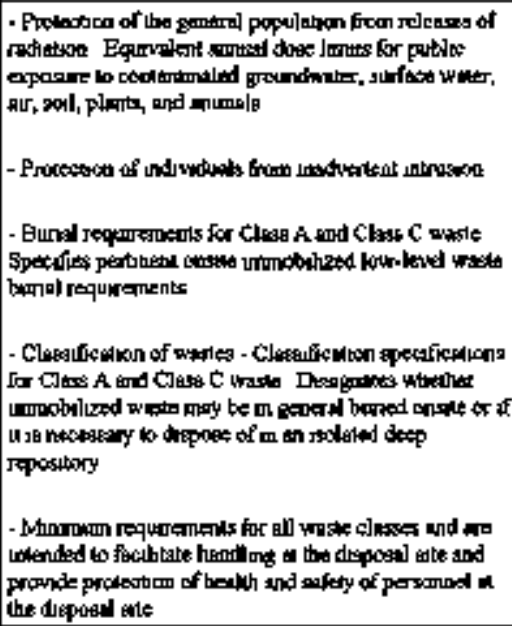 \\
\hline $10 \mathrm{CFR} 800$ & 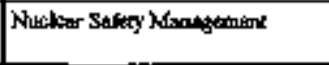 & 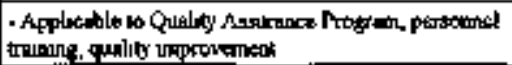 \\
\hline $14 \mathrm{CFR} 835$ & 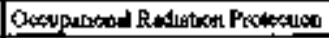 & 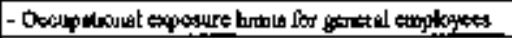 \\
\hline $10 \mathrm{CFR} 962$ & 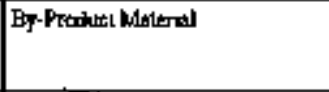 & 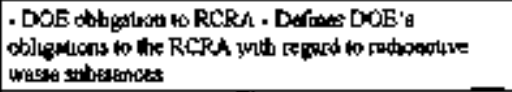 \\
\hline 29 CFR 1910 & 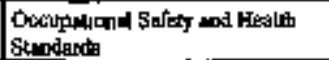 & 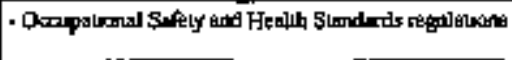 \\
\hline
\end{tabular}


Tabte C-I Single-Shell Tank Interim Stabilization Project Extenally Imposed Requirements Code of Feder al Regulationg (4 Sheots)

\begin{tabular}{|c|c|c|}
\hline & Tkle & 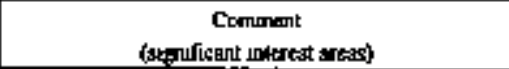 \\
\hline $40 \mathrm{CF}$ S 50 & 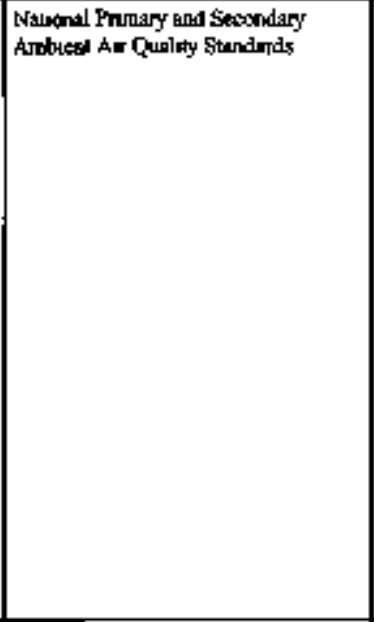 & 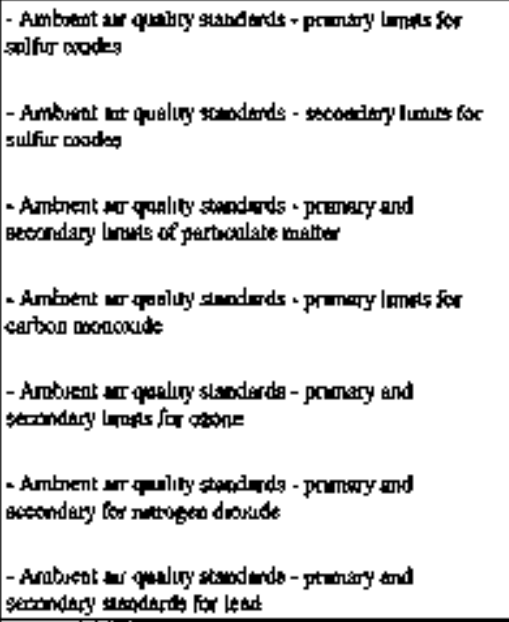 \\
\hline 40 CFR 61 & 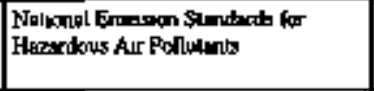 & 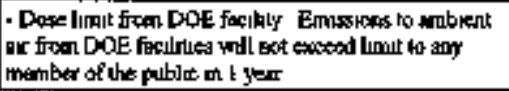 \\
\hline 40 CFR เ91 & 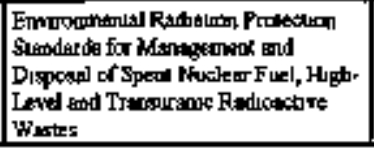 & 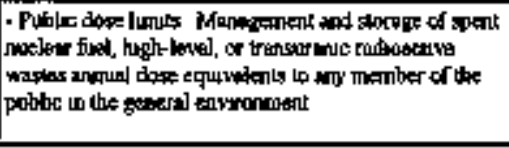 \\
\hline
\end{tabular}




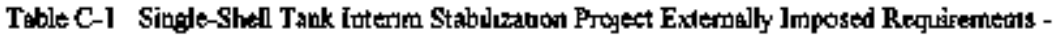
Code of Federal Regulations (A Sheets)

\begin{tabular}{|c|c|c|}
\hline & Tite & 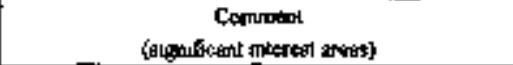 \\
\hline 40 CFR 264 & 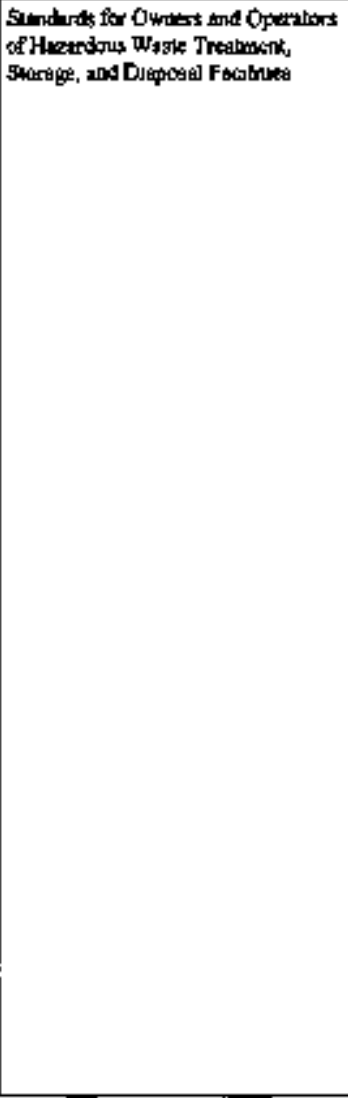 & 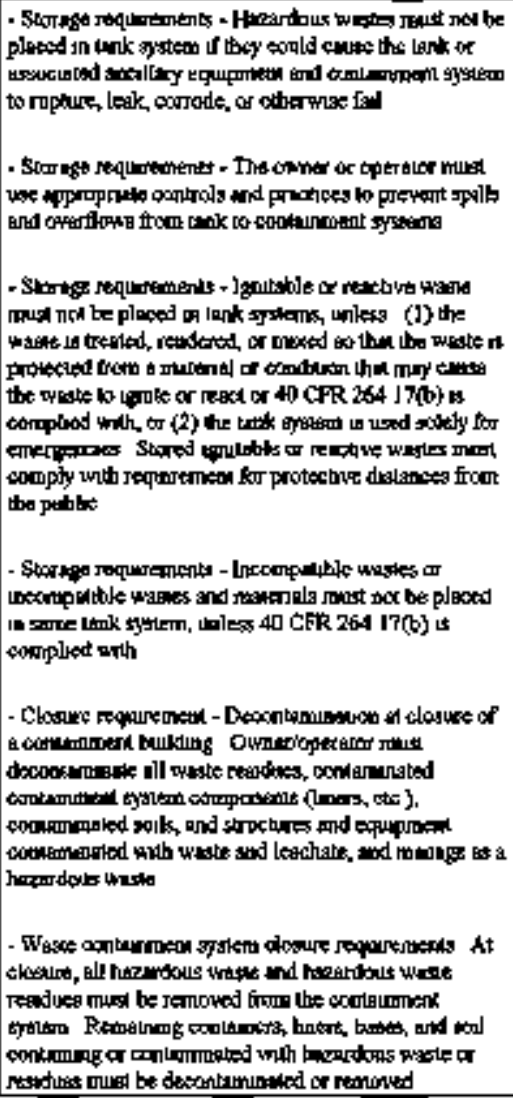 \\
\hline
\end{tabular}


HNF.2358 Rer. I

Table C-1. Single-Shell Tank Imerim Stabilization Project Externilly Lnposed Requirements Code of Federal Regulations. (4 Sheets)

\begin{tabular}{|c|c|c|}
\hline & Tithe & 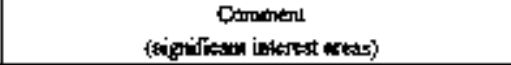 \\
\hline $40 \mathrm{CFR} 265$ & 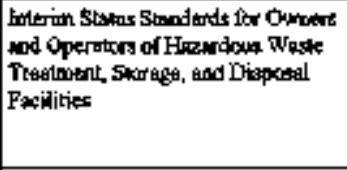 & 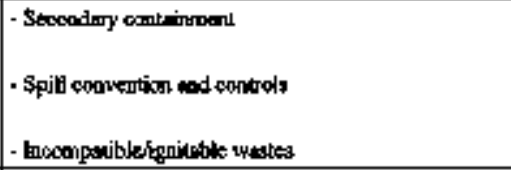 \\
\hline 40 CFR 268 & 1 and Dotponal Restridionts & 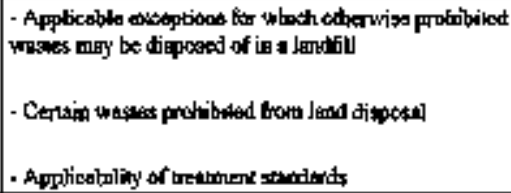 \\
\hline
\end{tabular}

CFR - Code of Fodetal Renditions

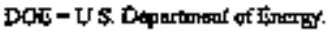

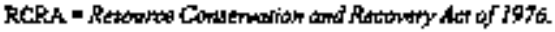


Table C.2 Singlo-Shel Tank Jnterin Stabilization Projext Extemally Imposed Requirements Washington Administrative Code.

\begin{tabular}{|c|c|c|}
\hline $\begin{array}{c}\text { Extemal Code os } \\
\text { Regentaricen }\end{array}$ & Title & 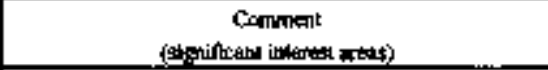 \\
\hline WAC 173.200 & 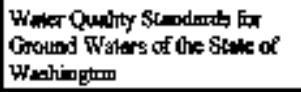 & 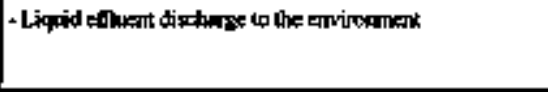 \\
\hline WA[ JJ3.201A & 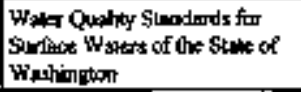 & 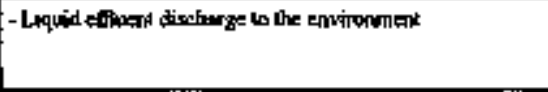 \\
\hline$w \wedge 173-300$ & 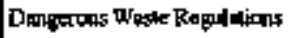 & 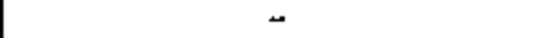 \\
\hline WAC J J3.400 & 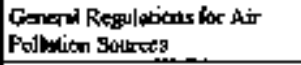 & 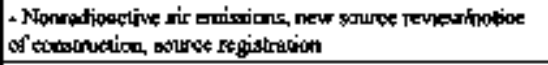 \\
\hline WAC: $173-401$ & 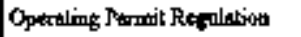 & - \\
\hline WAC $173-460$ & 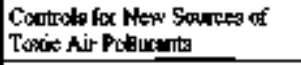 & 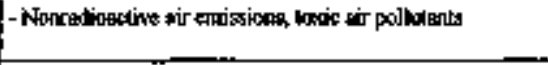 \\
\hline WAC J73-490 & 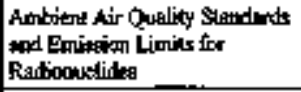 & $\pi$ \\
\hline WAC 246-247 & 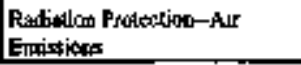 & 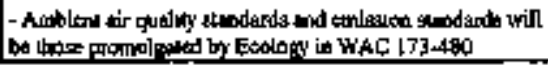 \\
\hline
\end{tabular}


Tabie C-3. Single-Shell Tank Inuerin Stabilization Project Externally Imposed Requiremenus U.S. Departnout of Energy Orderg and Other Federal Regulations.

\begin{tabular}{|c|c|c|}
\hline $\begin{array}{c}\text { Extenal Coda ac } \\
\text { Re alntion }\end{array}$ & Tlus & 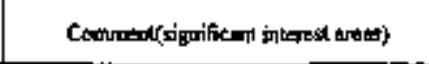 \\
\hline \multicolumn{3}{|c|}{ 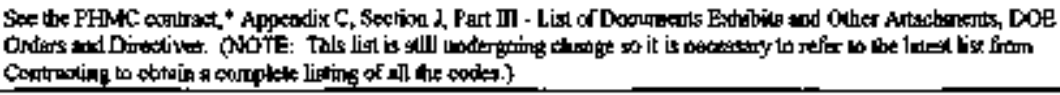 } \\
\hline \multicolumn{3}{|c|}{ 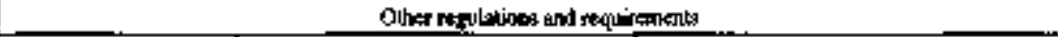 } \\
\hline $\begin{array}{l}\text { Extemel todk ot } \\
\text { reguldice }\end{array}$ & Tiuls: & 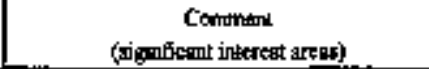 \\
\hline 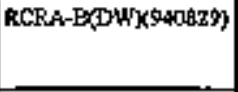 & 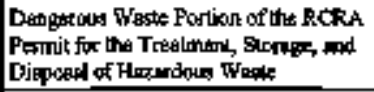 & 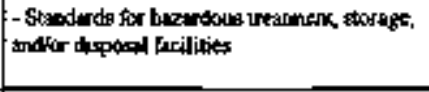 \\
\hline $\begin{array}{l}\text { Proiext Hanfoed polinies } \\
\text { and frocondwes }\end{array}$ & (Nhunerons) & - \\
\hline 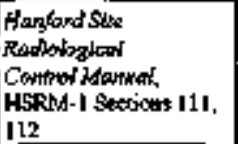 & - & - Sumbiny of benlh and sufetr regulationst \\
\hline
\end{tabular}

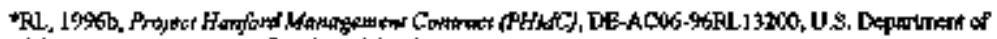

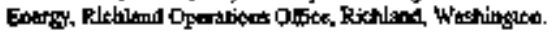

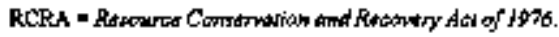


Table C-4 Soturce Documbat DOERL-96-92, Hanford Strateric Plan

\begin{tabular}{|c|c|}
\hline $\begin{array}{l}\text { HSTD } \\
\text { Refarace }\end{array}$ & Extrested Rexpurathemt \\
\hline $\begin{array}{l}\text { HSP CP } \\
\text { EM AREA } \\
\text { GOAE }\end{array}$ & 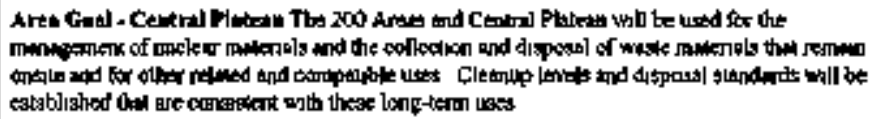 \\
\hline HESPE 4 而 & 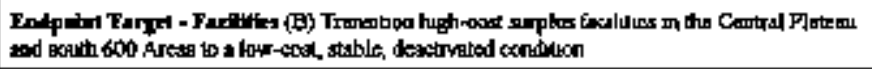 \\
\hline HSP药的少 & 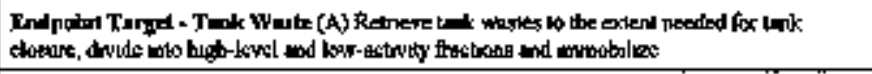 \\
\hline HSPP ET GE & 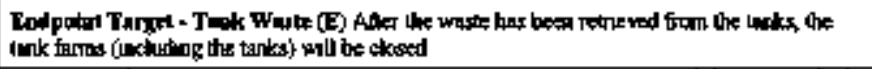 \\
\hline $\mathrm{HE} P \mathrm{~J}$ & 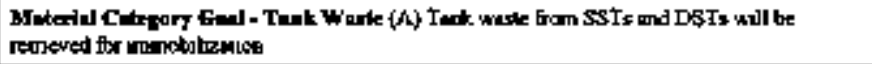 \\
\hline HSP FACC & 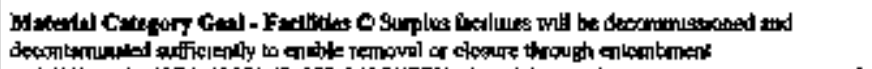 \\
\hline
\end{tabular}

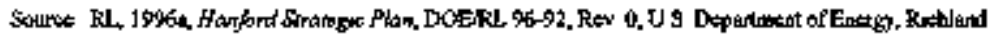

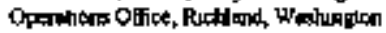

DST $=$ deable-tball the

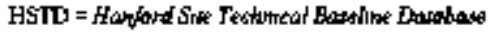

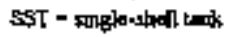


Table C-5 Source Document DOERIS-022:2D, Draft Hanford Remedial Acton Envirtorarntal Impact Statemeat and Compreahensive Land Use Plan

\begin{tabular}{|c|c|}
\hline $\begin{array}{l}\text { HSTD } \\
\text { Referteres }\end{array}$ & Extrapled Refarense \\
\hline CEU P $\$ 32200$ & 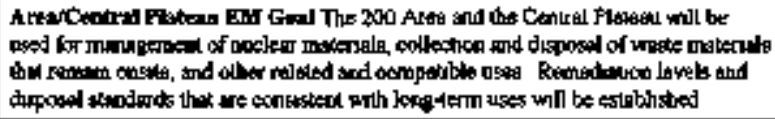 \\
\hline CUPs 32 INT 3200 & 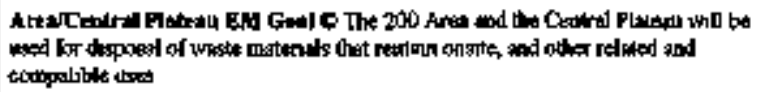 \\
\hline CLUP 53.2 INI 4200 & 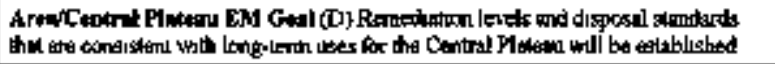 \\
\hline CLAP $\$ 32 \mathrm{~b}$ & 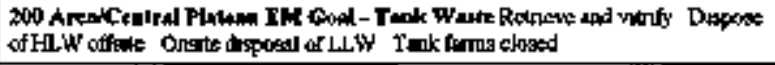 \\
\hline CLUP 532 b INT & 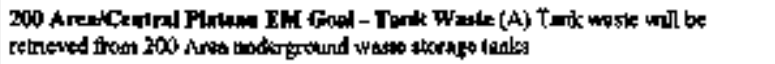 \\
\hline cLurs 532 b tort 2 & 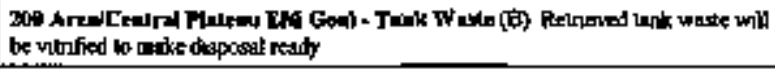 \\
\hline GUP 532 ldst 3 & 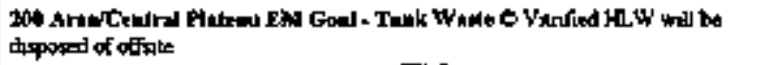 \\
\hline aups32f & 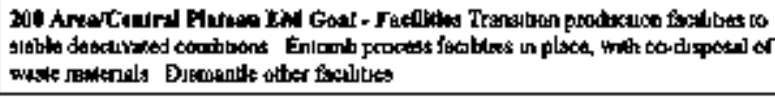 \\
\hline
\end{tabular}

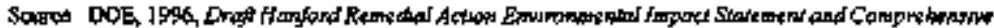

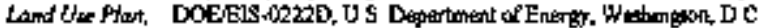

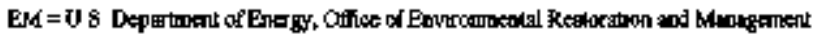

HE

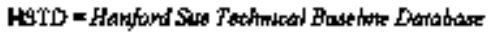

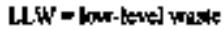


Table C.6. Source Docutrert: DE-AC66-96RL 13200, Project Hatford Manageraturt Contract, Fhror Daniel Hanford, Inc.

\begin{tabular}{|c|c|}
\hline $\begin{array}{l}\text { HSTD } \\
\text { Referenos }\end{array}$ & Extricked Retiatnce \\
\hline [urk. I.J.] & 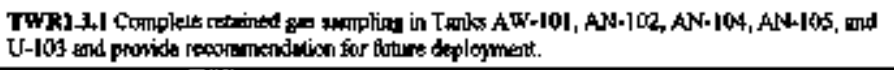 \\
\hline TwR.t.3.5 & 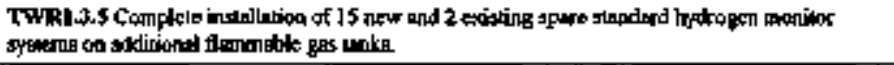 \\
\hline ThR.4.1.1 & 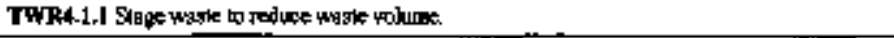 \\
\hline TWRS.1.J & 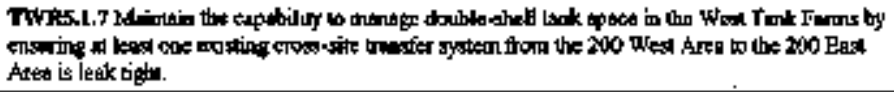 \\
\hline TWR.5.].s & 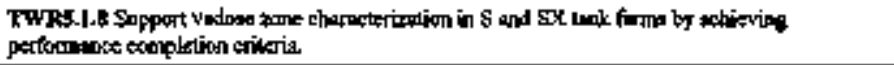 \\
\hline
\end{tabular}

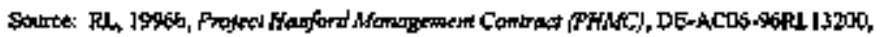

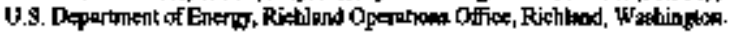

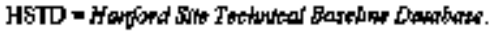


Tabje C-7 Source Document DOE/RL-89-10, Hanford Federal Fachtty Agreement and Cousent Order (Tn-Party A झ̈enement), Rev 4 (3 \$beets)

\begin{tabular}{|c|c|c|}
\hline $\begin{array}{l}\text { HSTD } \\
\text { Refteायमएe }\end{array}$ & 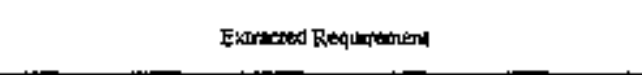 & Dus Dave \\
\hline TPAM 400 & 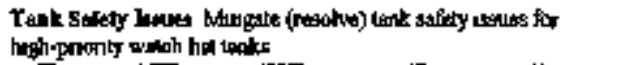 & 96302001 \\
\hline TPAMAl OA & 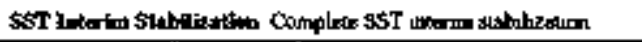 & $2 / 302000$ \\
\hline JPAM $410 \mathrm{~b}$ & 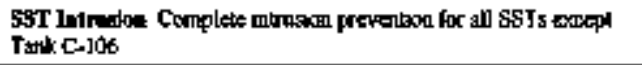 & 90,000000 \\
\hline TPAM 43 | & 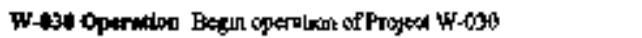 & 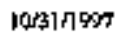 \\
\hline TFAM 43 T & 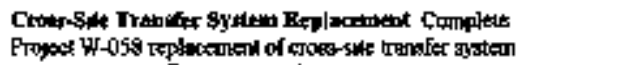 & 2281998 \\
\hline TPAM $437 \mathrm{~B}$ & 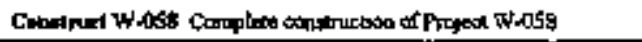 & 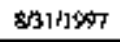 \\
\hline TFAM $43 T C$ & 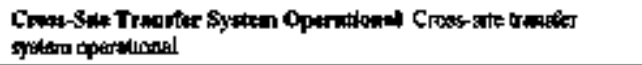 & 2287998 \\
\hline IFA M 450 & 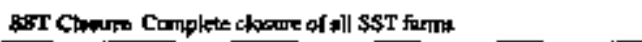 & 95302024 \\
\hline TPAMA33A a & 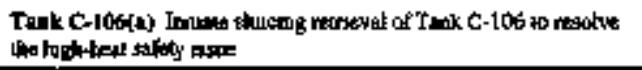 & $10651,199 t$ \\
\hline TPAM $453 \mathrm{Ab}$ & 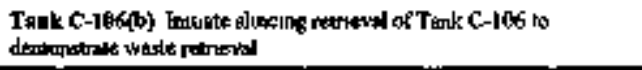 & $1031 / 1997$ \\
\hline TPAM 459 I ] & 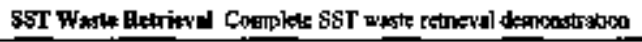 & 95002003 \\
\hline TPA M $453 T 2$ & 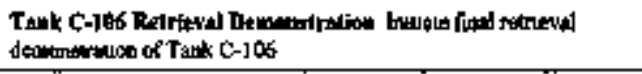 & $6 / 3012001$ \\
\hline TPAM $454 \mathrm{~T}$ & 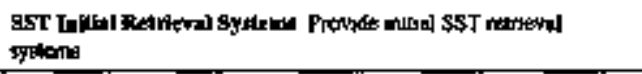 & I L9tx3003 \\
\hline TPAMASAT3 & 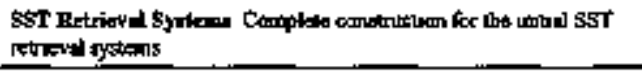 & $6 / 302003$ \\
\hline TPA M 455 & 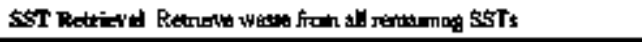 & 9302018 \\
\hline TPA M $455 \mathrm{~T}$ I & 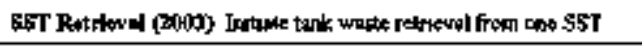 & 12312003 \\
\hline $\operatorname{TPAMA5} 5 \mathrm{TZ}$ & 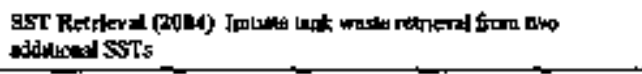 & 25302004 \\
\hline TPAM 4S ST3 & 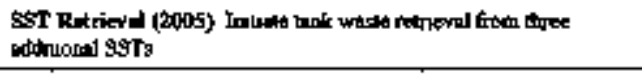 & $90130 \times 2005$ \\
\hline JPAM 45 5T4 & 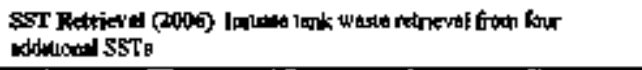 & st302006 \\
\hline TFAM 4SSTS & 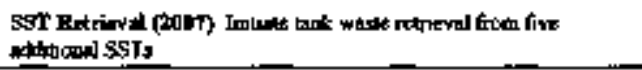 & 9302007 \\
\hline
\end{tabular}


Table C-7 Sourw Documeat DOERL-89-10. Fanford Federad Facilty Agreement and Consent Order (Tri-Party Agresmest), Rev 4 (3 \$hęets)

\begin{tabular}{|c|c|c|}
\hline $\begin{array}{l}\text { HSTD } \\
\text { Refareme }\end{array}$ & 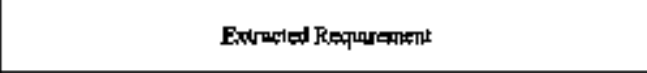 & Dave Dave \\
\hline TPAM 45 T 6 & 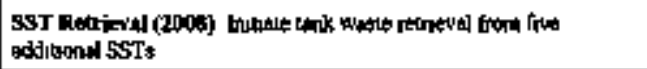 & 93012000 \\
\hline TPAM \$S 5 T B & 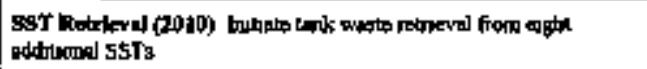 & siscoutio \\
\hline TPAM 4SST\& & 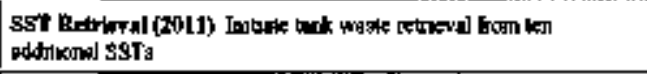 & grand \\
\hline TPAM455T I0 & 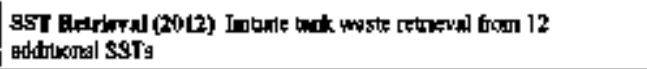 & 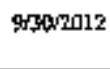 \\
\hline TPAM4ssT II & 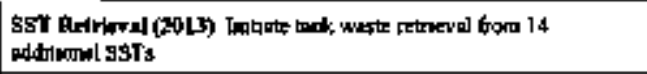 & 950213 \\
\hline TPAM 45 T T 12 & 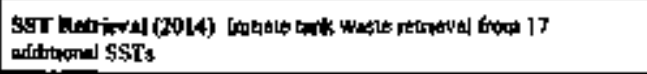 & ortang \\
\hline TPAM4S S T 13 & 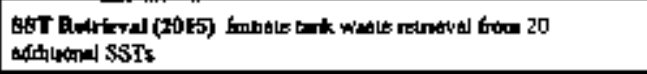 & $9+302015$ \\
\hline IPA M 455 T 14 & 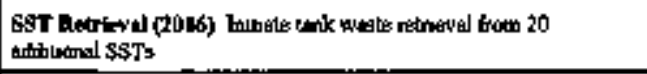 & 950m2 \\
\hline TPAM 455T 15 & 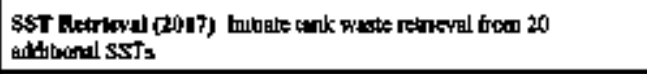 & 990\%인 \\
\hline$T P A M 456$ & 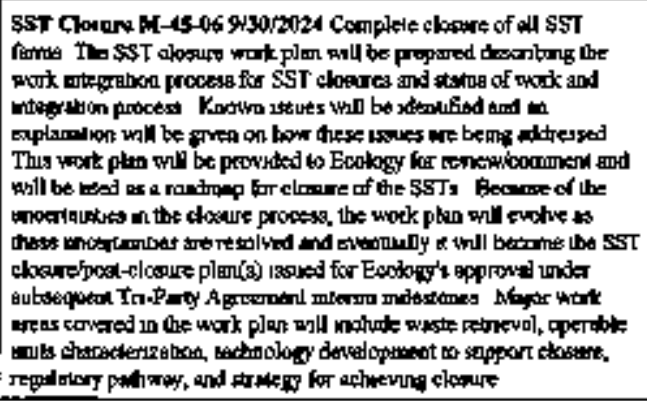 & .. \\
\hline TPA.M 45 $6 \mathrm{~T} 2$ & 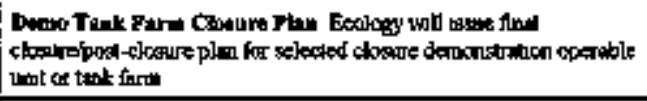 & 9302006 \\
\hline TPAM 45.6T3 & 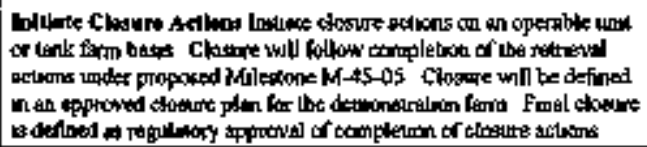 & 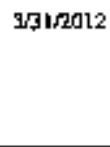 \\
\hline
\end{tabular}




\section{HNF-2358 Rev i}

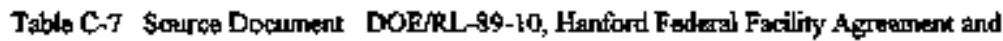
Content Order (Tri-Party Ajertemenl), Rev 4 (3 Shete)

\begin{tabular}{|c|c|c|}
\hline $\begin{array}{l}\text { HSTB } \\
\text { Rofittence }\end{array}$ & Extracted RequTremsed & Due Dare \\
\hline TPA M 45 6 T 4 & 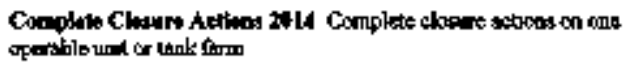 & अ31,2014 \\
\hline TPAM 458 & 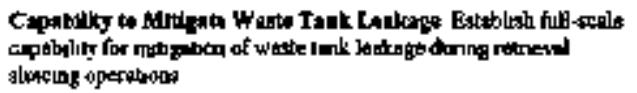 & $\cos 2000$ \\
\hline TPAM 45 B B & 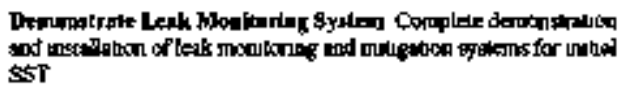 & $6 \sqrt{30 / 2003}$ \\
\hline
\end{tabular}

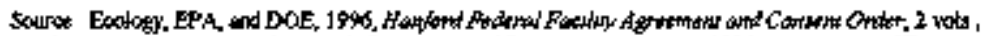

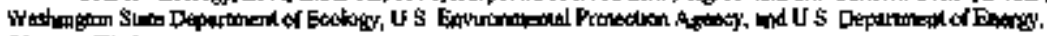

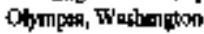

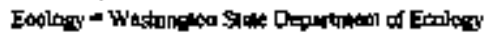

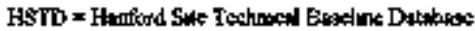

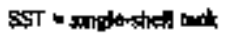

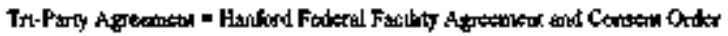


HNF-2356 REY. I

\section{TABLI REFERENCES}

Ac1s

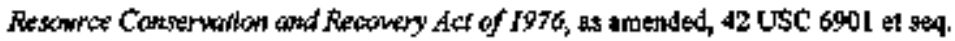

\section{Code of Federal Regulationy}

I0 CFR 6I, 1997, "Licensing Requirements for land Disposal of Radioactive Wastes," Cack of Foderal Regulations,

10 CFR 830, 1997, "Nuded 8afety Managenemt," Coik of Federat Regriathons.

10 CFR 835, 1993, "Ocaupational Radiation Pratection," Cade of Fedtral Regulations.

10 CFR 962, 1997. "By-RToduct Material," Code of Federat Rexwlations.

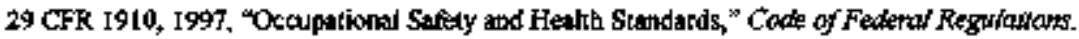

40 CFR 50, 1996, "National Primary and \$econdary Ambieat Air Quality Stamiards," Code of Fecteral Regutiations.

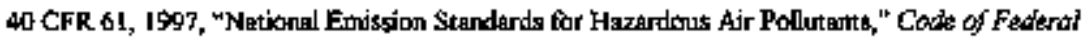
Regalations.

40 CFR 191, 1996, "Emironutejtal Radiation Protection Siendards for Mantigentent and Disposol of Spent Thelear Fuel, High-Leved and Transuranic Radionctive Wastes," Cadp of Federal Regalations.

40 CFR 264, 1996, "Standads for Owares and Opentort of Hazardous Waste Treatment, Storage, and Disposal Facilities," Code of Federat Regalationts.

40. CFR 265, 1996, "Interiun Sulus Standarts for Owners and Operators of Hazardous Wase Treatmen, Slorage and Disposas Facilities," Cado of Federal Reguterions,

40 CFR 268, 1996, "Land Disposal Resuraions," Code of Federwi Regalatious. 


\section{HNF-2358 Rer. 1}

\section{Databuses}

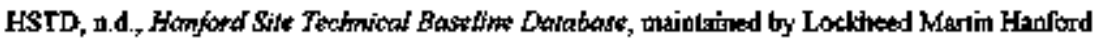
Corporation for Fluor Daniel Hanford, Inc., Richland, Washington.

\section{Wubtitgton Administrative Code}

WAC 173-200, "Water Quality \$landards for Ground Waters of the \$tate of Waghington," Washingtion Adwinstrattve Code, as aniended.

WAC 173-20IA. "Wales Quality Stardards for Suthes Waters of the State of Wastington,"

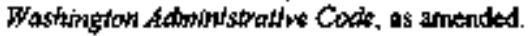

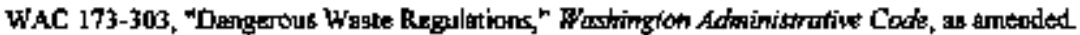

WAC 173-400, "General Regulations for Air Polution Sources," Washinglon Adoninistrative Codk, an ameaded.

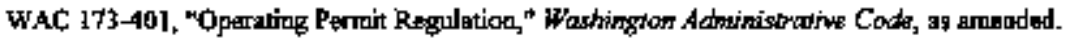

WAC 173-460, "Controls for New Sources of Toxic Air Poltulants," Washingtom Adminigtrotive Cock, al ameaded

WAC 173-480, "Ambieal Air Dutlity Siandords tod Eustission Limits for Radiomuclides," Washingron Adninistrative Coots, as emended.

WAC 246-247, "Radiation Protection-Ajr Emissions," Wadhingtest Adninistraylue Code, as amended.

\section{Dorwinents}

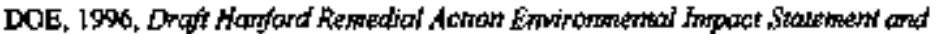

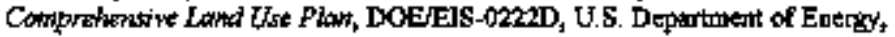
Washington D.C.

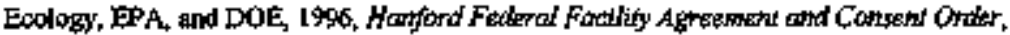
2 vols., Wastington Siate Departmetst of Ecology. U.S. Envitonmental Protection Agency, and U.S. Departmeat of Energy, Otymigin, Washingston. 
HSRCM4-I, 1994, Howford Site Radilological Control Mamat, Rev. 2, prepaned for the

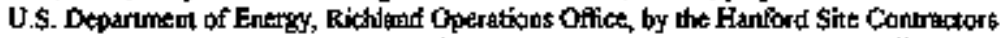
and manasged by Paciffe Northwest National laboratory Records Manasgentenl Office, Richland, Wastington.

RL, I996a, Fawford Straicgte Plan, DOE/RL 96-92, Rev. 0, U.S. Depsrtment of Energy, Riathignd Operations Office, Richland, Washington.

RL, 1996b, Profecr Honford Managemen Conthat (PHMC), DE-ACO6-96RL13200, U.S. Department of Energy, Richland Operations Office, Richland, Washington. 
HNF-2358 Rov 1

This pege intentionally left bumk

C.16 
HNF-2358 Rev I

ATPENDLC D

SINGLE-SHELL TANK INTERDM STABILUZATION INTLGRATED SCHIDULE DETAL

D-i 
HDNF-2358 Rev, :

This page intentionaly lat blond

\section{D-ii}




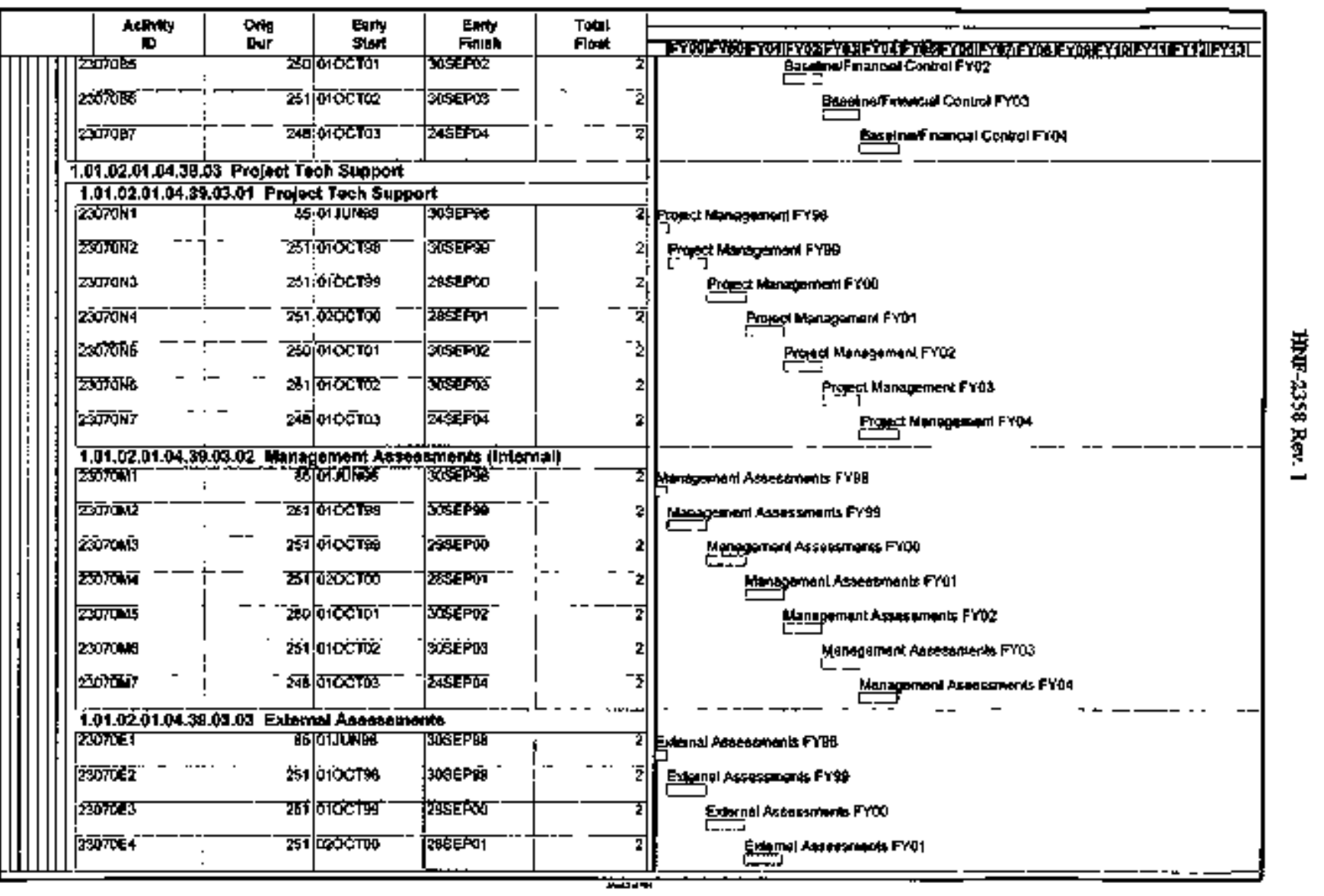

0-2 


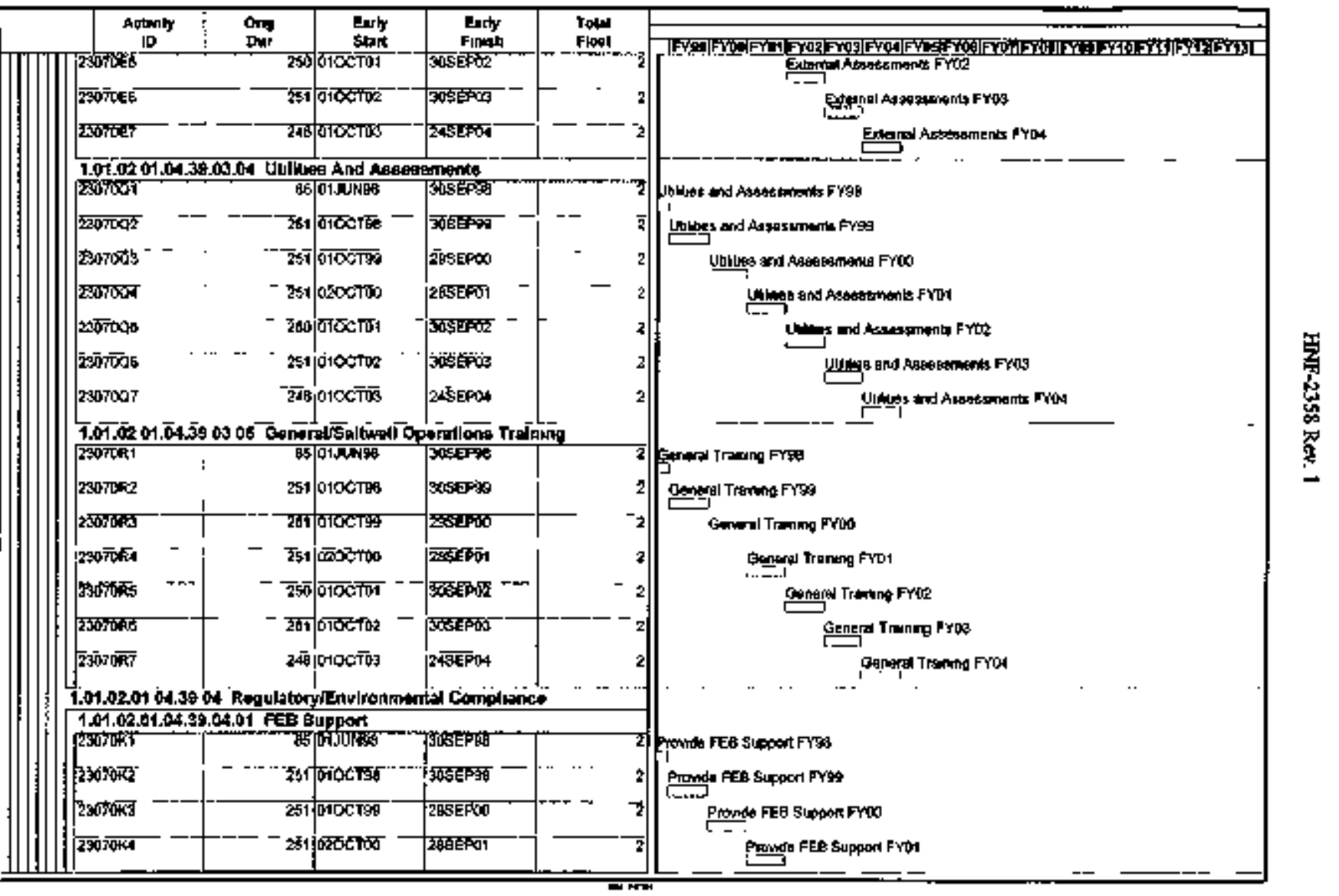




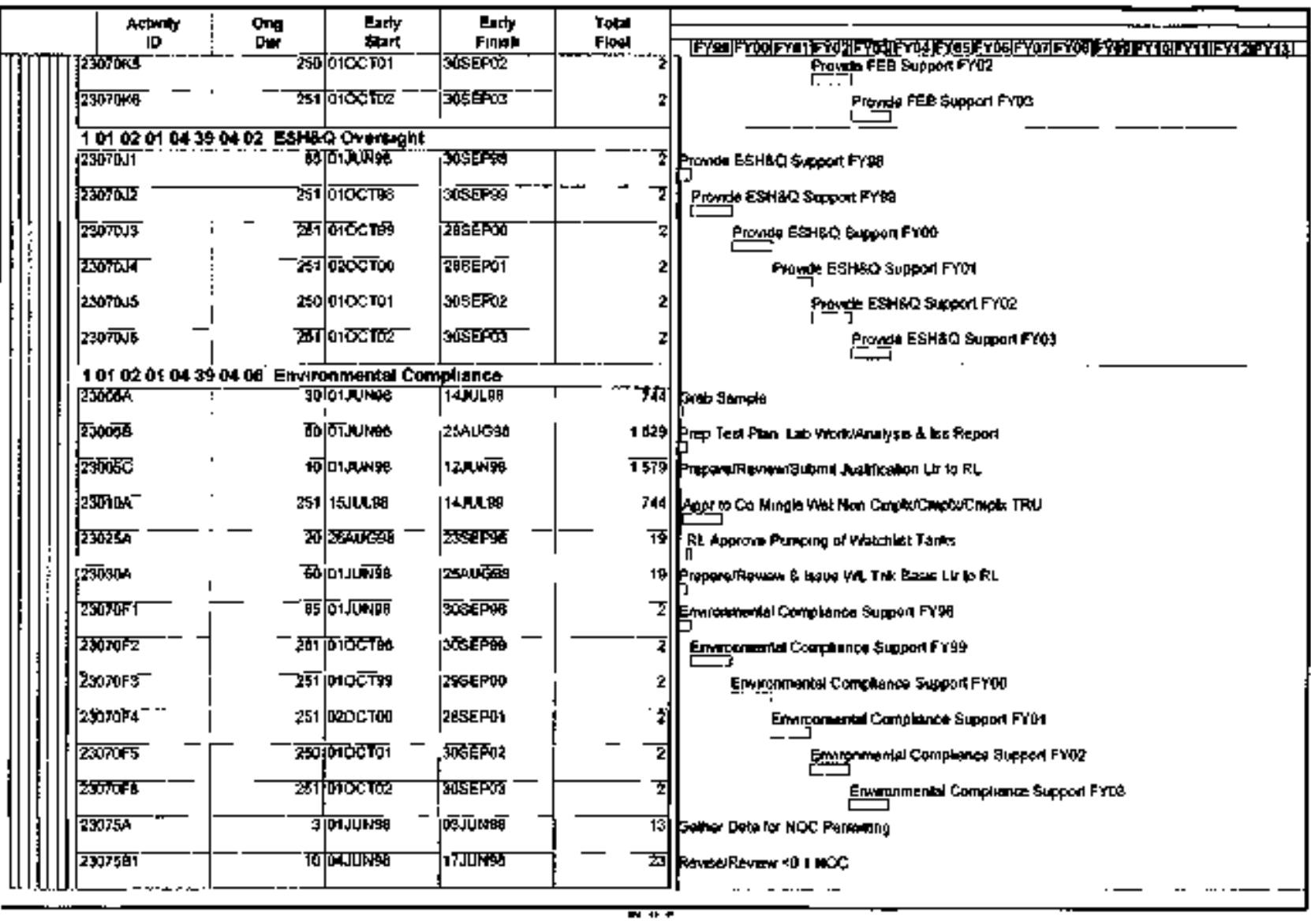




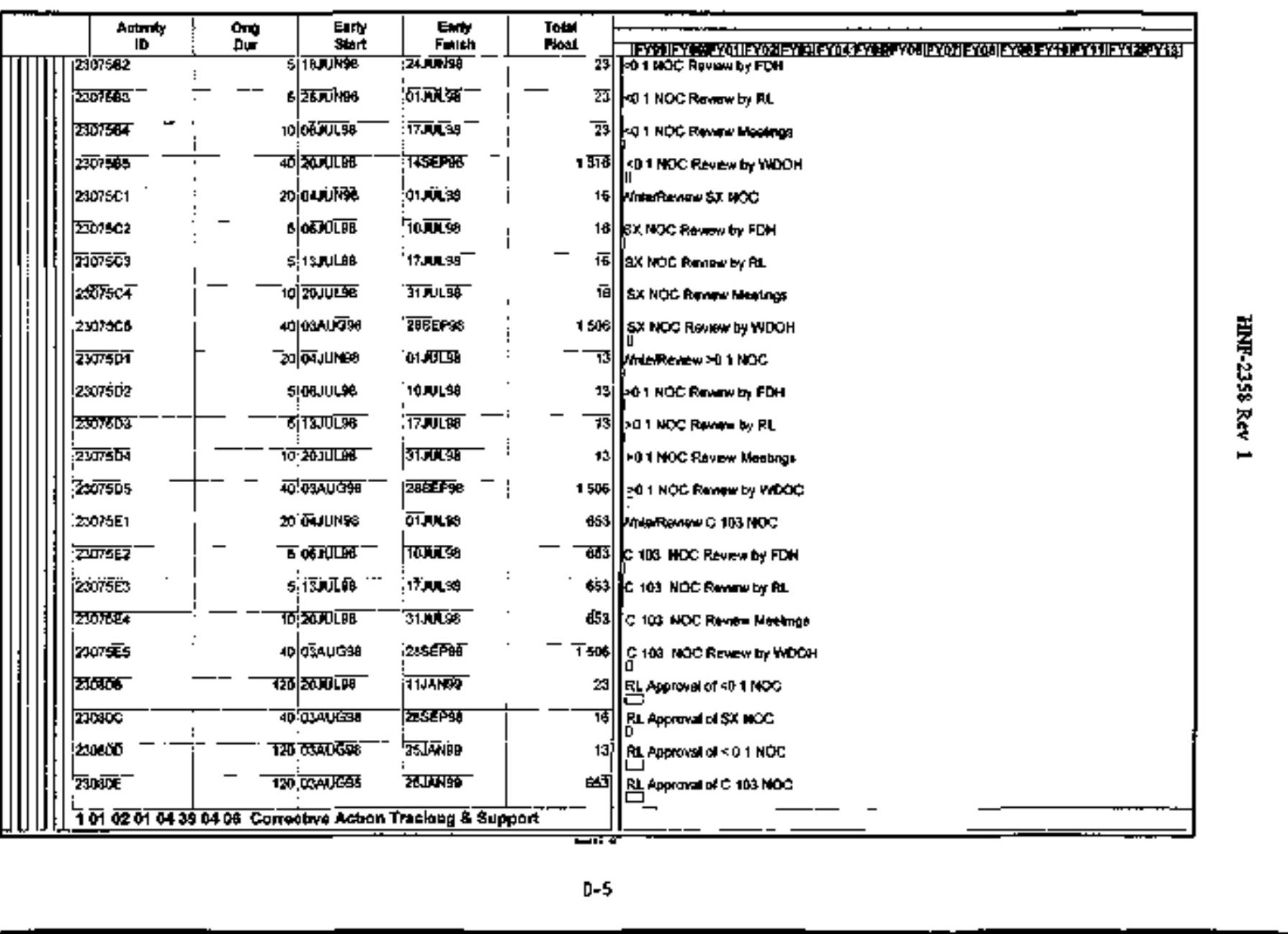




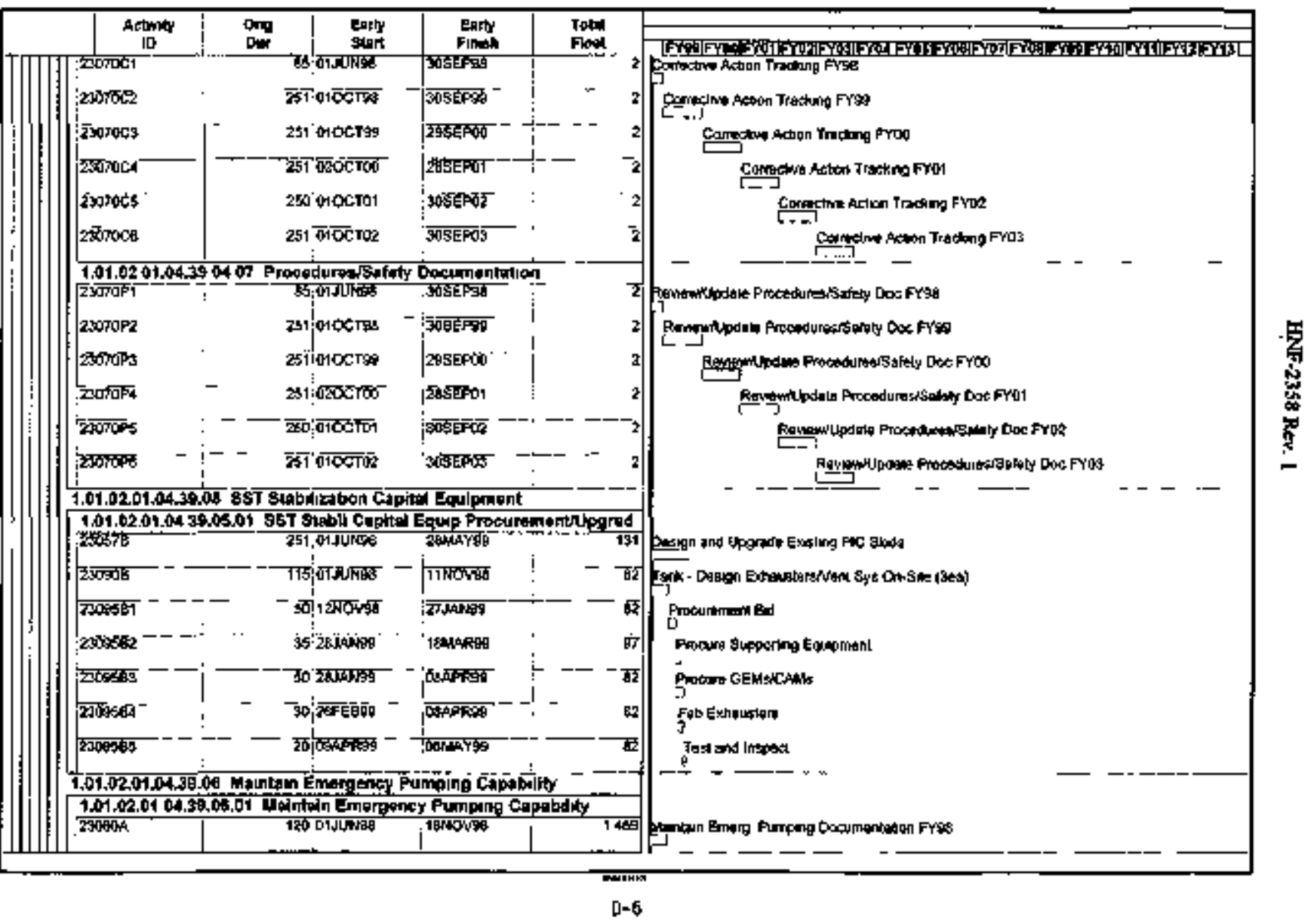




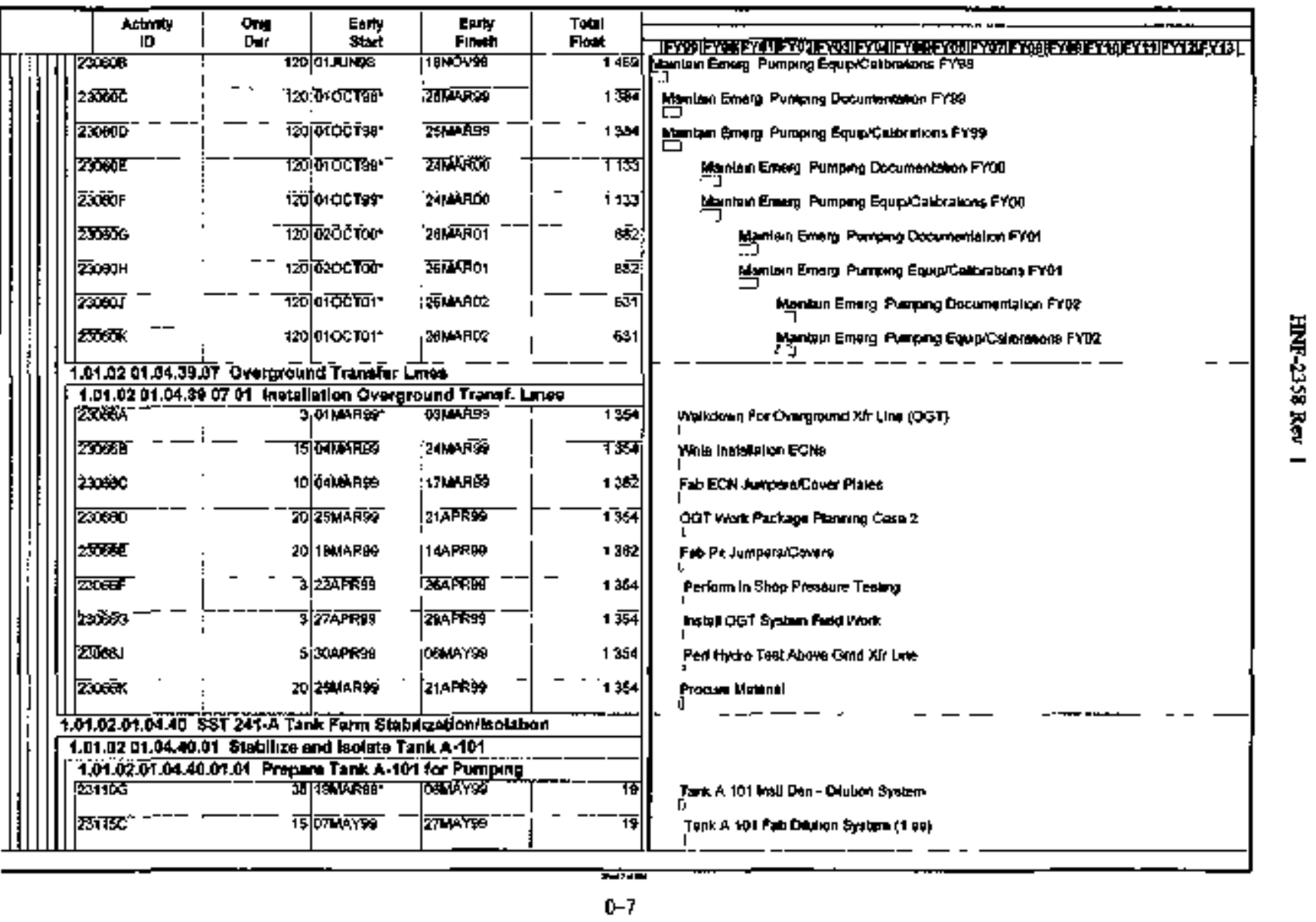




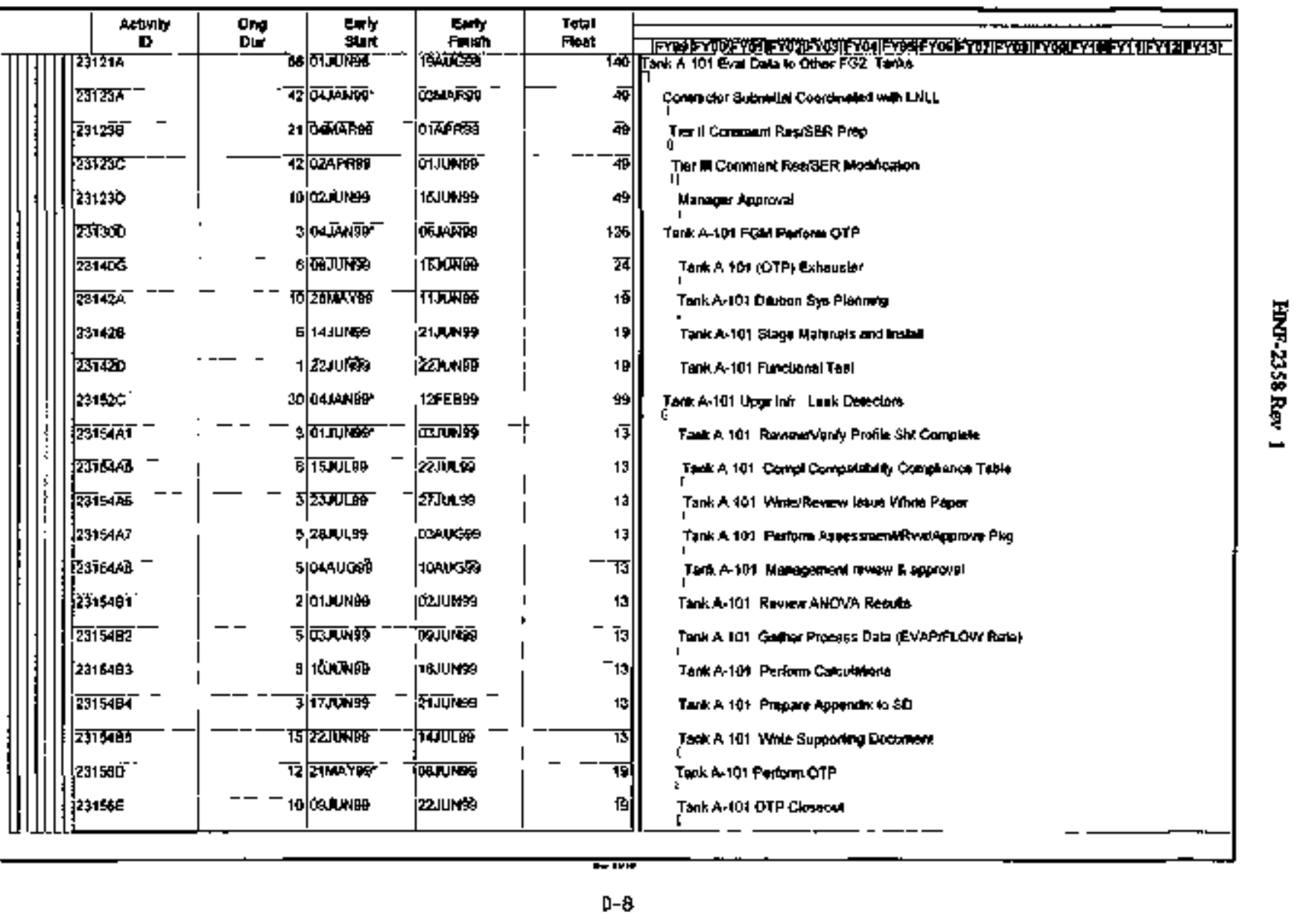




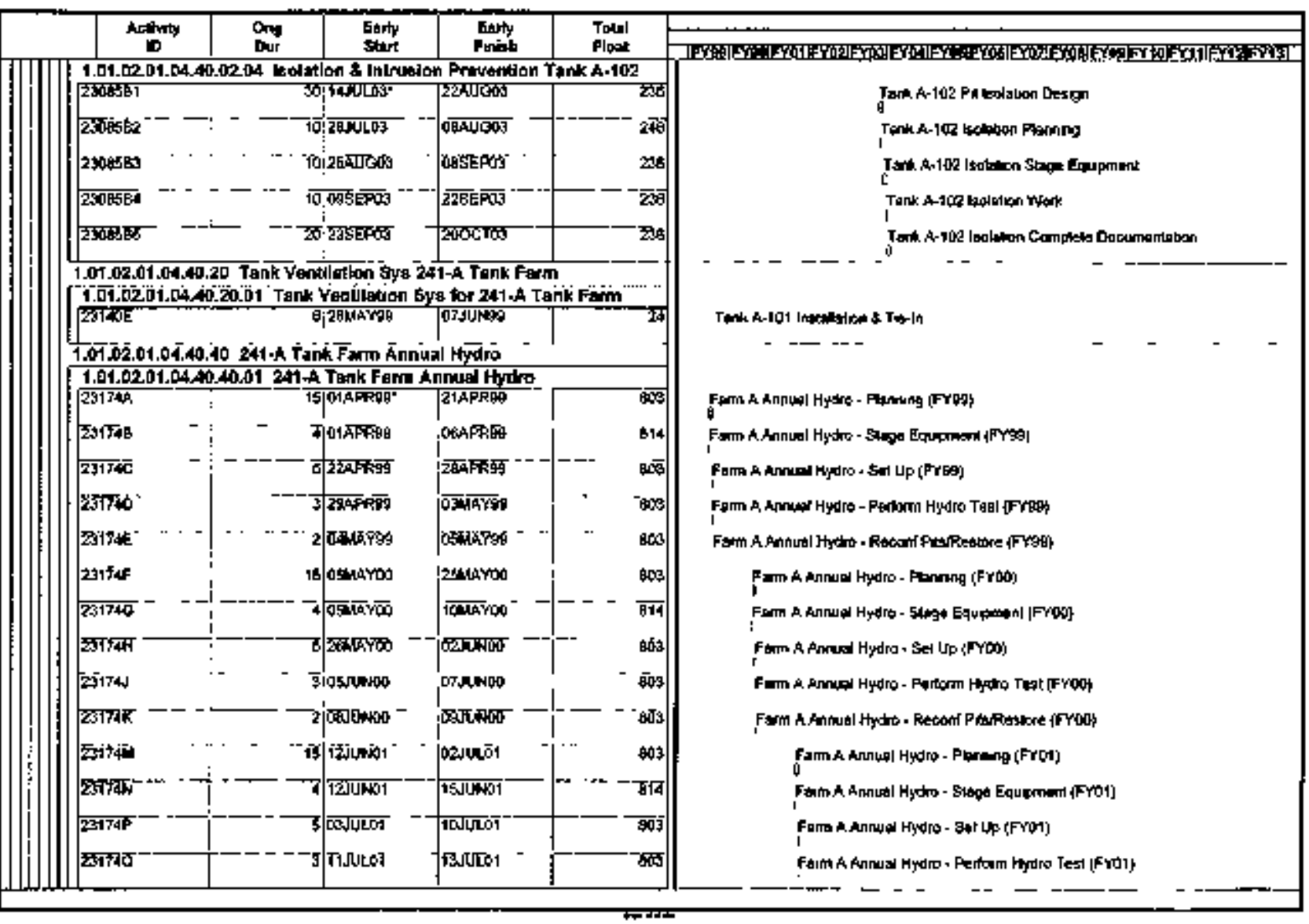




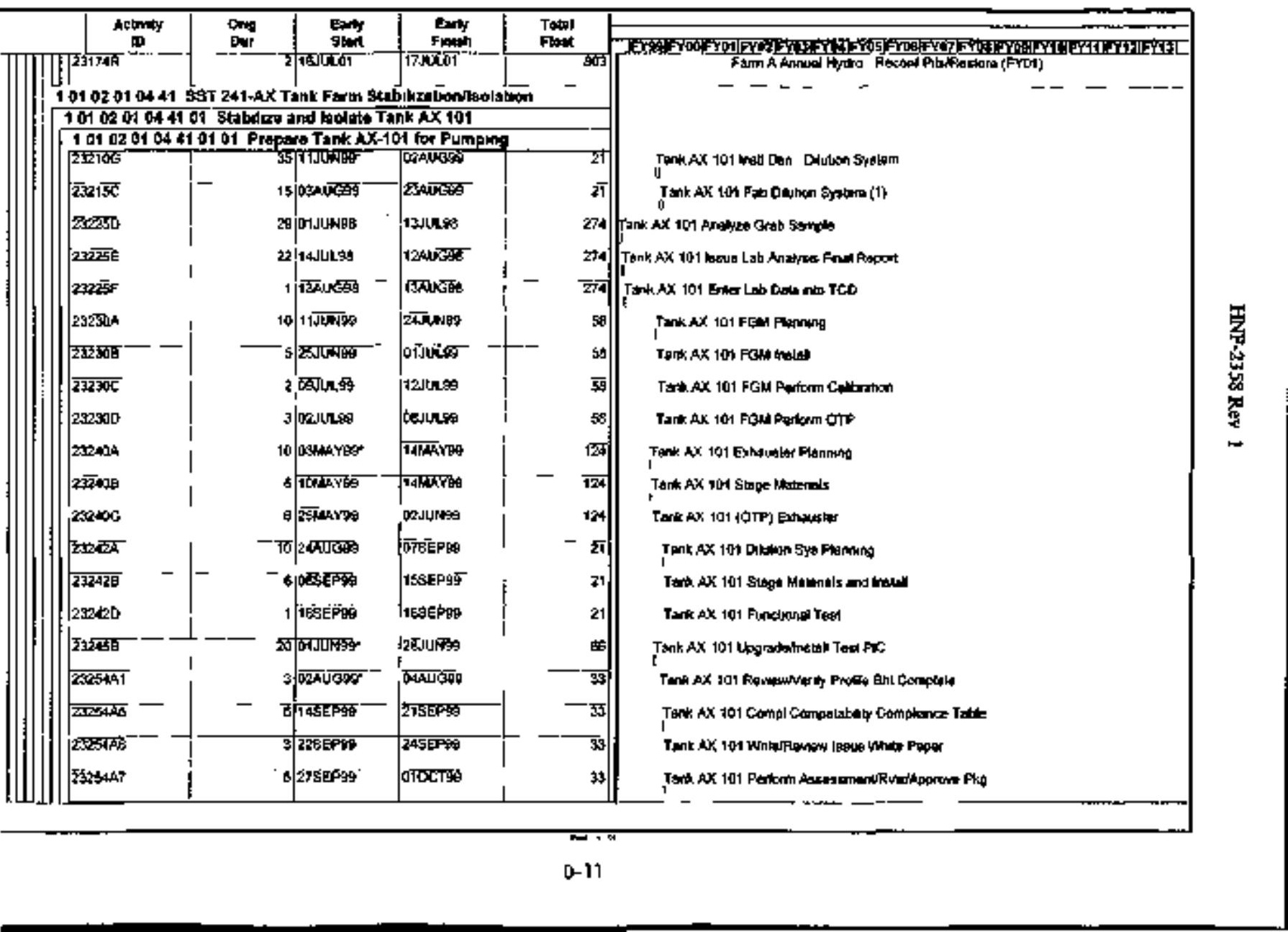




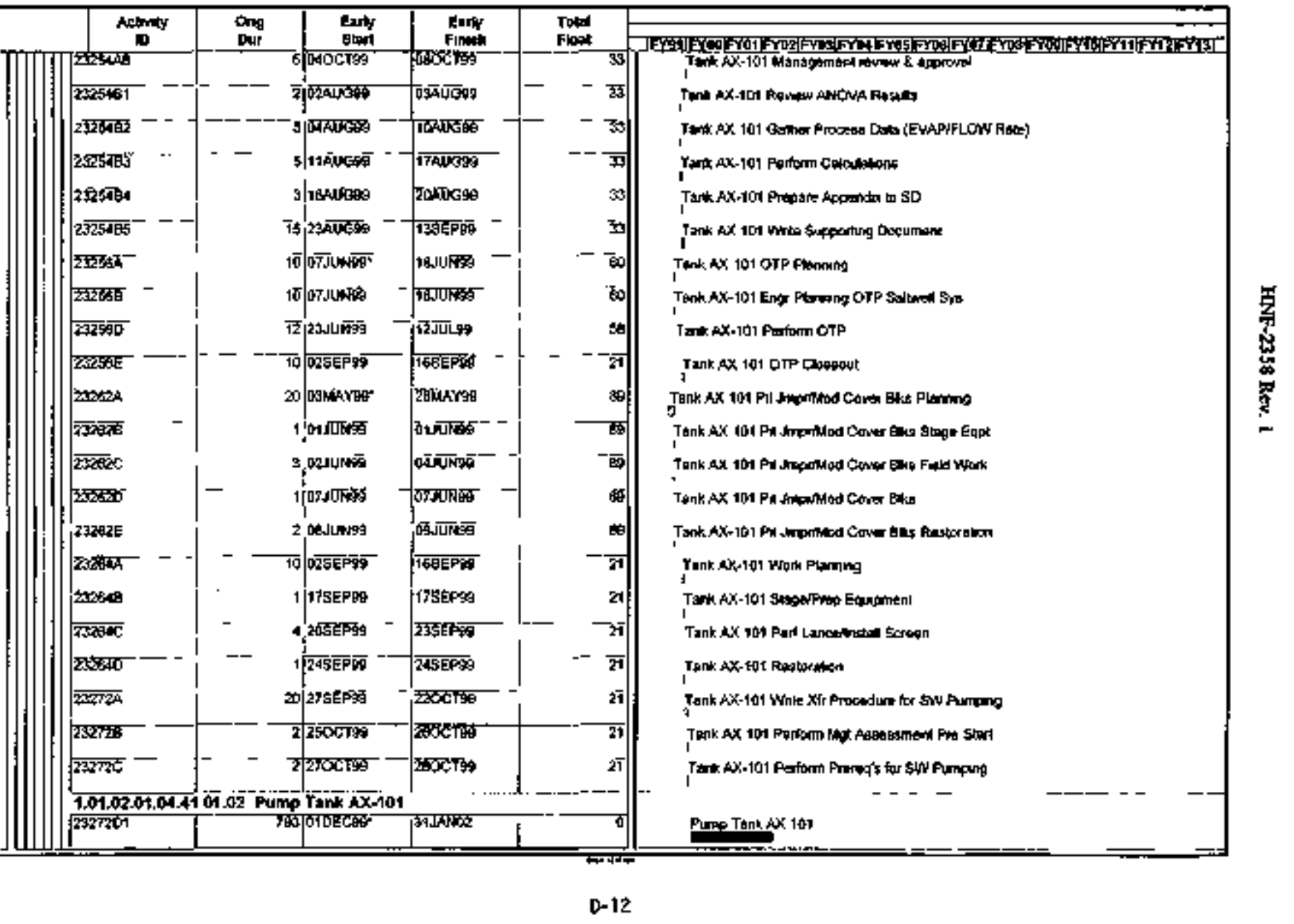




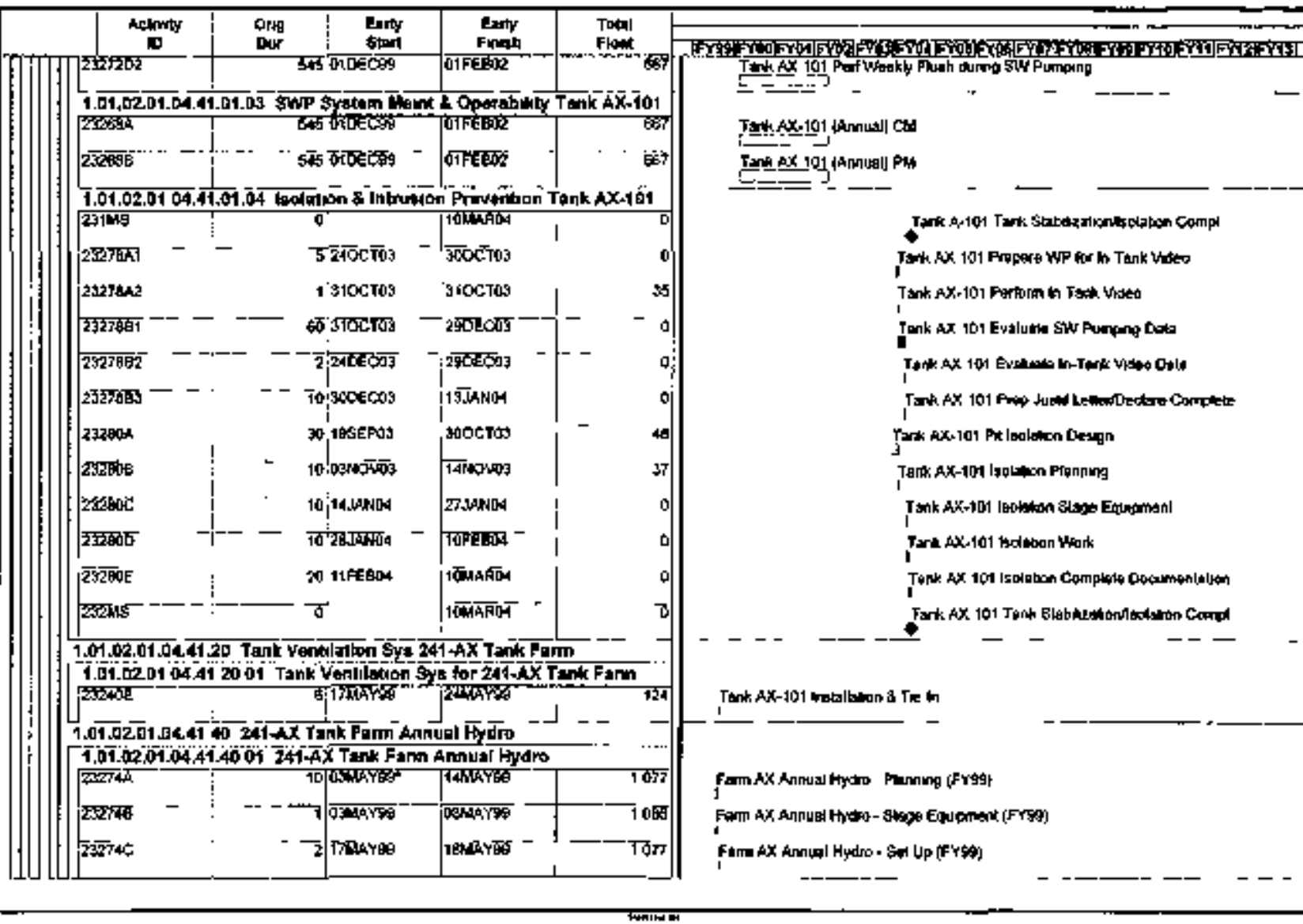




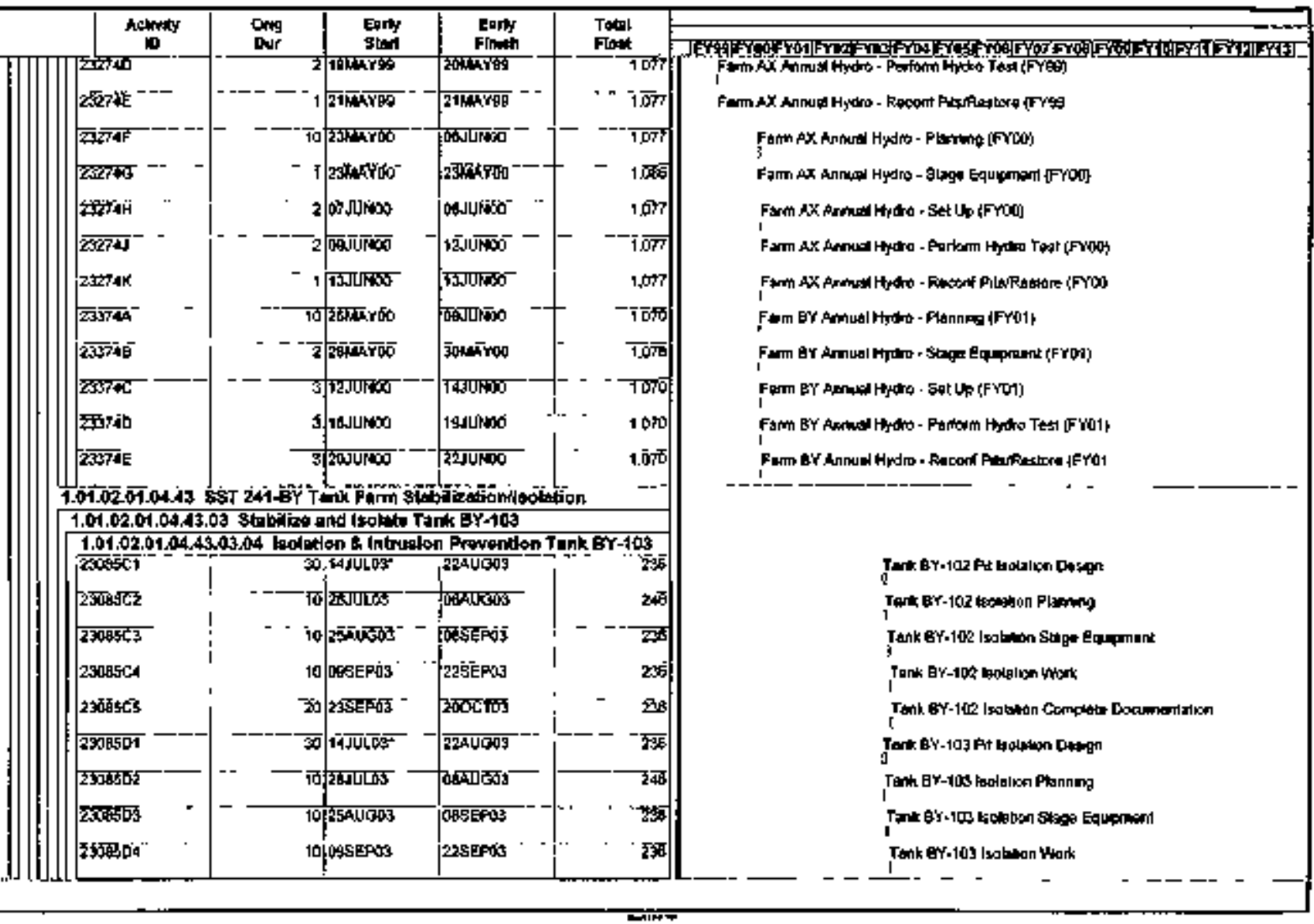




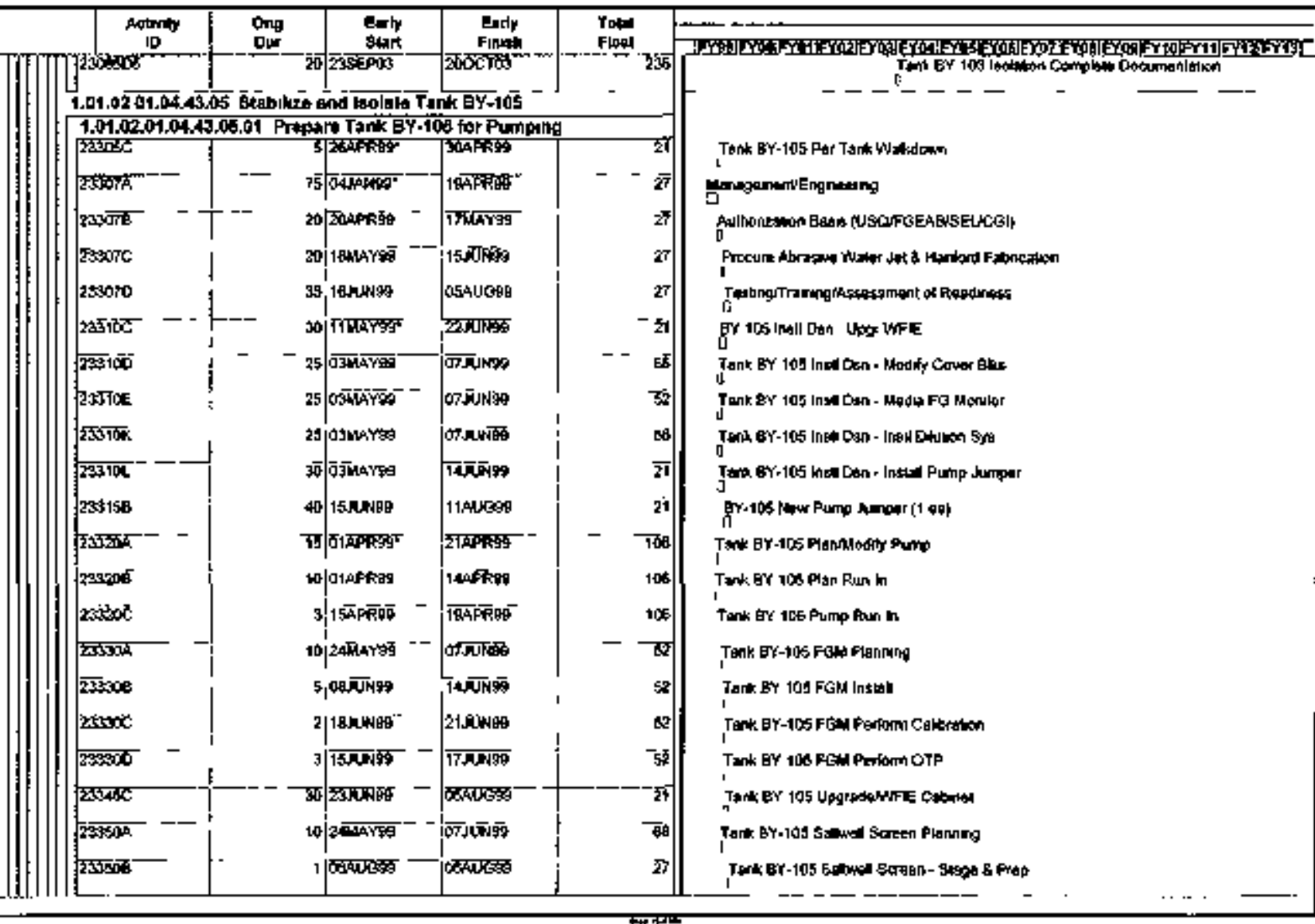




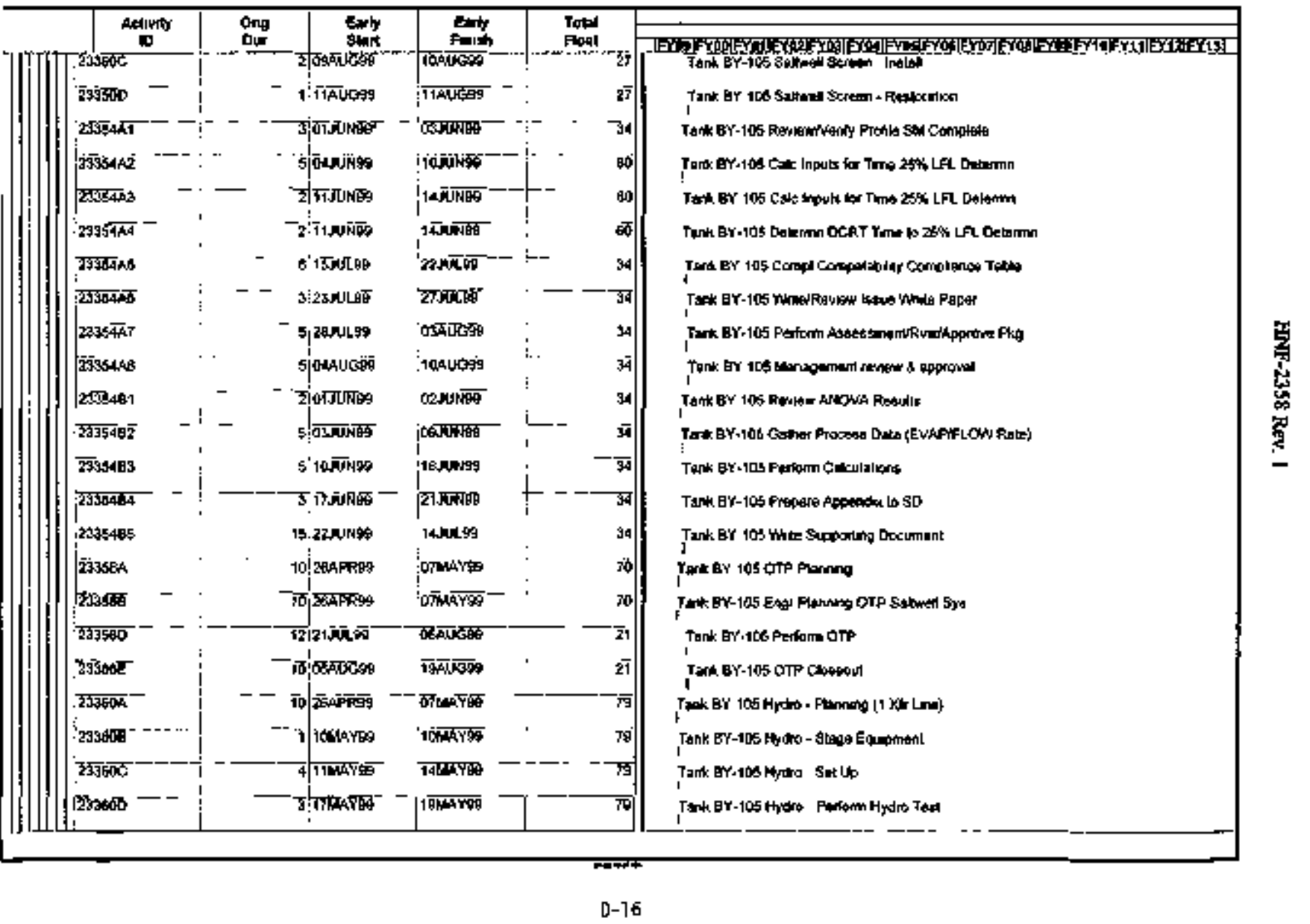




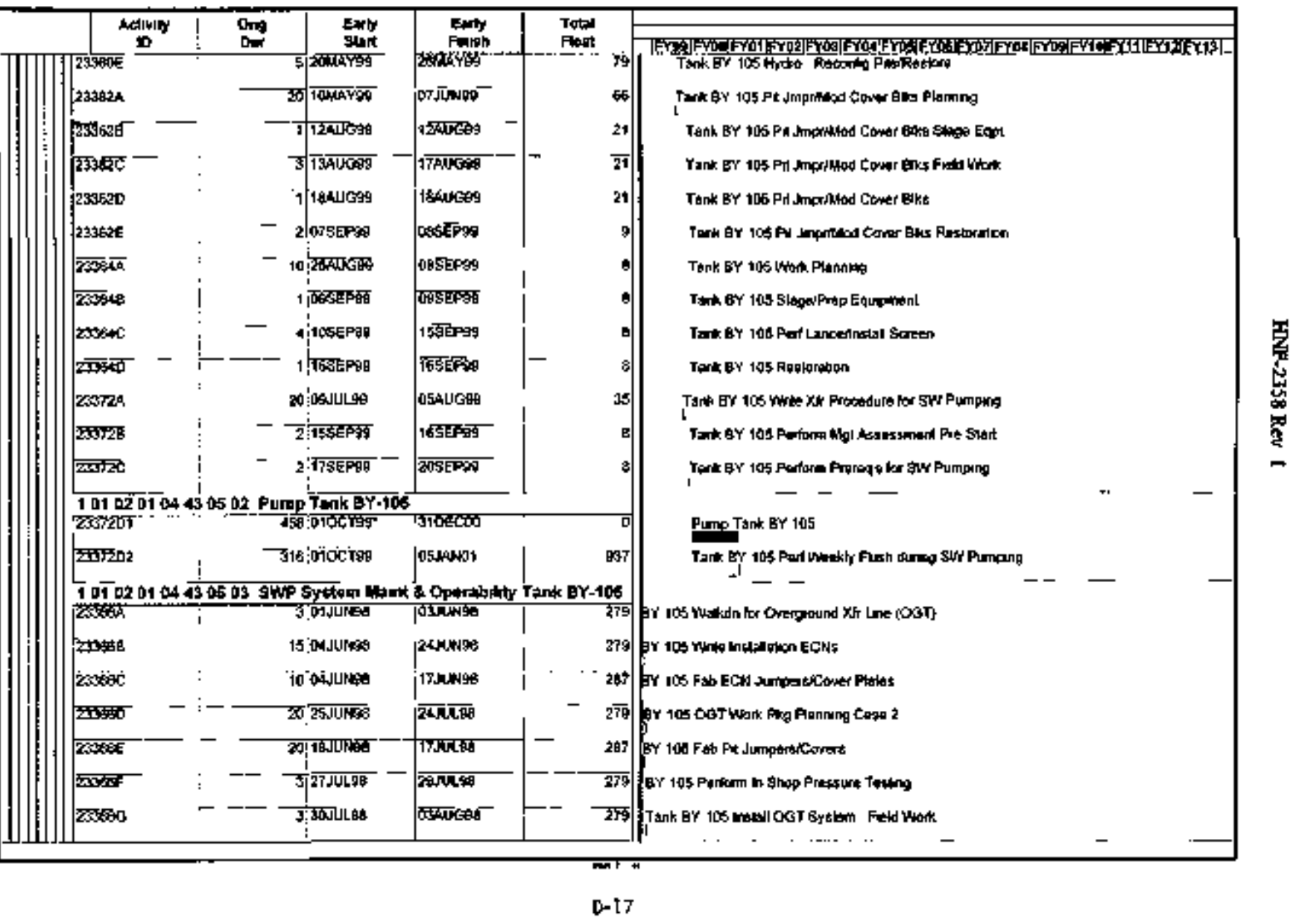




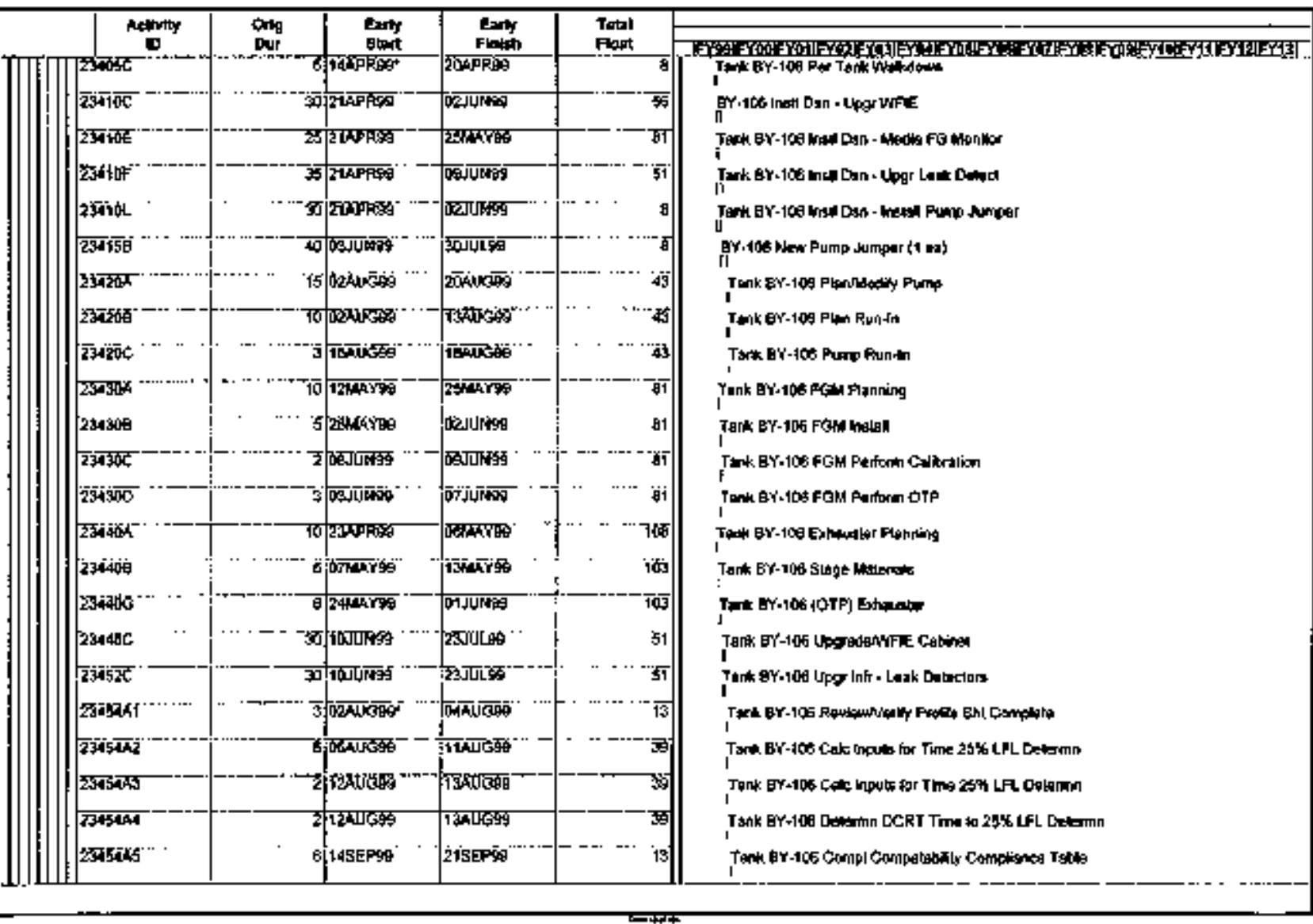




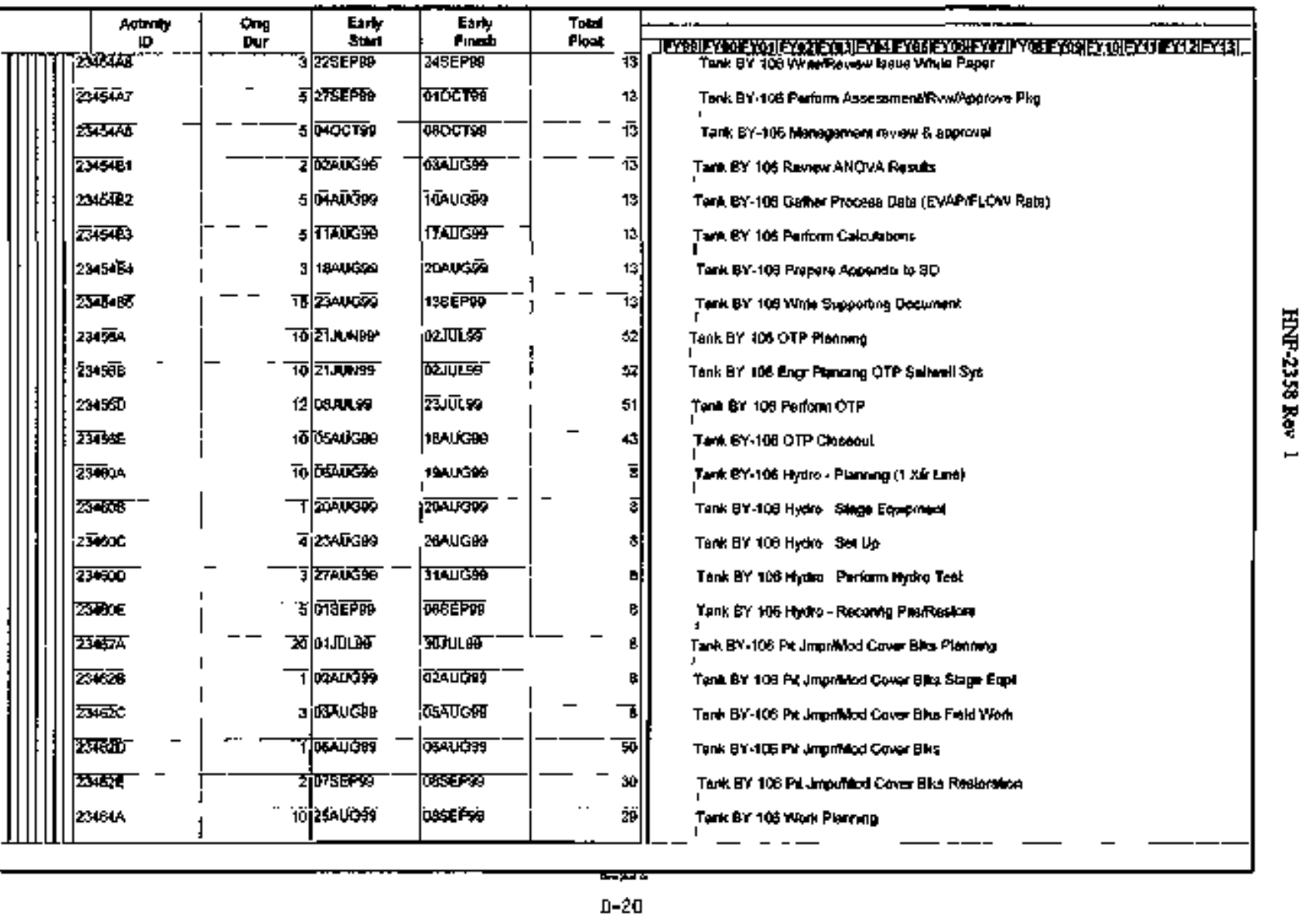




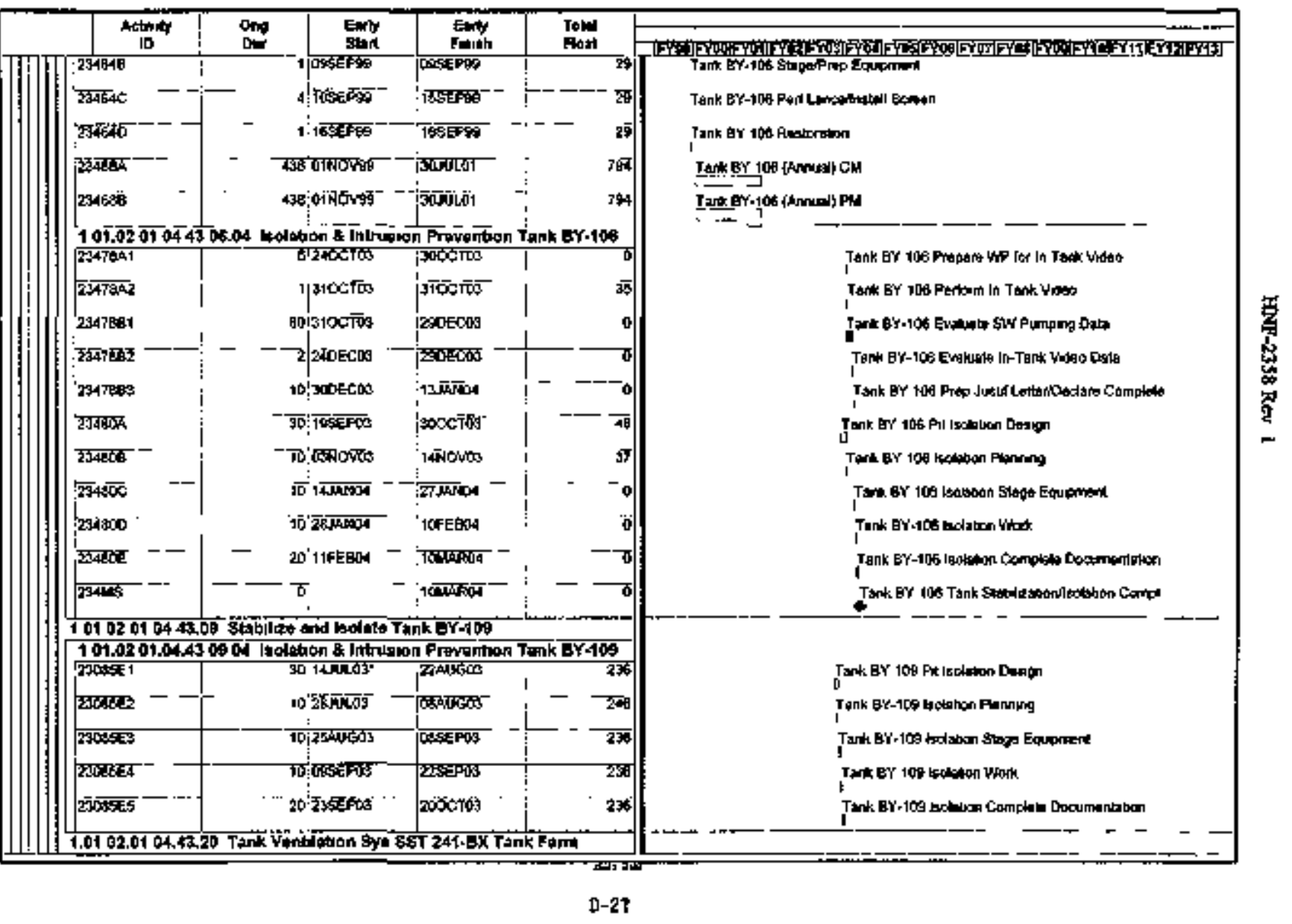




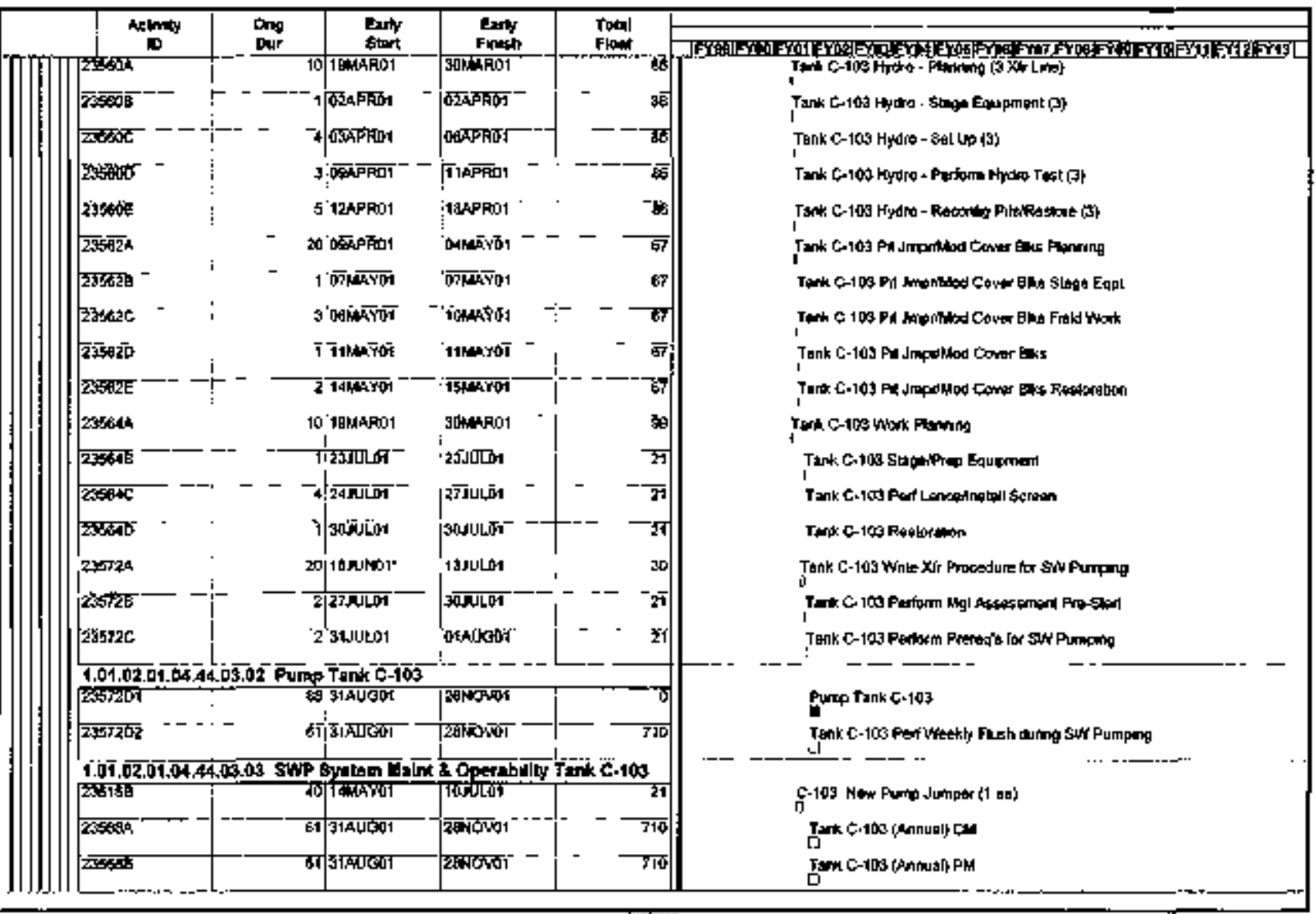




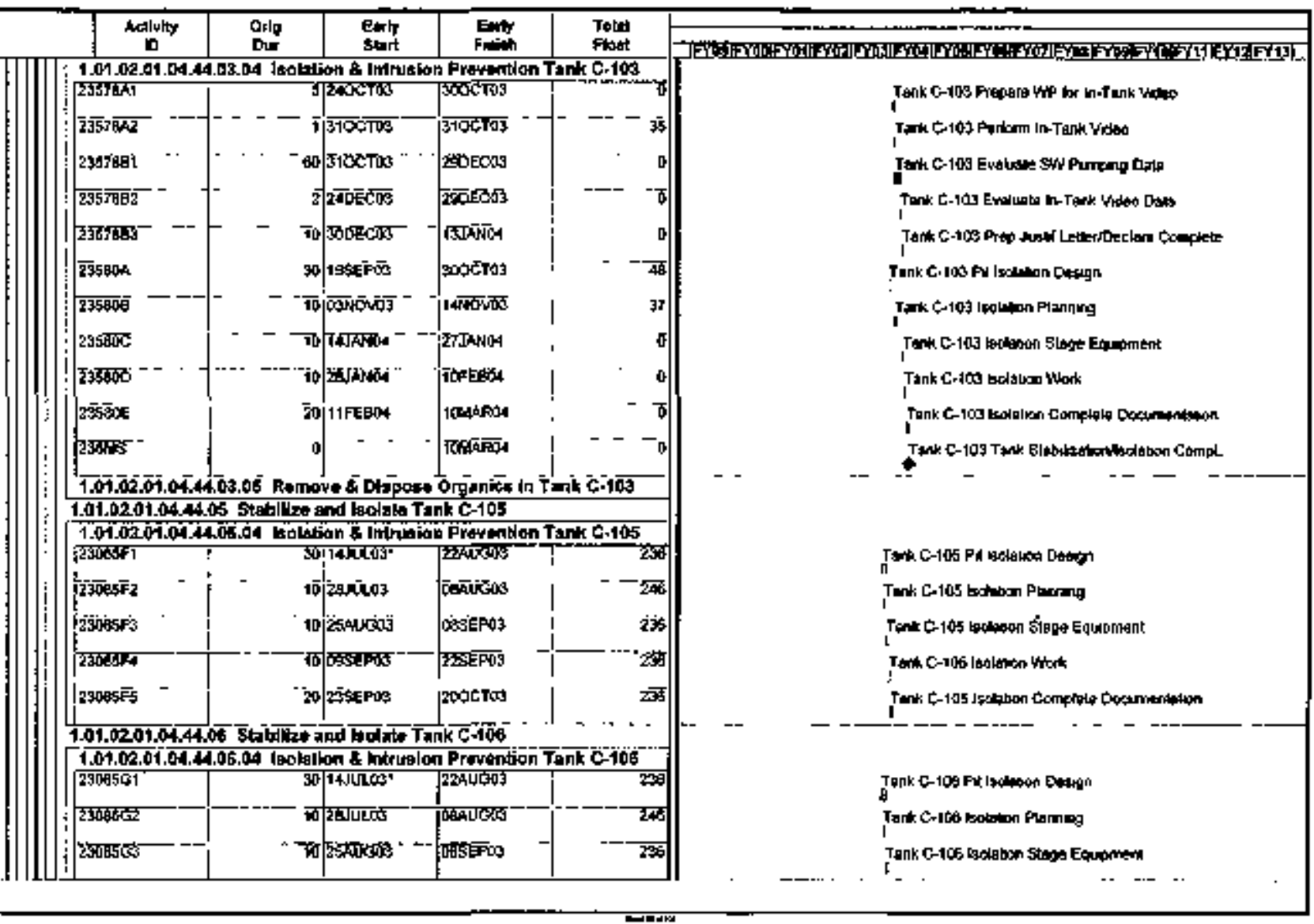




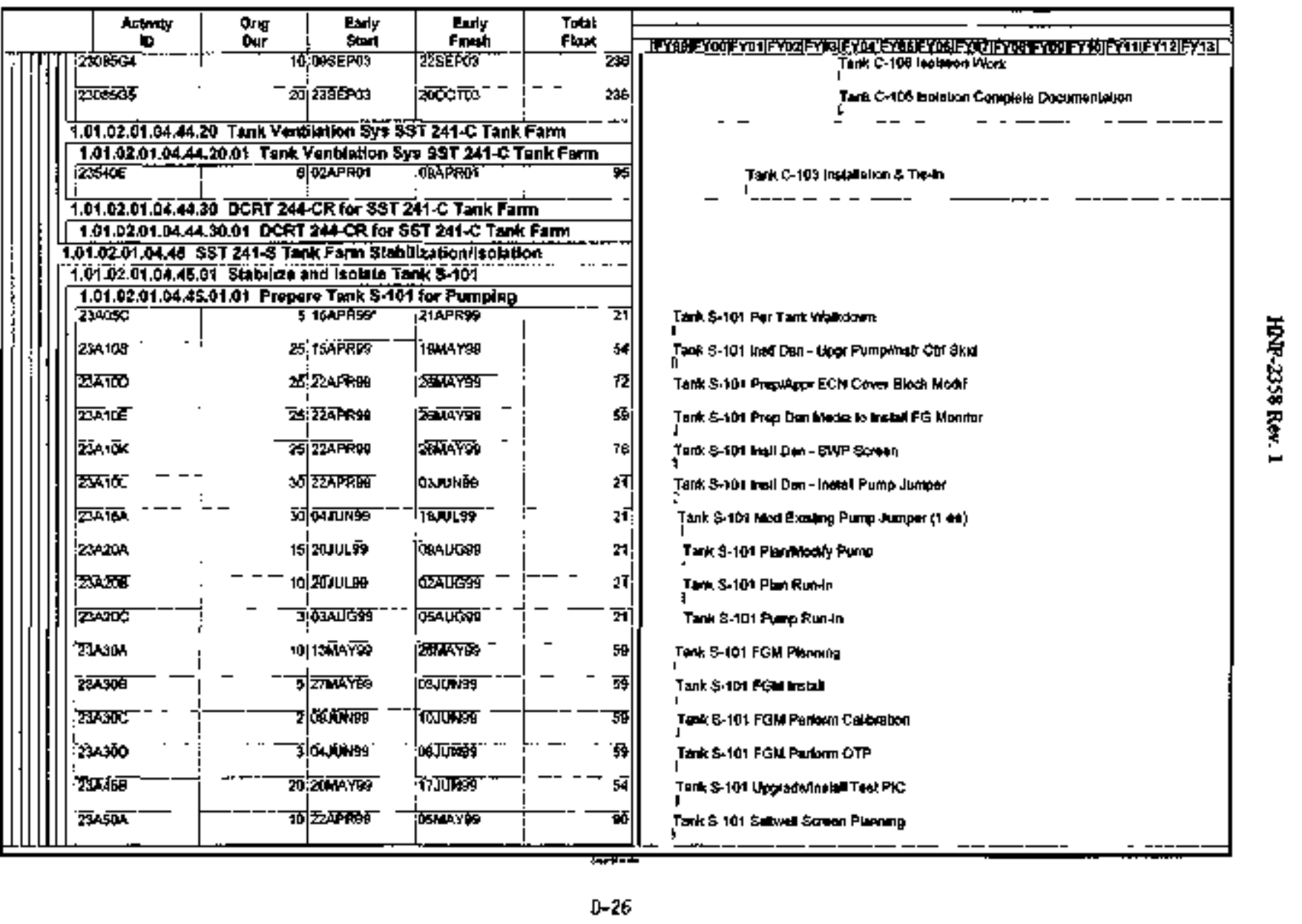




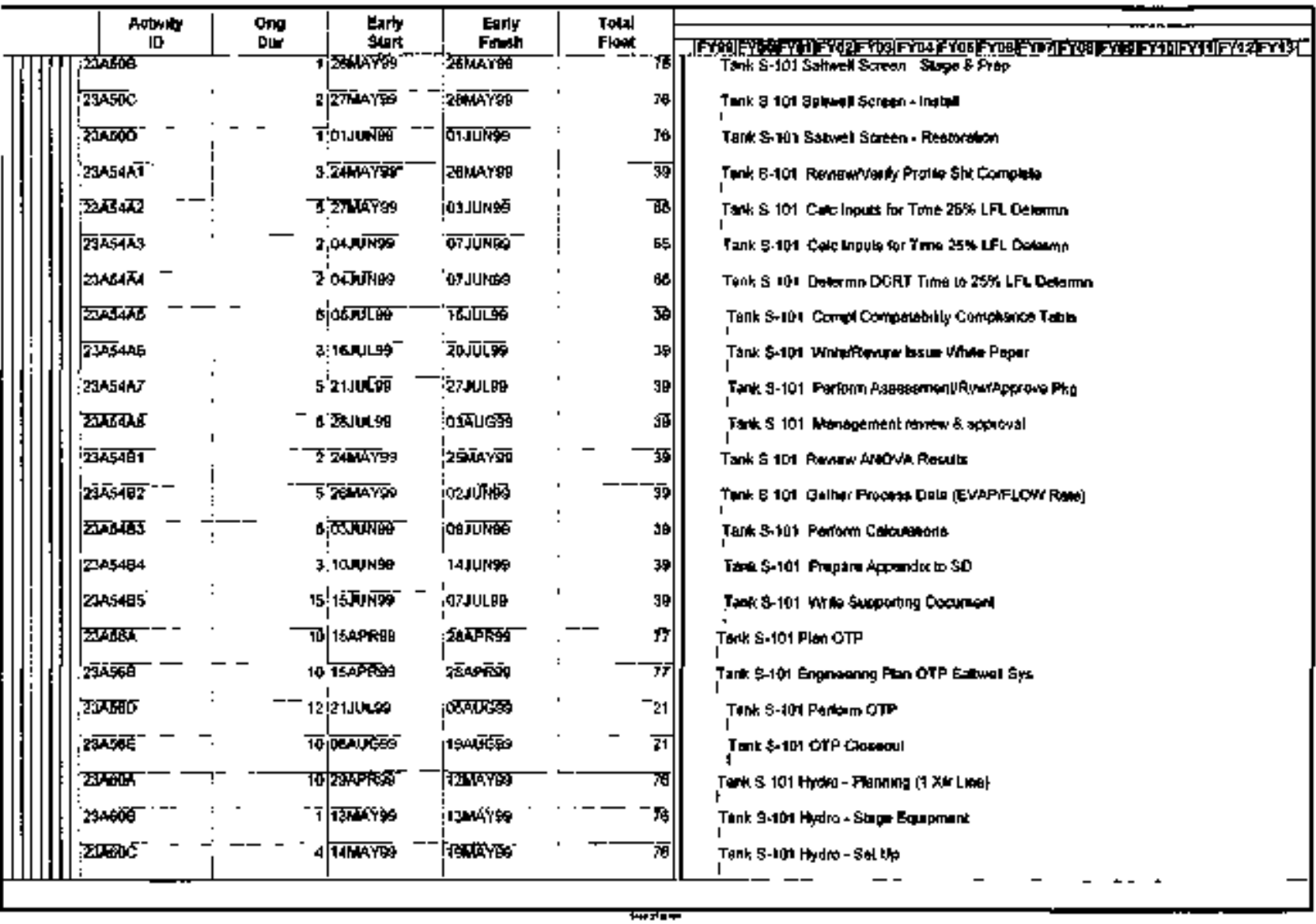




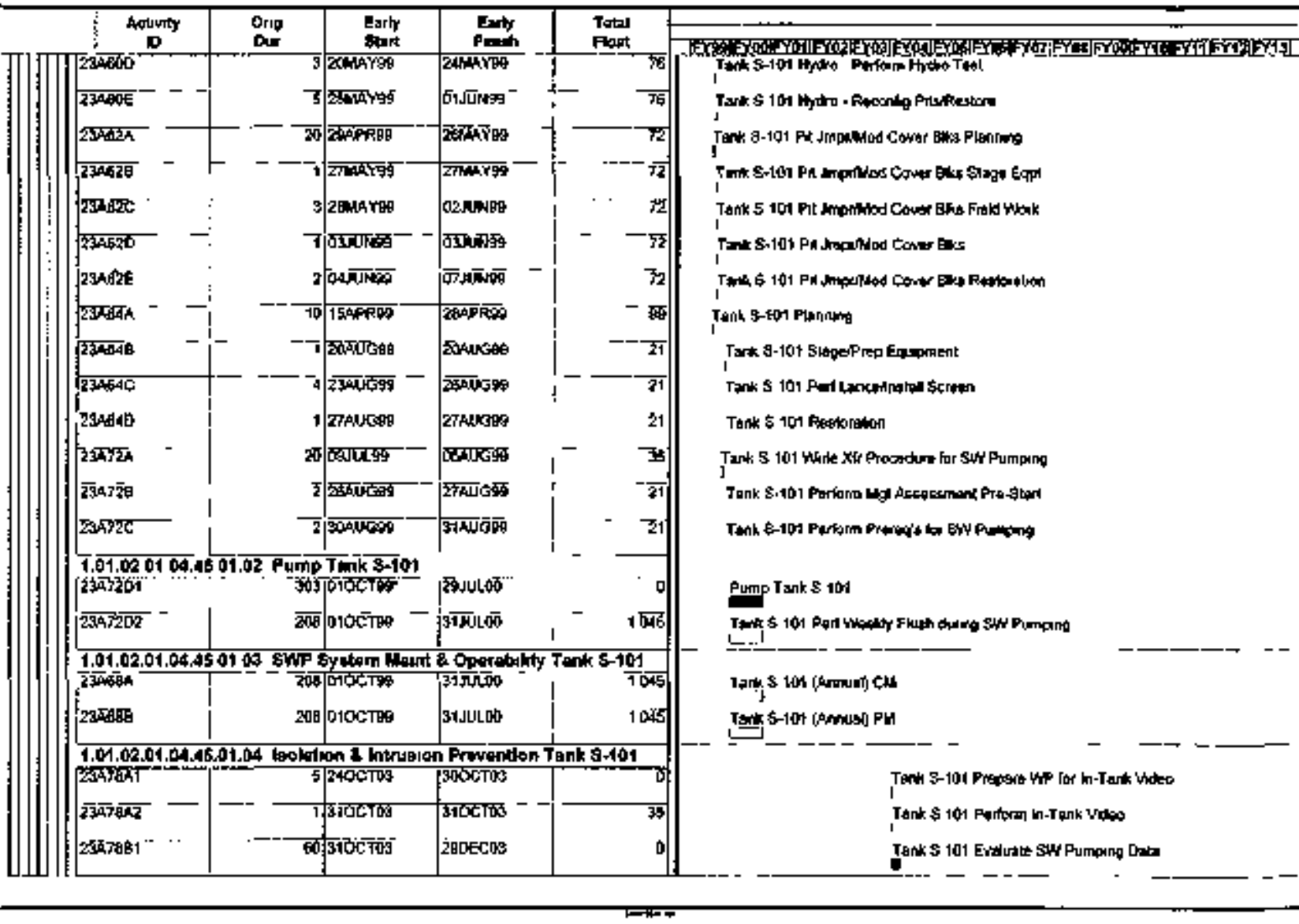




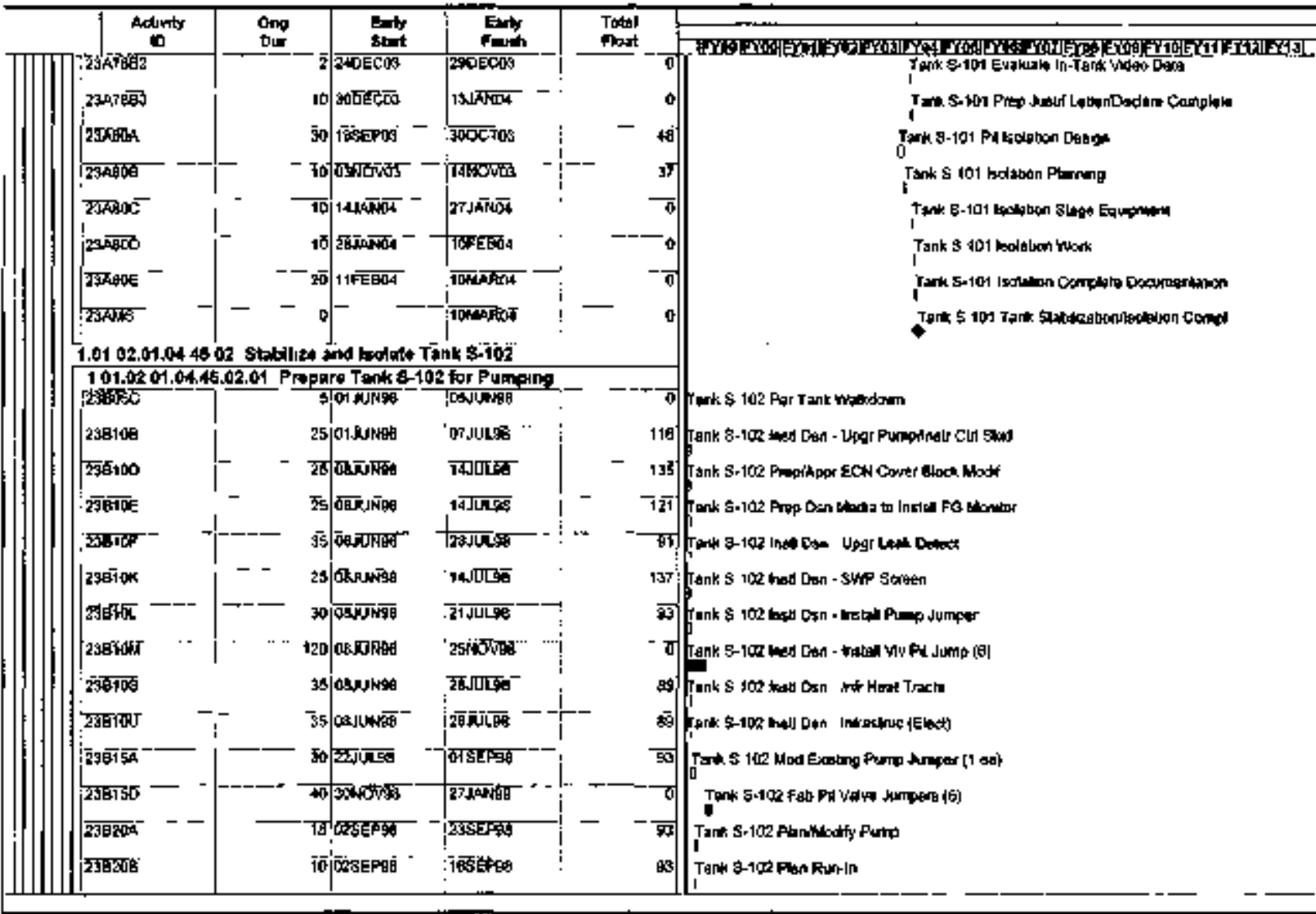




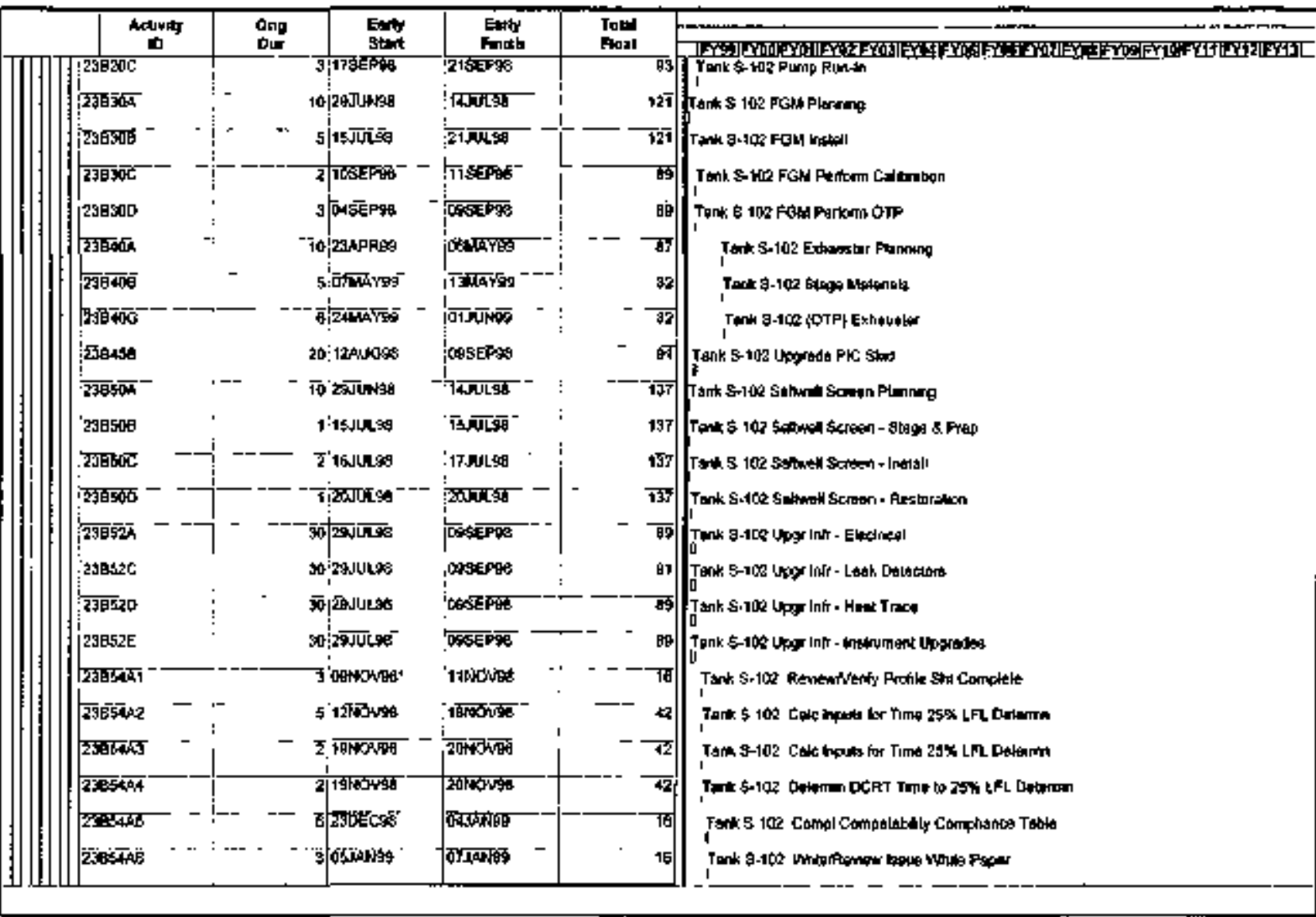




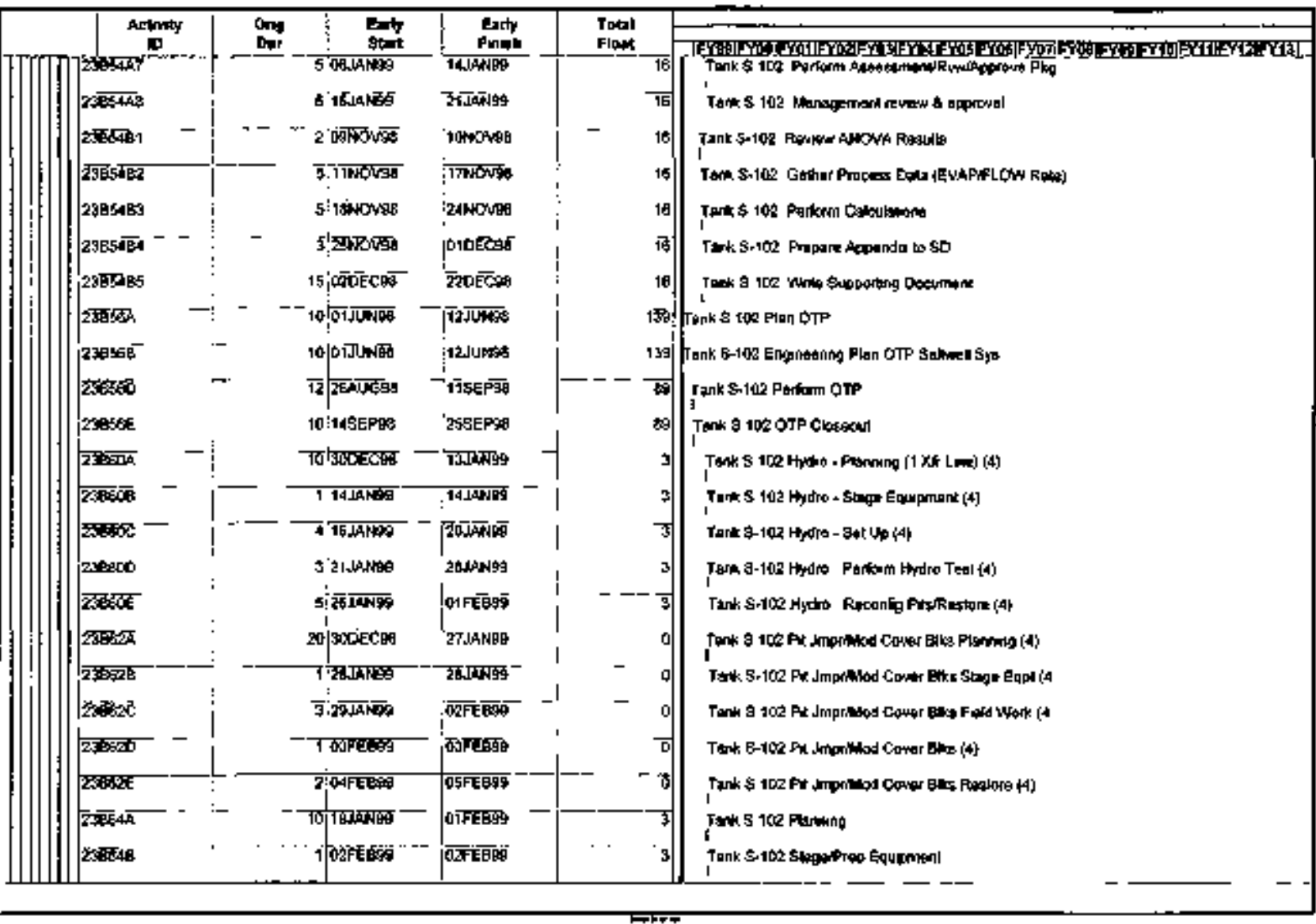




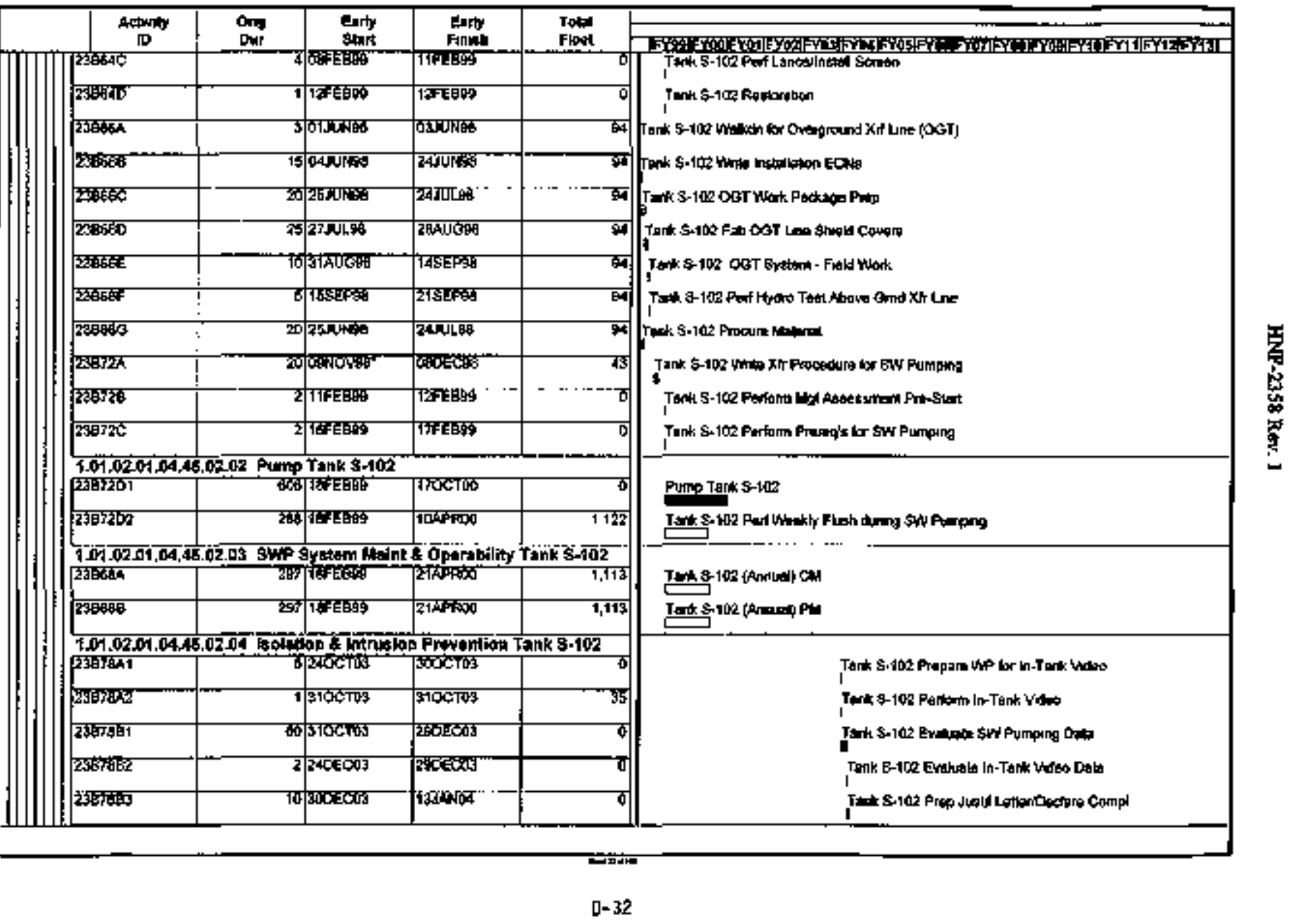




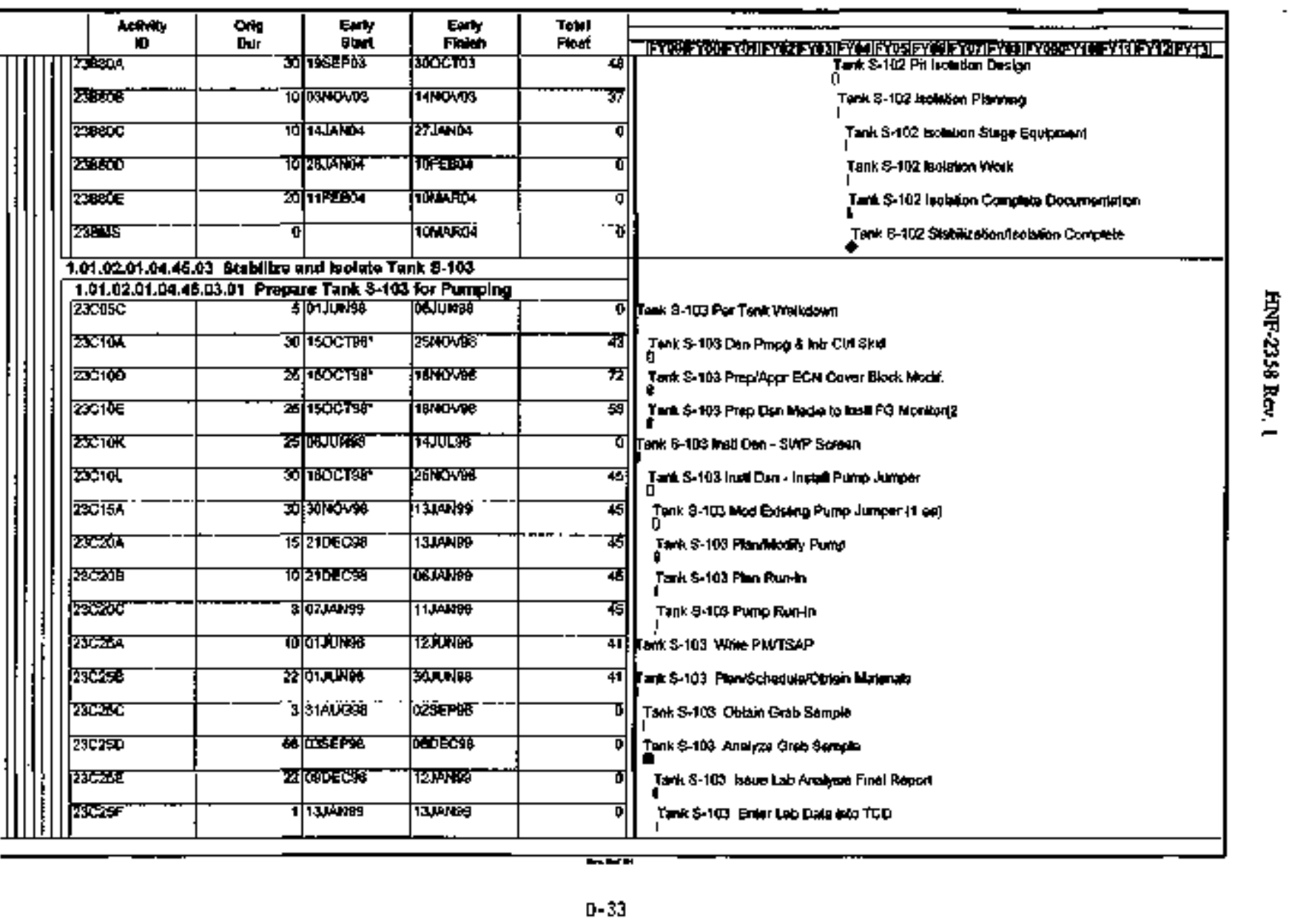




\begin{tabular}{|c|c|c|c|c|c|}
\hline D & $\begin{array}{l}\text { Orts } \\
\text { Dur }\end{array}$ & {$\left[\begin{array}{l}\text { Enty } \\
\text { Etat }\end{array}\right.$} & Eanty & $\begin{array}{l}\text { Totw } \\
\text { Fowt }\end{array}$ & 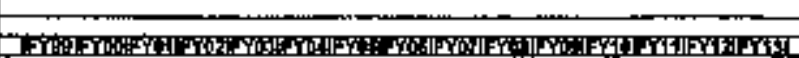 \\
\hline 250309 & & 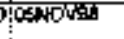 & 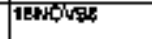 & $\$$ & 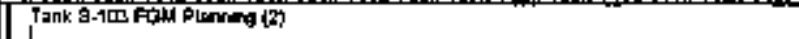 \\
\hline 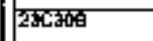 & & if & 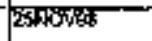 & tot & 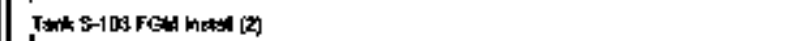 \\
\hline 29c5ic & & ?osoces & parosen & 59 & 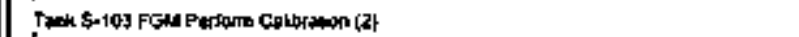 \\
\hline 23050 & & :300 & DRDECE & St. & 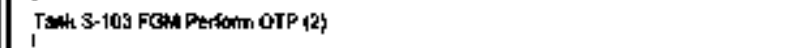 \\
\hline $25 \mathrm{CA} \mathrm{S}_{-1}^{-1}$ & 30 & 5 & 200BCक & 9 & 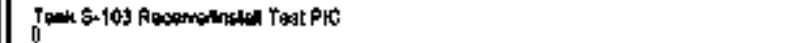 \\
\hline 25CSh & To & 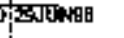 & 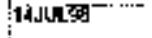 & 0. & 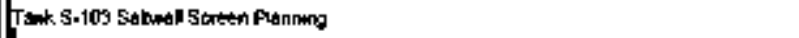 \\
\hline 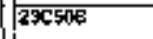 & & 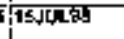 & ISULga & ब & 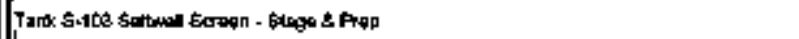 \\
\hline 2 政 $\$ 0 \mathrm{C}$ & 2 & 19八刀大的 & f750的 & 0 & 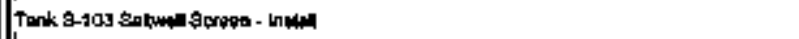 \\
\hline 250500 & T & $\pi$ 2010\% & करतएक & 20 & 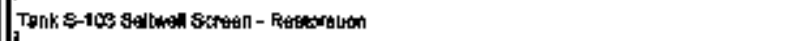 \\
\hline 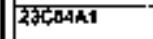 & 3 & 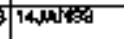 & इसमसR & 6) & 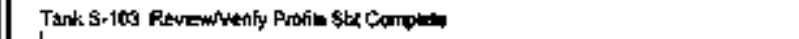 \\
\hline 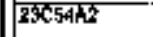 & 5 & ज्ञास & 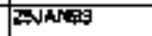 & 36 & 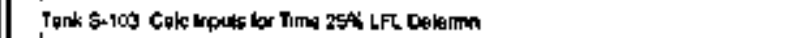 \\
\hline ZFCEARE & & 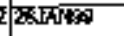 & 27JANOA & 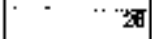 & 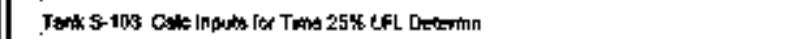 \\
\hline 23C5A4A & & : & ;2TIARS & 30 & 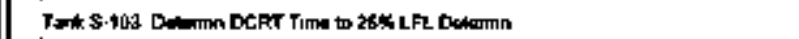 \\
\hline 2305405 & & 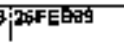 & 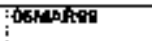 & का & 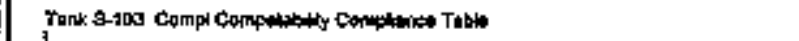 \\
\hline ECSक्स & & 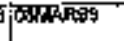 & $\mathrm{j}^{\mathrm{Th}+\mathrm{K}}$ & 8 & 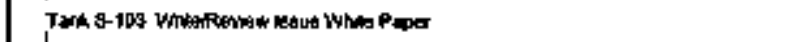 \\
\hline ZरCERT & & 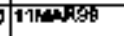 & 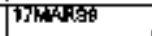 & 可 & 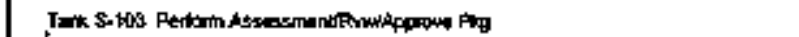 \\
\hline 2305 西乐 & & 5 19rafis & 24TeAs9 & 0 & 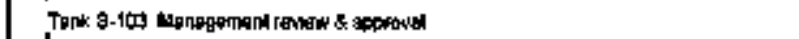 \\
\hline ZZCET:T & & 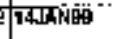 & 15.sindes & D & 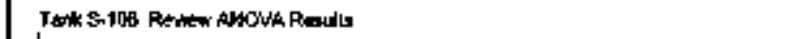 \\
\hline 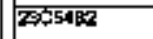 & & $5: 18$ सW & 22IAWD & D & 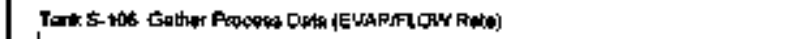 \\
\hline 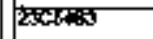 & & 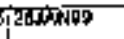 & Z200 & 0 & Tonh 8-100 Pellorm Colatobons \\
\hline 205904 & & पन्ध一彑 & DFFE & 0 & 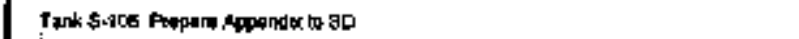 \\
\hline $2 \cos 465$ & 75 & DAfFe & zonteds & 0 & Tank S-108 uth wo Suphating Document \\
\hline 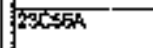 & iot & 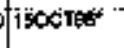 & 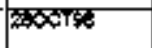 & $-y_{1}$ & 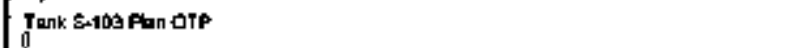 \\
\hline
\end{tabular}




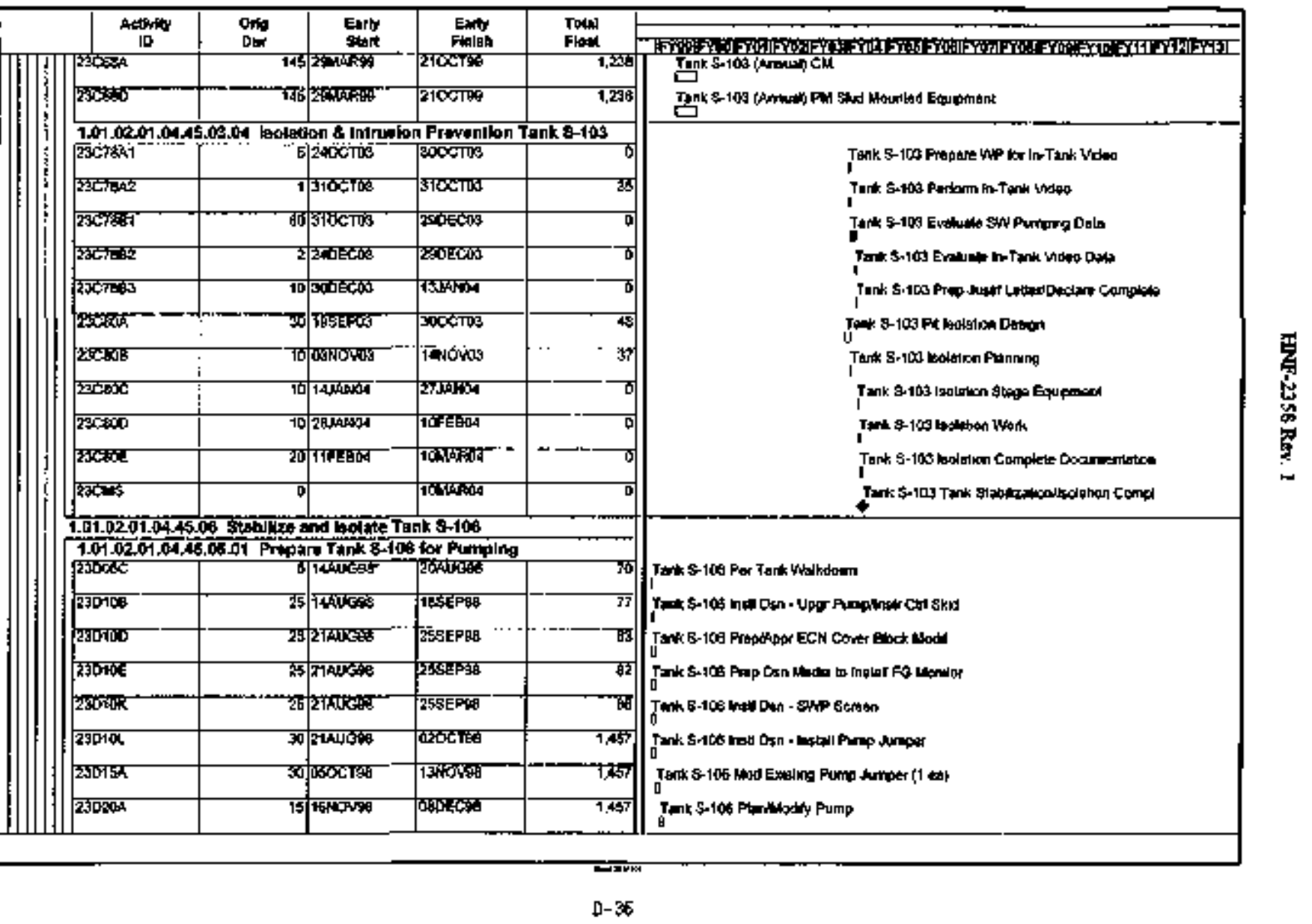




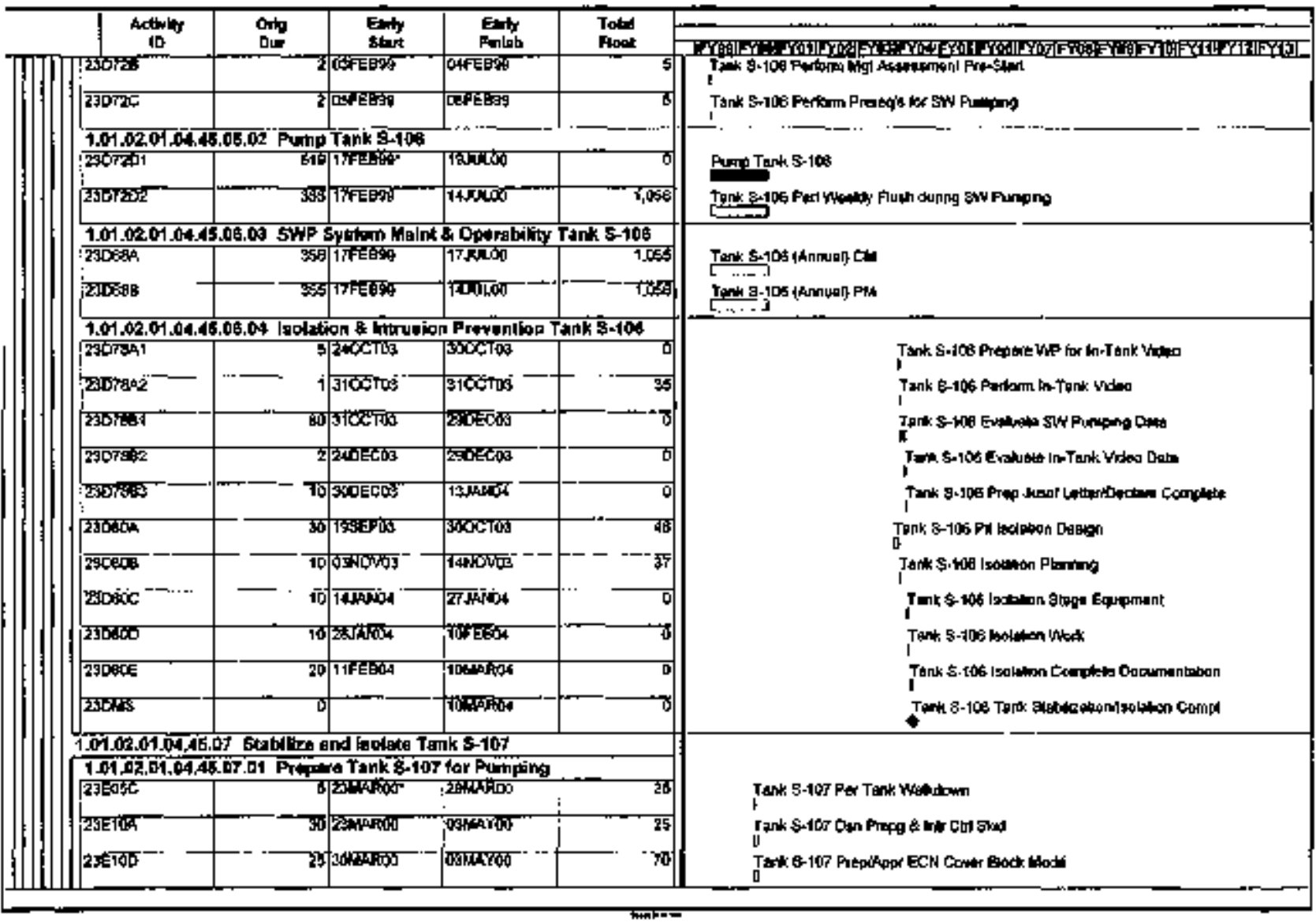




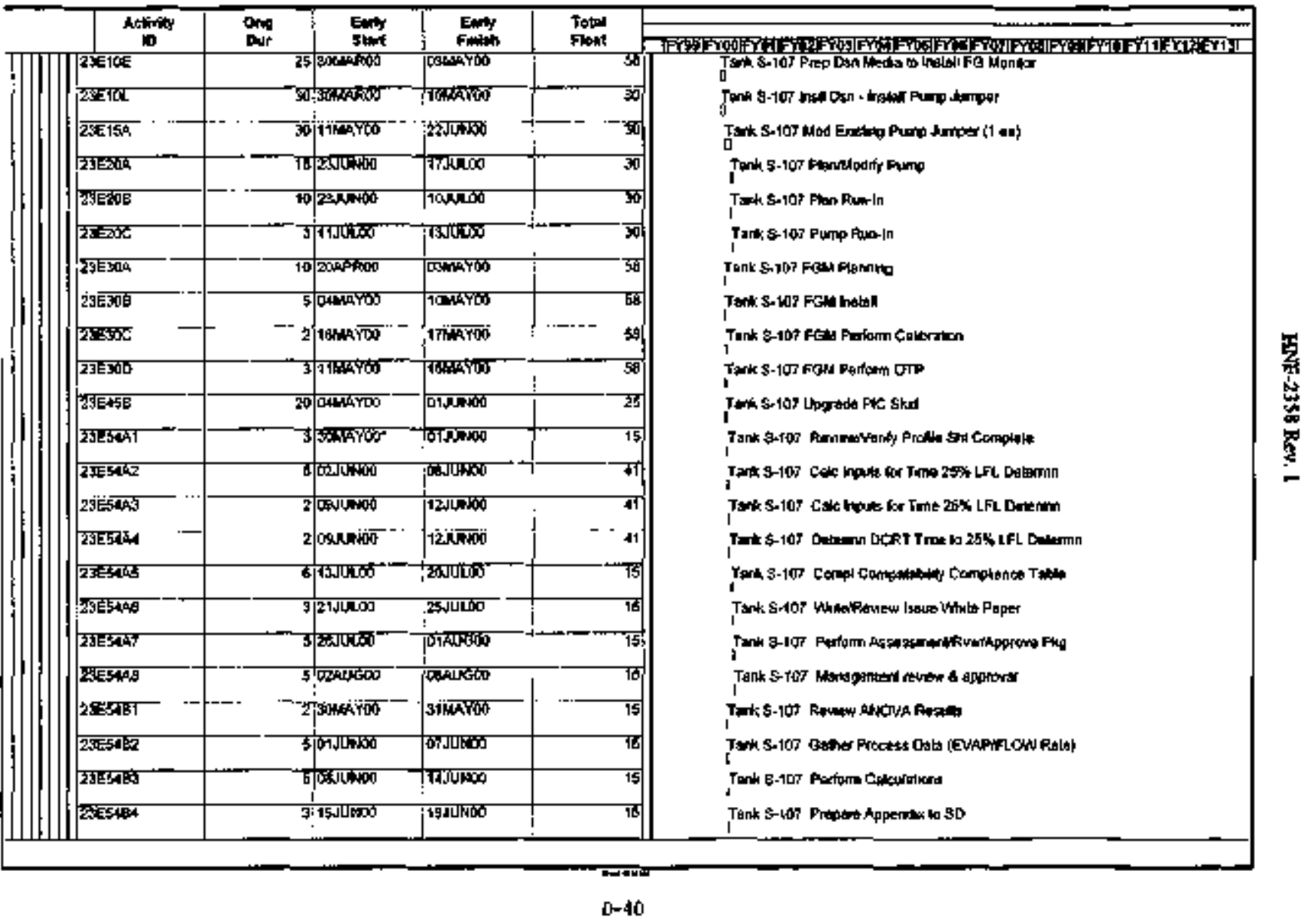




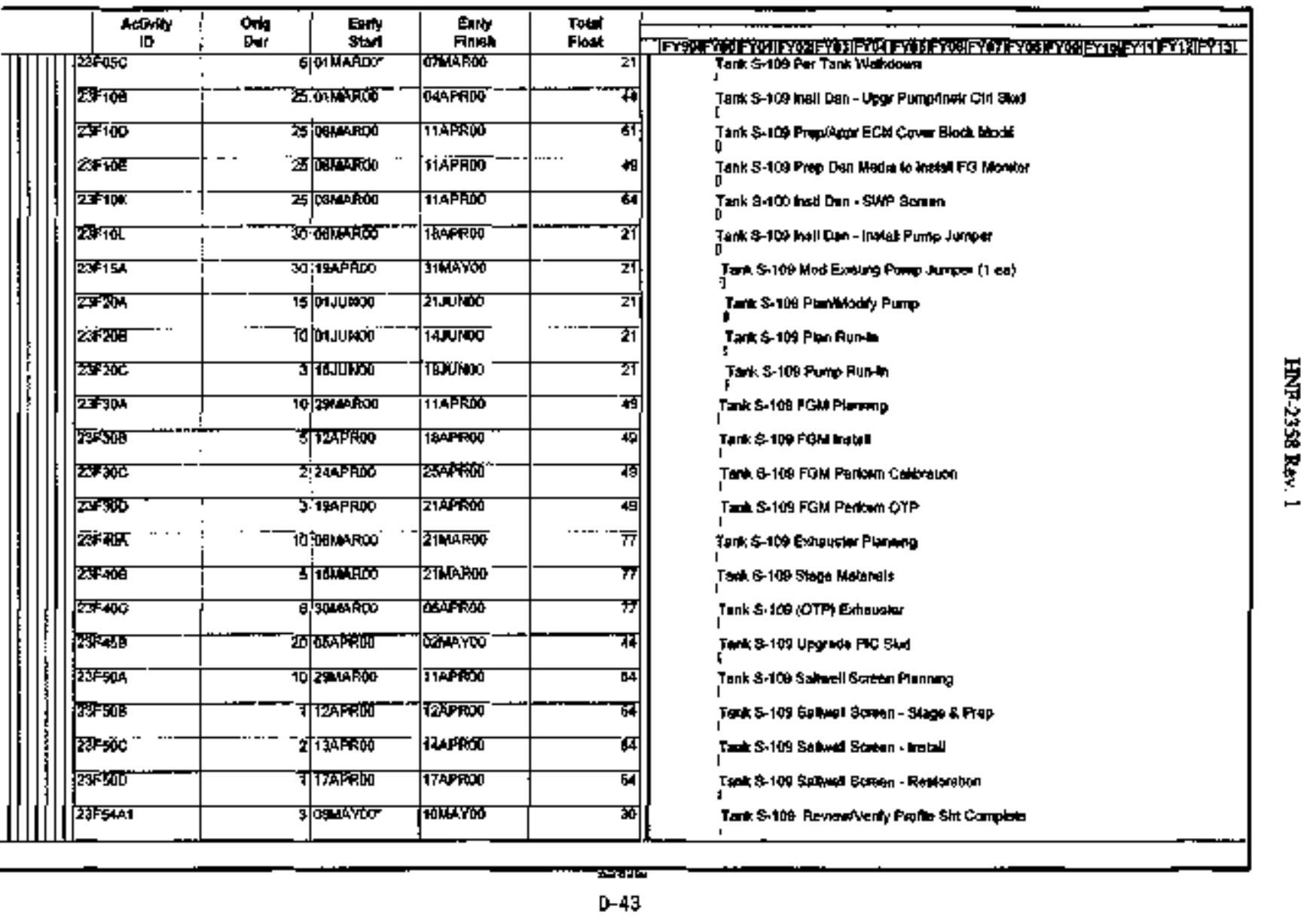




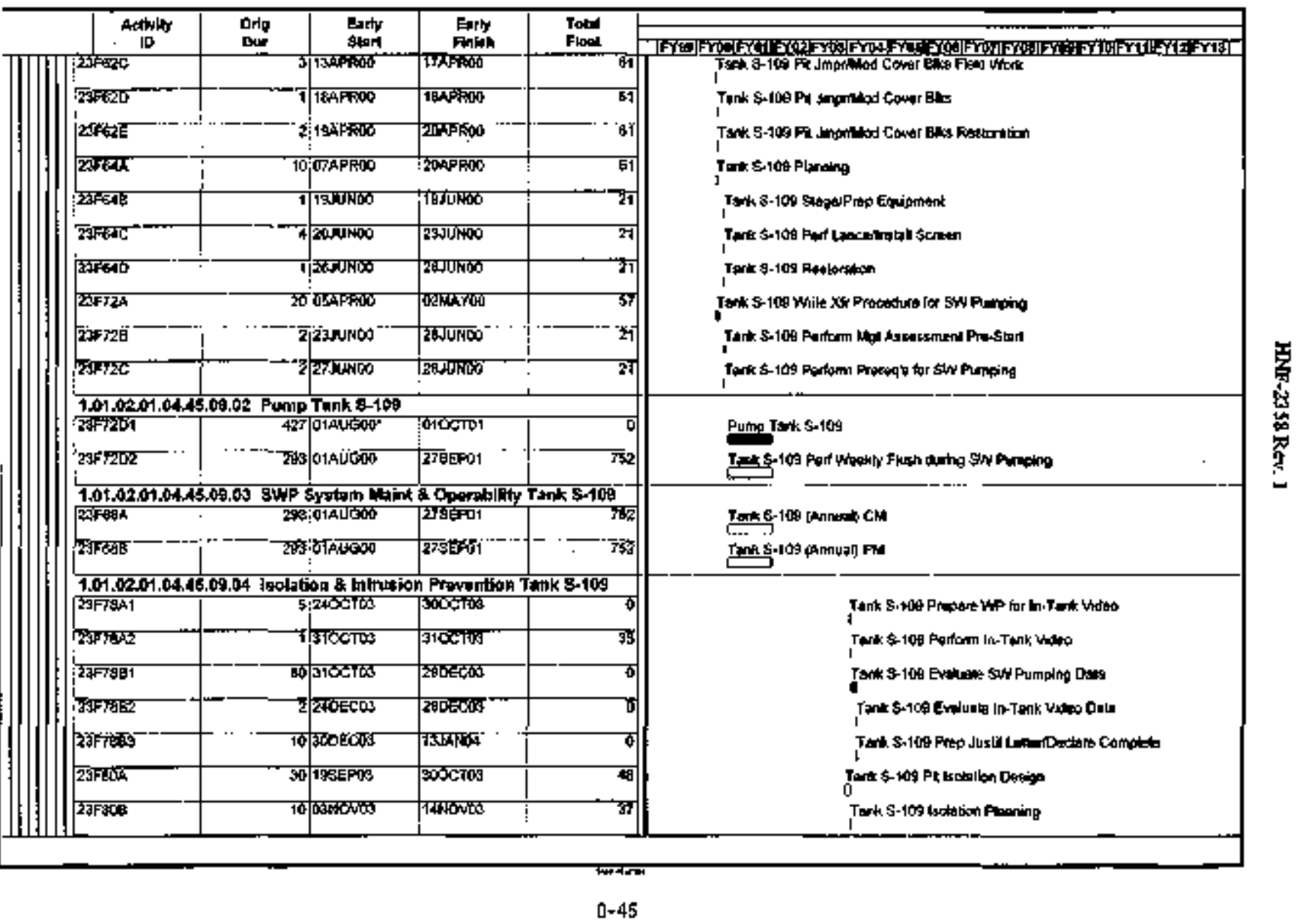




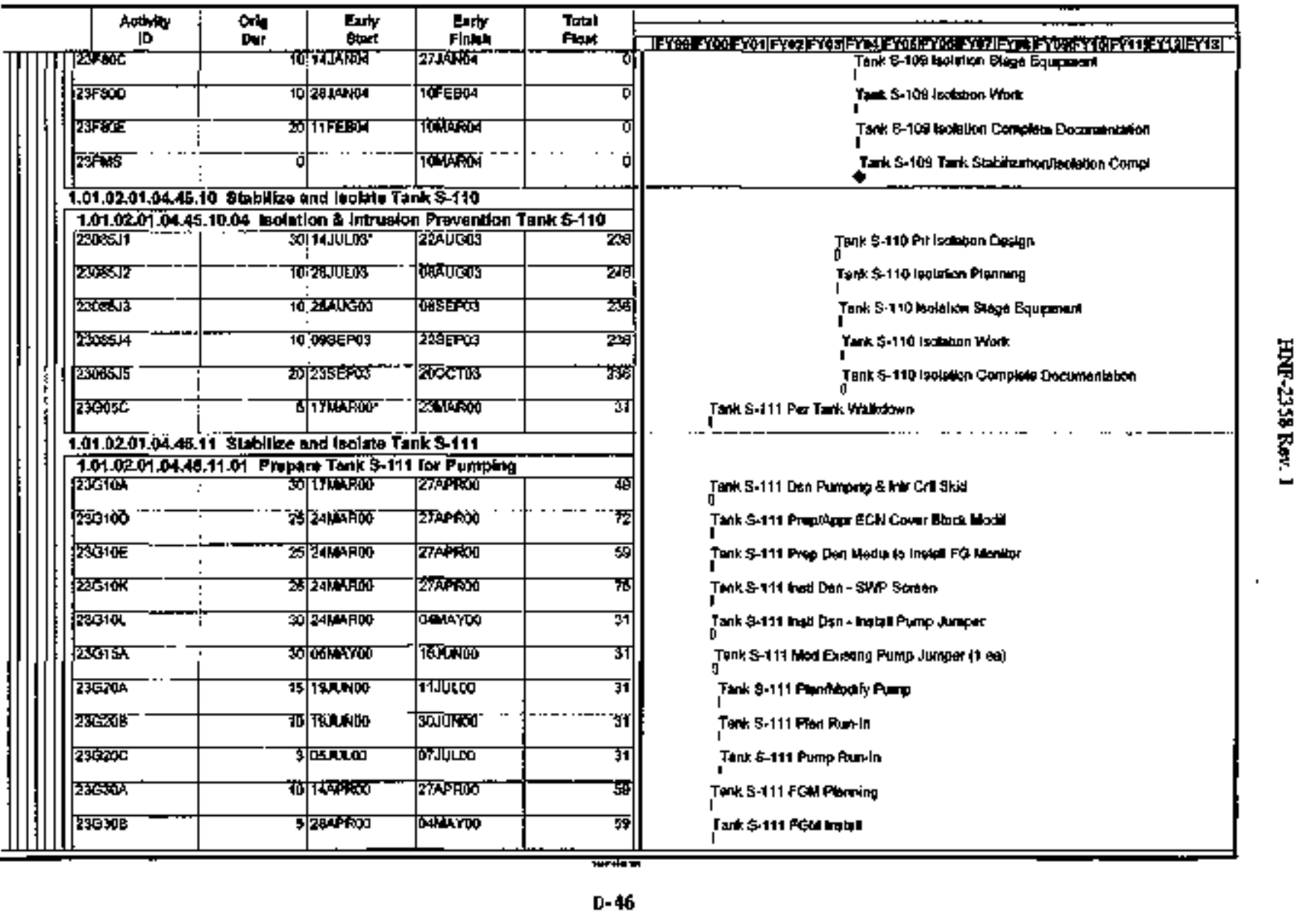




\begin{tabular}{|c|c|c|c|c|c|}
\hline Actrutity & $\begin{array}{l}\text { Ond } \\
\text { Dur }\end{array}$ & $\begin{array}{l}\text { Exty } \\
\text { sut }\end{array}$ & Embun & $\begin{array}{l}\text { Total } \\
\text { Plast }\end{array}$ & 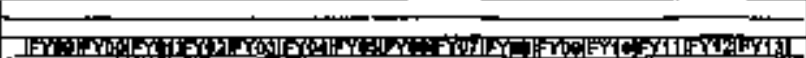 \\
\hline 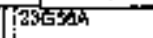 & $\pi$ & itherang & 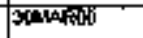 & $\pi$ & 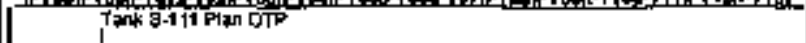 \\
\hline उअ्यद्व & 10 & $1749 k 0$ & 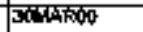 & $M$ & 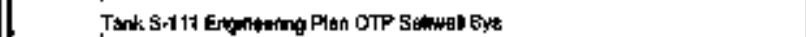 \\
\hline 2369860 & & TAONONO & 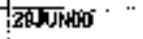 & 25 & Tank 6-111 Porkem ort \\
\hline 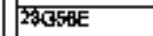 & 10 & ऊण्रासफ & TT.DLLO & 26 & This S-111 OTP Closenoul \\
\hline 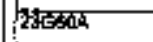 & 商 & 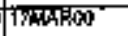 & 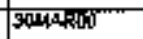 & 䕎 & 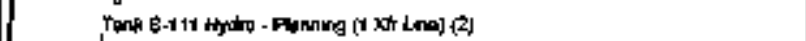 \\
\hline रु०000 & 1) & TIMMERO & 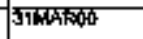 & $\mathrm{E}$ & 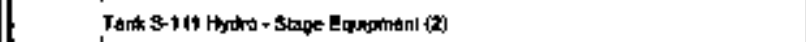 \\
\hline 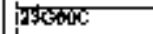 & $i$ & (4) & OAAFOU & B8 & Yenk 5.111 hatro Set Up $\{2\}$ \\
\hline 20G00 & & Q67 & 11AP्मा' & 旺 & 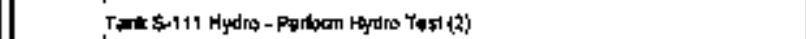 \\
\hline सintos & & T2APROA & Tिसमझ०ण & 68 & Tank \$-111 Hyd \\
\hline 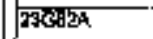 & 分 & S1TABADO & 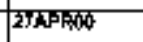 & $\sqrt{2}$ & 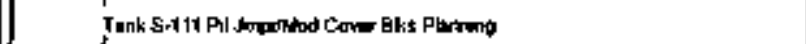 \\
\hline 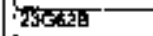 & & 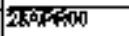 & 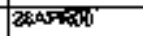 & $\overline{72}$ & 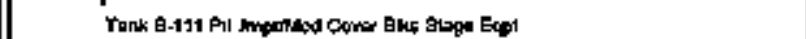 \\
\hline 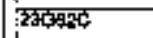 & & 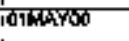 & 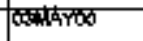 & 72 & 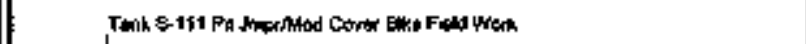 \\
\hline 230d8 & & Peraro & aremapo & $\sqrt{2}$ & 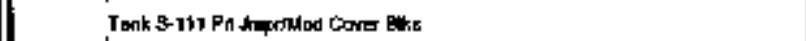 \\
\hline 2JSGERE & & D5: & 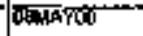 & 72 & 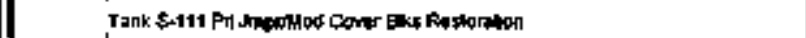 \\
\hline $201064 a$ & & 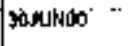 & :77vidoo & 25 & Isak \&-111 Fuming \\
\hline $2{ }^{3} B_{A B}$ & 1 & 120000 & $i 15 \times 1 \times 00$ & 20 & 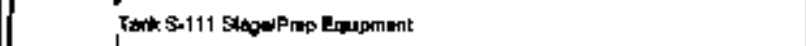 \\
\hline 2RESETC & 4 & 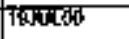 & 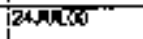 & 事 & 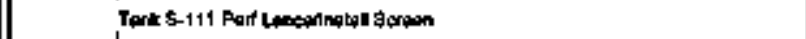 \\
\hline राक्मकाए & T & 2000 & 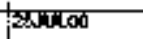 & 20 & Tath \&-111 Rastonator \\
\hline 2KGT2A & 20 & 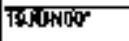 & $18 \pi 00$ & 20 & 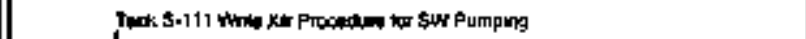 \\
\hline i200 & 2 & EETLEOO & लक्मक्क & Tक्ष & 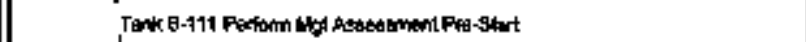 \\
\hline 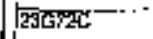 & 2 & OAAREOO & $0+34000$ & ت̈ & 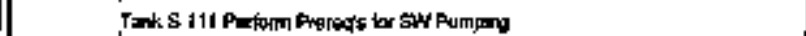 \\
\hline $1,04.02,01,04$ & 02 Pump & Tonk 3-111 & & & \\
\hline FrbraU & 神! & 01 क्सP00 & $\$ 300001$ & 可 & Pum Ist S.111 \\
\hline 230 何 & उुप्यां & 'DTSEPO & WसमART: & EB & Tork \\
\hline
\end{tabular}




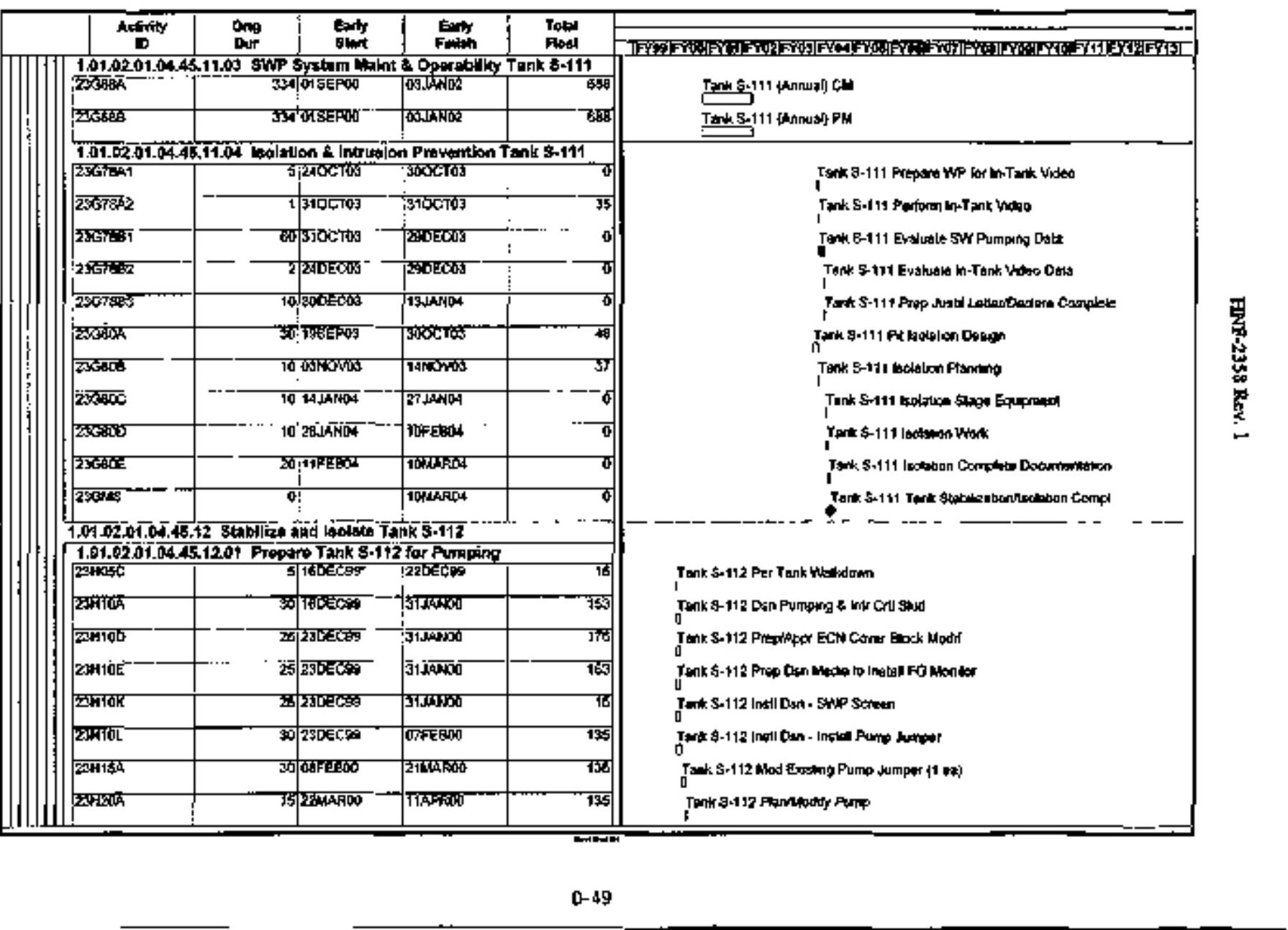




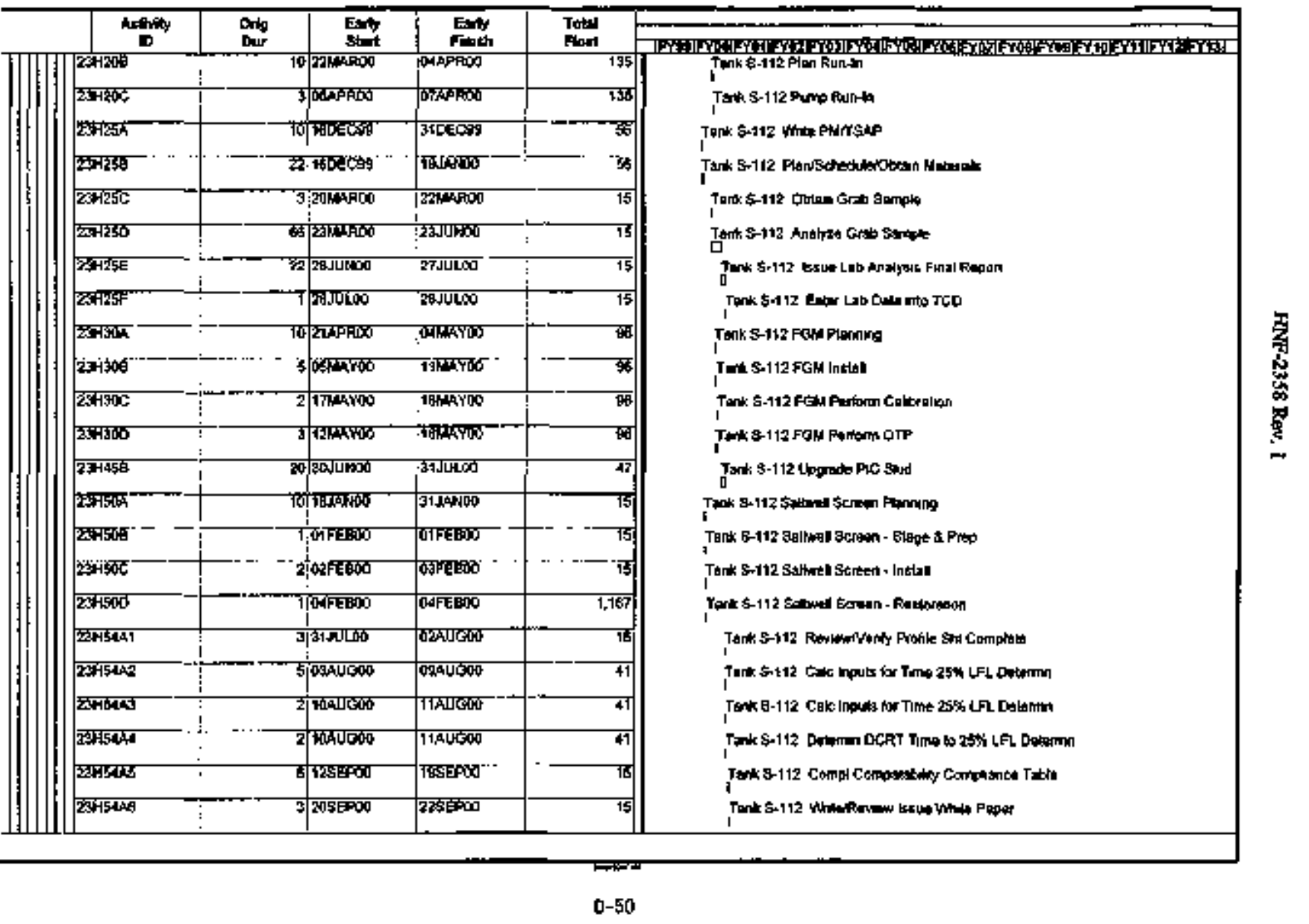




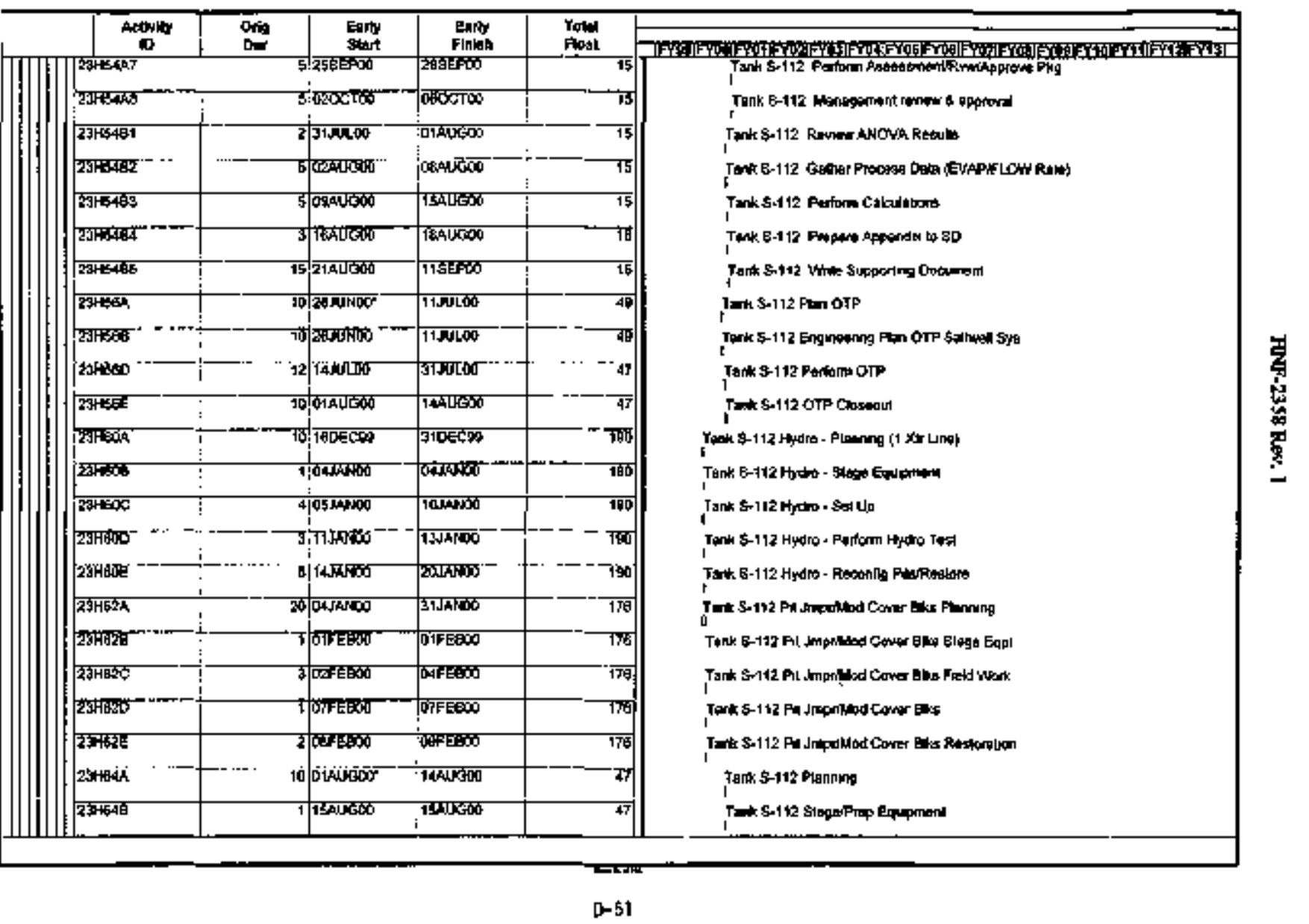




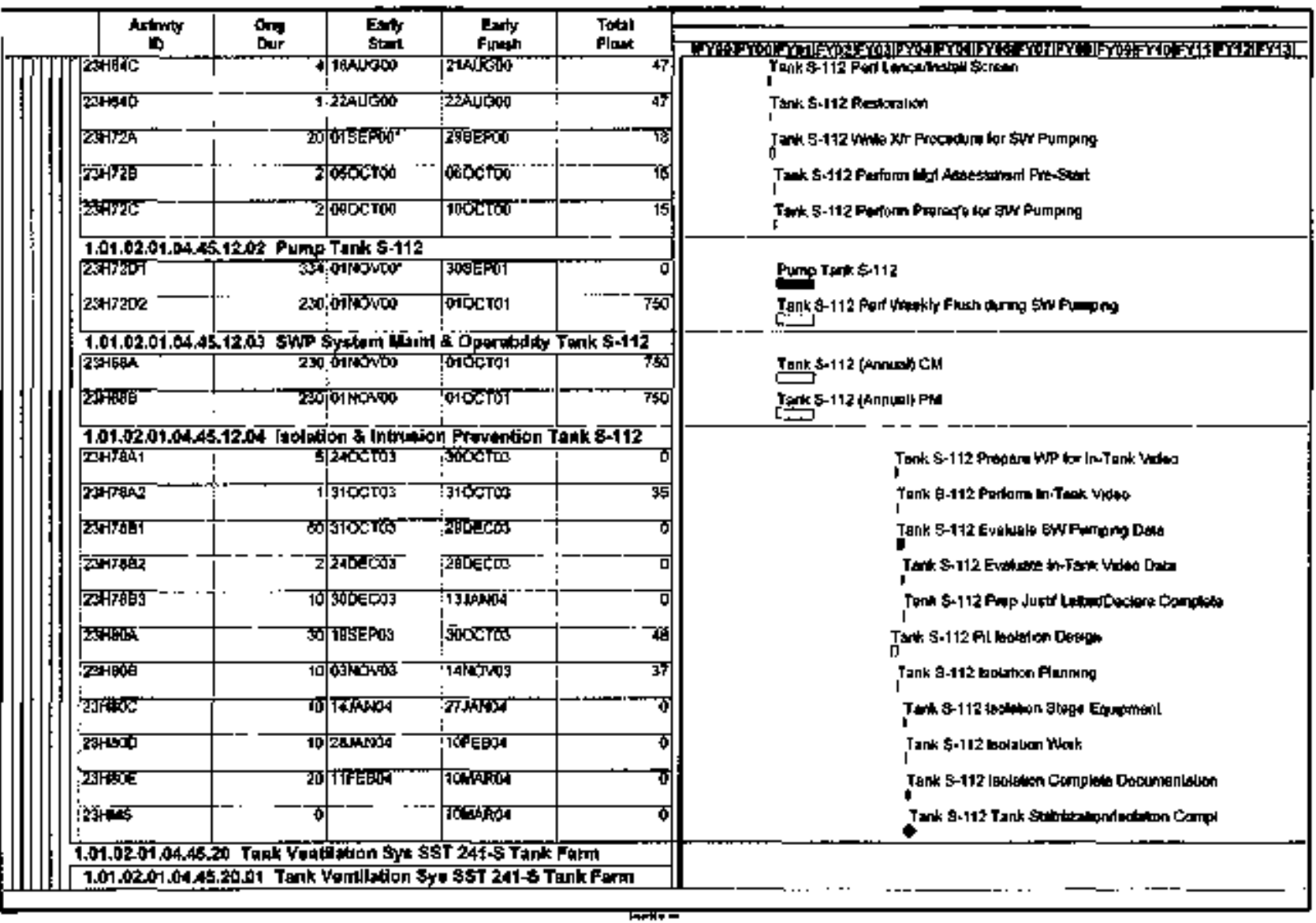




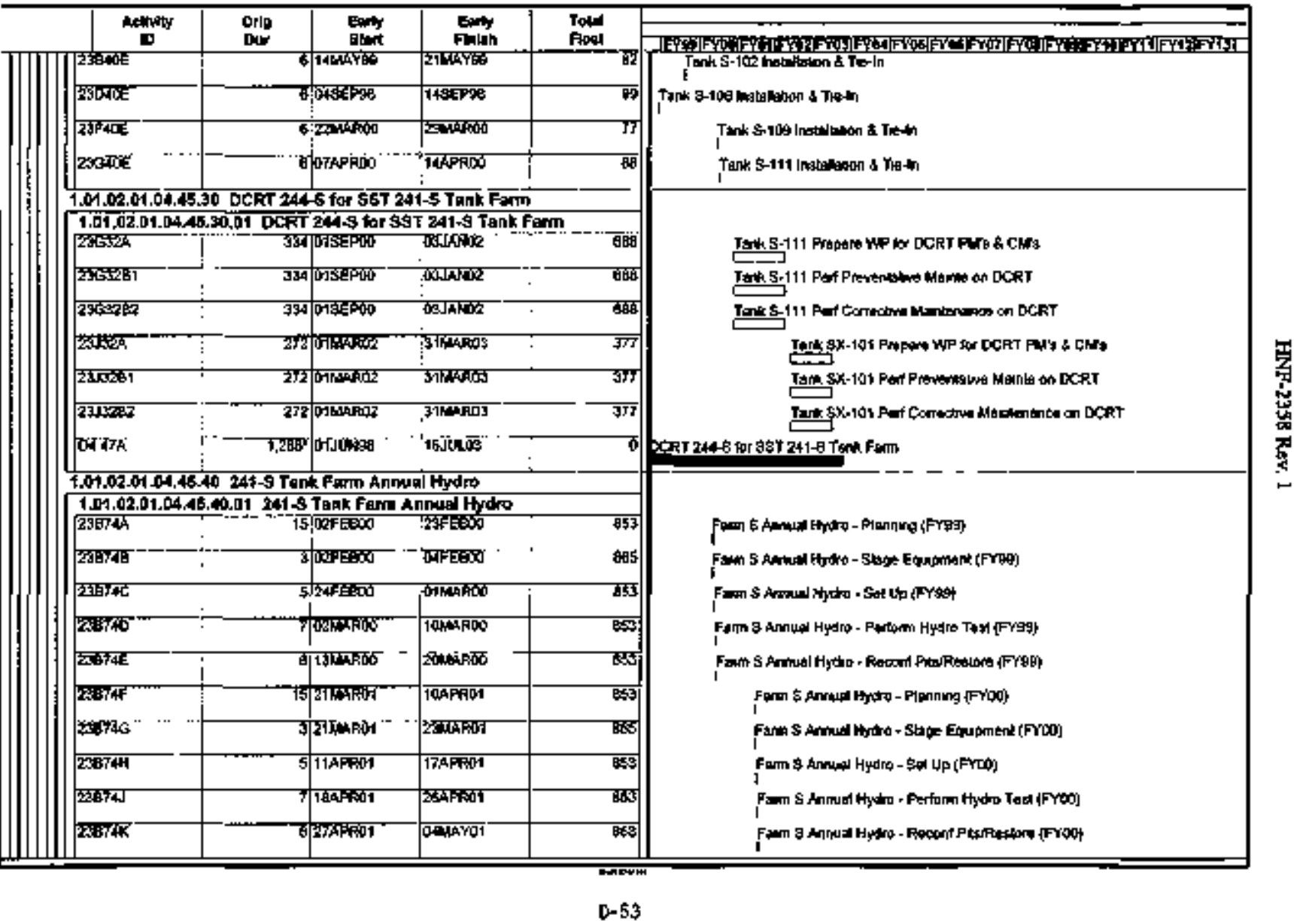




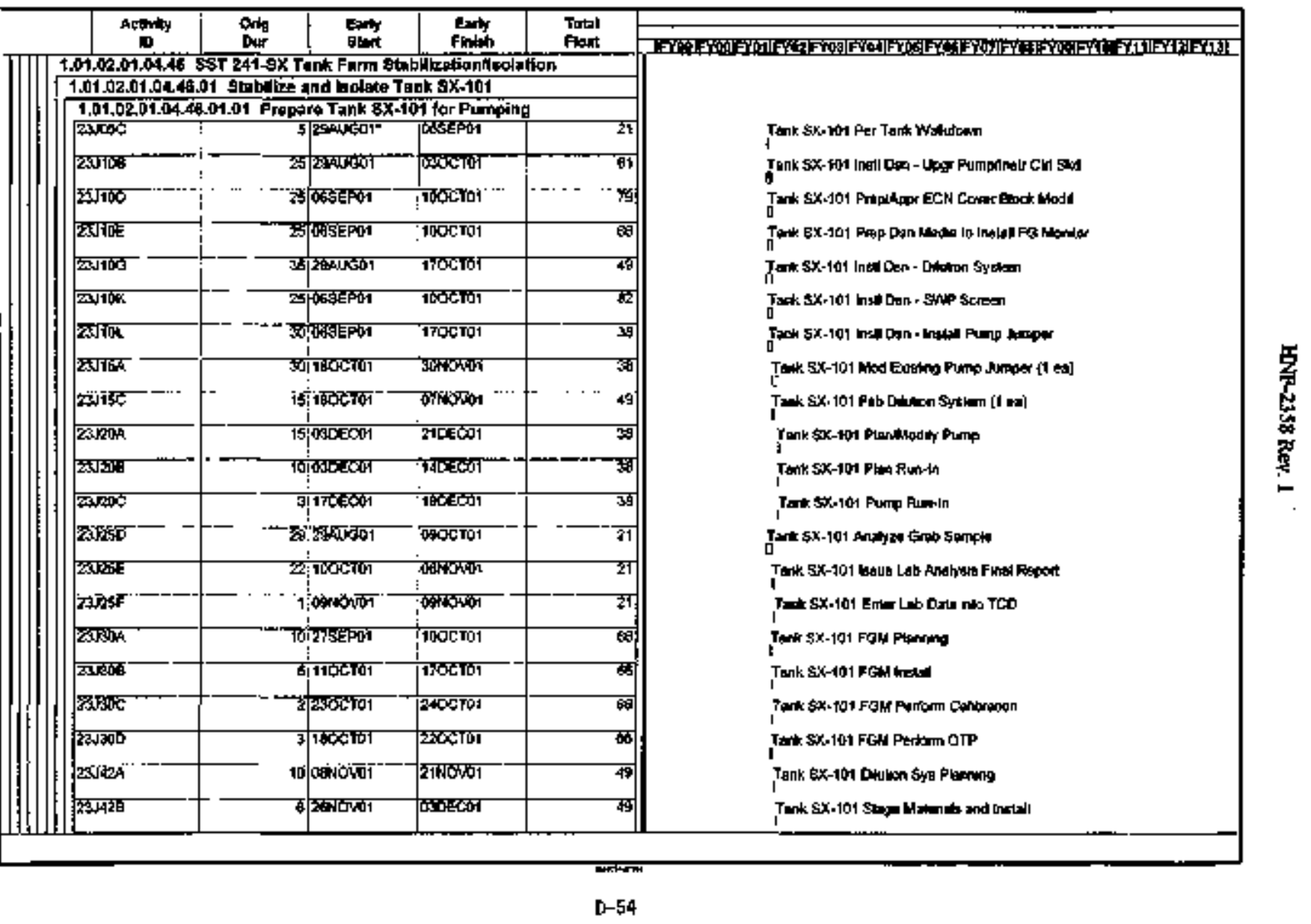




\begin{tabular}{|c|c|c|c|c|c|}
\hline $\operatorname{lin}_{10}$ & On & Earty & Eminy & Tolet & 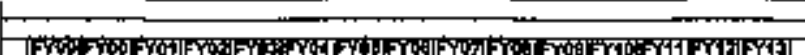 \\
\hline 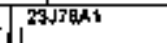 & & 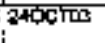 & 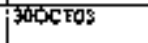 & D & 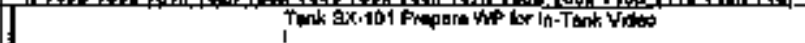 \\
\hline 23] & & उद्वर्य & $510 \mathrm{TEB}$ & 35 & 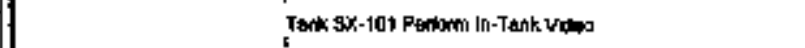 \\
\hline 25J7861 & & 9100T03 & zonges & 匀 & 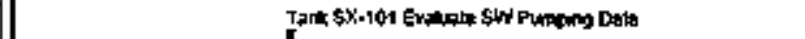 \\
\hline $23 \ln _{908} \cdots$ & & $2 \operatorname{AOCCCOS}$ & 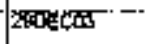 & 0 & 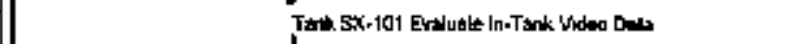 \\
\hline 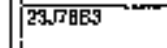 & T10 & अDECDO & 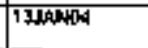 & D & 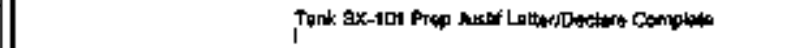 \\
\hline उसक & ॐ0 & 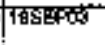 & 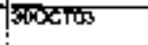 & ats & Tork 5x-101 Pk loxtsoon Design \\
\hline 23, & $\overline{T D}$ & 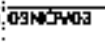 & 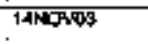 & 37 & 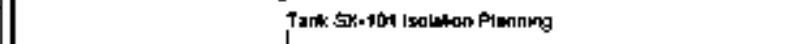 \\
\hline 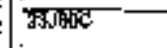 & & $14 \sin 104$ & 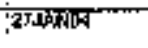 & 0 & 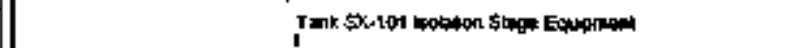 \\
\hline 2WEO & & 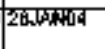 & 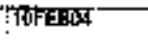 & 0 & Tron ax-101 kefoluon whorh \\
\hline 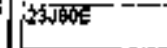 & 20 & 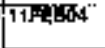 & 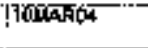 & 0 & 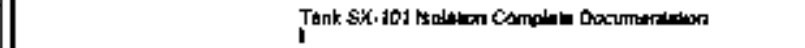 \\
\hline 23 WhS & & & 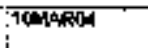 & 0 & 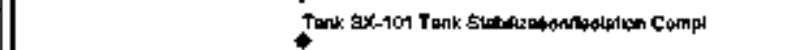 \\
\hline$\frac{1.01,0201.04 .4}{1.01 .02 .04 .04}$ & itabilizat & 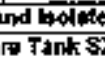 & 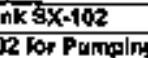 & & \\
\hline 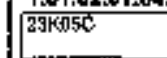 & & $10 \operatorname{sing} 1^{\circ}$ & is & 21 & $T_{1}^{T}$ and $5 x-102$ Por Tank Wakdoum \\
\hline 2ikikite & & 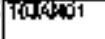 & 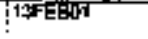 & intat & 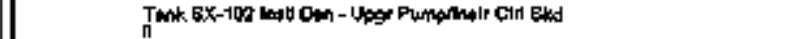 \\
\hline 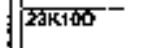 & 26 & Tनमसक & इTतEBOH & TाB & 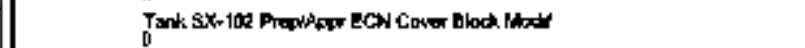 \\
\hline सअग्स & 25 & 17JAED 1 & 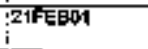 & 190 & 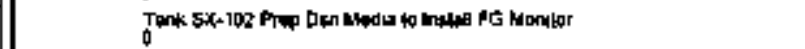 \\
\hline खारार्डs & 96 & Tिस्मान & TREBW & 762 & Tank 5x-100 had Den - Dwerken Sy blem \\
\hline 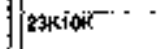 & 25 & TIJREBT1 & 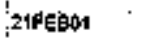 & & $T_{0}$ ank $S x-102$ last Dan + SWP Sann \\
\hline $28 K 10 L$ & 80 & 17JAKDT & 39FEEOT- & $1+1$ & 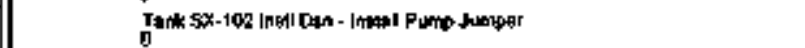 \\
\hline 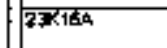 & $\mathbf{3 0}$ & काष्यमा & 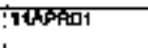 & कात्रा & 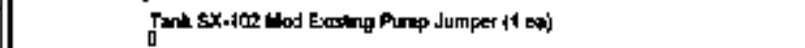 \\
\hline 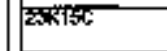 & & 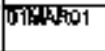 & सापरण & 13: & 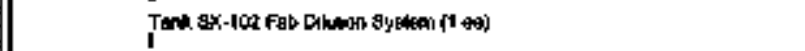 \\
\hline 25030 & & 12सPसD & 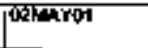 & 141 & 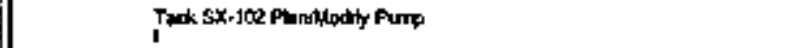 \\
\hline ZCKRIB $\cdots$ & 10 & 12A\%RD1 & 25मpस & $1+1\}$ & $\begin{array}{l}\text { Tork } 8 x-102 \text { Plan Rinth } \\
\text { I }\end{array}$ \\
\hline
\end{tabular}




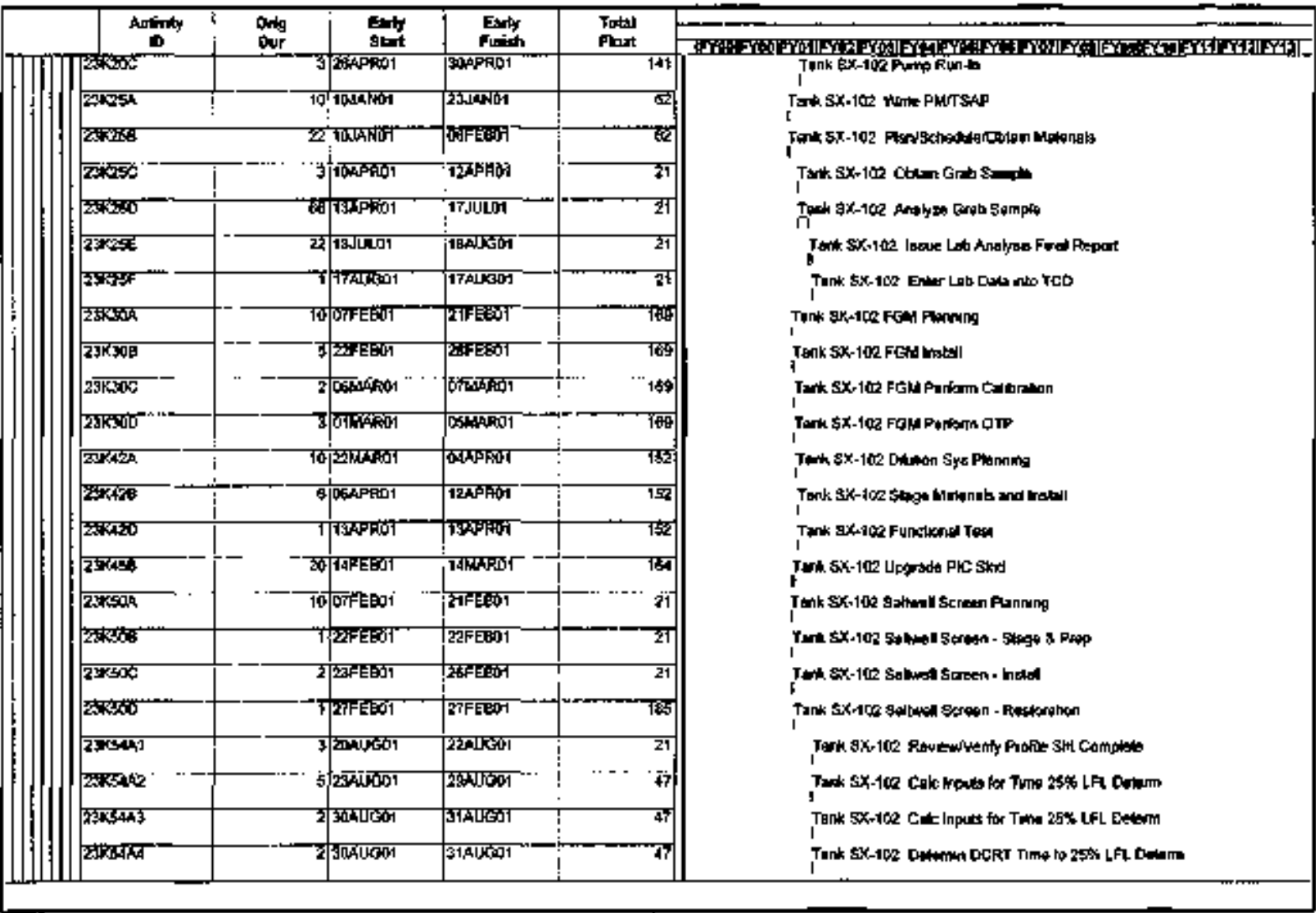




\begin{tabular}{|c|c|c|c|c|}
\hline Meffoth & \begin{tabular}{l|l} 
Orip & Euty \\
Dur & gitit \\
\end{tabular} & Eoty & $\begin{array}{l}\text { Tobㅂ } \\
\text { Post }\end{array}$ & 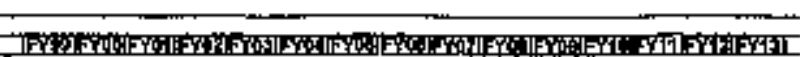 \\
\hline 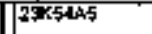 & 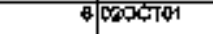 & 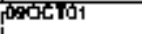 & 21 & 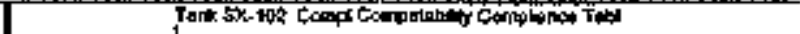 \\
\hline 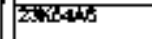 & 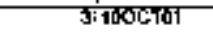 & 7200\% & 27 & 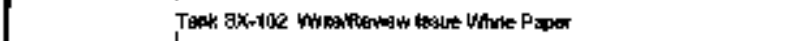 \\
\hline 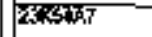 & 5'15OCOTO1 & 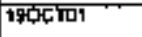 & 71 & 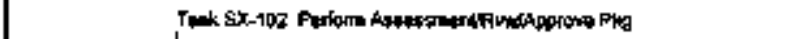 \\
\hline ZForida & 5 2100TU1 & 12BOCTO1 & 27 & 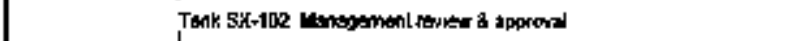 \\
\hline 2SW5 & 2 एक्याओ & 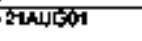 & 21 & 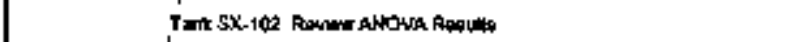 \\
\hline 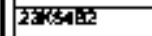 & उस्समझ & समाहुज & 27 & 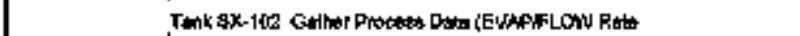 \\
\hline 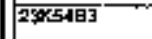 & 5 ख्समझन & DESEFO1 & 21 & Tonk Sx-102 Purdorm talcutions \\
\hline 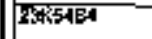 & \$क्OSEPO1 & TRSEPO1 & 27 & 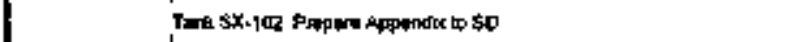 \\
\hline 28KKSAE5 & 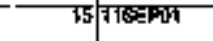 & proctor & & 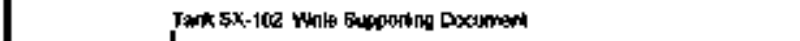 \\
\hline 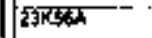 & 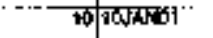 & 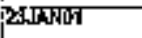 & Tक् & Tonk SX-102 Pt- OTP \\
\hline $29 \mathrm{k}$ 的 & 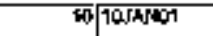 & 23LANO & 187 & 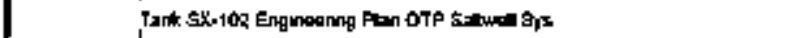 \\
\hline $230 B 0$ & 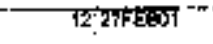 & 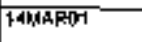 & a) & 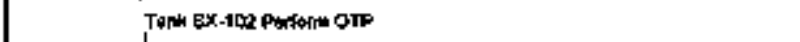 \\
\hline 25TSGEE & 10. 17APAD & ऊDRFAT & 141 & Tonk SX-102 OTP Crooeout \\
\hline 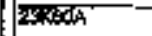 & 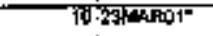 & 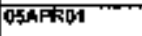 & 145 & 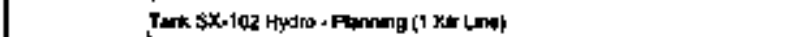 \\
\hline $25 \times 3 D_{13}$ & 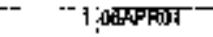 & 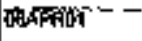 & 1ब5 & 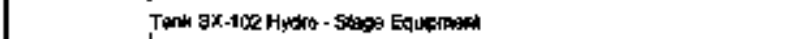 \\
\hline 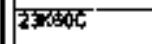 & 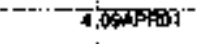 & 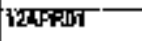 & 145 & Tark 5X-102 Hydro. Sen lop \\
\hline $25 \times 600$ & S:07RAYM & करागAYप & 128 & 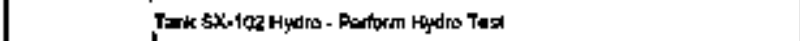 \\
\hline 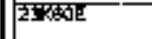 & 3!'TसEसTH & 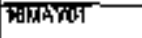 & $\sqrt{2}$ & 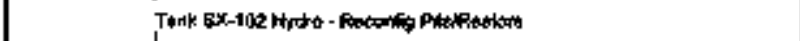 \\
\hline 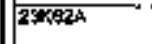 & 30:23APFAT" & छीTATEA & 1200 & 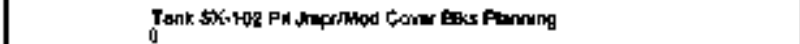 \\
\hline 25BRE & $1: 20$ KATW & 2Tात्रक्जिए & 120 & 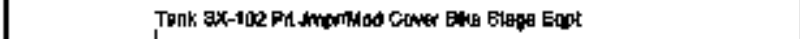 \\
\hline 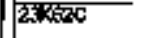 & $3,300 \mathrm{~m}$ rod & कीजाएक & 115 & 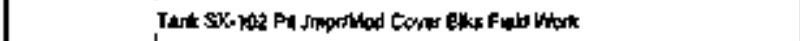 \\
\hline सROD & 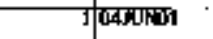 & oidisinai & $T$ & 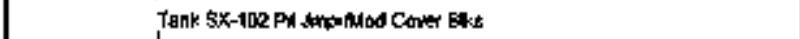 \\
\hline Z2W65E & 20500101 & DEThA & 115 & 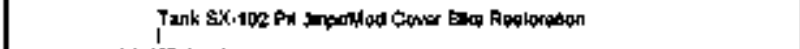 \\
\hline
\end{tabular}




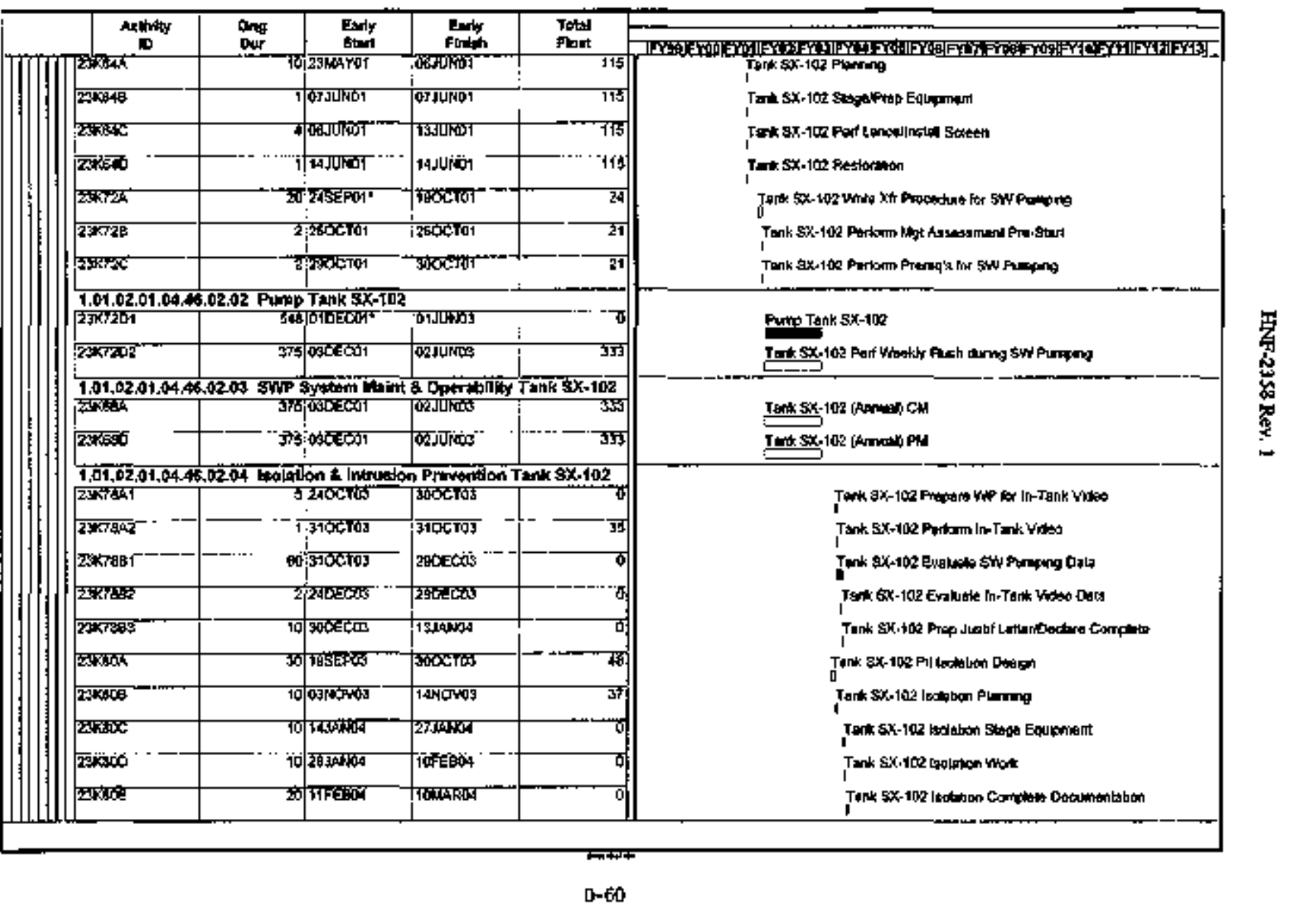




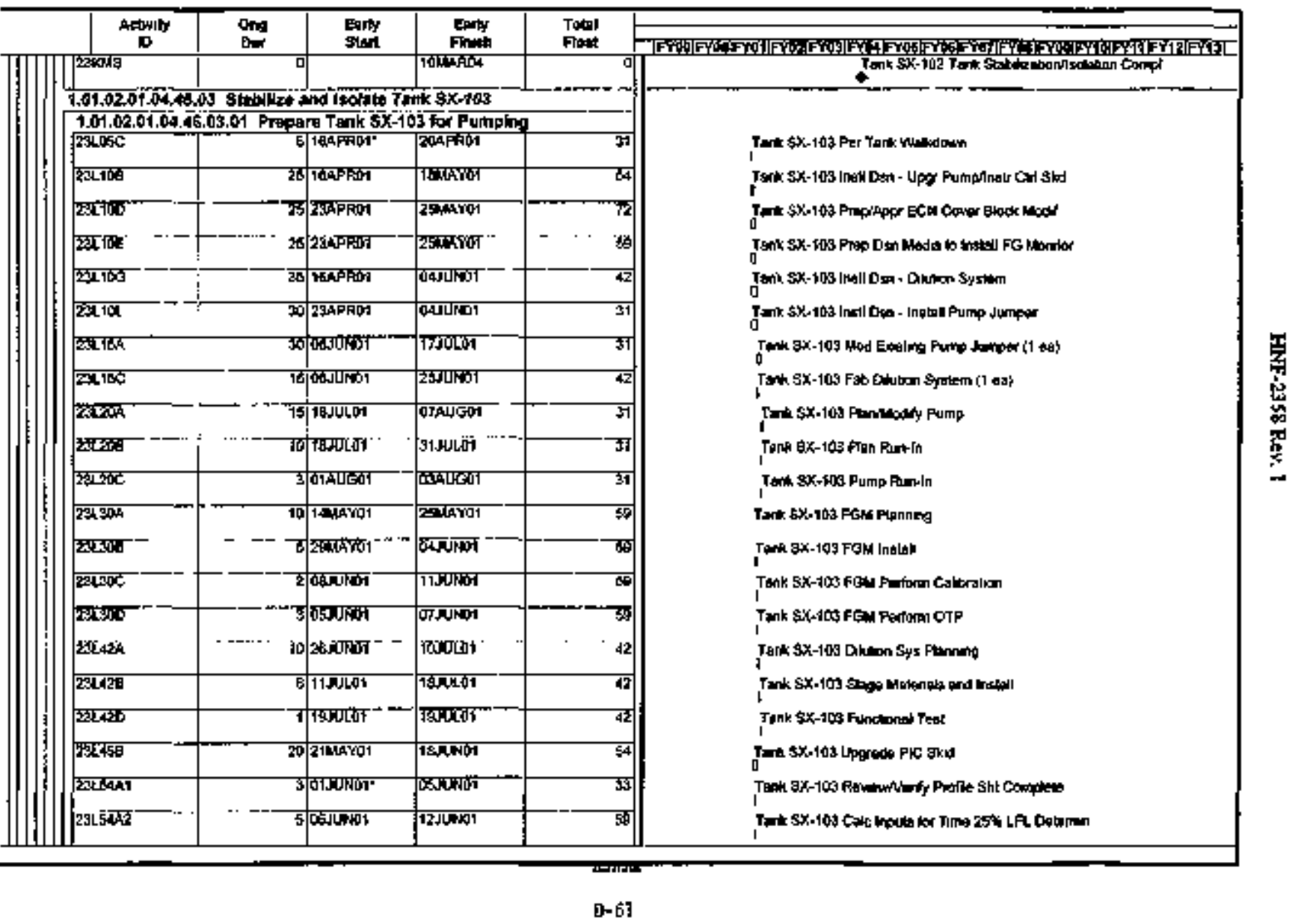




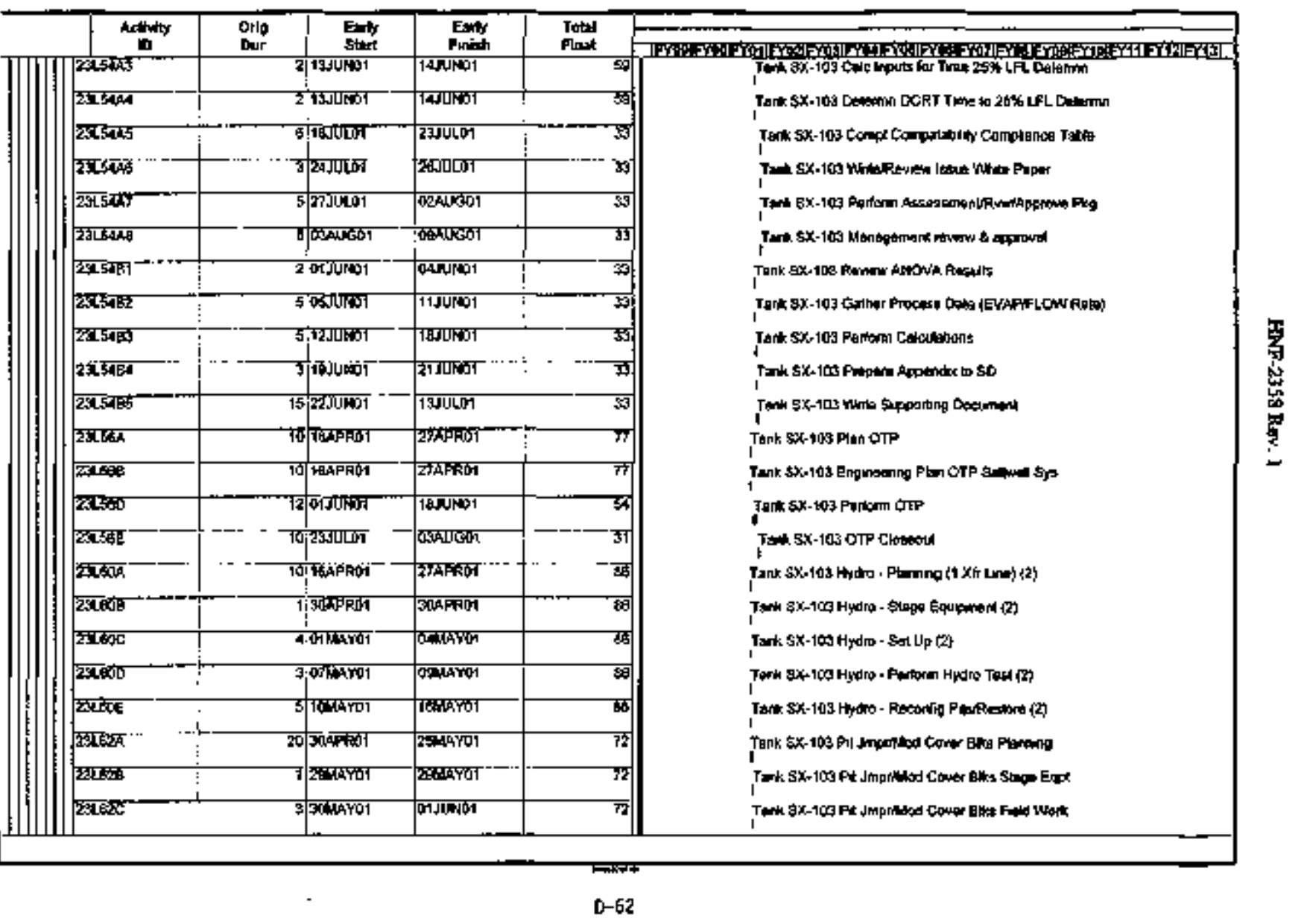




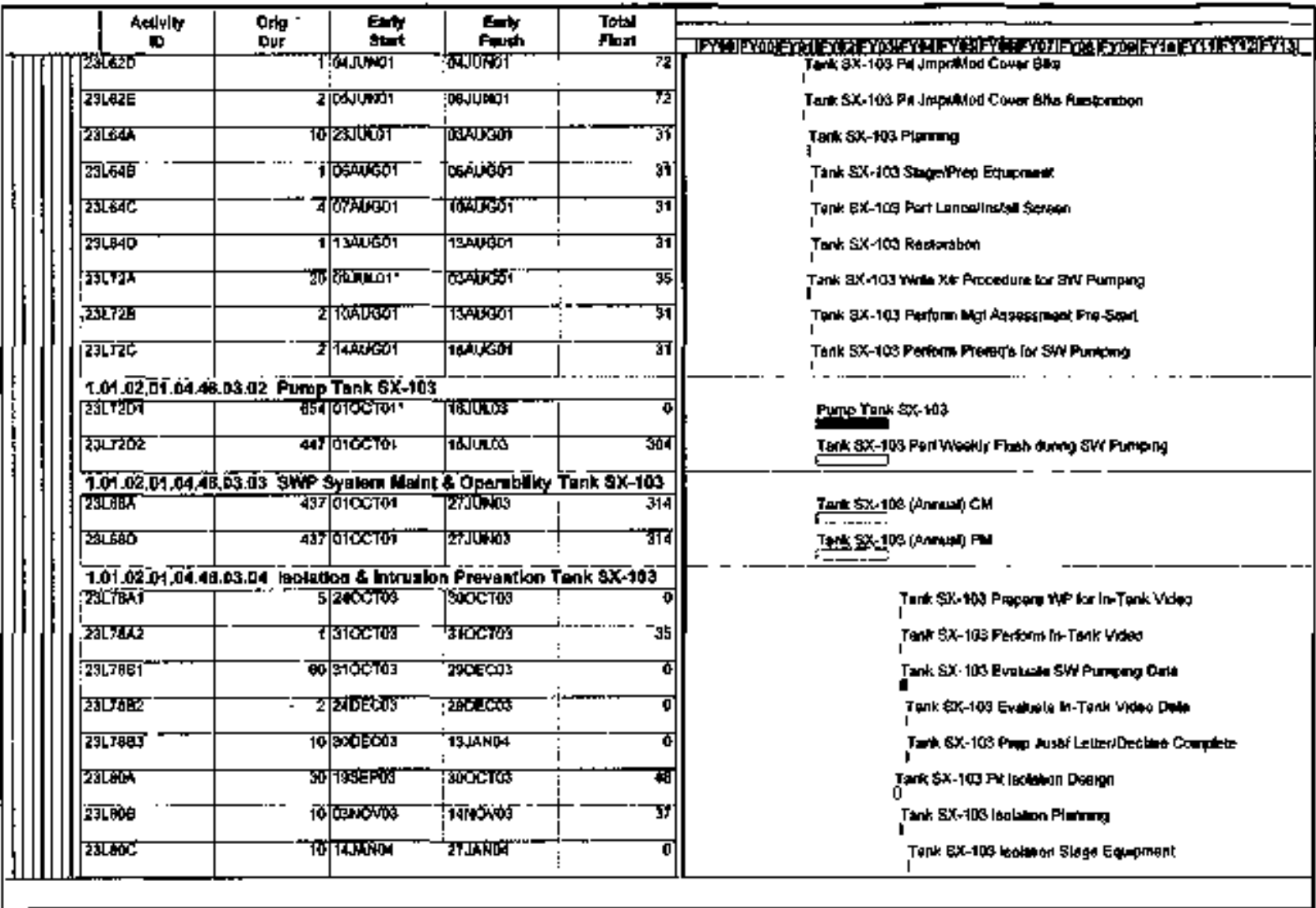




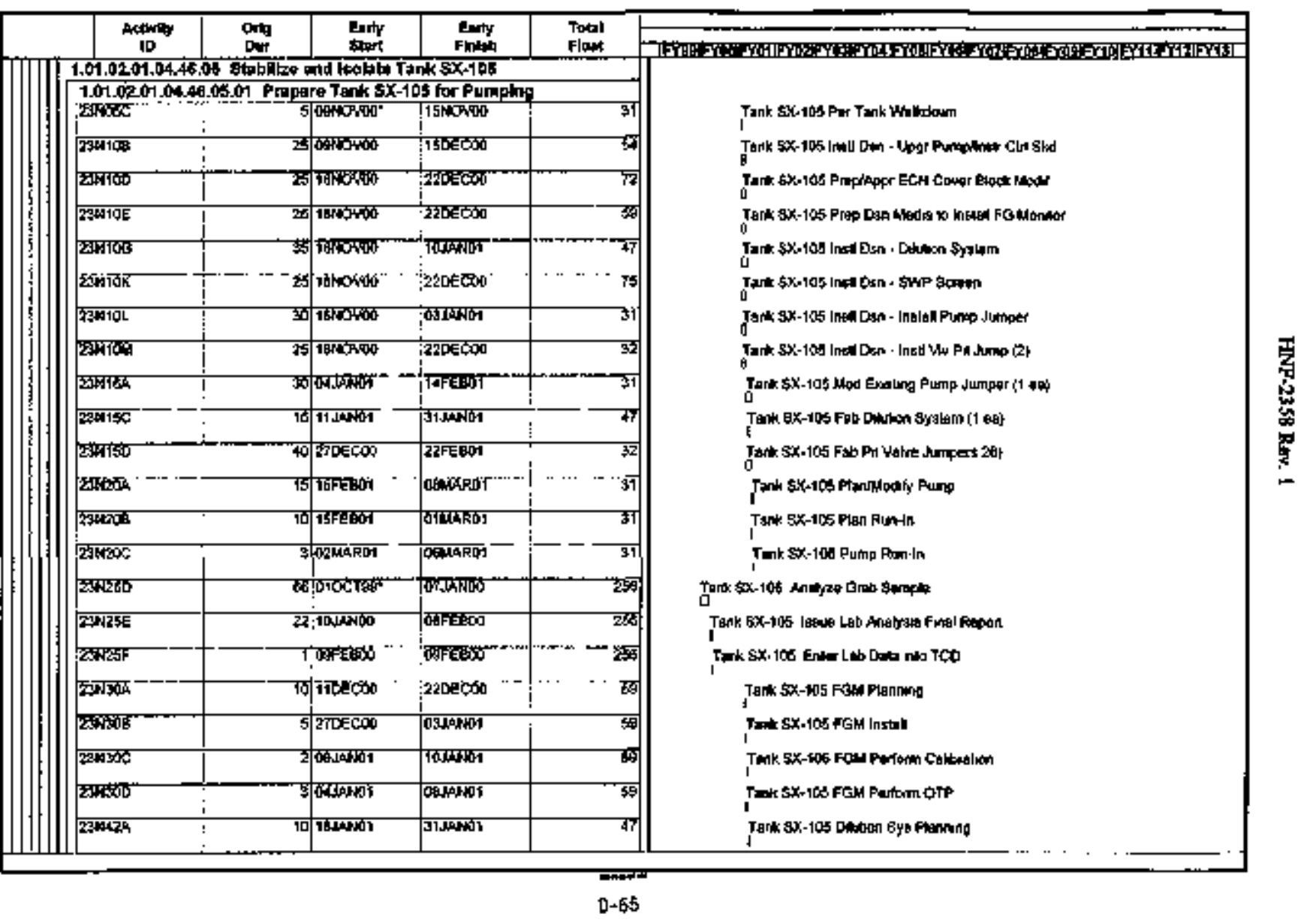




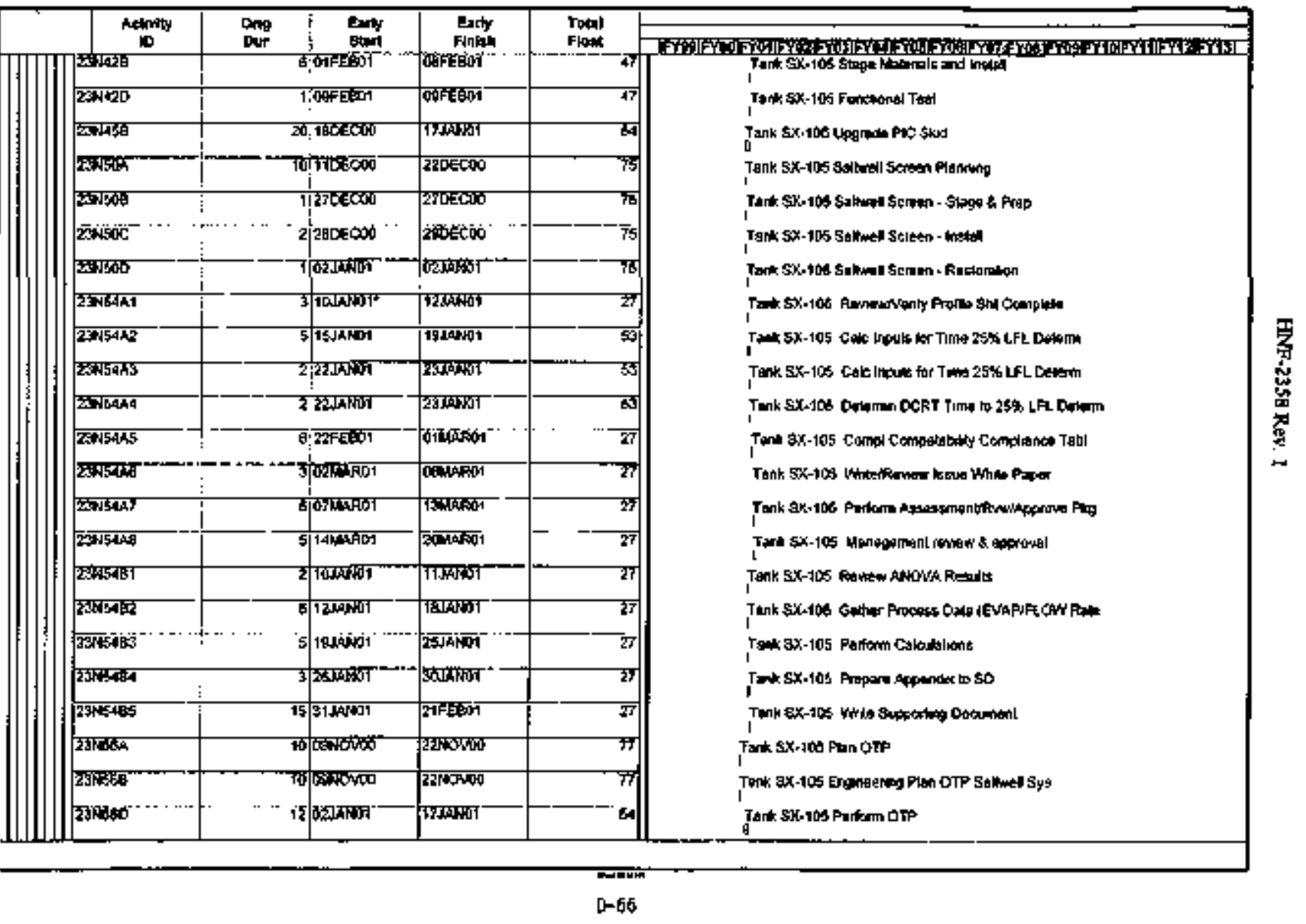




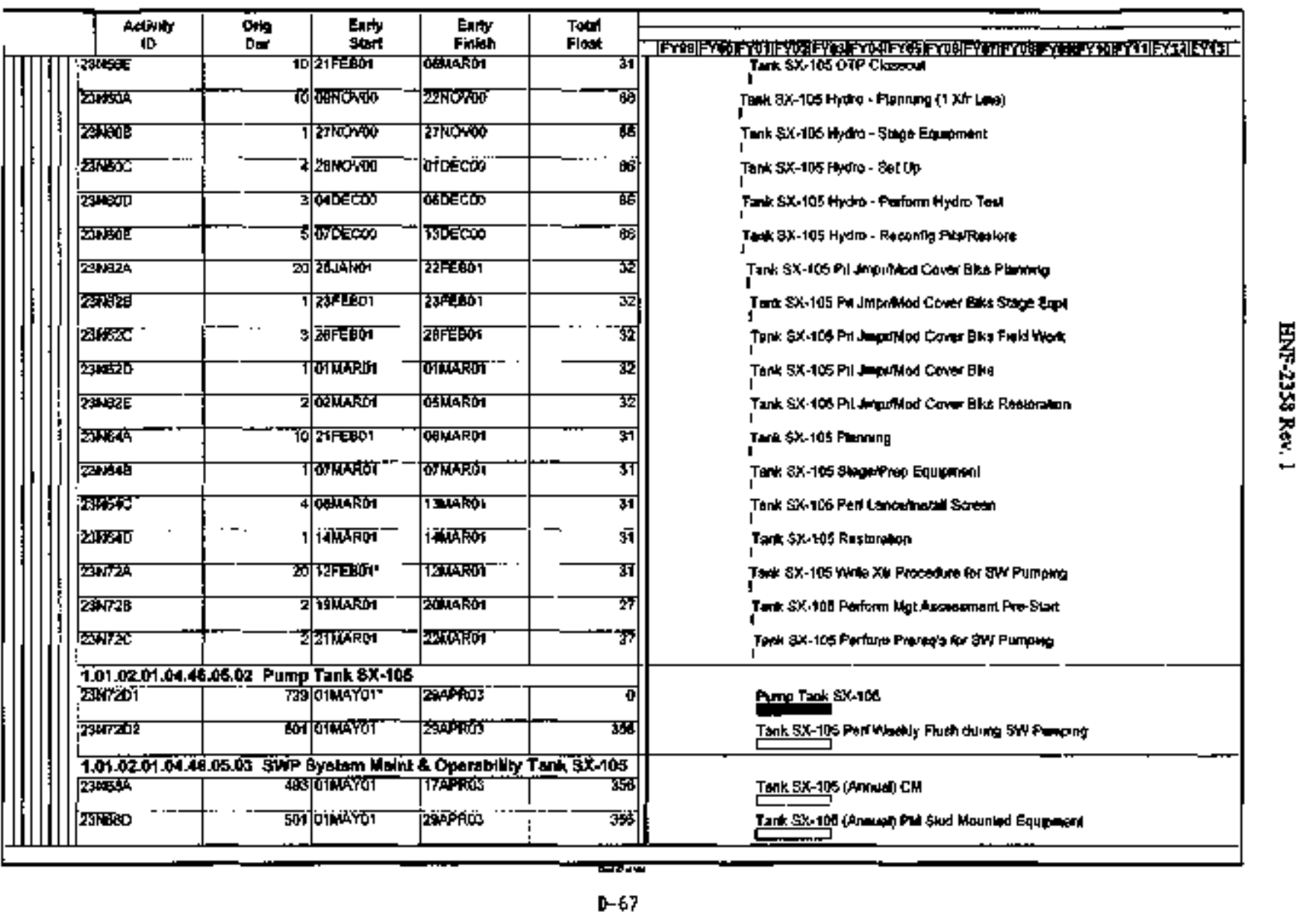




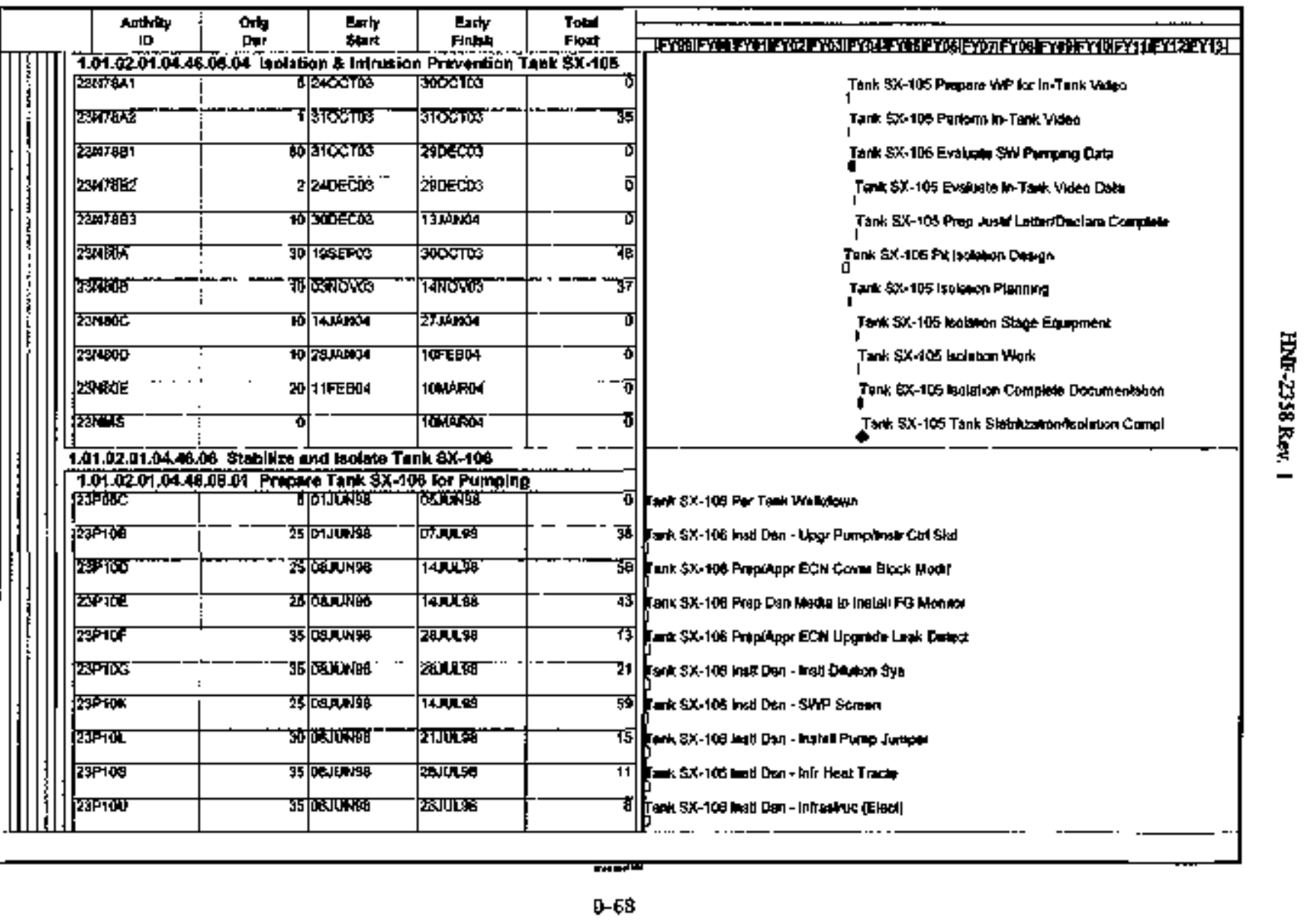




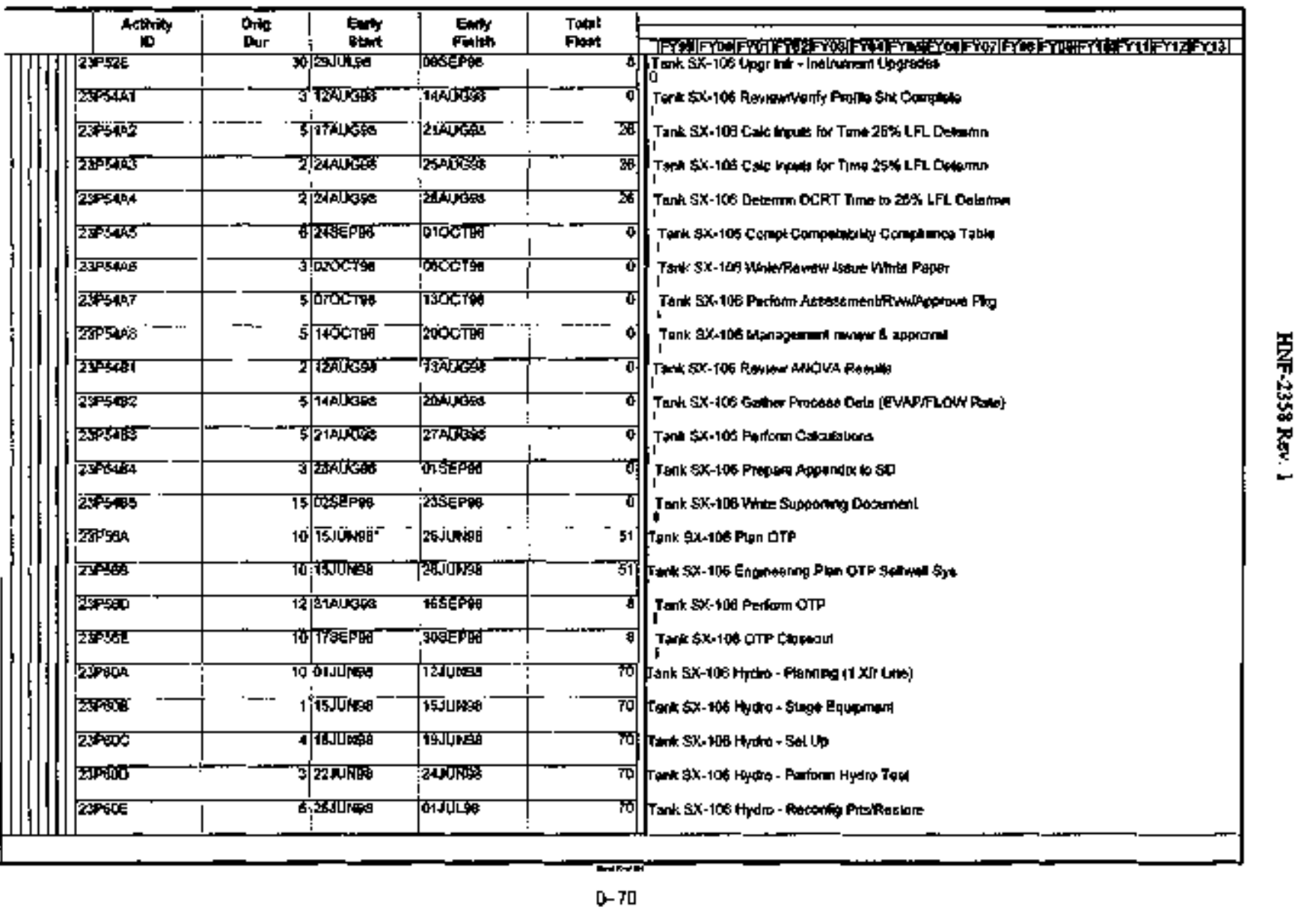




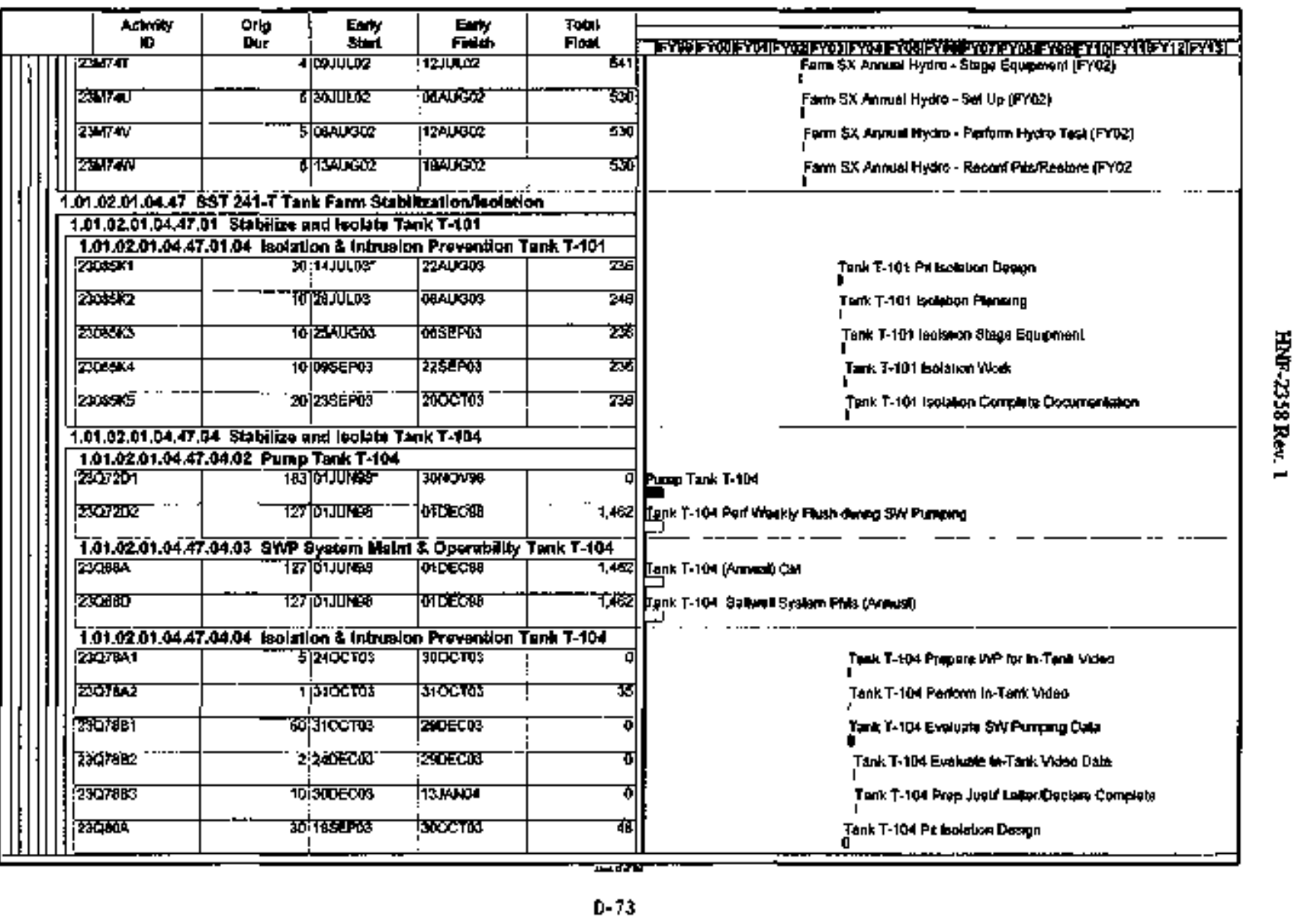




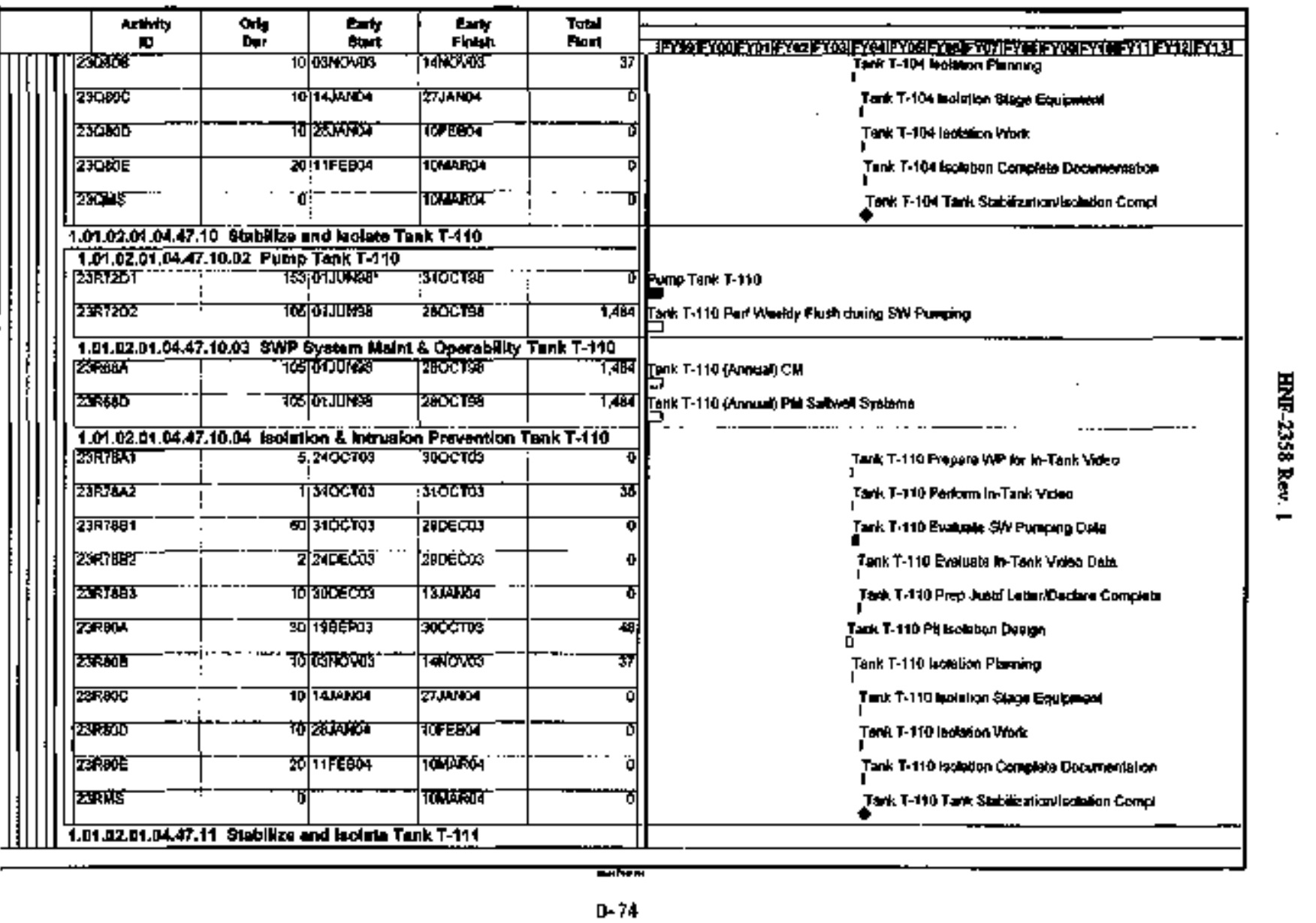




\begin{tabular}{|c|c|c|c|c|c|}
\hline Aetilly & Orlo & $\begin{array}{l}\text { Enty } \\
\text { Butst }\end{array}$ & Finty & $\begin{array}{l}\text { Tollel } \\
\text { Fhost }\end{array}$ & PY, \\
\hline 235304 & w & 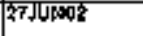 & $12 \mathrm{~d} d 0^{6}$ & \$9 & 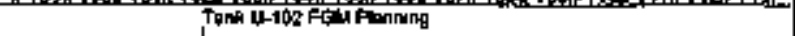 \\
\hline 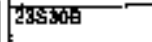 & & 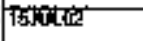 & 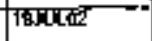 & 68 & 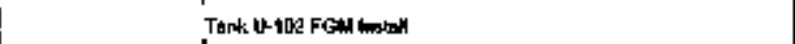 \\
\hline 23 & & 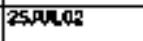 & 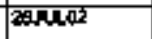 & 89 & 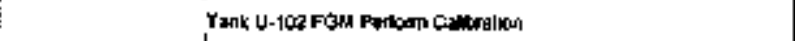 \\
\hline 238506 & I & 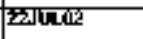 & 2400 & 6 & Itank U.102 FGA Pertmon OTP \\
\hline उुडबयद & 30 & 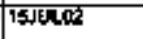 & 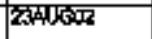 & 49 & 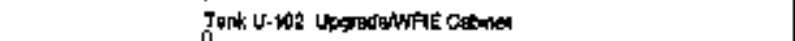 \\
\hline 23ESBa & T4 & 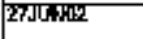 & 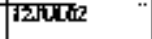 & \& & 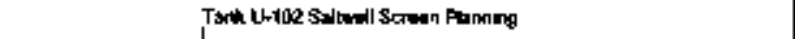 \\
\hline 295590 & & 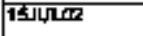 & 15ारिक्स & 鸟 & 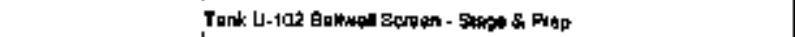 \\
\hline $29500 \mathrm{C}$ & 2 & 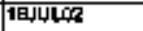 & $17+000$ & 85 & Tank L-192 gnkwed Forten - hatwl \\
\hline $2 \sqrt{2} \times 5$ & & सिखापद्ध & DEISTE & 85 & Twak U-108 Semwel Satten - Rastambon \\
\hline 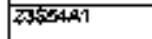 & 3 & 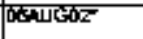 & Destuks & 30 & 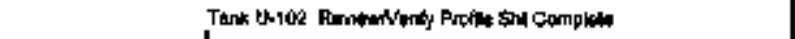 \\
\hline 2365 & & Fan: & 15मणूस & क्ष & 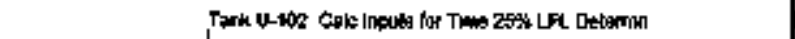 \\
\hline 238525 & $-\cdots$ & IEAUKi:C2 & 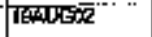 & 可 & 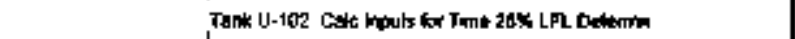 \\
\hline 235394 & 2 & 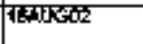 & ThatX2 & 栗 & 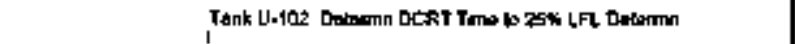 \\
\hline 2055405 & 5 & 1E्9EPW2 & 2 ESEPR2 & 30 & 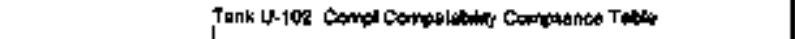 \\
\hline 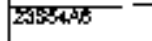 & & 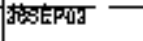 & SOSLFUT & 30 & Tank U-1Ce Winafievew lesue Whuta Puper \\
\hline 23\$34P7 & & DOTER & किण्फ़पद्स & 3 & 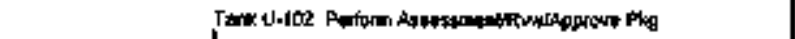 \\
\hline Z3SA+B & & PeOCFO2 & $140 \overline{\mathrm{C} T} \overline{\mathrm{g}}$ & क्र & 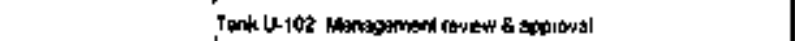 \\
\hline ZESCLIST & & DHALGLV & 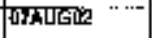 & 30 & 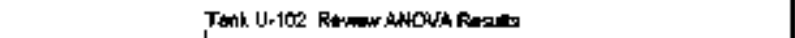 \\
\hline 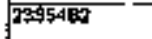 & 3) & 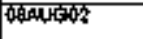 & 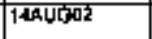 & $\$$ & 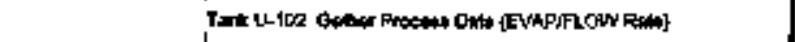 \\
\hline 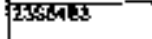 & & I5 & 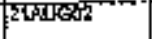 & का. & 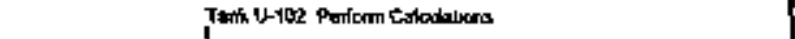 \\
\hline 2395484 & 可 & 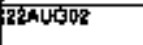 & ZRAUCFB & $\$ 0$ & 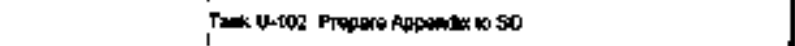 \\
\hline 2स364:65 & 15 & 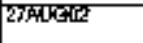 & 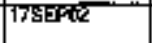 & 30 & 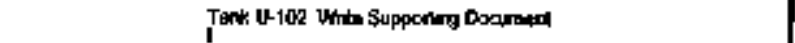 \\
\hline$\sqrt{23555 A}$ & का & 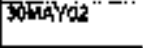 & 12Nunar & 67 & Tank U102 Plan OTP \\
\hline
\end{tabular}




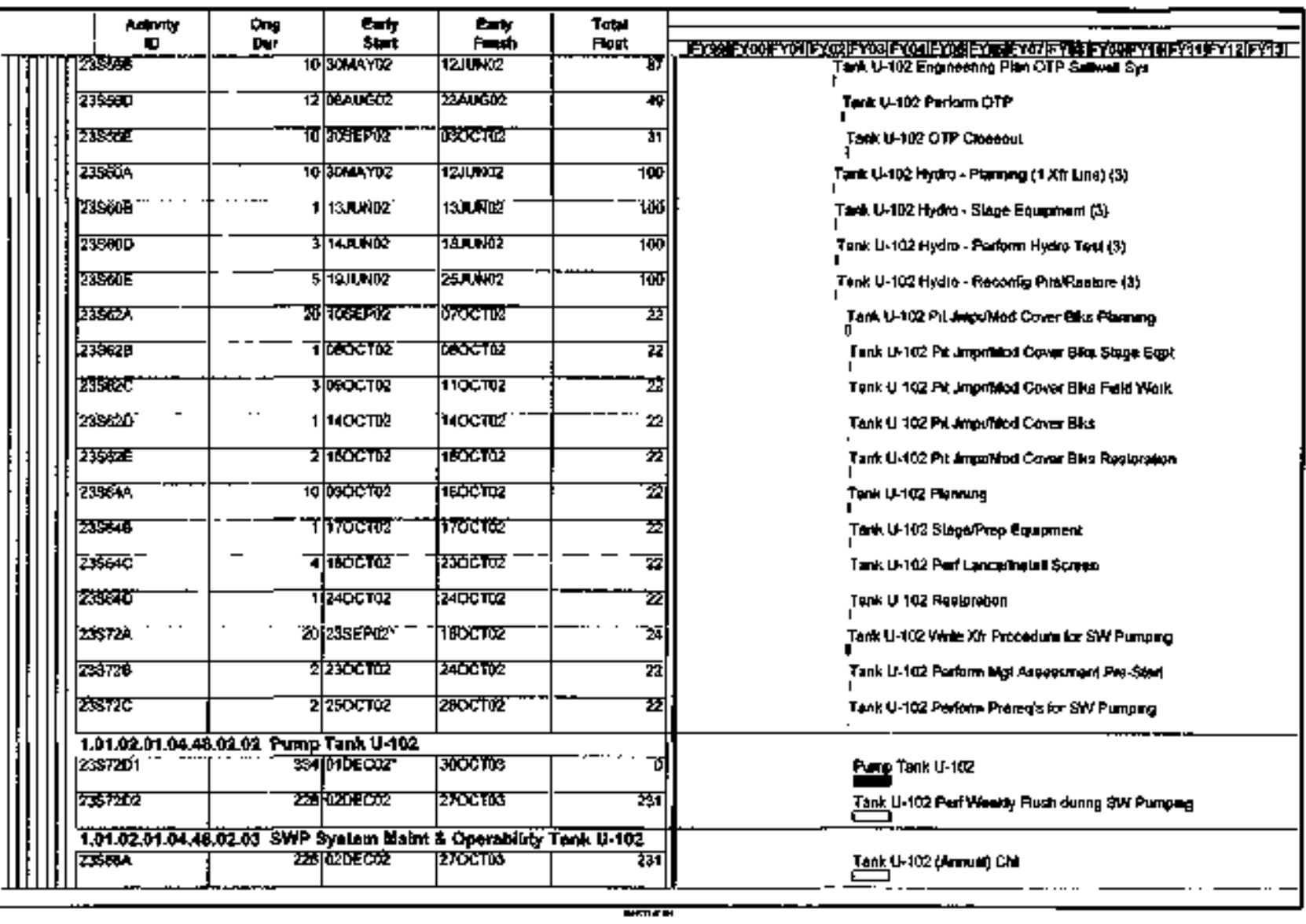




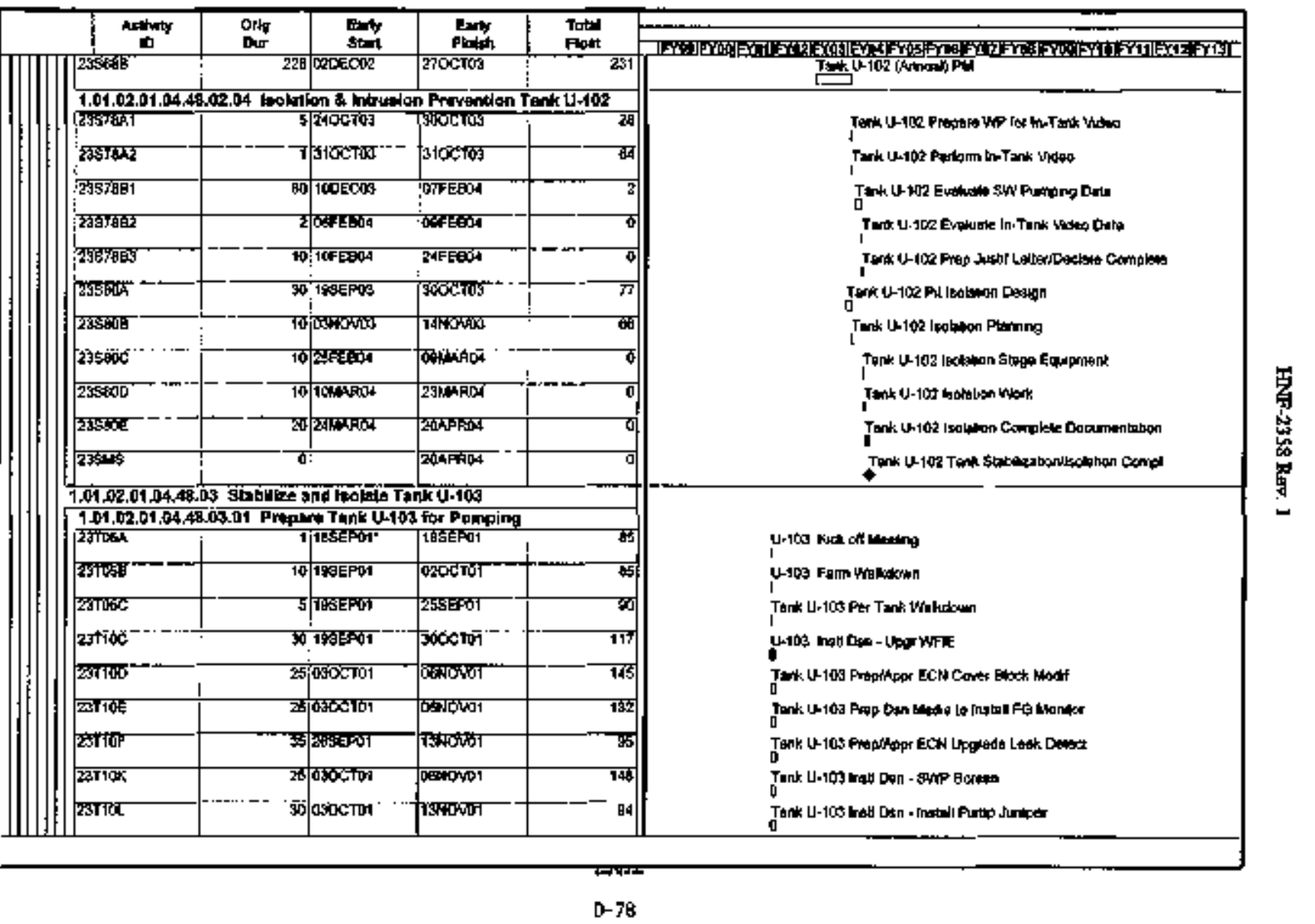




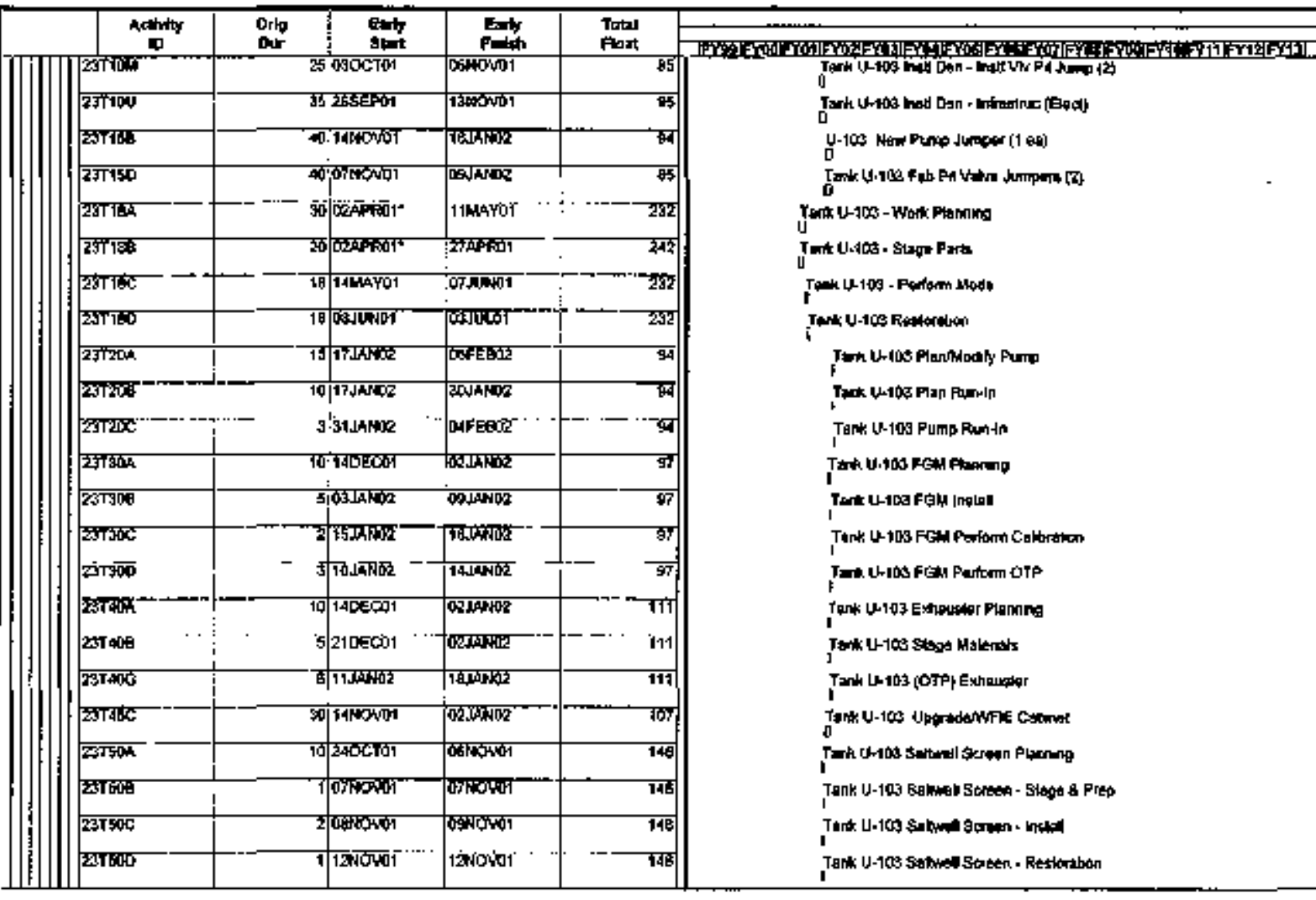




\begin{tabular}{|c|c|c|c|c|c|}
\hline D & Onip & $\begin{array}{l}\text { Enrly } \\
\text { stant }\end{array}$ & $\begin{array}{l}\text { Enrly } \\
\text { Finish }\end{array}$ & $\begin{array}{l}\text { Tolw } \\
\text { Flosil }\end{array}$ & 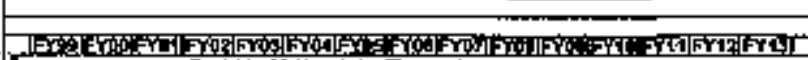 \\
\hline 53125 & 30 & 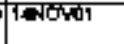 & 西和五 & 可) & 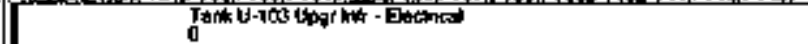 \\
\hline 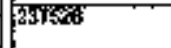 & 30 & 1400401 & 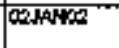 & 67 & 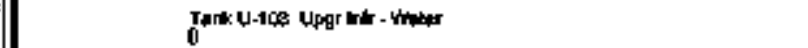 \\
\hline 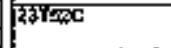 & 36 & 18 Nדים1 & 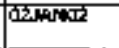 & क्5 & 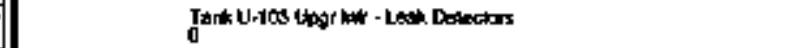 \\
\hline ESTS60 & 30 & Tarorif & $\sigma_{A} \omega_{2}$ & $8 \overline{7}$ & 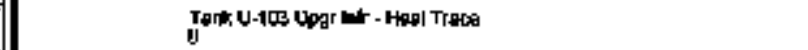 \\
\hline 33150 & 30 & 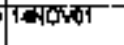 & 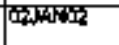 & क\$ & 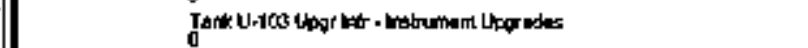 \\
\hline 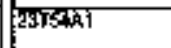 & 3 & O1MARER" & 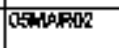 & प्रत्र & 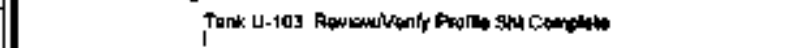 \\
\hline इसास्कार & of & DERSR & 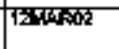 & की & 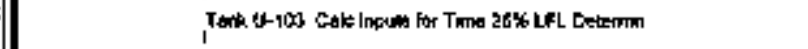 \\
\hline $23 \mathrm{TS4}$ & 3 & 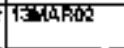 & 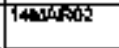 & 唫 & 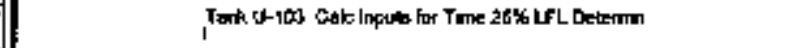 \\
\hline 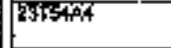 & 2 & 13 MAROZ & 1440,502 & क्ष & 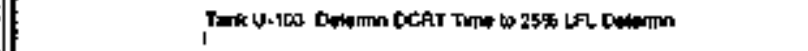 \\
\hline 28TSसES & 6 & $1200 \times 12$ & 180002 & उत्ब & 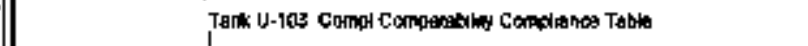 \\
\hline 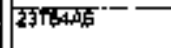 & 3 & 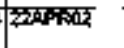 & 20Apin & 田 & 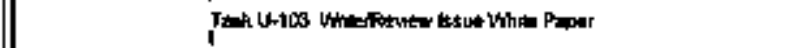 \\
\hline 2STSAA7 & 5 & 2saphos & DIFAYYK & 30 & 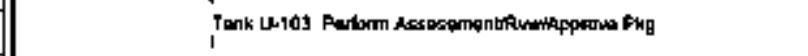 \\
\hline 28TLसक्ष & 析 & 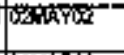 & 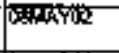 & ज्ञ & 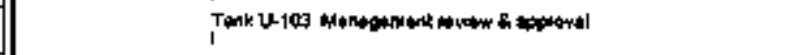 \\
\hline 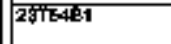 & 2 & D1새졈 & 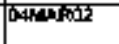 & 3a & 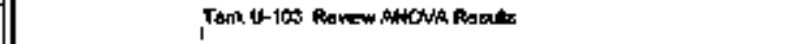 \\
\hline $23+5469$ & 5 & $F_{10} 60_{02}$ & 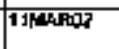 & $\because \quad 34$ & 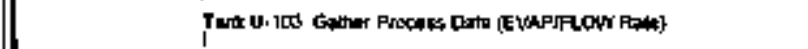 \\
\hline खTSAIB & 6 & TZRBRER & 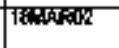 & उब्व & 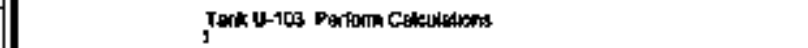 \\
\hline 25itsidi & 3 & 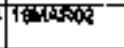 & ह1ग & $\cdots \cdot$ & T \\
\hline 235 & 15 & 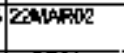 & 11APR 02 & उa & 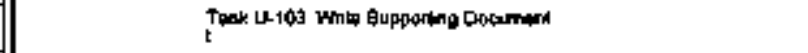 \\
\hline 2atrich & का & 140ECDA & 英W & 砫 & Tonk U-10s Pton OTP \\
\hline $2 \operatorname{sil}$ & 10 & 1+DECO1 & DaDANAR & 75 & 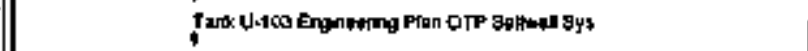 \\
\hline 2उफ़क & 12 & 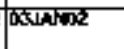 & IEIANDK & 串 & Tank U-109 Poform OTP \\
\hline 2गाहகE & 10 & रहाAाW & DMFí: & ज्ञ & T; \\
\hline 20 & वरा & 1SGEF & 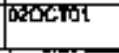 & 1क्ज & 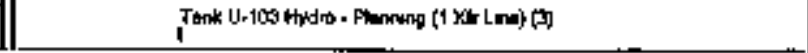 \\
\hline
\end{tabular}




\begin{tabular}{|c|c|c|c|c|c|}
\hline Acturtly & $\begin{array}{l}\text { Orls } \\
\text { Dur }\end{array}$ & Euty & Emb & $\begin{array}{l}\text { Totd } \\
\text { Fongl }\end{array}$ & 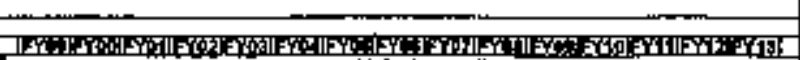 \\
\hline 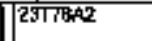 & & 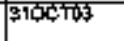 & 3नchos & 35 & 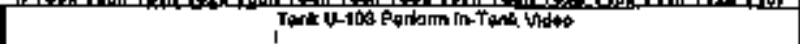 \\
\hline 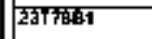 & w & 5TकC:ण & 2EOECOC & 아 & 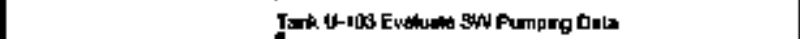 \\
\hline 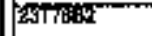 & 2 & $240500 \%$ & Exolats & 7 & 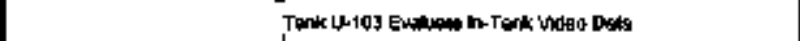 \\
\hline 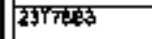 & 10 & 30OECDS & 1झ्साक4 & 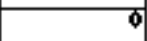 & Itank U-103 Prep Justr L \\
\hline $28 \pi 20$ & 30 & TSGEF & 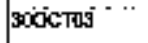 & 48 & 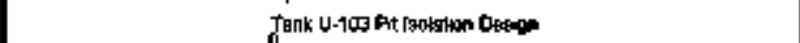 \\
\hline 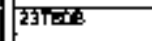 & 70 & 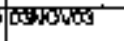 & 14मSNE & 37 & 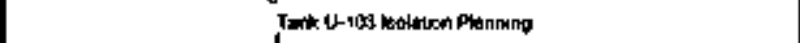 \\
\hline 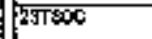 & $\overline{10}$ & $1+\sqrt{A 100 A}$ & 27 IANO4 & $\overline{0}$ & Yark U-103 | \\
\hline mexacos & w0 & ZSWAOA & 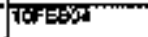 & 7 & 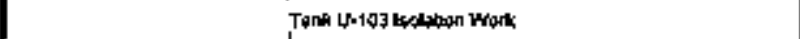 \\
\hline 203ró & 20 & PrFan & 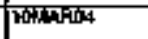 & t] & 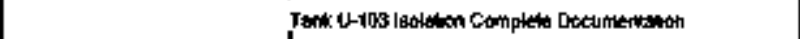 \\
\hline $29 \pi \mathrm{sis}$ & 0 & & HOPMADM & 0 & Tunk U.105 Tunk Stubleztentaplatron Compl \\
\hline 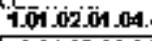 & inbles a & and loolate & a & · & $\cdot$ \\
\hline $1,01,02,01.04$ & DI Pr\$p & ThU & For Pumplng & & \\
\hline ALWक्ष & & Tणसजास & किलिएक & Af & Itatk W-W06 Per Tant Wokdtomn \\
\hline isuluc & & 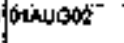 & $125 E P X Q$ & & 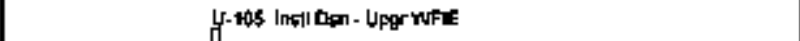 \\
\hline 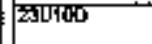 & & 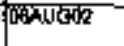 & 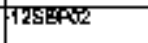 & 8 & 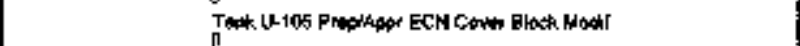 \\
\hline 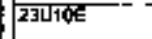 & 凹 & 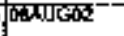 & 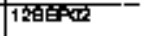 & & 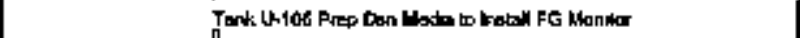 \\
\hline Zिएक & 7 & 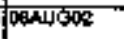 & $1285 x_{2}$ & 8 & 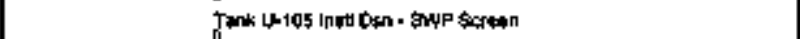 \\
\hline 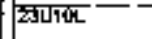 & (2) & 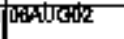 & TRESERT & 荞 & Tank U-105 Intb Dan - Inatal Pumb-Jumper \\
\hline सण1क्म & $\bar{s}$ & 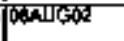 & $1296+0$ & a & 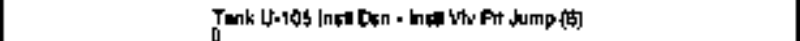 \\
\hline 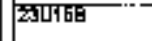 & 0 & 20s் & 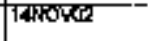 & \$2 & 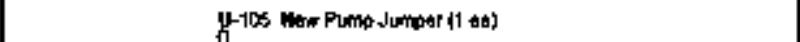 \\
\hline Z\$सम & 40 & Fुख & 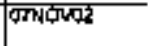 & 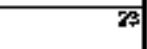 & 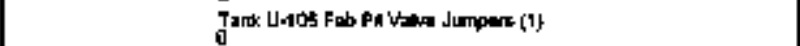 \\
\hline 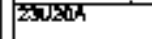 & 行 & T5Nơnd & Dotoscon & 32 & 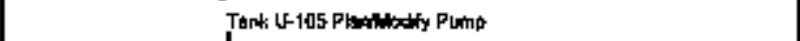 \\
\hline 230200 & Tा & 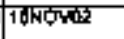 & 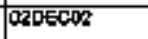 & \$ & 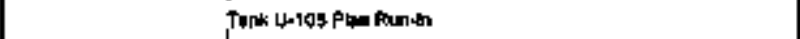 \\
\hline 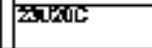 & & disotion & مOSEDIR & 32 & Tonth U-fos Pmom Runth \\
\hline
\end{tabular}




\begin{tabular}{|c|c|c|c|c|c|}
\hline Acthity & Orfor & enty & Elity & Toted & 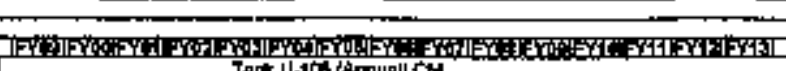 \\
\hline 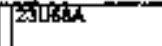 & "3. & QRAFEB & DAAPROA & 124 & Tant \\
\hline 270890 & 293 & प्रFFe & 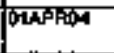 & 1200 & 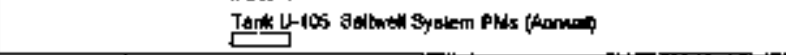 \\
\hline \multicolumn{5}{|c|}{ 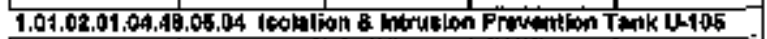 } & \multirow{21}{*}{ 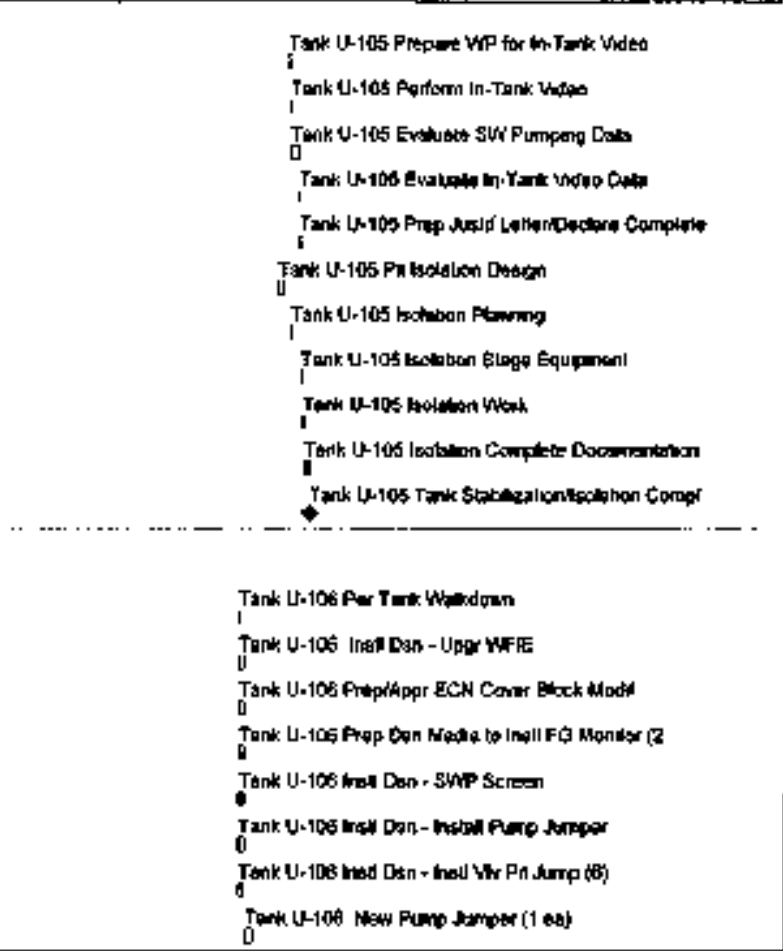 } \\
\hline 23UPBA1 & & $15+4 Y^{2} 4$ & TITRT04 & -i] & \\
\hline ZुDTER2 & & 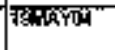 & 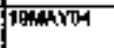 & 鶝 & \\
\hline 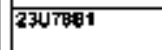 & 60 & 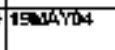 & 17 गएक & 2 & \\
\hline 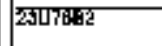 & & IETCW & 19VULA & 0 & \\
\hline Z2MTE:S & Tर्ष & $200 \times$ & 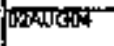 & $-\overline{0}$ & \\
\hline 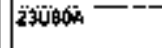 & 远 & 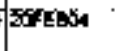 & for $A$ PPind & Ga & \\
\hline 2खणम0 & 10 & 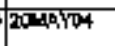 & कर्पुणक्य & 40 & \\
\hline 230toc & 格 & DSx- & 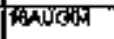 & $\overline{9}$ & \\
\hline अउपष्ठक & 16 & 17PADE & 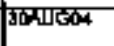 & 7 & \\
\hline स्वापर्र & 0 & & 26BSEXVA & - & \\
\hline \multirow{2}{*}{\multicolumn{5}{|c|}{ 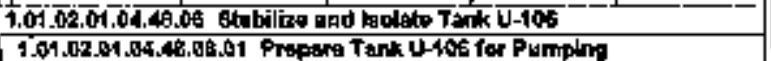 }} & \\
\hline & & & & & \\
\hline 2SWI5C & & OSTAPOS & bintarus & 27 & \\
\hline 3क्ज小 & $\begin{array}{ll}* & \cdot\end{array}$ & OXYMPES & 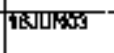 & 80 & \\
\hline 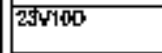 & 25 & 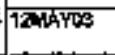 & 15 पस्सू & 83 & \\
\hline उद्वVOE & 20 & 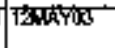 & [D: & 象 & \\
\hline $29410 \mathrm{~K}$ & 25 & 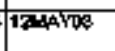 & 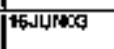 & $\overline{\theta 6}$ & \\
\hline 23016 & Sor & $1{ }^{2}{ }^{\prime}$ & 2खDणास & s? & \\
\hline क्जिय & D & 124AYD3 & 16 p) 103 & स] & \\
\hline 2ड़जयद & 40 & 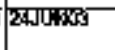 & 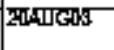 & $\bar{z}$ & \\
\hline
\end{tabular}




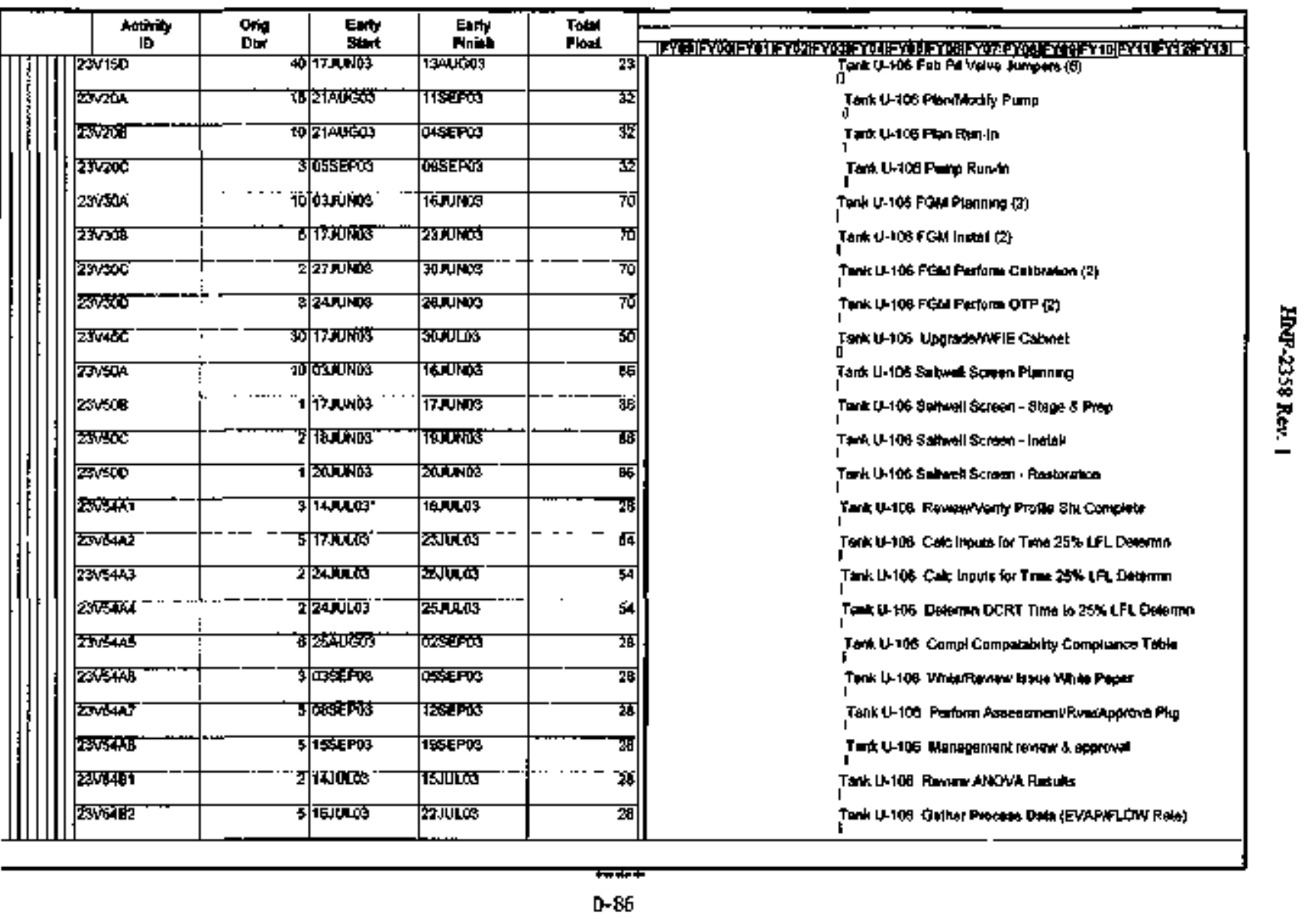




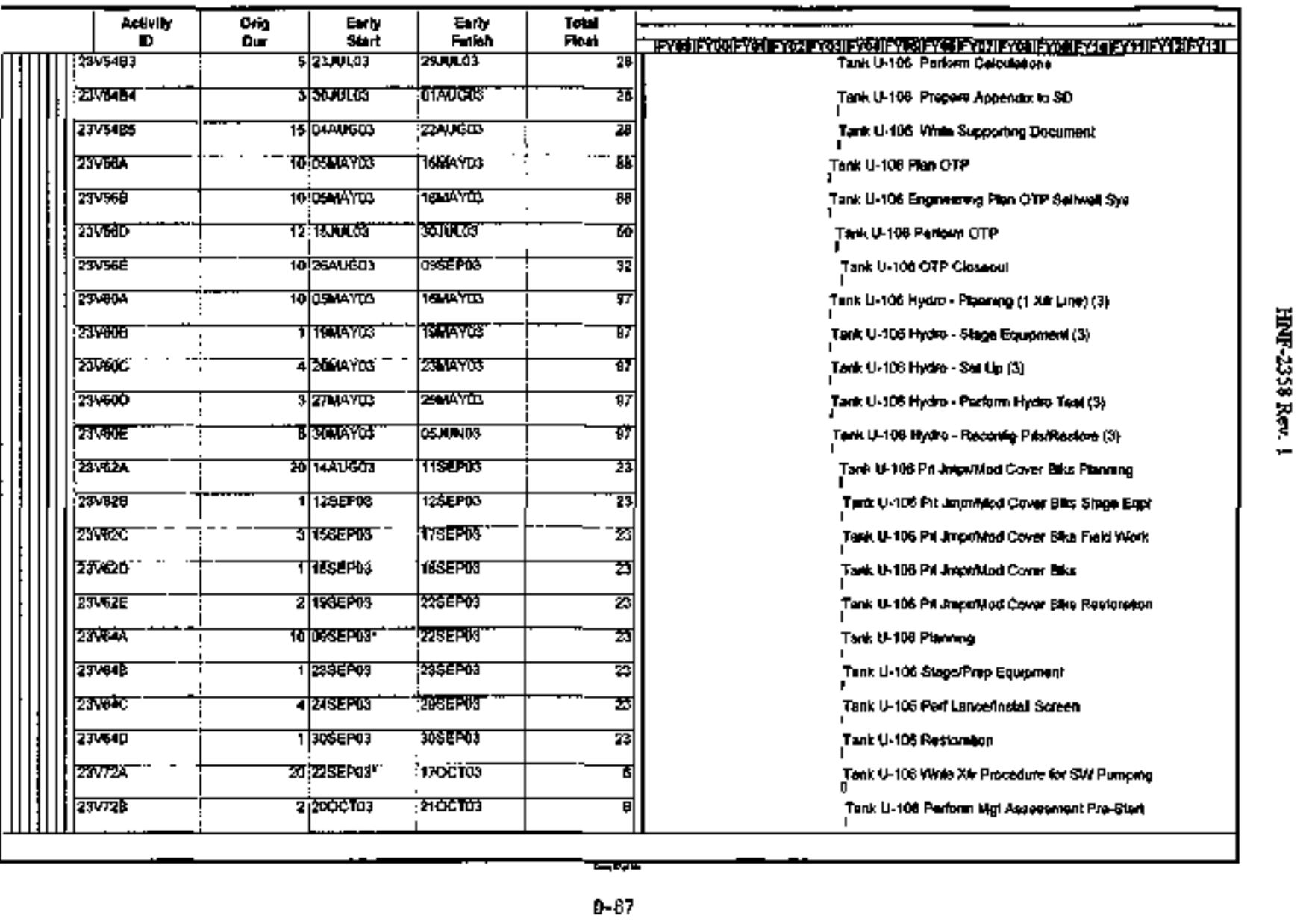




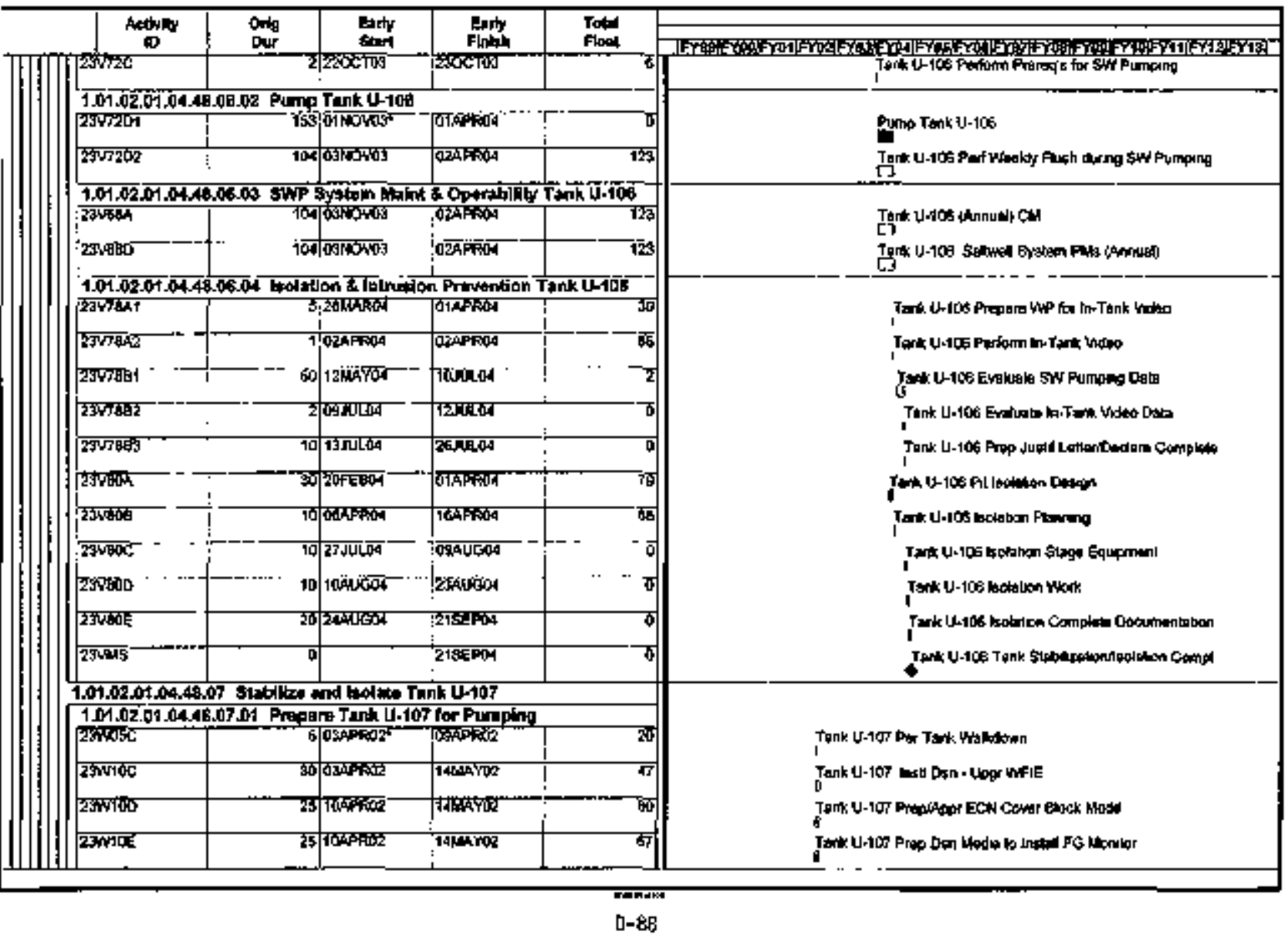




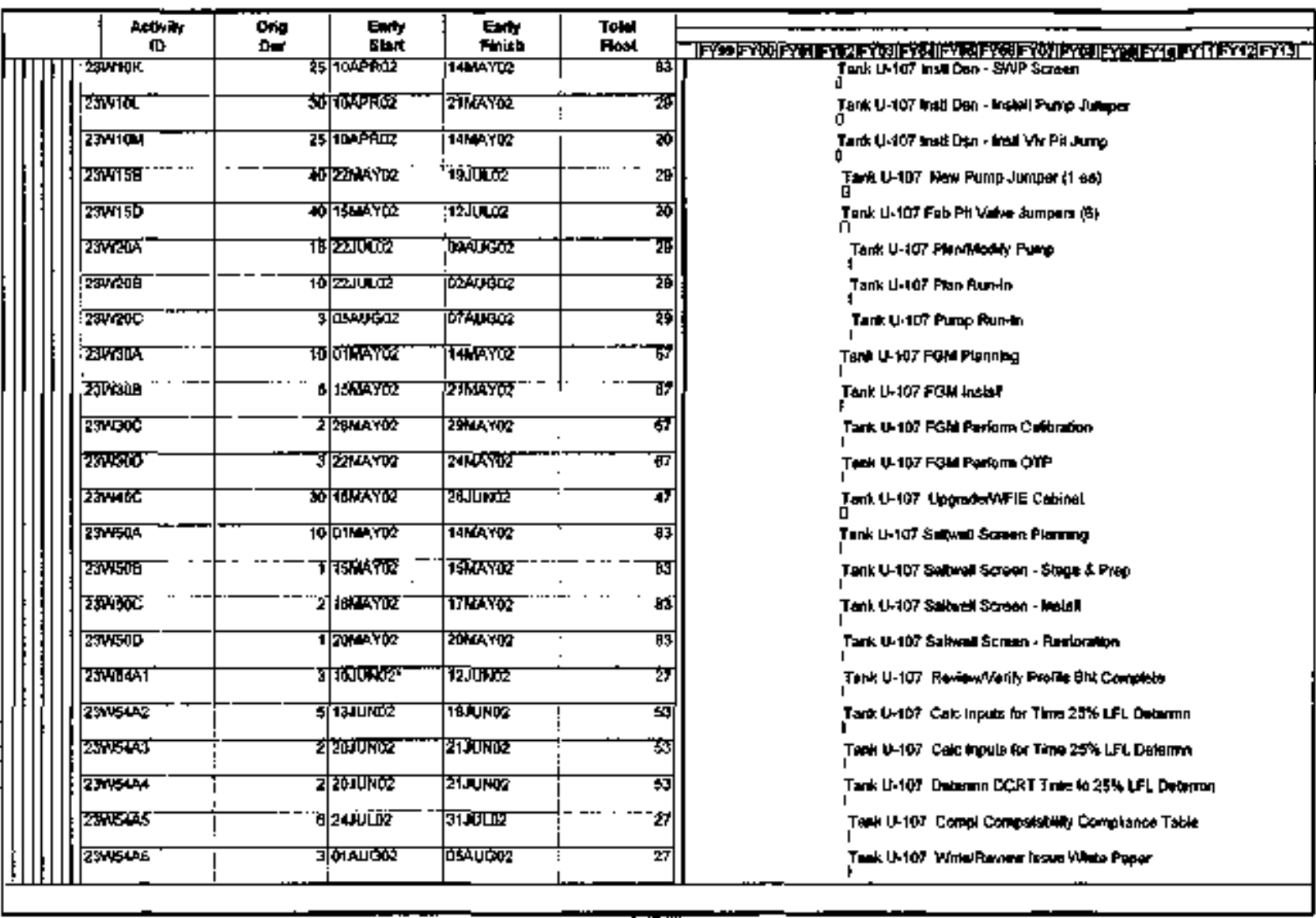




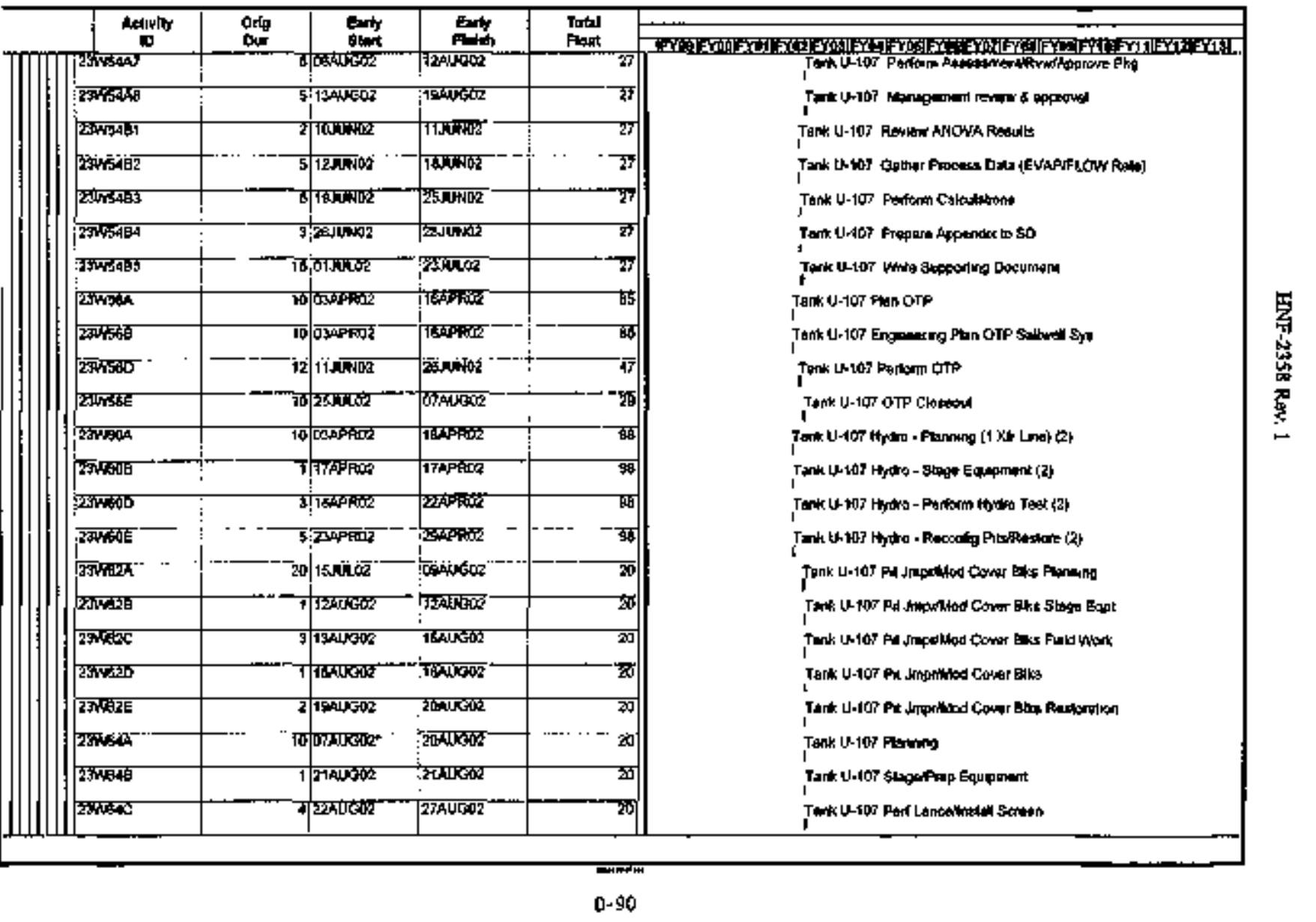




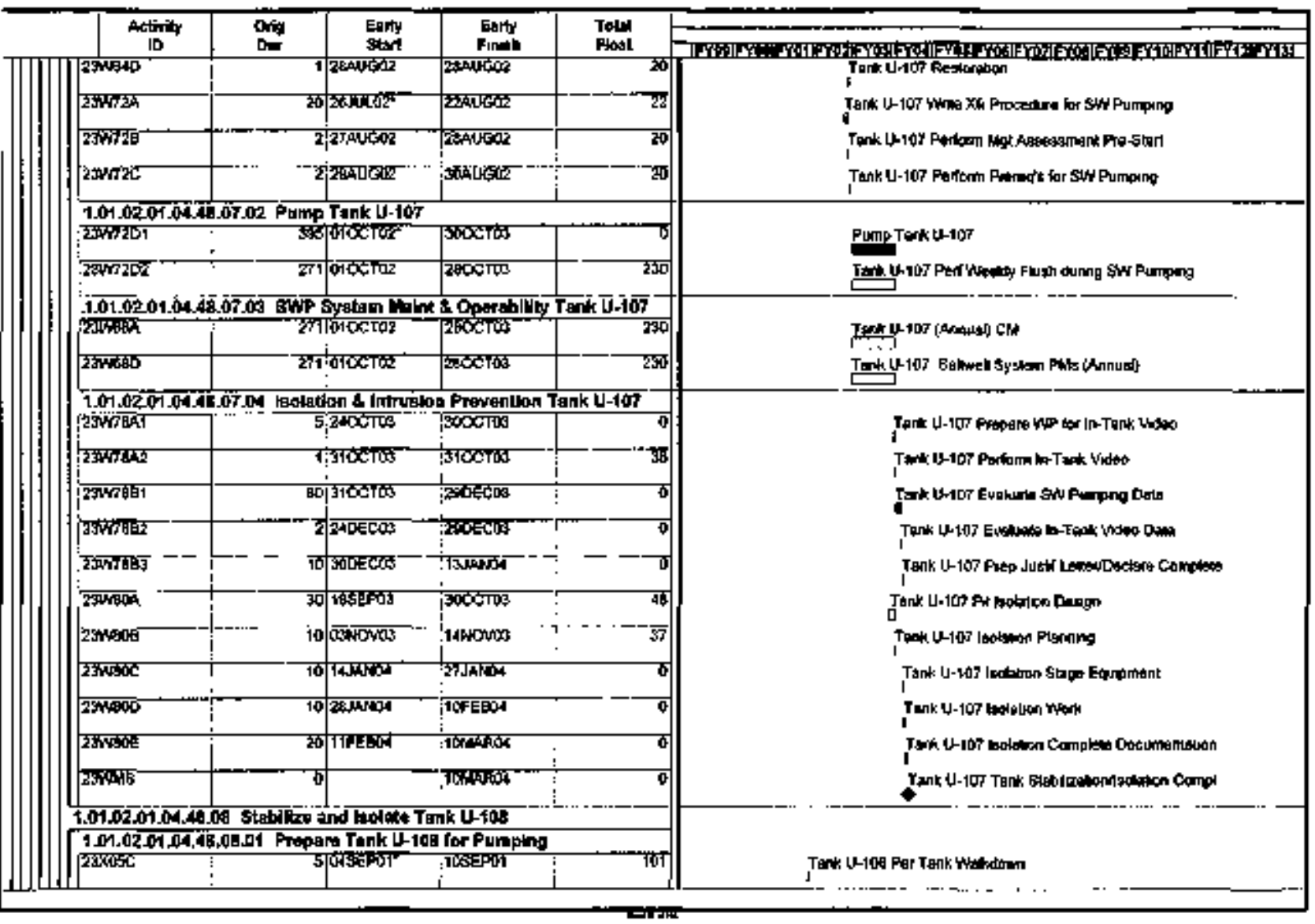




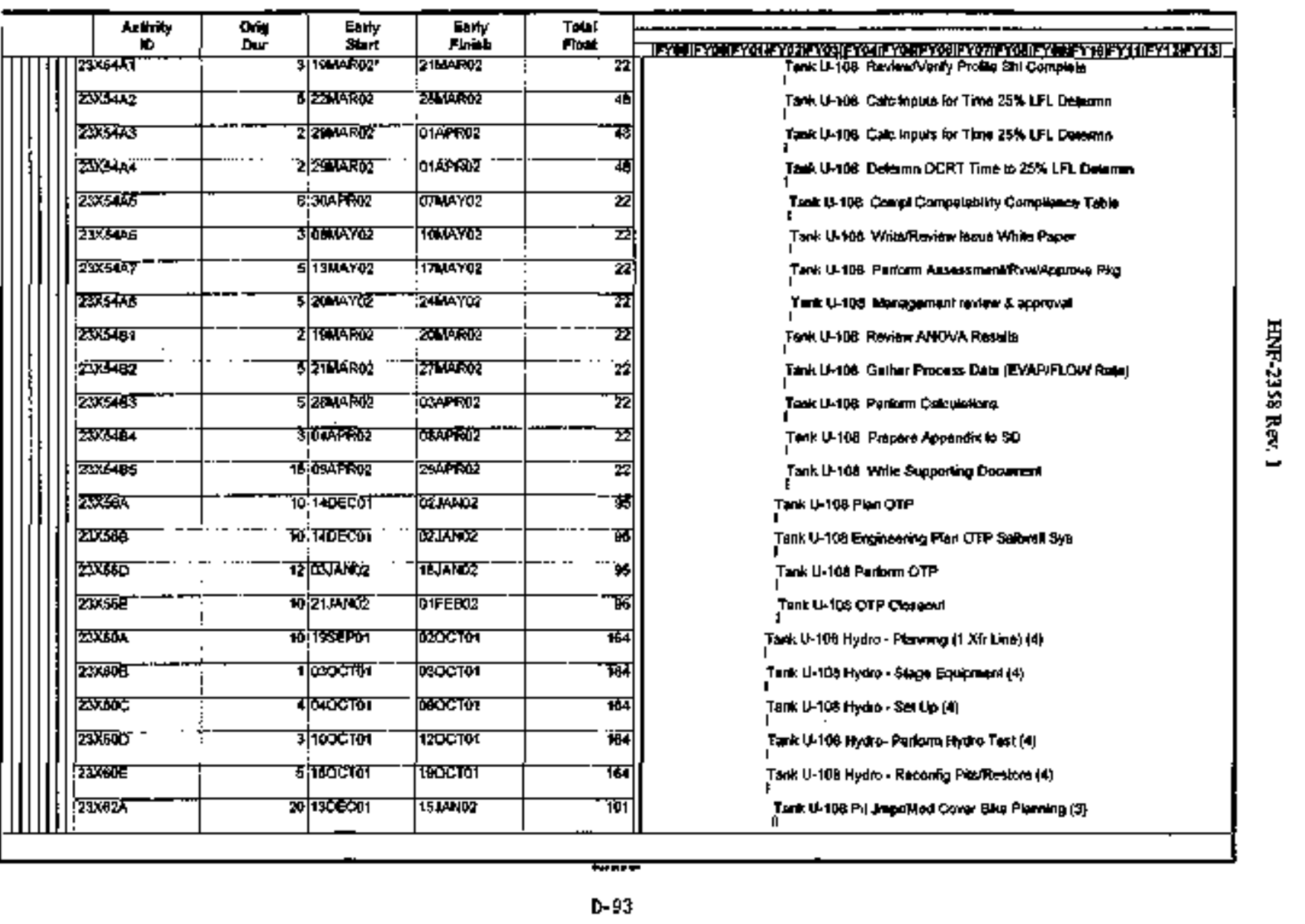




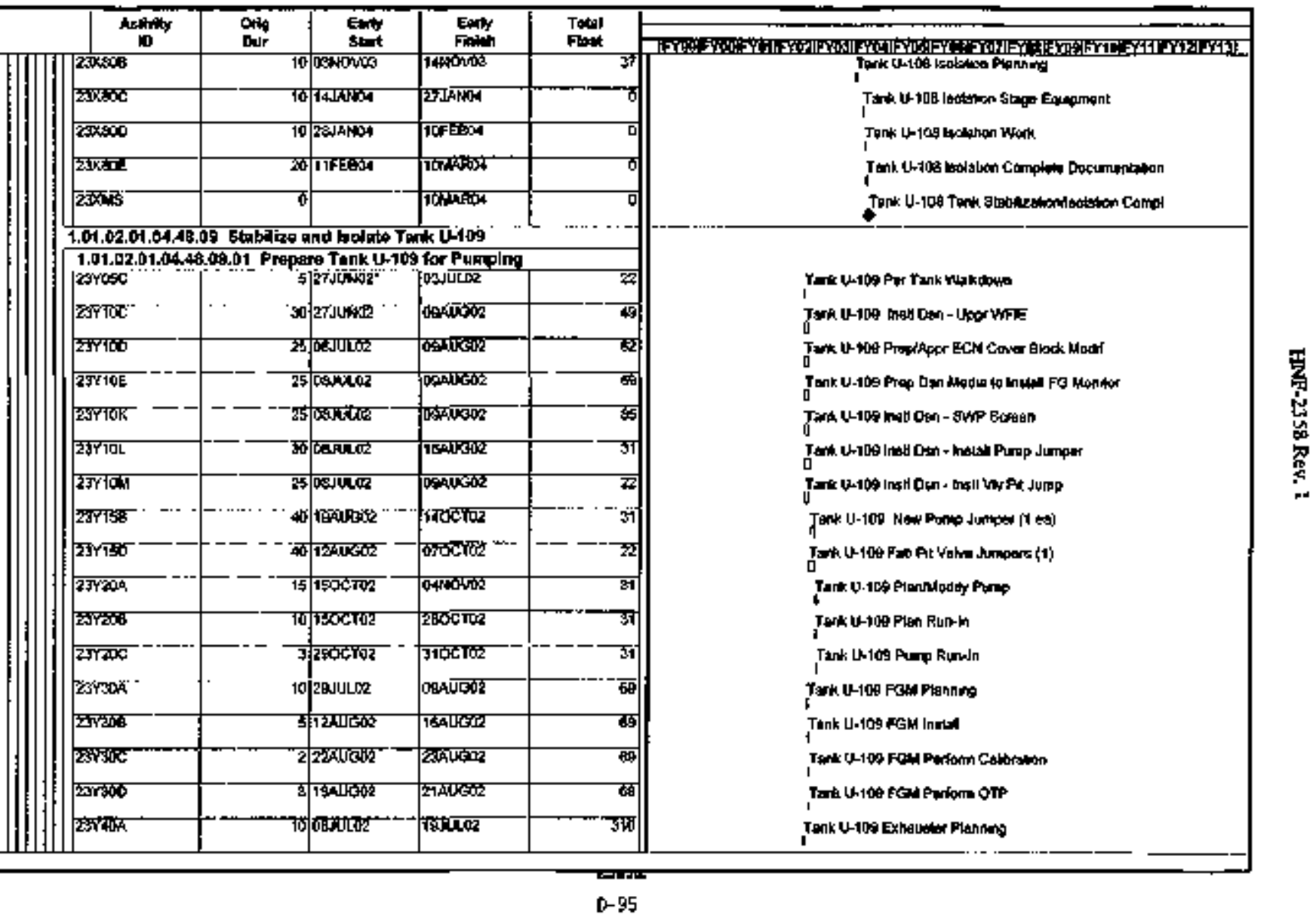




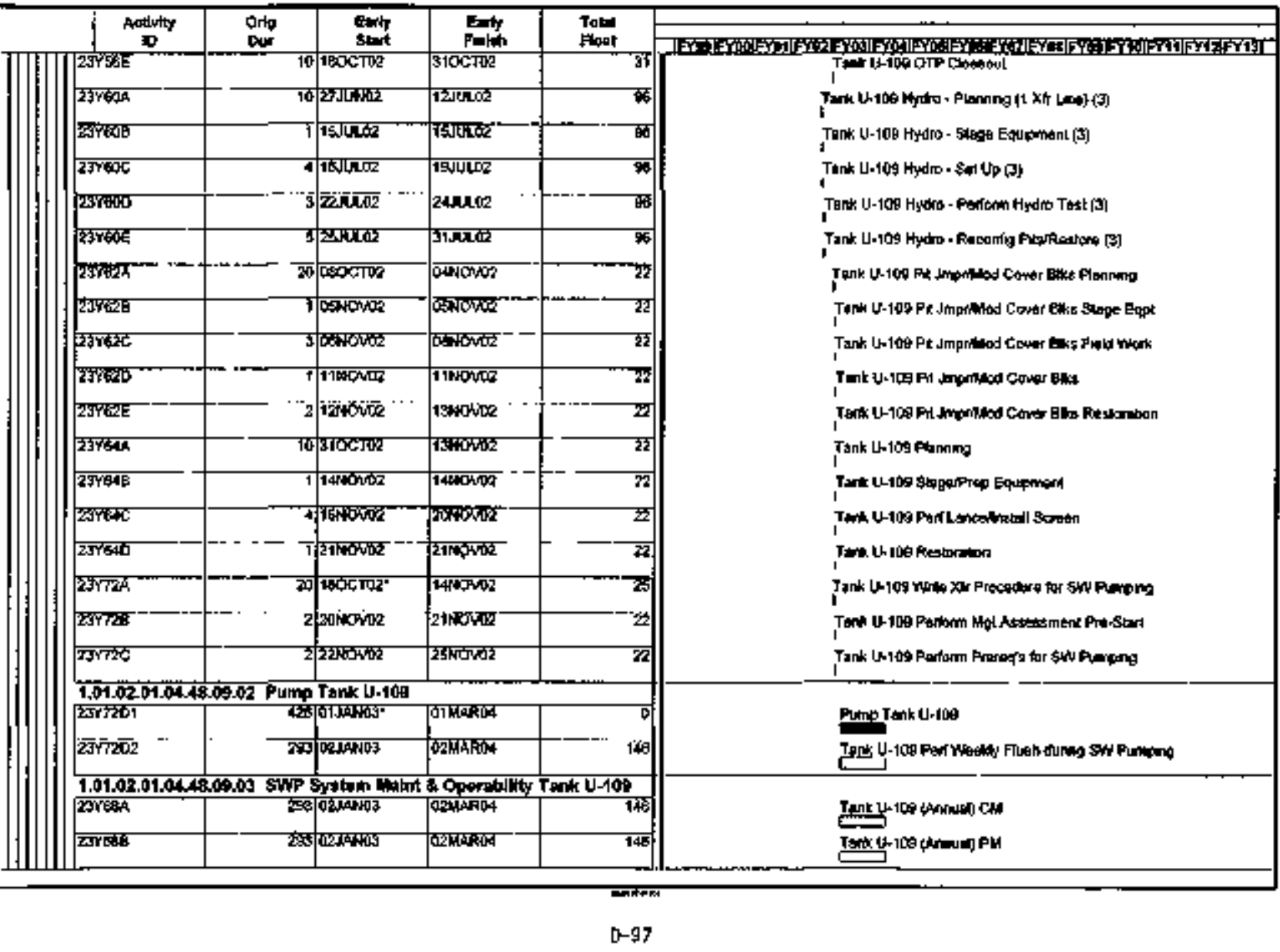




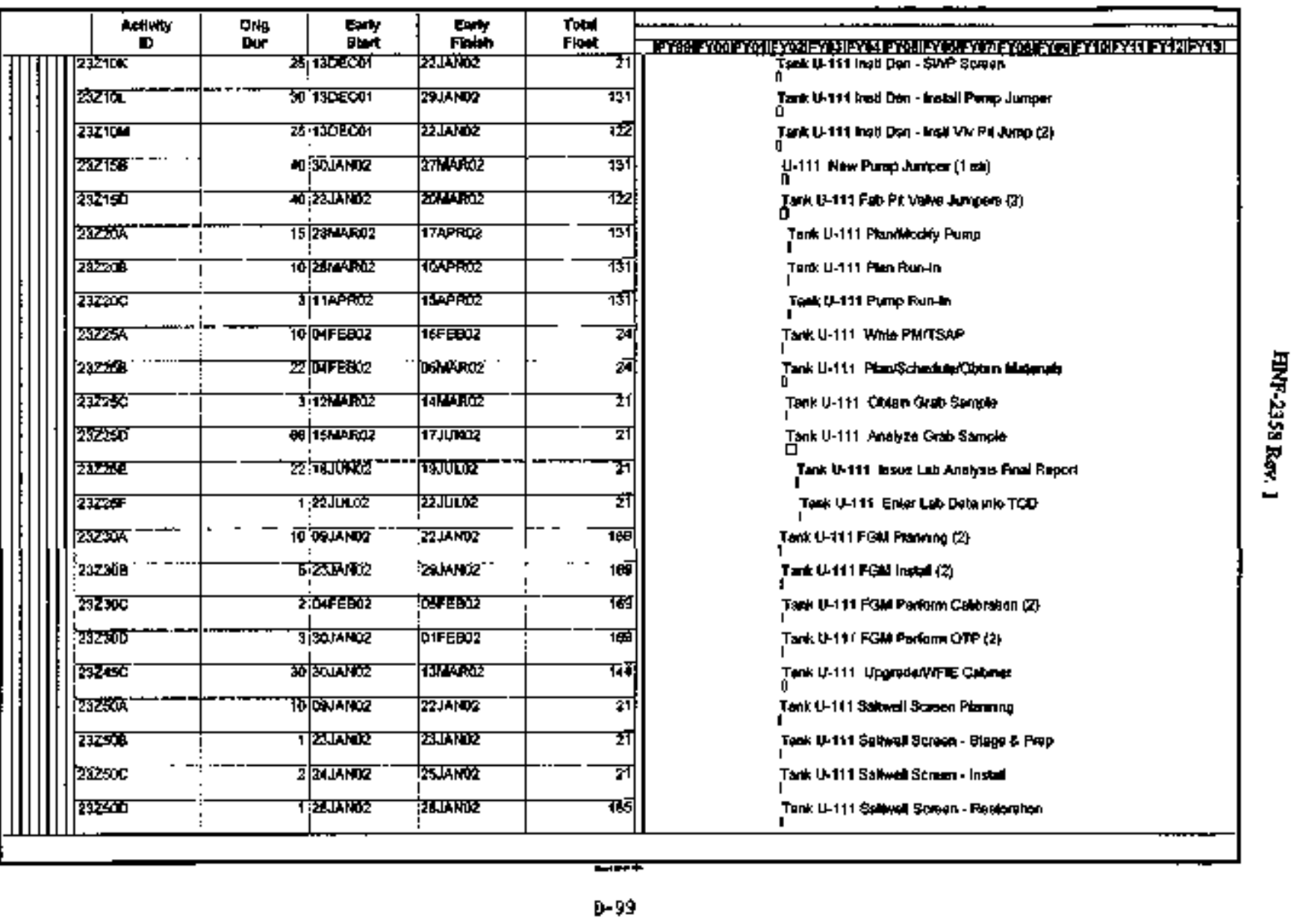




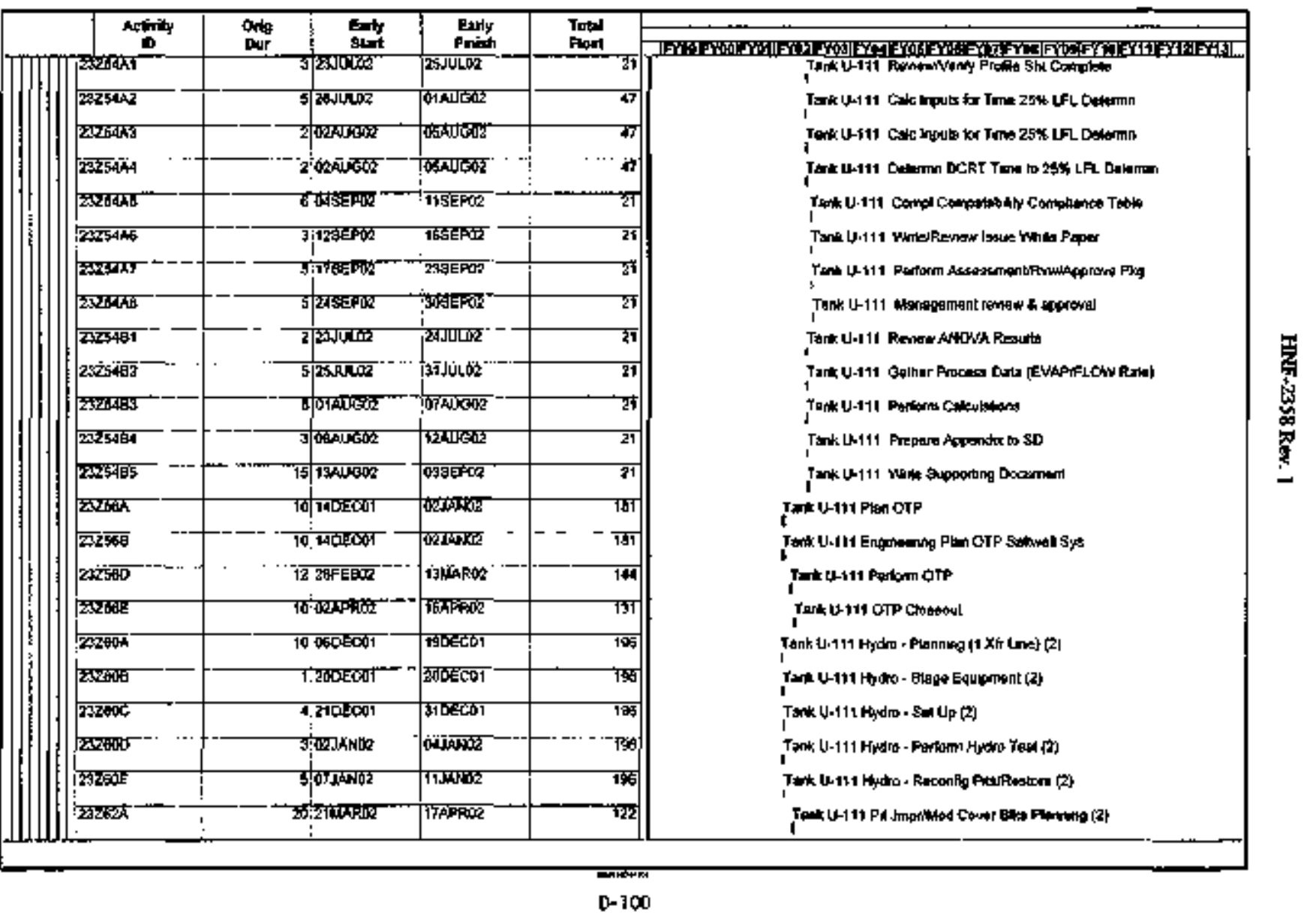




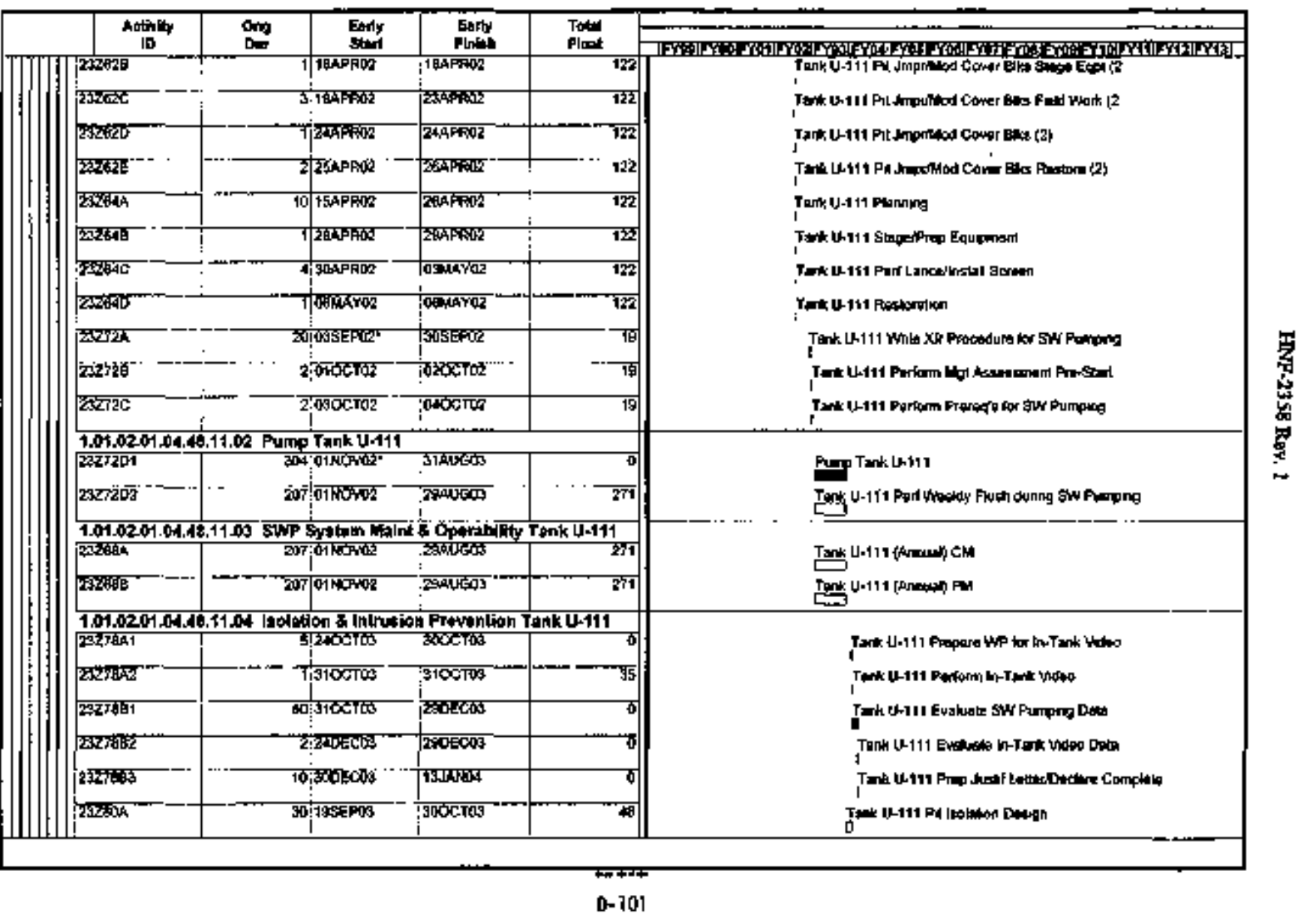




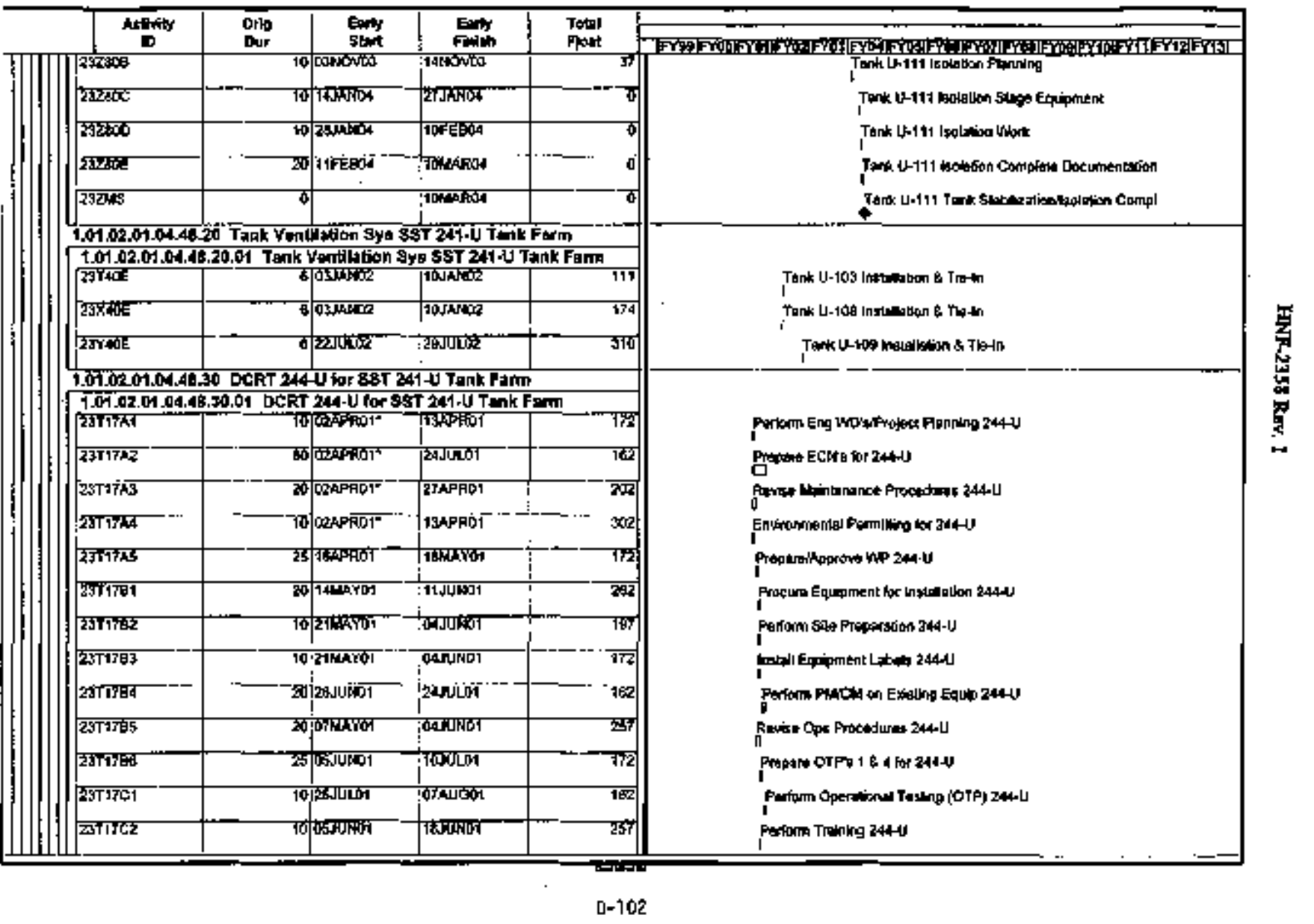




\begin{tabular}{|c|c|c|c|c|c|}
\hline Neliwty & $\begin{array}{l}\text { Ong } \\
\text { Der }\end{array}$ & enty & Earty & $\begin{array}{l}\text { fotal } \\
\text { Fiont. }\end{array}$ & 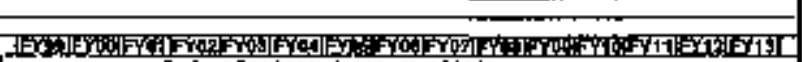 \\
\hline 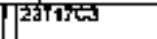 & 60 & & ऊुक्टिम & $T+2$ & 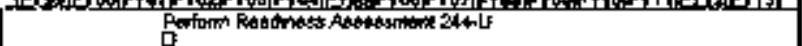 \\
\hline 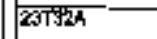 & 397 & $01 \sqrt{00}$ & ; & 2 & 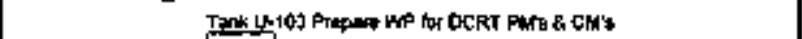 \\
\hline चज़ाइ्सूप & $33 \%$ & |वायत & 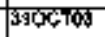 & 27 & 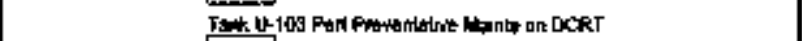 \\
\hline $29 \bar{T}_{32}$ & $\sqrt{3} \overline{3}$ & $01, \sqrt{102}$ & 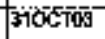 & 22 & 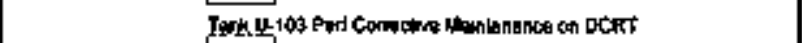 \\
\hline $23 \sqrt{3} 2 \pi$ & Wh3 & 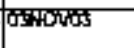 & DTसP:B & T24 & 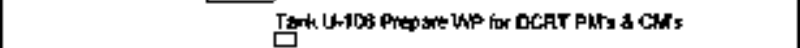 \\
\hline $25 \sqrt{28 B 1}$ & 1003 & 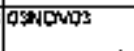 & D1APROA & 124 & 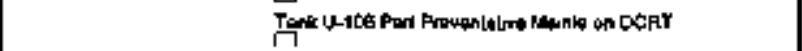 \\
\hline 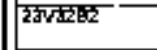 & 163 & 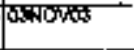 & 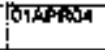 & 12ब & 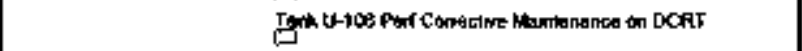 \\
\hline 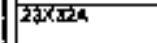 & 2947 & 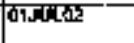 & 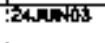 & Z酧 & 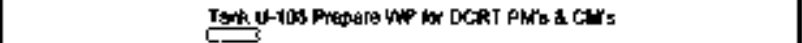 \\
\hline $2+3 \times 3821$ & 258 & (01, & 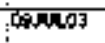 & 50 & 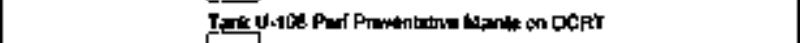 \\
\hline 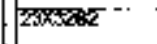 & 285 & Hotsurica & 2ग000 & $\ddot{\alpha} \otimes$ & 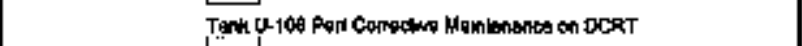 \\
\hline Crald & बवर्ण & 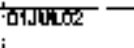 & OTAPFin & 0 & DCRT 244.0 its SST 241-U T=k Fmm \\
\hline 1.01 .08 .01 .04 & 241-UTan & fam Aanu & 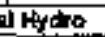 & & \\
\hline $1,01,02,01,04$ & 01241 & Tonic Farm d & nilut Hy & & \\
\hline $23+7 d A$ & 16 & $2000 \mathrm{~T}$ & 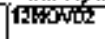 & क्ष & 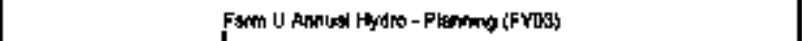 \\
\hline 25746 & 3 & ZWOCTK & 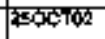 & 舟 & 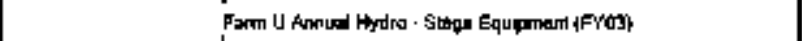 \\
\hline S28Tiac & $\cdots$ & 13 norias & 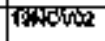 & $\overline{470}$ & 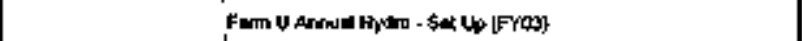 \\
\hline 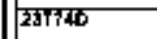 & 6 & 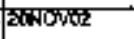 & 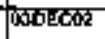 & कास & 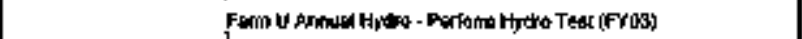 \\
\hline 2 2गT4E & 7 & OADCEDR & 1205002 & 450 & 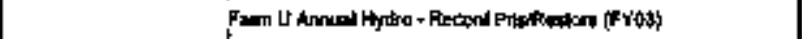 \\
\hline $1,01 . \overline{02}, 01,04$ & Sitsing & ian Puriping & & & --- \\
\hline $1,01,02,0101$ & Pumplng & Gr Romninin & $3 \mathrm{BT}^{2}=12$ & & \\
\hline ग्यास & $5 \%$ & minuspar & iroctoo & 0 & Prmang Summany' 1 Craws \\
\hline 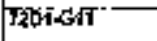 & $68 y^{\circ}$ & DTSEPRE' & sonedion & 0 & Pumang Surnor 2 crew-? \\
\hline $7201-39$ & 7ars & DANWWO & रrJULDO3 & 0 & phryantommey a onul 1 \\
\hline 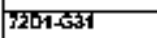 & FEन & 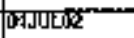 & अLOELA & 古 & 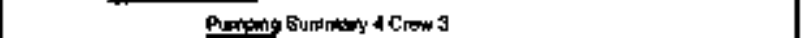 \\
\hline 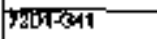 & $935^{\circ}$ & 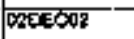 & 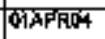 & 0 & Arremp \$ormeny s crew 3 \\
\hline
\end{tabular}

[0103 


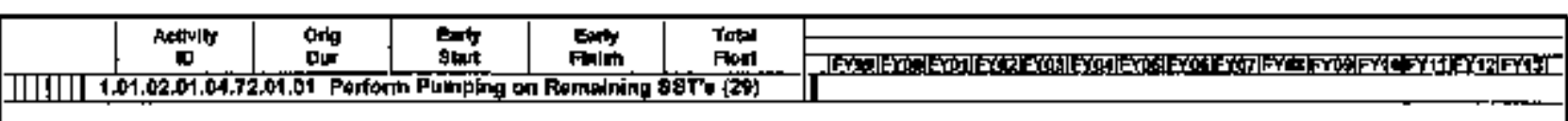


HNF-235S Rev 1

\section{APTENDEX E}

SINGLE-SHELL TANK INTERIM STABILIZATION

LEVEL 1 LOGICS

E-i 
HPF-2358 Rey. t

This page intentionalky lept blank.

E-ii 


\section{CONTENTS}

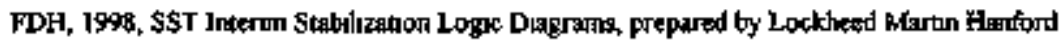

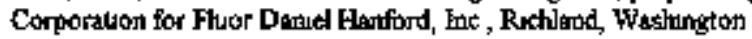

E-1 SST Jreerm Stabuloption Level / Logic, A-101

E-2 SST Interm Stabilization Lewel I Loge, AX-IOI

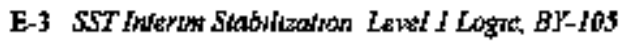

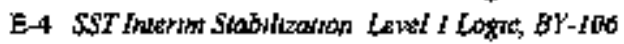

E-S $5 S T$ interm Stabilizatron Level I Logrc, C-JOS

E-6 SST Intersm Stabitizaton Level I Logic, S-10I

E-7 SST Inims Stablization Level I Logre, S-102

E-8 SST Interm Stabilization Level t Loge, \$-10s

B-9 SST IRterms Stabihation Level I Logie, Snl06

E-10 SST interim Stabitizarion Level I togrc, S-107

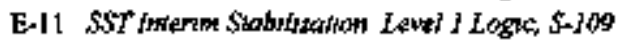

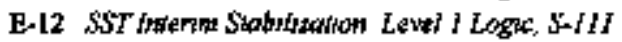

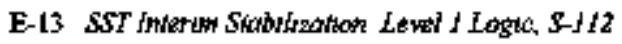

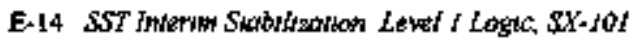

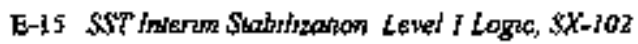

E-16 SST inderm \$tabuzation Level I Lage, $\$ X-103$

E-17 SST Internm Spabiluation Level I Laga, $S X-104$

E-18 SST Interm Skabitiontion Level I Logre, $\$ X$-10S

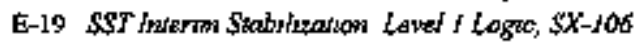

E-20 SST interros Stabulitation Level / Logrc, TrFOA

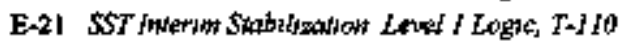

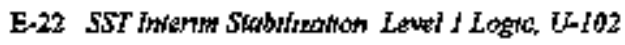

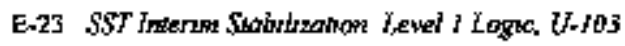

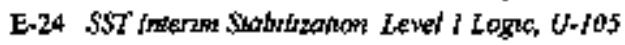

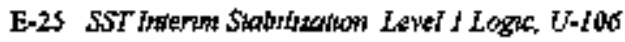

E-26 SST Imienm Sabuthwion Lewi / Logk. U-107

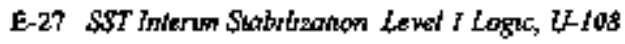

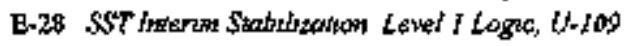

E-29 SST Intervat Stabtuwillon Lew I Loge, U-HI 
HNF-2758 Rev. 1

This page intentiotsally left blank.

E-jv 


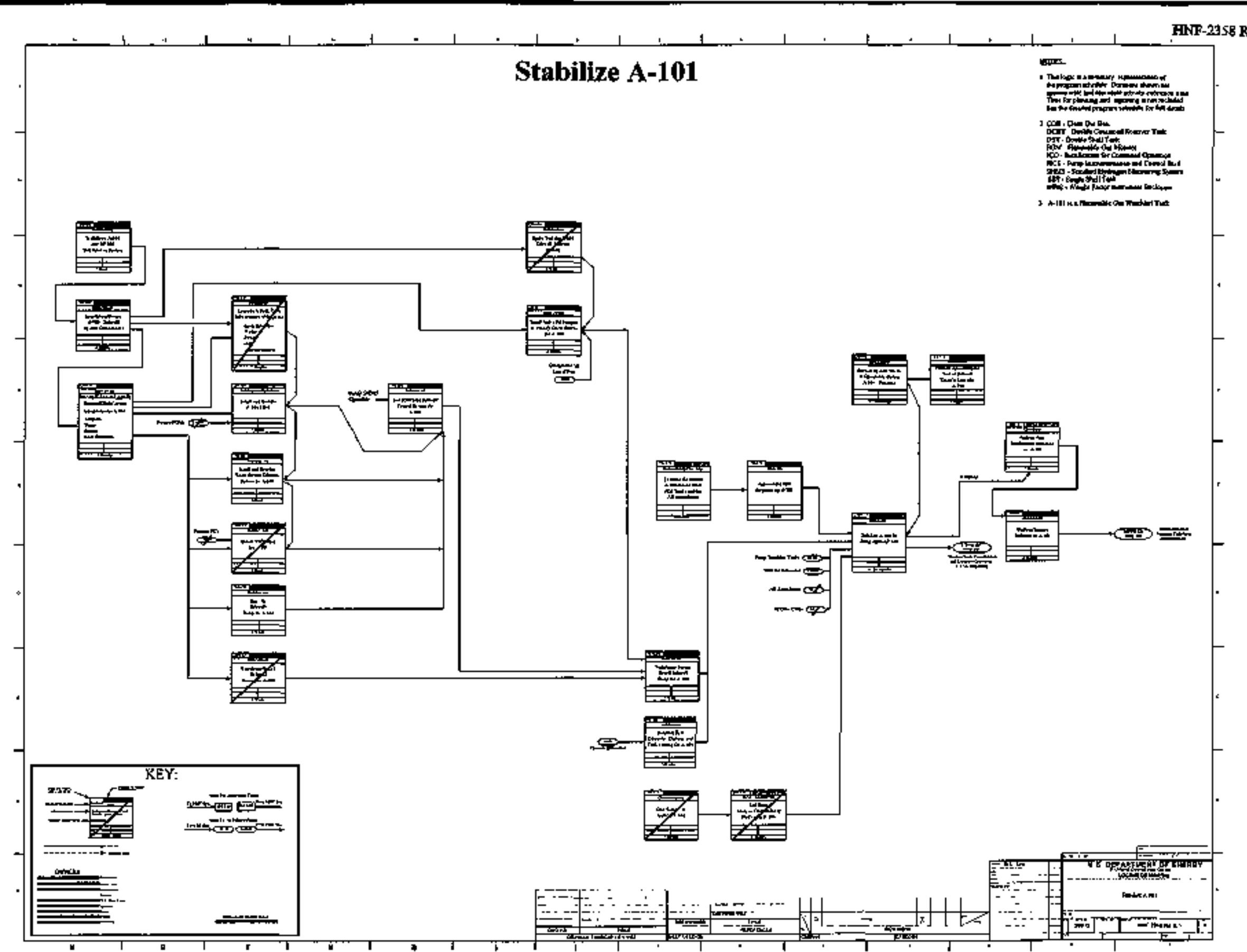




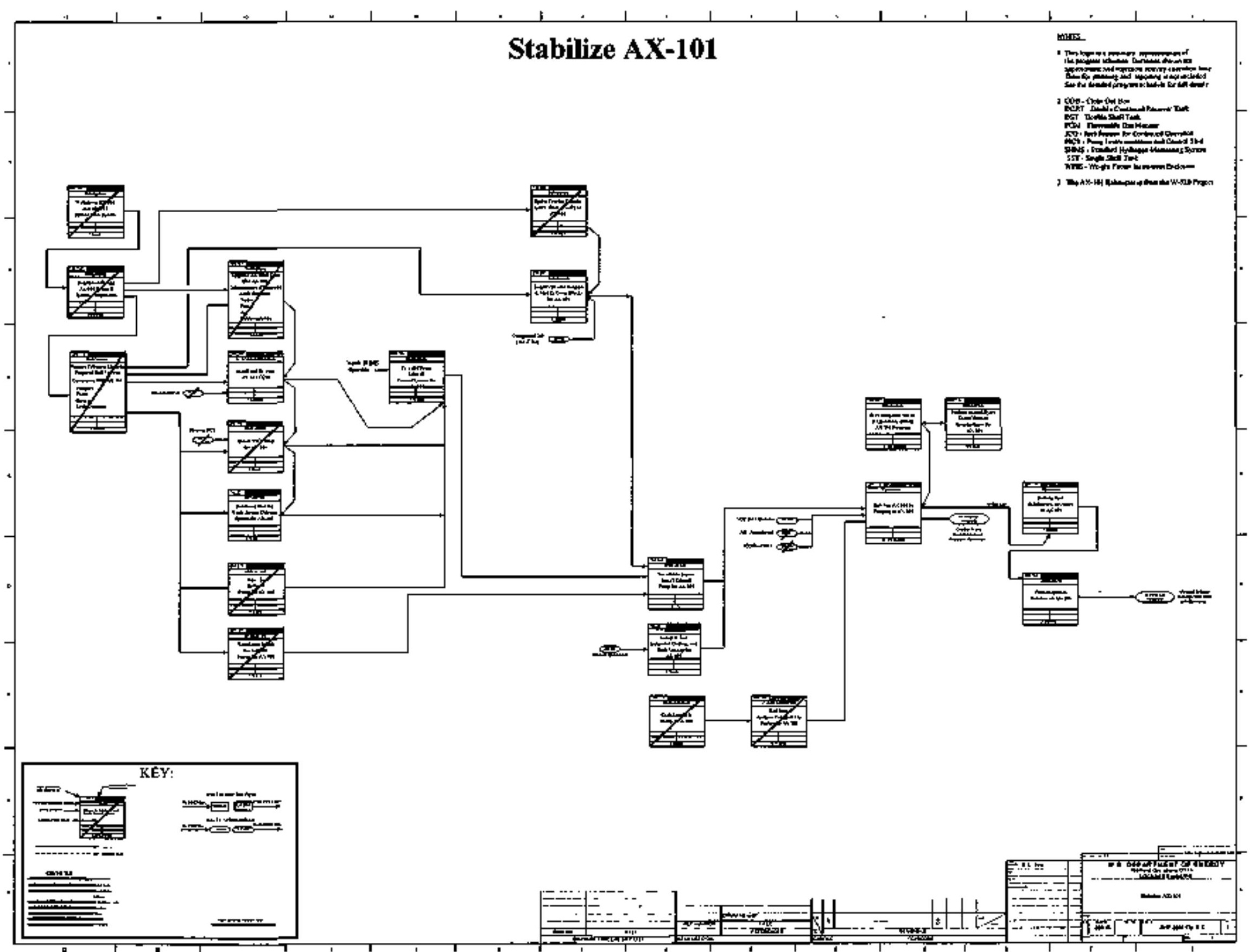




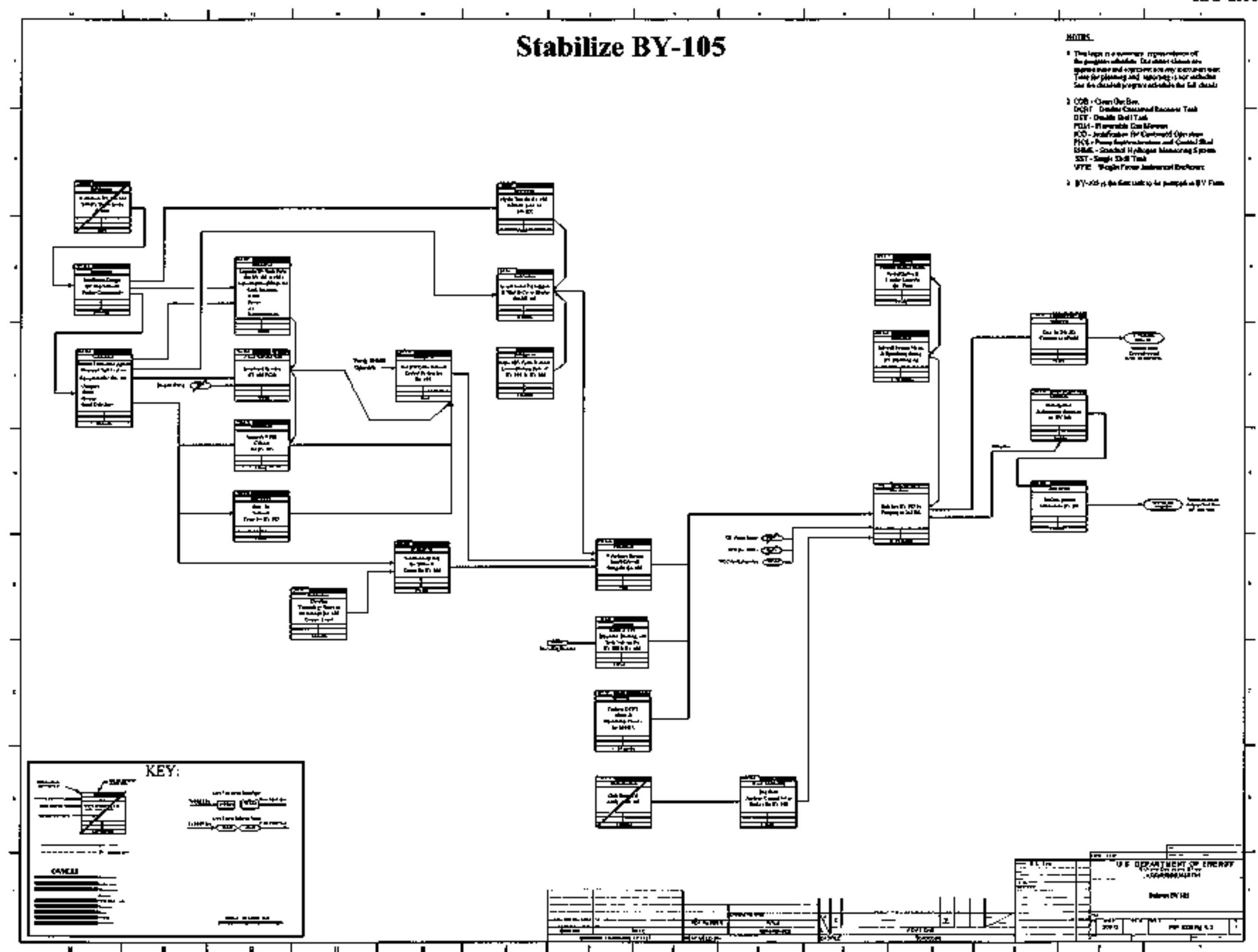




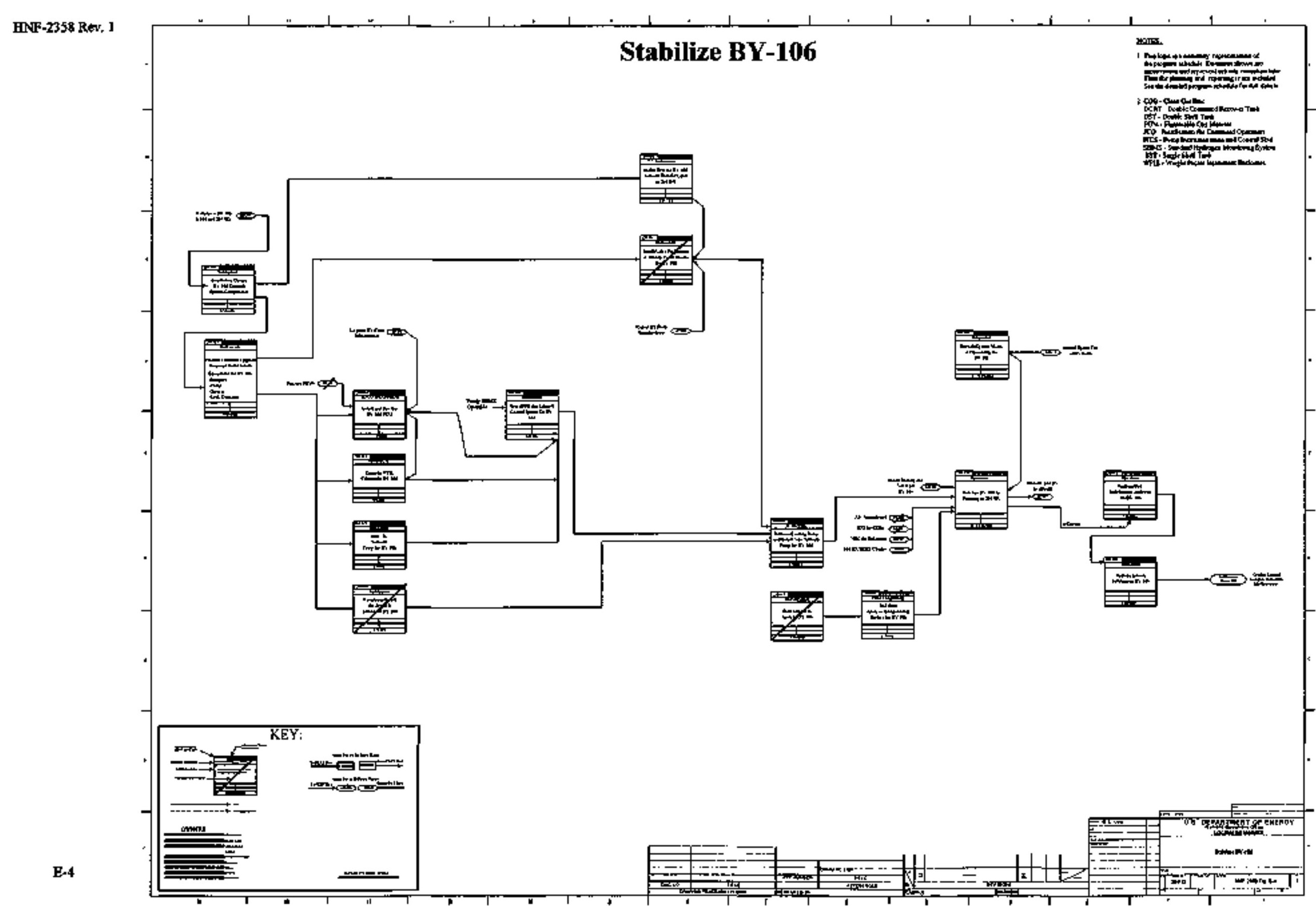




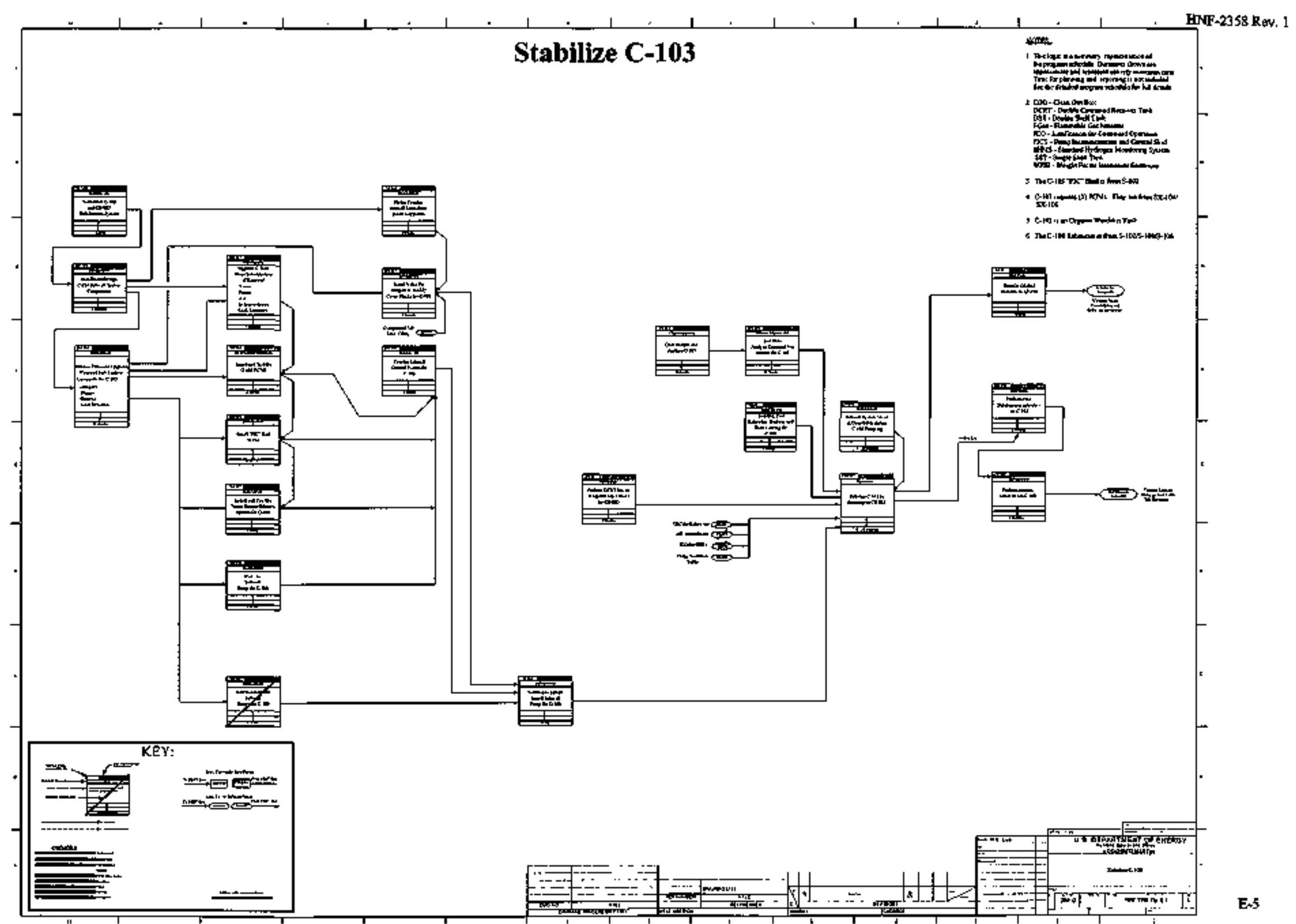




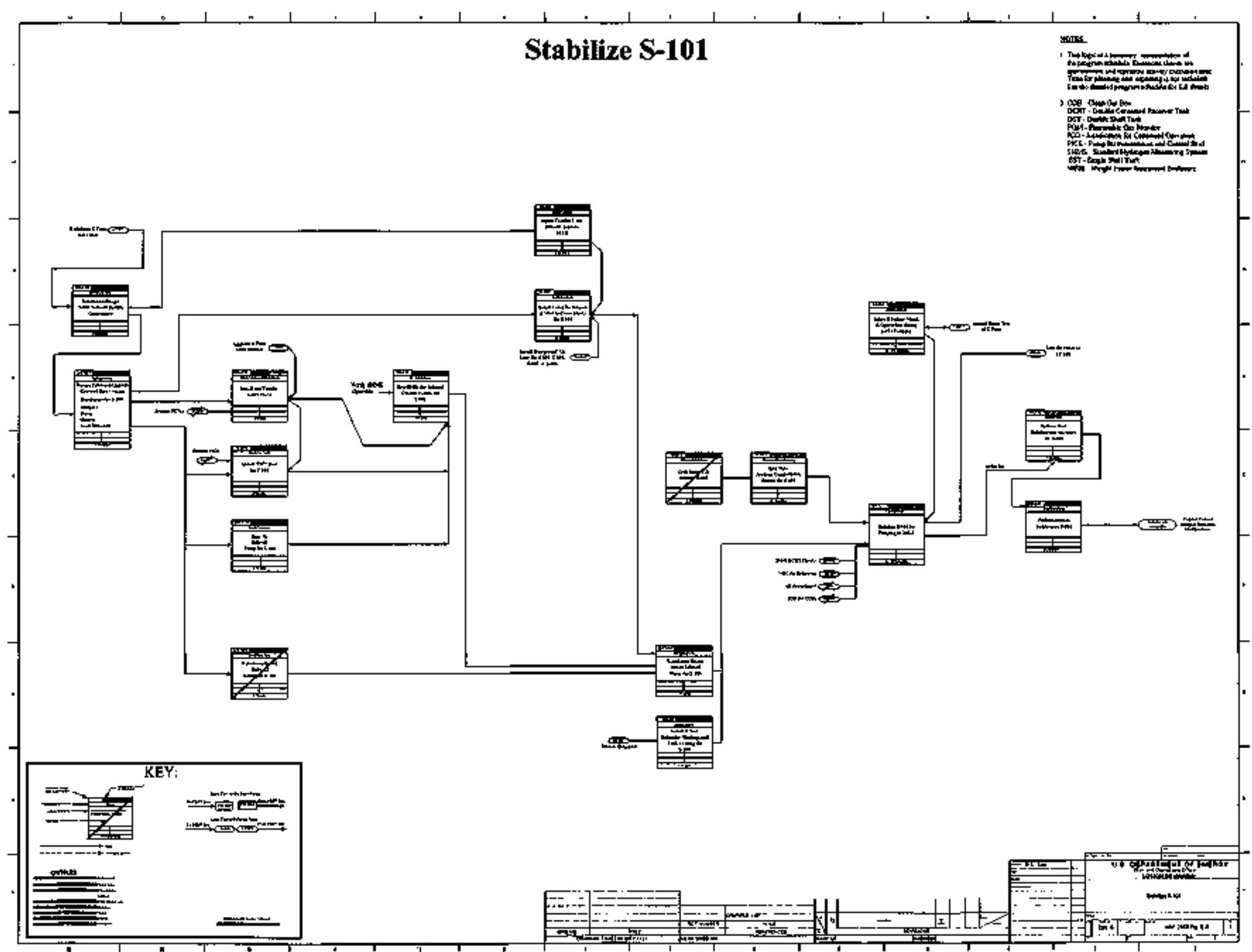




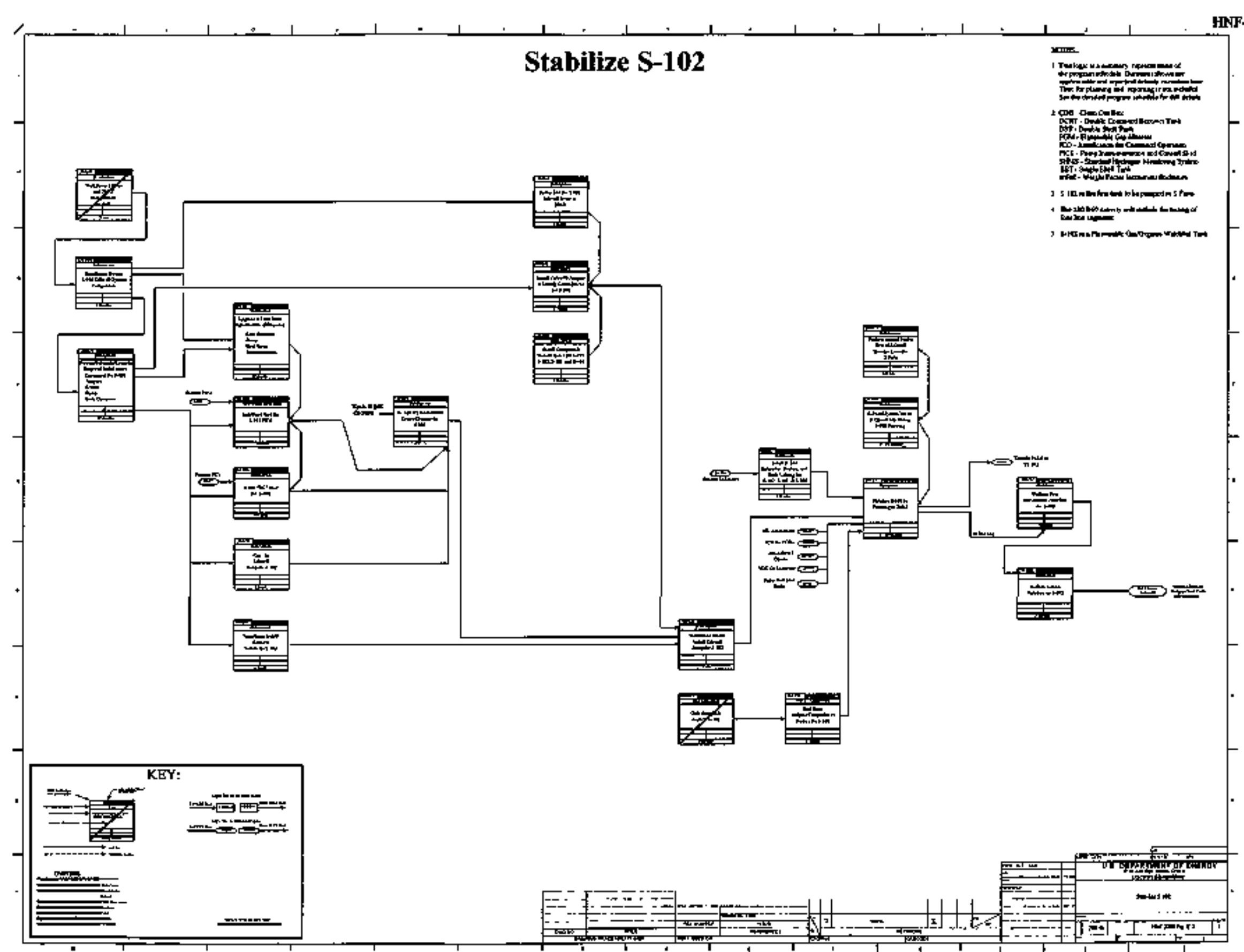




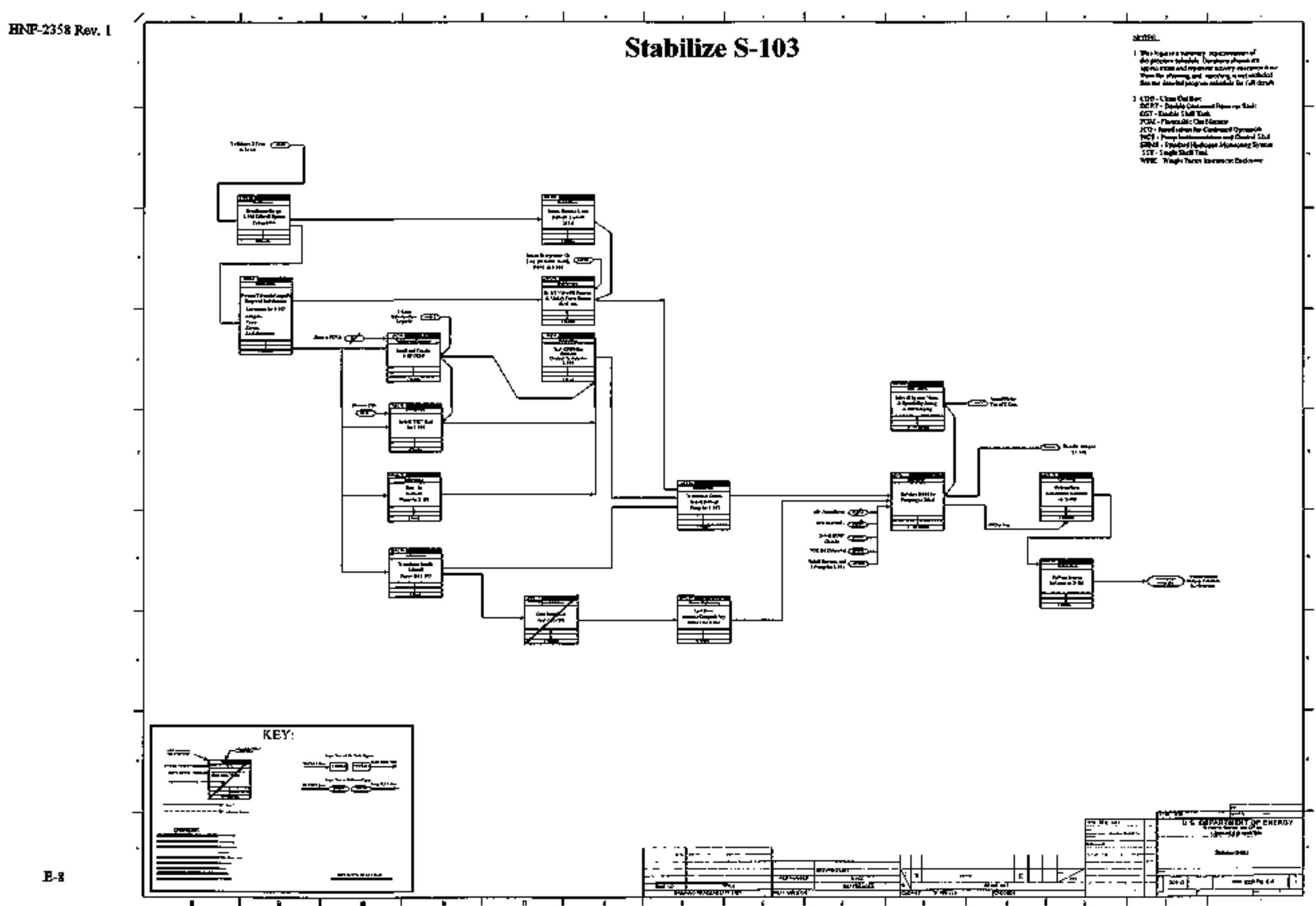




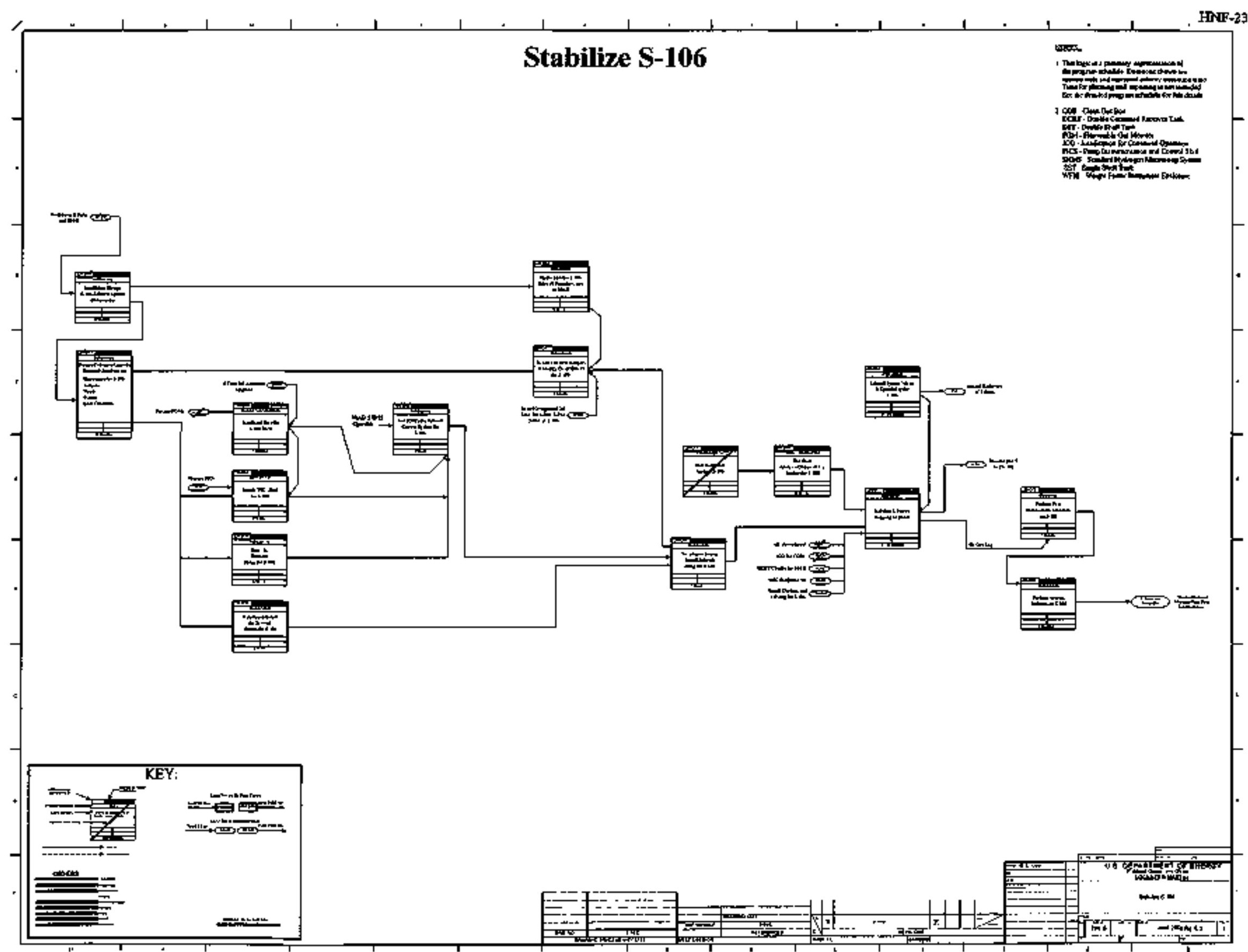


FINF-2358 Rev. I

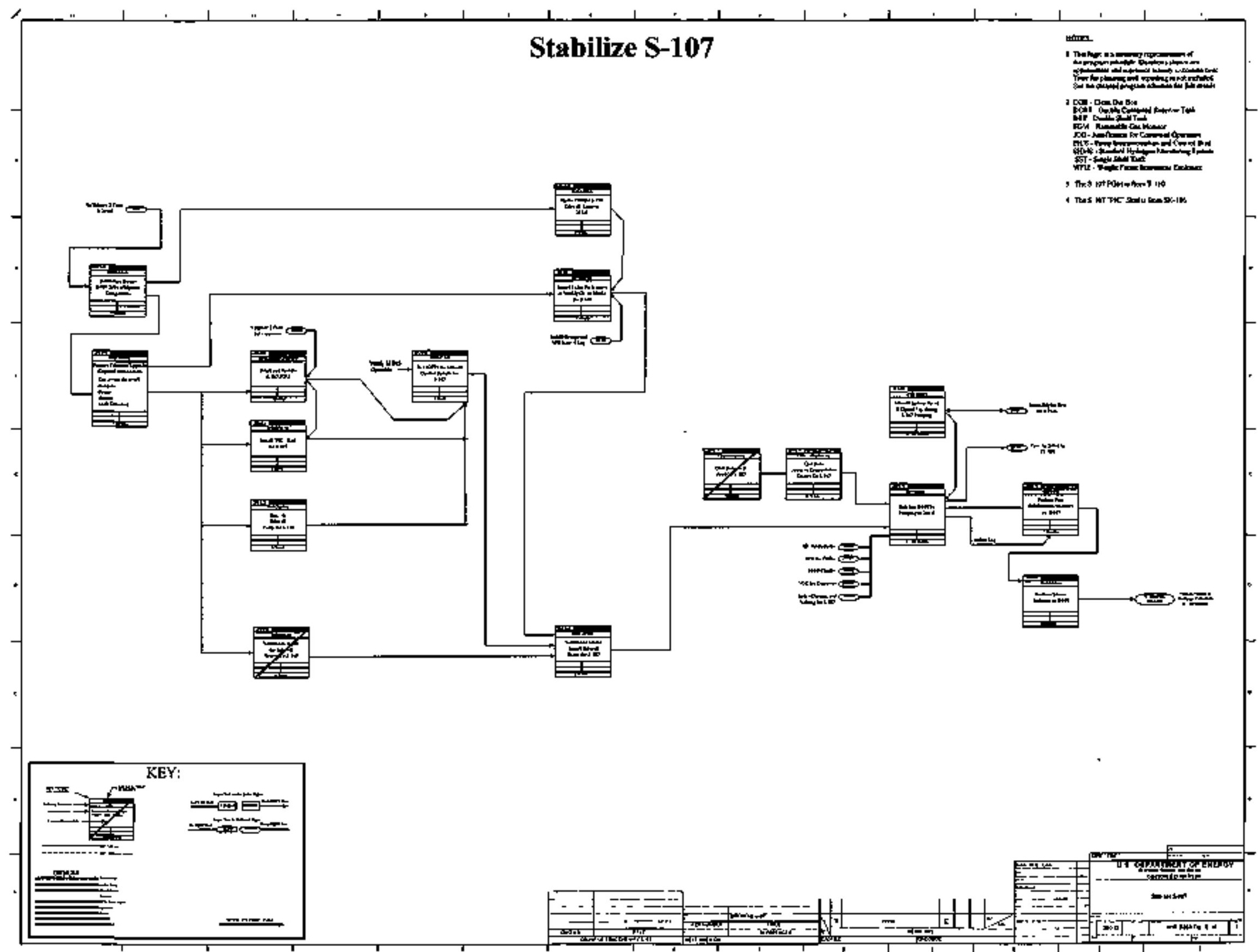




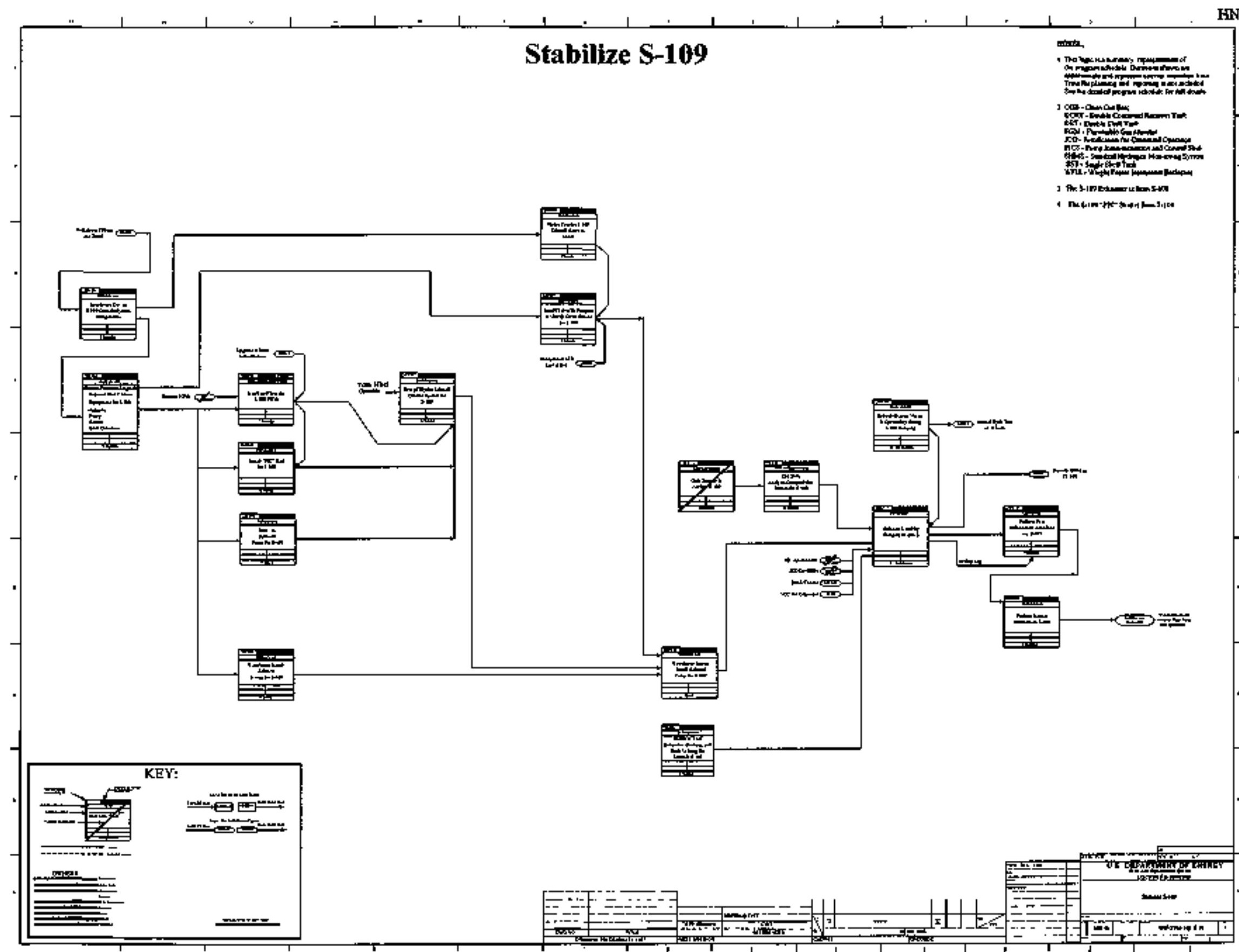




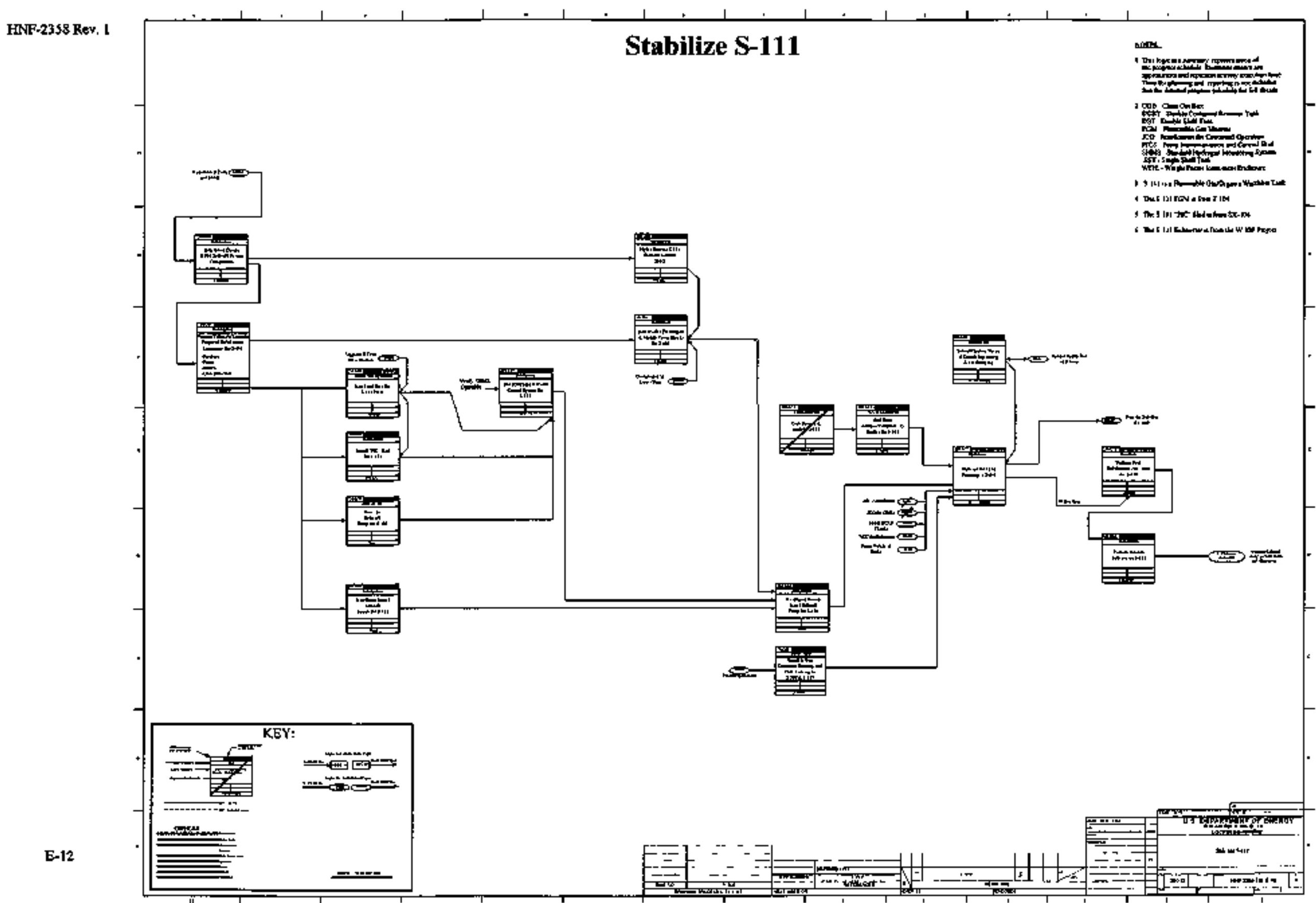




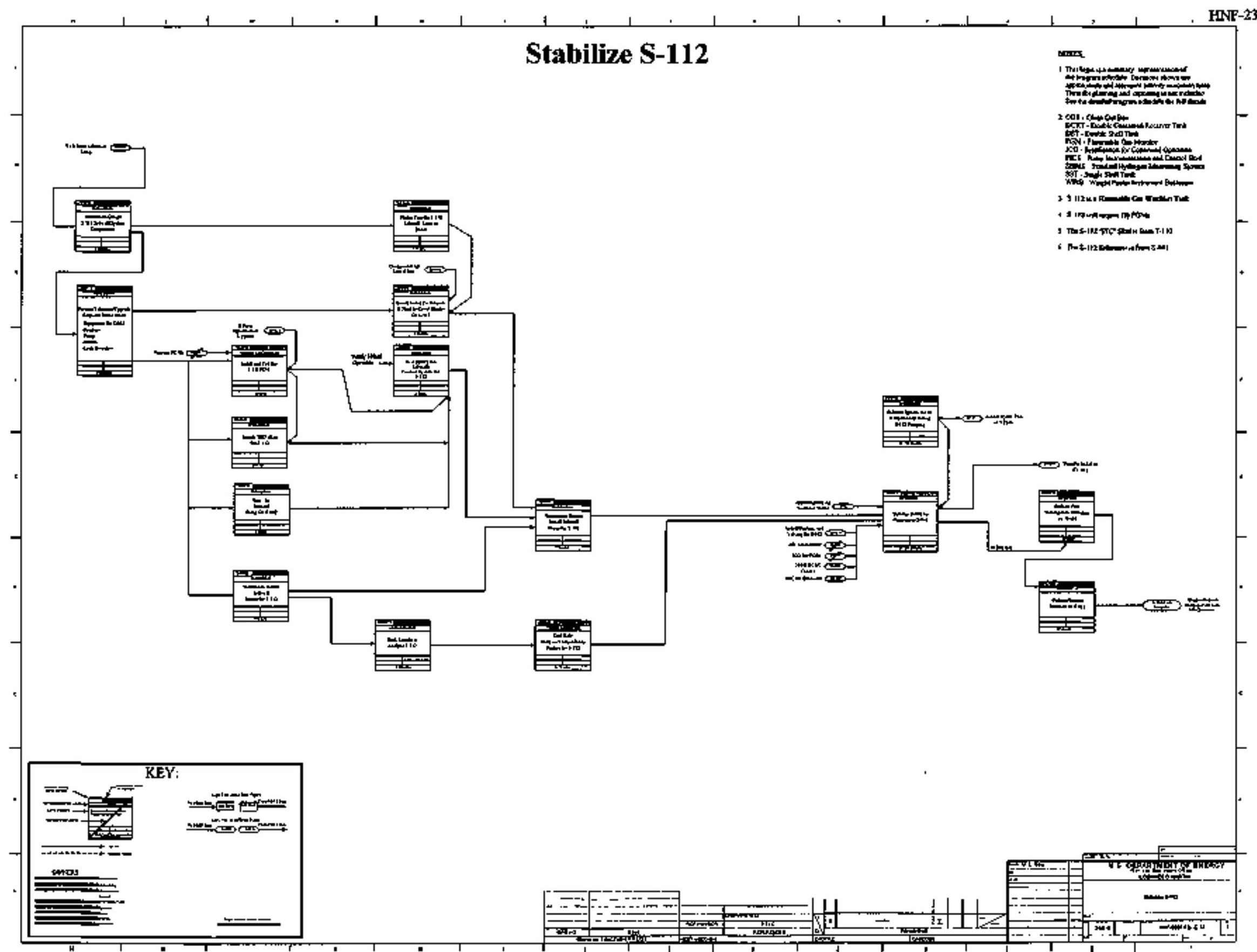




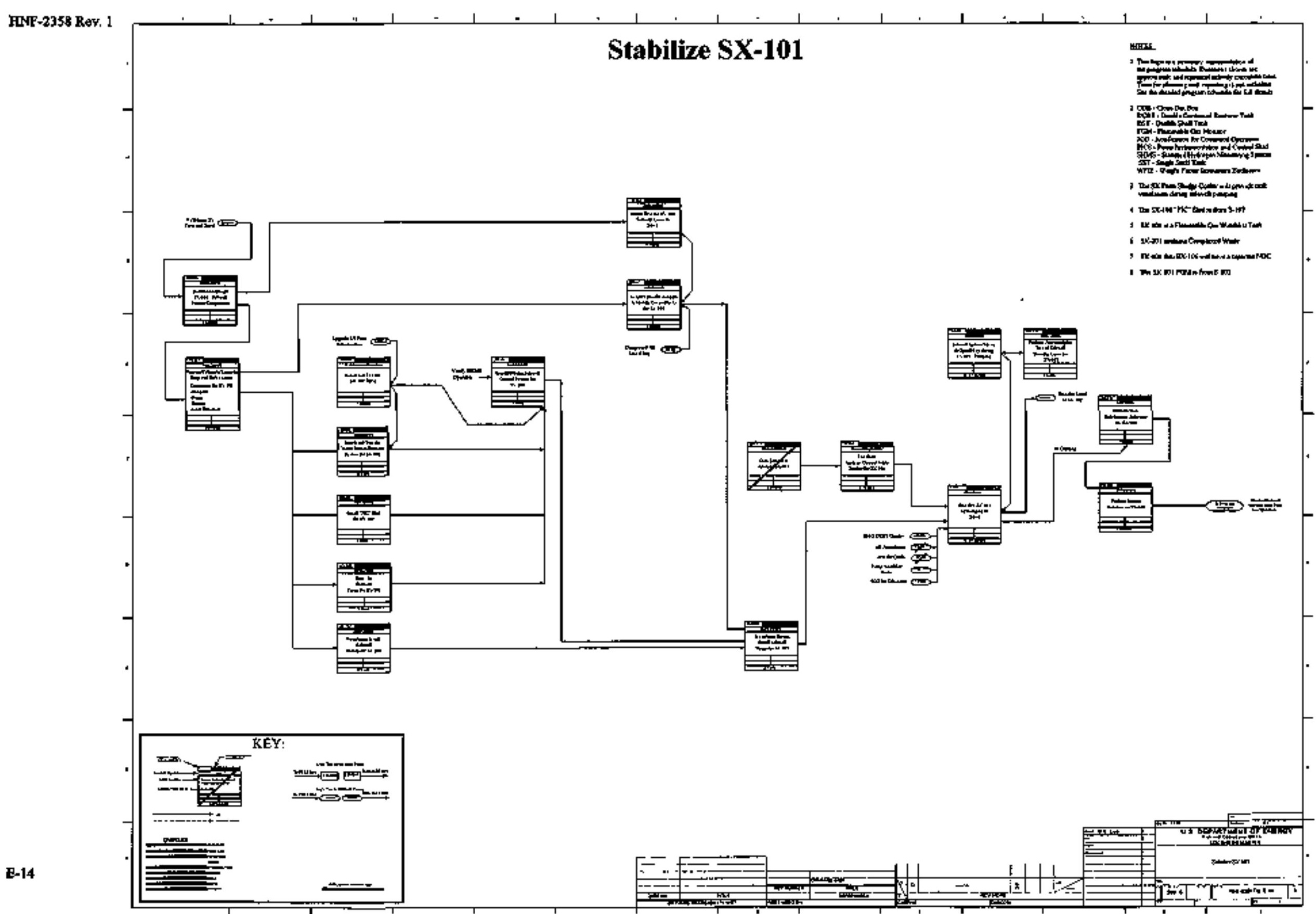




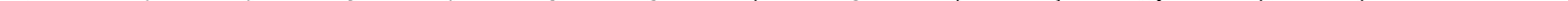

E-1s 


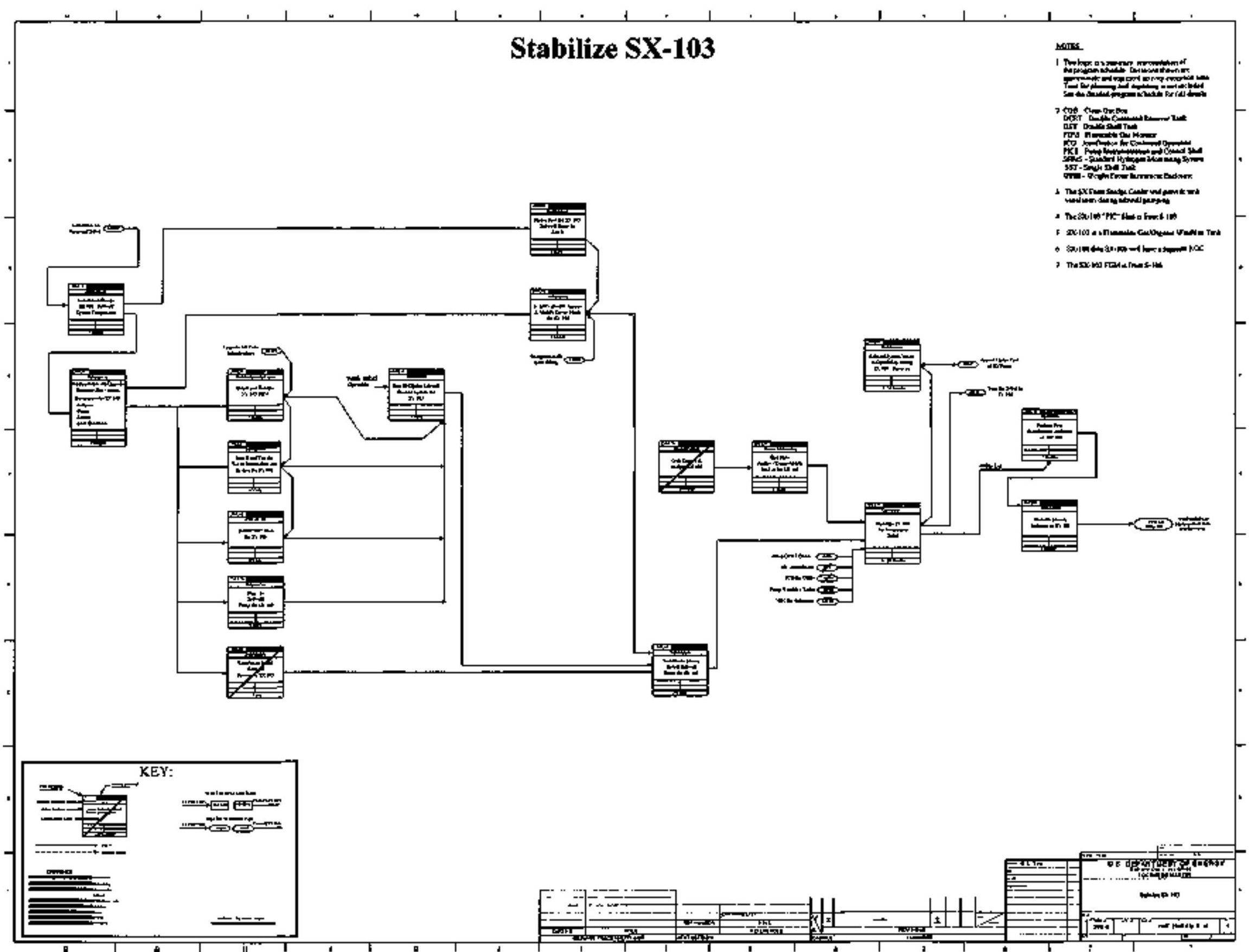




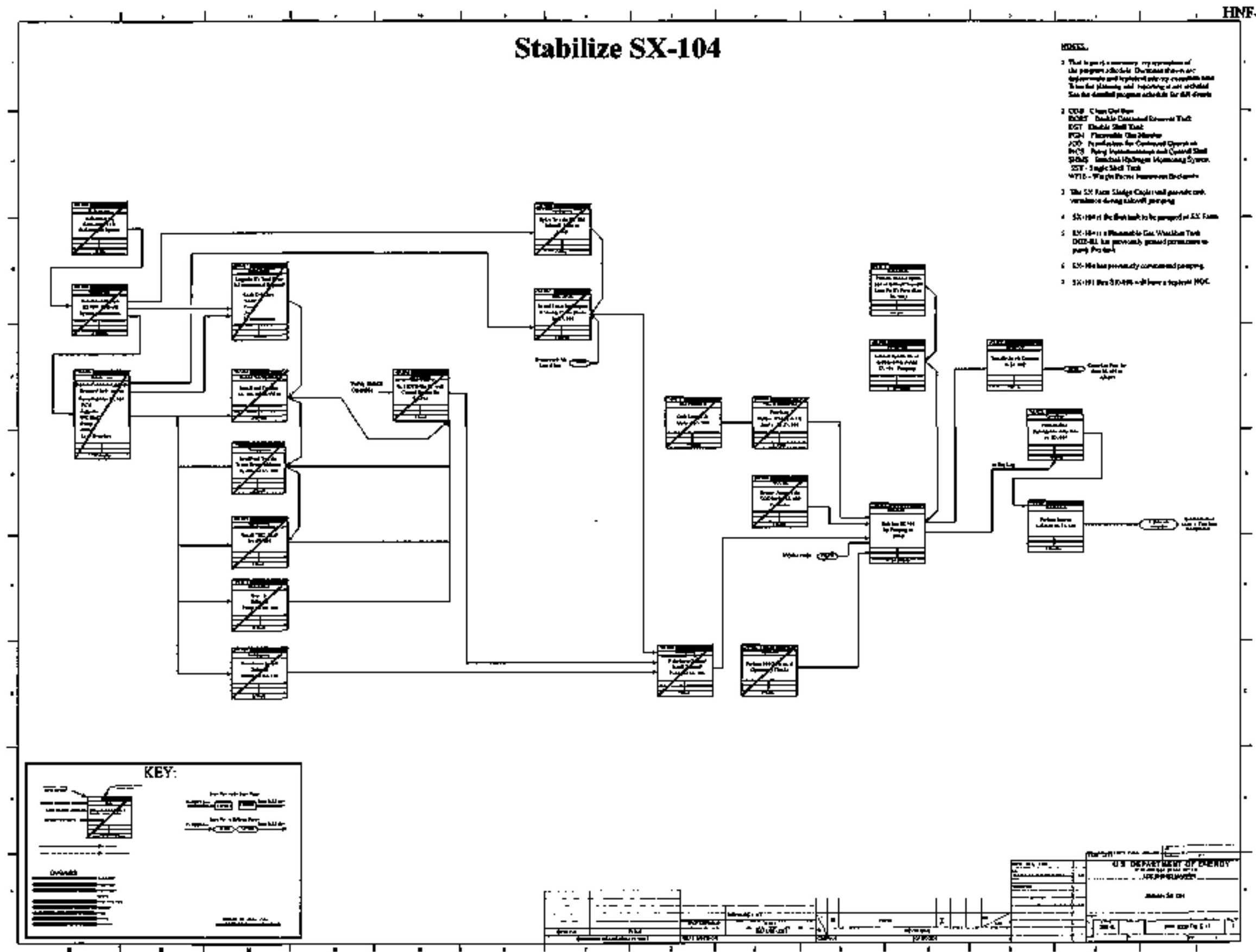




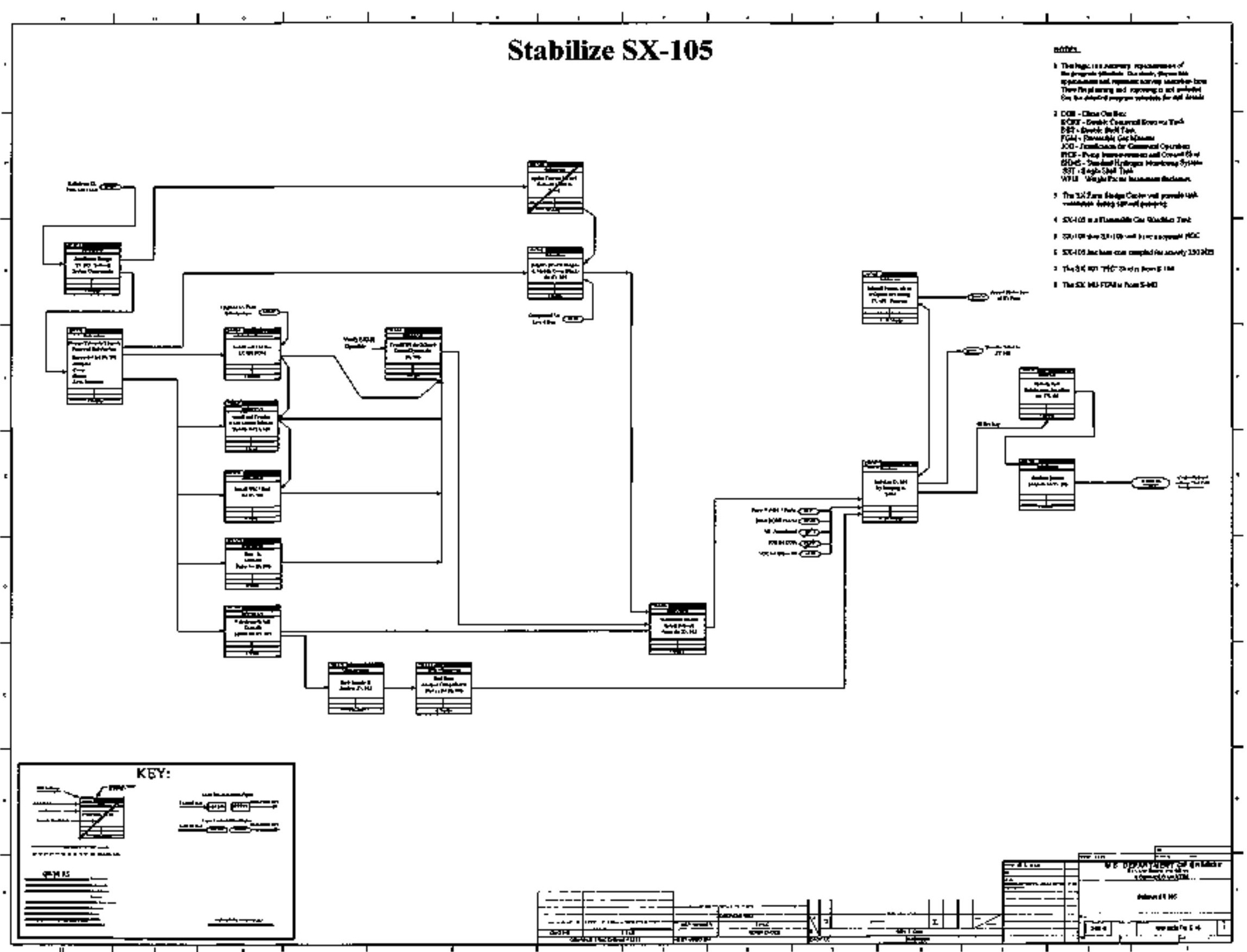




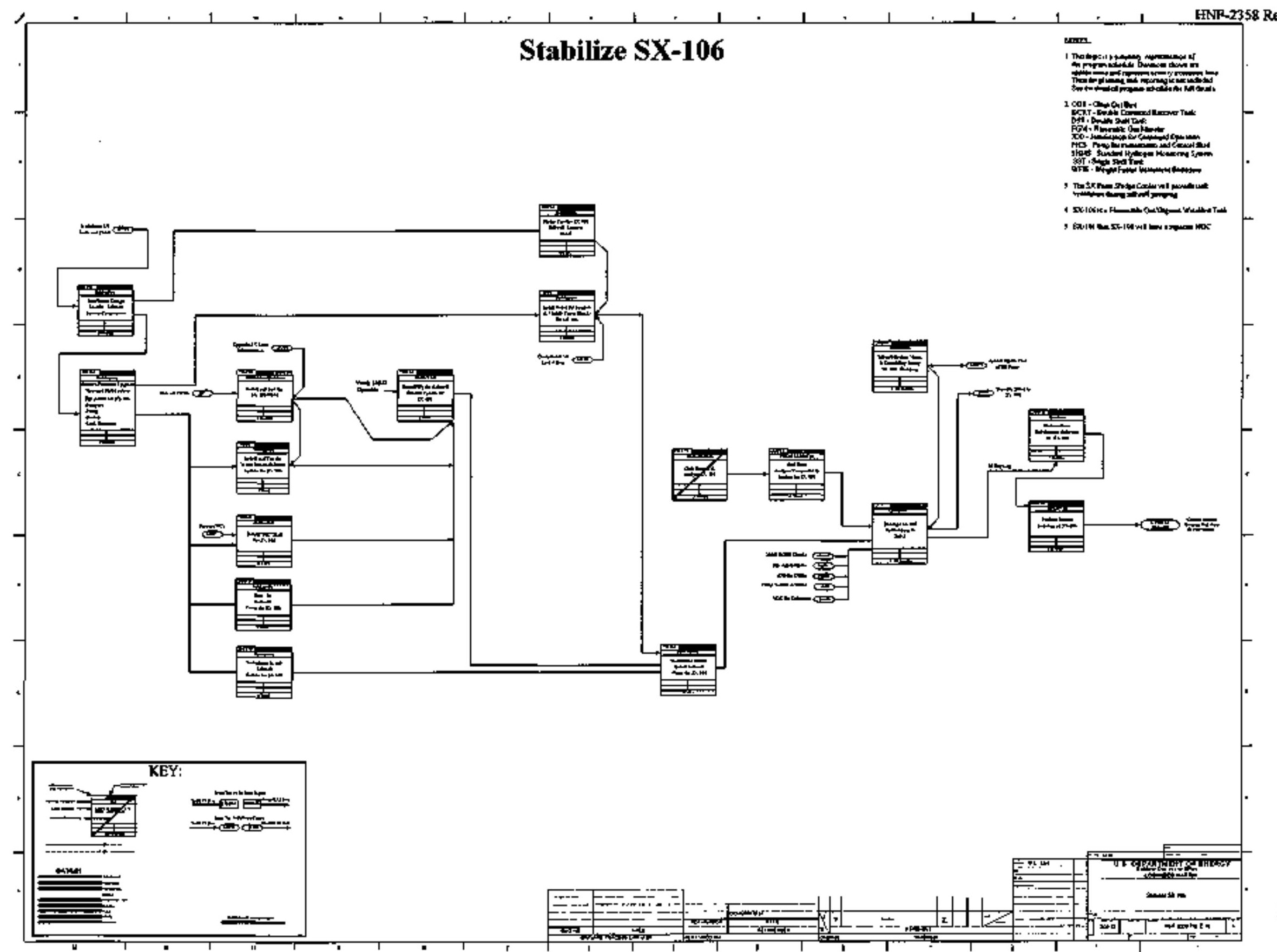




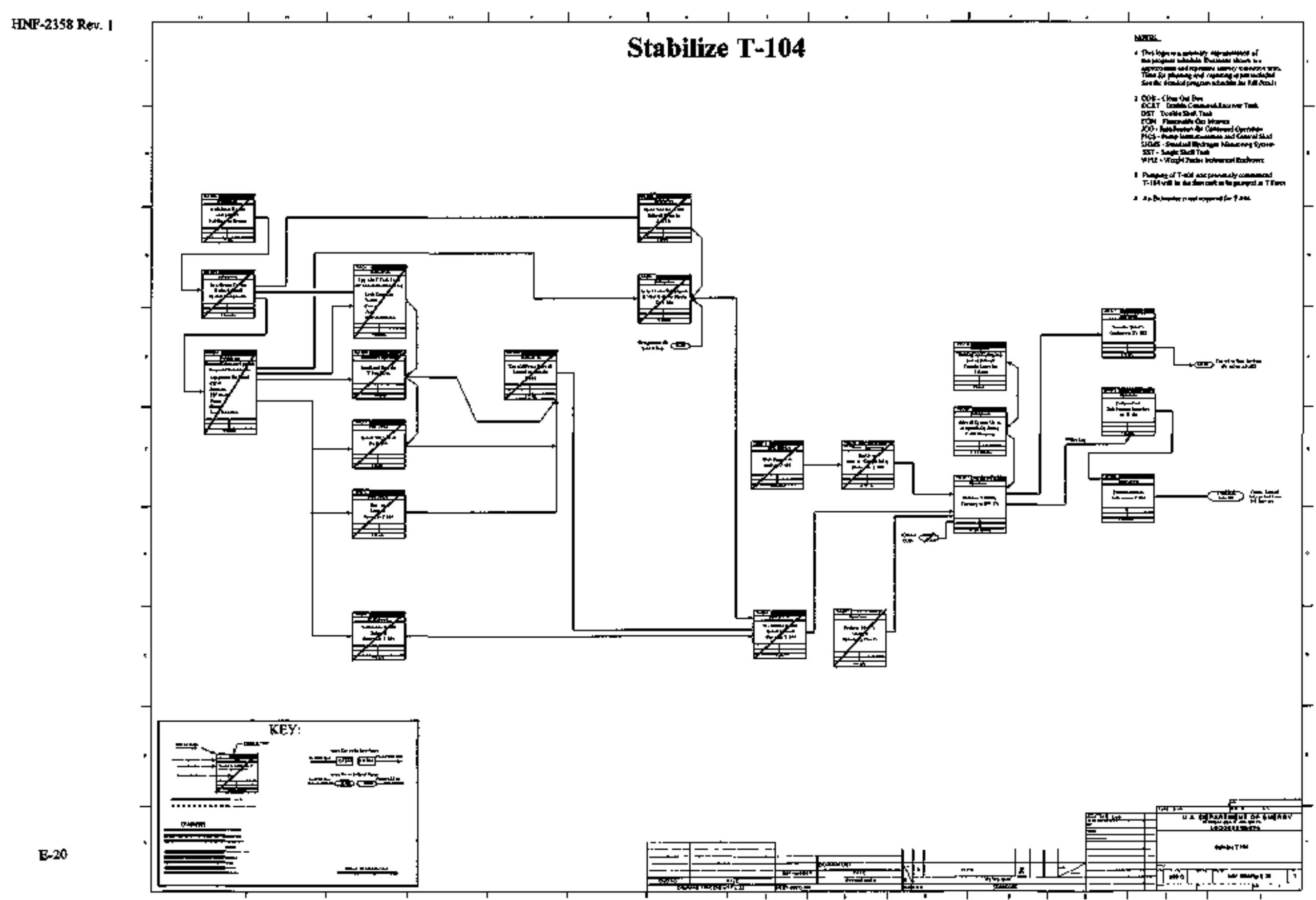




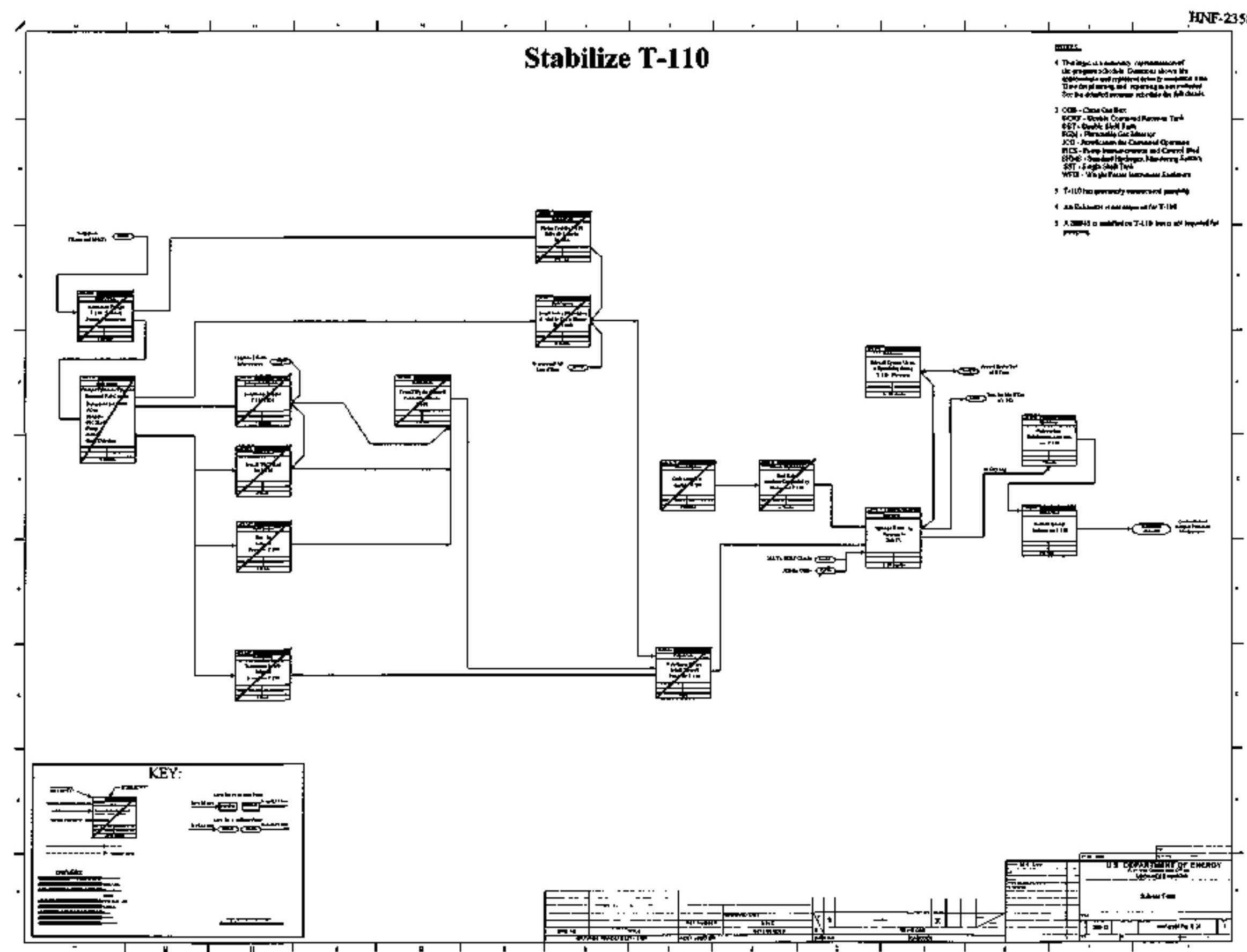




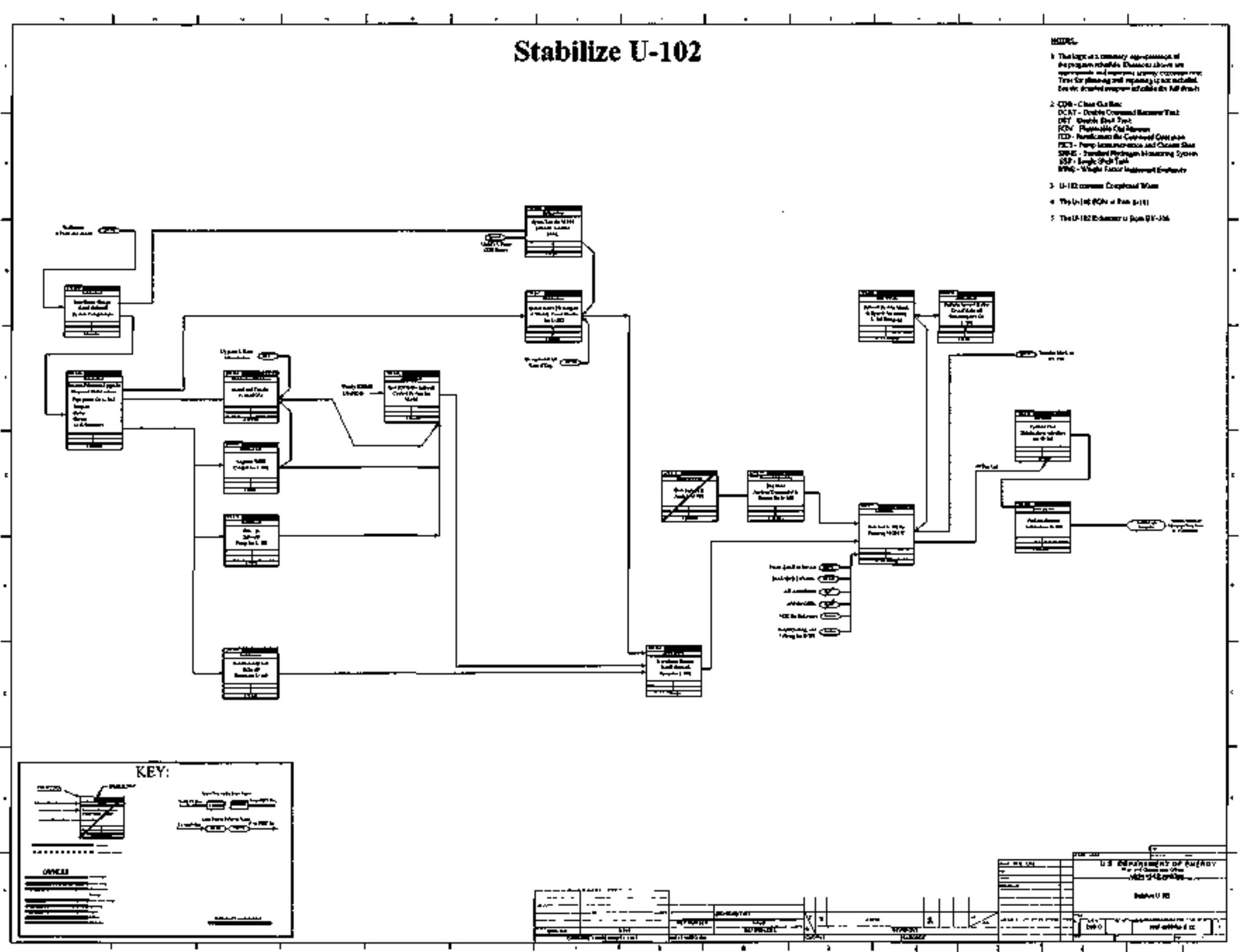

E-22 


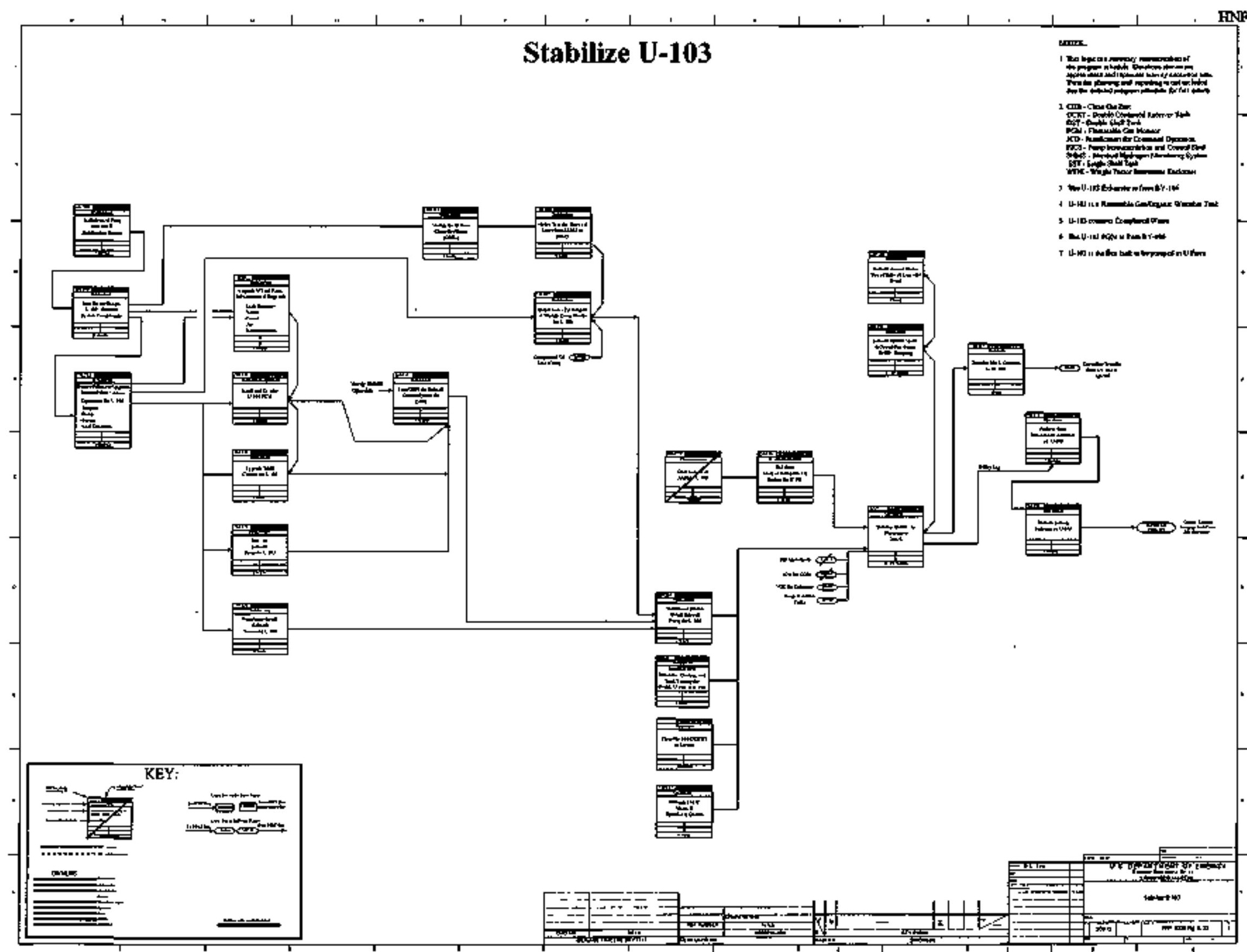




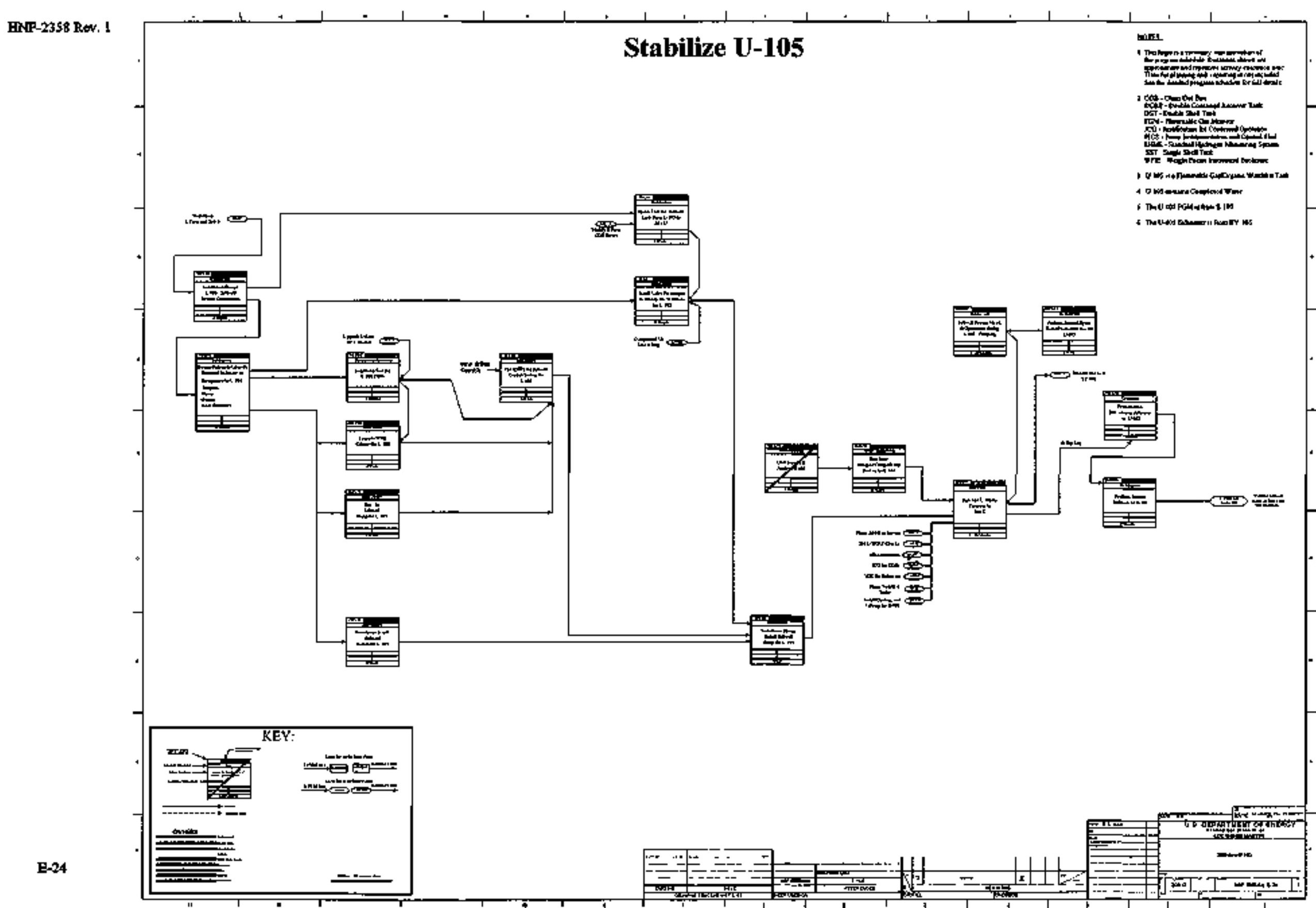




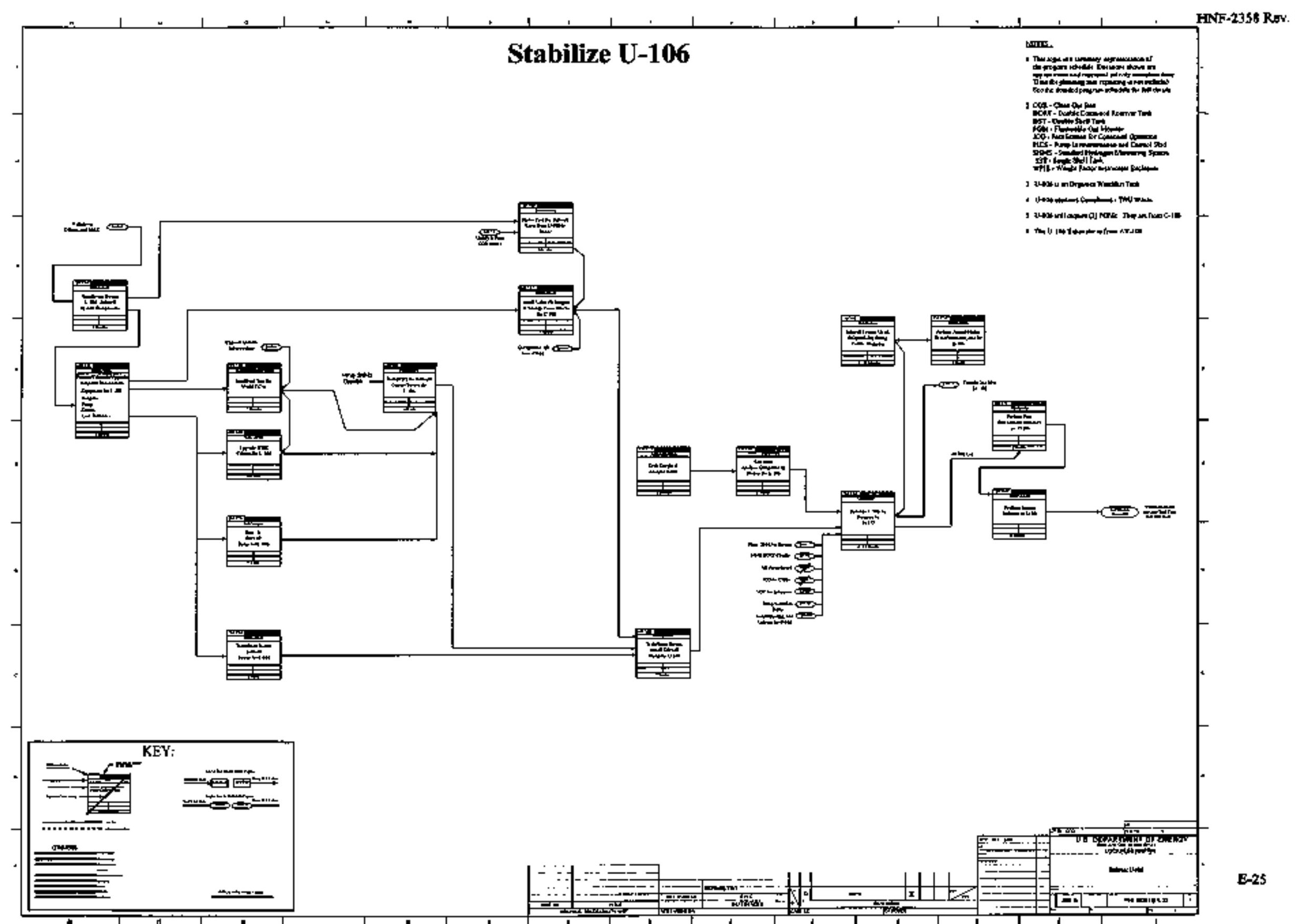




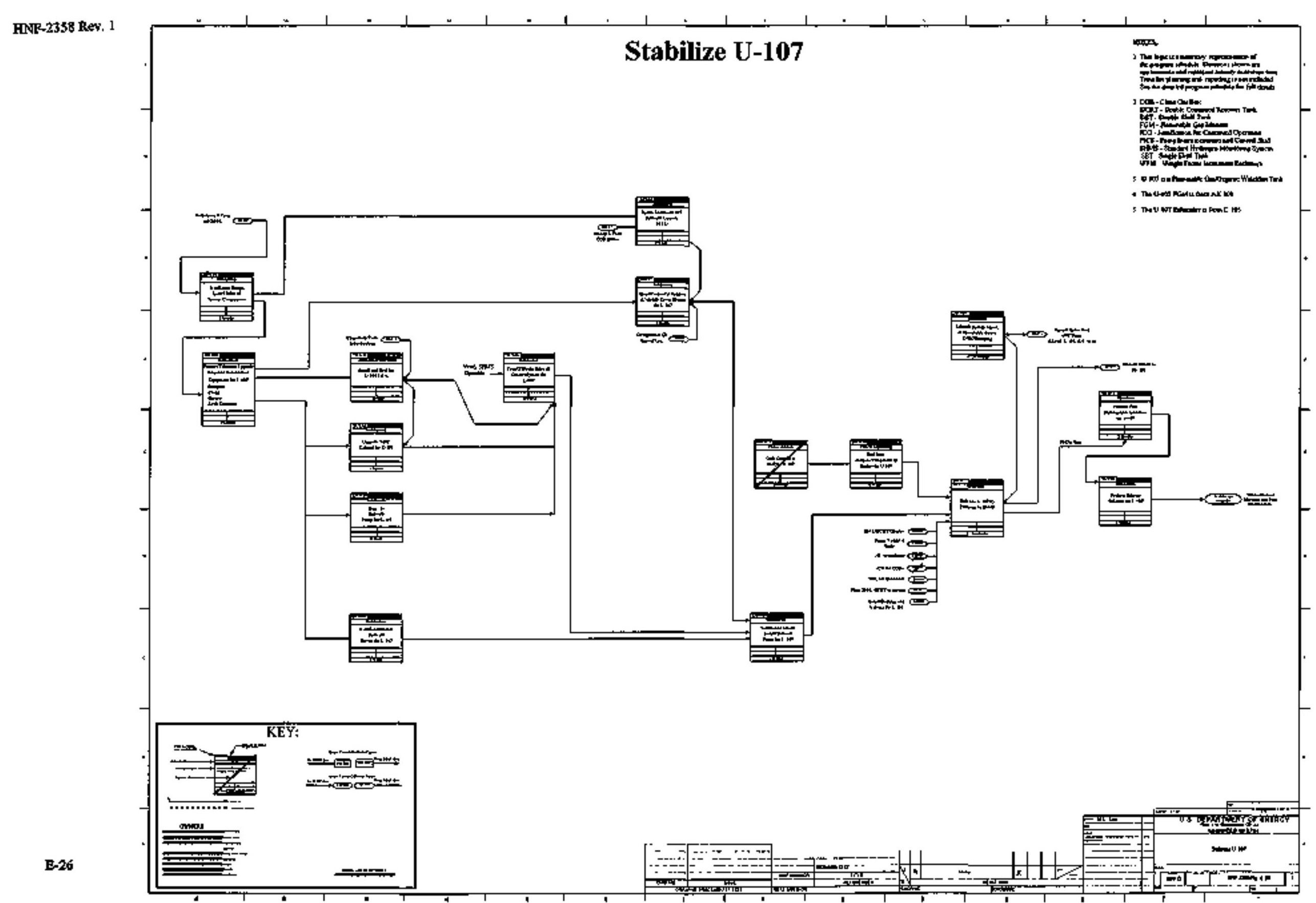




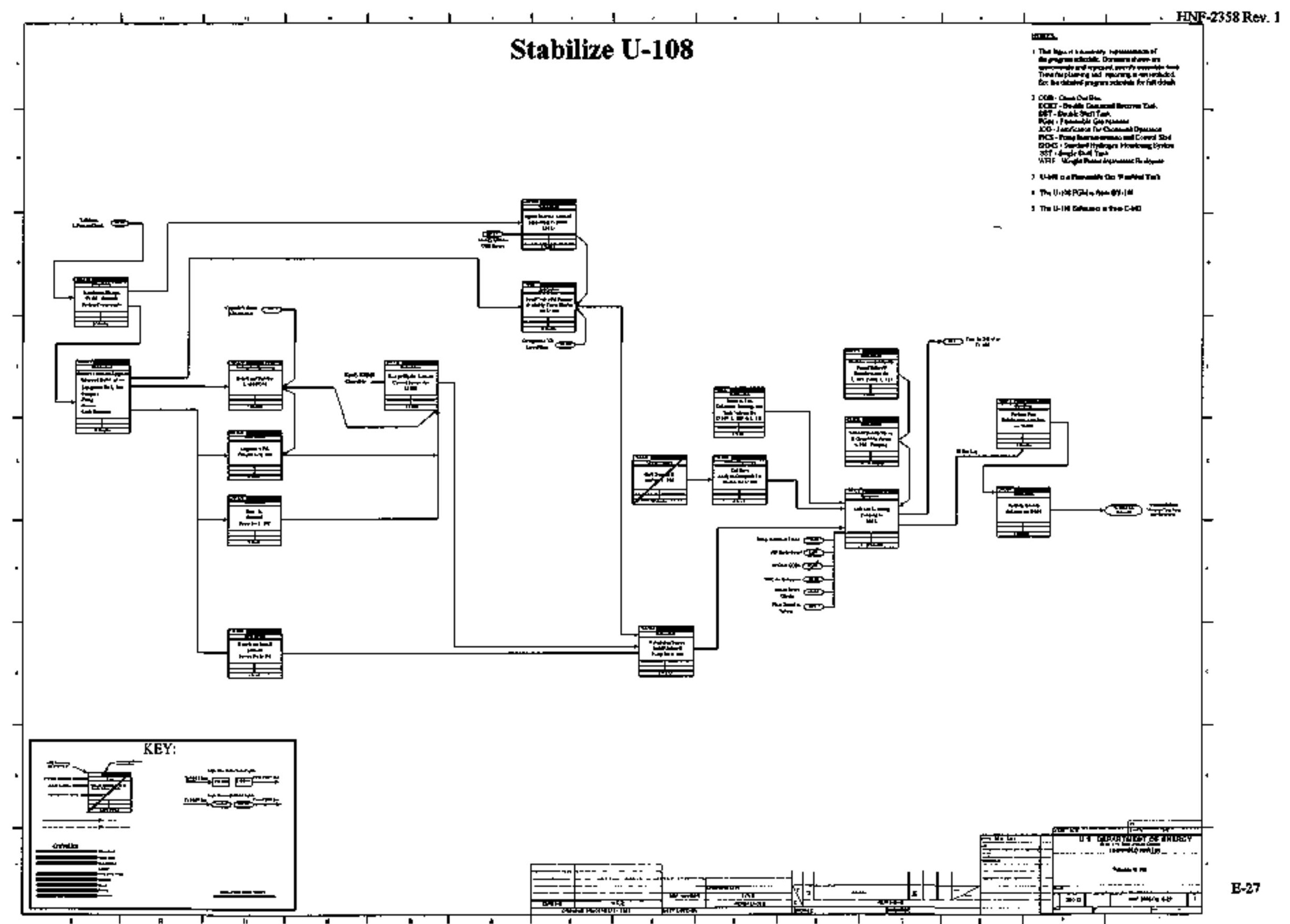




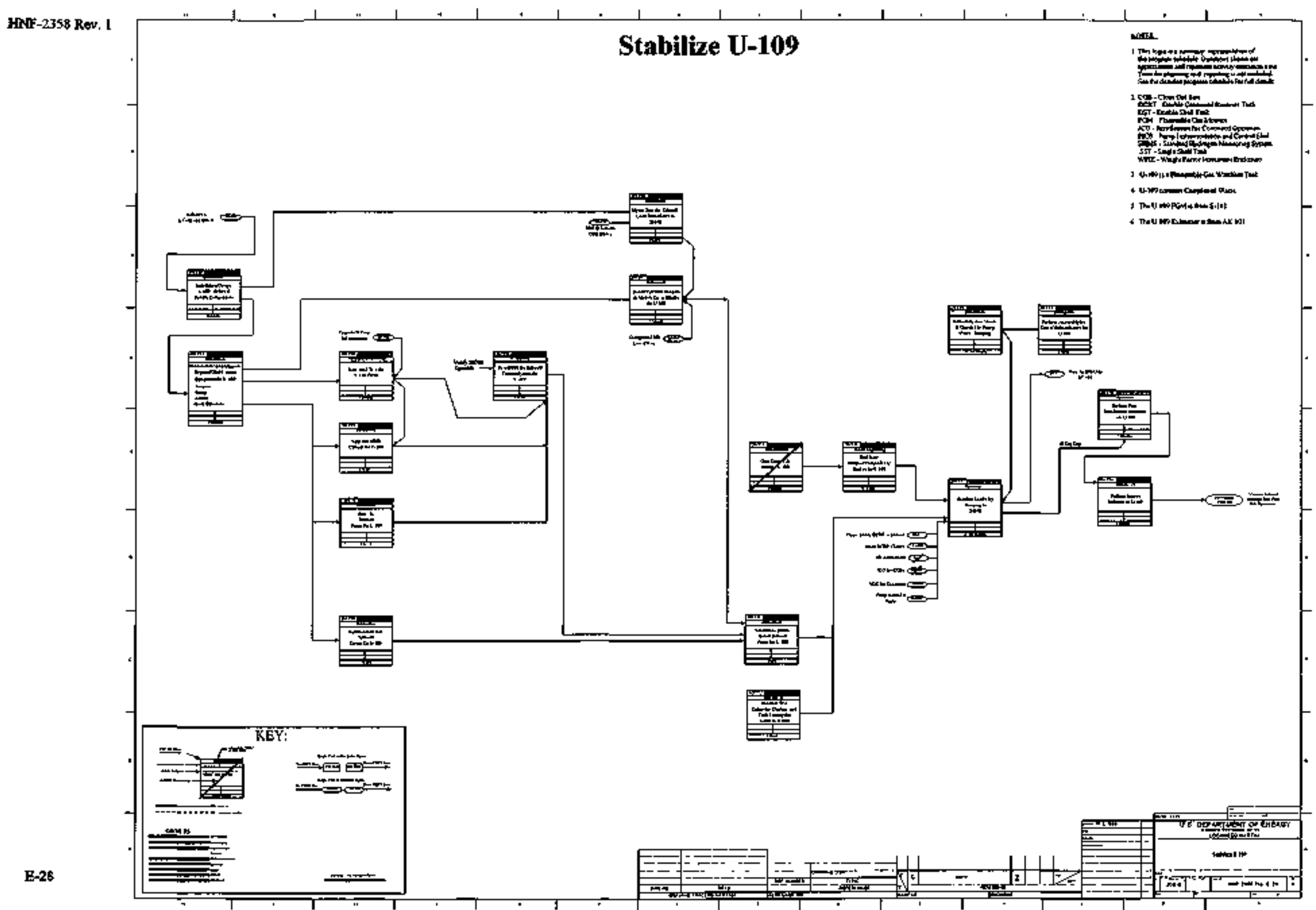




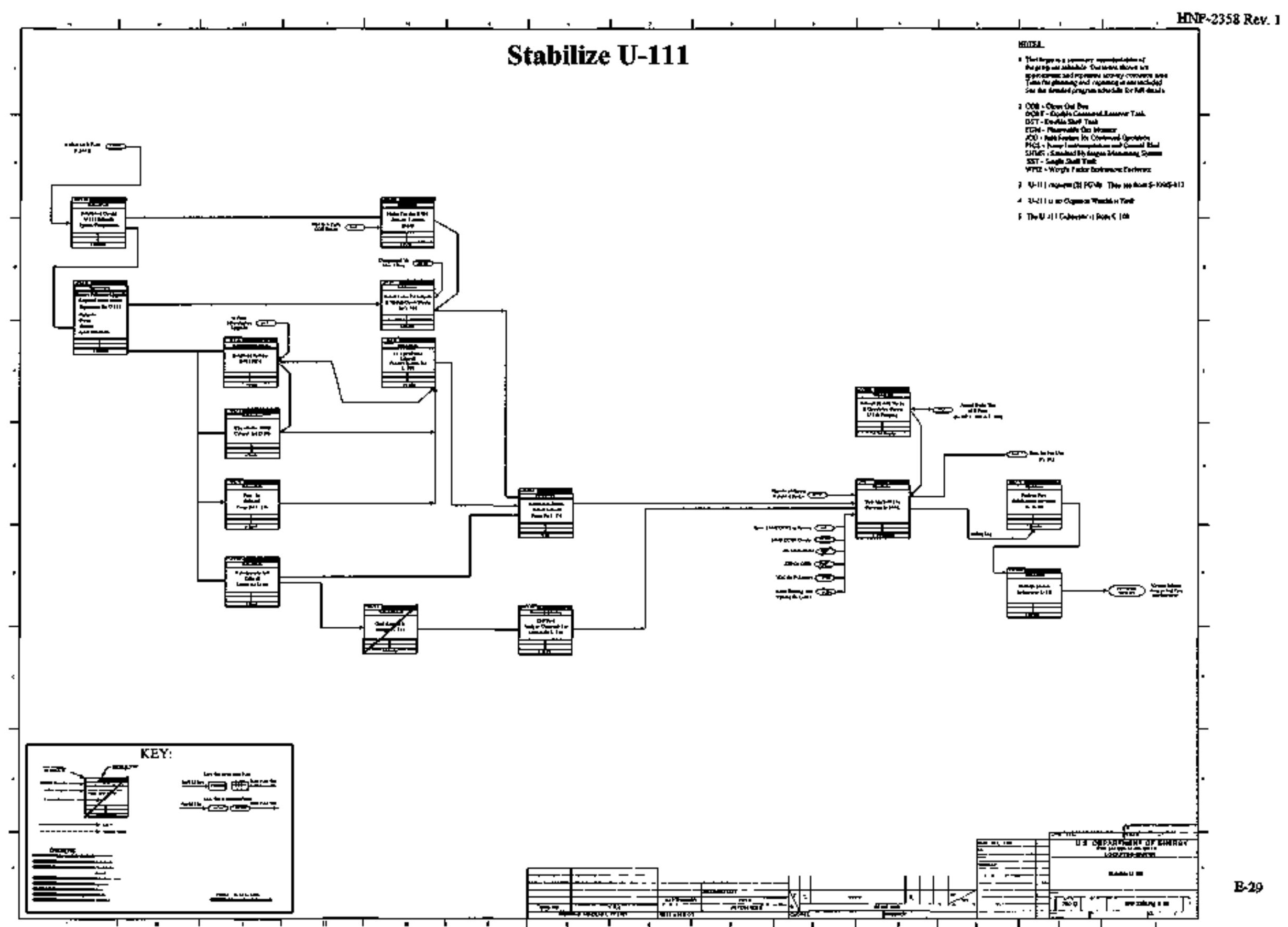


HNF-2358 REY I

This poge ingotionally left blank 


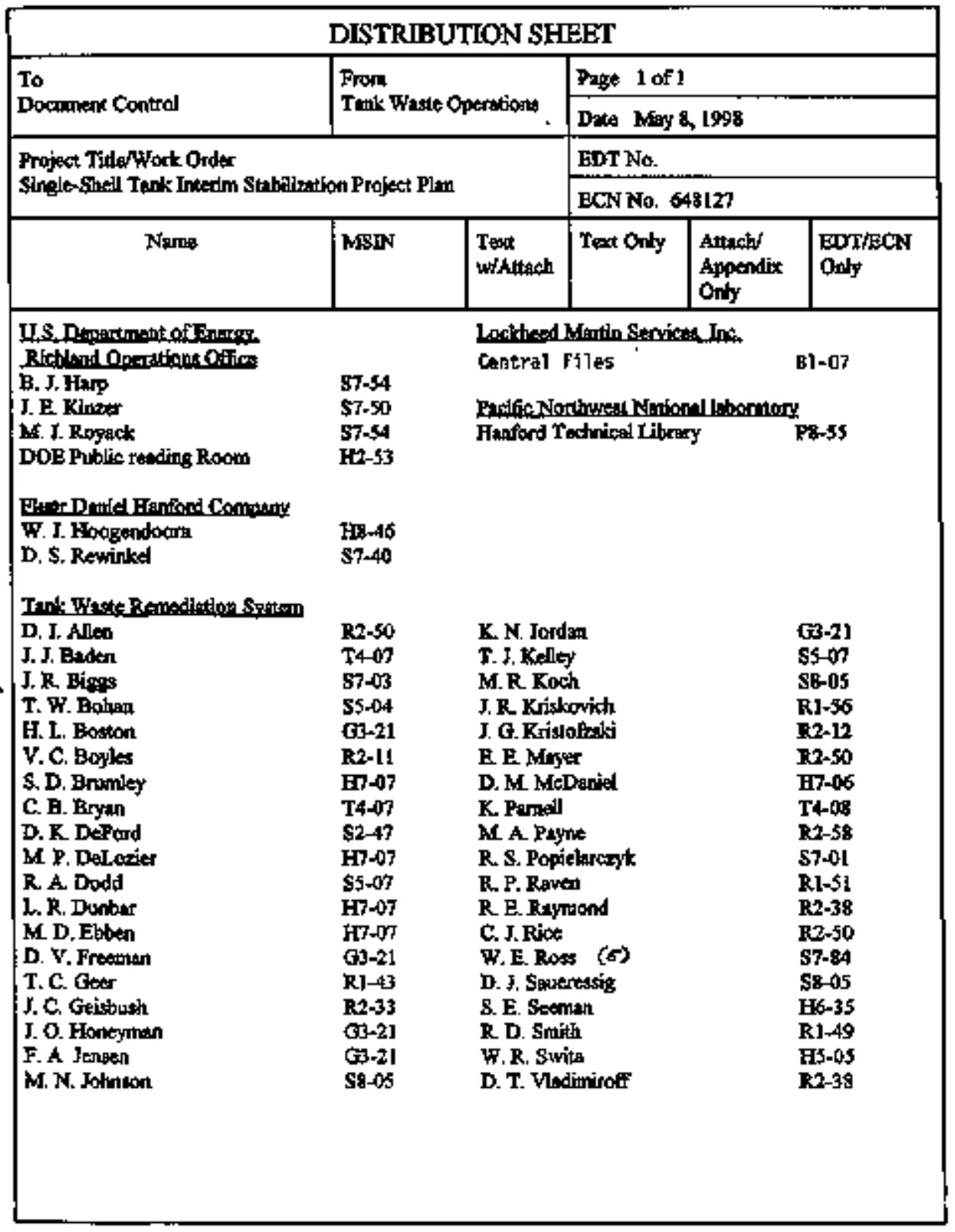

